\title{
British Infantry Battalion Commanders in the First World War
}

\author{
by \\ Peter Eric Hodgkinson
}

A thesis submitted to the University of Birmingham for the degree of

Doctor of Philosophy

School of History and Cultures

College of Arts and Law

University of Birmingham

August 2013 


\section{UNIVERSITYOF BIRMINGHAM}

\section{University of Birmingham Research Archive \\ e-theses repository}

This unpublished thesis/dissertation is copyright of the author and/or third parties. The intellectual property rights of the author or third parties in respect of this work are as defined by The Copyright Designs and Patents Act 1988 or as modified by any successor legislation.

Any use made of information contained in this thesis/dissertation must be in accordance with that legislation and must be properly acknowledged. Further distribution or reproduction in any format is prohibited without the permission of the copyright holder. 


\begin{abstract}
The evolution of infantry battalion commanders in the First World War progressed from a pre-war system based mainly on promotion by seniority to one largely based on merit. It remained a weighted process, however, favouring the professional officer, particularly during the first two years, and biased against the Territorial. The quality of the pre-war officer appears higher than has been estimated.
\end{abstract}

Average command lasted 8.5 months. Eleven per cent of COs were killed, ten per cent promoted, and 18 per cent invalided. The army practised quality control, removing 38 per cent from command, although reduction in removals as the war progressed indicates a refinement of quality. The army committed itself to professional development, teaching technical aspects of the $\mathrm{CO}$ role, as well as command and leadership.

Citizens of 1914 with no previous military experience rose to command, this progress taking on average three years. Despite the social opening-up of the officer corps, these men tended to be from the professional class. By The Hundred Days, infantry battalion commanders were a mix of professional soldiers, pre-war auxiliaries and citizens younger, fitter and richly experienced; many being quick thinkers, self-assured, and endowed with great personal courage and well-developed tactical ability. 


\section{Dedication}

This thesis is dedicated to my parents, Allan and Norma Hodgkinson, for their steadfast support throughout my life.

It is further dedicated to three soldiers of the Great War: my grandfather, Private Peter Rimmer 168093 ASC; my great-uncle, Private William R. Moxey 206165 ASC; and my great-uncle, Corporal Henry J. Boyd 113481 RE (Special Brigade). Without these men's stories in my childhood, my passion for the Great War would have been the less. 


\section{Acknowledgements}

My thanks are due to the encouragement and support of my supervisor, Dr John Bourne, and my adviser, Professor Peter Simkins, who planted the seed of the idea.

Thanks are also due to the following individuals who assisted in identifying battalion commanders: Lieutenant-Colonel George Latham, Highlanders Regimental Museum; Ian Hook and colleagues, Essex Regiment Museum; Matthew Richardson; G Crump, Cheshire Military Museum; C Ford, Regimental Headquarters, Duke of Wellington's Regiment; Jane Davies and colleagues, Museum of the Queen's Lancashire Regiment; Captain Robert Bonner, Museum of the Manchester Regiment; David Thompson; Barrie Bertram; David Read, Soldiers of Gloucestershire Museum; Lieutenant-Colonel Changboo Kang; Major W H White, Regimental Museum, Duke of Cornwall's Light Infantry; Barrie Duncan, South Lanarkshire Council; Jonathan Capek; I G Edwards, Sherwood Foresters Collection; D Bird, Royal Norfolk Regimental Museum; Sandy Leishman, Royal Highland Fusiliers Museum; the Museum of the Royal Irish Fusiliers; Martin Everett of the Regimental Museum of the Royal Welsh; Rod Mackenzie of the Home Headquarters, Argyll and Sutherland Highlanders; and Dicky Bird of the Royal Norfolk Regimental Museum.

Further thanks are due to Trevor Harvey, for reading parts of the text, furnishing information, and for many conversations on the Great War; and Nikki Oatham, both for reading the text and assistance with psychological concepts of leadership. 


\section{Contents}

Page

\section{Introduction}

Chapter One

\section{"Their Heart Failed Not" - The Battalion Commanders of August} 1914

1.1 The Regular COs of August 1914

1.1.1 Careers to appointment

1.1.2 Age, tenure and further promotion 24

$\begin{array}{lll}\text { 1.1.3 War service } & 25\end{array}$

$\begin{array}{ll}\text { 1.1.4 Staff service in peace } & 28\end{array}$

1.1.5 Staff service in war 32

$\begin{array}{lll}\text { 1.2 The Special Reserve COs of August } 1914 & 34\end{array}$

1.3 The Territorial Force COs of August 1914

1.3.1 Ex-Regulars $\quad 35$

1.3.2 Former Volunteer COs 36

$\begin{array}{lll}\text { 1.3.3 War service } & 37\end{array}$

1.4 The Quality of the Battalion Commanders of August $1914 \quad 38$

1.4.1 The Regulars 38

1.4.2 The Auxiliaries 45

1.5 Attrition of Command in the BEF in 1914

$\begin{array}{llr}1.6 & \text { Conclusion } & 54\end{array}$

$\begin{array}{ll}\text { Chapter Two } & 56\end{array}$

Raising the New Armies and Expanding the Territorial Force - Battalion Command 1914-15

2.1 New Army Infantry Service Battalions 56

2.1.1 First COs - K1

2.1.2 First COs $-K 2 \quad 58$

2.1.3 First COs - K3 59

2.1.4 First COs - Locally-raised battalions $\quad 60$

2.1.5 Overview 62 
$\begin{array}{lll}2.3 & \text { The New Territorial Force Battalions } & 70\end{array}$

$\begin{array}{lll}2.4 & \text { Dugouts } & 73\end{array}$

2.5 Quality of COs who Took their Battalions to War 83

$\begin{array}{llr}2.6 & \text { Conclusion } & 93\end{array}$

\section{Chapter Three 95}

\section{Evolution of Battalion Command - Organisational and Individual Aspects}

3.1 Evolution - Organisational Characteristics 96

3.1.1 Source of Commanding Officers 96

$\begin{array}{ll}3.1 .2 & \text { Regimental Affiliation } \\ & 101\end{array}$

$\begin{array}{llr}3.2 & \text { Evolution - Individual Characteristics } & 103\end{array}$

$\begin{array}{llr}3.2 .1 & \text { Age } & 103\end{array}$

$\begin{array}{lll}3.2 .2 \text { Rank } & 110\end{array}$

$\begin{array}{lll}\text { 3.2.3 Staff service - Adjutancy } & 111\end{array}$

3.2.4 Staff service - Extra-regimental 112

$\begin{array}{llr}3.3 & \text { Turnover } & 115\end{array}$

3.3.1 Turnover by month 115

$\begin{array}{ll}3.3 .2 & \text { Turnover by battalion } \\ 3.3 .3 & 117\end{array}$

$\begin{array}{ll}3.3 .3 & \text { Number of commands } \\ 3.3 .4 & 118\end{array}$

$\begin{array}{ll}\text { 3.3.4 Length of command } & 128\end{array}$

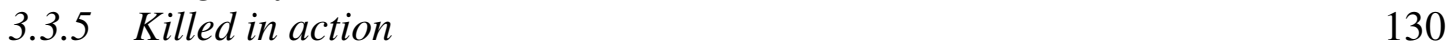

$\begin{array}{lll}3.3 .6 & & 132\end{array}$

$\begin{array}{lll}3.3 .7 & \text { Promotion } & 140\end{array}$

$\begin{array}{lll}3.3 .8 & \text { Replacement } & 143\end{array}$

$\begin{array}{llr}3.4 & \text { Conclusion } & 156\end{array}$ 


\section{Chapter Four}

Evolution of Command - Regular, New Army and Territorial Battalions

$\begin{array}{llr}\text { 4.1 } & \text { The Regular Battalions } & 158\end{array}$

$\begin{array}{lll}\text { 4.1.1 } & 5^{\text {th }} \text { Division } & 160\end{array}$

4.1.2 Case study - $1^{\text {st }}$ Battalion Hampshire Regiment 165

$\begin{array}{lll}4.2 & \text { Service Battalions } & 172\end{array}$

$\begin{array}{lll}\text { 4.2.1 } & 9^{\text {th }} \text { Division } & 178\end{array}$

4.2.2 Case study - 13 ${ }^{\text {th }}$ Battalion (West Ham) Essex Regiment 181

$\begin{array}{llr}4.3 & \text { Territorial Battalions } & 189\end{array}$

4.3.1 42 $2^{\text {nd }}$ Division 193

4.3.2 Case Study - 1/4 ${ }^{\text {th }}$ Royal Berkshire 199

$\begin{array}{llr}\text { 4.4 Senior Officer School } & 205\end{array}$

$\begin{array}{lll}4.5 & \text { Conclusion } & 210\end{array}$

$\begin{array}{ll}\text { Chapter Five } & 212\end{array}$

"Men to be Followed, Feared and Loved" - Command and Leadership

$\begin{array}{lll}\text { 5.1 Leadership and command } & 214\end{array}$

5.2 The experience of command - the perspective of the Other Ranks 221

5.3 The experience of command - the battalion officer's perspective 227

$\begin{array}{lll}\text { 5.3.1 Paternalism } & 227\end{array}$

$\begin{array}{lll}\text { 5.3.2 Popularity } & 228\end{array}$

5.3.3 Expert power 233

$\begin{array}{ll}\text { 5.3.4 Consultative style } & 234\end{array}$

5.3.5 Courage, personal example and modelling 235

$\begin{array}{lll}\text { 5.3.6 The unpopular } \mathrm{CO} & 239\end{array}$

5.4 The experience of command - the CO's perspective 247

$\begin{array}{ll}\text { 5.4.1 Taking over } & 247\end{array}$

$\begin{array}{ll}\text { 5.4.2 Making a mark } & 250\end{array}$

$\begin{array}{lll}5.4 .3 & \text { Stress and strain } & 256\end{array}$

$\begin{array}{ll}\text { 5.4.4 Promotion } & 259\end{array}$

5.5.5 Demotion 263

$\begin{array}{lll}\text { 5.6 Decorations } & 265\end{array}$ 


\section{Chapter Six}

"Professional Men of War" - The Citizen COs

$\begin{array}{lll}\text { 6.1 The Citizen COs } & 271\end{array}$

$\begin{array}{lll}6.1 .1 & \text { Age } & 272\end{array}$

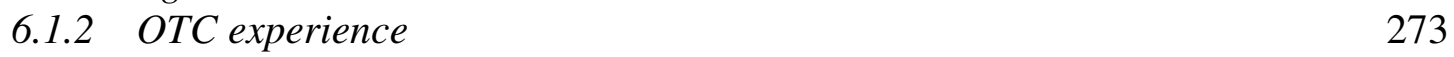

$\begin{array}{lll}\text { 6.1.3 Pre-war occupations and social status } & 273\end{array}$

$\begin{array}{lll}6.1 .4 & \text { Commission routes } & 288\end{array}$

$\begin{array}{ll}\text { 6.1.5 Pace of promotion } & 289\end{array}$

$\begin{array}{lll}6.2 & \text { "Military geniuses"? } & 292\end{array}$

$\begin{array}{lll}\text { 6.3 Conclusion } & 304\end{array}$

Chapter Seven $\quad 307$

Meritocracy in Battalion Command in the Hundred Days Lions Led by Tigers?

$\begin{array}{lll}7.1 & \text { Rat-Catchers and Fire-Eaters } & 308\end{array}$

$\begin{array}{lll}\text { 7.2 } & \text { The COs of The Hundred Days } & 314\end{array}$

$\begin{array}{lll}7.3 & 5^{\text {th }} \text { Division } & 318\end{array}$

$\begin{array}{lll}\text { 7.4 } & 9^{\text {th }} \text { (Scottish) Division } & 326\end{array}$

$\begin{array}{lll}\text { 7.5 } & \text { 42 } & \text { (East Lancashire) Division } \\ \end{array}$

7.6 Initiative and Devolved Command in The Hundred Days 341

$\begin{array}{lll}7.7 & \text { Conclusion } & 349\end{array}$

$\begin{array}{ll}\text { Conclusion } & 353\end{array}$

Appendix One 368

Database of Infantry Battalion Commanding Officers of Regiments of the Line 


\section{Appendix Two}

The Special/Extra Reserve Commanding Officers of August 1914

1. Ex-Regulars as Special Reserve COs

2. Former Militia COs

3. War Service

Appendix Three

Commanding the Infantry Battalions of the Home Army

1. Special and Extra Reserve Battalions

2. New Army Reserve Battalions

$2.1 \mathrm{~K} 4$ reserve battalions

2.2 Locally-raised reserve battalions

3. Territorial Reserve Battalions 382

4. Second-line Territorial Battalions 386

5. Conclusion 388

Appendix Four 389

From: The Battalion Commander's Handbook

\section{Bibliography}




\section{Tables}

Page

1.1 Comparison of entry routes of Regular COs with all officer entry 20 routes to the infantry

1.2 Posts held in August 1914 by predecessors of Regular COs 25

1.3 Pre-1914 war service of Regular COs 26

$1.4 \quad$ Peacetime staff experience of Regular COs 31

1.5 Wartime staff posts held by Regular COs 33

1.6 Entry routes of ex-Regular TF COs in post August 1914 compared 35 with entry routes of Regular COs

1.7 Peace and wartime Staff service of ex-Regular TF COs in post August 36 1914 and Regular COs

$\begin{array}{lll}1.8 & \text { War service of TF COs } & 38\end{array}$

2.1 Active officers appointed as first COs to Service Battalions 63

2.2 Retired officers appointed as first COs to Service Battalions 64

2.3 Officers appointed as first COs to second-line TF Battalions and 72 those taking battalions on active service

2.4 Comparison of first COs of Service Battalions with those taking 81 battalions on active service

3.1 Relative contribution of various arms of the infantry to active battalion 96 command

3.2 Relative contribution of various bodies of the infantry to active battalion 97 command on 29 September 1918

3.3 Relative contribution of various arms of the services to active battalion 98 command

3.4 Internal/external regimental origin of active COs 101

3.5 Internal/external regimental origin of active COs according to battalion 102 type on 29 September 1918

$\begin{array}{lll}3.6 & \text { Average and range of ages of COs } & 104\end{array}$

3.7 August 1914 ranks of COs of 29 September $1918 \quad 110$

3.8 Staff posts held by active infantry COs prior to assuming command 113

3.9 Number of commands held by individual active COs 119

$\begin{array}{ll}3.10 \text { Contribution of professional soldiers to multiple battalion command } & 126\end{array}$

$\begin{array}{ll}3.11 & \text { Length of battalion command } \\ 3.12 & 128\end{array}$

$\begin{array}{ll}3.12 & \text { Average days in post for COs prior to major battles } \\ & 129\end{array}$

3.13 Infantry COs killed in action/died of wounds 130

3.14 August 1914 status of Brigadier-Generals promoted from battalion $\quad 140$ command

$\begin{array}{lll}3.15 & \text { COs fate after replacement } & 144\end{array}$

3.16 Staff posts of replaced COs 145

3.17 Number of "new broom" replacements by Brigadier-Generals in 5th, 9th 152 \& 42nd Divisions 
3.18 Number of "new broom" replacements by Major-Generals in 5th, 9th \& 154 42nd Divisions

$\begin{array}{lll}4.1 & \text { Origins of COs of Regular battalions } & 159\end{array}$

$\begin{array}{lll}4.2 & \text { Reasons for turnover of COs in } 5^{\text {th }} \text { Division } & 164\end{array}$

$\begin{array}{lll}4.3 & \text { Origins of active COs of Service Battalions } & 172\end{array}$

4.4 August 1914 origins of New Army COs in France \& Flanders on $29 \quad 172$

September 1918

4.5 Reasons for turnover of COs of Service Battalions in 9th Division 181

4.6 Origins of active COs of first and second-line TF battalions 189

4.7 August 1914 origins of first-line TF COs in France \& Flanders on $29 \quad 190$

September 1918

4.8 Reasons for turnover of COs of battalions in 42nd Division 199

4.9 Officers acting as CO during absences of Lieutenant-Colonel R.J.Clarke 202

6.1 Officer numbers and commissions granted 1914-1918 271

6.2 Ages of citizen COs compared with all officers, Warwickshire Regiment

6.3 Occupations of demobilised officers and 1914 occupations of citizen 274 COs

6.4 Civilian occupations of officers of the Royal Warwickshire Regiment 276 and citizen $\mathrm{COs}$

6.5 Entry routes of citizen COs v. distribution of officers 288

6.6 Type of first commission and battalion command 289

7.1 Reasons for COs leaving command during The Hundred Days 315

7.2 Career progression of COs of 5th Division who commanded during 317

The Hundred Days

7.3 Career progression of COs of 9th Division who commanded during 325

The Hundred Days

7.4 Career progression of COs of 42nd Division who commanded during 335 The Hundred Days

7.5 Comparison of August 1914 status of COS of 5th, 9th \& 42nd Divisions 349 with COs of entire BEF on 29 September 1918

A2.1 Comparison of entry routes of ex-Regular SR COs and Regular COs $\quad 369$

A2.2 Comparison of peace and wartime staff service of ex-Regular SR COs $\quad 370$ and Regular COs

A2.3 War service of Special Reserve COs 372

A3.1 First COs of K4 reserve battalions 378

A3.2 First COs of locally-raised reserve battalions 382

A3.3 First appointments to TF Reserve Battalions 384

A3.4 First and last appointments to TF Reserve Battalions expressed as 385 percentages in terms of rank in August 1914

A3.5 First COs of home service second-line TF battalions 386

A3.6 Status in August 1914 of first and last COs of the second line TF 387 Battalions 


\section{Figures}

2.1 Retirement years of 'dug out' COs either not suitable for active service, or first to take service battalions on active service

$\begin{array}{lll}3.1 & \text { Monthly CO appointments } & 116\end{array}$

6.1 Number of monthly citizen CO appointments 290

6.2 Length of citizen CO commands 291

A3.1 Changes of CO in Special/Extra Reserve Battalions 1914-1918 374 


\section{Abbreviations}

\begin{tabular}{|c|c|}
\hline $\mathrm{AAG}$ & Assistant Adjutant General \\
\hline AAQMG & Assistant Adjutant \& Quartermaster General \\
\hline $\mathrm{ADC}$ & Aide de Camp \\
\hline AMS & Assistant Military Secretary \\
\hline ANZAC & Australian and New Zealand Army Corps \\
\hline AQMG & Assistant Quartermaster General \\
\hline ASC & Army Service Corps \\
\hline BA & Bachelor of Arts \\
\hline $\mathrm{BEF}$ & British Expeditionary Force \\
\hline $\mathrm{BM}$ & Brigade Major \\
\hline Bt. & Baronet \\
\hline CEF & Canadian Expeditionary Force \\
\hline C-in-C & Commander in Chief \\
\hline $\mathrm{CO}$ & Commanding Officer \\
\hline CPRC & Ceylon Planters Rifle Corps \\
\hline DAAG & Deputy Assistant Adjutant General \\
\hline DAAQMG & Deputy Assistant Adjutant \& Quartermaster General \\
\hline DAQMG & Deputy Assistant Quartermaster General \\
\hline DSO & Distinguished Service Order \\
\hline $\mathrm{F} \& \mathrm{~F}$ & France \& Flanders \\
\hline GHQ & General Headquarters \\
\hline GOC & General Officer Commanding \\
\hline GSO & General Staff Officer $(1,3$ or 3$)$ \\
\hline HAC & Honourable Artillery Company \\
\hline HMSO & His/Her Majesty’s Stationery Office \\
\hline HQ & Headquarters \\
\hline IWM & Imperial War Museum \\
\hline $\mathrm{K} 1$ & Kitchener 1 - first 100,000 New Army recruits \\
\hline $\mathrm{K} 2$ & Kitchener 2 - second 100,000 New Army recruits \\
\hline K3 & Kitchener 3 - third 100,000 New Army recruits \\
\hline K4 & Kitchener 4 - fourth 100,000 New Army recruits \\
\hline KIA & Killed in action \\
\hline KOSB & King's Own Scottish Borderers \\
\hline KRRC & King's Royal Rifle Corps \\
\hline LHCMA & Liddell Hart Centre for Military Archives \\
\hline LAC & Libraries and Archives Canada \\
\hline LRO & Lancashire Record Office \\
\hline $\mathrm{MC}$ & Military Cross \\
\hline MP & Member of Parliament \\
\hline NAM & National Army Museum \\
\hline $\mathrm{NCO}$ & Non-commissioned officer \\
\hline NLS & National Library of Scotland \\
\hline $\mathrm{OC}$ & Officer commanding \\
\hline ORs & Other ranks \\
\hline
\end{tabular}




$\begin{array}{ll}\text { OTC } & \text { Officer Training Corps } \\ \text { PBI } & \text { Poor bloody infantry } \\ \text { POW } & \text { Prisoner of war } \\ \text { PRO } & \text { Public Record Office } \\ \text { psc } & \text { Passed staff college } \\ \text { RAMC } & \text { Royal Army Medical Corps } \\ \text { RE } & \text { Royal Engineers } \\ \text { RMA } & \text { Royal Military Academy (Woolwich) } \\ \text { RMC } & \text { Royal Military College (Sandhurst) } \\ \text { RUSI } & \text { Royal United Services Institute } \\ \text { SMLE } & \text { Short Magazine Lee Enfield } \\ \text { SR } & \text { Special Reserve } \\ \text { TF } & \text { Territorial Force } \\ \text { TNA } & \text { The National Archives } \\ \text { UK } & \text { United Kingdom } \\ \text { VC } & \text { Victoria Cross } \\ \text { WO } & \text { War Office }\end{array}$




\section{Introduction}

There are no bad regiments, only bad colonels.

Attributed to Napoleon Bonaparte ${ }^{1}$

This thesis examines the evolution of the infantry battalion commanders of the regiments of the line of the British Army during the First World War. ${ }^{2}$

The battalion was the building block of the infantry, ${ }^{3}$ its basic tactical unit. ${ }^{4}$ The Commanding Officer $(\mathrm{CO})$ was a Lieutenant-Colonel. Each British regiment (with the exception of the ten Territorial Force regiments) had at least two Regular battalions, ${ }^{5}$ one Special Reserve battalion, ${ }^{6}$ and most had at least one Territorial battalion. ${ }^{7}$ A regiment could, in 1914, have between four and 26 Lieutenant-Colonels.

\footnotetext{
${ }_{1}^{1}$ A. D. Vandam, 'Officers in the French Army', North American Review, 165 (413) (1897), pp. $722-732$

${ }^{2}$ The infantry regiments of the British Army were listed in precedence related to order on parade, the regiment to the extreme right of the monarch (left of the line), having the lowest number. Until the reforms of 1881, the regiments were numbered, thus, the Royal Scots, next in line after the Guards regiments, were the $1^{\text {st }}$ Regiment of Foot.

${ }^{3}$ The infantry battalion was a unit comprising, in 1914, 1007 officers and men deployed in four rifle companies - see Chapter Two for more detail. The word battalion comes from Old French bataillon, from Italian battaglione, augmentative of battaglia (battle), from Late Latin battualia, originally from Latin battuere (pound, beat hit, strike). [Oxford English Reference Dictionary (Oxford: Oxford University Press, 1996), p.119].

${ }^{4}$ Andy Simpson states that "the infantry division, consisting of three brigades of four battalions apiece, was considered at the time to be the basic tactical unit of all arms". (A. Simpson, "The Operational Role of British Corps Command on the Western Front 1914-1918', PhD thesis, University of London, 2001, p.20). Field Service Regulations Part II states: "The basis of the field army organization is the division". [General Staff, Field Service Regulations Part II - Organization and Administration (War Office, October 1914), p.25]. The division was therefore the organisational structure of a combined arms formation, the infantry battalion was the basic tactical unit of the infantry thereof.

${ }^{5}$ The Royal Fusiliers, King's Royal Rifle Corps, Rifle Brigade, Middlesex and Worcestershire Regiments had four Regular battalions.

${ }^{6}$ Twenty-two of the 70 regiments of infantry of the line had one and four had two Extra Reserve battalions. See Appendix Three.

${ }^{7}$ Irish regiments had none. The Territorial London Regiment had 26.
} 
In 1997 John Bourne identified:

A fundamental weakness in the British historiography of the war, which has traditionally concentrated on the activities of GHQ and its relationship with a small number of army commanders, or on the experiences of the ordinary soldier in the front-line trench. The chain of command which stretched between them ... has been as little studied as commanders themselves. Filling this gap remains a major task for historians of the First World War. ${ }^{8}$

In the intervening years, some of this deficit has been remedied. Both Simon Robbins ${ }^{9}$ and John Bourne ${ }^{10}$ have produced studies of corps, division and brigade command; Changboo Kang has studied the officer corps of the Royal Warwickshire Regiment; ${ }^{11}$ and an initial descriptive study has been made of non-commissioned officers. ${ }^{12}$ The level of battalion command has, however, yet to be examined.

The importance of studying the battalion level of formation is set out by Chris McCarthy. Whilst acknowledging that the Western Front was dominated by artillery, he observes that "instead of declining into obsolescence, the infantry unit evolved to become a key element in the 'weapons system' that in 1918 carried the BEF to victory". ${ }^{13}$ The principal reason for studying battalion commanders is given by David French: "Whether on the battlefield

\footnotetext{
${ }^{8}$ J.M. Bourne, 'British Generals in the First World War', in G.D. Sheffield, ed., Leadership and Command: the Anglo-American Military Experience since 1861 (London: Brassey's, 1997), p.94

${ }^{9}$ S. Robbins, British Generalship on the Western Front 1914-18: Defeat Into Victory (Abingdon: Frank Cass, 2005).

${ }^{10}$ J. Bourne, 'British Divisional Commanders during the Great War: First Thoughts', Gun Fire: A Journal of First World War History, 29 (no date), p. 26

${ }^{11}$ C. Kang, 'The British Regimental Officer on the Western Front in the Great War, with Special Reference to the Royal Warwickshire Regiment', unpublished PhD Thesis, University of Birmingham (2007). Several recent descriptive studies have also been published. These include: J. Lewis-Stempel, Six Weeks - The Short and Gallant Life of the British Officer in the First World War (London: Weidenfeld \& Nicholson, 2010); and C. Moore-Bick, Playing the Game: The British Junior Infantry Officer on the Western Front 1914-1918 (Solihull: Helion, 2011).

${ }^{12}$ S. Penny, 'Discipline and Morale: the British Non-Commissioned Officer on the Western Front 19141918', unpublished M.Phil thesis, De Montfort University (2003)

${ }^{13}$ C. McCarthy, 'Queen of the Battlefield: The Development of Command Organisation and Tactics in the British Infantry Battalion during the Great War', in G. Sheffield \& D. Todman, eds., Command and Control on the Western Front (Staplehurst: Spellmount, 2004), p.173
} 
or in barracks, the most important person in any unit was its CO. His knowledge could make or break his unit". ${ }^{14}$ In the closest that the British Army came to doctrine, emphasis was placed on the judgement of the 'man on the spot', ${ }^{15}$ and the battalion commander was most often the senior officer in that generally uncomfortable location. ${ }^{16}$ Linking these two themes is Patrick Brennan's claim that battalion commanders "were central"17 to the process of "tactical learning" that brought battlefield success. ${ }^{18}$

The unprecedented expansion of the British army during the war has been described by Peter Simkins as resulting in "the largest and most complex single organisation created by the British nation up to that time". ${ }^{19}$ UK enlistment from all sources to 11 November 1918 totalled 4,970,902 men, and 5,704,000 served. ${ }^{20}$ At the outbreak of war the officer corps numbered 28,$060 ;{ }^{21}$ and at the Armistice it numbered 164,$255 ;{ }^{22} 229,316$ commissions having been granted. ${ }^{23}$ The infantry battalions of the regiments of the line expanded in number from 470 to 1,762 . The first question for this research is who the COs were, and how and where resources were found from the small officer corps of 1914 to cope with the burgeoning requirement for battalion commanders.

\footnotetext{
${ }^{14}$ D. French, Military Identities: The Regimental System, The British Army and the British People c. 18702000 (Oxford: Oxford University Press, 2005), p. 147

${ }^{15}$ General Staff, Field Service Regulations Part I (War Office, 1909), p.27

${ }^{16}$ With SS143's emphasis on the platoon as the tactical unit, the platoon commander is most correctly seen as the ultimate 'man on the spot' from 1917 onwards. [General Staff, SS143: Instructions for the Training of Platoons for Offensive Action (War Office, February 1917)].

${ }^{17}$ Italics in original.

${ }^{18}$ P.H. Brennan, 'Good Men for a Hard Job: Infantry Battalion Commanders in the Canadian Expeditionary Force', Canadian Army Journal, 9 (1) (2006), pp.9-28

${ }^{19}$ P. Simkins, Kitchener's Army: The Raising of the New Armies 1914-1916 (Barnsley: Pen \& Sword, 2007), p. xiv

${ }_{20}$ Statistics of the Military Effort of the British Empire during the Great War 1914-1920 (London: HMSO, 1922), p. 363; Simkins, Kitchener's Army, p. xiv

21 On 4 August 1914 there were 12,738 Regular Officers; 2,557 Special Reserve; 9,563 Territorial; and 3,202 in the Reserve of Officers. Statistics, p.234

${ }^{22}$ On 11 November 1918 there were 74,200 Regular and New Army officers; 28,000 Special Reserve officers; 60,055 Territorial officers; and 2,000 in the Reserve of Officers. (Statistics, p.234).

${ }^{23}$ War Office, Statistics, pp.234-35. See also Chapter Six, Table 6.1.
} 
The second question concerns the need for these men to be able - the matter of quality. The quality of the pre-war British officer has been the subject of considerable debate, in which a principal critic has been Tim Travers. ${ }^{24}$ Travers' thesis is that the officer corps on the eve of war was still largely Victorian and public school in many of its attitudes, with "an overwhelming emphasis on individual personalities, and on social and regimental hierarchies", a system operating through "the influence of dominant personalities, of social traditions, and of personal friendships and rivalries". Put simply, they were professionals lacking professionalism. Travers relegates the lessons of the Second Boer War (18991902) simply to forcing "a discussion of new tactics", insights "often altered to fit the traditional ideal". Travers' critical arguments are only set out for the highest levels of army command and he states that "this does not mean that at the lower levels the army was not well trained and well led in 1914". ${ }^{25}$ What levels exactly he deems competent are not specified.

Timothy Bowman and Mark Connelly continue this theme, describing the officer corps as "drawn from a tiny section of society" with selection processes being "far from rigorous". They state that officer training "was of a poor standard" and that "professional development was very limited", with most promotion "simply by seniority". ${ }^{26}$ These negative observations of the officer corps need, however, to address the single most important fact, namely that it was under its guidance that the supposedly more professional

\footnotetext{
${ }^{24}$ T. Travers, The Killing Ground: The British Army, the Western Front, and the Emergence of Modern Warfare 1900-1918 (Barnsley: Pen \& Sword, 2003), pp.3-36

${ }^{25}$ Travers, Killing Ground, p.6

${ }^{26}$ T. Bowman and M. Connelly, The Edwardian Army: Recruiting, Training and Deploying the British Army 1902-1914 (Oxford: Oxford University Press, 2012), pp.39-40
} 
German Army was beaten. ${ }^{27}$ Bowman and Connelly argue that the successful expansion was "based on rapidly commissioning groups, principally promising NCOs and OTC cadets", ${ }^{28}$ yet as this thesis demonstrates, during the victorious Hundred Days nearly half of infantry battalions were led by pre-war professional officers. ${ }^{29}$

Simon Robbins acknowledges many of Travers' observations concerning the senior officer group, yet points out that:

The interpretation that the social background of the officer corps was responsible for the failings of the Army ... while providing a possible answer for the shortcomings of some officers remains dubious and conveys the impression of monolithic stupidity among the officer corps which is not convincing. ${ }^{30}$

He concludes: "Enjoying the social activities of their class and era did not preclude soldiers from being professional once on the battlefield". ${ }^{31}$

Travers' evidence is nearly always anecdotal, rarely data-driven. His sole comment concerning battalion commanders is a reference to Brigadier-General J.A.L. Haldane's alleged attempt to:

Get rid of a certain Colonel Churcher before the war. Subsequently Churcher's conduct at Mons was such that he was sent home .... Overall, Haldane recalled that three out of four Battalion commanding officers were not fit for command, and all had been sent home by the end of September 1914. Haldane may have been over-critical, but the ratio of incompetent officers in the $10^{\text {th }}$ Infantry Brigade was probably not unique. $^{32}$

\footnotetext{
${ }^{27}$ For the alleged superiority of the German army and its command see M. Samuels, Command or Control?: Command, Training and Tactics in the British and German Armies 1888-1918 (London: Frank Cass, 1995).

${ }^{28}$ Bowman and Connelly, Edwardian Army, p.40

${ }^{29}$ See Chapter Three, Table 3.2. The Hundred Days campaign of 1918 is the period 8 August to 11 November 1918.

${ }^{30}$ Robbins, Generalship, p. 17

${ }^{31}$ Robbins, Generalship, p.17

${ }^{32}$ Travers, Killing Ground, p.14
} 
10 Brigade was not actually at Mons, first seeing action at Le Cateau on 26 August. Haldane had, however, long been unhappy with the performance of Lieutenant-Colonel D.W. Churcher, $1^{\text {st }}$ Royal Irish Fusiliers, who was replaced on 10 September $1914 .{ }^{33}$ The other two COs 'sent home' were Lieutenant-Colonels J.F. Elkington, $1^{\text {st }}$ Royal Warwickshire, and A.E. Mainwaring, $2^{\text {nd }}$ Royal Dublin Fusiliers, who were both courtmartialled after their surrender of St Quentin on 27 August $1914 .{ }^{34}$ Travers therefore chooses one of the most unusual occurrences of the war involving battalion commanders as a means of condemning them en masse. If it is intended to imply that 75 per cent of the BEF's infantry COs of 1914 were incompetent, then the data presented in this thesis shows this to be incorrect. ${ }^{35}$

Travers' assertion that the British Army's failings in South Africa led merely to "discussion of new tactics" is also inaccurate - the period 1902-14 was one of significant change. The administrative and organisational changes are well documented. ${ }^{36}$ Much less

\footnotetext{
${ }^{33}$ P.T. Scott, Dishonoured (London: Tom Donovan, 1994) pp. 4-5. Scott quotes Haldane concerning Churcher: "There is too much 'eyewash' about this battalion; they do not take interest in anything but sport and the C.O. is a humbug". Humbug or not, Churcher served as a GSO2 from 15 December 1914 and a GSO1 from 1 July 1916 until the end of the war.

${ }^{34}$ Two parties of these battalions, led by their exhausted COs, arrived at St Quentin on 27 August 1914 from the Battle of Le Cateau the previous day. The mayor implored them to sign a surrender document to save the townspeople from any fighting with the pursuing German Army. The COs complied, but an element of $2^{\text {nd }}$ Cavalry Brigade, led by Major G.T.M. Bridges intervened, recovered the document, and galvanised the pair and their battalion remnants. Both Lieutenant-Colonels were court-martialled and cashiered. Mainwaring, not a well man, returned to civilian life. Elkington joined the Foreign Legion serving on the Western Front until wounded. He was reinstated in his original rank and awarded the DSO. See also Chapter Three, section 3.3.6.

${ }^{35}$ The army had its contemporary critics during this period, who were prepared to speculate about even more negative percentages than Travers. Viscount Esher, a member of the Elgin South African War Commission, declared in 1904 that "only two out of every forty regimental officers were any good at all. The rest were 'loafers"', an obviously untestable assertion.[B. Bond, The Victorian Army and the Staff College (London: Eyre Methuen, 1972), p.183].

${ }^{36}$ See, for instance, E.M. Spiers, Haldane: An Army Reformer (Edinburgh: Edinburgh University Press, 1980). Administrative changes, which had little direct impact on the average regimental officer, included the abolition of the post of Commander-in-Chief, the establishment of the Army Council, and the establishment of the Committee of Imperial Defence. Staff reform centred on the creation of a General Staff and the revitalisation of the Staff College. Organisational reform, which had most impact on the Militia and Volunteers, included the creation of the Special Reserve and the Territorial Force out of the Militia and Volunteers.
} 
acknowledged is the fact that by the end of the Boer War, the British Army had undergone a revolution in tactics, ${ }^{37}$ changes which affected every regimental officer and soldier, advances downplayed by Travers.

The infantry had adopted 'fire and movement' tactics to address the problem of crossing the fire-swept zone by changing from attack in formation to advancing in extended order in rushes using cover. Secondly, there had been considerable advances in artillery-infantry cooperation, and a form of direct suppressive fire was regularly used. ${ }^{38}$ Thirdly, British eyes had opened to sophisticated use of trenches, and entrenchment to repel counterattack became standard practice. Lastly, the army came to appreciate the value of individual marksmanship in addition to the power of volley fire, leading to a major focus on this area in the inter-war years. These profound changes were encapsulated in Combined Training 1902. ${ }^{39}$ At a battalion level there were further changes, with an emphasis (stemming directly from open order assault) on junior leadership, battalion organisation changing from eight to four companies in 1913, giving more officers per company. ${ }^{40}$ Field Service Regulations 1909, which is referred to by modern historians far more frequently than

\footnotetext{
${ }^{37}$ S. Jones, 'The Influence of the Boer War (1899-1902) on the Tactical Development of the Regular British Army 1902-1914', unpublished PhD thesis, University of Wolverhampton, (2009). [See also: S. Jones, From Boer War to World War: Tactical Reform of the British Army 1902-1914 (Oklahoma: University of Oklahoma Press, 2012)]. A.J. Risio, 'Building the Old Contemptibles: British Military Transformation and Tactical Development from the Boer War to the Great War 1899-1914', unpublished Master of Military Art \& Science thesis, Georgia Institute of Technology and Fort Leavenworth, (2005).

${ }^{38}$ The artillery was also becoming increasingly aware of the importance of indirect fire.

${ }^{39}$ War Office, Combined Training (London: HMSO, 1902).

${ }^{40}$ The Territorial Force still had to change to a four company system on the outbreak of war. In terms of equipment the Short Magazine Lee Enfield Mark I (SMLE) was procured in 1903, and the only area of infantry weaponry in which the British lagged was the machine gun, not necessarily in number but, as Spencer Jones suggests, more in tactical doctrine, being seen primarily as a weapon of defence (Jones, 'Influence', pp.85-7). The School of Musketry at Hythe was, in contrast, advocating the use of the light machine gun in attack. Other equipment developments in communication included increase in the use of telephones and changes in signalling.
} 
Combined Training, ${ }^{41}$ arguably impacted less directly than the latter on the battalion's effectiveness in combat. One author describes the comparison as from "baseline new doctrine in Combined Training 1902 to the capstone doctrine in Field Service Regulations $1909,{ }^{42}$

Mark Connelly, whilst critical in general terms of the officer corps, is clear in his study of the East Kent Regiment that training was taken seriously, ${ }^{43}$ and that "pre-war soldiering for the Buffs concentrated on sharpening rifle and bayonet skills and adapting training to the lessons learnt in the South African War" ${ }^{44}$ The implication is whatever the overarching problems in the composition of the officer corps and its formative training, within-battalion skill development was active and on-going. Simon Robbins quotes a contemporary source: "Impressed by its tactical expertise the Germans called the British professional Army 'a perfect thing apart'", ${ }^{45}$ Without good quality officering at the battalion level this perception would not have been possible. John Bourne concludes:

It is difficult to reconcile the fit, adaptable, energetic, resourceful, pragmatic men who emerge from the prewar Army's multi-biography with the somnolent, dogma-ridden, unprofessional, unreflecting institution depicted by Tim Travers and Martin Samuels.

In terms of the evolution of battalion commanders during in the First World War, many of the officers who served at this level had been Lieutenants or Captains during this period,

\footnotetext{
${ }^{41}$ War Office, Field Service Regulations - Parts One and Two (London: HMSO, 1909). For example, G. Sheffield \& D. Todman, Command and Control on the Western Front - The British Army's Experience 1914-18 (Staplehurst: Spellmount, 2004), in which there are references on 12 pages. FSR dealt primarily with operations.

${ }^{42}$ Risio, 'Building', p.9. Army mandarins of the time would, however, have shuddered at the idea of having created 'doctrine'.

${ }^{43}$ The East Kent Regiment was known as "The Buffs" because it had been issued soft buff leather coats when it first served abroad in the Netherlands.

${ }^{44}$ M. Connelly, Steady the Buffs! A Regiment, A Region and the Great War (Oxford: Oxford University Press, 2006), Kindle edition location 199

${ }^{45}$ Colonel R. Macleod, Memoirs, p.99, Macleod Papers 1/1, LHCMA. Quoted in Robbins, Generalship, p.91
} 
and had either learnt their craft in war or experienced the developments of the ensuing 12 years. The course of their earlier professional development had been redolent with change. Not all could or would adapt and evolve either in peacetime or war, but those who were able and willing to apply learning and foster it in others would likely be those who proved successful in battalion command. ${ }^{46}$ The third question for this research therefore considers not simply overall quality, but exactly what qualities were perceived as making an effective CO.

Garth Pratten's discussion of historiography in his study of Australian COs during the Second World War is just as applicable to the First. In official histories and divisional histories, battalion commanders are "seldom discussed at length". In unit histories, the focus on the "birth narrative" means that the "first CO often receives the most attention", and whilst "humorous anecdotes featuring the $\mathrm{CO}$ are recounted with relish" and acts of "bravery or endurance" described, there is very often little concluded "of their tactical abilities or of their ultimate effectiveness as a commander". ${ }^{47}$ Criticism is sparing and, in British regimental histories, brief eulogy is the rule.

Tim Travers is correct to observe that the British Army, governed by seniority, was largely antithetical to the rise of talent on merit. The fourth question for this research is therefore to what extent a meritocracy developed at the level of battalion command. Arnold Harvey is the only British historian to have shown an interest in battalion command during the war

\footnotetext{
${ }^{46}$ Garth Pratten, in his discussion of the first battalion commanders of the Australian Imperial Force in World War Two, cites contemporary opinion that many of these COs were handicapped by their First World War experience, having failed to train within an evolving doctrine since that point - in short, they had not experienced enough change to be able to evolve further. G. Pratten, Australian Battalion Commanders in the Second World War (Melbourne: Cambridge University Press, 2009), pp.32-4

${ }^{47}$ Pratten, Australian Battalion Commanders, pp.6-8
} 
in an account of promotion in the "catastrophically overheated demand for battalion commanders". His view is not particularly positive, concluding that "the appointment of the officers ... does not indicate they were, or were ever considered to be, military geniuses of a calibre superior to what might be found in the Regular army". 48

Patrick Brennan alone has shown sustained interest in systematically studying First World War battalion commanders, and that purely in the Canadian Corps. ${ }^{49}$ Of 179 COs who served, 75 per cent were Militia and nine per cent Regulars, ${ }^{50}$ with six per cent having no previous military experience, the remaining 10 per cent being retired. The Canadian reliance on amateur soldiers limits his study's comparability to the British Army. The average age of his cohort was 45 in 1914, dropping to 37 in November 1918: "A clear reflection of the physical, psychological and intellectual demands of combat command on the Western Front". ${ }^{51}$ Average tenure was nine and a half months; just over a quarter were wounded at least once, with one in eight being killed in action. Two were promoted to division and 11 to brigade command. Whilst Brennan was able to identify the disposal of officers leaving post, he found difficulty in determining whether officers had been 'sacked'. He concluded, indeed, that "one is struck that so few were removed from their posts". ${ }^{52}$ On the other hand, there were a significant number of long-serving COs: "Men who obviously performed well, clearly possessing the requirements for the job, and yet

\footnotetext{
48 A.D. Harvey, 'A Good War: Wartime Officers Who Rose to Command Level in the First World War', RUSI Journal, 153 (2) (2008), pp.76-80

${ }^{49}$ P.H. Brennan, 'Good Men for a Hard Job: Infantry Battalion Commanders in the Canadian Expeditionary Force', Canadian Army Journal, 9 (1) (2006), pp. 9-28. Brennan has also produced a somewhat more anecdotal study of psychological breakdown in Canadian senior officers, [P.H. Brennan, 'Completely Worn Out by Service in France', Canadian Military History, 18 (2) (2009), pp. 5-14].

50 Four British and 12 Canadian. The Canadian regular army in 1914 only numbered 3110 men http://www.veterans.gc.ca/eng/history/firstwar/canada/Canada3 (accessed 11 March 2013).

${ }^{51}$ Brennan, 'Good Men', p.15

${ }^{52}$ Brennan, 'Good Men', p.20. Italics in original.
} 
were never promoted". ${ }^{53}$ Brennan is thus indicating a difference between a 'good fighting battalion commander' and an officer suitable for commanding larger formations.

The analysis upon which this thesis depends is prosopographical in nature. As Katherine Keats-Rohan has noted: "Prosopography is about what the analysis of the sum of data about many individuals can tell us about the different types of connexion between them, and hence about how they operated within and upon the institutions - social, political, legal, economic, intellectual - of their time". 54 She describes the link between prosopography and computing as "a marriage made in heaven", at least for highly structured information. For this study, therefore, a computerised database of all infantry COs of regiments of the line of the British Army during the First World War was constructed covering basic biographical details and details of their pre-war and war service, containing over 5000 individuals. $^{55}$

This was achieved by examining the Monthly Army List ${ }^{56}$ and synthesising the sometimes inaccurate information ${ }^{57}$ with regimental, division and battalion histories (as well as the

\footnotetext{
${ }^{53}$ Brennan, 'Good Men', p.28

54 K.S.B. Keats-Rohan, 'Prosopography and Computing: A Marriage Made in Heaven?', History and Computing, 12 (2000), pp.1-11. A similar method was utilised by John Bourne and Simon Robbins in their study of generals.

${ }^{55}$ Utilising Microsoft Access. This is attached in abbreviated form in Appendix One as a Microsoft Excel spreadsheet.

${ }^{56}$ The National Archives holds a variety of Army Lists, detailing the officers serving in all branches of the army, from 1759 onwards. Two types are used in this study. Firstly, the official Monthly Army List, which began publication in 1798, and which is organised by branch of the army and by regiment, listing for the infantry the Regular, Special Reserve and Territorial battalions, in that order. Officers are listed by rank in order of seniority (date of rank). Secondly, the official Quarterly Army List, which lists Regular and retired officers only (i.e. not active Territorial or Special Reserve officers, although it lists retired Territorial and Special Reserve officers). The list is organised without regard to branch of the army or regiment, listing officers by rank and seniority (gradation), containing date of birth, promotions, and staff service, as well as war service (in the annual January issue). Hart's Army List, an unofficial production, which contained elements of both official lists, ceased publication in 1915, and the final issue was also used.

${ }^{57}$ Presentation of information in the Monthly Army List suffered from a time lag and sometimes missed out shorter appointments.
} 
records of regimental museums in certain cases), then checking this information against the relevant London Gazette entries. ${ }^{58}$ Gaps were completed by reference to unit war diaries, ${ }^{59}$ which were reviewed wherever possible. Biographical and service details for Regular officers were abstracted from The Quarterly Army List, and for Territorial officers and civilians relevant biographical information was also abstracted from civil registration records and census returns, ${ }^{60}$ as well as from regimental, division and battalion histories.

This method identified a range of individuals, including Majors or lower ranks who stood in for their $\mathrm{CO}$, but the analysis here includes only those who served as Acting, Temporary, Brevet or substantive Lieutenant-Colonels. ${ }^{61}$ Such a database could never be entirely complete, as not even battalion Adjutants necessarily recorded all changes of command, but it is reasonably certain that all the principal individuals have been identified.

Written accounts, diaries and letters, published and unpublished, of other ranks, officers and in particular Commanding Officers were utilised where appropriate to provide illustration. COs have left comparatively few written records, the reason for which is not

\footnotetext{
${ }^{58}$ The London Gazette has been an official journal of record of the British government since 1665, recording, amongst other things, the promotions and appointments of military officers, hence the term "gazetted" in relation to rank.

${ }^{59}$ Battalion War Diaries were the formal daily record of the unit's activities, written by the Adjutant on a standardised form, and (usually) signed at the end of the month by the CO. A copy was sent to the higher formation and the regimental depot. These are held in The National Archives, Kew.

${ }^{60}$ Civil registration of births, deaths and marriages began in 1837, records being held by the General Register Office, and available from a variety of web-based services. The annual population census began detailed personal recording on a ten-year cycle from 1841 onwards, original returns being held by The National Archives, and again available from a variety of web-based services up to and including 1911.

${ }^{61}$ Substantive rank is a permanent regimental rank governing pay and allowances; brevet rank is an army rank given in recognition of service, and not being commissioned, had no financial implications. Both acting and temporary rank were gazetted, acting rank being relinquished on leaving the specific post, temporary rank lasting beyond a specific post if required (and hence having pension implications). No distinction between the acting, temporary or substantive rank of Lieutenant-Colonel is made in this study as they all represent a formal appointment to battalion command.
} 
clear. ${ }^{62}$ Some chose to write unit histories, formally or otherwise, and these in general give little insight into the process or experience of command. ${ }^{63}$ Other volumes are more revealing, such as the edited memoirs of Lieutenant-Colonel W.D. Villiers-Stuart. ${ }^{64}$ Published volumes of letters and surviving manuscript correspondence tend to yield more candid observations. ${ }^{65}$ Other ranks refer little to their COs, and officer memoirs are patchy in their discussion, although Alan Thomas's A Life Apart is an example of keen observation and analysis in his dissection of Lieutenant-Colonel W.R.A. Dawson. ${ }^{66}$

The argument is structured chronologically, examining the battalion commanders of the army of 1914; those of the New Armies during their development in 1914-15; their changing characteristics in the period 1915-1918; and their final evolutionary point in the victorious armies of The Hundred Days in 1918. Key moments of contrast are used in the developing chronology; the Battle of Neuve Chapelle (10-13 March 1915); the first day of the Battle of Loos (25 September 1915); the first day of the Battle of the Somme (1 July 1916); the first days of the Battle of Arras (9 April 1917) and Third Ypres (31 July 1917); and finally the pivotal moment of The Hundred Days campaign, 29 September $1918 .{ }^{67}$ The COs of three of the most effective divisions in attack during The Hundred Days identified

\footnotetext{
${ }^{62}$ They may simply, as expressed in Chapter Five, have had enough of paperwork.

${ }^{63}$ J.M. Findlay, With the $8^{\text {th }}$ Scottish Rifles 1914-1919 (London: Blackie, 1926), is such a volume.

${ }^{64}$ R.M. Maxwell, Villiers-Stuart Goes to War (Edinburgh: Pentland, 1990).

${ }^{65}$ A. Nason (ed.), For Love and Courage - The Letters of Lieutenant Colonel E.W. Hermon from the Western Front 1914-1917 (London: Preface, 2008); and R. Fielding, War Letters to a Wife, J. Walker (ed.), (Staplehurst: Spellmount, 2001), are good examples of the published genre. IWM Docs 12339, containing the letters of Brigadier-General G.A. Stevens, is a good example of the manuscript genre.

${ }^{66}$ A. Thomas, A Life Apart (London: Gollancz, 1968). Dawson commanded $6^{\text {th }}$ Royal West Kent from November 1916 to October 1918. See Chapter Four, section 4.2.

${ }^{67}$ When all five armies of the BEF were in action on the Western Front together for the first time, and the Hindenburg Line was broken.
} 
by Peter Simkins [the $5^{\text {th }}$ (Regular), $9^{\text {th }}$ (New Army), and $42^{\text {nd }}$ (Territorial)] are used as contrast to the overall analysis. ${ }^{68}$

Chapter One examines the Regular, Territorial and Special Reserve battalion commanders of the army at the outbreak of war. In reviewing their careers it attempts to evaluate the quality of the men who had risen to command in a system based largely on seniority. Finally, it considers the erosion of this stock of officers in the fierce battles of 1914.

Chapter Two reviews the process of providing COs for the rapidly expanding army, namely the Service battalions of the New Armies and the second-line battalions of the Territorial Force. The principles applied in providing COs are elucidated; turnover prior to going on active service is examined; and an attempt is made to evaluate their quality, placing the negative image of the retired 'dugout' officer into a factually derived perspective.

Chapter Three considers general patterns in the evolution of battalion commanders in the period 1915-18, particularly institutional aspects including origin within the army and regimental affiliation; individual aspects including age, rank in 1914, staff service, and length and number of commands. It further examines turnover month by month and by battalion with the reasons for this, namely death, invalidity, promotion, and replacement.

Chapter Four explores the different evolutionary patterns of COs in Regular, Service and Territorial units, both across the whole army and in the $5^{\text {th }}, 9^{\text {th }}$ and $42^{\text {nd }}$ Divisions, and

\footnotetext{
${ }^{68}$ From information supplied by Peter Simkins. See also his 'Co-stars or Supporting Cast? British Divisions in The Hundred Days, 1918' in P. Griffith, ed., British Fighting Methods in the Great War (London: Frank Cass, 1996), pp.50-69.
} 
presents a case study of a battalion of each type. It also considers the army's formal attempts to train COs.

Chapter Five reviews leadership and battalion command. From the examination of memoirs, diaries and letters, the experiences of other ranks, officers, and COs are brought together. An attempt is made to reach a view on the key elements of leadership and command both on the battlefield and as understood by the British Army at the time, within the framework of modern theories of leadership.

Chapters Six and Seven concentrate on the development of merit-based promotion in the army. Chapter Six concerns the rise of citizen COs, men who had not previously served. Their characteristics and the pace of their advancement are reviewed. Chapter Seven considers the battalion commanders of The Hundred Days campaign, investigating the experience, abilities, and qualities of the COs of this critical period, both in general and in the three chosen divisions. 


\title{
Chapter One
}

\section{"Their Heart Failed Not" - The Battalion Commanders of August 1914}

\begin{abstract}
The Colonel, usually spoken of as "the CO" (Commanding Officer) and spoken to as "Sir," is "IT," and must be treated accordingly. On Parade, you will treat him as you would the King (whose authority he represents), off parade as you would treat a rich uncle from whom you have expectations. Honour and obey him; perhaps you may even learn to love him - in time!
\end{abstract}

Advice to New Army recruits ${ }^{2}$

The infantry battalion Commanding Officer, the Lieutenant-Colonel, was generally referred to as "The Colonel", 3 a title not to be confused with the post of Colonel of the regiment, a senior serving or retired officer appointed for life as the "titular head" of the regiment. ${ }^{4}$ In contrast, a substantive Colonel held a non-regimental post.

\footnotetext{
1 "They went forth first a little Army: All its men were true as steel. The hordes of the enemy were hurled against them; they fell back, but their heart failed not". Psalm written by A.W. Pollard, used at a special service in 1918. Quoted in: J.E. Edmonds, Military Operations: France and Belgium 1914, Vol. II (London: Macmillan, 1925), p.465

${ }^{2}$ Unknown, A Regimental "Who's Who" p.20, reproduced in T. Carter, Birmingham Pals (Barnsley: Pen \& Sword, 1997), p.65

${ }^{3}$ The title 'Colonel', perhaps the most obscure in the panoply of military ranks, arose in use in the late sixteenth century and derives from the Italian colonello, a 'little column'. Whilst it might be romantic to see the rank deriving from the man at the head of the 'little column', it has been suggested that the word column did not acquire a military meaning until late in the seventeenth century, and that the 'little column' in question may have been a baton of office. [J. Corbett, 'The Colonel and his Command,' American Historical Review, 2 (1) (1896), pp.1-11]. Lieutenant-Colonel W.D. Villiers-Stuart, $9^{\text {th }}$ Rifle Brigade, however, noted that General E.H.H. Allenby, then commanding V Corps: "Always addressed battalion commanders as 'Colonel' - I never heard any other high officer do that". R.M. Maxwell, Villiers-Stuart Goes to War (Kippielaw: Pentland Press, 1990), p.61

${ }^{4}$ D. French, Military Identities (Oxford: Oxford University Press, 2005), p.79. The Regimental Colonel had certain official functions, including appraising potential officers, and presided (unpaid) over such institutions as the Regimental Association. His position was regularised by the Army Council in 1920.
} 
A Lieutenant-Colonel's command in 1914 numbered 1007 men; 30 officers and 977 other ranks. A Major was second-in-command. Battalion Headquarters (HQ), comprising six officers and 93 men, included the Adjutant, responsible for battalion administration, who was either a Captain or Lieutenant, as was the Quartermaster. ${ }^{5}$ A Lieutenant commanded the machine-gun section, and an officer of the Royal Army Medical Corps was attached. The Regimental Sergeant-Major and a number of Sergeants and other Non-Commissioned Officers (NCO) fulfilled specialist roles. ${ }^{6}$ The bulk of the battalion was made up by four rifle companies, each commanded by either a Major or Captain with a Captain as secondin-command. Each company had four platoons commanded by a Lieutenant or $2^{\text {nd }}$ Lieutenant.

\subsection{The Regular COs of August 1914}

In April 1914 there were 1171 Lieutenant-Colonels on the active list. ${ }^{7}$ Of the 167 Regular infantry Lieutenant-Colonels, ten were in staff/training posts or on half-pay, the remainder comprising the COs of the 73 infantry regiments.

\subsubsection{Careers to appointment}

The social origins of senior officers during this period are well documented. Edward Spiers' analysis of Colonels of 1914 reveals seven per cent from the peerage and baronetage; 26 per cent from the gentry; 23 per cent from an armed services background; ${ }^{8}$

\footnotetext{
${ }^{5}$ Responsible for stores and transport.

${ }^{6}$ R. Gibson \& P. Oldfield, Sheffield City Battalion (Barnsley: Pen \& Sword, 2006), p.222

${ }^{7}$ The Quarterly Army List for the Quarter Ending 31 $1^{\text {st }}$ March 1914 (London: HMSO, 1914), p. 312. Indian Army 323; Cavalry and Infantry 232; Indian Medical Service 151; Royal Artillery 137; Royal Army Medical Corps 124, Royal Engineers 87; Army Pay Department 47; Army Service Corps 23, Royal Marines 23; Army Ordnance Department 18; Army Veterinary Corps 6.

${ }^{8}$ A significant proportion being "either sons of serving officers or had relatives in the services". [S. Robbins, British Generalship on the Western Front 1914-18 (London: Frank Cass, 2005), p.6].
} 
14 per cent from the clergy; and 12 per cent professional. ${ }^{9}$ A Lieutenant-Colonelcy was largely the province of the landed gentry and upper middle classes. ${ }^{10}$

Only four COs of August 1914 were titled, namely: Lieutenant-Colonels Lord R. Le N. Ardee (1 $1^{\text {st }}$ Grenadier Guards); ${ }^{11}$ The Hon. G.H. Morris (1 ${ }^{\text {st }}$ Irish Guards) ${ }^{12}$ The Hon. C.J Sackville-West ( $4^{\text {th }}$ Kings Royal Rifle Corps) ${ }^{13}$ and Sir E.R. Bradford Bt. $\left(2^{\text {nd }}\right.$ Seaforth Highlanders). ${ }^{14}$ The preponderance were in prestige regiments.

To illustrate the variety of backgrounds, Lieutenant-Colonel A. Grant-Duff, $1^{\text {st }}$ Black Watch, was the son of Sir M. Grant-Duff (Liberal MP and Privy Counsellor), ${ }^{15}$ and had been educated at Wellington College and the Royal Military College (RMC). ${ }^{16}$ Another with a non-military background, Lieutenant-Colonel L.J. Bols, $1^{\text {st }}$ Dorsetshire, (a future

\footnotetext{
${ }^{9}$ E. M. Spiers, The Late Victorian Army 1868-1902 (Manchester: University Press, 1992), p.94. The remaining 18 per cent were "other" or "don't know."

${ }^{10}$ Timothy Bowman and Mark Connelly, analysing a sample of RMC cadets 1910-14, found the occupations of the fathers to be 39 per cent services officer; 30 per cent "gentleman"; eight per cent "other" (with "industrialists" and "new professionals" comprising few of the number); five per cent each clergy and legal; four per cent civil service; and three per cent each medical, civil engineer, and titled. T. Bowman and M. Connelly, The Edwardian Army: Recruiting, Training and Deploying the British Army 1902-1914 (Oxford: Oxford University Press, 2012), p.9; percentages extrapolated from Table 1.1.

${ }^{11}$ Reginald le Normand Ardee (family name Brabazon, $13^{\text {th }}$ Earl of Meath) was also a CO in the Irish Guards between 18 September 1914 and 3 November 1914. Wounded twice, which removed him from active service, he returned as Brigadier-General in February 1918, commanding 4 (Guards) Brigade for two months. ${ }^{12}$ George Henry Morris (second son of Michael Morris, $1^{\text {st }}$ Baron Killanin) was killed in action on 1 September 1914 at Villers-Cotterets on the retreat from Mons.

${ }^{13}$ Charles John Sackville-West (later $4^{\text {th }}$ Baron Sackville of Knole) became GSO2 on 30 September 1914, and went on to command three brigades (21, 190 \& 182) between December 1915 and September 1917.

${ }^{14}$ Evelyn Ridley Bradford ( $2^{\text {nd }}$ Baronet Bradford) was killed in action 14 September 1914 on the Aisne.

${ }^{15}$ Cementing his relationship with the aristocracy, he married the Hon. Ursula Lubbock, daughter of the $1^{\text {st }}$ Baron Avebury.

${ }^{16}$ At the point the COs of August 1914 were entering RMC Sandhurst, 55 prominent public schools and universities supplied all the RMC cadets. [P. E. Razzell, 'Social Origins of Officers in the Indian and British Home Army: 1758-1862', British Journal of Sociology, 14 (1963), p.259]. During the Second Boer War 62 per cent of Regular officers came from public schools, with 41 per cent from the 10 most prominent, with 11 per cent from Eton alone. [A. H. H. MacLean, Public Schools and the War in South Africa, (London: Stanford, 1902), p.12].
} 
Lieutenant-General) was the son of a Belgian diplomat, born in Cape Town and educated at Lancing College. ${ }^{17}$

Lieutenant-Colonel A.D. Geddes, $2^{\text {nd }}$ Buffs, was a model of military lineage, ${ }^{18}$ being educated at Cheltenham College and the son of Colonel J.G. Geddes. ${ }^{19}$ Lieutenant-Colonel O.G. Godfrey-Faussett, $1^{\text {st }}$ Essex, educated at Wellington College, was similarly the son of

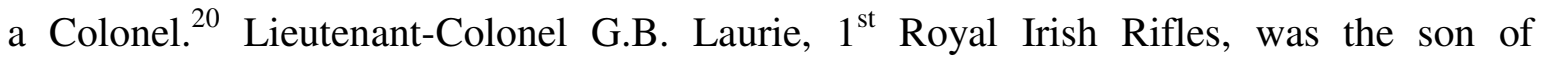
Lieutenant-General J.W. Laurie, but had been educated in Canada and attended military college there. ${ }^{21}$ Lieutenant-Colonel V.W. de Falbe, $1^{\text {st }}$ North Staffordshire, was of foreign ancestry but had more humble military connections, being the son of a Danish Navy Captain. $^{22}$ In contrast, Lieutenant-Colonel C.E.A. Jourdain, $2^{\text {nd }}$ Loyal North Lancashire, ${ }^{23}$ was the son of the rector of Mapleton, (Lieutenant-Colonel G.M. Gloster, $1^{\text {st }}$ Devonshire, ${ }^{24}$ also had a clerical father); the father of Lieutenant Colonel L.I. Wood, $2^{\text {nd }}$ Border, ${ }^{25}$ was a Suffolk solicitor; whilst the father of Lieutenant-Colonel A.W. Abercrombie, $2^{\text {nd }}$ Connaught Rangers, ${ }^{26}$ was a Bengal civil servant.

\footnotetext{
${ }^{17}$ Louis Jean Bols commanded 84 Brigade between February and September 1915, and then served in staff posts as BGGS XII Corps for two months and MGGS Third Army between October 1915 and September 1917.

${ }^{18}$ Augustus David Geddes was killed by a shell landing on Battalion HQ on 24 April 1915, during the Second Battle of Ypres. His brothers John Gordon Geddes and George Hessing Geddes were respectively a Brigadier-General and Lieutenant-Colonel of Royal Artillery.

${ }^{19}$ Late $44^{\text {th }}$ and $76^{\text {th }}$ Regiments.

${ }^{20}$ Owen Godfrey Godfrey-Faussett was killed in action 2 May 1915 on Gallipoli. The Turks called him by name, and he was shot by a sniper.

${ }^{21}$ George Brenton Laurie was killed in action on 12 March 1915 at Neuve Chapelle.

${ }^{22}$ Vigant William de Falbe commanded 185 Brigade, January 1916 to August 1917.

${ }^{23}$ Charles Edward Arthur Jourdain was the longest surviving CO of a Regular battalion, retaining his command until killed in action 29 July 1918, although his battalion only first saw active service in late 1916. His brother, Henry Francis Newdigate Jourdain of the Connaught Rangers commanded three battalions during the war, but survived.

${ }^{24}$ Gerald Meade Gloster was wounded in October 1914, and returned as Brigadier-General with 64 Brigade between August 1915 and June 1916.

${ }^{25}$ Lewis Ironside Wood was wounded in October 1914, returned to duty and was killed at Ypres on 16 May 1915.

${ }^{26}$ Alexander William Abercrombie was taken prisoner 28 August 1914, escaped but was killed in action on 5 November 1915.
} 
Of those who had military siblings, Lieutenant-Colonel W.L. Loring, $2^{\text {nd }}$ Royal Warwickshire, was one of three serving brothers, all of whom were dead by November 1915. ${ }^{27}$ On a more illustrious level, Lieutenant-Colonel C.L. Nicholson, $2^{\text {nd }}$ East Lancashire, was one of three brothers who became Major-Generals, ${ }^{28}$ another brother being an Admiral. The father of this remarkable quartet was General Sir L. Nicholson, Royal Engineers.

\begin{tabular}{|l|c|c|c|}
\hline & $\begin{array}{c}\text { Commissions } \\
\mathbf{1 8 8 5 - 1 9 0 6}^{29}\end{array}$ & $\begin{array}{c}\text { Selected infantry } \\
\text { battalions 1902-14 }^{30}\end{array}$ & $\begin{array}{c}\text { COs of } \\
\text { August 1914 }^{\text {Cunn }}\end{array}$ \\
\hline Ranks & $3 \%$ & $7 \%$ & $1 \%$ \\
\hline Militia/SR/Volunteers/TF & $41 \%$ & $35 \%$ & $28 \%$ \\
\hline RMC/RMA $^{31}$ & $51 \%$ & $49 \%$ & $71 \%$ \\
\hline University $^{32}$ & $4 \%$ & $7 \%$ & \multirow{2}{*}{ NA } \\
\hline Probationer & $<1 \%$ & $\mathrm{NA}$ & $0 \%$ \\
\hline Empire & $<1 \%$ & $1 \%$ & $0 \%$ \\
\hline Other & $\mathrm{NA}$ & $1 \%$ & \\
\hline
\end{tabular}

\section{Table 1.1: Comparison of entry routes of Regular COs with all officer entry routes to the infantry}

The COs of August 1914 had entered the army over a 12 year period. ${ }^{33}$ Their routes to commissioned rank are indicated in Table 1.1. An RMC graduate was more likely, and a

\footnotetext{
${ }^{27}$ Walter Latham Loring's brothers were Major C.B. Loring of the $37^{\text {th }}$ Lancers, Indian Army, (killed 26 December 1914); and Captain W. Loring of the Scottish Horse (died of wounds 24 October 1915). Walter Loring himself was killed on 23 October 1914.

${ }^{28}$ Cecil Lothian Nicholson was promoted Brigadier-General (16 Brigade) on 16 June 1916, and MajorGeneral on 25 July 1916 with $34^{\text {th }}$ Division, a post he retained for the rest of the war.

${ }^{29}$ Commissions in infantry and ASC as $2^{\text {nd }}$ Lieutenants only - Quartermasters are excluded. HMSO, Return as to the Number of Commissions Granted During Each of the Years 1885 to 1906 Inclusive, Parliamentary Paper 111, (1907), pp.403-5

${ }^{30}$ Bowman and Connelly, Edwardian Army, p.12; data extrapolated from Table 1.2, taken from the 'Records of Service' of officers of eight Regular battalions.

${ }^{31}$ The Royal Military College (RMC) Sandhurst trained infantry officers, the Royal Military Academy (RMA) Woolwich trained artillery officers.

${ }^{32}$ Entry to Foot Guards only.

${ }^{33}$ The earliest commissions were those given to B.E Ward (CO $1^{\text {st }}$ Middlesex) and H.E. Lawrence (CO $2^{\text {nd }}$ East Surrey), both of whom had been commissioned on 10 May 1882; the last being A. McN. Dykes (CO $1^{\text {st }}$ Royal Lancaster) who had been commissioned $2^{\text {nd }}$ Lieutenant on 12 December 1894.
} 
Militia entrant or a man who had been commissioned from the ranks was less likely to achieve battalion command than overall percentages would predict. ${ }^{34}$ The years spent at RMC collectively covered the years 1880-92. The bulk attended in the period following the War Office assumption of responsibility, when it was made compulsory that all commissioned officers should be RMC graduates, ${ }^{35}$ and educational standards required for admission were tightened. ${ }^{36}$

They had taken nearly 25 years to reach the rank of Lieutenant-Colonel. ${ }^{37}$ Forty (25 per cent) had achieved brevet Major appointments; ${ }^{38}$ and 16 (10 per cent) brevet LieutenantColonel. At the outbreak of war, three were brevet Colonels (S.C.F. Jackson, $1^{\text {st }}$ Hampshire ${ }^{39}$ W.C.G. Heneker, $2^{\text {nd }}$ North Staffordshire; ${ }^{40}$ and W.R. Marshall, $1^{\text {st }}$ Sherwood

\footnotetext{
${ }^{34}$ From 1872, each regiment was allowed to nominate one $2^{\text {nd }}$ Lieutenant for commission each year, as long as he was between 19 and 22, had attended at least two annual trainings, and had passed the required examination. To give an example, Lieutenant-Colonel H.O.S Cadogan, CO $1^{\text {st }}$ Royal Welsh Fusiliers on the outbreak of war, was schooled at the Royal Academy, Gosport, where he failed the exam for both Woolwich and Sandhurst, passing 'The Preliminary' but not 'The Further.' He was commissioned in the $4^{\text {th }}$ Royal Welsh Fusiliers, and came under the patronage of Colonel Hon. Savage Mostyn, late CO of the $1^{\text {st }}$ Battalion. He attended a crammer in Camberley run by Lieutenant-Colonel T.G.R. Mallock and after 11 months passed the Militia Comprehensive Exam and acquired a commission in his patron's late battalion. [H. Cadogan, The Road to Armageddon (Wrexham: Bridge Books, 2009), pp.23-6].

${ }_{35}^{35}$ Excluding Militia officers and promoted NCOs.

${ }^{36}$ Curriculum change, to "a far wider and more practical curriculum", was, however, only effected from about 1890 onwards. A. Sheppard, Sandhurst (Aylesbury: Country Life, 1980), p.95. Timothy Bowman and Mark Connelly produce evidence from the Report of the Committee appointed to consider the Education and Training of Officers of the Army (Cd. 982) (1902) to suggest that the education at RMC was still found wanting and that following this report standards were raised. (Bowman and Connelly, Edwardian Army, pp.18-19).

${ }^{37}$ They had spent on average two years five months as 2nd Lieutenant; seven years six months as Lieutenant (53.5 per cent of first commissions were as Lieutenant); nine years three months as Captain; and seven years nine months as Major.

${ }^{38}$ All bar two were granted during the Second Boer War. A brevet appointment was army rather than regimental, and was given (often in the field) in response to exceptional proficiency.

${ }^{39}$ Sydney Charles Fishburn Jackson was wounded and taken prisoner at an engagement at Nauroy, 27 August 1914 , on the retreat from Mons.

${ }^{40}$ William Charles Giffard Heneker was promoted Brigadier-General in March 1915, serving with 54 \& 190 Brigades, before becoming Major-General commanding $8^{\text {th }}$ Division from December 1916 until the end of the war.
} 
Foresters). ${ }^{41}$ Sixteen per cent of the group had achieved the rank of Lieutenant-Colonel in a different regiment from the one in which they had achieved their Majority, indicating that the regimental system was not sufficiently rigid to prevent the able moving for promotion. $^{42}$

Since the abolition of purchase of commissions, ${ }^{43}$ promotion beyond the rank of Lieutenant had been governed by seniority within the regimental list balanced by the positive recommendation of the $\mathrm{CO}$ and confirmatory success in qualifying examinations. ${ }^{44}$ This was not a system designed to allow officers of equal ability the same opportunity to rise to battalion command. As the Official Historian noted: "Military talent is rare and is not immediately evident. Seniority rules bar its ascent" ${ }^{45}$ Lieutenant-Colonel H.O.S. Cadogan, $1^{\text {st }}$ Royal Welsh Fusiliers, was, however, able to write to his mother from India: "Lloyd, who is senior to me, [has] been passed over and ... I [have] got command of this Battalion" ${ }^{46}$ In the three years prior to August 1914, 15 per cent of CO appointments

\footnotetext{
${ }^{41}$ William Raine Marshall was promoted Brigadier-General in January 1915 with 87 Brigade; Major-General in June 1915 with $42^{\text {nd }} \& 29^{\text {th }}$ Divisions in Gallipoli; and Lieutenant General on 24 September 1916 with III Indian Corps in Mesopotamia.

${ }^{42}$ Prior to the abolition of purchase, officers moved frequently between regiments to achieve promotion. Following abolition, promotion was based on seniority within regiment and "this usually kept the LieutenantColonelcy in the regiment itself'". (Spiers, Late Victorian Army, p.93).

${ }^{43}$ The price of commissions, governed by regulations, had remained steady since 1821 with adjustments made in 1860. The price of a Lieutenant-Colonelcy in a line regiment was $£ 4,500$ ( $£ 321,000$ in 2008 values). If a Majority was sold for its price of $£ 3,200$ ( $£ 228,000$ ), a further $£ 1,300$ ( $£ 92,700)$ therefore had to be found. [C. G. Slater, 'The Problem of Purchase Abolition in the British Army 1856-1862', South African Military History Society Journal, 2(6) 1979, www.samilitaryhistory.org accessed 26 November 2010)].

${ }^{44}$ HMSO, Parliamentary Paper C.1569 Report of the Royal Commission on Army Promotion and Retirement (1876).

${ }^{45}$ J.E. Edmonds \& \& R. Maxwell-Hyslop, Military Operations France and Belgium 1918 Vol. V (London: Imperial War Museum, original date 1947) p.593

${ }^{46}$ Cadogan, Armageddon, p.157, letter dated 7 April 1912. Cadogan wrote: "I must say I shall be a very proud man indeed for I shall be one of the youngest Colonels in the service, being only two days over 44 ... I shall be entitled to my pension two days after reaching my $48^{\text {th }}$ year $\ldots £ 420$ a year is a very different pension from $£ 200$ which is all I should have got if I had been passed over." It is likely that in these 15 per cent of cases the more senior Majors had every good reason not to wish to be passed over, and that most retired soon after. Cadogan did not live to enjoy his pension, being killed at Zandvoorde on 30 December 1914.
} 
involved passing over a more senior Major, indicating that the seniority principle was not immutable.

The examination for promotion to Lieutenant-Colonel was a test of "Tactical Fitness for Command". ${ }^{47}$ The candidate would firstly be examined in a three hour theoretical paper. This consisted of a tactical problem involving the operations of a force "not exceeding a brigade of infantry with a brigade of artillery and a regiment of cavalry, and a proportion of mounted infantry, RE, ASC, and RAMC". ${ }^{48}$ The candidate then had to write: "(i) A general appreciation of the situation; (ii) The action which he proposes to take; and (iii) The orders necessary for the execution of his plan". 49

The second part of the examination took place in the field with troops,${ }^{50}$ overseen by a board of three officers, the president of which was a General. The task was to command in:

Any minor tactical operations which may be ordered, a mixed force, of which the strength must not be less than one battalion of infantry, a battery of artillery, and one squadron of cavalry, to which may be added ... a proportion of mounted infantry and $R E$.

The exams, both written and practical, it will be noted, encompassed combined arms operations. In the practical exam, which was against a real 'enemy', the candidate was given the "general idea" the night before and a "special idea" on the ground, to which he had half-an-hour to respond and issue his written orders. Credit was given for "intelligence, judgment, commonsense, and readiness of resource in making the best of any situation". The balance of marks was 300 for the written exam, 100 for the practical test.

\footnotetext{
${ }^{47}$ HMSO, The King's Regulations and Orders for the Army, 1912. Reprinted with Amendments Published in Army Orders up to 1 August 1914, Appendices XII \& XIII, pp.452-456

${ }^{48}$ Royal Engineers, Army Service Corps and Royal Army Medical Corps.

${ }^{49}$ Candidates with a psc (Passed Staff College) qualification could forego Part I.

${ }^{50}$ Outside the UK the candidate might be examined by a staff ride only, over 3 days.
} 
Success was not a formality - 38 per cent of candidates failed "Fitness to Command" in $1912 . .^{51}$

\subsubsection{Age, tenure and further promotion}

The Regular COs had an average age of 47 years 11.5 months, and had been in post an average 23 months when war broke out. ${ }^{52}$

The changes in army organisation effective from 1 July 1881 decreed that "a LieutenantColonel, after 5 years' actual service, will become a Colonel, and will be eligible for employment during 5 years or until the age of 55; when, if he is not promoted to MajorGeneral, retirement will be compulsory". ${ }^{53} \mathrm{He}$ was limited to four years in command of a battalion. $^{54}$

What might these COs have been looking forward to in terms of career progression following the surrender of command? The August 1914 Army List reveals the fate of their predecessors. For just over half ( 52 per cent), the end of battalion command had effectively meant the end of career. Fourteen were Colonels and 55 Lieutenant-Colonels in the

\footnotetext{
${ }^{51}$ TNA PRO WO 279/57. Report on the Staff Conference held at the Staff College, Camberley, 17-20 Jan. 1927. [Cited in D. French, Military Identities: The Regimental System, The British Army and the British People c. 1870-2000 (Oxford: Oxford University Press, 2005), p.158]. Adrian Carton de Wiart, taking his exam for promotion to Major, "failed gloriously", but noted: "How lucky that wars wash out examinations". [A. Carton de Wiart, Happy Odyssey (London: Pan, 1950) p.39].

${ }_{52}$ Two had been in post for only one month, namely D.C. Boger, CO 1st Cheshires; and R.A. Rooth, CO 1st Royal Dublin Fusiliers; whilst D.M. Stuart, CO 2nd Royal Scots Fusiliers, had served 47 of his allotted 48 months. Boger was badly wounded in the leg at Mons and taken prisoner. After escaping from hospital, he was the first soldier to be sheltered by Nurse Edith Cavell, after hiding for three months. Attempting to reach England via Ghent, he was recaptured and spent the rest of the war as a POW. Rooth was killed in action on 25 April 1915 on Gallipoli landing from the River Clyde at Cape Helles. Stuart served as Brigadier-General from 8 July 1915 to 19 January 1916 with 58 Brigade, but thereafter was OC No. 2 District.

${ }^{53}$ HMSO, Parliamentary Paper C.2922 Revised Memorandum Showing Principal Changes in Army Organization from July 1881(1881).

${ }^{54}$ The Lieutenant-Colonel's pay was to be 18 shillings a day, and for COs of the Foot Guards, an extra $£ 200$ per annum was payable.
} 
Reserve of Officers. ${ }^{55}$ Sixteen were untraceable, and hence likely to be in complete retirement or dead.

\begin{tabular}{|l|c|}
\hline Post & \\
\hline Brigade Commander & 22 \\
\hline District Commander & 3 \\
\hline CO Nigeria Regiment & 1 \\
\hline Training Establishment & 5 \\
\hline Attached General Staff (Brigadier-General) & 1 \\
\hline GSO Overseas & 3 \\
\hline GSO UK & 3 \\
\hline AAG & 6 \\
\hline AQMG & 4 \\
\hline AAQMG & 1 \\
\hline Departmental Assistant-Director & 2 \\
\hline Assistant Military Secretary & 1 \\
\hline Other (unspecified) & 5 \\
\hline Unemployed active list & 12 \\
\hline Half-pay & 3 \\
\hline
\end{tabular}

Table 1.2: Posts held in August 1914 by predecessors of Regular COs

Of the remaining 72, all but six were full Colonels, and one was a Temporary BrigadierGeneral. Their various posts are listed in Table 1.2. Thirty per cent had achieved brigade commands; 30 per cent were in staff posts, and seven per cent were in training posts. Twenty-two per cent, however, were unemployed or on half-pay.

\subsubsection{War service}

Nineteen (12 per cent) of the Regular COs had had no previous war service. The remaining 138 had served in approximately two campaigns each. ${ }^{56}$ Table 1.3 shows the spread of active service and number of participating COs.

\footnotetext{
${ }^{55}$ Officers who retired and received retired pay were required to serve in the Reserve of Officers.

561.7 precisely.
} 


\begin{tabular}{|c|c|}
\hline War Service & \\
\hline First Sudan War 1884-5 & 7 \\
\hline Third Burma War 1885-9 & 14 \\
\hline Hazara War (North-West Frontier) 1888 & 3 \\
\hline Zulu War (South Africa) 1888 & 1 \\
\hline Chin-Lushai War (Burma) 1889-90 & 6 \\
\hline Zhob Expedition (North-West Frontier) 1890 & 3 \\
\hline Manipur Expedition (North-East India) 1891 & 1 \\
\hline Hazara Expedition (North-West Frontier) 1891 & 3 \\
\hline Miranzai Expeditions (North-West Frontier) 1891 & 1 \\
\hline Isazai Expedition (North-West Frontier) 1892 & 1 \\
\hline Chin Hills Expedition (Burma) 1892-3 & 1 \\
\hline Burma Expedition 1889-92 & 7 \\
\hline First Matabele War (Rhodesia) 1893 & 2 \\
\hline Waziristan Expedition (North-West Frontier) 1894-5 & 1 \\
\hline Defence and Relief of Chitral (North-West Frontier) 1895 & 6 \\
\hline Sana Kachin Expedition (Burma) 1895-6 & 1 \\
\hline Third Ashanti War (West Africa) 1895-6 & 1 \\
\hline Dongola Expedition (Sudan) 1896 & 2 \\
\hline Bechuanaland Expedition (South Africa) 1896-7 & 2 \\
\hline Niger Operations (West Africa) $1897-8$ & 3 \\
\hline North-West Frontier (including Tirah campaign) 1897-8 & 31 \\
\hline Reconquest of Sudan 1896-9 & 12 \\
\hline Sierra Leone Operations (West Africa) 1898-9 & 1 \\
\hline Uganda Operations (East Africa) 1898-9 & 2 \\
\hline Benin Expedition (West Africa) 1899 & 1 \\
\hline Second Boer War 1899-1902 & 110 \\
\hline Fourth Ashanti War (West Africa) 1900 & 1 \\
\hline Boxer Rebellion (China) 1900 & 3 \\
\hline Southern Nigeria Operations (West Africa) 1901-3 & 1 \\
\hline Somaliland Operations (East Africa) 1902-4 & 2 \\
\hline Aden (interior) Operations 1903 & 1 \\
\hline Tibet Expedition 1903-4 & 1 \\
\hline North-West Frontier 1908 & 4 \\
\hline
\end{tabular}

Table 1.3: Pre-1914 war service of Regular COs 
Lieutenant-Colonel F.G. Anley, $2^{\text {nd }}$ Essex, had served in six campaigns: Sudan 1884-5; Dongola 1896; Nile 1897, 1898 and 1899; and South Africa 1899-1902. ${ }^{57}$ Three had served in five campaigns each. E.P. Strickland, CO $1^{\text {st }}$ Manchester, ${ }^{58}$ had served in Burma 1887-9, Dongola 1896, and Nile 1897, 1898, and 1899; Lieutenant-Colonel C.R. Ballard, $1^{\text {st }}$ Norfolk, ${ }^{59}$ had served in Burma 1891-2, Chitral 1895, North-West Frontier 1897-8, South Africa 1899-1902, and East Africa 1902-4; and Lieutenant-Colonel H.R. Davies, $2^{\text {nd }}$ Oxfordshire and Buckinghamshire, ${ }^{60}$ had served in Burma 1887-8, North-West Frontier 1897-8, Tirah 1897-8, China 1900, and South Africa 1901-2.

Six COs had served in four campaigns; 19 in three; and 32 in two. Of the remaining 77 who had experienced only one campaign, all except 16 had served in the Second Boer War. Sixteen and a half per cent of the collective war experience had been gained against African tribes; 37 per cent had been gained in Asia (primarily India and Burma) and 46.5 per cent against the Boers.

Thirteen had previous experience of command in the field. Lieutenant-Colonel W.C.G. Heneker, $2^{\text {nd }}$ North Staffordshire, had been thrice in command in Southern Nigeria 19023. ${ }^{61}$ Eight had commanded mounted infantry in South Africa. Others had commanded

\footnotetext{
${ }^{57}$ Frederick Gore Anley became Brigadier-General of 12 Brigade in October 1914 until June 1916, and was later Commander Machine Gun Corps and Major-General, January-June 1917.

${ }^{58}$ Edward Peter Strickland served as Brigadier-General between January 1915 and June 1916 with the Bareilly, Jullundur \& 98 Brigades; and was promoted Major-General $1^{\text {st }}$ Division from June 1916 until the end of the war.

${ }_{59}$ Colin Robert Ballard became Brigadier-General between November 1914 and April 1917 with 7, 95 \& 57 Brigades, and then became Military Attaché to Rumania.

${ }^{60}$ Henry Rodolph Davies was Brigadier-General between February 1915 and May 1917 with 3 \& 33 Brigade; and was Major-General from 12 May 1917 with $11^{\text {th }}$ Division.

${ }^{61}$ Heneker wrote a book of tactical guidance, Bush Warfare (London: H. Rees, 1907), based on his experiences, indicating, as does the Journal of the Royal United Services Institution for the period, that British regimental officers of this period had questing minds unrecognised by Tim Travers.
} 
colonial or native troops. Lieutenant-Colonel J. Ponsonby, $1^{\text {st }}$ Coldstream Guards, ${ }^{62}$ had commanded the $5^{\text {th }}$ New Zealand Regiment in South Africa, where Lieutenant-Colonel G.C. Knight, $1^{\text {st }}$ Loyal North Lancashire, ${ }^{63}$ had both raised and commanded the $1^{\text {st }}$ New South Wales Mounted Infantry Regiment. Lieutenant-Colonel W.M. Watson, $1^{\text {st }}$ Duke of Wellington's, ${ }^{64}$ had commanded a Chinese regiment at the relief of Tientsin and Peking.

\subsubsection{Staff service in peace}

Some form of staff service was the mark of both an ambitious officer and one perceived as having the qualities to rise in the regiment or army. ${ }^{65}$ It was not, however, necessary to have such service to rise to the rank of Lieutenant-Colonel as 19 (12 per cent) of the Regular COs had not served in any staff post.

At the most basic level of staff experience, battalion administration, 56 (36 per cent) had been Adjutants to a Regular battalion and 59 (38 per cent) Adjutants in their regiment's Militia or Volunteers. Overall, 59 per cent (92) had thus served. ${ }^{66}$

Outside the regiment a range of staff positions were to be had, which might lead to, or result from, passing the two-year course at the Staff College, Camberley to become $p s c .{ }^{67}$

\footnotetext{
${ }^{62}$ John Ponsonby became Brigadier-General in August 1915 with 2 (Guards) Brigade; and Major-General in August 1917 with 40th then 5th Division.

${ }^{63}$ Guy Cunninghame Knight was killed by shrapnel on the Marne, 11 September 1914.

${ }^{64}$ William Milward Watson became a Brigade Commander in India on 1 January 1916.

${ }^{65}$ To what extent it might also have been the result of patronage is unclear. Timothy Bowman and Mark Connelly suggest that the effects of patronage were limited in the Edwardian army. (Bowman and Connelly, Edwardian Army, pp.36-7).

${ }^{66}$ Some had served as both Regular and Auxiliary Adjutants. The adjutancy carried extra pay. LieutenantColonel H.O.S. Cadogan, $\mathrm{CO} 1^{\text {st }}$ Royal Welsh Fusiliers on the outbreak of war, then a Second-Lieutenant with the battalion in India in the late 1880s, was relying on extra finance from his widowed mother and wrote to her: "It must be such a drag on you, if only I could get the adjutancy of the regiment it would be everything but they only give it to such senior subalterns and generally to a captain". (Cadogan, Armageddon, p. 83).
} 
Thirty-four of the Regular COs (22 per cent) were psc. Eight (26 per cent) had attended in the period immediately prior to the Second Boer War when a "new progressive spirit" was apparent, ${ }^{68}$ and the remaining 74 per cent in its aftermath, a period when the course became "more practical and up to date", 69 incorporating the lessons of that conflict.

Forty-six per cent (72) had achieved extra-regimental staff posts. Lieutenant-Colonel C.L. Nicholson, $2^{\text {nd }}$ East Lancashire ${ }^{70}$ had perhaps the most richly experienced staff career. A pre-1899 psc, he had served as ADC to the Governor and Commander-in-Chief, Gibraltar 1891-3, as Staff Captain then DAQMG for Mobilisation, India (1901), and had then been DAQMG at the headquarters of Bengal East Command for four years, returning as DAQMG for Mobilisation before returning home and serving successively as BrigadeMajor to 15 and 16 Brigades, Irish Command (1905-9), and finally serving as a GSO2 in South Africa (1911-12).

Lieutenant-Colonel S.C.F. Jackson, $1^{\text {st }}$ Hampshire had no $p s c$ qualification, but had served as ADC to a Major-General, Bengal (1889-93), as ADC to the Commander-in-Chief, East Indies (1893-4), and as a Station Staff Officer, India (1897) before moving to be DAAG at

${ }^{67}$ Officers who were "in every respect thoroughly good regimental officers" (HMSO, The King's Regulations and Orders for the Army, 1912 p.163) were eligible to be recommended for attendance by their COs after three years' service.

${ }^{68}$ B. Bond, The Victorian Army and the Staff College (London: Eyre Methuen, 1972), p.148. The authors of this spirit were Colonels H.J.T. Hildyard and G.F.R. Henderson. Hildyard reduced the importance of examinations, and introduced continuous assessment of classroom and field exercises. Henderson introduced the thoroughly modern technique of role-play to work through the decision making of campaign commanders. That Staff College graduates who had obtained their psc prior to this period were not universally admired is indicated by Lieutenant-Colonel H.O.S. Cadogan, who wrote of his then CO: "He is most awfully unpopular ... he is a Staff College man for one thing and therefore does not know his drill and has impracticable theories about everything which he has tried until they do not succeed". (Cadogan, Armageddon, pp.48-9).

${ }^{69}$ Under a new Commandant, (Sir Henry Rawlinson from 1903). Bond, Victorian Army, p.197

${ }^{70}$ Nicholson, as already noted, rose to the rank of Major-General in 1916. 
Army HQ in Bombay (1897-1902). He had then served as DAAQMG to both $8^{\text {th }}$ and $6^{\text {th }}$ Divisions, Irish Command (1906-10).

If Viscount Esher's vision had been for Staff College graduates to provide a professionally trained General Staff, ${ }^{71}$ then indeed some of the Regular COs of 1914 had scaled these heights. Lieutenant-Colonel A. Grant-Duff $p s c, 1^{\text {st }}$ Black Watch, had been Assistant Military Secretary to the Committee of Imperial Defence from October 1910 to September 1913, where he had been responsible for the production of the 'War Book' ${ }^{72}$ LieutenantColonel A.D. Geddes $p s c, 2^{\text {nd }}$ Buffs, had been both GSO3 and GSO2 at Army Headquarters (1904-8) and then had spent two years as GSO2 at the War Office. Lieutenant-Colonels A.R.S. Martin psc, $1^{\text {st }}$ Royal Lancaster, ${ }^{73}$ and D.C. Boger (without $p s c), 1^{\text {st }}$ Cheshire, had both been attached to the General Staff at the War Office, as had Lieutenant-Colonel H.P. Hancox $p s c, 2^{\text {nd }}$ Royal Inniskilling Fusiliers.

\footnotetext{
${ }^{71}$ Reginald Baliol Brett, $2^{\text {nd }}$ Viscount Esher (1852-1930), was a member of the Elgin South African War Commission, and chaired the War Office Reconstitution Committee, which proposed changes in the reorganization of the War Office, including the setting up of the Committee of Imperial Defence.

${ }^{72}$ The War Book: "Detailed the steps to be taken to mobilize the army, the additional duties of each branch and the extra staff required". [C. Messenger, Call to Arms (London: Weidenfeld \& Nicholson, 2005), p.29]. It was instigated by the Committee of Imperial Defence. Covering 12 Government departments in 12 chapters it charted the incremental steps from "precautionary" to "strained relations" to "war stage", i.e. full mobilisation to meet any threat. Grant-Duff devised a column format which allowed easy reference to what each department might do at each stage. (http://pw20c.mcmaster.ca/case-study/adrian-grant-duff-preparingfirst-world-war, accessed 20 June 2012.) Sadly, for a man of such obvious ability, Adrian Grant-Duff was killed early in the war on 14 September 1914, on the Aisne.

${ }^{73}$ Aylmer Richard Sancton Martin was killed in action on 9 May 1915, during the Second Battle of Ypres.
} 


\begin{tabular}{|c|c|c|c|}
\hline Location & Post & No psc & psc \\
\hline Overseas & ADC to Viceroy/Governor/C-in-C/General Officer & 10 & 4 \\
\hline Overseas & Military attaché & 1 & 2 \\
\hline Overseas & Assistant or Military Secretary & 3 & \\
\hline Overseas & Training post & 6 & 2 \\
\hline Overseas & GSO2 & 2 & 3 \\
\hline Overseas & Brigade Major & 4 & 5 \\
\hline Overseas & DAAG & 6 & 9 \\
\hline Overseas & DAAQMG & 4 & 6 \\
\hline Overseas & DAQMG & & 6 \\
\hline Overseas & Staff Officer/Captain & 8 & 3 \\
\hline Overseas & Adjutant & 1 & \\
\hline Home & ADC to King & 1 & \\
\hline Home & ADC to General Officer & 3 & 1 \\
\hline Home & Attached General Staff & 4 & 4 \\
\hline Home & Assistant or Military Secretary & 2 & \\
\hline Home & GSO2 HQ/Division & & 14 \\
\hline Home & GSO3 HQ & & 3 \\
\hline Home & Brigade Major & & 12 \\
\hline Home & GSO2/DAAG Staff College & & 10 \\
\hline Home & DAAG HQ/District & 2 & 4 \\
\hline Home & DAAQMG HQ/District & 5 & 5 \\
\hline Home & Staff Captain & 8 & 3 \\
\hline Home & Post RMC Sandhurst & 7 & 6 \\
\hline Home & Other training post & 6 & 6 \\
\hline Home & Other & 5 & 2 \\
\hline
\end{tabular}

Table 1.4: Peacetime staff experience of Regular COs

Three officers had served as Military Attachés. Lieutenant-Colonel H.C. Lowther (without psc), $1^{\text {st }}$ Scots Guards, ${ }^{74}$ had served in Madrid, Lisbon and Paris; and Lieutenant-Colonel J.D. McLachlan $p s c, 1^{\text {st }}$ Cameron Highlanders, ${ }^{75}$ in Washington and Mexico. Lieutenant-

\footnotetext{
${ }^{74}$ Henry Cecil Lowther was promoted Brigadier-General in November 1914 with 1 (Guards) Brigade, and in September 1915 became Military Secretary at GHQ BEF for four months. He later served as a MGGS from October 1917.

75 James Douglas McLachlan became GSO1 in April 1915, Brigadier-General with 8 Brigade in October 1915, Brigadier-General (AAG) June-July 1916, finally serving as Military Attaché to Washington from September 1917.
} 
Colonel C. Wanliss (without $p s c$ ), $2^{\text {nd }}$ South Lancashire, had likely had his patience tried at the Seistan Arbitration Commission. ${ }^{76}$

Table 1.4 sets out the range of peacetime staff experience. The main difference between those who were psc and those not is in home appointments. An officer did not become a GSO2, a GSO3, or a Brigade Major (or, more obviously, gain a Staff College post) in the UK without having the qualification. ${ }^{77}$

\subsubsection{Staff service in war}

Sixty-one (44 per cent) of the 139 COs who had war service had performed extraregimental staff service in war. Twenty-four (17 per cent), had served as Adjutants to their battalions in the field, 11 proceeding to extra-regimental service.

Of the eight who were psc by the time of the Second Boer War, four had no staff experience in war by 1914; and only Lieutenant-Colonel C.R. Ballard, $1^{\text {st }}$ Norfolk, had rich war staff service experience. He had been Transport Officer in Tirah, 1898; and in South Africa 1899-1902 was variously Adjutant of Roberts' Light Horse, Staff Captain to a Station Commandant, and Staff Officer to a Mounted Infantry Corps Mobile Column. Lastly, in 1903 he had been Transport Officer to the Somaliland Field Force. Six of the 23 who acquired their psc status after the Boer War had no wartime staff experience by 1914.

\footnotetext{
76 This notoriously protracted commission (1903-5) laid down the boundaries between Persia and Afghanistan.

${ }^{77}$ This challenges Martin Samuels' assertion that the army was in the grip of a 'cult of rank' where battalion officers were almost excluded from the work of the General Staff. See M. Samuels, Command or Control? (London: Frank Cass, 1995), pp. 34-60
} 


\begin{tabular}{|c|c|c|c|}
\hline & psc pre-1899 & psc post-1902 & No psc \\
\hline & (4 officers) & (16 officers) & (37 officers) \\
\hline ADC to Lieutenant-General & & 2 & \\
\hline ADC Major-General & & 1 & 1 \\
\hline Brigade Major & & 2 & 1 \\
\hline DAAG & 2 & 6 & 3 \\
\hline DAAG Intelligence & & & 1 \\
\hline Provost Marshall & & & 1 \\
\hline Assistant Provost Marshall & 1 & & \\
\hline Commandant & & 4 & 7 \\
\hline Staff Captain Intelligence & & 1 & 1 \\
\hline Staff Officer & 4 & 5 & 8 \\
\hline Station Staff Officer & & & 4 \\
\hline Railway Staff Officer & & 1 & \\
\hline Transport Officer & 2 & 1 & 1 \\
\hline Disembarkation Officer & & 1 & \\
\hline Garrison Adjutant & & & 3 \\
\hline Orderly Officer & & & 2 \\
\hline Censor & & 1 & 1 \\
\hline Signalling Officer & & & 1 \\
\hline Special Service Officer & & 1 & 11 \\
\hline
\end{tabular}

Table 1.5: Wartime staff posts held by Regular COs

If the officer was of the group identified as suitable for staff progression, not having the $p s c$ initials was no bar to a rich war staff experience. Lieutenant-Colonel T.O. Marden, $1^{\text {st }}$ Welsh, ${ }^{78}$ had served in South Africa as variously Commandant Worcester; Railway Staff Officer; Staff Officer to the Commandant, Colesberg; Staff Officer to the Assistant Inspector General; on Lines of Communication work; and as Commandant, Colesburg. More prestigiously, Lieutenant-Colonel N.R. McMahon, $4^{\text {th }}$ Royal Fusiliers, had served in

\footnotetext{
${ }^{78}$ Thomas Owen Marden was wounded 24 May 1915 at 2nd Ypres. He was promoted Brigadier-General between November 1915 and August 1917 with 114 Brigade; and then served as Major-General with 6th Division until the end of the war.
} 
South Africa as ADC to a Major-General commanding an Infantry Brigade, and as Brigade-Major and DAAG. ${ }^{79}$

Prestigious staff jobs could however go to men (some perhaps favourites, some undoubtedly talented) who did not have a psc and who were never going to obtain one. Thus, Lieutenant-Colonel C.S. Davidson, $2^{\text {nd }}$ South Staffordshire, ${ }^{80}$ was ADC to the Major-General of an Infantry Brigade in South Africa, and later Brigade-Major. As can be seen from Table 1.5, however, lower-order staff jobs were likely to be the province of such officers.

\subsection{The Special Reserve COs of August 1914}

The Special Reserve had been created out of the Militia by the 1907 reforms with the express purpose of providing reinforcements for the Regular army. ${ }^{81}$ In August 1914 there were 101 Special/Extra Reserve Battalion COs in post. $^{82}$

Given that only four battalions saw active service, these officers will not be considered in detail. ${ }^{83}$ Suffice it to say that they were of two sorts. Forty per cent were ex-Regulars, who had an average age of 48 years seven months and who had been retired on average exactly

\footnotetext{
${ }^{79}$ Both were to attend Staff College in the post-Second Boer War period. Norman Reginald McMahon was Chief Instructor and Staff Officer, School of Musketry, Hythe, for four years from June 1905. In 1907 he advocated the provision of six machine guns per battalion. Rebuffed, the 'Musketry Maniac' was instrumental in the development of the 15 aimed-shot 'mad minute' enshrined in Musketry Regulations (1909), and put to effective use at Mons in August 1914. [M. Barthrop, The Old Contemptibles (Oxford: Osprey, 1989), p.22]. He was killed in action at Ypres on 11 November 1914, prior to taking command of 10 Brigade.

${ }^{80}$ Charles Steer Davidson commanded 123 Brigade for a year from September 1915.

${ }^{81}$ The Territorial and Reserve Forces Act (1907), the work of R.B. Haldane as Secretary of State for War. 80 per cent of the Militia and Militia Reserve joined the Special Reserve. (Messenger, Call To Arms, p.22).

8274 Reserve and 27 Extra Reserve Battalions.

${ }^{83}$ See Appendices Two and Four for further discussion of the Special Reserve COs on the outbreak of and during the war.
} 
seven years. The rest were officers whose careers had been spent entirely in the Special Reserve.

\subsection{The Territorial Force COs of August 1914}

The Territorial Force (TF) had been created out of the Volunteers by the 1907 reforms with the express purpose of providing home defence. In August 1914 there were 207 Territorial Force COs.

\subsubsection{Ex-Regulars}

Thirty-three of the TF COs (16 per cent) were ex-Regulars. They had an average age of 45 years four months, and were therefore two years six months younger than their counterparts who had remained in the Regular army. Ten per cent had retired as Lieutenant, 45 per cent as Captain, and 45 per cent as Major, and they had been retired for an average of 8 years three months. ${ }^{84}$ It is probable that these men retired because they were unlikely to be promoted beyond the rank of Major. Three, however, were recently retired Lieutenant-Colonels from the Indian Army. ${ }^{85}$

\begin{tabular}{|l|c|c|c|}
\hline & Ranks & Militia & RMC/University/Probationer \\
\hline Regular COs & $1 \%$ & $28 \%$ & $71 \%$ \\
\hline Ex-Regular TF COs & $0 \%$ & $35 \%$ & $65 \%$ \\
\hline
\end{tabular}

Table 1.6: Entry routes of ex-Regular TF COs in post August 1914 compared with entry routes of Regular COs

\footnotetext{
${ }^{84}$ The longest retired having done so in November 1900, the most recently retired having done so in February 1913.

${ }^{85}$ Lieutenant-Colonel Hugh David McIntyre, CO $5^{\text {th }}$ Argyll and Sutherland Highlanders; Lieutenant-Colonel Hugh Morris Allen, CO $5^{\text {th }}$ Black Watch; and Lieutenant-Colonel George Dashwood Maxwell Moore, CO $6^{\text {th }}$ London. All retired between May 1911 and October 1913.
} 
Table 1.6 shows their entry routes into the army. None had been commissioned from the ranks, and there was a higher level of Militia entrants. As Table 1.7 shows, they had a much lower level of occupancy of staff posts than their Regular counterparts. All these features suggest their careers prospects in the Regular army had been more limited.

\begin{tabular}{|l|c|c|}
\hline & Pre-WW1 Staff Service & Pre-WW1 war Staff Service \\
\hline Regular COs & $82 \%$ & $91 \%$ \\
\hline Ex-Regular TF COs & $30 \%$ & $55 \%$ \\
\hline
\end{tabular}

Table 1.7: Peace and wartime Staff service of ex-Regular TF COs in post August 1914 and Regular COs

\subsubsection{Former Volunteer COs}

The remaining 174 TF COs had all been Volunteers. Their average age was 47 years eight months, with considerable variation. ${ }^{86}$ Lieutenant-Colonel Sir M. Sykes, $5^{\text {th }}$ Yorkshire, was the youngest at 35 years five months, whilst 32 per cent (28) were over the age of 50, the oldest being Lieutenant-Colonel A. R. Meggy, $4^{\text {th }}$ Essex, who was 59 years three months old. ${ }^{87}$

Officers commanding TF units were "appointed for 4 years, but extensions (not more than two) for 4 years" could be granted. Officers other than those holding commands or staff appointments were required to retire at 60 , but again might be "allowed an extension of service, which will not be granted for more than 2 years at a time, or beyond $65 " .{ }^{88}$ The

\footnotetext{
${ }^{86} 88 \mathrm{COs}$, ages accurate to 1.5 months with a quarter midpoint taken from the Registrar General's quarterly registers of births, marriages and deaths.

${ }^{87}$ Sir Mark Sykes would earn notoriety for his part in the Asia Minor or Sykes-Picot Agreement, which defined British and French spheres of interest and control in the post-war Middle East, Arthur Robert Meggy retired just prior to his battalion's departure for Gallipoli.

${ }^{88}$ The Territorial Year Book (London: Hodder \& Stoughton, 1909), p.22
} 
$207 \mathrm{TF}$ COs had been in post for an average of three years and one month. Forty-six (22 per cent) had been in post over four years, 15 being COs of Volunteer battalions, and two had been in post since before the turn of the century. ${ }^{89}$ Overall, 95 per cent of TF CO appointments were within-regiment.

There was clear reason for a TF CO to keep hold of his command, as relinquishing it was very likely to be the end of his career. Of the predecessors of the TF COs of August 1914, only 12 out of 207 ( 6 per cent) were actively employed. Four had found another battalion command, six had found other posts (although three were 'unattached'), and two had achieved promotion. ${ }^{90}$

\subsubsection{War service}

Of the 34 ex-Regular TF COs, seven (20 per cent) had no war service. Of the remaining 26, three had served in three campaigns, seven in two, and the remainder in one campaign. Of the 173 'pure' TF COs, 138 (80 per cent) had no previous war service. The remainder had service in the Second Boer War only.

Table 1.8 shows the spread of active service. One per cent of the collective war experience had been gained against African tribes; 21 per cent had been gained in Asia (primarily India and Burma), and 78 per cent against the Boers.

\footnotetext{
${ }^{89}$ Lieutenant-Colonel Cecil Socera Clarke had been a CO since 18 January 1899, originally with the 1 st Volunteer Battalion, Sussex Regiment; and the Earl of Denbigh and Desmond had been CO of the Honourable Artillery Company since 4 March 1893. Clarke was transferred as $\mathrm{CO}$ to the second-line battalion in October 1914 and was retired by the end of 1915; Desmond was promoted full Colonel before the end of August 1914 and never took his battalion abroad.

${ }^{90}$ Charles Strathavon Heathcote-Drummond-Willoughby, formerly a Scots Guards officer and CO 15th London Regiment, was a Colonel commanding the 6th London TF Infantry Brigade; and Noel Lee, formerly of the 6th Manchester Regiment, was a Colonel commanding the Manchester TF Infantry Brigade.
} 


\begin{tabular}{|l|c|c|}
\hline Active service & TF only & Ex-Regular \\
\hline Third Burma War 1885-9 & & 3 \\
\hline Hazara Expedition (North-West Frontier) 1891 & & 1 \\
\hline Chin Hills Expedition (Burma) 1892-3 & & 1 \\
\hline Defence and Relief of Chitral (North-West Frontier) 1895 & & 1 \\
\hline Third Ashanti War (West Africa) 1895-6 & & 1 \\
\hline North-West Frontier (including Tirah campaign) 1897-8 & & 5 \\
\hline Second Boer War 1899-1902 & 34 & 19 \\
\hline Boxer Rebellion (China) 1900 & & 2 \\
\hline Waziristan (North-West Frontier) 1901-2 & & 1 \\
\hline Tibet Expedition 1903-4 & & 1 \\
\hline North-West Frontier 1908 & & 2 \\
\hline
\end{tabular}

Table 1.8: War service of TF COs

\subsection{The Quality of the Battalion Commanders of August 1914}

\subsubsection{The Regulars}

The education of the Regular Lieutenant-Colonels of August 1914 was better than that of their predecessors, but was very patchy. Around 70 per cent had attended RMC, yet virtually all had done so before the course had become more practical in the 1890s. Their basic military education was therefore inferior compared to that of most of the Captains who in 1914 might have aspired to succeed them. Twenty two per cent were, however, psc, and three-quarters of these had attended Camberley after 1902 when the lessons both contained in Combined Training 1902 and the Boer War in general were central, an era when one instructor described that "some of very best soldiers in the army were to be met at Camberley". 91

\footnotetext{
${ }^{91}$ Lieutenant-Colonel E.S. May, quoted in Bond, Victorian Army, p.195
} 
Not all knowledge was acquired via formal education. In terms of 'on the job' development only 12 per cent had not served in any staff post, and whilst the regimental system has been criticised for keeping officers' "mental horizons ... confined to their own regiments", ${ }^{92} 64$ per cent had performed extra-regimental staff service in peace and war. Fifty-nine per cent had been regimental Adjutants. Given that the latter post was within the gift of the CO, it may be presumed that the most able served as Adjutants, not least as any CO would have wished it so to ensure that their own work load was as light as possible. The Regular COs were, therefore, largely administratively able. ${ }^{93}$

The true value of their war service is a matter for debate. David French has asserted that "between 1870 and 1970 the British army fought only four wars in which it found itself fighting against an enemy that was equipped to the same modern standard as itself, and was organized into large combined arms formations". Prior to the First World War, the only conflict that met this criterion was "the opening months of the Second Anglo-Boer War". 94

Forty-seven per cent of Regular COs had accumulated war service in South Africa in 1899. ${ }^{95}$ This experience had been at the highest rank of Captain, ${ }^{96}$ and all but ten had not had command experience. However, it was not simply the experience of 1899 , but the processed lessons of these months which became established practice during 1900, which

\footnotetext{
${ }^{92}$ French, Military Identities, p. 3

${ }^{93}$ The Adjutant's job was "to organize the daily routine, run an office, cope with correspondence, write orders, answer queries from brigade, anticipate company needs, stave off troubles and ensure the proper deportment of ORs and junior officers. A quick mind helped". [K. Radley, 'First Canadian Division, CEF 1914-1918'unpublished PhD Thesis, Carleton University, Ottawa (2000), p.85]. The CO usually selected his Adjutant: "From the most able and promising of his peers". [D. Langley, Duty Done: $2^{\text {nd }}$ Battalion The Royal Welch Fusiliers in the Great War (Caernarfon: Royal Welch Fusiliers Museum, 2001), p.111].

${ }^{94}$ French, Military Identities, p.265

${ }^{95}$ HMSO, Quarterly Army List, January 1914.

${ }^{96}$ Except for two brevet-Majors.
} 
were important; and 71 per cent of COs saw service 1900-02. Their key learning had likely been done before they were too set in their ways.

Much of their war experience, both before and after the Second Boer War, had been in the 'policemen of the empire' role. G.F. Ellison, psc (a keen military observer who ended the First World War as a Major-General having served in staff posts), ${ }^{97}$ writing in the immediate aftermath of the Boer War, had deep reservations about the value of this 'small war' military service.

Whilst not suggesting complete inapplicability to a large force European conflict, Ellison believed that "the qualities of both body and mind that make for success in the leadership of small expeditions and for the conquest of savage tribes" did not enable a commander to develop the mental facility "to deal with administrative questions of the most complex nature or to solve strategical problems on which the fate of nations may depend", continuing: "Something more is required than mere physical bravery, a strong will, nerves of iron and a body impervious to fatigue". The prime dangers in a small force were, he believed, those of developing a failure to delegate and believing that in the power of improvisation lay the "whole art of successful administration". 98

\footnotetext{
${ }^{97}$ Sir Gerald Francis Ellison (1861-1947). He served as close adviser to R. B. Haldane whilst he was devising his army reforms of 1907.

${ }^{98}$ G. F. Ellison, Considerations Influencing the Selection of Officers for Command and the Staff, NAM 870435 Ellison Mss. No. 30. Ellison's main complaint, mirroring Esher, was the lack of an intellectual approach to a science of soldiering. He thought that the small war experience could lead to "a dangerous narrowing of the intellectual vision" through the view that "war could only be learnt from war", and, moreover, that only the British way in war was worth learning from. In short, the army had learnt the wrong thing by concentrating on the wrong experiences.
} 
The campaigns of conquest, suppression of insurrection or punitive expeditions indeed bore little resemblance to continental European warfare, but this was counterbalanced to some extent by the South African experience. The British army of 1914 had experience of tactical diversity, and in its campaigns conducted amidst hostile geography and nature, its commanders had become masters of small-force tactics and logistics. Whilst they had passed through some sort of intellectual quality-control for promotion, it was the rich patina of experience that marked this group as exceptional in terms of staff and war service.

Far from necessarily suffering from narrowed vision, the Regular COs of 1914 had the potential for a broad vision provided by varied empire experience balanced against nearly 12 years of training suitable to continental war with the revised tactics of the post-1902 period. Not all achieved this, of course. Lieutenant-Colonel W.M. Bliss, $2^{\text {nd }}$ Scottish Rifles, had become CO on 10 October 1913. Aged 48, he had no war experience, but had served as a Regular Adjutant 1894-98. One of his officers described him as "Crimean in many ways - steeped in outmoded tradition and not prone to delegation of duties". Reviewing his officers' opinions of him, John Baynes summarises: "He might not have been very clever ... [but] ... he was genuine and sincere, and within his limitations a sound, practical officer". 99

For the COs of August 1914, their war experience suited them to managing battalions in the encounter battles of 1914, and may even have been particularly appropriate in handling the retreat from Mons. Once trenches were dug for more than momentary inhabitation,

\footnotetext{
${ }^{99}$ J. Baynes, Morale: A Study of Men and Courage (London: Cassell, 1967), p. 113. This had not been a popular appointment as Bliss had come from the 1st Battalion. He was killed at Neuve Chapelle on 10 March 1915.
} 
their store of experience, as for all officers, irrespective of nationality, no longer served them as well.

No objective competence rating can be achieved for the Regular COs. In terms of perceived incompetence, in addition to the two who were court-martialled, LieutenantColonels Elkington and Mainwaring, ${ }^{100}$ six infantry Lieutenant-Colonels were relieved of command before 31 December $1914 .^{101}$ This does not necessarily mean they were incompetent. Of these, Lieutenant-Colonel N.A.L. Corry, $2^{\text {nd }}$ Grenadier Guards, had been sent home for withdrawing without orders (being out of contact with his Brigadier) from Bois la Haut (Mons) on 23 August 1914, and the War Office noted him as "not an inefficiency case". ${ }^{102}$ Corry had simply fallen foul of the vagaries of being the "man on the spot'. 103

The remaining five were a different matter. Lieutenant-Colonel C. Wanliss was sent home on 29 August 1914, judged "totally unfit to command in the field" by his divisional commander. ${ }^{104}$ Lieutenant-Colonel D.W. Churcher, 1st Royal Irish Fusiliers, was replaced

\footnotetext{
${ }^{100}$ See Introduction.

${ }^{101}$ D/APC/HD/ABLW/187116 Army Personnel Centre - War Office letter dated 17 January 1915 in the file of Lieutenant-Colonel Cecil Wanliss.

${ }^{102}$ D/APC/HD/ABLW/187116 Army Personnel Centre

103 "Colonel Corry determined to take upon himself the responsibility of ordering the retirement of the two battalions. His impression was that in the case like this, when local conditions could not be known to the Divisional Staff, it was for the man on the spot to make his own decision. Superior authority, however, afterwards held that while under exceptional circumstances such powers might well be delegated to the man in mediis rebus, in a case like this it could not be admitted that an officer in actual touch with the enemy was the best judge of how long a position should be held. It was felt that there were many considerations in the decision of the sort, of which the officer in the front line could know very little. Colonel Corry was therefore severely blamed to his action, and was a fortnight later relieved of his command". Sir F. Ponsonby, The Grenadier Guards in the Great War, 1914-1918 Vol. 1 (London: Macmillan, 1920), p. 27. Corry assumed command of $3{ }^{\text {rd }}$ Grenadier Guards on 29 November 1914, and took them to France.

${ }^{104}$ Major-General H. Hamilton. This decision was approved by Lieutenant-General Smith-Dorrien, FieldMarshal French and F. W. N. McCracken, his Brigadier. Wanliss was put on the sick list, prescribed complete rest, and was sent back to England. He saw the report on him prepared by McCracken, and
} 
on 10 September $1914 .{ }^{105}$ Similarly, Lieutenant-Colonels H.P. Hancox of the $2^{\text {nd }}$ Royal Inniskilling Fusiliers; J.K. O'Meagher of the $2^{\text {nd }}$ Munster Fusiliers; and H.P. CreaghOsborne of the $1^{\text {st }}$ Royal Lancaster were sent home. ${ }^{106}$

It is possible to assess viability as a $\mathrm{CO}$ in the wider group in terms of endurance and promotability. If the number of COs who were either killed in action ( $40-24$ having been killed before the end of 1914$) ;{ }^{107}$ wounded unable to return to command (14); ${ }^{108}$ prisoners of war (eight); ${ }^{109}$ or who remained in India (five); ${ }^{110}$ is subtracted, 90 COs remain whose progress can be followed. Of these, 15 were invalided (i.e. either their constitution was genuinely not up to active service or invalidity was used as a euphemism), ${ }^{111} 15$ were

endorsed by Major General F.D.V. Wing and Smith-Dorrien, and submitted a detailed rebuttal, but the Army Council felt they had "no alternative but to accept the opinion formed" by the reporting officers.

${ }^{105}$ See Introduction. He clearly had an unhappy pre-war relationship with his Brigade Commander, who viewed him as running a less than competent battalion.

${ }^{106}$ Henry Percy Hancox served as AA\&QMG from 12 October 1914 to 18 October 1915, and after periods on half-pay, ended the war in the Labour Corps. John Kevin O'Meagher commanded a Service battalion, $8^{\text {th }}$ Munster, from 6 September 1914 to 8 May 1915, following which he served as in a Special Appointment as Staff Captain, and finally commanded the $3^{\text {rd }}$ Garrison Royal Irish Fusiliers from 7 December 1916 to 2 October 1918. Herbert Pearson Creagh-Osborne, a Depot Major in 1914, returned to active service commanding Hood Battalion, Royal Naval Division, briefly in December 1916 (see Chapter Three section 3.3.3).

${ }^{107}$ A further 16 commanding as a Major or lower rank also killed during 1914 whilst acting-up.

${ }^{108}$ Lieutenant-Colonels M.C. Coles ( $2^{\text {nd }}$ Queen's); H.E.B. Newenham ( $2^{\text {nd }}$ Royal Fusiliers); St. J.A. Cox $\left(2^{\text {nd }}\right.$ Royal Irish); H.E.B. Leach ( $1^{\text {st }}$ South Wales Borderers); C.M. Stephenson $\left(2^{\text {nd }}\right.$ King's Own Scottish Borderers); W.B. Wallace ( $1^{\text {st }}$ Suffolk); J.A.C. Gibbs $\left(2^{\text {nd }}\right.$ Duke of Wellington's); M.D. Graham ( $1^{\text {st }}$ Royal Berkshire); C.P. Higginson ( ${ }^{\text {st }}$ Shropshire Light Infantry); A.W. Hasted ( $1^{\text {st }}$ Wiltshire); R.W.H. Ronaldson $\left(1^{\text {st }}\right.$ Highland Light Infantry); D.L. MacEwen $\left(2^{\text {nd }}\right.$ Cameron Highlanders); W.T.M. Reeve ( $2^{\text {nd }}$ Leinster $)$; H.M. Biddulph ( $1^{\text {st }}$ Rifle Brigade).

${ }^{109}$ Lieutenant-Colonels R.G.I. Bolton $\left(2^{\text {nd }}\right.$ Scots Guards - POW 26 October 1914); H. McMicking ( $2^{\text {nd }}$ Royal Scots - POW 27 August 1914); S.H. Enderby ( $2^{\text {nd }}$ Northumberland Fusiliers - POW 8 May 1915); D.C.Boger $\left(1^{\text {st }}\right.$ Cheshire - POW 24 August 1914); S.C.F. Jackson ( $1^{\text {st }}$ Hampshire - POW 27 August 1914); E.A.F. Lethbridge ( $1^{\text {st }}$ Ox \& Bucks - POW 29 April 1916); R.C. Bond ( $2^{\text {nd }}$ Yorkshire Light Infantry - POW 26 August 1914); J.F. Forbes ( $2^{\text {nd }}$ Wiltshire - POW 24 October 1914).

${ }^{110}$ Lieutenant-Colonels G. D. Crocker ( $2^{\text {nd }}$ Kings Liverpool); E.H.R.C.R. Platt $\left(2^{\text {nd }}\right.$ Somerset Light Infantry); G. Christian ( $1^{\text {st }}$ Green Howards); W.M. Watson $\left(1^{\text {st }}\right.$ Duke of Wellington's); and C.C. Luard ( $1^{\text {st }}$ Durham Light Infantry).

${ }^{111}$ Lieutenant-Colonels H.C. de la M. Hill ( $1^{\text {st }}$ Buffs - to OC MGC Training Centre); E.H. Swayne $\left(1^{\text {st }}\right.$ Somerset Light Infantry - to Training Reserve); H. Delme-Radcliffe ( $2^{\text {nd }}$ Royal Welsh Fusiliers - to Training Reserve); A.E. Lascelles ( $1^{\text {st }}$ Worcestershire - to Special Employment); H.D. Lawrence $\left(2^{\text {nd }}\right.$ East Surrey - to Special Employment); W.M. Campbell ( $2^{\text {nd }}$ Black Watch - Temporary Brigadier-General UK); R.H. Hayes $\left(2^{\text {nd }}\right.$ Middlesex - to Home Service Battalion); H.L. James ( $2^{\text {nd }}$ Manchester - instructional duties); F.H. Neish $\left(1^{\text {st }}\right.$ Gordon Highlanders - retired); H.L. Henderson ( $1^{\text {st }}$ Argyll \& Sutherland Highlanders - Commandant Lines of Communication); S.R.L. White $\left(1^{\text {st }}\right.$ Leinster - to home service battalion); E.O. Smith $\left(1^{\text {st }}\right.$ 
retired or sidelined into inactive administrative posts; ${ }^{112}$ and two court-martialled. ${ }^{113}$ One took up a series of senior staff posts. ${ }^{114}$ Twenty-eight were promoted to brigade command, ${ }^{115} 25$ to divisional command, ${ }^{116}$ and three to corps command, ${ }^{117}$ giving a

Northamptonshire - to Special Appointment); A.C. Lovett $\left(1^{\text {st }}\right.$ Gloucestershire - to Brigade Commander not on active service); B.F.B. Stuart ( ${ }^{\text {rd }}$ Worcestershire - to Brigade Commander not on active service); A.A. Wolfe-Murray ( $2^{\text {nd }}$ Highland Light Infantry - to Brigade Commander not on active service).

${ }^{112}$ Lieutenant-Colonels N.A.L. Corry (2nd Grenadier Guards - relieved of command on 9 September 1914 as a result of ordering retirement of his battalion and the Irish Guards at Mons on 23 August 1914, restored to command of $3^{\text {rd }}$ Battalion but placed on half-pay January 1916); H.W.U. Coates $\left(2^{\text {nd }}\right.$ Bedfordshire - never saw active service, to half pay in 1915); D.A. Callender ( $1^{\text {st }}$ Royal Scots - to Labour Corps); R. FowlerButler ( $1^{\text {st }}$ Royal Fusiliers - to Commandant Lines of Communications); G.F. Phillips ( $2^{\text {nd }}$ West Yorkshire Military Attache \& District Commander); M.J. Sweetman $\left(2^{\text {nd }}\right.$ East Yorkshire - to training reserve); H.V.S. Ormond $\left(1^{\text {st }}\right.$ Lancashire Fusiliers - to training reserve); H.P. Hancox $\left(2^{\text {nd }}\right.$ Royal Inniskilling Fusiliers - to AAQMG \& Labour Corps); C. Wanliss $\left(2^{\text {nd }}\right.$ South Lancashire - to training reserve); A.G. Marrable $\left(1^{\text {st }}\right.$ Yorkshire Light Infantry - Commandant); E.C. Cobbold $\left(2^{\text {nd }}\right.$ York \& Lancaster - to Special Reserve battalion); B.W.L. McMahon ( $2^{\text {nd }}$ Durham Light Infantry - to Scholl of Musketry); H.P. Moulton-Barrett $\left(2^{\text {nd }}\right.$ Argyll \& Sutherland Highlanders - to Special Appointment); H.E. Tizard ( $1^{\text {st }}$ Royal Munster Fusiliers - to training reserve); J.K. O'Meagher ( $2^{\text {nd }}$ Royal Muster Fusiliers - to Special Appointment).

${ }^{113}$ Lieutenant-Colonels J.F. Elkington ( $1^{\text {st }}$ Royal Warwicks) and A.E. Mainwaring ( $2^{\text {nd }}$ Royal Dublin Fusiliers).

${ }^{114}$ Lieutenant-Colonel D.W. Churcher $p s c$ became a GSO2 then a GSO1 to the end of the war.

11514 were appointed to Brigade command alone, namely Lieutenant-Colonels E.C.Peebles $\left(2^{\text {nd }}\right.$ Norfolk -19 Brigade 25 January 1916); J.O. Travers $\left(2^{\text {nd }}\right.$ Devonshire -199 Brigade 20 May 1916); F.W. Towsey $\left(1^{\text {st }}\right.$ West Yorkshire - 122 Brigade 27 September 1915); C.R.J Griffith $\left(1^{\text {st }}\right.$ Bedfordshire 108 Brigade 4 December 1915); T.H.F. Pearse ( $2^{\text {nd }}$ Cheshire -84 Brigade 27 September 1915); H.G. Casson $\left(2^{\text {nd }}\right.$ South Wales Borderers -87 Brigade 11 July 1915); C.B. Westmacott $\left(2^{\text {nd }}\right.$ Worcestershire -2 Brigade 23 November 1914); M.N. Turner ( $1^{\text {st }}$ Duke of Cornwall's Light Infantry -15 Brigade 28 June 1915); R.M. Ovens $\left(1^{\text {st }}\right.$ South Staffordshire -149 Brigade 14 September 1916); C.S. Davidson (2 ${ }^{\text {nd }}$ South Staffordshire -123 Brigade 30 September 1915); C.S. Prichard $\left(2^{\text {nd }}\right.$ Northamptonshire 119 Brigade 8 May 1916); E. PearceSerocold $\left(2^{\text {nd }}\right.$ King's Royal Rifle Corps -68 Brigade 3 June 1915); C. Gosling $\left(3^{\text {rd }}\right.$ King's Royal Rifle Corps - 7 Brigade 23July 1915); H.S. Ainslie ( $1^{\text {st }}$ Northumberland Fusiliers -18 Brigade 29 May 1915). 14 were appointed to Brigade command and to subsequent staff posts, namely Lieutenant-Colonels R. le N. Ardee $\left(1^{\text {st }}\right.$ Grenadier Guards -4 Guards Brigade 8 February 1918); H.C. Lowther ( ${ }^{\text {st }}$ Scots Guards -1 Guards Brigade 13 November 1914); C.R. Ballard ( $1^{\text {st }}$ Norfolk -7 Brigade 23 November 1914); G.M Gloster (1 $1^{\text {st }}$ Devonshire - 64 Brigade 18 August 1915); D.M. Stuart ( $2^{\text {nd }}$ Royal Scots Fusiliers -58 Brigade 8 July 1915); H.D. Tuson $\left(2^{\text {nd }}\right.$ Duke of Cornwall's Light Infantry - 23 Brigade 7 September 1915); C.L. Macnab ( $1^{\text {st }}$ Royal Sussex - 1 Royal Naval Bde 27 May 1916); F.G. Anley (2 $2^{\text {nd }}$ Essex -12 Bde 4 October 1914); C.J. Sackville-West $\left(4^{\text {th }}\right.$ King's Royal Rifle Corps -21 Brigade 8 December 1915); V.W. De Falbe ( ${ }^{\text {st }}$ North Staffordshire -185 Brigade 4 January 1916); J.D. McLachlan ( ${ }^{\text {st }}$ Cameron Highlanders -8 Brigade 3 October 1915).

${ }^{116}$ Lieutenant-Colonels J. Ponsonby ( $1^{\text {st }}$ Coldstream Guards $-40^{\text {th }}$ Division 4 August 1917); C.E. Pereira $\left(2^{\text {nd }}\right.$ Coldstream Guards $-2^{\text {nd }}$ Division 27 December 1916); G.P.T Feilding ( $3^{\text {rd }}$ Coldstream Guards - Guards Division 3 January 1916); W.E.B. Smith $\left(1^{\text {st }}\right.$ Lincolnshire $-52^{\text {nd }}$ Division 11 July 1916); H.L. Croker $\left(1^{\text {st }}\right.$ Leicestershire $-28^{\text {th }}$ Division 21 March 1915); C.G. Blackader $\left(2^{\text {nd }}\right.$ Leicestershire $-38^{\text {th }}$ Division 12 July 1916); W.D. Smith ( $1^{\text {st }}$ Royal Scots Fusiliers $-20^{\text {th }}$ Division 8 March 1916); P.R. Robertson $\left(1^{\text {st }}\right.$ Cameronians $-17^{\text {th }}$ Division 13 July 1916$)$; D.E. Cayley $\left(4^{\text {th }}\right.$ Worcestershire $-29^{\text {th }}$ Division 19 March 1918); C.L. Nicholson ( $2^{\text {nd }}$ East Lancashire $-34^{\text {th }}$ Division 25 July 1916); J.R. Longley $\left(1^{\text {st }}\right.$ East Surrey $-10^{\text {th }}$ Div 21 December 1915); F.A. Dudgeon $\left(1^{\text {st }}\right.$ South Lancashire $-56^{\text {th }}$ Division 10 August 1917); T.O. Marden $\left(1^{\text {st }}\right.$ Welsh $-6^{\text {th }}$ Division 21 August 1918$)$; H.R. Davies $\left(2^{\text {nd }}\right.$ Ox \& Bucks $-11^{\text {th }}$ Division 1 May 1917); E. Feetham $\left(1^{\text {st }}\right.$ Royal Berkshire $-39^{\text {th }}$ Division 20 August 1917); R.J. Bridgford $\left(2^{\text {nd }}\right.$ Shropshire Light Infantry - $31^{\text {st }}$ Division 21 March 1918); C.P.A. Hull ( $4^{\text {th }}$ Middlesex $-56^{\text {th }}$ Division 6 February 1916); E.P Strickland $\left(1^{\text {st }}\right.$ Manchester $-1^{\text {st }}$ Division 12 June 1916); W.C.G. Heneker $\left(2^{\text {nd }}\right.$ North Staffordshire $-8^{\text {th }}$ Division 8 December 1916); A.B. Ritchie ( $1^{\text {st }}$ Seaforth Highlanders $-11^{\text {th }}$ Division 5 December 1916); P.R.Wood $\left(2^{\text {nd }}\right.$ 
viability, or 'endurance or promotability' rate of 64 per cent. The indication is that nearly two thirds of these COs were leaders of stamina and quality.

\subsubsection{The Auxiliaries}

Of the auxiliary infantry, the Special/Extra Reserve had always received more extensive training than the Territorials. ${ }^{118}$ Their officers were, of course, denied staff experience. ${ }^{119}$ The auxiliary COs, apart from those who were ex-Regulars, were, therefore, deficient in both education and staff experience.

In respect of the Special Reserve, only four battalions would actually see active service as units, ${ }^{120}$ and only one was taken overseas by its CO of August $1914 .{ }^{121}$ In all, 15 of the SR COs of August 1914 saw active service. Eight saw service as COs of Service battalions; ${ }^{122}$ five with TF battalions; and one, briefly, with a Regular battalion. Sixty per cent were exRegulars and hence previous professional experience was one of the principal reasons they

Royal Irish Fusiliers $-33^{\text {rd }}$ Division 12 September 1917); H.S.L. Ravenshaw $\left(1^{\text {st }}\right.$ Connaught Rangers $-27^{\text {th }}$ Division 23 September 1916); G.H. Thesiger $\left(4^{\text {th }}\right.$ Rifle Brigade $-9^{\text {th }}$ Division 9 September 1915); L.J. Bols $\left(1^{\text {st }}\right.$ Dorsetshire $-24^{\text {th }}$ Division 18 May 1917); E. Northey ( $1^{\text {st }}$ King's Royal Rifle Corps was promoted Major-General commanding the Nyasaland Rhodesia Field Force in German East Africa).

117 Lieutenant-Colonels R.B. Stephens ( $2^{\text {nd }}$ Rifle Brigade - X Corps 3 July 1918); W.R Marshall ( $1^{\text {st }}$ Sherwood Foresters - III Indian (Tigris) Corps 24 September 1916); R.H.K Butler ( $2^{\text {nd }}$ Lancashire Fusiliers III Corps 26 February 1918).

${ }^{118}$ The Militia officer had four months training in his first year and one month in every subsequent year. The TF officer had to partake in drills, (40 in the first year, 10 thereafter), and 15 days annual summer camp, and undergo a course in musketry. The one month Initial Course at a training centre was optional, but to progress beyond Captain, the 21 day course at the School of Musketry, Hythe, was obligatory.

${ }^{119}$ Regulars filled the role of Adjutant in their Battalions.

${ }^{120}$ The four were Extra Reserve Battalions of the Liverpool, Bedfordshire and North \& South Staffordshire Regiments. Haldane had always intended that the Extra Reserve Battalions "might be sent to the Mediterranean as garrison battalions or to the Continent for line of communication duties". [K.W. Mitchinson, Defending Albion (Basingstoke: Palgrave Macmillan, 2005), p.5].

${ }^{121}$ Lieutenant-Colonel J.W. Allen of the $4^{\text {th }}$ King's Liverpool, who saw 456 days active service. The CO of the $4^{\text {th }}$ North Staffordshire, Lieutenant-Colonel B.I. Way was transferred to the $8^{\text {th }}$ East Yorkshire and was wounded twice as $\mathrm{CO}$ before retiring. The $4^{\text {th }}$ South Staffordshire were taken overseas by a pre-war Regular Major (T.R. Stokoe) and the $4^{\text {th }}$ Bedfordshire by their senior Major (R.P. Croft).

${ }^{122}$ See, for instance, Chapter Two, Table 2.4. 
were selected for active service. One, indeed, was promoted to brigade command. ${ }^{123}$ Each spent nearly ten months on average on active service, and one, the redoubtable LieutenantColonel G.T.B. Wilson (4 ${ }^{\text {th }}$ Argyll \& Sutherland Highlanders) had four active service commands, (including 60 days with $2 / 7^{\text {th }}$ Lancashire Fusiliers, 359 with $1 / 4^{\text {th }}$ King's Own Scottish Borderers, and 333 with $2 / 6^{\text {th }}$ Manchester). It may be concluded that some were capable of giving better service than might have been expected. ${ }^{124}$

The TF COs were similarly deficient in not only education and staff experience, but also exposure to war. Even the ex-Regulars had only half as much war experience as their active Regular counterparts, ${ }^{125}$ and that of the ex-Volunteers was confined to South Africa, eight per cent of them having seen service there in 1899 and 26 per cent between 1900 and 1902.

Again, no objective competence rating can be calculated for the TF COs of August 1914. The first test of suitability for command was, of course, whether they took their battalions on active service. (Whilst it might be argued that they were never primarily intended to see service abroad, ${ }^{126}$ TF COs certainly faced the potential of commanding their battalions in action on home soil).

\footnotetext{
${ }^{123}$ Lieutenant-Colonel Arthur Corrie Lewin ( $3^{\text {rd }}$ Connaught Rangers) was promoted to the command of 40 Brigade on 19 October 1915.

${ }^{124}$ Lord Kitchener, on taking up post as Secretary of State for War described these men as "those old gentlemen I have seen parading with umbrellas in Hyde Park," confusing them with the National Reserve. (C. Harris, 'Kitchener and the Territorials' The Times, 28 August 1928, p. 13. Sir Charles Harris was Assistant Financial Secretary, War Office, throughout the war.)

${ }^{125}$ See Tables 1:3 and 1:8.

${ }^{126}$ Haldane "expressed the hope that between one-sixth and one-quarter" of the TF would "actually opt to undertake a foreign service obligation". [Hansard, $4^{\text {th }}$ Series Vol. 169, 1301, 25 February 1907, cited in Mitchinson, Defending Albion, p.6].
} 
Of the 206 battalions, ${ }^{127} 26$ COs did not see active service because their battalions remained in England or were posted to a non-combat zone. Of the remaining 180, 71 were removed from the command of their battalions before they went abroad. The remaining 109 give an 'appropriate to command in war' rate of 61 per cent. ${ }^{128}$

The reasons for 39 per cent not proceeding on active service are probably twofold. ${ }^{129}$ (It was not connected with previous experience as 56 per cent of 'Territorial only' COs went abroad in comparison with 60 per cent of ex-Regulars). Firstly, their regimental histories often refer to age and health. Whilst health remains an unknown factor, ${ }^{130}$ the TF COs who did not take their battalions abroad were only two years older than those who did. ${ }^{131}$ It is, of course, possible that in these part-time soldiers who might be less fit than Regulars of the same age, two years made a difference. It is more likely that 'age and health' was to an extent euphemistic and that foremost was perceived appropriateness/competence. Lord Derby ${ }^{132}$ described Lieutenant-Colonel H.L. Beckwith of the $4^{\text {th }}$ Loyal North Lancashire as "absolutely useless ... to show you what sort of man he is he says he cannot go out now to

\footnotetext{
127 There were technically 207 battalions, but one, $7^{\text {th }}$ King's Liverpool, the one remaining Volunteer battalion, was not commanded by a Lieutenant-Colonel.

${ }^{128}$ Seven of the TF COs of August 1914 saw active service at the heads of battalions other than those they were commanding at the outbreak of war.

${ }^{129}$ Lieutenant-Colonel David Christie Campbell, CO $1 / 6^{\text {th }}$ Black Watch, was removed from command by death, in the autumn of 1914, and hence never had the chance to lead his battalion. Lieutenant-Colonel Sir Mark Sykes, CO 1/5 ${ }^{\text {th }}$ Green Howards, was pressed into service by Lord Kitchener onto the de Bunsen Committee, advising on Middle-Eastern affairs. Lieutenant-Colonel Bernard Alexander Firth, CO $1 / 4^{\text {th }}$ York \& Lancaster, who was a member of the prominent Sheffield steel family, resigned to pursue a career the munitions industry. Lieutenant-Colonel Walter Naish, $1 / 4^{\text {th }}$ Hampshire, was an ordained clergyman whose bishop would not allow him to go overseas with his battalion. The point is the same - these three men were inappropriately positioned for battalion command if, in the event of war, they could not lead their battalions.

${ }^{130}$ Lieutenant-Colonel William Johnston Younger ( $4^{\text {th }}$ Royal Scots), for instance, resigned his commission on the grounds of ill-health in January 1915 without seeing active service.

13148 years three months versus 46 years three months, on average.

${ }^{132}$ The $17^{\text {th }}$ Earl of Derby, MP, appointed Director-General of Recruitment in 1915, was one of the originators of the local recruitment ('Pal's Battalions') movement.
} 
the Front but he would be ready to go out later when the weather gets warmer". ${ }^{133}$ The best perspective that might be put on the refusal of Lieutenant-Colonel R.G. Hayes, $15^{\text {th }}$ London, to take the Imperial Service Obligation was that he recognised his limitations. ${ }^{134}$ Garth Pratten's observation on Australian Militia COs on the outbreak of World War Two is absolutely applicable to these auxiliary COs: "Senior command was perhaps beyond all but the most committed part-time officer". ${ }^{135}$ As William Mitchinson summarises: "Although usually keen and proud of their unit, many ... were, in the opinion of the professionals, not up to the task of commanding a battalion". ${ }^{136}$ The TF County Associations had clearly had difficult in asserting authority over the local interests involved in battalion command that had historically been marked. ${ }^{137}$

The first Territorial battalion to go into action was, famously, the $1 / 14^{\text {th }}$ Battalion, London Regiment (London Scottish), on the Messines Ridge on 31 October. Having landed in France on 16 September it had been put to lines of communication duties. Sent to Ypres on 29 October, it was commanded by 42 year-old Lieutenant-Colonel G.A. Malcolm, an East India merchant and 'pure' TF CO, who on 10 October was "greatly indignant" about being

\footnotetext{
${ }^{133}$ Derby papers LRO 920 DER(17)33 13 February 1915 [quoted in P. Simkins, Kitchener's Army: The Raising of the New Armies 1914-1916 (Barnsley: Pen \& Sword, 2007) p.221]. Beckwith resigned in October 1914, but later served as a Major in the Labour Corps.

${ }^{134}$ The Imperial Service Obligation was a voluntary agreement to serve overseas. Robert George Hayes was relegated to the $2 / 15^{\text {th }}$, then the $3 / 15^{\text {th }}$. His leadership example seems to have degraded morale and led to a good deal of refusal of Imperial Service in his battalion. One of the other ranks noted that the arrival of his successor, the Earl of Arran, "bucked things up a lot". J. Knight, The Civil Service Rifles in the Great War (Barnsley: Pen \& Sword, 2004), p.33

${ }_{135}$ G. Pratten, Australian Battalion Commanders in the Second World War (Melbourne: Cambridge University Press, 2009), p.31

${ }_{136}^{136}$ Mitchinson, England's Last Hope, p.159

${ }^{137}$ Volunteer battalions had been very much the personal fiefdoms of their COs - indeed, they had a major personal interest, being personally responsible for any debts incurred.
} 
“too late to have a look in". ${ }^{138}$ Malcolm's 'look in' lasted until 15 February 1915, when he was invalided home.

Of the 109 TF COs of 1914 who proceeded to command battalions on active service, thirty-seven per cent were lost to command through being killed (15), seriously wounded (five), or invalided (20). Nineteen (17 per cent) were relieved and retired, and 18 (16 per cent) were relieved but employed further in third-line battalion commands or administrative jobs. ${ }^{139}$ Fifteen commanded their units into late 1917/1918, and four were promoted Brigadier General. ${ }^{140}$

In an attempt to review the overall viability as $\mathrm{CO}$ of those who took their battalions to war, a period in command of six months will be assumed as likely to reveal the effects of age, health and ability. Removing those who could not have furthered their careers because of death or serious wounds, there remains a group of 89 men and of these 63 ( 71 per cent) were promoted or served over six months, and hence were viable commanders.

If the group who did not take their battalions overseas are included, the overall viability rate for the TF COs in a sustained continental war falls to 31 per cent. This may not have been what they were primarily intended to do, but it was what they were required to do. The majority were not up to the challenge.

\footnotetext{
${ }^{138}$ J.C. Dunn, The War the Infantry Knew (London: Jane's, 1987), p. 69

${ }^{139}$ Those who were given another job were in post for 330 days (16 per cent served under three months, five per cent between three and six months, and 79 per cent served over six months); those who were not given another job were in post for 243 days, indicating that the group who were retired had less endurance/ability. Of this latter group, 31 per cent served under three months, 16 per cent between three and six months, and 53 per cent served over six months.

${ }^{140}$ Lieutenant-Colonel Viscount Hampden ( $1^{\text {st }}$ Hertfordshire - 140 Brigade, 15 July 1916); LieutenantColonel A. A. Howell (1/3 ${ }^{\text {rd }}$ London - 167 Brigade, 30 June 1916) on 11 October 1916; Lieutenant-Colonel F. G. Lewis (1/13 ${ }^{\text {th }}$ London -142 Brigade, 14 August 1915); Lieutenant-Colonel J. B. Pollok-McCall $\left(1 / 5^{\text {th }}\right.$ Royal Scots Fusiliers - 25 Brigade, 3 June 1918).
} 


\subsection{Attrition of Command in the BEF in 1914}

By the end of 1914 the BEF had passed through the battles of Mons, Le Cateau, the Marne and the Aisne, and had been violently mauled at First Ypres. By this time there were 123 Regular and 23 TF battalions in France. After First Ypres ${ }^{141}$ it has been claimed that "in most cases, there were barely one officer and 30 men left" from the battalions who had arrived in France in $1914 .^{142}$

By 31 December 1914, 1,278 officers had died, 2,209 were wounded, and 783 were missing or prisoners, comprising a total of 4,041 Regular officers (4271 including Indian Army and Territorials), or nearly 32 per cent of the 12,738 Regular officers of August 1914. ${ }^{143}$ Keith Simpson notes that from $1^{\text {st }}$ Queen's, of 26 officers, 24 were casualties by this date; from $1^{\text {st }}$ Norfolk, 15 of 26 ; from $3^{\text {rd }}$ Worcestershire, 15 of 28 ; and from $1^{\text {st }}$ Northamptonshire, 26 of $26 .^{144}$

By the end of 1914, 18 of the Regular COs of August 1914 were dead. ${ }^{145}$ Five were prisoners of war. ${ }^{146}$ Two had been lost through court martial, six had been promoted to

\footnotetext{
14119 October to 22 November 1914.

${ }^{142}$ I.F.W. Beckett, Ypres - The First Battle 1914 (Harlow: Pearson, 2004), p.177

${ }^{143}$ Statistics of the Military Effort of the British Empire during the Great War 1914-1920 (London: HMSO, 1922), p. 353 and p.234

${ }^{144}$ Edmonds, France and Belgium 1914, Vol. II, p.467. K. Simpson, 'The Officers', in I.F.W. Beckett \& K. Simpson, eds. A Nation in Arms: A Social Study of the British Army in the First World War (Manchester: Manchester University Press, 1986), p.69

${ }^{145}$ Lieutenant-Colonels A.McN. Dykes ( $1^{\text {st }}$ Kings Own Royal Lancaster) and C.A.H. Brett ( $2^{\text {nd }}$ Suffolk) were killed on 26 August 1914 at Le Cateau. Lieutenant-Colonel G.H. Morris ( ${ }^{\text {st }}$ Irish Guards) was killed at Villers-Cotterets on 1 September 1914. Lieutenant-Colonel G.C. Knight ( $1^{\text {st }}$ Loyal North Lancashires) was killed on 11September 1914 on the Marne. Lieutenant-Colonels A. Grant-Duff ( $1^{\text {st }}$ Black Watch) and E.H. Montresor ( $2^{\text {nd }}$ Royal Sussex) were killed on 14 September 1914 on the Aisne as were Lieutenant-Colonels L.St.G. Le Marchant and E. R. Bradford ( $2^{\text {nd }}$ Seaforth Highlanders) on 14 September 1914, LieutenantColonel D. Warren $\left(1^{\text {st }}\right.$ Queens Royal West Surrey) on 17 September 1914, and Lieutenant-Colonel R.E. Benson $\left(1^{\text {st }}\right.$ East Yorkshires $)$ on 20 September 1914. Lieutenant-Colonel B.E. Ward $\left(1^{\text {st }}\right.$ Middlesex $)$ was killed on 22 October 1914 at Armentieres. Lieutenant-Colonel W.L. Loring ( $2^{\text {nd }}$ Royal Warwicks) was killed on 23 October 1914 at $1^{\text {st }}$ Ypres, as were Lieutenant-Colonels E.S. Bannatyne ( ${ }^{\text {st }}$ Kings Liverpool) on 24 October 1915, H.O.S. Cadogan ( $1^{\text {st }}$ Royal Welsh Fusiliers) and C.A.C. King ( $1^{\text {st }}$ Yorkshires $)$ on 30 October
} 
brigade command, twenty-four had been wounded, 10 had been invalided, and six replaced. On 31 December 1914, 52 (42 per cent) original Regular Lieutenant-Colonels were still in command of their battalions. The high levels of dead and wounded may be seen as either profligacy with a crucial resource, or a reflection of the ferocity of the fighting. Fifty-four battalions (44 per cent) were commanded by men who were Majors at the outbreak of war; ${ }^{147} 16$ (13 per cent) were commanded by men who had been Captains, ${ }^{148}$ and one by a $2^{\text {nd }}$ Lieutenant. ${ }^{149}$ (All of the TF battalions were still commanded by the men who had brought them to France, except for two COs who had swiftly been invalided). ${ }^{150}$

This snapshot suggests that notwithstanding a 58 per cent attrition in original COs, the state of battalion command in the BEF would not appear at first glance to have been fatally 'deskilled' given the proportion of Lieutenant-Colonels and pre-war Majors in command. At times, however, the situation had been desperate.

$1^{\text {st }}$ Coldstream Guards had landed in France on 13 August 1914 under Lieutenant-Colonel J. Ponsonby. When he was wounded on 15 September 1914, the second-in-command, Major the Hon. L. d'H Hamilton took over only to be killed on 29 October 1914. Depletion of officers meant that Lieutenant J. Boyd took over for two days, being replaced on 1

1914, C.B. Morland ( $2^{\text {nd }}$ Welsh) on 31 October 1914, and N.R. McMahon on 11 November 1914. Lieutenant-Colonel R. Alexander ( $3^{\text {rd }}$ Rifle Brigade) died of wounds on 22 November 1914.

${ }^{146}$ Lieutenant-Colonels D.C. Boger ( $1^{\text {st }}$ Cheshires $)$, and R.C. Bond $\left(2^{\text {nd }}\right.$ Kings Own Yorkshire Light Infantry at Le Cateau on 26 August 1914, Lieutenant-Colonel H. McMicking ( $2^{\text {nd }}$ Royal Scots) on 27 August 1914, and Lieutenant-Colonel J.F. Forbes ( $2^{\text {nd }}$ Wiltshire) on 24 October 1914, and Lieutenant-Colonel R.G.I. Bolton ( $2^{\text {nd }}$ Scots Guards) on 26 October 1914.

${ }^{147}$ One was a retired Regular who was a Major in the Special Reserve, the other a retired Regular Major.

${ }^{148}$ One was a retired Captain from the Special Reserve, the other a retired Regular Captain.

$1492^{\text {nd }}$ Lieutenant G.C.B Clark, $2^{\text {nd }}$ Royal Scots had, however, been promoted to Major.

150 Lieutenant-Colonel G.A. Blair (1/10 ${ }^{\text {th }}$ Liverpool), a Major in the TF Reserve in August 1914, was invalided on 25 November 1914, after 23 days in France. Lieutenant-Colonel G.B. Heywood (1/6 ${ }^{\text {th }}$ Cheshire) a TF Captain in August 1914 was invalided on 18 December 1914 after 38 days in France. 
November by Captain E.G. Christie-Miller, who was taken prisoner the following day. Command devolved on Lieutenant Boyd again for another two days before he was replaced by Captain G.J. Edwards, who was superseded by the return of LieutenantColonel Ponsonby on 21 November.

$1^{\text {st }}$ Cheshire found themselves in similar straits. After Lieutenant-Colonel D.C. Boger was taken prisoner on 24 August 1914, there were no Majors present to assume command of the shattered battalion, and Captain J.L. Shore became CO until 16 September. His replacement by Major F.B. Young, a Major from the Reserve of Officers, was part of a succession of seven COs during the month of October. Young was replaced by Major C.B. Vandeleur, ( $1^{\text {st }}$ Scottish Rifles), who was succeeded by three Captains of $1^{\text {st }}$ Cheshire, ${ }^{151}$ and one of $2^{\text {nd }}$ Munster Fusiliers. ${ }^{152}$ Lieutenant T.L. Frost of $1^{\text {st }}$ Cheshire was in command as October came to a close. He was replaced after five days by a Major from the Reserve of Officers, J.A. Busfeild, who gave way to Major H.S. Hodgkin, a Regular Captain in August 1914, who was in command at the year's end.

The flavour of being in temporary command during this period is given by Captain H.C. Rees, $2^{\text {nd }}$ Welsh. ${ }^{153}$ On 31 October 1914 at Gheluvelt, after the death of Lieutenant-Colonel C.B. Morland, ${ }^{154}$ Rees was left in command with one other officer and 25 men. On 18 or 19 January 1915, he gave way to Captain W.M. Hore. Rees was the sixth senior (and

\footnotetext{
${ }^{151}$ Captains F.H. Mahony, J.L Shore (again) and B.E. Massy.

${ }^{152}$ Captain G.A. Woods. Neither the Munsters nor the Scottish Rifles were in the same brigade as the Cheshires - this extra-regimental support was therefore very ad hoc.

${ }^{153}$ As the first of four brigade commands, Rees would be commanding 94 Brigade opposing Serre on 1 July 1916.

154 "It was then that a shell burst in front ... mortally wounding Colonel Morland on my right. It was a final blow. Colonel Morland was a terrible loss. I never saw him the slightest degree upset by anything that happened. He remained to the very end as cool and collected as if he was on parade at home". BrigadierGeneral H. C. Rees, A Personal Record of the First 7 Months of the War, IWM 77/179/1
} 
second most junior) Captain in the $2^{\text {nd }}$ Battalion; Hore (who had been serving with the $3^{\text {rd }}$

Battalion on the outbreak of war) was the fifth senior. ${ }^{155}$ Rees noted:

Captain Hore arrived from England and being just senior to me, I had to relinquish command of the battalion. I remained as second-incommand and discussed on most questions connected with the battalion as it was very difficult for him just out from home to at once grasp the tactics of the war.

In an encounter with Brigadier-General J. Gough: ${ }^{156}$

I asked him to let me go home to England for a job. I pointed out that I had commanded the battalion through three strenuous months, and that having built them up from the remnants remaining after the First Battle of Ypres, I found my position somewhat difficult.

These comments inform us firstly about Rees's vanity and ambition; secondly about the bond a $\mathrm{CO}$ could develop with a battalion he was rebuilding; and thirdly how the traditional principle of seniority could override hard-won experience and demotivate a keen and able officer. Lastly, and positively, it suggests that junior officers were quickly learning new tactics and the skills of command.

Balancing the picture of those in command on 31 December 1914 against the accounts of both $1^{\text {st }}$ Coldstream Guards and $1^{\text {st }}$ Cheshire, and other examples such as $2^{\text {nd }}$ Welsh being commanded by their second most junior Captain for three months, the most alarming reality for the BEF was that attrition was taking place not just at senior level but also extensively at the level of middle-ranking officers.

\footnotetext{
${ }^{155}$ Rees was promoted Captain on 12 June 1912, Hore on 1 April 1912. Rees, born 26 March 1882, and commissioned from the Militia on 28 Jan 1903, was 32 when he assumed command with 11 years' service with the Regular army.

156 “Johnnie" Gough VC, was Sir Douglas Haig's Chief of Staff with both I Corps and First Army.
} 


\subsection{Conclusion}

If, as James Edmonds states, "in every respect the Expeditionary Force of 1914 was incomparably the best trained, best organized, and best equipped British Army which ever went forth to war", ${ }^{157}$ then the Regular COs of 1914 were almost certainly the most competent group of COs that the army had ever put in the field. Contrary to Tim Travers' assertion that the supposed 75 per cent incompetence rate of COs in 10 Brigade was probably "not unique", ${ }^{158}$ an overall 64 per cent 'endurance or promotability' competence rate is indicated.

Whatever the limitations of their education, their richly textured biographies speak to considerable 'on the job' professional development. They possessed a considerable depth of staff and wartime experience, particularly of tactical diversity, within an army somewhat less hidebound by seniority and regimental particularism than has been supposed. They had ascended their professional ladder during a period of change when the infantry became much more tactically suited to the continental war of which it lacked experience. From the percentage who failed the test of "Fitness to Command", their promotion had been no formality.

In comparison, however, only a third of the Territorial Force COs, a group which, in its defence, had not been intended to embark on continental campaigning, proved viable battalion commanders. Many lacked the fitness, stamina and will required, let alone the ability.

\footnotetext{
${ }^{157}$ J.E. Edmonds, Military Operations, France and Belgium 1914, Vol. 1 (Nashville: Battery Press, originally published 1933), p.10

${ }_{158}$ T. Travers, The Killing Ground: The British Army, the Western Front, and the Emergence of Modern Warfare 1900-1918 (Barnsley: Pen \& Sword, 2003), p.14
} 
The ferocity of the fighting of 1914 and the requirement to provide brigade command to the expanding army, however, began to erode not only the stock of experienced senior officers available to the Regular battalions, but also the stock of middle-ranking officers. These men would be increasingly required to step up to the mark of battalion command not only in their own units but also those of the New Armies and the expanding Territorial Force. The next three chapters explore how this organisational challenge was met. 


\title{
Chapter Two
}

\section{Raising the New Armies and Expanding the Territorial Force - Battalion Command 1914-15}

\author{
'Dug-outs.' They were but ghosts of the past inserted by the War \\ Office to fill a blank cubby hole.
}

\author{
Colonel W.N. Nicholson ${ }^{1}$
}

As the BEF in France was locked in its struggle with the German army, so Lord Kitchener, Secretary of State for War, was enacting his most important contribution to victory, the raising of the New Armies. ${ }^{2}$

\subsection{New Army Infantry Service Battalions}

During 1914-15, 703 New Army infantry Service Battalions were raised. Of these, 404 saw active service, including 40 pioneer battalions. ${ }^{3}$ One hundred and fifty-three were retained

\footnotetext{
${ }^{1}$ Nicholson was actually referring to staff 'dug-outs'. His phrase, however, captures the negative light in which these retired officers, who have come to symbolise command in the nascent battalions of the New Armies, have come to be seen. W.N. Nicholson, Behind the Lines An Account of Administrative Staffwork in the British Army 1914-1918 (Stevenage: Tom Donovan, 1989), p.12

${ }^{2}$ Lord Kitchener of Khartoum, a career soldier of the Royal Engineers, had joined the Egyptian Army and risen to be its Sirdar, or Commander-in-Chief. Following his victory at Omdurman in 1898 he became Governor-General of Sudan. He was Commander-in-Chief in South Africa from November 1900, and subsequently Commander-in-Chief in India to 1909. He was British agent in Egypt in 1914, but was on leave in London when war broke out. A national hero who would inspire unity behind a government of whom he was a member, he became Secretary of State for War on 5 August 1914. Kitchener's decision to raise the New Armies outside of the existing structure of the Territorial Force has provoked controversy. Charles Messenger is typical in attributing this simply to "deep prejudice against 'amateur' soldiers". [C. Messenger, Call to Arms - The British Army 1914-18 (London: Weidenfeld \& Nicholson, 2005), p.94]. Whilst there may be truth in this attitude, Peter Simkins presents a reasoned argument that Kitchener took into account the possibility of invasion, in the repulsion of which the TF would have been expected to play a major role, against a background of initial sluggish commitment to Imperial Service on the part of TF battalions. [P. Simkins, Kitchener's Army: The Raising of the New Armies 1914-1916 (Barnsley: Pen \& Sword, 2007], pp.41-6).

${ }^{3}$ Each division had an attached pioneer battalion which was responsible for engineering/labour tasks such as digging entrenchments.
} 
in the UK as reserve battalions; 54 saw service abroad or in the UK as Labour, Transport or Dock Work battalions; and 92 served as Garrison or Home Service battalions.

\subsubsection{First COs: K1}

Kitchener's call to arms for the first 100,000 volunteers to create six new divisions was published on 7 August 1914.

Of the $80 \mathrm{~K} 1$ battalions raised, ${ }^{4}$ all were supplied with professional officers as $\mathrm{CO}, 82$ per cent receiving active Regulars, 65 Majors and a Lieutenant-Colonel. One received an active Indian Army Lieutenant-Colonel. ${ }^{5}$ Seven were given retired Regulars from the Reserve of Officers, including five Lieutenant-Colonels, one Major and a Captain, who had been retired on average only one year eight months (range three years four months to one month) and had an average age of 49 years five months. Three battalions received COs from amongst active Special Reserve officers (two Lieutenant-Colonels already commanding SR battalions and one Major, ${ }^{6}$ all retired Regulars) with an average age of 42 years eight months. Lastly, three were allocated other ex-Regulars (a Colonel, Major and Captain) who had been retired on average seven years seven months (range 10 years to four years five months), with an average age of 51 years eight months. ${ }^{7}$

\footnotetext{
${ }^{4}$ Each infantry regiment of the line raised one new battalion, but the Royal Scots, Highland Light Infantry, Royal Munster Fusiliers, Royal Dublin Fusiliers, Royal Irish Fusiliers and the Royal Fusiliers provided two, the Rifle Brigade and King's Royal Rifle Corps raising three K1 battalions. In the latter, the formation of the second battalion was started as soon as 100 recruits were allotted to the first. When the second battalion numbered 100, drafts were sent to each equally. (Circular from Adjutant-General's Department to GOCs-inC of Commands, 24 August 1914, TNA WO 162/3, cited in Simkins, Kitchener's Army, p.67).

${ }^{5}$ Lieutenant-Colonel Arthur Grant - see below concerning his short career.

${ }^{6}$ William Ernest Sykes, a Captain of the Lancashire Fusiliers was transferred to the Special Reserve of the Worcestershire Regiment with the rank of Major on 17 February 1912, and was given command of the $9^{\text {th }}$ Worcestershire. This elevation did him no good, as he died of natural causes on 8 January 1915.

7 In 1910 the TF County Associations were "tasked with maintaining a register of trained officers and soldiers who were under no further obligation to serve in the Forces of the Crown", the National Reserve,
} 


\subsubsection{First COs: K2}

Kitchener's second appeal for a further 100,000 was made on 27 August $1914 .^{8}$ Seventynine $\mathrm{K} 2$ battalions were raised. ${ }^{9}$

The well had not entirely run dry on active Regulars, and seven Majors and four Lieutenant-Colonels (two of the latter on half-pay), as well as one Colonel and four Lieutenant-Colonels from the Indian Army were appointed. Twenty per cent active professional soldiers were found for K2 compared with 84 per cent for K1. There was, therefore, a large increase in the number of retired officers used; 12 per cent for $\mathrm{K} 1$ compared with 78 per cent for K2. From the Reserve of Officers there were two Colonels, 11 Lieutenant-Colonels, 11 Majors and one Captain. ${ }^{10}$ Their average age was 50 years three months, and they had been retired on average two years nine months (range 11 years seven months to 10 days). Of the other retired officers, 25 were Colonels (substantive, brevet or honorary), seven Lieutenant-Colonels, and five Majors. All were ex-Regulars. In addition, one Lieutenant-Colonel from the unattached list of the Special Reserve was

(Messenger, Call to Arms, p.23). The military authorities thus kept track of officers who had left the Reserve of Officers.

${ }^{8}$ This tranche of recruits was intended to bring all Special Reserve battalions up to a strength of 2000 (Minutes of meeting of the Military Members of the Army Council, 27 August 1914, TNA WO 163/44, cited in Simkins, Kitchener's Army, p.60). The second series of six divisions was, however, authorised on 1 September 1914.

${ }^{9}$ The King's Own Scottish Borderers, Gordon Highlanders, Royal Irish, Royal Inniskilling, Royal Dublin and Royal Munster Fusiliers raised two; and the King's Royal Rifle Corps and Rifle Brigade raised three K2 battalions.

${ }^{10}$ Captain Sir Mervyn Edward Manningham-Buller Bt. had retired from the Rifle Brigade, having served as Adjutant, on 3 January 1903. He was invalided from $12^{\text {th }}$ Rifle Brigade in September 1915 and saw no further active service. 
appointed. ${ }^{11}$ Their average age was 55 years seven months, and they had been retired on average seven years 11 months (range 23 years to eight months). ${ }^{12}$

\subsubsection{First COs: K3}

On 9 September 1914 Kitchener authorised the formation of twelve more divisions, the Third New Army being raised immediately, the Fourth to be formed from any surplus sent to the Special Reserve battalions. ${ }^{13}$ Eighty-nine K3 battalions were formed. ${ }^{14}$

Five active Regulars were found to command. They were somewhat more remote from regimental employ; a Colonel and a Lieutenant-Colonel on the unemployed active list; a Lieutenant-Colonel on half-pay; and two Majors, one attached to the Colonial Office. Fifteen active Indian Army officers were used, seven Colonels and eight LieutenantColonels. Only one officer from the Special Reserve was appointed, an ex-Regular Major; and for the first time, a Territorial Force Major was used, (an ex-regular Captain). ${ }^{15}$ Seventy-five per cent of K3 COs were retired officers. From the Reserve of Officers there

\footnotetext{
${ }^{11}$ Lieutenant-Colonel William Kemmis was the first non-regular appointee to a Kitchener battalion, namely $11^{\text {th }}$ Hampshire (Pioneers). He had served with the $4^{\text {th }}$ Royal Lancaster, seen active service in South Africa 1900-1, and had served as Commandant, Port Elizabeth.

${ }^{12}$ Lieutenant-Colonel Edward Stuart St. Aubyn, $12^{\text {th }}$ King's Royal Rifle Corps, had retired from the King's Royal Rifle Corps as a Captain in 1891, but had been recalled during the Boer War.

${ }^{13}$ Minutes of meetings of the Military Members of the Army Council, 9 October 1914, TNA WO 163/44 cited in Simkins, Kitchener's Army, p.69. The decision was subsequently taken to redesignate the K4 battalions as Reserve Battalions. Command of these is considered in Appendix Three.

${ }^{14}$ Thirteen regiments formed no K3 battalions, 17 formed two, five formed three, and two formed four. The 13 active Irish 'UVF' battalions that made up $36^{\text {th }}$ (Ulster) Division were chronological compatriots of K3 although conceptually they were locally-raised. Of the 13 active battalions, one received a regular Major as CO; two received Indian Army Colonels; seven received COs from the Reserve of Officers (three LieutenantColonels, two Majors and two Captains) with an average age of 46 years seven months and having been retired six years three months; and the remaining three received other retired officers (a Colonel, LieutenantColonel and Major). The average age of the retired officers was 49 years, and they had been retired on average six years eight months. Eighty-five per cent were from outside the regiment, but 46 per cent had served in Irish regiments. Timothy Bowman notes that only 7 had been "UVF members". [T. Bowman, 'Officering Kitchener's Armies: A Case Study of the 36th (Ulster) Division', War In History, 16 (2) (2009), pp. 189-212].

${ }^{15}$ Major Sir William Stewart-Dick-Cunyngham Bt. had retired from the Black Watch as a Regular Captain on 4 February 1903, but in August 1914 was a TF Major serving as District Remount Officer, Scottish Command.
} 
were three Colonels, seven Lieutenant-Colonels, nine Majors and a Captain. Their average age was 50 years six months, and they had been retired on average five years seven months (range 14 years eight months to five months). Of the other retired officers, 28 were Colonels, 15 Lieutenant-Colonels, three Majors and one a Captain. Eighty-seven per cent were retired Regulars/Indian Army, half coming from the latter. ${ }^{16}$ Their average age was 55 years four months, and they had been retired on average five years five months (range 21 years six months ${ }^{17}$ to two months).

\subsubsection{First COs: Locally-raised battalions}

Towards the end of August 1914, battalions began to be raised through various local authorities, some of these becoming known as "Pals" battalions. ${ }^{18}$ Through this mechanism, the War Office deferred the cost and relieved pressure on the recruiting system. $^{19}$

One hundred and twenty-eight locally-raised battalions were formed for active service. ${ }^{20}$ Seven received active Regulars as COs (two Lieutenant-Colonels, four Majors and one Captain), and three received Indian Army officers (two Colonels and a LieutenantColonel). Six received Special Reserve officers (four Majors and two Captains); and two

\footnotetext{
${ }^{16}$ Colonel Arthur Craigie FitzHardinge Vincent, first CO of the $10^{\text {th }}$ Yorkshire Regiment, was a retired officer of the Scottish Rifles, but his retirement as a Colonel was from the Ceylon Volunteers.

${ }^{17}$ Lieutenant-Colonel Henry Curties, $11^{\text {th }}$ Royal Warwickshire, had retired from the Militia Royal Engineers (Milford Haven Division Submarine Miners) as a Captain on 8 February 1893.

18 'Pals' in terms of recruitment from specific workplaces or local association. This recruiting concept was not the brainchild of, but was given its main impetus by Lord Derby, then chairman of the West Lancashire Territorial Association. Much modern sentimentality collects around these battalions, omitting to remember that the first-line Territorial battalions were often recruited on much the same principles.

${ }^{19}$ Simkins, Kitchener's Army, p.87

${ }^{20}$ Four locally-raised bantam battalions were amalgamated with other battalions prior to going overseas. Command of the 64 locally-raised reserve battalions is considered in Appendix Three.
} 
received TF Majors. One received a Colonel of empire volunteers. ${ }^{21}$ Eighty-three per cent received retired officers. Twenty-five were from the Reserve of Officers (three Colonels, three Lieutenant-Colonels, nine Majors, nine Captains and a Lieutenant ${ }^{22}$ ) with an average age of 49 years and having been retired on average seven years seven months (range 21 years six months ${ }^{23}$ to two days after the outbreak of war). Five were from the TF Reserve (two Colonels, a Lieutenant-Colonel, a Major and a Captain). ${ }^{24}$ Of the 76 remaining, 29 were Colonels, 14 Lieutenant-Colonels, 18 Majors, 13 Captains and two Lieutenants, ${ }^{25}$ with an average age of 52 years seven months, and having been retired seven years 10 months (range 27 years one month ${ }^{26}$ to three months). Thirty-eight per cent were retired Regulars, 33 per cent Territorials/Volunteers, 18 per cent Special Reserve/Militia, nine per cent Indian Army, and two per cent empire volunteers. Three battalions received local/national politicians. ${ }^{27}$

\footnotetext{
${ }^{21}$ Lieutenant-Colonel Robert Edward Pemberton Pigott of the Bombay, Baroda \& Central India Railway Volunteer Rifles was given command of $12^{\text {th }}$ Suffolk.

${ }^{22}$ Lieutenant-Colonel John Stuart-Wortley, $21^{\text {st }}$ Royal Fusiliers was a retired regular Lieutenant of the Highland Light Infantry, although he had entered the Regular army from the post of Captain of Militia in the Scottish Rifles. He had been commissioned into the Scottish Horse during the Second Boer War whilst a private in the Imperial Yeomanry. He was seconded to the North Nigeria Regiment, and was in charge of the transport in the Anglo-French Boundary Expedition to Lake Chad in 1903. He was posted to the 11th Sudanese Regiment, and became a civil administrator until 1912. His perceived talent justified his elevation to battalion command in early September 1914, (having been made an ADC on 5 August 1914). When the $21^{\text {st }}$ Royal Fusiliers became GHQ troops in 1916, he was transferred to the South Staffordshire Regiment and was given command of the $2 / 6^{\text {th }}$ Battalion, being killed at Bullecourt, 21 March 1918.

${ }^{23}$ Lord Southampton, appointed CO $18^{\text {th }}$ Durham Light Infantry, had retired from the $10^{\text {th }}$ Hussars as a Captain on 1 February 1893 and was 47 years old.

${ }^{24}$ Formed in March 1910, the TF Reserve was supposed to have an establishment of 100,000 men but only numbered approximately 2000 when war broke out.

${ }^{25}$ Lieutenant-Colonel the Hon. William Frederick John North, $26^{\text {th }}$ Royal Fusiliers, had retired as a Lieutenant of the Oxfordshire Hussars in October 1896. Lieutenant-Colonel L.F. Beatson had retired as a regular Lieutenant from the Warwickshire Regiment in October 1893.

${ }^{26}$ Lieutenant-Colonel Louis Edward Fawcus, $19^{\text {th }}$ Northumberland Fusiliers, had retired from the $5^{\text {th }}$ Surrey Volunteers as a Captain on 25 June 1870.

${ }^{27}$ Lieutenant-Colonel William Emsley Raley, $14^{\text {th }}$ York \& Lancaster, was a solicitor and Barnsley Alderman; Lieutenant-Colonel Sir Harry Webb Bt., an MP, commanded $13^{\text {th }}$ Gloucestershire and $14^{\text {th }}$ Worcestershire, both pioneer battalions.
} 


\subsubsection{Overview}

Detailed analysis of the appointment of the first New Army COs indicates the priorities of the War Office concerning battalion command during the first months of the war.

The first principle was use of available active Regular soldiers (see Table 2:1). If Kitchener, as he avowed, "could take no account of anything but Regular soldiers", 28 then this was completely achieved with K1, the primary mechanism being the use of 54 Majors serving as Depot Commanders. ${ }^{29}$ These Majors had an average age of 44 years three months; 60 per cent had served as Adjutants; and 42 per cent had extra-regimental staff service. They were three years 8.5 months younger than the Lieutenant-Colonels of their regiments, had a comparable amount of war service, ${ }^{30}$ had more frequently acted as Adjutant, and had performed nearly as much extra-regimental staff service. LieutenantColonel W.D. Villiers-Stuart, a Gurkha officer commanding $9^{\text {th }}$ Rifle Brigade, was, however, disparaging towards 'Depot Majors' on active service who "knew nothing of field fortifications". ${ }^{31}$ There is, however, no objective reason to believe that 'Depot

\footnotetext{
${ }^{28}$ C. Harris, "Kitchener and the Territorials", The Times, 28 August 1928, p. 13

${ }^{29}$ The Regimental Depot was the regiment's headquarters, where recruits were trained, stores assembled, and officers and other ranks awaiting posting were based. The Depot Commander was attached to the Special Reserve battalion based at the depot, and hence did not go overseas with his regular battalion. In addition to Regular officers attached to the Special Reserve who remained in the UK on the outbreak of war, a small cadre of officers and NCOs remained to organise and train the K1 battalions.

${ }^{30}$ An average of 1.5 campaigns compared with the Lieutenant-Colonels' 1.7.

${ }^{31}$ R.M. Maxwell, Villiers-Stuart Goes to War (Edinburgh: Pentland Press, 1990) p.92. Villiers-Stuart was vituperous concerning Lieutenant-Colonel A. Grant, also a Gurkha officer, the first commander of the $9^{\text {th }}$ Rifle Brigade. He states: "Apparently, when Kitchener was selecting officers from the Indian Army list of officers on leave he said, 'Well, he'll either cause a mutiny or produce a first class battalion.' When Kitchener was making out these appointments, the 'Depot Majors' got wind of it and demanded command of the new battalions as their 'right'. Though he tried to prevent it, the Depot Majors' lobby was too powerful for Kitchener - but those officers who had already been appointed did not lose their positions and Grant was one of these." The idea of the advocates of a group of Regular Majors being "too powerful" for Kitchener in August 1914 is barely credible. Grant was the only Indian Army appointee for K1, and, as will be seen, Kitchener did no such choosing. No Depot Major was appointed for the Rifle Brigade as the depot was commanded on the outbreak of war by a full Colonel, and indeed other non-Depot Major appointments in K1 were made where the depot commander was either a Colonel or a Captain, or when two K1 battalions were raised and the 'Depot Major' had already been used. It is of course possible that given Kitchener's lack of detailed knowledge of the UK-based army that the potential use of Depot Majors was pointed out to him.
} 
Majors' had any less ability or knowledge, based on their experience, than those commanding the Regular battalions. They were simply men whose position in the list of seniority meant that they would never be the $\mathrm{CO}$ or senior Major of a battalion.

\begin{tabular}{|l|l|c|c|c|c|}
\hline & & K1 & K2 & K3 & Local \\
\hline Regular & Col & 0 & 0 & 1 & 0 \\
\hline & $\begin{array}{l}\text { Lt- } \\
\text { Col }\end{array}$ & 1 & 4 & 2 & 2 \\
\hline & Maj & 65 & 7 & 2 & 4 \\
\hline & Capt & 0 & 0 & 0 & 1 \\
\hline Indian & & $82 \%$ & $14 \%$ & $6 \%$ & $6 \%$ \\
\hline Army & Col & 0 & 1 & 7 & 2 \\
\hline & Lt- & 1 & 4 & 8 & 1 \\
\hline Col & & $1 \%$ & $6 \%$ & $17 \%$ & $2 \%$ \\
\hline Rpecial & $\begin{array}{l}\text { Lt- } \\
\text { Col }\end{array}$ & 3 & 1 & 0 & 0 \\
\hline & Maj & 1 & 0 & 1 & 4 \\
\hline & Capt & 0 & 0 & 0 & 2 \\
\hline Territorial Force & Maj & 0 & 0 & 1 & 2 \\
\hline & & $0 \%$ & $0 \%$ & $1 \%$ & $2 \%$ \\
\hline Empire & $\begin{array}{l}\text { Lt- } \\
\text { Col }\end{array}$ & 0 & 0 & 0 & 1 \\
\hline & & $0 \%$ & $0 \%$ & $0 \%$ & $<1 \%$ \\
\hline
\end{tabular}

\section{Table 2.1: Active officers appointed as first COs to Service Battalions}

The second principle was next use of retired Regular officers (see Table 2:2). Seventyeight per cent were used for $\mathrm{K} 2$ as against 12 per cent for $\mathrm{K} 1$, with more recently retired officers being used first. K1 COs had been retired one year eight months; K2 two years nine months; K3 five years seven months; and locally-raised battalions six years six months. All had similar average ages, (49 years 10 months overall), being just under two years older than their active Regular counterparts. 
The third principle, emerging in $\mathrm{K} 2$ appointments, was use of the most senior remaining officers, i.e. those with experience of battalion command. Forty-four per cent of the retired officers were Colonels, a fact which served to push up the age of retired officers: 51 years eight months for $\mathrm{K} 1 ; 55$ years seven months for $\mathrm{K} 2 ; 55$ years four months for $\mathrm{K} 3$; and 52 years four months for locally-raised battalions.

\begin{tabular}{|c|c|c|c|c|c|}
\hline & & K1 & K2 & K3 & Local \\
\hline \multirow[t]{6}{*}{ Regular } & Col & 1 & 27 & 19 & 5 \\
\hline & Lt-Col & 5 & 18 & 12 & 4 \\
\hline & Maj & 2 & 16 & 10 & 19 \\
\hline & Capt & 2 & 1 & 0 & 11 \\
\hline & $\mathrm{Lt}$ & 0 & 0 & 0 & 1 \\
\hline & & $13 \%$ & $79 \%$ & $46 \%$ & $32 \%$ \\
\hline \multirow{5}{*}{$\begin{array}{l}\text { Indian } \\
\text { Army }\end{array}$} & Col & 0 & 0 & 9 & 5 \\
\hline & Lt-Col & 0 & 0 & 9 & 4 \\
\hline & Maj & 0 & 0 & 2 & 0 \\
\hline & Capt & 0 & 0 & 0 & 1 \\
\hline & & $0 \%$ & $0 \%$ & $22 \%$ & $8 \%$ \\
\hline \multirow{6}{*}{$\begin{array}{l}\text { Special } \\
\text { Reserve/ } \\
\text { Militia }\end{array}$} & Col & 0 & 0 & 2 & 7 \\
\hline & Lt-Col & 0 & 0 & 1 & 2 \\
\hline & Maj & 0 & 0 & 0 & 5 \\
\hline & Capt & 0 & 0 & 2 & 4 \\
\hline & $\mathrm{Lt}$ & 0 & 0 & 0 & 1 \\
\hline & & $0 \%$ & $0 \%$ & $6 \%$ & $15 \%$ \\
\hline \multirow{6}{*}{$\begin{array}{l}\text { Territorial } \\
\text { Force/ } \\
\text { Volunteers }\end{array}$} & Col & 0 & 0 & 0 & 16 \\
\hline & Lt-Col & 0 & 0 & 0 & 8 \\
\hline & Maj & 0 & 0 & 0 & 3 \\
\hline & Capt & 0 & 0 & 0 & 6 \\
\hline & $\mathrm{Lt}$ & 0 & 0 & 0 & 1 \\
\hline & & $0 \%$ & $0 \%$ & $0 \%$ & $28 \%$ \\
\hline \multirow[t]{5}{*}{ Empire } & Col & 0 & 0 & 1 & 1 \\
\hline & Lt-Col & 0 & 0 & 0 & 0 \\
\hline & Maj & 0 & 0 & 0 & 1 \\
\hline & Capt & 0 & 0 & 0 & 1 \\
\hline & & $0 \%$ & $0 \%$ & $1 \%$ & $2 \%$ \\
\hline
\end{tabular}

Table 2.2: Retired officers appointed as first COs to Service Battalions 
The fourth principle was then to use active and retired Indian Army officers, a convention emerging in K3. Colonel W.A.B. Dennys sheds light on the process. A retired Indian Army Colonel and Brigade Commander, ${ }^{32}$ he was living in the UK at the outbreak of war, and was asked by General Sir Edward Barrow, Military Secretary at the India Office, to head the "Classification Staff", ${ }^{33}$ identifying Indian Army officers in England. ${ }^{34}$ "Very soon letters came pouring in from both the War Office and I.O. (India Office) asking for recommendations ... we put the names in order of preference". ${ }^{35}$ After six weeks, (a date that corresponds well to the authorisation of K3), "an urgent letter came from the War Office, asking that the retired Colonels of the I.A. would kindly sink all personal interests for higher appointments, in order to take command of regiments about to be raised in Kitchener's Army". Not only did Kitchener have no predilection towards Indian officers as COs at the outset, he seemingly played no major part in the process beyond general policy direction.

The fifth and last principle was the eventual greater use of ex-Special Reserve/Militia and ex-Territorial Force/Volunteer officers, notably in locally-raised battalions. ${ }^{36}$ Service battalions raised by the War Office virtually completely shunned the initial use of TF officers.

\footnotetext{
${ }^{32}$ William Annesley Burton Dennys had commanded $31^{\text {st }}$ Punjabis for seven years and the Bannu Brigade for three months in 1906 and from May to November 1908.

${ }^{33}$ With two other colonels.

${ }^{34}$ The information was obtained from the Pay Department. Dennys had a total approaching 2000 names of retired/active officers, and sent out forms to each asking for information.

${ }^{35}$ W.A.B. Dennys, Some Reminiscences of My Life (Privately printed, 1935).

${ }^{36}$ Including bantam battalions, which were often locally-raised.
} 
In $\mathrm{K} 1,92.5$ per cent of appointments were within regiment; ${ }^{37}$ in $\mathrm{K} 282$ per cent; in $\mathrm{K} 340$ per cent; whilst for locally-raised battalions the figure was 26 per cent. Peter Simkins notes:

In the Pals battalions, command was generally given to an elderly retired officer on the recommendation of the Mayor or head of the raising committee. While open to abuse this method of selection also had some virtues, as such officers often lived in the town or city concerned and were known to the raisers as a result of their connections with a local Volunteer, Militia or Territorial unit. ${ }^{38}$

For these locally-raised units, however, over two-thirds of COs were certainly not local in the strict regimental sense.

At the beginning of September 1914 Kitchener instructed the Adjutant-General to:

Get from Post Offices names and addresses of every officer to whom letters are arriving addressed Colonel, Major, Captain and Lieutenant; and write a civil letter to each of them, if he has not already sent in his name, inviting him to do so in such a manner that he can hardly refuse. ${ }^{39}$

Whether these intrusive tactics were required to deliver command at battalion level is unlikely given the analysis above which reveals clear evolving priorities and strategies, indicating a process less than haphazard. There were certainly plenty of formal sources for locating retired senior officers in addition to local knowledge which would have readily primed the process of local suggestion balanced against central confirmation.

The most obvious and easily accessible source of the Regular officers desired was the Reserve of Officers, on which all officers receiving retired pay were required to be

\footnotetext{
${ }^{37}$ The $\mathrm{CO}$ of the Service battalion had served in the same regiment.

${ }^{38}$ Simkins, Kitchener's Army, p.219

39 Notes on Supply of Officers: Instructions of Secretary of State, 6 September 1914, Adjutant-General's papers, TNA WO 162/2, cited in Simkins, Kitchener's Army, p.217
} 
registered, confirming their addresses each year. In August 1914, however, there were 103 ex-Regular Lieutenant-Colonels in the Reserve of Officers, only potentially sufficient to cover one tranche of New Army recruitment. Ninety-eight of these were unoccupied at the outbreak of war, five enjoying administrative posts overseas. Two were appointed to brigade command; 23 to staff posts (16 more slotting into depot command, replacing the Majors appointed to K1); 31 to battalion command, with 26 remaining unemployed. This indicates firstly that battalion command was far from being the only demand on resources at senior level, more being placed in staff/administrative posts than as COs. Secondly, the number remaining unemployed indicates that there was clear reflection on suitability, and that exclusion applied rather than senior appointment at any price.

\subsection{Taking the Service Battalions to War}

Many first-appointed did not, however, take their battalions on active service. In K1, 65 per cent were taken abroad by their first CO. Twenty-nine per cent had one change of CO, and six per cent two changes. In K2, 53 per cent were taken abroad by their first $\mathrm{CO}$. Thirty-three per cent had one change, 11 per cent two changes, and three per cent three changes. In K3, 52 per cent were taken abroad by their first CO. Thirty-six per cent had one change, 11 per cent two changes, and one per cent four changes. Of the locally-raised battalions, only 41 per cent were taken abroad by their first CO. Fifty one per cent had one change, six per cent two changes, and two per cent three changes.

The increasing number of changes through $\mathrm{K} 1$ to the locally-raised battalions is not surprising, given the increasing number (and varied pedigrees) of retired officers employed. The 35 per cent turnover in $\mathrm{K} 1$ is for the most part accounted for by the 
replacement of 21 Regular Majors promoted CO, 15 being transferred as COs to their Regular battalion in France, indicating both the attrition of those battalions and the priority given by the BEF and War Office to keeping the fighting units properly officered. Two were transferred to other service battalions, one to a Brigade-Major post; and three appear to have been genuine cases of ill-health (rather than using this as a euphemism for sacking). Only one seems not to have been up to the mark, being transferred back to depot command. ${ }^{40}$

Examples indicate the nature of these battalion command changes. The $12^{\text {th }}$ Highland Light Infantry (K2) underwent three changes of $\mathrm{CO}$ before going on active service. LieutenantColonel A. Giles, ${ }^{41}$ an Indian Army Lieutenant-Colonel, lasted 60 days in command (seeing no further service in the war), to be replaced by Lieutenant-Colonel A.S. Begbie, another Indian Lieutenant-Colonel, ${ }^{42}$ who lasted 124 days (several months later receiving a Special Appointment graded Staff Captain). The next CO was Lieutenant-Colonel F.M. Sandys-Lumsdaine, ${ }^{43}$ who served for 123 days (later serving as CO with the $2 / 6^{\text {th }}$ Argyll and Sutherland Highlanders, a home service battalion), being replaced seven days before the battalion left for active service under Lieutenant-Colonel J.H. Purvis, a Regular captain retired seven years from the regiment. ${ }^{44}$ The subsequent careers indicate that these men emerged as unfit for command or active service.

\footnotetext{
${ }^{40}$ Lieutenant-Colonel Ralph Peyton Sadler, $9^{\text {th }}$ Sherwood Foresters, whose tenure of command lasted from 9 August 1914 until 25 October 1914.

${ }^{41}$ Albert Giles, aged 52 in 1914, was still on the active list, but had commanded $11^{\text {th }}$ Rajputs.

42 Arundel Sinclair Begbie had, aged 48 in 1915, had commanded $16^{\text {th }}$ Rajputs, and had retired in August 1914.

${ }^{43}$ Francis Myles Sandys-Lumsdaine, aged 48 in 1914, was a retired Regular Major of the Highland Light Infantry, and had been retired for 18 months.

44 John Henry Purvis had been acting as an ADC from 18 September 1914 to 6 January 1915, and commanded until 6 March 1916 when he was replaced and not used as a CO again.
} 
The $8^{\text {th }}$ Leicestershire (K3) underwent four changes of command. Colonel E.R. Scott, ${ }^{45}$ an ex-Regular, lasted 14 days in command whereupon he was transferred to the $10^{\text {th }}$ Essex (where he lasted 148 days before being transferred again to the $2 / 4^{\text {th }}$ Loyal North Lancashire, from whence he retired again without seeing active service). The second CO was Colonel C.H. Shepherd, ${ }^{46}$ also an ex-Regular, who lasted 53 days before replacement (being used again approximately a year later as $\mathrm{CO} 1^{\text {st }}$ Garrison Battalion Lincolnshire Regiment in India). The third was the retired Indian Army Lieutenant-Colonel H.P. Bell, ${ }^{47}$ who served for 180 days (being appointed a Group Commander in France in November 1914). Bell was replaced by Lieutenant-Colonel F.J. Radford, ${ }^{48}$ an ex-Regular who had already been replaced as a Brigade-Major, but who only served 46 days, a new CO (Lieutenant-Colonel J.G. Mignon, a Regular 13 years retired from the regiment) ${ }^{49}$ being appointed the day before the battalion went on active service. Again, an active process was clearly evaluating fitness for command. Twenty-eight battalions (seven per cent) experienced a change of $\mathrm{CO}$ in the two months prior to active service.

Of the COs of K1 14 per cent were removed before going on active service and not used again to command a battalion on active service; for $\mathrm{K} 2$ the figure was 26 per cent; for $\mathrm{K} 3$, 32 per cent; and for locally-raised battalions, 35 per cent. Overall, 27 per cent of the COs appointed to command New Army battalions were removed before they went on active service, clearly unsuitable for such service on likely grounds of either physical fitness or

\footnotetext{
45 Edmund Richard Scott was a 57 year-old brevet Colonel, a retired Regular Lieutenant-Colonel of the Leicestershire Regiment, who had been retired for just over seven years in August 1914.

${ }^{46}$ Charles Herbert Shepherd was a 68 year-old substantive ex-Regular Colonel who had been retired over 11 years in August 1914.

${ }^{47}$ Henry Phillips Bell, aged 48 in August 1914, had been retired one month from the $44^{\text {th }}$ Infantry.

${ }^{48}$ Frederic John Radford, aged 42 in 1914, was an ex-Regular Major of the Sherwood Foresters, who had retired in August 1912. Radford finished the war in the Labour Corps.

${ }^{49}$ Jephson George Mignon commanded until 14 July 1916 when he was killed on the Somme on the Bazentin Ridge.
} 
competence. The 27 per cent replacement figure compares favourably with the 39 per cent of TF $\mathrm{COs}^{50}$ who were removed from command before their battalions proceeded overseas.

The problems faced in some divisions, however, are indicated by the account of Captain H.C. Rees, $2^{\text {nd }}$ Welsh, ${ }^{51}$ who was appointed GSO1 $38^{\text {th }}$ (Welsh) Division on 21 April 1915. Here:

The standard of knowledge of the brigadiers and commanding officers was, as a rule, so low that any progress in field training was manifestly impossible. I therefore started staff rides for the senior officers. These staff rides soon convinced the General ... that changes were absolutely essential. $^{52}$ Eventually two Brigadiers and nine of the original Commanding Officers were replaced before the division sailed for France. $^{53}$

As $38^{\text {th }}$ Division comprised locally-raised battalions, a group identified above as having the highest rate of CO replacement, Rees' experiences are unsurprising. ${ }^{54}$

\subsection{The New Territorial Force Battalions}

Despite any prejudice in Kitchener's attitude towards the TF, it was allowed to continue recruiting, and orders issued from 21 August 1914 permitted County Associations to form second-line battalions for each first-line battalion accepted for overseas service, and to

\footnotetext{
${ }^{50}$ See Chapter One, section 1.4.2

${ }^{51}$ See also Chapter One, section 1.5 .

${ }^{52}$ Major-General I. Phillips.

${ }^{53}$ IWM 77/179/1Brigadier-General H. C. Rees, 'A Personal Record of the First 7 Months of the War', p.80

54 The offending COs, who were all replaced in the month prior to going on active service, can be identified as: Lieutenant-Colonel C.E. Willes, $13^{\text {th }}$ Royal Welsh Fusiliers, a Regular captain retired in 1905 who had subsequently served in the Volunteers; Lieutenant-Colonel W.A.L. Fox-Pitt $15^{\text {th }}$ Royal Welsh Fusiliers, an ex-Grenadier Guards Major who had retired in 1904; Colonel T.A. Wynne-Jones, retired from the TF in 1913; Colonel E.L. Holloway, 10 $0^{\text {th }}$ Welsh Regiment, retired from the Indian Army (Pioneers) in 1913; Lieutenant-Colonel W. Watts, $13^{\text {th }}$ Welsh Regiment, retired from the Special Reserve in 1910; LieutenantColonel H.W. Benson, $14^{\text {th }}$ Welsh Regiment, a Regular Major retired in 1903; Lieutenant M.J.G. Scobie, $15^{\text {th }}$ Welsh Regiment, a retired honorary TF Colonel; Lieutenant-Colonel the Hon. H.R.L. Lloyd-Mostyn, a Colonel of Militia retired in 1904; Lieutenant-Colonel H.E. Porter, $11^{\text {th }}$ South Wales Borderers, an Indian Army Major retired in 1901.
} 
raise a third-line unit when the first-line went overseas. ${ }^{55}$ During 1914-15, 205 second and 211 third/fourth-line TF infantry battalions were raised. Of these, 97 second and seven third-line battalions saw active service, the remainder becoming reserve/home service battalions.

Of the 97 second-line battalions (see Table 2.3), one received a Regular officer as first CO. ${ }^{56}$ Twenty-eight per cent received active TF officers (14 were COs removed from the first-line battalion; 12 were Majors and two Captains, all from their first-line units). ${ }^{57}$ Seven per cent received retired Regulars; and four per cent received retired Special Reserve/Militia officers. The remainder (60 per cent) received retired TF officers. Of this group, 29 were (mainly honorary) Colonels, 17 Lieutenant-Colonels, nine Majors and three Captains. The retired officers had an average age of 49 years eight months and had been retired on average five years two months (range 23 years 11 months $^{58}$ to two months). Overall 82 per cent were, retired or otherwise, internal regimental appointments; and 88 per cent were TF or retired Volunteers. ${ }^{59}$

A strong local and Territorial character is therefore clear, although notably shunning any local Special Reserve officers, a matter unsurprising as the County Associations were

\footnotetext{
${ }^{55}$ Simkins, Kitchener's Army, pp.45-6

${ }^{56}$ Major Cecil Fane of the 12 th Lancers became CO of $2 / 7^{\text {th }}$ Sherwood Foresters.

${ }^{57}$ Whilst one of the two Captains was from the first-line battalion, the other, Captain F.W.D. Bendall, promoted to $\mathrm{CO} 2 / 3^{\text {rd }}$ London, was an unattached TF Captain commanding the Bridlington Grammar School OTC at the outbreak of war, where, as a Cambridge graduate, he was classics teacher. He later commanded both $1 / 7^{\text {th }} \& 1 / 8^{\text {th }}$ Middlesex. After being wounded in 1917, he published a book of poetry, Front Line Lyrics (London: E. Mathews, 1918). After the war he became an Inspector of Schools, and in the Second World War served as Director of Army Education.

${ }^{58}$ Lieutenant-Colonel John E. Jameson, $2 / 24^{\text {th }}$ London, had retired from the Worcestershire Yeomanry as a Major on 26 August 1890.

${ }^{59}$ Twenty per cent of these were ex-Regulars.
} 
putting forward nominations for War Office approval. As with the Service Battalions, a preference for the most senior officers available (Colonels) is obvious.

\begin{tabular}{|l|c|c|c|c|c|c|c|c|c|c|c|c|}
\hline & \multicolumn{2}{|c|}{ Colonel } & \multicolumn{2}{c|}{ Lt-Col } & \multicolumn{2}{c|}{ Major } & \multicolumn{2}{c|}{ Captain } & \multicolumn{2}{c|}{ Lieutenant } & \multicolumn{2}{|c|}{ 2nd Lieutenant } \\
\hline & 1 st & AS & 1 st & AS & 1 st & AS & 1 st & AS & 1 st & AS & 1 st & AS \\
\hline Active & & & & & & & & & & & & \\
\hline Regular & 0 & 0 & 0 & 0 & 1 & 4 & 2 & 16 & 0 & 2 & 0 & 0 \\
\hline Ind Army & 0 & 0 & 0 & 1 & 0 & 0 & 0 & 0 & 0 & 0 & 0 & 0 \\
\hline SR & 0 & 0 & 0 & 1 & 0 & 1 & 0 & 3 & 0 & 0 & 0 & 0 \\
\hline TF & 0 & 0 & 14 & 2 & 12 & 11 & 2 & 13 & 0 & 1 & 0 & 0 \\
\hline Retired & & & & & & & & & & & & \\
\hline Regular & 1 & 0 & 1 & 2 & 2 & 4 & 2 & 5 & 0 & 2 & 0 & 1 \\
\hline SR/Militia & 1 & 0 & 2 & 1 & 0 & 1 & 1 & 2 & 0 & 0 & 0 & 0 \\
\hline TF/Vols & 29 & 5 & 17 & 7 & 9 & 3 & 3 & 6 & 0 & 0 & 0 & 0 \\
\hline Empire & 0 & 0 & 0 & 0 & 0 & 0 & 0 & 0 & 0 & 1 & 0 & 0 \\
\hline
\end{tabular}

Table 2.3: Officers appointed as first COs to second-line TF Battalions and those taking battalions on active service (AS)

These battalions saw active service at different points in the war. Of the 10 that went overseas in 1915, eight were commanded by their first COs, two by their second. Of the 29 who went overseas in 1916, eight were commanded by their first COs; 15 had been commanded by one previous CO; six by two. Of the 55 who went overseas in 1917,15 were taken by their first $\mathrm{CO} ; 25$ by their second; 16 by their third; and one by their fourth. Of the two who finally went overseas in 1918 , one had been commanded by two previous COs, the other three.

Again, to give a flavour of the nature of these changes, command of $2 / 9^{\text {th }}$ King's Liverpool went first to Lieutenant-Colonel L. Watts, ${ }^{60}$ displaced from the $1 / 9^{\text {th }}$ Battalion, on 22 December 1914. On 18 June 1915 he was replaced by Colonel R. Eccles, an ex-Regular,

\footnotetext{
${ }^{60}$ This battalion went overseas on 14 February 1917.
} 
who had been removed from command of the $14^{\text {th }}$ Durham Light Infantry. ${ }^{61}$ Watts returned on 1 November 1915 as Eccles died, being replaced on 8 January 1916 by LieutenantColonel T.F. Parkinson, a Major from the Kent Cyclist Battalion, who was in turn replaced on 10 October 1916 by Lieutenant-Colonel A.F.S. Leggatt, a Regular Captain of the $2^{\text {nd }}$ Royal Scots promoted Major, who had been in France and Flanders since 14 August 1914, and who took the battalion to war four months later. Clearly whilst some attention was being paid to suitability for command throughout, as active service approached, the issue of fitness for warfare on the Western Front came into sharper focus. ${ }^{62}$

Table 2.3 indicates that, as with the Service Battalions, there was a notable decrease in reliance on retired Colonels for active service. This trend was also noticeable for retired Lieutenant-Colonels, and only two out of 14 of the ex-first-line battalion COs eventually saw active service. There was a marked increase (as might be expected from the example of the elevation of Captain Leggatt to command $2 / 9^{\text {th }}$ Liverpool at war) in the number of active Regular and TF Captains being the first $\mathrm{CO}$ to take their battalions on active service.

\subsection{Dugouts}

As noted at the start of this chapter, the phrase 'dugout' swiftly became common parlance in place of the word 'retired', attracting over the years a dismissive quality, redolent of the plump, pompous and irascible Colonel Blimp. ${ }^{63}$ Captain I.H. Beith described how his CO,

\footnotetext{
${ }^{61}$ Robert Eccles was a 62 year-old brevet Colonel who had retired 10 years previously from the Oxfordshire \& Buckinghamshire Light Infantry.

${ }_{62}^{62}$ Leggatt served as CO until being wounded on 11 June 1917.

${ }^{63}$ Colonel Blimp was a cartoon character created by David Low for the London Evening Standard in the 1930s, a jingoistic British stereotype.
} 
Lieutenant-Colonel A.F. Mackenzie, ${ }^{64} 10^{\text {th }}$ Argyll and Sutherland Highlanders (K1), was "pleased to call himself a "dug-out"". He noted how "a fortnight ago he was fishing in the Garry, his fighting days avowedly behind him, and only the Special Reserve between him and embonpoint". 65

Second-Lieutenant A. Thomas, $4 / 4^{\text {th }}$ Royal West Kent, noted: "I had expected the C.O. to be a tall, lean hard-bitten man, with at least two rows of medals - terribly efficient and exacting”. Instead, Lieutenant-Colonel C.D. Disney-Roebuck was "short and plump and gave the impression of soft living ... the C.O. did not in fact look like a soldier at all ... he looked like a city man and his manners had the silkiness of a financier's". ${ }^{66}$ SecondLieutenant H. Macmillan, $14^{\text {th }}$ King's Royal Rifle Corps, found his battalion commanded by 56 year-old Lieutenant-Colonel Sir T.E. Milbourne-Swinnerton-Pilkington, who had retired as a Regular Major in 1898 and as an Honorary Colonel of Special Reserve in 1908: "With his white hair, rubicund complexion, and aquiline nose, he was a figure from the past ... lovable and bewildered"' ${ }^{67}$

Retired COs were often easy to lampoon, their idiosyncrasies a popular subject for record. Second-Lieutenant S. Cloete, $9^{\text {th }}$ King's Own Yorkshire Light Infantry, noted how his CO,

\footnotetext{
${ }^{64}$ Alexander Francis Mackenzie was a Lieutenant-Colonel in the Special Reserve of the Seaforth Highlanders and a Major in the Reserve of Officers of the Argyll and Sutherland Highlanders.

${ }^{65}$ I. Hay, The First Hundred Thousand (Boston: Houghton Miflin, 1916), p.6

${ }^{66}$ A. Thomas, A Life Apart (Letchworth: Garden City Press, 1968), p.35. Claude Delevel Disney-Roebuck was an ex-Regular Captain of the Northamptonshire Regiment, who had retired nine years earlier. He commanded until 1 January 1917.

67 H. Macmillan, Winds of Change (London: Macmillan, 1966), p.62. Thomas Edward MilbourneSwinnerton-Pilkington had served with the King's Royal Rifle Corps in South Africa in 1881 and Egypt in 1882. He commanded until July 1916 and then held a Special Appointment until the Armistice.
} 
Lieutenant-Colonel G.L. Holland, Indian Army "sometimes, in a fit of absent mindedness, addressed his Yorkshiremen in Hindustani". ${ }^{68}$

On what grounds would a retired officer prove adequate or inadequate as $\mathrm{CO}$ ? Firstly, an issue which applied to all officers, retired or otherwise, was simple grounds of general attitude. Lieutenant-Colonel W.D. Villiers-Stuart, second CO of $9^{\text {th }}$ Rifle Brigade, described the coup against his predecessor (and fellow Gurkha), the hard-of-hearing Colonel A. Grant, whom he had described as "a rotten soldier - apart from his pluck". He continued:

\begin{abstract}
I was ordered to report to the Brigadier. I saw at once that Champain ${ }^{69}$ had been going behind the back of the $C O$ and making insinuations to the $B M$ (Brigade-Major), whom he had known before. The Brigadier told me that he had heard that Colonel Grant's officers were all agreed that they could not serve under him any longer.
\end{abstract}

Villiers-Stuart denied that this was true in his case and that Grant had been "scrupulously fair" to him, having given him "a free hand in my work and always listened to anything I have to say". Other officers were interviewed:

And then Grant went in. When he came out he told me that he had resigned his command. That I was to act for him temporarily and that he would always remember what I had done for him and how I had spoken of him to the Brigadier. ${ }^{70}$

Secondly, there was the issue of age and the linked matter of physical fitness and stamina. Colonel W.A.B. Dennys raised and commanded the K3 $10^{\text {th }}$ Loyal North Lancashire on the Western Front until 23 December 1915, when:

\footnotetext{
${ }^{68}$ S. Cloete, A Victorian Son (Glasgow: Collins, 1972), p.203. Guy Lushington Holland, aged 53 in 1914 , was a retired Lieutenant-Colonel of the Sikh Pioneers. He never saw overseas service, being replaced after nine months on 21 June 1915, becoming CO of a Pioneer Depot and serving as a Staff Lieutenant in 1917.

${ }^{69}$ Major C.E. Bateman-Champain, another fellow Gurkha officer.

${ }^{70}$ Maxwell, Villiers-Stuart, pp.8 \& 16. William Desmond Villiers-Stuart, aged 42 in August 1914, had served with the $5^{\text {th }}$ Gurkha Rifles.
} 
Our Army Corps Commander, General Sir E. (sic) Snow ... said that he didn't consider it was fair on me that I, at the age of fifty-six, and with my experience, should have to serve under ... Brigadiers, who were subalterns at the time I left India He therefore asked me if I would like to have the command of a Brigade at home, as I was too old to have one in France ... I had not once gone sick. ${ }^{71}$

Reading between the lines, age was the issue.

J.F.C. Fuller quoted Baron von der Goltz:" "Good health and a robust constitution are invaluable to a general ... In a sick body, the mind cannot possibly remain permanently fresh and clear", continuing: "The three pillars of generalship - courage, creative intelligence and physical fitness" were "the attributes of youth rather than of middle age". ${ }^{73}$ If true of generals, then this was even more applicable to battalion commanders.

The Barnsley Chronicle recorded the cause of the removal of Lieutenant-Colonel J. Hewitt, ${ }^{74}$ the first CO of $13^{\text {th }}$ York \& Lancaster, on 13 November 1915 , as "inability to physically stand the strain of an overseas campaign." Hewitt had clearly been previously marked for overseas service, having been sent on a Commanding Officers' course in York in March 1915 and on a CO training visit to France in July $1915 .^{75}$ The health of the CO of $14^{\text {th }}$ York \& Lancaster, Lieutenant-Colonel W.E. Raley, broke down at camp in June 1915,

\footnotetext{
${ }^{71}$ Dennys, Reminiscences, p.39. Dennys did not get a brigade in the UK on the grounds that he would be too old to take it on active service. He claimed to have been recommended for a brigade 16 times when with the $10^{\text {th }}$ Loyal North Lancashire, but was turned down on age grounds on each occasion.

${ }^{72}$ Major-General John Frederick Charles Fuller was a staff officer from 1916 in the HQ of the Machine Gun Corps Heavy Branch which was later to become the Tank Corps. In the post-war era he enjoyed a career as a military theorist. Baron Wilhelm Leopold Colmar Freiherr von der Goltz (1843-1916) was a Prussian FieldMarshall and military writer.

${ }^{73}$ J.F.C. Fuller, Generalship, Its Diseases and their Cure: A Study of the Personal Factor in Command (London: Faber \& Faber, 1933), p.32

${ }^{74}$ Joseph Hewitt, a solicitor aged 47 in 1914, was a retired Volunteer of the York \& Lancaster Regiment.

${ }^{75}$ J. Cooksey, Pals: the 13th \& 14th Battalions, York and Lancashire Regiment (Leo Cooper: London, 1986), p.99. Hewitt's son had been seriously wounded in France in July and there may have been a psychological element.
} 
and he was replaced. ${ }^{76}$ Similarly, Colonel C.V. Mainwaring, ex-Indian Army and CO $12^{\text {th }}$ York and Lancaster, departed without warning from their training camp: "He had been in poor health for some time due to the lengthy spell he had spent in the Far East. He was not seen again by the battalion during the war". ${ }^{77}$ In $16^{\text {th }}$ and $18^{\text {th }}$ West Yorkshire, in camp at Ripon: "There was muttering in the ranks when it was noticed that both of the Pals' Colonels had a tendency to stay in camp during bad weather when the men were sent on route marches". ${ }^{78}$ In contrast, Major F.P. Crozier, $9^{\text {th }}$ Royal Irish Rifles, described his CO Lieutenant-Colonel G.S. Ormerod, 58 years old in 1914, as a "grand old chap ... he has suffered agonies lest it should be said he was too old for war", and once on French soil, was "younger than ever". 79

Others had carried embonpoint to a fine art. Second-Lieutenant B.H. Liddell Hart $\left(11^{\text {th }}\right.$ King's Own Yorkshire Light Infantry) described Lieutenant-Colonel J.W. Stead, a retired TF CO, as "ludicrously fat". ${ }^{80}$ Lieutenant-Colonel E.E. "Bullfrog" Wilford (who replaced Lieutenant-Colonel Hewitt in $13^{\text {th }}$ York $\&$ Lancaster) was reported by Private T. Oughton

\footnotetext{
${ }^{76}$ Cooksey, Pals, p.88. Raley had no previous military service. His son had been killed in France, and hence the reasons for his breakdown in health may also have been partly psychological. He commanded the $15^{\text {th }}$ (Reserve) Battalion between 6 August 1915 and 31 August 1916.

${ }^{77}$ R. Gibson \& P. Oldfield, Sheffield City Battalion (Wharncliffe: Barnsley, 1988), p.66. Charles Vaughan Mainwaring, aged 52 in August 1914, was a retired Colonel who had commanded $89^{\text {th }}$ Punjabis. He saw no further service in the war. His replacement, Lieutenant-Colonel J.A. Crosthwaite, a Regular who had already been on active service in France and Flanders commanding $2^{\text {nd }}$ Durham Light Infantry from 5 January to 10 June 1915, was also in poor health and never saw active service with the battalion.

${ }^{78}$ D. Raw, Bradford Pals:A Comprehensive History of the 16th and 18th (Service) Battalions the Prince of Wales' Own West Yorkshire Regiment (Pen \& Sword: Barnsley, 2005), p. 96. The sedentary COs were Lieutenant-Colonel Charles Wallace Warden $\left(16^{\text {th }}\right.$ Battalion $)$ and Lieutenant-Colonel George Herbert Muller $\left(18^{\text {th }}\right.$ Battalion). Warden was a 59 year-old veteran of the 1879 Zulu War with the Middlesex Regiment who had fought with the Imperial Yeomanry in South Africa. The 58 year-old Muller was the Yorkshire yarn agent for Cortaulds on the outbreak of war, having retired in 1904 after succeeding his father as CO of the $2^{\text {nd }}$ Volunteer Battalion West Yorkshire.

${ }^{79}$ F. P. Cozier, A Brass Hat in No Man's Land (London: Jonathan Cape, 1930), p.58. George Sumner Ormerod was an ex-Regular/ex-Special Reserve Lieutenant-Colonel of the Royal Munster Fusiliers.

${ }^{80}$ B.H. Liddell Hart, The Memoirs of Captain Liddell Hart, Vol. 1 (London: Cassell, 1965), p.12. John Walter Stead, aged 55 in 1914, was a retired Territorial Lieutenant-Colonel, and commanded $15^{\text {th }}$ West Yorkshire from 1 September 1914 to 13 May 1915, and $11^{\text {th }}$ King's Own Yorkshire Light Infantry from 13 May 1915 to 25 April 1916.
} 
to be "a big fellow. I don't know how his horse carried him". ${ }^{81}$ Wilford was an active

Indian Army Major, indicating that not all active officers were free from excess weight. ${ }^{82}$

Thirdly, there was the issue of current military knowledge, which might be thought to be

closely related to date of retirement. Peter Simkins states:

Many retired officers who were suddenly handed senior commands found that they could not adapt to the changes wrought in drill, tactics and equipment in the decade before the war, and particularly since the introduction of the new Field Service Regulations in 1909. ${ }^{83}$

In this he followed Captain Basil Williams, contemporary historian of the New Armies, who wrote: "Others were not up to date, and had not the capacity for making themselves so" ${ }^{84}$ Almost certainly it was the issue of 'capacity' that was key.

The time points of development of revised tactics in the British Army during and following the Second Boer War, set out in the Introduction, allow certain conclusions to be drawn

\footnotetext{
${ }^{81}$ Cooksey, Barnsley Pals, p.99. Ernest Edmund Wilford, was aged 48 in August 1914. He was the son of Colonel E. P. Wilford, late Gloucestershire Regiment . He joined the East Yorkshire Regiment as a $2^{\text {nd }}$ Lieutenant in 1896 and transferred to the Indian Army two years later. He served as Major and Squadron Commander, 30th Lancers (Gordon's Horse) with the Indian Corps in France in 1914. He commanded $13^{\text {th }}$ York \& Lancaster from 11 November 1915 to 21 May 1917 when he was wounded by a shell. Wilford's courage was not in doubt. On 1 July 1916, at Serre, Brigadier-General H.C. Rees noted: "Col Wilford, commanding the 13th Yorks and Lancs came in to say that two shelters, which he had occupied as his headquarters, had been blown in the in succession and that, on the last occasion, his adjutant had been killed. Wilford was nicknamed 'The Swashbuckler' and he lived up to his reputation on the 1st July. He said 'as far as I can make out, General, I have two companies left. If you would like me to charge at their head, I shall be delighted to do so." (Rees, 'Personal Record' p.93).

${ }^{82}$ Weight was not a prohibitive handicap. Lieutenant-Colonel (later Brigadier-General) E.A. Wood $\left(6^{\text {th }}\right.$ Shropshire) was a man of "ample proportions", who at the Battle of Langemarck, 16 August 1917, sunk so deep in mire that his release was greeted by "loud applause". He commanded his battalion on active service for 705 days. [G. Dugdale, Langemarck and Cambrai (Uckfield: Naval \& Military, 2005), p.74.] Wood commanded $6^{\text {th }}$ King's Shropshire Light Infantry from 7 October 1915 to 11 September 1917, was wounded five times, gassed twice, buried once, and recommended for the VC twice - weight never held him back from the brigade command he later achieved. He always wore a large bandanna silk handkerchief stuck out of his breast pocket, with which he gave direction in battle, (Dugdale, Langemarck, p.25). Patrick MacGill noted that embonpoint was not achieved on the same diet as the other ranks, quoting the charming rhyme about a CO: "Long may the colonel with us bide, His shadow nee'er grow thinner, (It would, though, if he ever tried some Army stew for dinner)." P. MacGill, The Amateur Army (London: Herbert Jenkins, 1916), p.21

${ }^{83}$ Simkins, Kitchener's Army, p.217

${ }^{84}$ B. Williams, Raising and Training the New Armies, (London: Constable, 1918), p.60
} 
about officers' possession of up-to-date knowledge. Every infantry officer serving in South Africa to 1902 would have been perfectly aware of tactical development. Any Regular officer in the post-war years would have trained using the new precepts. By 1910 the auxiliaries were also using the Combined Training 1902 tactics. ${ }^{85}$ The only issue would have been whether in all units across the army the changes would have been practiced with the same vigour. Any Regular officer retiring in 1902 with experience in South Africa would have been largely tactically up-to-date, as would any regular without South African experience retiring after, say $1903{ }^{86}$ Any auxiliary officer serving in South Africa would also have been largely up-to-date, and, theoretically, any auxiliary officer retiring after 1910. It is the group of auxiliaries who did not have experience of South Africa and who retired at the time of the organisational changes of 1908, who would have been most out of date. $^{87}$

If the premise is taken that the earlier a CO's retirement, the more out-of-date and the less likely he would be to take his Service Battalion on active service, then Figure 2.1 is instructive. The direction of the curve for number of CO's taking their battalions on active service is as might be expected, rising with later retirement dates (i.e. officers retired for shorter periods taking their battalions overseas in greater numbers).

\footnotetext{
${ }^{85}$ The French General Langlois, observing a Territorial Army unit advancing against a Regular Army unit in force on force manoeuvres in 1910, noted the Territorial unit advanced "by rushes" advancing "methodically" to the flank of the defender. [H. Langlois, The British Army in a European War, (London: Hugh Rees, 1910), p.25, cited in A.J Risio, 'Building the Old Contemptibles: British Military Transformation and Tactical Development from the Boer War to the Great War 1899-1914', Master of Military Art \& Science thesis, Georgia Institute of Technology and Fort Leavenworth, (2005) p.47].

${ }^{86}$ Both would, however, have missed the introduction of the four-company system.

87 The auxiliaries would also not have had the Short Magazine Lee Enfield rifle, nor changed to a four company system.
} 


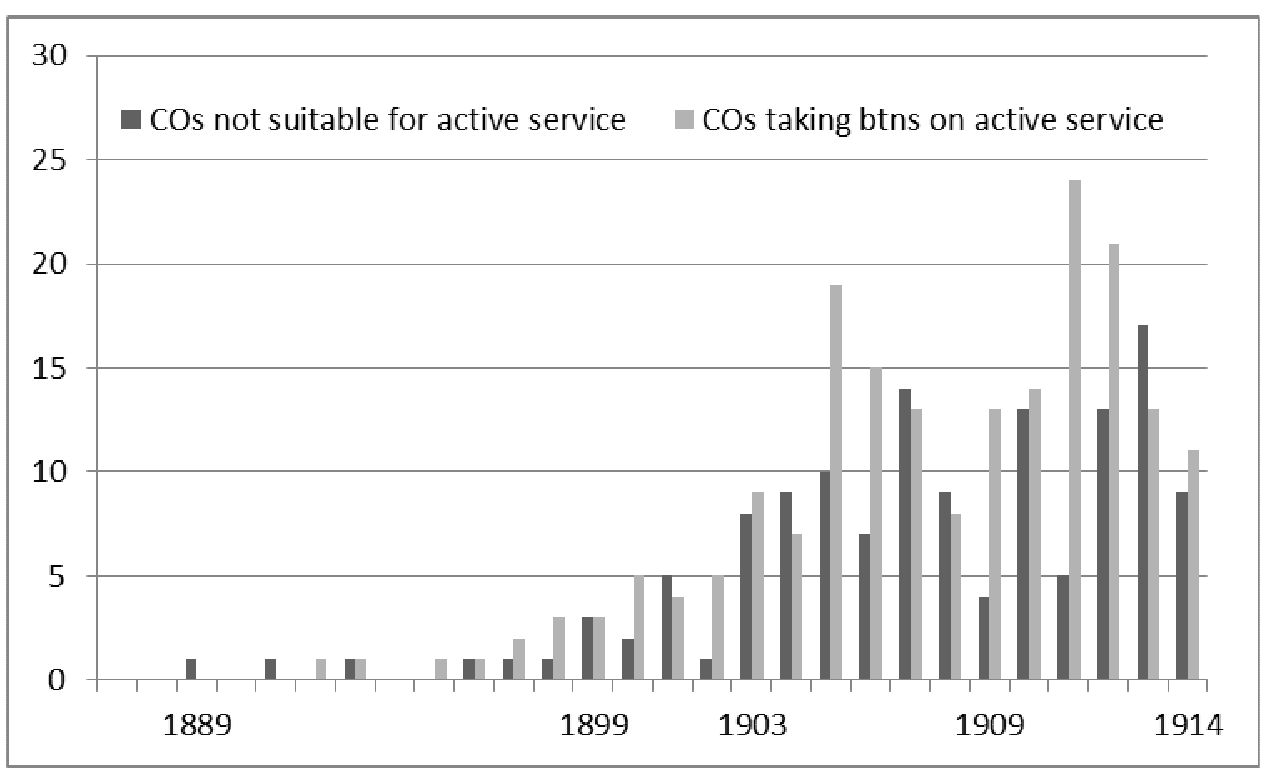

Figure 2.1: Retirement years of 'dug out' COs either not suitable for active service, or first to take service battalions on active service

The direction of the curve for COs removed from command and never seeing active service is counterintuitive. With the exception of one or two years, it mirrors the curve for COs proceeding to active service, with many officers recently retired being discounted, when the premise would predict the reverse. The only conclusion is that date of retirement per se, with associated possible knowledge problems, did not particularly affect a CO's chance of seeing active service. ${ }^{88}$ As Williams suggests, it was likely individual capacity to become up-to-date rather than being out-of-date that mattered.

Table 2.4 shows the main changes in Service battalions from first $\mathrm{CO}$ to first active service $\mathrm{CO}$, namely a reduction in the use of retired Colonels and an increase in the use of retired

\footnotetext{
${ }^{88}$ Twelve COs who took their Service battalions abroad had retired before the Second Boer War. The longest retired of these was Lieutenant-Colonel Stewart MacDougall, $10^{\text {th }}$ Gordon Highlanders, who had resigned as a Major from the Gordon Highlanders on 21 September 1892. He was killed in action on 21 May 1915, aged 61 , only a matter of days after his battalion arrived in France. His son Iain, Adjutant of the $2^{\text {nd }}$ Grenadier Guards had been killed in action in 1914, and thus the male line of the MacDougalls of Lunga was extinguished.
} 
Regular Majors and Captains, and active Regular Captains. These COs had an average age of 47 years and those who were not active had been retired seven years five months.

\begin{tabular}{|l|c|c|c|c|c|c|c|c|c|c|c|c|}
\hline & \multicolumn{2}{|c|}{ Colonel } & \multicolumn{2}{c|}{ Lt-Col } & \multicolumn{2}{c|}{ Major } & \multicolumn{2}{c|}{ Captain } & \multicolumn{2}{c|}{ Lieutenant } & \multicolumn{2}{|c|}{ 2nd Lieutenant } \\
\hline & 1 st & AS & 1 st & AS & 1 st & AS & 1 st & AS & 1 st & AS & 1 st & AS \\
\hline Active & & & & & & & & & & & & \\
\hline Regular & 1 & 0 & 9 & 4 & 78 & 67 & 1 & 16 & 0 & 0 & 0 & 0 \\
\hline Ind Army & 10 & 8 & 14 & 11 & 0 & 4 & 0 & 1 & 0 & 0 & 0 & 0 \\
\hline SR & 0 & 3 & 4 & 6 & 6 & 9 & 2 & 4 & 0 & 0 & 0 & 0 \\
\hline TF & 0 & 0 & 1 & 0 & 3 & 1 & 0 & 1 & 0 & 1 & 0 & 0 \\
\hline Empire & 0 & 0 & 0 & 1 & 0 & 0 & 0 & 0 & 0 & 0 & 0 & 0 \\
\hline Retired & & & & & & & & & & & & \\
\hline Regular & 52 & 14 & 39 & 37 & 47 & 64 & 14 & 44 & 1 & 6 & 0 & 1 \\
\hline Ind Army & 14 & 7 & 13 & 8 & 2 & 5 & 1 & 1 & 0 & 0 & 0 & 0 \\
\hline SR/Militia & 9 & 6 & 3 & 6 & 5 & 4 & 6 & 7 & 1 & 1 & 0 & 0 \\
\hline TF/Vols & 16 & 3 & 8 & 5 & 3 & 4 & 6 & 4 & 1 & 2 & 0 & 0 \\
\hline Empire & 2 & 2 & 0 & 1 & 1 & 0 & 1 & 2 & 0 & 0 & 0 & 0 \\
\hline
\end{tabular}

Table 2.4: Comparison of first COs of Service Battalions with those taking battalions on active service (AS)

In comparison with the data presented on first COs above (overall average age 50 years six months; time since retirement five years five months), those who took their battalions on active service were somewhat younger. Those who proceeded on active service who were retired in August 1914 had, however, been retired two years longer than the first-appointed COs. This, again, reinforces the 'capacity' argument.

Brigade or division commanders were very active in ensuring poor COs were replaced. Local judgement (as implied by Rees' account) about individual ability, balanced by health and stamina, was the key to proceeding to active service. Major-General I. Maxse, training the $18^{\text {th }}$ Division, for example sought the removal of Lieutenant-Colonel C.J. Hawker, $10^{\text {th }}$ Royal Fusiliers, an unemployed Lieutenant-Colonel of the Coldstream Guards, on the 
grounds that he would "ruin a magnificent battalion". ${ }^{89}$ Maxse's GSO1, LieutenantColonel T.H. Shoubridge, wrote to his wife from France in October 1915: "I can't tell you how much all the trouble the General took about getting good Brigadiers and COs is repaying him now".90

A good summary of the reasons for a CO's removal are set out in the case of LieutenantColonel R.A.A. Bottomley of $2 / 5^{\text {th }}$ West Yorkshire. ${ }^{91}$ Forty-three year old Bottomley had retired as CO of $6^{\text {th }}$ West Yorkshire on 11 May 1910, and was described in the 1907 Annual Inspection report as "able and energetic". ${ }^{22}$ However, Brigadier-General V.W. de Falbe, who took over 185 Brigade on 4 January 1916, replaced him on 20 May 1916. De Falbe, who had commanded $1^{\text {st }}$ North Staffordshire on active service for 15 months, had reported on Bottomley on 27 January 1916, finding him "fit", but now, with greater knowledge, stated that Bottomley did not "possess the qualities and experience necessary for the successful training of a battalion for active service". He observed that he lacked "the power of organizing", was indecisive, left "matters to his subordinates without exercising the supervision necessary", thus showing "want of initiative and power of command". Southern Command concurred, but noted: "Ill health has been a contributory cause". Bottomley never served again. ${ }^{93}$ Not only does this clarify what was expected of COs, but also indicates the active role of brigade commanders in sifting them.

\footnotetext{
${ }^{89}$ J. Baynes, Far from a Donkey (London: Brassey's, 1995), p.124. Claude Julian Hawker commanded $10^{\text {th }}$ Royal Fusiliers from 6 September to 22 November 1914. He was removed to a GSO1 post, and later served as a Provost Marshal. He never served in an active unit, but finished the war a Brigadier-General serving as a military governor.

${ }^{90}$ Baynes, Donkey, p.129

${ }^{91}$ Richard Arthur Augustus Bottomley commanded 2/5 ${ }^{\text {th }}$ West Yorkshire from 14 October 1914 to 20 May 1916.

${ }^{92}$ F. Skirrow, Massacre on the Marne: The Life and Death of the $2 / 5^{\text {th }}$ Battalion West Yorkshire Regiment in the Great War (Barnsley: Pen \& Sword, 2007), p.48

${ }^{93}$ TNA WO 374/7817, Officers' services, Richard Arthur Augustus Bottomley.
} 


\subsection{Quality of COs who Took their Battalions to War}

Excluding the COs of pioneer battalions, the careers of 347 COs who first took Service Battalions overseas can be followed. These men spent on average exactly eight months in command on active service (range six days to three years eight months). ${ }^{94}$

Fifty-six (16 per cent) were killed in action or died of wounds. ${ }^{95}$ Lieutenant-Colonel E.H. Chapman, $6^{\text {th }}$ Yorkshire, had the unhappy honour to be the first $\mathrm{CO}$ to die in the first offensive action of a New Army battalion on 7 August 1915 on Gallipoli. ${ }^{96}$ In 1915, 13 were killed on Gallipoli and 12 at Loos, Lieutenant-Colonel M.V. Hilton, $7^{\text {th }}$ East Lancashire, having the ill-luck to be killed at Loos (20 October 1915) on the day he was appointed Brigadier-General. ${ }^{97}$ Twenty-one were killed on the Somme (nine on the first day), and one in Mesopotamia. Nine were simple, if tragic, 'trench wastage' in France and Flanders, typical of these deaths being that of Lieutenant-Colonel F.H. Gaskell, $16^{\text {th }}$ Welsh, who had already been wounded in November 1914 serving with the $2^{\text {nd }}$ Welsh, shot by a sniper at night on 17 May $1916 .^{98}$

In an attempt to review the overall viability as COs of those who took their Service battalions to war, a cut-off of six months will be again be taken as likely to reveal the effects of age, health and ability. Removing those who could not have furthered their careers through death (56) or serious wounds (12), there remains a group of 277 men

\footnotetext{
94 Lieutenant-Colonel John David Beveridge Erskine, $8^{\text {th }}$ Shropshire Light Infantry, a retired Regular Captain, was in command from 8 March 1915 to 1 November 1918, but much of this time was spent in Salonika, where CO turnover was comparatively low.

${ }^{95}$ This is higher than the overall average of 10 per cent (see Chapter Three, section 3.3.5), Gallipoli and the Somme taking their toll.

${ }^{96}$ Edward Henry Chapman was a Depot Major with the Yorkshire Regiment.

${ }^{97}$ Muray Venables Hilton, a brevet Colonel retired from the Worcestershire Regiment, commanded $7^{\text {th }}$ East Lancashire from 1 October 1914 to 20 October 1915.

${ }^{98}$ Frank Hill Gaskell, a Special Reserve Captain of the $3^{\text {rd }}$ Welsh, commanded $16^{\text {th }}$ Welsh between 25 November 1914 and 17 May 1916.
} 
whose careers can be followed. Eleven are known to have been invalided and 57 were replaced, not known to have been wounded or invalided, i.e. 25 per cent of the cohort. Seventy-five per cent achieved over six months' active service or were promoted, and hence were viable commanders, a level bearing good comparison with the 'endurance or promotability' rate of 64 per cent of the regular COs of August 1914. ${ }^{99}$

Forty-eight were promoted Brigadier-General (17 per cent of those who could possibly have been promoted). Twenty-nine were active professionals in August 1914. One was a Regular Lieutenant-Colonel, twenty-one were Regular Majors ${ }^{100}$ and four were Regular Captains; ${ }^{101}$ and one was a Colonel and two were Lieutenant-Colonels of the Indian Army. The remainder were retired at the outbreak of war (12 Regulars, ${ }^{102}$ four Indian Army, and two from the Special Reserve/Militia). Only the two retired from the Special Reserve/Militia had no previous professional service, ${ }^{103}$ so 96 per cent of those promoted from this group to Brigadier-General had a professional background.

The careers of 97 COs who first took second-line Territorial Battalions overseas can also be followed. These men spent on average 7.9 months in command on active service (range

\footnotetext{
${ }^{99}$ See Chapter One section 1.4.1

${ }^{100} 44$ per cent of the group of Regular Majors who took Service Battalions on active service.

10122 per cent of the group of Regular Captains who took Service Battalions on active service.

102 Notable amongst these was Lieutenant-Colonel James Dayrolles Crosbie, $11^{\text {th }}$ Lancashire Fusiliers. He had retired from the Royal Welsh Fusiliers, where he had served as Adjutant, on 20 January 1893. On 4 June 1916 he was promoted Brigadier-General commanding $12^{\text {th }}$ Brigade, $4^{\text {th }}$ Division, which he was commanding on the first day of the Somme offensive. He served until 17 January 1917, then serving until November 1918 as $\mathrm{CO}$ of a home service unit, $16^{\text {th }}$ Queen's.

${ }^{103}$ Lieutenant-Colonel Noble Fleming Jenkins, $7^{\text {th }}$ East Yorkshire, had retired from the Special Reserve of the Border Regiment on 29 August 1910, and was promoted Brigadier-General 75 Brigade on 8 February 1916, although he was removed on 9 July 1916 to become Deputy Commandant of the Machine Gun Corps training centre. Lieutenant-Colonel John Henry Lloyd, $15^{\text {th }}$ Lancashire Fusiliers, had retired from the Militia of the Royal Lancaster Regiment on 18 December 1907, and was promoted Brigadier-General 90 Brigade, 18 October 1916 to 18 November 1917, later serving as Assistant Controller of Salvage.
} 
six days to one year nine months), ${ }^{104}$ almost identical to their Service Battalion counterparts. Only five of this cohort were killed in action (five per cent, a figure three times lower than the first active Service battalion COs, probably because they were seeing service later in the war when there was more concern not to lose COs in action).

Removing those who could not have furthered their careers through death (five) or serious wounds (two), there remains a group of 90 men whose careers can be followed. Ten are known to have been invalided, and 29 were replaced, not known to have been wounded or invalided, i.e. 43 per cent of the cohort. Fifty-seven per cent had over six months active service or were promoted, and hence were viable commanders, somewhat less than the viability rate of 75 per cent of their Service battalion counterparts, and that of the 71 per cent for COs of first-line TF battalions who first took their units overseas.

Only two of this group were promoted to Brigadier-General, namely Lieutenant-Colonel H.E.P. Nash, 2/4 ${ }^{\text {th }}$ Duke of Wellington's (a Regular Major of the Royal Scots in August 1914); ${ }^{105}$ and Lieutenant-Colonel W.J. Woodcock, 2/7 ${ }^{\text {th }}$ Manchester (a Special Reserve Major of the Lancashire Fusiliers in August 1914, but an ex-Regular). ${ }^{106}$

The previous war experience of these men makes good comparison with the Regular and TF COs of August 1914. Of the first active Service battalion COs only 18 per cent had

\footnotetext{
${ }^{104}$ Lieutenant-Colonel Thomas Begby Houghton Thorne (an ex-Regular Lieutenant) commanded $2 / 6^{\text {th }}$ North Staffordshire from 7 June 1916 to 21 March 1918, when he was killed in action.

${ }^{105}$ Henry Edward Palmer Nash, aged 45 in 1914, was a Regular Major of the $1^{\text {st }}$ Royal Scots in 1914, and commanded $13^{\text {th }}$ Royal Scots from 6 September 1914 to 23 June 1915, and 2/4 ${ }^{\text {th }}$ West Riding from 13 July 1916 to 5 May 1918 from which point he commanded 49 Brigade until the Armistice.

${ }^{106}$ Wilfred James Woodcock, aged 36 in August 1914, was an ex-Regular serving as a Major in the Special Reserve of the Lancashire Fusiliers. He commanded $7^{\text {th }}$ Border from 13 September to 31 October 1916, and 2/7 ${ }^{\text {th }}$ Manchester from 11 February to 27 December 1917. He served as GOC 101 Brigade from 23 April 1918 to the Armistice. He had also served as CO to a battalion of the Machine Gun Corps from 27 December 1917 until his promotion.
} 
seen no active service (compared with 12 per cent for the Regular COs of August 1914), the remainder serving on average in approximately two campaigns each. ${ }^{107}$ Fifty-five per cent of the first active second-line TF COs had no previous active service (compared with 50 per cent of the TF COs of August 1914), the remainder serving on average in one campaign. ${ }^{108}$ The picture was different, owing to the mixed nature of the groups, in relation to staff service. Fifty-two per cent of the first active Service Battalion COs had had staff experience (compared with 88 per cent of regular COs of August 1914), ${ }^{109}$ and 25 per cent of the first active second-line TF COs (compared with 8 per cent for the TF COs of August 1914). ${ }^{110}$

The examples of three officers convey the rich experience possessed by some of those who took their Service battalions on active service. Lieutenant-Colonel T.B. Sellar, $8^{\text {th }}$ King's Own Scottish Borderers, had retired as a Regular Major from that regiment in May 1913. He had no staff experience but had been with the Chitral Relief Force (1895), and had served on the North-West Frontier (1897-8), Tirah (1897-8), and in South Africa (18991900) as a Captain (including the defence of Ladysmith). He had been with his battalion in the UK following the introduction of Combined Training, 1902, and with the exception of absence of experience of the four company system, was almost completely up-to-date. He served from the battalion's formation to his wounding on 28 October 1916, and returned to command the merged $7 / 8^{\text {th }}$ battalion on 20 January 1917 until his wounds got the better of him and he was invalided on 21 April 1917.

\footnotetext{
107 1.9, an average higher than the 1.7 campaigns of Regular COs of August 1914.

108 1.2, an average higher than the .3 campaigns of TF COs of August 1914.

${ }^{109}$ See Chapter One section 1.1.5

${ }^{110}$ See Chapter One section 1.3.1
} 
Lieutenant-Colonel D.H.A. Dick, $14^{\text {th }}$ Highland Light Infantry, who was a Major in the $3^{\text {rd }}$ Royal Scots Fusiliers had served as Adjutant to this battalion before retiring as a Regular Major in July 1910. He had served on the North-West Frontier (1897-8 with the Tochi Field Force), in Tirah (1897-8), and in South Africa (1899-1900) as a Captain, including the Battle of Colenso and the relief of Ladysmith. Like Sellar, with the caveat of lack of experience of the four company system, he was thus almost completely up-to-date. The battalion's second CO, having already commanded the $1^{\text {st }}$ Royal Scots Fusiliers for two extended periods in 1914-5, he served from 24 November 1915 to 19 May 1917. ${ }^{111}$

Lieutenant-Colonel F.E.P. Curzon, $6^{\text {th }}$ Royal Irish Regiment, had retired as a LieutenantColonel from that regiment in 1907. He had, without the benefit of Staff College attendance, served two spells as an Adjutant with the Scottish Rifles and Royal Irish Rifles, two spells as ADC (firstly to GOC Southern District, 1889-90, and secondly to the Governor and C-in-C Gibraltar, 1890-91), had been a Special Service Officer with the Rhodesian Field Force, and a DAAG during the Second Boer War. He had seen service on the Nile (1898, Battle of Khartoum), Sierra Leone (1898-9) and South Africa (1899-1902). The battalion's first CO, he served until killed in action on 9 September 1916, at Ginchy.

There were therefore clearly many richly experienced and competent COs amongst the 'dug-outs' and others who were the first to take the Service and second-line TF battalions to war. Lieutenant-Colonel P.W. Machell, $11^{\text {th }}$ Border, became his battalion's factotum in the early days, and demonstrating the required power of organisation and initiative:

Every detail had to be taught by him, for the officers, with very few exceptions, knew no more than the men, and had to be taught themselves

${ }^{111}$ Dick commanded the regiment's $3^{\text {rd }}$ Battalion until the end of the war. 
before they could teach. The simplest orderly room work, such as making out 'crimes' 'guard reports', and 'details' etc. were done by him ... All attestations were made out, and recruits personally approved by him ... He organised the feeding of the men ... He arranged for the hutting, the clothing, the water supply, the lighting and conservancy of the camp ... These things alone would have occupied the activities of six ordinary men, but in addition to all this the $C O$ was constantly on parade, training and smartening up both officers and men, drawing up the programmes of work and seeing that they were carried out. ${ }^{112}$

Machell had retired as a Regular Captain from the Essex Regiment on 30 September 1896, when he was 34 . He had served in four campaigns in the Sudan and had been attached to the Egyptian Army. Following his retirement he served as Inspector General of the Egyptian Coastguard, and as Advisor to the Egyptian Ministry of the Interior until 1908, when he took up a post with the London County Council. It is therefore not surprising that his organisational capabilities proved high. Machell had corresponding high expectations of others, an NCO writing after his death: "To some of the men he may have appeared in the light of a martinet, as at time he was most severe in irony when dealing with defaulters". ${ }^{113}$ Machell was killed on 1 July 1916 with 10 of his officers and 100 ORs, attempting to reach the Leipzig Salient, debouching from Authuille Wood.

A burden of training fell on these retired officers. ${ }^{114}$ C.E. Montague, a Sergeant in the $24^{\text {th }}$ Royal Fusiliers, was sarcastic about that offered by Colonel A. de B.V. Paget, a brevet Colonel retired in 1903 from the Durham Light Infantry, whom he described as "the old, cold colonel, upright, dutiful, drawn away by a genuine patriotism from his roses and

\footnotetext{
${ }^{112}$ P.G.W. Diggle, in V.M. (ed.) Record of the XIth (Service) Battalion Border Regiment (Lonsdale) from September 1914 to July $1^{\text {st }} 1916$ (Whitehead: Appleby, ND), pp.7-8. (Captain Diggle was the battalion Adjutant during this period.)

${ }^{113}$ From a letter in the Westmorland Gazette, http://border-regiment.kerchi.co.uk - accessed 24 February 2011.

${ }^{114}$ Captain Basil Williams describes the training of the "Fourth and Fifth Armies" suffering in particular as "the training had to depend almost entirely on the idiosyncracies of the commanding officers" (Williams, Raising, p.74).
} 
croquet", lecturing with Infantry Training 1914 in his hand, "bringing his laboured jets of darkness to show the way though sunlight, elucidating plainness itself with the tangled clues of his own mind's confusion". ${ }^{115}$ In comparison, however, the energy of LieutenantColonel W.D. Villiers-Stuart surpassed Machell. Being particularly interested in the use of machine guns, with Vickers guns being unavailable: "I wrote to Erith and asked them (Maxim's people) if they could let me have one for instructional purposes - and they sent me one at once ... I started classes on it for the young officers". ${ }^{116}$ Similarly, after problems with bayonet training: "I started classes in the evenings for the officers and in a short time bayonet fighting was done well". He continued: "I made sure that the battalion learned how to dig properly and how to ring and revet trenches". ${ }^{117}$ Training his men hard to give them the best possible chances, Villiers-Stuart wrote ominously before going on active service: "I knew what was going to happen to all these boys who were so close to my heart". 118

As 1915 progressed, the personal burden on the $\mathrm{CO}$ of providing training altered. Major A.G. Wauchope of the Black Watch, ${ }^{119}$ wounded and in the UK as a bombing trainer, noted:

A syllabus of work was brought out by the War Office for a course of twelve weeks training, and for the average recruit this was found

\footnotetext{
${ }^{115}$ C.E. Montague, Disenchantment (London: Chatto \& Windus, 1924), p.22. Lieutenant-Colonel Charles Sydney Collison, the ex-regular (second) CO of the $11^{\text {th }}$ Royal Warwickshire, wrote: "That I had no alternative but to start elementary instruction from the very beginning is an instance of the entire want of method that obtained in the training of some units of the New Army. Officers without the faintest idea of how to train men, and often as ignorant of their work as the people they were supposed to teach, were occasionally put in command of these battalions and the results were deplorable". TNA WO/95/2536, War Diary 112 Infantry Brigade.

${ }_{116}^{116}$ Maxwell, Villiers-Stuart, p.20

${ }^{117}$ Maxwell, Villiers-Stuart, p.22

${ }^{118}$ Maxwell, Villiers-Stuart, p.39

${ }^{119}$ Arthur Grenfell Wauchope, a Captain of $2^{\text {nd }}$ Black Watch in August 1914, served as CO of the battalion from 6 September 1915 to 20 April 1917 before becoming a Brigade Commander in the Indian Army in Palestine.
} 
sufficient. Specialist officers paid periodical visits of inspection, each specialist being convinced that his speciality only could win the war, be it bombing, bayonet fighting, musketry or physical drill. The Commanding Officer had to satisfy each and every specialist officer, to preserve his temper and maintain a well-balanced system of training. ${ }^{120}$

It is clear that both officers and other ranks recognised and appreciated organisational ability in these early COs where it existed. Second-Lieutenant F. Buckley, $3 / 7^{\text {th }}$ Northumberland Fusiliers, wrote of his CO, Lieutenant-Colonel J.J. Gillespie, a Territorial Major, that he was "a man of great personality ... a great organiser and a hard worker" who did "much to make the drafts efficient". ${ }^{21}$ Private O. Burgess of the $14^{\text {th }}$ York \& Lancaster wrote of Lieutenant-Colonel W.B. Hulke who took his battalion overseas: "He was a regular Army man and he knew his job". ${ }^{122}$ Lieutenant J.L. Middleton, $12^{\text {th }}$ York $\&$ Lancaster, wrote in his diary of Colonel C.V. Mainwaring, ex-Indian Army, that he "looks a terror" but "the men worked harder than ever under Mainwaring's leadership", and that they had "the greatest respect for him". ${ }^{123}$ Captain J.H. Beith stated of Lieutenant-Colonel A.F. Mackenzie how on the parade ground he liked "a clean finish to any piece of work", yet he was also capable of overlooking shortcomings that needed no remark: "He was a good Colonel". 124

\footnotetext{
${ }^{120}$ A.G. Wauchope, A History of the Black Watch, Royal Highlanders, in the Great War 1914-1918: Vol. 1 (London, Medici Society, 1926), p.349

${ }^{121}$ F. Buckley, Q.6.A. and Other Places (London: Spottiswoode Ballantyne, 1920), p.13. James John Gillespie was a 42 year-old Major of the $7^{\text {th }}$ Northumberland Fusiliers in August 1914.

${ }^{122}$ Cooksey, Barnsley Pals, p.88. Walter Backhouse Hulke was a 43 year-old who had retired as a Regular Captain of the Lincolnshire Regiment in February 1911 and saw 21 months active service in two spells. He was still in command when the battalion was disbanded in February 1918. He was promoted GOC 115 Brigade between 16 April and 3 August 1918.

${ }^{123}$ Gibson \& Oldfield, Sheffield City Battalion, p.34

${ }^{124}$ Hay, First Hundred Thousand, p.30. Mackenzie took his battalion to France and was badly wounded at Loos on 27 September 1915. Beith's book ends with the Colonel's wounding, as if a significant chapter was over.
} 
A prime example of the enduring Service battalion CO is Lieutenant-Colonel A.W. Rickman, $11^{\text {th }}$ East Lancashire. He was the second CO, taking over from Colonel R. Sharples, on 1 March 1915. ${ }^{125}$ Thirty-nine years old in August 1914, he had retired as a Captain from the $2^{\text {nd }}$ Northumberland Fusiliers, having served in South Africa 1899-1902, and was a Captain in the Special Reserve of that regiment on the outbreak of war. He was awarded the DSO for his efforts at Serre on 1 July $1916,{ }^{126}$ on which day he was wounded by a shell and invalided, returning to command on 31 May 1917. He was wounded again on 11 November 1917, returning in time for the German offensives of 1918, winning a bar to his DSO leading his battalion on $12-13$ April $1918 .{ }^{127}$ He took over temporary command of 92 Brigade before returning to his battalion. ${ }^{128}$

Inevitably, empire 'characters' are represented in this group. One such colourful individual was Lieutenant-Colonel D.P. Driscoll, of the (somewhat atypical) $25^{\text {th }}$ Royal Fusiliers, ${ }^{129}$ who commanded his battalion throughout its career. Driscoll was probably born in Burma, and was 53 in August 1914. He had served in the Indian Merchant Navy and was involved in the Burma campaign of 1866-8. After leaving the navy he is thought to have served in the Upper Burma Rifles, becoming a crack shot. On the outbreak of the Boer War he travelled to South Africa and joined the Border Mounted Rifles, being asked in 1900 to

\footnotetext{
${ }^{125}$ Richard Sharples, a 64 year-old retired TF Colonel, returned to retirement.

${ }^{126}$ A January 1917 New Year honour, garnering no citation.

127 "This officer commanded his battalion, covering the retirement of the brigade to a new position after both flanks had been turned. He displayed great courage and judgement. The following day he held an extended front against three determined attacks, and when the troops on his right flank were driven in he rallied them under close fire, and formed a defensive flank with them”. London Gazette, 16 September 1918, page unknown.

${ }^{128}$ After surviving the exigencies of the Western Front, Rickman died in an accident at home in 1925.

${ }^{129}$ This battalion was raised by the Legion of Frontiersmen especially for service in East Africa.
} 
form 'Driscoll's Scouts'. In 1907 he joined the Legion of Frontiersmen, a group of adventurers comprising a patriotic paramilitary group, rising by 1914 to be its head. ${ }^{130}$

Perhaps the most extraordinary career was that of Lieutenant-Colonel I. Thord-Gray, who took over command of $11^{\text {th }}$ Northumberland Fusiliers on 18 June 1915 and took them on active service. A Swede, ${ }^{131}$ Thord-Gray had joined the Cape Mounted Rifles as a Private in 1897, fighting in Bechuanaland and Pondoland (1897) and the Second Boer War, following which he joined the South African Constabulary in 1902. Between 1903 and 1906 he served in various units (Lydenburg Militia, Royston's Horse, and the Nairobi Mounted Police), and also with German forces in South-West Africa, before serving with the Americans in the Philippine Constabulary in 1906. He spent some time as planter in Malaya, but served with the French Foreign Legion in Tonkin in 1909, with the Italians in the Italian-Turkish war of 1911 in modern-day Libya, and with Sun Yat Sen in China in 1912. In 1913-14 he fought in the Mexican War as commander of artillery with Pancho Villa, and later as Chief of Staff of the $1^{\text {st }}$ Mexican Army as a Colonel.

Predictably, he joined the British army as a Major in October 1914. After a period as CO $11^{\text {th }}$ Northumberland Fusiliers (allegedly resigning after a row with his Brigadier) he was appointed CO $25^{\text {th }}$ London Regiment, although the battalion was disbanded, after which he was suspected of being a German agent, a case of mistaken identity. Resigning from the British Army, he joined the American Army in 1917, being appointed Brigade Commander in the aborted Theodore Roosevelt Division. He served as a Lieutenant-Colonel in the Canadian Expeditionary Force to Russia, then as commander of the $1^{\text {st }}$ Siberian Assault

\footnotetext{
${ }^{130}$ www.nigeldriscoll.au accessed 24 February 2011.

${ }^{131}$ Born in Stockholm 17th April 1878 as Ivar Thord Hallström.
} 
Division, before being wounded and becoming a Major-General and representative of the Provisional Siberian Government. His last foreign military venture was as LieutenantGeneral in the revolutionary army of Venezuela in $1928 .{ }^{132}$

\subsection{Conclusion}

Initial provision of commanding officers to the newly-raised infantry battalions was made according to a developing set of principles. Service Battalion appointments reflected, in order, deference to: (i) active Regular army status; (ii) retired Regular status; (iii) seniority of rank of retired professional officers; (iv) Indian Army status; (v) and, lastly, sparing use of auxiliaries. In the second-line Territorial units, TF pedigree and seniority of rank were the guiding principles. Kitchener units were provided with command from a better stocked pond than were the locally-raised and second-line TF battalions.

Anecdotal accounts and the data presented indicate, unsurprisingly, that a number of COs proved unfit for command. In the intervening months between unit establishment and active service, a weeding-out process took place, conducted at brigade and divisional levels, amounting to 27 per cent of COs of the Service Battalions, never to see active service.

That this process generated a reasonably good quality of $\mathrm{CO}$ is reflected in the fact that 75 per cent of New Army COs achieved over six months active service or were promoted. The figure for second-line Territorials was less at 57 per cent, reflecting the limitations of the stock of officers from whom these COs were selected. Although many of the Service

\footnotetext{
${ }^{132}$ S. Bojerud, Ivor Thord-Gray - Soldat under 13 Fanor (Stockholm, Sivart Förlag AB, 2008).
} 
Battalion COs saw their active service in the quieter months prior to (but also during) the Somme offensive, there were clearly many talented individuals, as indicated by the rate of promotion to brigade command. Overall, the data again speaks to a greater depth of competence in the reserves available to the British officer corps during the early part of the war than it has been given credit for.

The stereotype of the 'dug-out' CO, at least on the battlefield, as old and out-of-touch is therefore found unsound. Length of time since retirement proved not to be a factor in proceeding on active service, indicating that even in this early period, merit-based selection was operating. Ability was the key, those without fitness, stamina or capacity being identified and excluded in spite of seniority. 


\title{
Chapter Three
}

\section{Evolution of Battalion Command - Organisational and Individual Aspects}

\begin{abstract}
I haven't the slightest idea why I was pitchforked into this job - except that the last $\mathrm{CO}$ was booted and the former second-in-command has gone home sick and I don't know how long I'm expected to remain.
\end{abstract}

Lieutenant-Colonel H.E. Trevor, 13 November $1915^{1}$

To date, 5185 infantry battalion commanders have been identified serving between 4 August 1914 and 11 November 1918 with the rank of substantive, temporary or acting Lieutenant-Colonel. ${ }^{2}$ Of these, 4055 (78 per cent) saw active service.

The prosopographical approach to this group of officers identifies overall patterns of evolution in command, both organisational and individual in nature. Organisational aspects mainly concern source of officers. Individual aspects include age, progression in rank, and army experience such as staff service. Overall patterns of turnover and matters bearing on it can be examined, such as number, length and reasons for leaving command.

\footnotetext{
${ }^{1}$ IWM P229 HET/3, H.E.Trevor, Letters

${ }^{2}$ A substantive rank is a permanent rank. Acting rank was granted to officers to fulfil particular posts, and was confirmed after 28 days and the individual granted the pay of that rank. It was gazetted on confirmation, but when that officer left that post he relinquished his Acting rank, unless he was appointed to a post which bore the same rank. Temporary rank could be carried beyond the immediate post. Many were given Temporary Lieutenant-Colonelcies in 1915-6 for a matter of days, whereas in 1917, far more Acting Lieutenant-Colonelcies were granted. The matter of Temporary rank was discussed in parliament on 22 April 1915 (Hansard, House of Commons debate, 22 April 1915, Vol 71 cc 434-552), the Under-Secretary of State for War, Harold Tennant stating: "I have to announce a new departure ... In the case of a Lieutenant-Colonel being appointed a Brigadier-General, or his being wounded or sick, the next senior officer will command for a month in his previously existing rank, and if the vacancy extends beyond a month he will then commence to draw the pay and allowances of a Lieutenant-Colonel, and he will be granted the temporary rank". In the post-war period Acting rank was converted to Temporary rank automatically after three months in post.
} 


\subsection{Evolution - Organisational Characteristics}

\subsubsection{Source of Commanding Officers}

Table 3.1 shows that the Regular army of August 1914 provided 45 per cent of active infantry COs during the war. ${ }^{3}$ Given that only 18 per cent of battalions were Regular, their disproportionate contribution is clear. If retired Regulars and active/retired Indian Army officers are included, professional soldiers provided 60 per cent of active COs. Conversely, serving Territorials of 1914 provided 18 per cent of active COs (rising to 24 per cent when retired TF officers are taken into account) yet Territorial battalions comprised 35 per cent of active infantry battalions. Territorial officers were therefore under-represented. ${ }^{4}$ The Special/Extra Reserve provided six per cent, and Empire regiments two per cent of COs. Men who were citizens in 1914 provided eight per cent. ${ }^{5}$

\begin{tabular}{|l|c|}
\hline & Commands \\
\hline Regular & $45 \%$ \\
\hline Retired Regular & $11 \%$ \\
\hline Indian Army & $2 \%$ \\
\hline Retired Indian Army & $2 \%$ \\
\hline Special Reserve & $4 \%$ \\
\hline Retired Special Reserve & $2 \%$ \\
\hline Territorial & $18 \%$ \\
\hline Retired Territorial & $6 \%$ \\
\hline Empire & $1 \%$ \\
\hline Retired Empire & $1 \%$ \\
\hline Citizens & $8 \%$ \\
\hline
\end{tabular}

Table 3.1: Relative contribution of various arms of the infantry to active battalion command

The position on 29 September 1918 was somewhat different, as Table 3.2 shows, with a lower number of retired officers (22 compared with 18 per cent). This is unsurprising,

\footnotetext{
${ }^{3}$ Of the 12,738 Regular officers of 4 August 1914 [War Office, Statistics of the Military Effort of the British Empire, (1922) p.234], 13 per cent would become battalion COs of an active infantry battalion.

${ }^{4}$ This is examined in more detail in Chapter Four section 4.3.1

${ }^{5}$ This group is examined in detail in Chapter Six.
} 
older retired officers having been called on earlier in the war. ${ }^{6}$ There was a lower number of active Regular/professional officers (47 per cent overall compared with 32), and a higher number of Territorial officers (24 per cent overall compared with 31 ), with the contribution of Special Reserve officers dropping (six per cent overall compared with four). The significant discrepancy is in the increased number of citizen COs, (eight per cent overall compared with 22).

\begin{tabular}{|l|c|c|c|c|c|c|c|}
\hline & Regular & $\begin{array}{l}\text { Indian } \\
\text { Army }\end{array}$ & Territorial & $\begin{array}{c}\text { Special } \\
\text { Reserve }\end{array}$ & Empire & Citizens & Total \\
\hline Active & $32 \%$ & $0 \%$ & $25 \%$ & $2 \%$ & $1 \%$ & $22 \%$ & $82 \%$ \\
\hline Retired & $8 \%$ & $>1 \%$ & $6 \%$ & $2 \%$ & $2 \%$ & $\mathrm{n} / \mathrm{a}$ & $18 \%$ \\
\hline Total & $40 \%$ & $>1 \%$ & $31 \%$ & $4 \%$ & $3 \%$ & $22 \%$ & $100 \%$ \\
\hline
\end{tabular}

\section{Table 3.2: Relative contribution of various bodies of the infantry to active battalion} command on 29 September 1918

Table 3.3 shows that the infantry provided 93 per cent of infantry COs, the only other significant contributor being the cavalry. Two hundred and thirty-nine cavalrymen commanded infantry battalions on active service, and of these 42 per cent were active or retired Yeomanry; 34 per cent were active or retired Regular cavalrymen; 17 per cent were active or retired Indian Army cavalrymen; five per cent were from Empire regiments; and two per cent Special Reserve. ${ }^{8}$ In this area, the Territorial Force in the form of the Yeomanry was well represented.

\footnotetext{
${ }^{6}$ See Chapter Two.

${ }^{7}$ There were 56 units of Yeomanry at the outbreak of war.

${ }^{8}$ There were only three Special Reserve cavalry regiments, the North and the South Irish Horse, and King Edward's Horse.
} 
To provide an example of a cavalryman turned infantry CO, A.M. Mills was a Captain in the $18^{\text {th }}$ King George's Own Lancers in August 1914, Adjutant and Quartermaster at the Quetta College. ${ }^{9}$ His regiment joined the Indian Cavalry Corps in France in late 1914, and after serving as a Staff Captain with the Ambala Brigade from 5 June to 8 November 1915, Mills went to $14^{\text {th }}$ Gloucestershire as a Major, second-in-command. As he noted:

The New Army battalions ... needed senior officers. The British infantry of the line had been milked dry of officers, but in the cavalry, and more especially the Indian cavalry, which had not so far been seriously engaged, there was a suitable source of supply. ${ }^{10}$

He served as CO of the 17th Lancashire Fusiliers from 19 April 1916 to 5 July $1917 .{ }^{11}$

\begin{tabular}{|l|c|}
\hline & $\%$ \\
\hline Infantry & 93 \\
\hline Cavalry & 6 \\
\hline Royal Artillery & $<1$ \\
\hline Royal Engineers & $<1$ \\
\hline Royal Marines & $<1$ \\
\hline Royal Flying Corps & $<1$ \\
\hline Royal Navy & $<1$ \\
\hline
\end{tabular}

Table 3.3: Relative contribution of various arms of the services to active battalion command

In contrast, D.W.C. Davies-Evans was a Major in the Pembroke Yeomanry in August 1914. ${ }^{12}$ The battalion was dismounted in the UK in November 1915 and sent to Egypt in March 1916. Davies-Evans was transferred to $8^{\text {th }}$ Lincolnshire in France and commanded

\footnotetext{
${ }^{9}$ The Staff College was established at Quetta in 1907.

${ }^{10}$ NAM 1965-06-17, papers of Major-General Sir Arthur Mordaunt Mills.

${ }^{11}$ Mills spent a period of time away recovering from being wounded in a bombardment near Trones Wood on 21 July 1916. In July 1917 he returned to his own regiment, part of a general transfer of Indian officers, serving as a Squadron Commander in both France and Palestine.

12 Delme William Campbell Davies-Evans, aged 41 in 1914, had actually entered the infantry, Pembroke Volunteers, in 1900, but transferred to the Yeomanry in 1901.
} 
between 14 January and 12 February 1917 , being transferred to $8^{\text {th }}$ Somerset Light Infantry as a Major, later commanding $11^{\text {th }}$ Rifle Brigade from 23 April to 2 May 1918; $2 / 5^{\text {th }}$ Lincolnshire from 21 May to 1 August 1918; and 2/8 ${ }^{\text {th }}$ Worcestershire from 28 August until the Armistice.

On 29 September 1918, there were 37 cavalry officers commanding infantry battalions in France and Flanders, seven per cent of COs in post on that date. The contribution of the cavalry, although small, remained constant. Thirteen COs on that day originated from the artillery; 20 from the Royal Engineers; ${ }^{13}$ and six from the Royal Marines, (all retired officers). Five originated outside the army, being retired Royal Navy personnel. ${ }^{14}$

One officer was serving with the Royal Flying Corps in August 1914. C.J. Burke was a Major of the Royal Irish Regiment, and had served with the Aeroplane and Balloon School before commanding II(AC) Squadron for two years prior to the war. He commanded $2^{\text {nd }}$ Wing RFC in France then served as Commandant of the Central Flying School before commanding $2^{\text {nd }}$ Lancashire Fusiliers from 20 October to 20 December 1916 and $1^{\text {st }}$ East

\footnotetext{
${ }^{13}$ Nine were Regular Lieutenants/Captains in August 1914, namely: Captain W.L. de M. Carey (LieutenantColonel $14^{\text {th }}$ Leicestershire from 10 October 1918 to the Armistice); Lieutenant A.A. Chase (LieutenantColonel $8^{\text {th }}$ Sussex from 11 January to 11 March 1917) ; Lieutenant R.E. Dewing (Lieutenant-Colonel $8^{\text {th }}$ Berkshire from 19 July 1917 to 4 April 1918); Lieutenant E.N. Evelegh (Lieutenant-Colonel $15^{\text {th }}$ Lancashire Fusiliers from 14 to 20 April 1918); Lieutenant N.T. Fitzpatrick (Lieutenant-Colonel $6^{\text {th }}$ South Wales Borderers from 27 October 1917 to 14 April 1918); Captain A.W. Reid (Lieutenant-Colonel 2/4 ${ }^{\text {th }}$ Somerset Light Infantry from 10 September 1918 to the Armistice); Captain A.R.C. Sanders (Lieutenant-Colonel $1^{\text {st }}$ Essex from 19 April to 7 September 1918); Lieutenant G.B.F. Smyth (Lieutenant-Colonel $6^{\text {th }}$ Scottish Borderers from 15 October 1916 to 3 October 1918); and Captain F.V. Thompson (Lieutenant-Colonel $9^{\text {th }}$ Essex from 25 May to 14 October 1917).

${ }^{14}$ Of these the most senior was Lieutenant-Commander Sir Henry Archer Colt. Aged 33 in August 1914 he had become a midshipman in 1898 , retiring in 1912. He commanded $12^{\text {th }}$ Gloucestershire from 25 October 1917 to 19 October 1918 and was twice wounded. During the Second World War he was a Squadron Leader in the RAF Volunteer Reserve, his career thus spanning all three services. (Obituary, The Times, 13 February 1951, p.6).
} 
Lancashire from 13 February to 9 April 1917, being killed on the opening day of the Battle of Arras. He was said to be "a better leader of men than a pilot"! 15

All the artillerymen were retired, apart from T.A. Cubitt, a Regular Major of the Royal Artillery who commanded $8^{\text {th }}$ Lincolnshire from 12 February to 5 April 1917, before being promoted to command 57 Brigade. ${ }^{16}$ One Engineer of interest was G.P. Pollitt, a pre-war chemical engineer who enlisted as a despatch rider in August 1914, and was commissioned $2^{\text {nd }}$ Lieutenant on 25 October 1914, first in the Intelligence Corps then the Royal Engineers, rising to the rank of Major commanding a battalion of the Special Brigade on 9 January 1916. He won a bar to his DSO for courage and leadership in his conduct of gas operations at Bullecourt in May 1917, ${ }^{17}$ and a second bar for "example and leadership" whilst commanding the $11^{\text {th }}$ Lancashire Fusiliers in the German attack of 27 May 1918 on the Aisne. ${ }^{18}$ He had commanded $1 / 6^{\text {th }}$ Lancashire Fusiliers from 4 April to 12 May 1918, and the $11^{\text {th }}$ Battalion from 14 to 28 May $1918 .^{19}$

\footnotetext{
${ }^{15}$ http://www.twosqnassoc.co.uk/pages/bosses/burke.htm (accessed 16 November 2011) Charles James Burke was aged 32 in August 1914.

${ }^{16}$ Thomas Astley Cubitt, $p s c$, aged 43 in 1914, had served prior to the Great War as a Brigade-Major. He had served in five campaigns in West Africa between 1898 and 1903.

17 "He made constant and dangerous personal reconnaissances in connection with gas attacks. His close supervision and fearlessness in the front line contributed very largely to successful operations, and the men under his command owed their spirit and determination in no small degree to his magnificent example." London Gazette, 17 July 1917, p.7210

18 "For conspicuous gallantry during the fighting on 27th May, 1918, on the Aisne. He had his battalion in repeated local counter-attacks against overwhelming odds, holding up the enemy and inflicting severe casualties. Thanks to his example and leadership his battalion put up a splendid defence when over forty per cent, of them had become casualties and the remainder were almost surrounded." London Gazette, 10 December 1919, p.15280

${ }^{19}$ The VC and DSO Book Vol. III (Uckfield: Naval \& Military Press, 2010), p.324. George Paton Pollitt was aged 36 in 1914. In the post war period he became director of Brunner, Mond \& Co, which became part of ICI in 1926.
} 


\subsubsection{Regimental affiliation}

David French notes that "regiments were culturally defined organizations that were bound together by shared historical memories, customs and a myth of descent". ${ }^{20}$ Paddy Griffith claims that "the cap-badge continued to exercise a powerful magnetism and tribalism throughout the war", especially for officers "in the tightly knit 'social club' that was their battalion headquarters' mess". ${ }^{21}$ French, however, warns that "it is too easy to exaggerate the extent to which regimental particularism stood in the way of modernity". ${ }^{22}$ That we should temper our view of regimental particularism was confirmed in Chapter One, where it was noted that 16 per cent of the Regular COs of August 1914 had achieved their Lieutenant-Colonelcy in a different regiment from that in which they obtained their Majority. The exigencies of war were only likely to accelerate this cross-pollination.

\begin{tabular}{|l|l|c|c|}
\hline & & Internal & External \\
\hline Loos & 25 September 1915 & $78 \%$ & $22 \%$ \\
\hline Somme & 01 July 1916 & $54 \%$ & $46 \%$ \\
\hline Arras & 09 April 1917 & $58 \%$ & $42 \%$ \\
\hline Third Ypres & 31 July 1917 & $47 \%$ & $53 \%$ \\
\hline Hundred Days: France \& Flanders & 29 September 1918 & $47 \%$ & $53 \%$ \\
\hline Hundred Days: other & 29 September 1918 & $49 \%$ & $51 \%$ \\
\hline
\end{tabular}

Table 3.4: Internal/external regimental origin of active COs

The position at the time of the Battle of Loos in September 1915, as Table 3.4 shows, was not radically different from that of the pre-war Regulars, (16 to 22 per cent external). From this point onwards, however, there was a rapidly accelerating trend for COs on active

\footnotetext{
${ }^{20}$ D. French, Military Identities (Oxford: University Press, 2005), p.98

21 P. Griffith, 'The Extent of Tactical Reform in the British Army', in P. Griffith ed. British Fighting Methods in the Great War (Abingdon: Frank Cass, 1998), p.6

${ }^{22}$ French, Military Identities, pp. 259-60
} 
service to be external to the regiment. ${ }^{23}$ Nine months later, on the opening day of the Somme campaign, external appointees had doubled to 46 per cent. ${ }^{24}$ Although the figure dropped to 42 per cent external at the opening of the Battle of Arras, from mid-1917 the figures hover around a rough 50:50 split.

As Table 3.5 shows, however, the overall figures hide a distinct pattern. On 29 September 1918, the Regular battalions maintained a high proportion of internal appointments, 73 per cent. The first-line Territorial battalions had a rate of 48 per cent, ${ }^{25}$ Service Battalions 39 per cent. The second-line Territorial Battalions had the lowest internal appointment rate, 10 per cent. Thus, battalions with a pre-war identity maintained a stronger regimental particularism, with the Regulars perpetuating a particularly high level of exclusivity.

\begin{tabular}{|l|c|c|}
\hline & Internal & External \\
\hline Regular & $73 \%$ & $27 \%$ \\
\hline New Army & $39 \%$ & $61 \%$ \\
\hline First-line Territorial & $48 \%$ & $52 \%$ \\
\hline Second-line Territorial & $10 \%$ & $90 \%$ \\
\hline
\end{tabular}

\section{Table 3.5: Internal/external regimental origin of active COs according to battalion type} on 29 September 1918

An amusing note on the matter of external appointment can be found in the War Diary of $1 / 7^{\text {th }}$ Warwickshire on 22 May $1915 .^{26}$ The Adjutant, Captain B. Johnstone, wrote: "Col. L. Hanbury joined for duty ... there are several Lt-Cols of 7 Warwicks yet a stranger has been

\footnotetext{
${ }^{23}$ External is defined as the $\mathrm{CO}$ having had no previous service with the regiment in question.

${ }^{24}$ The first six months of 1916, despite the BEF conducting no major campaign, were ones of constant turnover (see Figure 3.9), with battalion command clearly under ongoing review with new COs increasingly reflecting perceived ability rather than simple progression by seniority and regimental affiliation.

${ }^{25}$ These battalions, as noted in Chapter One section 1.3, had a pre-war 95 per cent internal regimental appointment rate.

${ }^{26}$ TNA WO/95/2756 War Diary $1 / 7^{\text {th }}$ Royal Warwickshire Regiment
} 
appointed". Johnstone missed the irony of the fact that he was himself 'a stranger' from the West Kent Regiment, although he had served as Adjutant since 26 March 1913, his own case indicating that a sense of belonging could swiftly develop. ${ }^{27}$

\subsection{Evolution - Individual Characteristics}

\subsubsection{Age}

Alfred Vagts, in his discussion of age and generalship, notes: "The long-range record of military history speaks clearly against the army leader of advanced years, though, of course, not absolutely in favour of youth - youth does not safeguard against military folly". ${ }^{28}$ Experience may the best safeguard against folly and age is often the price paid for its acquisition, the hothouse of war lowering that price.

In Chapter Two, it was noted that the issue of the age of 'dugouts' was inevitably linked with matters of physical fitness and stamina. The Official Historian suggested that "age is biological and should not be reckoned by the calendar. Each case should be judged for itself". He continued:

Activity is the criterion; in 1914 some Lieutenant-Colonels could be seen running forward with the best of athletes; others collapsed because they were worn out by marching a few miles; not being able to ride their horses in battle, and two were tried by court martial for dereliction of duty, when bodily fatigue with consequent mental break-down was their offence.

\footnotetext{
${ }^{27}$ Bede Johnstone was fortunate that this battalion's COs were not apparently in the habit of signing off the War Diary each month. He was to command the $1^{\text {st }}$ Royal West Kent from 25 August 1917 to 9 October 1918. Lionel Henry Hanbury, aged 52 in 1914, and a retired Royal Berkshire Territorial, commanded $2 / 4^{\text {th }}$ Royal Berkshire between 23 September 1914 and 18 May 1915, giving up command nine days before they went on active service, but was transferred at this point to command $1 / 7^{\text {th }}$ Royal Warwickshire in France, a command he held from 22 May 1915 to 29 September 1916. He finally served as a Staff Lieutenant from 25 September 1917 to 12 January 1918, retiring before the war's end.

${ }^{28}$ A. Vagts, 'Age and Field Command', Military Affairs, 6 (1942), pp.13-20
} 


\begin{tabular}{|c|c|c|c|c|}
\hline & & Average age & Youngest & Oldest \\
\hline Outbreak & 04 August 1914 & $47 \mathrm{yrs} 10 \mathrm{mth}$ & 37 yrs 11 mth (Reg) & $\begin{array}{c}52 \text { yrs } 7 \text { mth } \\
\text { (Reg) }\end{array}$ \\
\hline & & & 31 yrs $3 \mathrm{mth}$ (TF) & 59 yrs 3 mth (TF) \\
\hline Loos & 25 September 1915 & 44 yrs $8 \mathrm{mth}$ & $30 \mathrm{yrs} 0 \mathrm{mth}$ & 65 yrs 2 mth \\
\hline Somme & 01 July 1916 & 42 yrs $1 \mathrm{mth}$ & 26 yrs $10 \mathrm{mth}$ & 57 yrs $5 \mathrm{mth}$ \\
\hline Arras & 09 April 1917 & 38 yrs 5 mth & 25 yrs 1 month & 53 yrs 6 mth \\
\hline Third Ypres & 31 July 1917 & 36 yrs $7 \mathrm{mth}$ & 24 yrs $8 \mathrm{mth}$ & 52 yrs 2 mth \\
\hline $\begin{array}{l}\text { Hundred } \\
\text { Days: F\&F }\end{array}$ & 29 September 1918 & $34 \mathrm{yrs} 11 \mathrm{mth}$ & 21 yrs $5 \mathrm{mth}$ & $48 \mathrm{yrs} 8 \mathrm{mth}$ \\
\hline $\begin{array}{l}\text { Hundred } \\
\text { Days: Other }\end{array}$ & 29 September 1918 & 39 yrs $0 \mathrm{mth}$ & 24 yrs 0 mth & $51 \mathrm{yrs} 8 \mathrm{mth}$ \\
\hline
\end{tabular}

Table 3.6: Average and range of ages of $\mathrm{CO}$

He further states: "In 1917 an order was issued that no one over the age of 35 should be given command of a battalion". ${ }^{29}$ David French notes the War Office conclusion that "in the closing stages of both World Wars the average age of unit commanders in the teeth arms was between 28 and 36", and that it was regarded as "conclusively proved" that this was the best age. ${ }^{30}$ Decline in the average ages of COs of August 1914 is therefore to be expected.

Table 3.6 shows the average and range of ages of infantry $\mathrm{COs}^{31}$ As can be seen, the average age of Lieutenant-Colonels in France and Flanders dropped 12 years 11 months between August 1914 and 29 September 1918, from 47 years 10 months to 34 years 11 months. This drop should not be attributed solely to design, as it was clearly strongly connected to attrition resulting from death, wounding, invalidity or promotion/removal of

\footnotetext{
${ }^{29}$ Brigadier-General J.E. Edmonds \& Lieutenant-Colonel R. Maxwell-Hyslop, Military Operations France and Belgium 1918, Vol. 5 (London: Imperial War Museum, 1993, originally published 1947), p.613

${ }^{30}$ French, Military Identities, p.275, citing TNA WO 32/13253. Memo of Military Secretary, 25 November 1946.

${ }^{31}$ Excluding the COs of pioneer battalions, who tended to have longevity in command and to be older.
} 
older COs. Any design element appears in the deliberate replacement of older COs for fitness reasons. Succession by younger men was, however, inevitable.

The widest spread of ages was demonstrated at the Battle of Loos. The youngest, Lieutenant-Colonel A.F.A.N. Thorne, $3^{\text {rd }}$ Grenadier Guards, had temporarily replaced Colonel N.A.L Corry at the age of exactly $30 .^{32}$ Lieutenant-Colonel F.C. Romer, CO $8^{\text {th }}$ Buffs, who was killed at Loos on 26 September 1915, was the oldest CO fatality of the war at the age of 63. Frederick Charles Romer was born on 15 February 1853 and had become a Lieutenant in the Essex Rifles at the age of 20. He had served in South Africa 1900-1, and had retired as Lieutenant-Colonel of the $6^{\text {th }}$ Lancashire Fusiliers in 1908. In 1914, he raised and trained the $8^{\text {th }}$ Buffs. As Honorary Secretary of Boodles Club, he brought with him two fellow members as Majors, three as Captains, and one as a Lieutenant, as well as two of the club waiters. ${ }^{33}$ Romer died leading his battalion against the German second position. Wounded in the shoulder he insisted on staying with his men, and was then shot through the heart. ${ }^{34}$

\footnotetext{
${ }^{32}$ Augustus Francis Andrew Nicol 'Bulgy' Thorne was born in 1875, son of an East India/China merchant and with no family military tradition, attended Eton and RMC, and was commissioned 2nd Lieutenant in the 3rd Grenadier Guards on 2 March 1904. Having been Assistant Adjutant of the 1st Battalion (1908) he was assigned to 1st Guards Brigade as a Staff Captain on the outbreak of war. He was promoted Major on 30 September 1915 and sent to the 1st Battalion on March 17 as second-in-command. He returned to command the battalion from 18 September 1916 to 31 August 1918, and was promoted Brigadier-General 184 Brigade on 14 October 1918. Noel Armar Lowry Corry, who had commanded both $2^{\text {nd }}$ and $3^{\text {rd }}$ Grenadier Guards, was promoted Brigadier-General AAG.ost-war he was Military Attaché in Berlin, and commanded 48th Division 1939-40, then relegated to Army Commander in Scotland, finishing the war as Head of the Allied Mission to Norway.

${ }^{33} \mathrm{http}: / / \mathrm{www} \cdot k e n t f a l l e n . c o m / p d f \% 20$ reports/sandwich.pdf accessed 11 October 2011.

${ }^{34}$ Lieutnant Aschenbach, observation officer of the 6th gun battery of the German 233 Feld-ArtillerieRegiment, remembered seeing "a white-haired Colonel on the wire" where Romer fell (http://www.greatwar.co.uk/french-flanders-artois/memorial-loos-memorial.htm, accessed 11 October 2011). His son Malcolm Romer commanded the $1^{\text {st }}$ Scots Guards (1 September 1917 to 6 March 1918) and 3rd Scots Guards (24 September 1918 to 11 November 1918).
} 
The youngest CO in the order of battle for 1 July 1916 was Lieutenant-Colonel J. Micklem of $1 / 6^{\text {th }}$ Gloucestershire, who was 26 years nine months old. ${ }^{35}$ The oldest CO who went into action that day was Brevet Colonel W.N. Wylie, CO $21^{\text {st }}$ Manchester, aged 56, whose battalion was involved in the capture of Mametz. ${ }^{36}$ He served until 15 May 1917, having been in post for 903 days.

The celebrated Lieutenant-Colonel R.B. Bradford was the youngest CO on the opening day of the Battle of Arras, ${ }^{37}$ commanding $1 / 9^{\text {th }}$ Durham Light Infantry at a month over 25 . The oldest was Lieutenant-Colonel J.E.G. Groves, CO $1 / 5^{\text {th }}$ Cheshire, who was just over 52 , and who commanded from the outbreak of war to 12 March 1918, a total of 1316 days. ${ }^{38}$ The youngest $\mathrm{CO}$ on the first day of the Third Battle of Ypres was Lieutenant-Colonel E.B. Greer, CO $2^{\text {nd }}$ Irish Guards, who was nearly $25 .{ }^{39}$ The oldest was Lieutenant-Colonel C.C. Carr, CO $11^{\text {th }}$ Royal Fusiliers, who was just over 52. Carr served from the formation of the battalion until 12 September 1917 , a total of 1102 days. $^{40}$

\footnotetext{
${ }^{35}$ John Micklem was a Captain of $1^{\text {st }}$ Rifle Brigade in August 1914 . He commanded $1 / 6^{\text {th }}$ Gloucestershire from 10 July 1915 to 7 January 1917. He later served in various staff posts, transferring to the Tank Corps where he rose to be Brigadier-General $4^{\text {th }}$ Tank Brigade in the last few days of the war.

${ }^{36}$ William Wylie Norman was a retired Indian Army Lieutenant-Colonel, $22^{\text {nd }}$ Cavalry, and had served in Tirah 1897-8. Clearly a thoughtful soldier, he was the author of The Service Sketching Case \& Note Book (London: Gale \& Polden, 1891), and Cavalry Reconnaissance (London: H. Rees, 1911).

${ }^{37}$ Roland Boys Bradford was a Regular $2^{\text {nd }}$ Lieutenant of Durham Light Infantry at the outbreak of war. He commanded the $1 / 9^{\text {th }}$ Battalion between 15 September 1916 and 5 November 1917. Awarded the Victoria Cross on the Somme, he was destined to become the youngest Brigadier-General in the BEF, with 186 Brigade, on 10 November 1917.

${ }^{38}$ John Edward Grimble Groves was commanding 1/5 ${ }^{\text {th }}$ Cheshire in August 1914, and continued until 12 March 1918. He was the Chairman of Groves and Withnall, brewers, and returned in this capacity post-war.

${ }^{39}$ Eric Beresford Greer was a 22 year-old Lieutenant of the Irish Guards in August 1914. He commanded $2^{\text {nd }}$ Irish Guards from 13 January 1917 until he was killed on the opening day of the Third Battle of Ypres, 31 July 1917, by a shrapnel ball or bullet standing outside advance battalion HQ at Boezinghe on the first objective.

${ }^{40}$ Charles Catley Carr, a 49 year-old retired Major of the Royal Fusiliers in August 1914, commanded the $11^{\text {th }}$ Battalion between 6 September 1914 and 12 September 1917, and after wounding, commanded $51^{\text {st }}$ Graduated Battalion, Highland Light Infantry
} 
In respect of those in post on 29 September 1918, a total of 41 per cent were over 35. (Pioneer COs are included on this occasion to give a sense of the complete age range). Of these, 60 per cent were appointed in 1918, the oldest being Lieutenant-Colonel E.H.St.L. Clarke, who was 57 when given command of $21^{\text {st }}$ West Yorkshire (Pioneers) on 13 October 1915, ${ }^{41}$ at which point a fellow Pioneer CO, Lieutenant-Colonel C.V. Trower of the $5^{\text {th }}$ South Wales Borderers was nearly 61 , the oldest infantry CO in France, having served since 6 September $1914 .^{42}$

The oldest 'combat' Territorial CO on 29 September was Lieutenant-Colonel W. Oddie of the $1 / 5^{\text {th }}$ West Yorkshire, who was 51 and who had been in post since November $1917 .^{43}$ The oldest 'combat' CO appointed in 1918 was a Territorial, Lieutenant-Colonel F.J. Popham, $2 / 5^{\text {th }}$ Royal Lancaster, who was nearly 48 when given command on 7 August 1918. ${ }^{44}$ The oldest appointee to a Regular battalion in 1918 was Lieutenant-Colonel A.E. Gallagher of $2^{\text {nd }}$ Royal Inniskilling Fusiliers, who was nearly 47 when promoted on 15 September, making him the oldest Regular CO on 29 September $1918 .^{45}$ The oldest Service Battalion CO appointed for the first time in 1918 was Lieutenant-Colonel H.T. Pomfret, who was 45 when given command of $11^{\text {th }}$ Manchester on 28 September $1918 .^{46}$

\footnotetext{
${ }^{41}$ Edward Henry St. Lawrence Clarke, born in 1857 , had commanded $12^{\text {th }}$ Worcestershire, a reserve battalion, from 4 November 1914 until 13 October 1915 when he was transferred to $21^{\text {st }}$ West Yorkshire, a command he held until the Armistice.

${ }^{42}$ Courtney Vor Trower, born in 1856, was a retired Regular brevet Colonel of the South Wales Borderers in August 1914. He commanded the $5^{\text {th }}$ Battalion from 6 September 1914 until his resignation on 14 October 1918.

${ }^{43}$ William Oddie, born in 1867, was a Territorial Major of $5^{\text {th }}$ West Yorkshire in August 1914, and commanded until the Armistice.

${ }^{44}$ Francis James Popham, born in 1871, was a retired Lieutenant of the London Yeomanry in August 1914. He commanded $2 / 5^{\text {th }}$ Royal Lancaster until the Armistice.

${ }^{45}$ Albert Ernest Gallagher, born in 1872, was a retired Captain of the Royal Munster Fusiliers in August 1914, and commanded $2^{\text {nd }}$ Royal Inniskilling Fusiliers until 2 October 1918.

${ }^{46}$ Hugh Tunbridge Pomfret, born in 1873, was a retired Territorial Lieutenant of the Manchester Regiment in August 1914, and commanded the $11^{\text {th }}$ Battalion until the Armistice.
} 
Lieutenant-Colonel C.E. Hudson of the 2nd Sherwood Foresters was the oldest Service battalion CO on 29 September, being 47 and having been appointed in November $1917 .{ }^{47}$

Clearly, there was a group of older COs whose constitutions and abilities outweighed any burden of their years. Brigadier-General F.P. Crozier, 119 Brigade, was sent LieutenantColonel H.C. Metcalfe in January 1918 to command $21^{\text {st }}$ Middlesex. He described Metcalfe as "an old soldier of some fifty-odd summers", ${ }^{48}$ and as he had "not been in France before", Crozier doubted his ability. ${ }^{49}$ Yet in the German Spring offensive: "Metcalfe is a stone wall when necessary, a thrusting lance when required", Crozier naming the first requirement in this fighting as "physical fitness". 50

In contrast, of the Dominion contingents, the average age of Australian Imperial Force infantry COs in August 1918 was "less than 33". 51 The average age of their Canadian Expeditionary Force counterparts prior to 1 January 1917 was 41 years six months (range 28 to 57 years). For COs appointed in 1918, the average age was 35 years eight months (range 26 to 44 years), 61 per cent of these being above the Official Historian's quoted 35 year cut-off. ${ }^{52}$ The British figure of 34 years 11 months sits between these two figures.

\footnotetext{
${ }^{47}$ Charles Edward Hudson, born in 1871, was a tea planter in Ceylon in August 1914 (he had previously failed his first year RMC exams), and had previously commanded $11^{\text {th }}$ Sherwood Foresters from 8 November 1917 until wounded in Italy on 15 June 1918.

${ }^{48} \mathrm{He}$ was in fact 54 .

${ }^{49}$ Herbert Charles Metcalfe had retired in 1902 as a Regular Captain of the Northamptonshire Regiment with service as Inspector of Musketry, and DAAG (Scottish Command). He served as a Staff Lieutenant in 1917.

${ }^{50}$ F.P. Crozier, A Brass Hat in No Man's Land (London: Jonathan Cape, 1930), p.194. Metcalfe's command was terminated on 11 April 1918 by wounding. Crozier took his successor to visit him in hospital: "There we see the old warrior with leg tied up to the roof, while on the foot flies a miniature Union Jack!" (p.210). His replacement, Lieutenant-Colonel G.F.P. Worthington was a $2^{\text {nd }}$ Lieutenant of the West India Regiment in August 1914, and was 24 when he took command.

51 G. Pratten, Australian Battalion Commanders in the Second World War (Cambridge: Cambridge University Press, 2009), p.33

${ }^{52}$ Calculations made from memoranda dated March 1941: Directorate of History and Heritage, Ottawa, ON 92/252 Series 7 Box 125 File 102.
} 
It is clear that any order concerning the prohibition of new commands to over-35s was notable by its breach. Of the 'over 35' appointees in 1918, 22 per cent were, however, COs of pioneer battalions, older COs therefore being disproportionately appointed to such units. Nearly 30 per cent of all 'combat' COs appointed in 1918 in post on 29 September were, however, over 35 .

The grave of Lieutenant-Colonel E.G. Bowden bears the following legend: "Promoted on the field of action from 2nd Lieutenant, he was one of the youngest Colonels in the British Army", 53 being 24 years and two months old at his death. Youth and high rank bore a fascination and pride then as now. Brigadier-General F.P. Crozier, observing "this is a war for youngsters", took the 24 year-old "baby-faced" Lieutenant-Colonel G.F.P Worthington into a hotel whereupon a 'Blimpish' Major mistakenly assailed him: "Well, why the devil don't you salute, you damned young cub?"54 The youngest known CO on 29 September 1918 was Lieutenant-Colonel A.L.W. Newth of the $16^{\text {th }}$ Cheshire, who was 21 when appointed on 30 April 1918, and he was likely the youngest of the war. ${ }^{55}$ At least 25 were younger than Bowden. Whilst it might be thought that the fact that COs became progressively younger is evidence of an emerging meritocracy of youth, the reality that older than average COs were still appointed in 1918 supports the Official Historian's view that age is purely biological, and not a bar to the appointment of a competent commander.

\footnotetext{
53 Buried in Cabaret Rouge cemetery, Souchez, Eric Gordon Bowden was a civilian in 1914, working as a clerk to a civil engineer. He commanded $11^{\text {th }}$ Royal West Surrey from 23 March 1918 until 2 May 1918.

${ }^{54}$ Crozier, Brass Hat, pp.210-11. Godfrey Francis Puget Worthington, born in 1894, was a $2^{\text {nd }}$ Lieutenant of the West India Regiment in August 194, and commanded 21 ${ }^{\text {st }}$ Middlesex from 11 April 1918 until 17 May 1918.

${ }^{55}$ Arthur Leslie Walter Newth, was born in 1897 and commanded $1 / 6^{\text {th }}$ Cheshire from 30 April 1918 to the Armistice. He served as a Brigadier-General in the Second World War.
} 


\subsubsection{Rank}

Given the decrease in average age of infantry COs between 1914 and 1918, it could be safely predicted that the ranks of those who had been active in August 1914 and who were commanding battalions on 29 September 1918 in France and Flanders, would be comparatively junior at the outbreak of war. Table 3.7 confirms this.

\begin{tabular}{|c|c|c|c|c|c|}
\hline ORs & 2nd Lieutenant & Lieutenant & Captain & Major & Lieutenant-Colonel \\
\hline $7 \%$ & $7 \%$ & $28 \%$ & $46 \%$ & $11 \%$ & $1 \%$ \\
\hline
\end{tabular}

\section{Table 3.7: August 1914 ranks of COs of 29 September 1918}

Sir Douglas Haig noted in his diary on 25 June 1915 that progress, "even if ample guns etc. provided", would be achieved only when "young capable commanders are brought to the front. Captains to command Battalions; Majors Brigades etc". ${ }^{56}$ His prophecy was fulfilled to the extent that nearly half (46 per cent) of infantry COs on 29 September 1918 were Captains in August 1914. ${ }^{57}$

Haig may not have foreseen that seven per cent of COs on 29 September 1918 would have been of the other ranks in August 1914. During the war, 69 ORs of August 1914 commanded battalions on active service, one per cent of the total ORs commissioned. ${ }^{58}$ Sixty-eight per cent were Regulars, 23 per cent Territorials, one per cent Special Reserve, and, perhaps surprisingly, 8 per cent from empire regiments. Of the 28 individuals in post

\footnotetext{
${ }^{56}$ National Library of Scotland, Acc. 3155, Field-Marshal Sir Douglas Haig, Manuscript Diary, 25 June 1915.

57 Although in 1915 a proportion of such would have been Majors, and many of the 2nd Lieutenants/Lieutenants of August 1914 who made up 35 per cent of COs on 29 September 1918 may have been Captains by the time Haig was writing.

${ }^{58} 6,713$ permanent officers were commissioned from the ranks during the war. [HMSO, Statistics of the Military Effort of the British Empire During the Great War 1914-1920 (London: HMSO, 1922), p.234].
} 
on 29 September 1918, three Regular ORs were commanding Regular battalions. Lieutenant-Colonel W. Daly, $1^{\text {st }}$ East Lancashire, had served in the ranks for nearly nine years and had been commissioned $2^{\text {nd }}$ Lieutenant from Warrant Officer Class II on 9 April 1916, and served as CO from 25 October 1917 to the Armistice, the journey from 2nd Lieutenant to Lieutenant-Colonel taking just over 18 months. Both $1^{\text {st }}$ and $2^{\text {nd }}$ Battalions of the Royal Irish Rifles were commanded in 1918 by other ranks (ORs) of August 1914, namely Lieutenant-Colonels J.P. Hunt and J.H. Bridcutt. Hunt, a retired Colour Sergeant of the Royal Dublin Fusiliers, commanded $9^{\text {th }}$ Dublin Fusiliers from 4 June 1917 to 25 October 1917 and $1^{\text {st }}$ Royal Irish Rifles from 28 March 1918. Bridcutt, who had served in the Coldstream Guards for over 12 years was commissioned $2^{\text {nd }}$ Lieutenant from Warrant Officer Class I in the Somerset Light Infantry on 6 March 1915 . He commanded $12^{\text {th }}$ Middlesex from 8 September to 30 November 1917, and $2^{\text {nd }}$ Royal Irish Rifles from 31 August 1918 until his death on 1 October 1918 on the Menin Road, Ypres. ${ }^{59}$

Twelve Service and 13 Territorial battalions were commanded by ORs of August 1914 on 29 September 1918.

\subsubsection{Staff service - Adjutancy}

Of all active COs who had been below the rank of Major in $1914,{ }^{60} 19$ per cent had been battalion Adjutants during the war prior to appointment. The figure on 29 September 1918 was 20 per cent, indicating a constant level. There was therefore an association, if weak,

\footnotetext{
${ }^{59}$ Captain A.O. Pollard of $1 / 1^{\text {st }}$ Honourable Artillery Company encountered him a month prior to his appointment when he was CO of No. 2 Reinforcement Training Camp at Abbeville. He was deeply impressed by his organisational ability in setting up the camp, noting: "He was an ex-sergeant-major of the Coldstreams which will amply explain why such an undertaking was not beyond him". Pollard added: "He was a great man and deserved better luck than he received". [A.O. Pollard, Fire-Eater (Uckfield: Naval \& Military, n.d.) p.255].

${ }^{60}$ It was rare for a Major to act as adjutant.
} 
between adjutancy (an indication of organisational competence) and later battalion command. ${ }^{61}$

\subsubsection{Staff service - Extra-regimental}

Fourteen per cent (552) of all active COs with the rank of Lieutenant-Colonel had experience of staff service post-August 1914 prior to appointment to command. ${ }^{62}$ The link between appointment as $\mathrm{CO}$ and staff service was therefore weaker than its association with adjutancy.

Of the appointments in G (General Staff), A (Adjutant General), and Q (Quartermaster General), ${ }^{63}$ as Table 3.8 shows, 185 were GSO1/2/3, 32 DAAG/AAG, and 24 DAQMG/AQMG. Forty-six were in joint A and Q posts (DAA\&QMG/AA\&QMG). There were therefore nearly double the appointments in G than in A and Q combined. When the 227 Brigade-Major appointments are taken into consideration, the predominance of $\mathrm{G}$ can be appreciated. It is understandable that men who were going to progress to battalion command would be more likely to have an operational staff background.

\footnotetext{
${ }^{61}$ This was lower than the figure of 59 per cent for Regular COs of August 1914. (Chapter One section 1.1.4).

${ }^{62}$ This was lower than the figure of 46 per cent for Regular COs of August 1914. (Chapter One section 1.1.4). Of those COs who had also had prior staff service outside the battalion and who had a rank below Major in August 1914, 22 per cent had acted as Adjutant during the war prior to staff appointment. Possession of the Adjutancy therefore did not significantly increase the likelihood of an extra-battalion staff appointment in those who would become COs.

${ }_{63}$ The General Staff consisted of General Staff Officers 1st, 2nd and 3rd Grade, respectively GSO1 (Lieutenant-Colonels), GSO2 (Majors) and GSO3 (Captains), and dealt with operations, intelligence and training matters. (At brigade level the ' $\mathrm{G}$ ' post was a Brigade-Major). The Adjutant-General's or 'A' Staff consisted of Assistant Adjutants-General (AAG, Lieutenant-Colonel), Deputy Assistant Adjutants-General (DAAG, Majors) and Staff Captains, and dealt with personnel matters (appointments and promotions, discipline, unit organisation, medals and awards, pay etc.). The Quartermaster-General's or 'Q' Staff consisted of Assistant Quartermasters-General (AQMG, Lieutenant-Colonel), Deputy Assistant QuartermastersGeneral (DAQMG, Majors) and Staff Captains, and dealt with supply, equipment, transport and veterinary matters. In some formations some of the functions of the A and Q Branches were combined, with an Assistant Adjutant and Quartermaster-General (AA\&QMG) as the senior administrative staff officer.
} 
To examine the G group in more detail, there were 285 GSO1, 526 GSO2 and 644 GSO3 appointments during the war. ${ }^{64}$ Those who went on to become COs comprised only seven, 15 and 13 per cent of these groups respectively.

\begin{tabular}{|l|c|c|c|c|c|}
\hline & G & A & Q & A \& Q & Other \\
\hline General Staff Officer 1 & 21 & & & & \\
\hline General Staff Officer 2 & 80 & & & & \\
\hline General Staff Officer 3 & 84 & & & & \\
\hline Deputy Assistant Adjutant General & & 26 & & & \\
\hline Assistant Adjutant General & & 6 & & & \\
\hline Deputy Assistant Quartermaster General & & & 21 & & \\
\hline Assistant Quartermaster General & & & 3 & & \\
\hline $\begin{array}{l}\text { Deputy Assistant Adjutant \& Quartermaster } \\
\text { General }\end{array}$ & & & & & 34 \\
\hline Assistant Adjutant \& Quartermaster General & & & & 12 & \\
\hline Brigade Major & & & & & 227 \\
\hline Staff Captain & & & & & 120 \\
\hline Staff Lieutenant & & & & & 5 \\
\hline Aide de Camp & & & & & 29 \\
\hline Assistant Provost Marshal & & & & & 19 \\
\hline AMS & & & & & 3 \\
\hline Special Appointment & & & & & 45 \\
\hline War Office Appointment & & & & & 18 \\
\hline School Post & & & & & 25 \\
\hline Officer Training Post & & & & & 15 \\
\hline Transport Post & & & & 41 \\
\hline
\end{tabular}

Table 3.8: Staff posts held by active infantry COs prior to assuming command

From probably late 1915 and certainly 1916, officers were being sent on the recommendation of their $\mathrm{CO}$ for a month's staff attachment to Brigade. If they wished, they could have a further month's attachment to a higher formation. This was often not popular, such officers wishing to return to front line duty where promotion was more

\footnotetext{
${ }^{64}$ Personal communication, Paul Harris, King's College, University of London.
} 
likely. ${ }^{65}$ Captain A. Hanbury-Sparrow, a future CO, was sent as staff learner to Corps in 1916. He felt out of place, observing that "the attitude of the staff was beyond question akin to that of the economic world", continuing: "You missed, in fact, the cult atmosphere of the trenches ... you were a peg in a round hole, and when you left, it was with a flea in your ear". 66

As noted in Chapter One, 22 per cent of the 157 Regular COs in post in August 1914 had passed staff college. Of all the 1478 Regular officers serving as active COs with the rank of Lieutenant-Colonel during the war, 128 (nine per cent) were $p s c$, and when those in post at the outbreak of war are removed from the equation, this figure drops to 7 per cent. Few officers with a $p s c$ therefore served as COs.

Seventy-six per cent of GSO1s who later became COs were, perhaps unsurprisingly, psc, and 52 per cent proceeded to brigade command, the overlap between these two groups being 82 per cent, i.e. only two who were promoted were not $p s c .{ }^{67}$ Forty-seven per cent of GSO2s who later became COs were $p s c$, and 40 per cent proceeded to brigade command, the overlap between the two groups being 84 per cent. Eighteen per cent of GSO3s who later became COs were psc, and only 8 per cent proceeded to brigade command, the overlap between the two groups being 43 per cent. Twelve per cent of Brigade-Majors who later became COs were psc, 21 per cent proceeding to brigade command, the overlap between the two groups being 29 per cent.

\footnotetext{
${ }_{65}^{65}$ Personal communication, Paul Harris, King's College, University of London.

${ }^{66}$ A. Hanbury-Sparrow, The Land-Locked Lake (London: Hazel, Watson \& Viney, 1932), pp.189-190. Arthur Alan Hanbury Hanbury-Sparrow was a 22 year-old Regular Lieutenant of the Royal Berkshire Regiment in August 1914. He was a GSO3 from 22 May to 3 July 1916. He did not command a battalion until July 1917.

${ }^{67}$ Only one of these, H.R. Cumming, gave the appearance of being rotated quickly through battalion command (17 days with $2^{\text {nd }}$ Durham Light Infantry) before promotion.
} 
The average rate of promotion (see below) of COs to brigade command was 10 per cent. The association between serving in a staff post, a substantial period as a $\mathrm{CO}$ and promotion to Brigadier-General was therefore highest for GSO1s and GSO2s by a factor of five and four respectively, with GSO3s not advantaged at all, and Brigade-Majors advantaged by a factor of two.

The existence of only a small overlap between the combat and staff groups indicates the shortage of skilled staff officers, men with psc, experience, or clear ability being hived off for the rapidly expanding staff domain, and hence bypassing battalion command.

\subsection{Turnover}

\subsubsection{Turnover by month}

Figure 3.1 shows the monthly number of $\mathrm{CO}$ appointments, both total and active-service only. There are three peaks. The first, and naturally most pronounced peak, was the period September to November 1914, marking the creation of the New Armies. The second peak was the period July to October 1916, corresponding with the Battle of the Somme. The third peak was the period March to May 1918, marking the German offensives. July 1916 and April 1918 saw the most rapid turnover of active COs of the war. Although the average monthly total for 1917 (81) is much the same as $1916(83)$, what is remarkable is that the BEF in France and Flanders was fighting virtually continuously for 10 months during $1917,{ }^{68}$ compared with five months in 1916 , and it might have been predicted that higher monthly turnover totals might have been manifest (which was only the case for July 1917). The conclusion can be drawn that in terms of infantry battalion command, the BEF

\footnotetext{
${ }^{68}$ From February to November this period included the German retirement to the Hindenburg Line and the battles of Arras, Messines, 3rd Ypres, and Cambrai.
} 


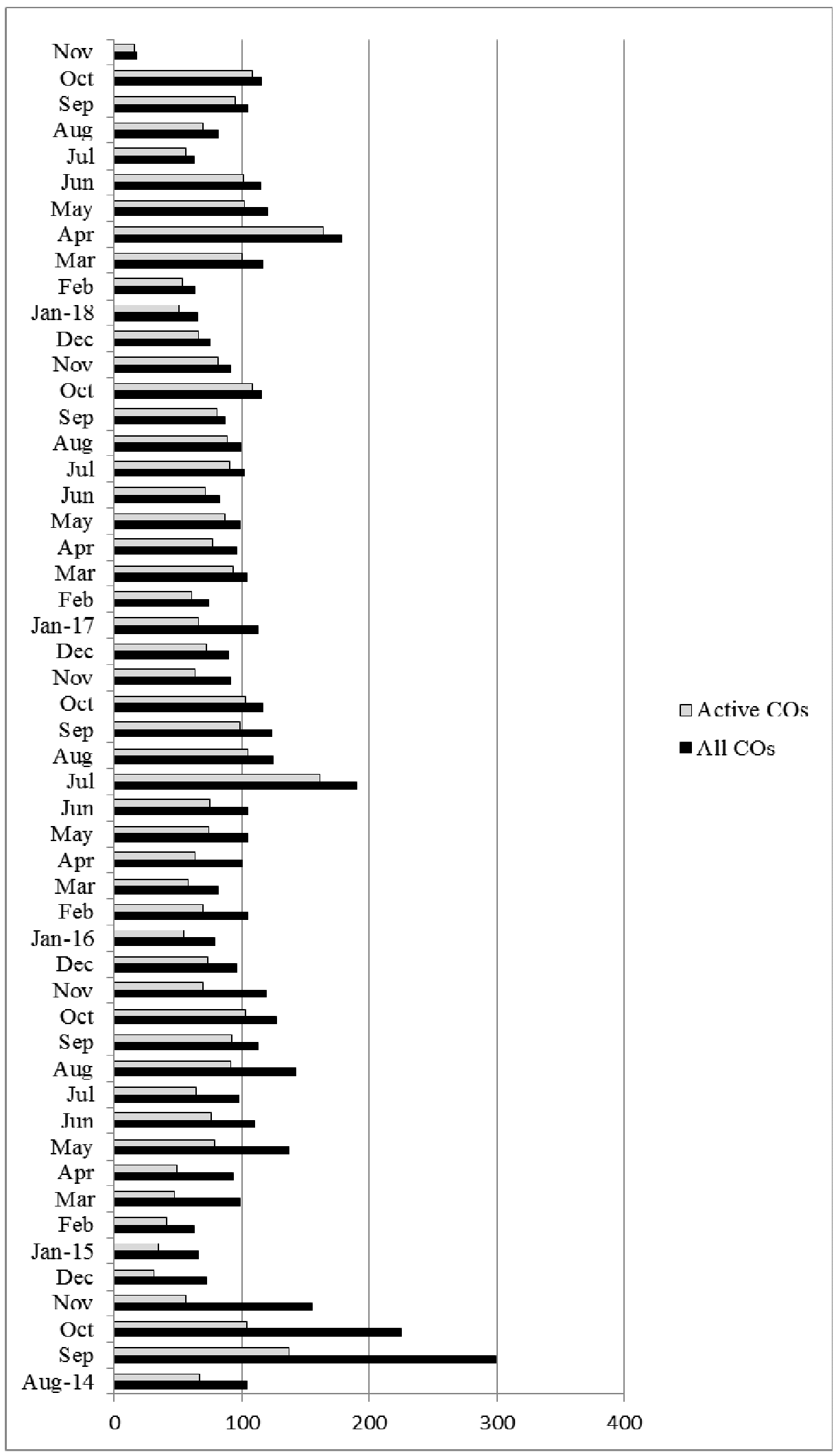

Figure 3.1: Monthly CO appointments 
had its most settled year in 1917 despite its overall activity, implying that by this time it had a group of largely competent and experienced men, younger and more resistant to exhaustion. Further, it was husbanding its resources more effectively by alternating Commanding Officer and second-in-command on days of offensive action. It is also notable that the turnover of the first half of 1916, when no major campaigns were in progress, is much the same as 1917 , indicating considerable honing of battalion command prior to the Somme.

\subsubsection{Turnover by battalion}

Of battalions on active service which had been in existence from the start of the war, ${ }^{69}$ Regular battalions had an average seven COs (range two to 14) between August 1914 and the Armistice. ${ }^{70}$ The handful of Special/Extra Reserve battalions on active service had an average six COs (range four to nine). ${ }^{71}$ The first-line Territorial battalions had an average of between five and six (range two to 12). ${ }^{72}$ Of battalions which came into existence during the war, New Army Service battalions had an average five COs (range two to 12) ${ }^{73}$ and the second and third-line active TF battalions had an average of four (range two to eight). ${ }^{74}$

It is not surprising that the Regular battalions had the highest turnover as they bore the brunt of the 1914 fighting and were more subject to loss of COs to promotion. The $2^{\text {nd }}$ Royal Munster Fusiliers was one of two battalions having the highest turnover of $14 \mathrm{COs}$

\footnotetext{
${ }^{69}$ Excluding pioneer, labour, garrison etc. battalions on active service.

${ }^{70}$ The exact average was 7.2.

71 The exact average was 5.7.

72 The exact average was 5.55 .

${ }^{73}$ The exact average was 5.2 .

${ }^{74}$ The exact average was 3.7 .
} 
(ten others standing in without the rank of Lieutenant-Colonel) ${ }^{75}$ Six were replaced; one was wounded and one invalided; four were killed in action; ${ }^{76}$ and one was cashiered. ${ }^{77}$

\subsubsection{Number of commands}

Seventy-nine per cent of those who commanded infantry battalions on active service did so only once. ${ }^{78}$ Twenty-one per cent had multiple commands. ${ }^{79}$

As Table 3.9 shows, the highest number of battalion commands as Lieutenant-Colonel held by an individual who saw active service was six, and this was achieved by two COs, albeit both with mixed results. Lieutenant-Colonel H.E. Walshe, second-in-command of $2^{\text {nd }}$ South Staffordshire (6 Brigade, $2^{\text {nd }}$ Division) in August 1914 , commanded $1^{\text {st }}$ Dorsetshire (15 Brigade, $5^{\text {th }}$ Division) from 12 December 1914 to 3 January $1915 .^{80}$ An example of the attrition of command in 1914, the first two COs, Lieutenant-Colonels L.J. Bols and C. Saunders had both been wounded, ${ }^{81}$ and the battalion had subsequently been commanded by a Captain and a Major. ${ }^{82}$ The unit's resources (and perhaps those of brigade and

\footnotetext{
${ }^{75}$ The other was $1^{\text {st }}$ Dorsetshire.

${ }^{76}$ Lieutenant-Colonels G.J. Ryan, 22 January 1915; V.G.H. Rickard, 9 May 1915; W.B. Lyons, 20 August 1916; and H.R.H. Ireland, 21 March 1918.

${ }^{77}$ Lieutenant-Colonel T.T. Stubbs was cashiered by verdict of court martial for drunkenness on 25 March 1916. Drunkenness was the most common offence causing an officer's court-martial. In contrast, Temporary Lieutenant-Colonel Grey d'Estoteville Herbert Fullerton, $\mathrm{CO} 9^{\text {th }}$ Warwickshire in Mesopotamia was tried after 33 days in post on two charges related to his command of his battalion when it had been subject to a night attack by arabs on 26/27 June 1916. Having immediately been forced to relinquish command, he was found guilty and sentenced "to be reprimanded" for "conduct to the prejudice of good order and military discipline" when he did not reform his column properly in the aftermath. He was found not guilty of failing to safeguard his unit through not posting protective detachments. (TNA WO 374/26035, Officers' Services, Grey d'Estoteville Herbert Fullerton).

${ }^{78} \mathrm{By}$ 'once' is meant the command of the same battalion, so if a $\mathrm{CO}$ returned after a period of absence, this is counted as the same command.

${ }^{79} \mathrm{By}$ 'multiple' is meant that the individual commanded different battalions.

${ }^{80}$ Henry Ernest Walshe was 48 in August 1914 and had served in South Africa 1899-1902.

${ }^{81}$ Neither would return to infantry battalion command, Bols through promotion (see Chapter One), and Saunders through lengthy recovery although he was an Acting Lieutenant-Colonel in the Tank Corps in mid1918.

${ }^{82}$ Captain H.S. Williams (14-19 November 1914) and Major W.A.C. Cumming (19-22 November 1914). Neither of these officers would ever have the opportunity to command again as both were later killed.
} 
division) were so depleted that Walshe was drafted in from another division. After 22 days Bols returned, and Walshe reverted to his own battalion, having missed his opportunity to command it, Lieutenant-Colonel C.S. Davidson having been invalided three days earlier, ${ }^{83}$ being replaced by Lieutenant-Colonel P.C.L. Routledge. ${ }^{84}$

\begin{tabular}{|l|c|c|c|c|c|c|}
\hline & \multicolumn{6}{|c|}{ Commands } \\
\cline { 2 - 7 } & Six & Five & Four & Three & Two & One \\
\hline Regular & 2 & 7 & 20 & 85 & 306 & 1052 \\
\hline Retired Regular & & 1 & 1 & 13 & 69 & 450 \\
\hline Indian Army & & & & 1 & 8 & 84 \\
\hline Retired Indian Army & & & & 4 & 6 & 64 \\
\hline Special Reserve & & 1 & 2 & 11 & 38 & 199 \\
\hline Retired Special Reserve & & & & 3 & 19 & 123 \\
\hline Territorial & & & 3 & 16 & 83 & 619 \\
\hline Retired Territorial & & & & 6 & 36 & 281 \\
\hline Empire & & & 1 & & 6 & 17 \\
\hline Retired Empire & & & & 1 & 5 & 26 \\
\hline Citizens & & & & 6 & 50 & 204 \\
\hline Retired Royal Navy & & & & & 1 & 2 \\
\hline$\%$ & $>1$ & $>1$ & 1 & 4 & 16 & 79 \\
\hline
\end{tabular}

Table 3.9: Number of commands held by individual active COs

Walshe missed his chance again when Routledge was killed in action on 17 May 1915, having been transferred to command $1^{\text {st }}$ South Staffordshire on 5 April, taking over from Captain A.B. Beauman, who had commanded for a month after Lieutenant-Colonel A.C. Buckle was invalided. ${ }^{85}$ He remained in command until 29 July before returning to his

\footnotetext{
${ }^{83}$ Charles Steer Davidson was commanding the battalion in August 1914 and did so in fits and starts until 24 September 1915 when he was promoted Brigadier General, 123 Brigade.

${ }^{84}$ Philip Charles Lytton Routledge was another Regular Major of $2^{\text {nd }}$ South Staffordshire in August 1914. He was killed in action at Festubert on 17 May 1915.

${ }^{85}$ Walshe was again transferred across Divisions (2nd to 7th), but was of course a within-regiment appointment. Archibald Bentley Beauman, a Regular Lieutenant of the South Staffordshire Regiment in August 1914, would command $1^{\text {st }}$ South Staffordshire from 23 September 1916 until 25 May 1918 when he was promoted Brigadier-General, 69 Brigade. Arthur Charles Buckle, a Major of $1^{\text {st }}$ South Staffordshire in
} 
regiment, but his perceived talent was now rewarded with promotion to Temporary Brigadier-General, 27 Brigade, from 14 October 1915 to 14 March 1916 when he was demoted. ${ }^{86}$ According to one source he was "sick", ${ }^{87}$ but he returned to command his old battalion for five days from 25 March 1916, whereupon he was transferred to command $24^{\text {th }}$ Royal Fusiliers until 18 June 1916 . He then had a period away from active service during which he was placed on half-pay, ${ }^{88}$ from whence he was restored on 1 March 1917 to command $3^{\text {rd }}$ Royal Berkshire, moving on 14 March 1917 to command another home service unit, $8^{\text {th }}$ Dorsetshire. ${ }^{89}$ Walshe had likely 'burnt out', a probable example of a talented officer thrust into multiple commands at a time, 1914-15, which might be considered the harshest period of the war for regimental officers.

The second $\mathrm{CO}$ who commanded six battalions was Lieutenant-Colonel H.P. CreaghOsborne. ${ }^{90}$ Depot Major of the Royal Lancaster Regiment in August 1914, he was given command of the $6^{\text {th }}$ Battalion on 19 August 1914, being transferred to France to take command of the $1^{\text {st }}$ Battalion after Lieutenant-Colonel A.McN. Dykes was killed (26 August 1914) and the senior Major, R.G. Parker, was wounded. ${ }^{91}$ However, on 18

\footnotetext{
August 1914 returned to command $2^{\text {nd }}$ Northamptonshire from 24 June 1915 to 7 July 1916 when he was wounded in the attack on Contalmaison, serving in 1917 as the CO of a Training Reserve Battalion.

${ }^{86}$ In terms of his demotion from Brigadier, the divisional history implies that at this time Major-General W.T. Furse "strove to foster the offensive spirit throughout the Division ... he exhorted all the battalions to make 'No Man's Land' 'Ninth Division Land"'. It may be that burn-out had left Walshe insufficiently aggressive. [J Ewing, The History of the 9th (Scottish) Division 1914-1919 (London: John Murray, 1921), p.77].

${ }^{87}$ A.F. Becke, Order of Battle of Divisions, Part 3a, New Army Divisions (9-26) (Uckfield: Naval \& Military Press, 2007), p.4

${ }^{88}$ From 25 August 1916.

${ }^{89}$ Which he did until they were disbanded in December 1917.

${ }^{90}$ Herbert Pearson Creagh-Osborne was 40 in August 1914, and had previously served as a Staff Captain and DAAG, seeing active service on the Nile in 1898.

${ }^{91}$ Alfred Mcnair Dykes psc had commanded the battalion from the outbreak of war, and was killed at Le Cateau on 26 August 1914 (see later in this chapter). Robert Gabbett Parker commanded between 26 August and 9 September 1914. After his recovery Parker served in staff posts, finishing the war as BGGS, IV Corps, from 19 March 1918.
} 
November 1914 he was removed for inefficiency. ${ }^{92}$ He was given command of $7^{\text {th }}$ King's Own Yorkshire Light Infantry, training in the UK, a month later. On 18 March 1915, he was transferred to command $5^{\text {th }}$ Middlesex, a Special Reserve unit. He returned thence to active service, commanding Hood Battalion, $63^{\text {rd }}$ (Royal Naval) Division, in France on 12 December 1916. Lieutenant-Commander A.M. Asquith had arrived two days earlier to take command, but was told by Major-General C. Shute that he had "insufficient knowledge of trench warfare in France". ${ }^{93}$ Asquith had spent 207 days on Gallipoli and 164 days on the Western Front, Creagh-Osborne only 46 days two years earlier - Shute simply wanted Regular officers in command. ${ }^{94}$ Creagh-Osborne went sick on 3 January 1917, although attempts to rehabilitate him continued as he was sent to command $2 / 5^{\text {th }}$ Royal Lancaster in April 1917. He did not, however, stay the course, for on 20 September 1917 he returned to the UK to a Special Appointment, becoming Commandant of a School of Instruction in April 1918.

Nine Lieutenant-Colonels held five commands, and unlike Creagh-Osborne and Walshe they all lasted in command well into 1918 and two were promoted to brigade command. ${ }^{95}$ Five had been Regular Captains in August 1914 (including the two promoted) ${ }^{96}$ two were

\footnotetext{
${ }^{92}$ Army Personnel Centre D/APC/HD/ABLW/187116 - War Office letter dated 17 January 1915 in the file of Lieutenant-Colonel C. Wanliss. The page for the days in question is interestingly missing from the unit war diary (TNA WO/95/1506).

${ }^{93}$ C. Page, Command in the Royal Naval Division (Staplehurst: Spellmount, 1999), p.99. Arthur Melland Asquith, aged 31 in 1914, was commissioned Temporary Sub-Lieutenant on 23 September 1914 in the Royal Naval Volunteer Reserve. He served with Anson Battalion during the 1914 Antwerp operations, but was transferred to Hood Battalion in October 1914.

${ }^{94}$ This was a matter which sparked a clash between the Admiralty and the War Office concerning awarding battalion command over the heads of those with long Royal Naval Division service (TNA ADM 1/8477-309, cited in Page, Command, p.112).

${ }^{95}$ R.I. Rawson served as GOC 103 Brigade from 31 August 1918 to the Armistice, and P.W. Brown as GOC 71 Brigade from 19 August 1917 to the Armistice.

${ }^{96}$ Lieutenant-Colonels F.R.F. Sworder, B. Cruddas, R.I. Rawson, P.W. Brown and H.W. Weldon.
} 
Regular Majors $;{ }^{97}$ one an ex-Regular CO from the Special Reserve ${ }^{98}$ and one a retired Regular Lieutenant. ${ }^{99}$

Lieutenant-Colonel R.I. Rawson demonstrated endurance and promotability. ${ }^{100}$ A Regular Captain of the Gloucestershire Regiment in August 1914 he was Adjutant of the $4^{\text {th }}$ Battalion, and his first command was $8^{\text {th }}$ Worcestershire ( $48^{\text {th }}$ Division), from 4 to 19 October 1915, whence he was transferred to command $1 / 6^{\text {th }}$ Argyll \& Sutherland Highlanders (51 ${ }^{\text {st }}$ Division) until 17 March 1917 (by which time the battalion had been converted into a Pioneer unit), and he was later transferred to $12^{\text {th }}$ Gloucestershire $\left(32^{\text {nd }}\right.$ Division), commanding from 18 March to 31 August 1917. He was then rested, returning to the UK to command $4^{\text {th }}$ Welsh from 22 November 1917 to 9 April 1918, returning to France to command $1^{\text {st }}$ Royal Fusiliers from 19 April to 24 August 1918, when he spent a further week in command of $12^{\text {th }}$ Gloucestershire, at which point he was appointed GOC 103 Brigade. He had spent 794 days in command of infantry battalions.

Lieutenant-Colonel B. Cruddas demonstrated extraordinary endurance. ${ }^{101}$ Whether he had potential beyond battalion command was untested, mainly because of serving between October 1915 and June 1918 in Salonika where there was reduced opportunity for advancement. A Regular Captain of the Northumberland Fusiliers, he was Adjutant of the $4^{\text {th }}$ Battalion in August 1914, with which unit he went to France in April 1915, thus, like Rawson, missing the depredations visited on the Regular army. He was transferred to the

\footnotetext{
${ }^{97}$ Lieutenant-Colonels C.S. Worthington and J.D. Mather.

${ }^{98}$ Lieutenant-Colonel G.T.B. Wilson.

${ }^{99}$ Lieutenant-Colonel P.S. Hall.

${ }^{100}$ Robert Ian Rawson, aged 39 in August 1914, had served in South-Africa 1899-1902 and in Sudan in 1905 and 1910 whilst employed with the Egyptian Army.

${ }^{101}$ Bernard Cruddas, aged 32 in August 1914, had been commissioned in 1900.
} 
$1^{\text {st }}$ Battalion, but his first command was of $2^{\text {nd }}$ Northumberland Fusiliers from 12 to 29

October 1915 after Lieutenant-Colonel C.A. Armstrong had been killed at Loos. ${ }^{102}$ Superseded, Cruddas remained with the battalion and proceeded to Salonika, where on 18 February 1916 he was appointed to command $8^{\text {th }}$ Oxfordshire and Buckinghamshire Light Infantry (Pioneers) until 17 April 1917 , when he was transferred to command $9^{\text {th }}$ South Lancashire until 12 May 1918. In June he was recalled to the Western Front, taking command of $1 / 4^{\text {th }}$ Royal Scots Fusiliers until 26 September 1918, when he came full circle, assuming command of $1^{\text {st }}$ Northumberland Fusiliers on 26 September $1918 .{ }^{103}$ Despite attacks of malaria, Cruddas served until the Armistice, having spent 976 days in command of infantry battalions. The history of the $1^{\text {st }}$ and $2^{\text {nd }}$ Northumberland Fusiliers notes: "Throughout the War ... the Fifth were fortunate in never having to look outside the Regiment for an officer to command either of their battalions ... Cruddas had varied and valuable experience". 104

Thirty active Lieutenant-Colonels had four commands. Twenty-one (73 per cent) were Regulars (one retired), six being Majors, 12 Captains, three Lieutenants, and one a $2^{\text {nd }}$ Lieutenant in August 1914. One was a Major of an Empire regiment, ${ }^{105}$ one a Special Reserve Captain, ${ }^{106}$ one a Militia Major, ${ }^{107}$ and three were Territorials. ${ }^{108}$

\footnotetext{
${ }^{102}$ Charles Arthur Armstrong, born in 1873, was the second most senior Captain in the Northumberland Fusiliers in August 1914, but had been a Captain for 14 years, and whilst being a brevet Major, probably had little chance of promotion, and in 1913 had been sent to the Belfast University Officer Training Corps as Adjutant. He commanded $2^{\text {nd }}$ Northumberland Fusiliers from 10 June to 1 October 1915, when he was shot through the head raising himself above the parapet to orient himself during the attack on the Hohenzollern Redoubt.

${ }^{103}$ When Lieutenant-Colonel W.N. Herbert was appointed to command 112 Brigade.

104 H.R. Sandilands, The Fifth in the Great War (Dover: Grigg \& Son, 1938), p.264. The Northumberland Fusiliers had been the Fifth Regiment of Foot.

${ }^{105}$ Lieutenant-Colonel J.A. Methuen, South Rhodesian Volunteers.

${ }^{106}$ Lieutenant-Colonel J.N. De La Perrelle, $7^{\text {th }}$ Royal Fusiliers.

${ }^{107}$ Lieutenant-Colonel R.R. Raymer, Jersey Militia.
} 
Lieutenant-Colonel N.M.S. Irwin was the most junior in August 1914 of those who held four commands, ${ }^{109}$ being a $2^{\text {nd }}$ Lieutenant, and took up his first on 12 April $1917,{ }^{110}$ when Lieutenant-Colonel S.G. Mullock was killed returning from a COs conference at Fampoux. ${ }^{111} \mathrm{He}$ was replaced on 31 May by Major R.N. Thompson who had already commanded the battalion. ${ }^{112}$ Irwin's next command was of $2^{\text {nd }}$ Lincolnshire on 19 August 1917, a post he held until 1 February 1918. He subsequently served as CO $8^{\text {th }}$ Leicestershire after Lieutenant-Colonel A.T. le M. Utterson was taken prisoner, ${ }^{113}$ from 6 April 1918 to 28 June 1918, whence he was transferred to command $1^{\text {st }}$ Lincolnshire, a post he held until the Armistice. ${ }^{114}$

Lieutenant-Colonel E.I. de S. Thorpe is another example of an officer of robust ability. ${ }^{115}$ A Major of $1^{\text {st }}$ Bedfordshire in August 1914, he took command of the $2^{\text {nd }}$ Battalion on 17 April 1915 until 20 May, at which point he was transferred to command $2^{\text {nd }}$ Border, a post he held for two years (with two periods of absence) until 19 May 1917. Thorpe then commanded $1 / 6^{\text {th }}$ Lancashire Fusiliers from 13 September 1917 to 28 December 1917 (returning briefly to command $2^{\text {nd }}$ Bedfordshire from 28 December 1917 to 16 January 1918) and lastly commanded his old battalion, $1^{\text {st }}$ Bedfordshire, from 7 February 1918 to

\footnotetext{
${ }^{108}$ Lieutenant-Colonel H.C. Woodcock, Lieutenant-Colonel Gloucestershire Regiment; Lieutenant-Colonel D.W.C Davies-Evans, Major Pembroke Yeomanry; and Lieutenant-Colonel W.R. Campion, Captain Sussex Regiment.

${ }^{109}$ Noel Mackintosh Stuart Irwin, aged 22 in August 1914, was a 2nd Lieutenant of 2nd Essex.

${ }^{110}$ By which time he held the rank of Major.

${ }^{111}$ Sidney Goss Mullock, aged 32 in August 1914, was a Special Reserve Captain of $3^{\text {rd }}$ Essex, and commanded from 26 January to 12 April.

112 Richard Neville Thompson, a 32 year-old Regular Captain of the Essex Regiment in August 1914, commanded $2^{\text {nd }}$ Essex on five occasions between July 1916 and May 1918, serving 446 days in command.

${ }_{113}$ Archibald Tito le Marchant Utterson, aged 29 in August 1914, was a Regular Captain of the Leicestershire Regiment. He commanded $8^{\text {th }}$ Leicestershire from 29 June 1917 until his capture on 21 March 1918.

${ }^{114}$ Irwin commanded 6 Brigade in France in 1940, taking command of $2^{\text {nd }}$ Division in the retreat to Dunkirk. In 1942 he commanded IV Corps in Iraq, thence promoted to command Eastern Army in India. Relieved of command after the abortive 1942-3 Arakan operation he never saw active service again, finishing his career as a Lieutenant-General.

${ }^{115}$ Edward Ivan de Sausmarez Thorpe, aged 43 in August 1914, had seen active service in Niger, 1897.
} 
16 April 1918. At this point he was briefly promoted Brigadier-General with 152 Brigade until 28 April, then with 107 Brigade until 14 September 1918, his appointment being terminated by wounding.

One hundred and forty-six Lieutenant-Colonels who had active service had three commands and six hundred and twenty-six had two.

The group who had three commands is dominated by Regular officers ( 68 per cent). It is in this group that citizens of $1914(\operatorname{six})^{116}$ and promoted ORs (three) ${ }^{117}$ appear. Of the promoted ORs, Lieutenant-Colonel F. Naden had served with the 4th Volunteer Battalion Cheshire Regiment and $6^{\text {th }}$ Cheshire, seeing service in South Africa 1900-1. ${ }^{118}$ He was a Company Sergeant Major with $1 / 6^{\text {th }}$ Cheshire in France in 1914 , and was commissioned 2nd Lieutenant in the battalion on 21 February 1915. He served as Adjutant in 1916, taking over temporary command after the wounding of Lieutenant-Colonel W.H. Stanway on 31

\footnotetext{
${ }^{116}$ Apart from R.S.H. Stafford (see below), the other five were: W.E. Thomas, a bank clerk, (CO $7^{\text {th }}$ East Yorkshire from 24 November 1917 to 30 March 1918; $10^{\text {th }}$ West Yorkshire from 31 March to 27 April 1918; and $7^{\text {th }}$ Border from 27 September to 21 October 1918 ); A.C. Barnes, son of a barrister, (CO $9^{\text {th }}$ Yorkshire from 24 December 1916 to 26 January 1917; $1 / 4^{\text {th }}$ Yorkshire from 11 June to 26 October 1918; and $15^{\text {th }}$ Durham Light Infantry from 15 October to the Armistice); J.H. Foster, a teacher, (CO $14^{\text {th }}$ Highland Light Infantry from 1 to 28 September $1917 ; 6^{\text {th }}$ Northamptonshire from 29 May to 8 August 1918 ; and $1 / 7^{\text {th }}$ Highland Light Infantry from 19 September 1918 to the Armistice); M.R. Dickson (CO $8^{\text {th }}$ Royal Scots Fusiliers from 15 January to 15 October 1917; $8^{\text {th }}$ Duke of Cornwall's Light Infantry from 6 May to 28 October 1918; and $12^{\text {th }}$ Argyll and Sutherland Highlanders from 29 October 1918 to the Armistice); A.D. Derviche-Jones, a solicitor, (CO 2/8 ${ }^{\text {th }}$ London from 2 June 1917 to 6 February 1918; 1/8 ${ }^{\text {th }}$ London from 31 July 1918 to the Armistice, during which he briefly commanded $1 / 12^{\text {th }}$ London).

${ }^{117}$ Apart from Frank Naden, the other two were Lieutenant Albert Grover, a retired OR of the Bedfordshire Regiment, who commanded $3 / 4^{\text {th }}$ London (18 June to 12 September 1918), $1 / 8^{\text {th }}$ London (24 September to 14 October 1918), and $1 / 12^{\text {th }}$ London (15 October 1918 to the Armistice); and James Walsh, a regular OR who was only commissioned $2^{\text {nd }}$ Lieutenant in the Liverpool Regiment on 30 January 1916 , yet commanded $13^{\text {th }}$ Essex (22 November 1917 to 10 February 1918), $6^{\text {th }}$ Northamptonshire 17 to 29 May 1918, and 3/2 ${ }^{\text {nd }}$ London from 10 August 1918 to the Armistice.

118 Roots and Branches, the Naden/Nadin/Neden/Nedin Family Society Magazine, ed. D. L. Nadin, 10 (2). Frank Naden was born 1878-9, the exact year of his birth being uncertain.
} 
July 1917. ${ }^{119}$ Thereafter he was CO 14th Hampshire from 3 November 1917 to 15 January 1918. He commanded his old battalion from 25 to 29 April 1918, and lastly $7^{\text {th }}$ Royal Irish Regiment from 11 September 1918 to the Armistice. ${ }^{120}$

Of the civilians, Lieutenant-Colonel R.S.H. Stafford, an ex-OTC cadet, had joined the Egyptian Civil Service in 1913 , but returned to be commissioned into $6^{\text {th }}$ King's Royal Rifle Corps as $2^{\text {nd }}$ Lieutenant on 6 March $1915 .{ }^{121}$ A rare example of a citizen commanding a Regular battalion, an indication of his ability, he commanded $1^{\text {st }}$ KRRC from 9 to 23 July 1917; $2 / 7^{\text {th }}$ Liverpool from 2 to 7 September 1917; and $17^{\text {th }}$ Middlesex from 9 September 1917 to 22 February 1918; commanding $1^{\text {st }}$ KRRC again from 23 February to 1 June 1918 before moving to a staff post.

\begin{tabular}{|c|c|c|c|c|}
\hline \multicolumn{5}{|c|}{ Commands } \\
\hline Two & Three & Four & Five & Six \\
\hline $60 \%$ & $68 \%$ & $73 \%$ & $100 \%$ & $100 \%$ \\
\hline
\end{tabular}

\section{Table 3.10: Contribution of professional soldiers to multiple battalion command}

Of the 626 who had two commands, 60 per cent were Regulars (either active or retired in 1914). As Table 3.10 shows, professional soldiers, who provided 60 per cent of battalion commands overall, contributed disproportionately to multiple battalion command, their numbers rising steadily as number of commands increase.

\footnotetext{
${ }^{119}$ William Henry Stanway had been in the ranks for just under 15 years when commissioned $2^{\text {nd }}$ Lieutenant in the Royal Welsh Fusiliers on 28 October 1914. He commanded $1 / 6^{\text {th }}$ Cheshire from 4 July 1916 until his wounding.

${ }^{120}$ Naden won the DSO and two bars. A flavour of this officer's ability and command style is given by his citation for his second bar to the DSO. "Near Neuve Eglise, on 1st September, 1918, he had launched his battalion to attack the village when he received orders to change direction from south to east. This was done, but the leading companies moved too far to the right. Seeing this, he personally led the right company on to its proper objective in the face of considerable machinegun and trench mortar fire. He was shortly afterwards wounded. But on this and the previous day he showed an absolute disregard of danger, and by his fine example and leadership inspired all ranks". London Gazette, 4 October 1919, p.12214.

${ }^{121}$ Ronald Semphill Howard Stafford was born in 1879.
} 
Finally, one $\mathrm{CO}$ who had four commands warrants individual attention, namely Lieutenant-Colonel J. Sherwood-Kelly. ${ }^{122}$ A mercurial South African, Sherwood-Kelly had served in the Boer War as a Lieutenant in the Imperial Light Horse, and later as a Sergeant, demoted to Private, in Somaliland. Sherwood-Kelly was gazetted Major in 10th Norfolk in November 1914, but requested transfer and on 23 July 1915 joined $1^{\text {st }}$ Kings Own Scottish Borderers in Gallipoli. Lieutenant-Colonel G.B. Stoney was killed on 15 October $1915,{ }^{123}$ and 'Bomb' Kelly, whom the battalion history describes as having "a quite remarkable disregard for danger", ${ }^{124}$ does not appear to have been first choice as CO, Captain C.S. Stirling-Cookson being appointed Temporary Major until 27 October, Sherwood-Kelly taking over on the 28th. ${ }^{125}$ What is remarkable is that there is no reference to him in the unit war diary until the following January, when the comings and goings of other officers were commonplace reference. The reality is that Sherwood-Kelly was undoubtedly unpopular - an outsider, an empire OR, commanding a Regular battalion. Leaving the KOSB on 22 January 1916, he served briefly as CO $1^{\text {st }}$ Essex until he was wounded on 4 June by a bullet through the lung. Recuperating, he was returned to the KOSB depot, where his unpopular past may have caught up with him. On 5 October he wrote to his CO asking to be returned to $10^{\text {th }}$ Norfolk as he found "some officers and many of the men at present in camp who served with the $1^{\text {st }}$ Battalion during my command". ${ }^{126}$ On 29 March 1917 he took over command of $1^{\text {st }}$ Royal Inniskilling Fusiliers, whom he led until

\footnotetext{
122 Jack Sherwood-Kelly was born in 1880 in Cape Colony.

${ }^{123}$ George Butler Stoney, aged 37 in August 1914, was a Regular Captain of King's Own Scottish Borderers serving with the Egyptian Army. He commanded the $1^{\text {st }}$ Battalion from 13 May to 15 October 1915 , when he was killed by a shell in Battalion HQ dugout on Gallipoli.

${ }^{124}$ S. Gillon, The K.O.S.B in the Great War (London: Thomas Nelson, 1930), p.166

${ }^{125}$ Charles Selby Stirling-Cookson was never to command a battalion, serving as Staff Captain and Brigade Major from February 1916.

${ }^{126}$ TNA WO 339/13469, Officers Services, John Sherwood-Kelly
} 
invalided on 4 December 1917, winning the VC at Cambrai on 20 November. ${ }^{127} \mathrm{He}$ finally commanded $12^{\text {th }}$ Norfolk (Yeomanry) in France from 23 September $1918 .{ }^{128}$

\subsubsection{Length of command}

Table 3.11 shows the average length in days a Lieutenant-Colonel spent in command of a battalion. Two hundred and fifty two days was the average length of a single command, or

\begin{tabular}{|l|c|}
\hline & $\begin{array}{c}\text { Days in } \\
\text { command }\end{array}$ \\
\hline One command & 252 \\
\hline Two commands & 326 \\
\hline Three commands & 386 \\
\hline Four commands & 496 \\
\hline Five commands & 706 \\
\hline Six commands & 258 \\
\hline
\end{tabular}

Table 3.11: Length of battalion command ${ }^{129}$

nearly eight and a half months, a figure slightly less than the nine and a half months indicated by Patrick Brennan for the COs of Canadian battalions. ${ }^{130}$

\footnotetext{
${ }^{127}$ His VC citation reads: "For most conspicuous bravery and fearless leading when a party of men of another unit detailed to cover the passage of the canal by his battalion were held up on the near side of the canal by heavy rifle fire directed on the bridge. Lt.-Col. Sherwood-Kelly at once ordered covering fire, personally led the lea-ding company of his battalion across the canal and, after crossing, reconnoitred under heavy rifle and machine gun fire the high ground held by the enemy. The left flank of his battalion advancing to the assault of this objective was held up by a thick belt of wire, whereupon he crossed to that flank, and with a Lewis gun team, forced his way under heavy fire through obstacles, got the gun into position on the far side, and covered the advance of his battalion through the wire, thereby enabling them to capture the position. Later, he personally led a charge against some pits from which a heavy fire was being directed on his men, captured the pits, together with five machine guns and forty six prisoners, and killed a large number of the enemy. The great gallantry displayed by this officer throughout the day inspired the .greatest confidence in his men, and it was mainly due to his example and devotion to duty that his battalion was enabled to capture and hold their objective". London Gazette, 11 January 1918, p.722

${ }^{128}$ Sherwood-Kelly was to command a battalion of the Hampshire Regiment in Russia in 1919, a venture which ended in his court martial after his outspoken public criticism of the campaign.

${ }^{129}$ The reason for the counterintuitive lower number of days for those who had six commands is due to the unusual careers of these two individuals as noted in the previous section.

${ }^{130}$ P.H. Brennan, 'Good Men for a Hard Job: Infantry Battalion Commanders in the Canadian Expeditionary Force', Canadian Army Journal, 9 (1) (2006), pp. 9-28. Lieutenant General Guy Simonds, the GOC of II
} 
Table 3.12 shows the average number of days in post served by COs commanding on the opening days of major battles. The figures suggest officers who had considerable experience of battlefield command. The high average for 1 July 1916, the opening day of the Battle of Somme, is, however, inflated by the number of COs who had commanded New Army battalions in the UK since they were raised.

\begin{tabular}{|l|l|c|}
\hline & & Days in post \\
\hline Neuve Chapelle & 10 March 1915 & 138 \\
\hline Loos & 25 September 1915 & 206 \\
\hline Somme & 01 July 1916 & 277 \\
\hline Arras & 09 April 1917 & 214 \\
\hline Third Ypres & 31 July 1917 & 252 \\
\hline Cambrai & 20 November 1917 & 223 \\
\hline Hundred Days: F\&F & 29 September 1918 & 185 \\
\hline Hundred Days:Other & 29 September 1918 & 372 \\
\hline
\end{tabular}

\section{Table 3.12: Average days in post for COs prior to major battles}

Perhaps the most interesting figures pertain to 1918. Apart from the Battle of Neuve Chapelle in early 1915, when the BEF had been depleted by the campaigns of 1914, 29 September 1918 yields the lowest average of days in post, reflecting the rapid turnover caused by death and wounding during the German offensives from March to May 1918. The reality is that the successful armies of The Hundred Days were led by men with less average experience of command, albeit with rich experience of fighting. On that day in other theatres of war, the length of time previously in post was double, reflecting the much lower turnover.

Canadian Corps, sent a memo to Canadian Military Headquarters in the UK in October 1944 in which he stated: "It has been amply demonstrated both in North Africa and Italy that when active operations are continuous, the Commanding Officer of an infantry battalion is good for about four to six months", recommending that rotating Commanding Officers out of their positions after a few months be made standard practice. Quoted by M. Dorosh, http://www.battlefront.com/community/showthread.php?t=32644 (accessed 2 April 2013). 


\subsubsection{Killed in action}

Seven hundred and twenty-seven officers with the rank of Lieutenant-Colonel died during the war according to Soldiers Died in the Great War, but this may be an underestimate. ${ }^{131}$ The database compiled here includes 452 infantry Lieutenant-Colonels killed in action or died of wounds whilst commanding their battalions, an 11 per cent attrition rate through death resulting from action. ${ }^{132}$ Patrick Brennan cites a 12.5 per cent rate for Canadian COs, noting: "It would seem that battalion commanders - if they were going to command effectively - had to place themselves in harm's way". ${ }^{133}$

\begin{tabular}{|l|c|c|c|c|c|}
\hline & $\mathbf{1 9 1 4}$ & $\mathbf{1 9 1 5}$ & $\mathbf{1 9 1 6}$ & $\mathbf{1 9 1 7}$ & $\mathbf{1 9 1 8}$ \\
\hline Total deaths & 24 & 108 & 97 & 99 & 124 \\
\hline Deaths per month & 5.6 & 9 & 8.1 & 8.2 & 11 \\
\hline
\end{tabular}

\section{Table 3.13: Infantry COs killed in action/died of wounds}

Table 3.13 sets out the deaths per year, and the average number of $\mathrm{CO}$ deaths per month. With only four and a half months of campaigning, 1914 produced the lowest number of CO deaths. However, this was from only 146 battalions, in comparison with the 507 of 29 September 1918. Multiplying the 1914 monthly total by a factor of three and a half gives a projected figure of nearly 20, indicative of the lethal nature of the fighting of that year.

The CO of 1914 typically led from the front, and of the two commanding officers who died when II Corps stood and fought at Le Cateau, both died in this location. Lieutenant-

\footnotetext{
${ }^{131}$ Soldiers Died in the Great War Version 2.5 (Naval \& Military Press, 2011). There are likely omissions, e.g. officers listed without the correct rank of Lieutenant-Colonel.

${ }^{132}$ Changboo Kang calculates that " 14.6 per cent of officers who served with the British Army during the war died, at least 30.9 per cent were wounded, and 2.5 per cent taken prisoners". [C. Kang, "The British Regimental Officer on the Western Front in the Great War, with Special Reference to the Royal Warwickshire Regiment', unpublished PhD Thesis, University of Birmingham (2007) p.19].

${ }^{133}$ Brennan, Good Men, p.16
} 
Colonel C.A.H. Brett of $2^{\text {nd }}$ Suffolk, found his battalion in a poor position. ${ }^{134}$ Brett gathered his officers and told them "they were committed to it, and everyone must do the best he could ... there was to be no retirement". ${ }^{135}$ Brett placed himself with his forward companies, and was killed early on by a shell. In the same battle, the $2^{\text {nd }}$ Royal Lancasters, commanded by Lieutenant-Colonel A. McN. Dykes, ${ }^{136}$ found themselves on top of a hill at Haucourt under heavy shellfire. In the frontline, Dykes fell early on, shouting instructions: "Men, if you want your lives for God's sake extend", and finally, "Good bye, boys". 137

1915 contained the second highest casualty rate of the four years 1915-18, reflecting perhaps the lack of tactical/operational sophistication of the fighting. Six COs were killed at Neuve Chapelle, 29 at Loos (11 on the opening day, 25 September 1915), and 'trench wastage' was high. ${ }^{138}$ The years 1916 and 1917 produced an almost identical number of CO monthly deaths. Twenty-eight COs (with the rank of Lieutenant-Colonel) died on the opening day of the Somme battle, 20 during the remainder of July. At the Battle of FlersCourcelette, 15 September 1916, a further 10 COs died, within a total of 31 from 1 August to 14 November 1916, giving a total of 79 during the whole battle. Only three COs were killed on the opening day of the Battle of Arras, 9 April 1917, 21 dying during the

\footnotetext{
${ }^{134}$ Charles Arthur Hugh Brett, commanding the battalion at the outbreak of war, was a 49 year-old veteran of Hazara (1888) and South Africa (1899-1902),

${ }^{135}$ C.C.R. Murphy, The History of the Suffolk Regiment 1914-1927 (London: Hutchinson, 1928) p.32

${ }^{136}$ Forty year-old Alfred McNair Dykes psc, had fought in South Africa 1899-1902.

${ }^{137}$ www.dnw.co.uk/medals/auctionarchive/viewspecialcollections/itemdetail.lasso?itemid=3809 (accessed 16 May 2012).

${ }^{138}$ Not all were by enemy action. Lieutenant-Colonel J.T.C Murray, $1^{\text {st }}$ Black Watch (and three others) were "accidentally killed when a lance corporal, swinging a grenade, accidentally struck the ground with it, causing it to explode", on 16 February 1915. [J. Cassells, The Black Watch, a Record in Action (New York: Doubleday, Page \& Co, 1918) pp.171-2].
} 
extended campaign. ${ }^{139}$ Eight died on the opening day of Third Ypres, 31 July 1917, and 42 during the four months of operations.

The two years 1916 and 1917 are broadly comparable in terms of number of battalions engaged, and given the reduction in number of battalions in February $1918,{ }^{140}$ it was 1918 that produced the disproportionately highest number of total $\mathrm{CO}$ deaths of these three years. Twelve died on the opening day of the German spring offensive, 21 March 1918, and five the following day. During the period of the German offensives from 21 March to 17 July 1918, 73 infantry COs with the rank of Lieutenant-Colonel were killed, 36 before the end of March. In contrast, during The Hundred Days from 8 August 1918 until the Armistice, 43 were killed. Thus in roughly comparable periods of time, almost twice as many were killed in defensive actions than offensive actions.

\subsubsection{Wounding and invalidity}

As noted previously, some COs were simply unfit physically for active service. In 10 Brigade in August 1914, derided by Tim Travers, ${ }^{141}$ Lieutenant-Colonel A.E. Mainwaring, ${ }^{142} 2^{\text {nd }}$ Royal Dublin Fusiliers, who arrived exhausted at St Quentin on 27 August and became involved in the town's surrender, should probably never have gone on active service. He was "subject to bouts of debilitating illness. During manoeuvres in September 1913 he suffered so severely from colitis that he was forced to return to

\footnotetext{
${ }^{139}$ Given that the daily casualty rates on the Somme and at Arras were 2943 and 4076 respectively, it is clear that more care was being taken of the $\mathrm{CO}$ resource. www.battlefields 1418.50 megs.com accessed 13 January 2012.

${ }^{140} 184$ battalions were affected by the infantry reorganisation of January to March 1918, being disbanded, amalgamated, or repurposed as pioneers.

${ }^{141}$ See Introduction. T. Travers, The Killing Ground: The British Army, the Western Front, and the Emergence of Modern Warfare 1900-1918 (Barnsley: Pen \& Sword, 2003), pp.3-36

${ }^{142}$ See also the Introduction and Chapter One.
} 
Gravesend ahead of his battalion". ${ }^{143}$ Similarly, Lieutenant-Colonel T.O. Lloyd, CO $9^{\text {th }}$ Black Watch and a sciatica sufferer, found the winter of 1915 too much for his condition and was replaced on 18 November 1915 after 133 days on active service. ${ }^{144}$ In contrast, Lieutenant-Colonel C.R.C. de Crespigny, $2^{\text {nd }}$ Grenadier Guards: “Although suffering much pain from internal ulcers ... refused to go sick", thereby winning the respect of his battalion. $^{145}$

The conditions of trench warfare were conducive to sickness, and falling ill in the front line could be both inconvenient and dangerous. ${ }^{146}$ Lieutenant-Colonel G.S. Guyon, CO $2^{\text {nd }}$ Royal Fusiliers, developed appendicitis on Gallipoli, and lay in his dugout for a week before he could be evacuated. ${ }^{147}$ Gallipoli was a harsh environment, and 54 year old Lieutenant-Colonel J.R. Harvey, $1 / 4^{\text {th }}$ Norfolk, joined his battalion on 10 September 1915 to be invalided with dysentery 15 days later, never to see active service again. ${ }^{148}$ The sixty year old Lieutenant-Colonel G.S. Ormerod, $9^{\text {th }}$ Royal Irish Rifles, went into the front line with pneumonia in March 1916, and had to be evacuated, but refused to be stretchered:

\footnotetext{
${ }^{143}$ P.T.Scott, Dishonoured (London: Tom Donovan, 1994), p.9

144 Thomas Owen Lloyd, aged 47 in 1914, a Major of the Reserve of Officers of the Black Watch, commanded the $9^{\text {th }}$ Battalion between 24 October 1914 and 18 November 1915.

${ }^{145}$ H. Macmillan, Winds of Change 1914-1939 (London: Macmillan, 1966) p.79. Claude Raul 'Crawly' Champion de Crespigny, born in 1878, a Captain of $3^{\text {rd }}$ Grenadier Guards in August 1914, commanded the $2^{\text {nd }}$ Battalion between 1 February and 22 September 1917 before being promoted to the command of 1 Guards Brigade.

${ }^{146}$ Lieutenant-Colonel G. Scott Jackson, $7^{\text {th }}$ Northumberland Fusiliers, "always looked a picture of robust strength, and never missed his cold bath even with the temperature near zero". [F. Buckley, Q.6.a. and Other Places (London: Spottiswoode, Ballantyne \& Co, 1920), p.100].

${ }^{147}$ George Sutherland Guyon, born in 1873, was a Major of $2^{\text {nd }}$ Royal Fusiliers, commanding the battalion between 6 August and 1 November 1915. He survived, but was killed in 1 July 1916 with $16^{\text {th }}$ West Yorkshire, a battalion he had commanded for only a week.

${ }^{148}$ John Robert Harvey, a retired Lieutenant of $7^{\text {th }}$ Hussars, was commanding $1 / 4^{\text {th }}$ Norfolk at the outbreak of war, and had had an unhappy relationship with his senior officers (see Chapter Five section 5.3.6). He served later as a Commandant of a Prisoner of War Camp, and as a Staff Lieutenant.
} 
"Me on a stretcher and the battalion walking out! If I am wounded it's different - I walk back to my horse and ride the rest!"149

Some injuries could seem quite trivial, yet prove handicapping in a trench environment. Lieutenant-Colonel C.H.D. Lyon-Campbell, $4^{\text {th }}$ Royal Fusiliers, sprained his knee after 12 days active service and was invalided, taking over the home service $2 / 4^{\text {th }}$ Norfolk in September $1916 .{ }^{150} \mathrm{He}$ was one of a number of COs replaced suffering knee problems. Lieutenant-Colonel W.T.M. Reeve, $2^{\text {nd }}$ Leinster, had his hand shot off by a sniper in November 1914, rejoining his battalion on 3 June 1915. By 1 July he was remarking that "his arm gave him hell and he could not sleep". ${ }^{151}$ He visibly deteriorated and left finally 19 days later. He took $1^{\text {st }}$ Garrison Battalion Essex Regiment to Gallipoli, but lasted only a matter of weeks before replacement.

Lieutenant-Colonel R.A. Smyth, $10^{\text {th }}$ Royal Inniskilling Fusiliers, was one of several COs injured in riding accidents. After 259 days on active service he fell from his horse on 30 June 1916 never to return to active service as a result of further ill-luck with transport, being killed in a motor accident in the UK. ${ }^{152}$ Lieutenant-Colonel R. Mander, $7^{\text {th }}$ Duke of Cornwall's Light Infantry, similarly had to surrender command on 13 June 1918, breaking

\footnotetext{
${ }^{149}$ Crozier, Brass Hat, p.78. George Sumner Ormerod, a 58 year-old retired Lieutenant-Colonel of the Royal Munster Fusiliers, commanded $6^{\text {th }}$ Royal Irish Rifles from 6 to 30 September 1914 when he was transferred to the command of the $9^{\text {th }}$ Battalion until his invaliding on 27 March 1916. He commanded $11^{\text {th }}$ Lincolnshire very briefly in March 1918 before becoming a Prisoner of War Camp Commandant.

${ }^{150}$ Charles Henry Donald Lyon-Campbell, aged 47 in August 1914, was a Major of the $2^{\text {nd }}$ Royal Fusiliers, and commanded the $4^{\text {th }}$ Battalion for only 12 days before his accident. He commanded $2 / 4^{\text {th }}$ Norfolk from 30 September 1916 to 11 March 1918.

${ }^{151}$ F.C. Hitchcock, Stand To - A Diary of the Trenches (Uckfield, Naval \& Military, n.d.), p.44. William Tankerville Monypenny "Terrier" Reeve, aged 48, commanded $2^{\text {nd }}$ Leinster from the outbreak of war until 20 July 1915. He took command of $1^{\text {st }}$ Garrison Battalion Essex Regiment on 13 August until 29 September 1915 , when he died.

15227 September 1917. Ross Acheson "Rossie" Smyth was a retired brevet Major of the Royal Irish Regiment who was born in 1862. He commanded $10^{\text {th }}$ Royal Inniskilling Fusiliers from 17 September 1914.
} 
his thigh when his horse fell. ${ }^{153} 1 / 1^{\text {st }}$ Oxfordshire and Buckinghamshire no doubt regarded themselves as particularly unlucky losing two successive COs to horse falls, LieutenantColonel C.P. Doig on 27 January 1916, ${ }^{154}$ and his successor Lieutenant-Colonel L.C. Hawkins on 2 June 1916, both of whom never returned to active service. ${ }^{155}$ Equally uncomfortably, but not from a horse, Lieutenant-Colonel E.S. Weldon, $6^{\text {th }}$ Dorsetshire, fell on a screw picket in the dark on 24 August 1918, but was able to return to duty on 20 October and served until the Armistice without further mishap. ${ }^{156}$

Sports behind the front-line also proved dangerous. Lieutenant-Colonel C.S. Nairne, $10^{\text {th }}$ Black Watch, fractured his collarbone running in a staff relay race on 15 September 1918. ${ }^{157}$ Lieutenant-Colonel A. Stone, $16^{\text {th }}$ Lancashire Fusiliers, broke the same bone playing left full back for the battalion officers' football team, a statement having to be provided by Captain A.N. Watts, the goalkeeper, to the effect that this was not a selfinflicted injury. ${ }^{158}$ Training might also be dangerous. Lieutenant-Colonel W. Keyworth, $9^{\text {th }}$ South Lancashire, fell victim to his own men whilst watching instruction in bomb-

\footnotetext{
${ }^{153}$ Reginald Mander, aged 43 in 1914, was a Regular Captain of the Duke of Cornwall's Light Infantry. He commanded the $7^{\text {th }}$ Battalion from 25 March 1918 until his tumble.

${ }^{154}$ Claude Prendergast Doig, aged 40 in 1914, was a Major of the $1^{\text {st }}$ Seaforth Highlanders. He had survived campaigns in Chitral 1895, the Nile 1898, South Africa 1899-1902, and the Northwest Frontier 1908 without mishap. He commanded $1 / 1^{\text {st }}$ Oxfordshire and Buckinghamshire Light Infantry from 9 March 1915 to 27 January 1916, and thereafter commanded home service battalions, namely: $3 / 9^{\text {th }}$ Royal Scots from 9 March 1917 to 23 April 1917 and the $3 / 4^{\text {th }}$ Battalion from that date to the Armistice.

${ }^{155}$ Lionel Combes Hawkins was a Territorial Captain of the Oxfordshire and Buckinghamshire Light Infantry in August 1914. He finished the war as an Instructor in a Military Convalescent Hospital.

${ }^{156}$ Ernest Steuart Weldon was a 37 year-old Regular Captain of the Dorset Regiment in August 1914. He commanded the $6^{\text {th }}$ Battalion from 26 April 1918. Lieutenant-Colonel E.A. Pope, $12^{\text {th }}$ South Wales Borderers, was less lucky. During the Battle of Arras he fell amidst rusty wire, puncturing his face. Invalided, he later commanded $3^{\text {rd }}$ Welsh in the UK, but: "Two years later a military funeral leaves Millbank Hospital and on the gun-carriage are the mortal remains of Pope. The dirty wire killed him". Crozier, Brass Hat, p.146 ${ }^{157}$ Charles Sylvester Nairne was a 34 year-old Regular Captain of the Seaforth Highlanders in August 1914. He commanded $10^{\text {th }}$ Black Watch from 3 January 1918 until his accident, but returned to command $2^{\text {nd }}$ Royal Scots Fusiliers four days before the Armistice.

${ }^{158}$ TNA WO 339/21909, Officers' Services, Arthur Stone. Stone was a 37 year-old retired Territorial OR and solicitor in August 1914. He commanded $15^{\text {th }}$ Lancashire Fusiliers from 5 October to 22 December 1916 before transferring to the $17^{\text {th }}$ Battalion as $\mathrm{CO}$ which he commanded from 5 April 1918 before being killed in action on 2 October.
} 
throwing in Salonika, 6 October 1915. He returned on 1 April 1916, but his wounds got the better of him and he was invalided on 28 September. ${ }^{159}$

Some COs struggled back to service after wounding but were beaten by their limitations. Lieutenant-Colonel A.V. Ussher, $10^{\text {th }}$ Scottish Rifles, had been wounded at Loos in September 1915, and resuming command of his battalion on 23 March 1916 lasted until 19 November before the effects of his previous injuries proved too severe. ${ }^{160}$ LieutenantColonel O.B. Pritchard commanded $2^{\text {nd }}$ Welsh from 15 November 1915 to 25 September 1916. ${ }^{161}$ Described as "rather beyond middle age" (he was in fact 47) he suffered from "serious wounds which he got during the retreat in 1914". ${ }^{162}$ In July 1916 the battalion was involved in the fighting for Munster Alley, near Pozieres, and Pritchard and his Adjutant were buried in their dugout by a shell. Soon after, in the fighting for High Wood, Major C.P. Clayton, second-in-command noted: "The recent fighting has affected his old wounds, and his one leg and foot are all swollen up so badly that I wonder he can walk at all". ${ }^{163}$ After the fighting he was described as "very deeply grieved by his losses". His leg worsened, and he was invalided, Clayton noting: "His going is pathetic ... it seems that he feels he will not return". ${ }^{164}$ On 27 November 1916 Pritchard shot himself. Clayton, his replacement, wrote: "He has done it in despair because he cannot come out and join us, but

\footnotetext{
${ }^{159}$ Walter Keyworth, a retired Indian Army officer, commanded $9^{\text {th }}$ South Lancashire from 22 February 1915.

${ }_{160}$ Alan Vesey Ussher, a 53 year-old retired Regular Lieutenant-Colonel of the Scottish Rifles in August 1914 whose first campaign had been 22 years earlier, Lagos 1892 , commanded $10^{\text {th }}$ Scottish Rifles from 6 September 1914 until 19 November 1916.

${ }^{161}$ Osborn Brace Pritchard was the second-in-command of the 2nd Welsh in August 1914.

${ }^{162}$ C.P. Clayton, The Hungry One (Gomer Press: Llandysul, 1978), p.133

${ }^{163}$ Clayton, Hungry, p.155

${ }^{164}$ Clayton, Hungry, p. 166
} 
I cannot help fearing that High Wood, and its consequences, preyed upon his sensitive mind". 165

As Clayton intimated, COs were not immune from the psychological reactions that became known as 'neurasthenia' and 'shellshock'. Lieutenant-Colonel H. Delme-Radcliffe was invalided from command of the $2^{\text {nd }}$ Royal Welsh Fusiliers in October 1914 with a "nervous breakdown" according to Private Frank Richards, whose diagnosis was confirmed by the Medical Officer of $19^{\text {th }}$ Field Ambulance with the words "a bit of a nervous wreck". 166 Lieutenant-Colonel B.H.S. Romilly, $1^{\text {st }}$ Scots Guards, was invalided with "shellshock" in July 1917 after a shell hit his HQ dugout, and never saw active service again. ${ }^{167}$ Similarly, Lieutenant-Colonel F.W. Parish, $8^{\text {th }}$ North Staffordshire, commanded his battalion from 16 July 1916 to be invalided with "shellshock" on 1 November. After rehabilitation in a Brigade-Major post from 1 April to 6 July 1917, he served twice again as a CO, with $1 / 15^{\text {th }}$

\footnotetext{
${ }^{165}$ Clayton, Hungry, p.177. Charles Pritchard Clayton was a 29 year-old teacher in August 1914. He commanded $2^{\text {nd }}$ Welsh both in 1916 and from 14 April to 4 August 1918. In terms of other "sensitive minds", Lieutenant-Colonel T.B. Shaw, a retired RE Captain was the first CO of $2 / 5^{\text {th }}$ Warwickshire, was removed due to ill-health long before they went overseas. Two months after his removal he was found floating in the sea off Cornwall. The Birmingham Daily Post, 11 September 1915, noted: "The peculiar circumstances in which his battalion were placed in regard of senior officers threw a great strain upon him, and overwork finally led to a nervous breakdown. He tried several resorts to effect a recovery". The word suicide was not mentioned. Suicide could be long delayed. Lieutenant-Colonel G. Green, a civilian schoolmaster in August 1914 who commanded $9^{\text {th }}$ Essex from 26 April 1917 to August 1918 when he was gassed, "ended his own life in 1957 with a service revolver as a result of his war service", (personal communication, Ian Hook, Keeper Essex Regiment Museum).

${ }^{166}$ F. Richards, Old Soldiers Never Die (London: Faber, 1965), p.55. T. Hampson, A Medical Officer's Diary and Narrative of the First World War,

http://myweb.tiscali.co.uk/philsnet/T\%20Hampson\%20WW1\%20Diary\%20100.htm accessed 20/09/2011. Henry Delme-Radcliffe, was the 48 year old $\mathrm{CO}$ of $2^{\text {nd }}$ Royal Welsh Fusiliers at the outbreak of war and commanded until his breakdown on 26 October 1914. He commanded the $12^{\text {th }}$ Battalion from 8 April to 31 August 1916 (see Appendix Three).

${ }^{167}$ Bertram Henry Samuel Romilly, a 35 year-old Regular Captain of the Scots Guards in August 1914, had seen active service in South Africa 1899-1902 and in four campaigns in the Sudan between 1906 and 1914. He commanded $1^{\text {st }}$ Scots Guards from 3 May to 29 July 1917, and thereafter commanded the $3^{\text {rd }}$ (Reserve) Battalion until 18 February 1918, later serving as an ADC.
} 
London from 6 July to 23 September 1917 (when he was invalided again, quite possibly with the same problem), and $1 / 17^{\text {th }}$ London from 11 March to 15 July $1918 .^{168}$

Others, however, managed to continue in command despite significant handicap. Lieutenant-Colonel G.F. Trotter had lost an arm during the Boer War but was promoted CO of $1^{\text {st }}$ Grenadier Guards serving from 14 July 1915 to 17 March $1916 .{ }^{169}$ When J.E.B. Seeley encountered him in the trenches he noted: "We were relieved by a Guards battalion, commanded by the one-armed Colonel Trotter. I never saw a man so cheerful under such distressing circumstances". ${ }^{170}$ Lieutenant-Colonel V.V. Pope, $1^{\text {st }}$ North Staffordshire, had his elbow shattered by a bullet on 21 March 1918 and lost his arm, but later served in the Tank Corps. ${ }^{171}$ The precise nature of the injury was an issue. Lieutenant-Colonel A.A. Kennedy, 5/6 ${ }^{\text {th }}$ Scottish Rifles, lost an eye on 20 July 1916 at High Wood. He returned to command on 3 December 1917, but could not cope in the front-line with monocular vision and was replaced in February 1918, thereafter serving as Lieutenant-Colonel in the Labour Corps. ${ }^{172}$ Lieutenant-Colonel A. Carton de Wiart, however, commanded lacking both eye and hand. ${ }^{173}$

\footnotetext{
${ }^{168}$ Francis Woodbine 'Gasper' Parish was a 30 year-old retired Special Reserve Captain of the Sussex Regiment in August 1914.

${ }^{169}$ Gerald Frederic Trotter was a 43 year-old retired Major of the Grenadier Guards in August 1914. On 17 March 1916 he was promoted Brigadier General with 27 and subsequently 51 Brigades.

${ }^{170}$ J.E.B. Seeley, Adventure (London: Heinemann, 1930), p. 223. John Edward Bernard Seeley was a Liberal MP who had been Secretary of State for War 1912-14. Resigning after the Curragh incident, he became a Major-General commanding the Canadian Cavalry Brigade.

${ }^{171}$ Vyvyan Vavasour Pope, a 22 year-old Regular $2^{\text {nd }}$ Lieutenant of $1^{\text {st }}$ North Staffordshire in August 1914, commanded the battalion from 18 June 1917 to 1 January 1918, and was wounded three times.

${ }_{172}$ Archibald Arrol Kennedy, a Territorial Captain of $5^{\text {th }}$ Scottish Rifles in August 1914 commanded the battalion from 29 May 1915. He commanded the $2 / 6^{\text {th }}$ Seaforth Highlanders at home during his recovery from 3 April to 20 September 1917.

${ }^{173}$ Adrian "Nelson" Carton de Wiart, a 34 year-old Captain of $4^{\text {th }}$ Dragoon Guards in August 1914, was wounded eight times during the Great War. He commanded $8^{\text {th }}$ Gloucestershire from 15 June to 26 October 1916, and $8^{\text {th }}$ North Staffordshire from 31 December 1916 to 11 January 1917.
} 
Lieutenant-Colonel E.A. Wood, $6^{\text {th }}$ King's Shropshire Light Infantry, was redoubtable in the face of injury, invalided from command after 705 days active service having been wounded five times, gassed twice and buried once, later to be promoted TemporaryBrigadier General on 5 November $1917 .{ }^{174}$ Another officer wounded five times was Lieutenant-Colonel E.T.F. Sandys, who took command of $2^{\text {nd }}$ Middlesex on 16 February 1916. He was severely wounded for the final time in front of La Boisselle on 1 July 1916. He committed suicide in the Cavendish Hotel, London on 13 September 1916. The inquest noted: "Very much distressed because in the attack on July 1 his battalion had suffered severely ... he wished he had been killed with his men", Sandys himself stating: "I have never had a moment's peace since July 1 ". ${ }^{175}$

Of active infantry Lieutenant-Colonels, 389 commands are known to have been terminated by invalidity. Of these, 250 were permanent, in that the individual never returned to active service command. ${ }^{176}$ This constitutes six per cent of the active infantry COs, but the figure is likely an underestimate, as these matters were not always recorded in unit diaries. Similarly, 635 commands are known to have been terminated by wounding. Of these 286 were permanent, a figure which constitutes seven per cent of the active infantry COs, but again, this figure is likely an underestimate. Patrick Brennan notes that just over onequarter of Canadian COs were wounded at least once, with 8 per cent never resuming command. ${ }^{177}$ Five per cent were removed for psychological reasons, with seven per cent

\footnotetext{
${ }^{174}$ Edward Allan Wood (see Chapter Five section 5.3.2) commanded $6^{\text {th }}$ Shropshire from 7 October 1915 to 11 September 1917, thereafter commanding 55 Infantry Brigade.

${ }^{175}$ The Times, 15 September 1916, p.3. Edwin Thomas Falkiner Sandys a 38 year-old Regular Captain of the Middlesex Regiment in August 1914.

${ }^{176}$ The individual concerned perhaps passing to the command of a home service battalion or being transferred to a staff post.

${ }^{177}$ P.H. Brennan, 'Good Men for a Hard Job: Infantry Battalion Commanders in the Canadian Expeditionary Force', Canadian Army Journal, 9 (1) (2006), pp. 9-28
} 
invalided for physical illness, ${ }^{178}$ a figure of 20 per cent overall, against 13 per cent known in this study for British COs.

\subsubsection{Promotion}

Some COs had the experience of brigade command during the brief normal absences of the incumbent, ${ }^{179}$ just as their Majors/Captains had experience of battalion command during their own absence. The expansion of the army and hence number of brigades, coupled with the turnover of commanders at that level, however, created an ongoing demand for Brigadier-Generals.

\begin{tabular}{|l|c|}
\hline Status August 1914 & \% \\
\hline Regular & 82 \\
\hline Retired Regular & 8 \\
\hline Indian Army & 3 \\
\hline Retired Indian Army & 0.5 \\
\hline Special Reserve & 1 \\
\hline Retired Special Reserve & 0.5 \\
\hline Territorial Force & 3.5 \\
\hline Retired Territorial & 0.5 \\
\hline Empire & $<1$ \\
\hline Retired Empire & $<1$ \\
\hline Citizen & 1 \\
\hline
\end{tabular}

Table 3.14: August 1914 status of Brigadier-Generals promoted from battalion command

As noted earlier, ten per cent (398 of 4055) active infantry COs were promoted to brigade command. As Table 3.14 shows, 93.5 per cent of these were professional soldiers in

\footnotetext{
${ }^{178}$ Brennan notes: "Five per cent were permanently removed because of 'stress' and another seven per cent for physical breakdown with accumulated stress clearly a contributing factor in most cases." He suggests that one element of stress for COs was that they "endured a more solitary existence than those in the lower ranks, and companionship was a critical bulwark against stress", "exhausting workloads and an almost paralyzing responsibility" being layered on top of the stresses shared with lower ranks. P.H. Brennan, 'Completely Worn Out by Service in France', Canadian Military History, 18 (2) (2009), pp. 5-14

${ }^{179}$ This acting-up generally being organised on a seniority principle.
} 
August $1914,{ }^{180}$ with 82 per cent active Regulars. Forty were further promoted to divisional command. All were Regulars and all bar one were serving in August 1914, ${ }^{181}$ twenty-six having been Lieutenant-Colonels in August 1914, 10 Majors, and three Captains. Three Regular Lieutenant-Colonels of August 1914 were promoted to Corps command. $^{182}$

With respect to promotion to Brigadier-General, eight per cent of such promotions were within the same brigade as the battalion the individual commanded, and nine per cent within the same division but not the same brigade, giving a within-division appointment rate of 17 per cent. ${ }^{183}$ This indicates a trajectory of promotion for the majority beyond the 'local' level. As John Bourne has noted, the Military Secretary's office kept lists of those flagged for promotion to brigade and division command. ${ }^{184}$ Little is known about the operation of the Military Secretaries, the records having been destroyed. ${ }^{185}$ However it seems that a senior Assistant Military Secretary (AMS) was attached to each army, their brief being 'talent-spotting' from battalion level upwards. ${ }^{186}$

\footnotetext{
180 Active or retired.

${ }^{181}$ C. A. Blacklock, a retired Lieutenant of the Kings Royal Rifle Corps was commissioned Captain in the $10^{\text {th }}$ KRRC on 4 November 1914, promoted Major 11 December 1914, and Lieutenant-Colonel 28 December 1915. Wounded at Guillemont on 4 September 1916, he was promoted Brigadier-General from 18 January 1917 with 182 and subsequently 97 Brigades, and Major-General from 20 March 1918 to the Armistice with $9^{\text {th }}, 39^{\text {th }}$ and $63^{\text {rd }}$ Divisions.

${ }^{182}$ See Chapter One, section 1.4.1.

${ }^{183}$ These figures are so low that it raises the question as to whether there was a 'policy' against local promotion e.g. to avoid favouritism.

${ }^{184}$ The Military Secretary to the Secretary of State for War was responsible for personnel management.

${ }^{185}$ In the bombing of the War Office repository, Walworth, in September 1940.

186 J. Bourne, 'Hiring and Firing on the Western Front', talk given at Cheshire Branch Western Front Association, 14 January 2011.
} 
H.E. Trevor began the war as the second senior Major of $2^{\text {nd }}$ King's Own Yorkshire Light Infantry, and on 26 November 1914 he became a Brigade-Major for the third time. ${ }^{187}$ On 1 November 1915 was promoted CO of $8^{\text {th }}$ KOYLI, 70 Brigade, $8^{\text {th }}$ Division, III Corps, First Army. On 7 May 1916 he wrote to his wife: "I gather I am one of the next on the list of promotion to Brig-Genl and that the orders might come any day"; ${ }^{188}$ and on 9 June: "As regards the brigade it is largely a matter of how long a man has commanded a $\mathrm{Bn}$ and how much fighting the Bn has seen. These things also go in Corps. As a matter of fact I couldn't be in a better corps for this purpose probably, as my Brigadier $^{189}$ and Div Commander ${ }^{190}$ have backed me up nobly." He was promoted Brigadier-General 103 Brigade, 34 ${ }^{\text {th }}$ Division, III Corps, on 3 July 1916.

His promotion from Staff Officer to $\mathrm{CO}$ was across Corps but within Army, his promotion to Brigadier-General was across Division but within Corps. His observations on promotion from $\mathrm{CO}$ to Brigadier are valuable, as "how long a man has commanded a $\mathrm{Bn}$ and how much fighting the Bn has seen" speaks to promotion according to experience-based merit principles.

His statement: "These things also go in Corps" may, however, merely be a reflection of his own experience, and not necessarily an accurate reflection of the wider picture. A sample of 50 first promotions of COs to Brigadier-General (spanning 1914-1918) shows that only 28 per cent were 'within corps' appointments, with 66 per cent 'within army'

\footnotetext{
${ }^{187}$ Herbert Edward Trevor was 42 in August 1914, and had served both at the Royal Military College and as a Brigade-Major with Northumberland Infantry Brigade, from 1 April 1911 to 1 April 1912, and $9^{\text {th }}$ London Infantry Brigade, from 2 April 1912 to 23 February 1913.

${ }^{188}$ Trevor, 'Letters'.

${ }^{189}$ Brigadier-General H. Gordon, 70 Brigade.

${ }^{190}$ Major-General H. Hudson; the commander of III Corps was Lieutenant-General W. Pulteney.
} 
appointments. In a separate sample of 50 first promotions covering the period 1917$1918,{ }^{191} 20$ per cent were within corps, and 48 per cent within army.

Lieutenant-Colonel A.C. Johnston, ${ }^{192} 10^{\text {th }}$ Cheshire, 7 Brigade, 25th Division, II Corps, Fifth Army, was told on 12 September 1917 he would be given command of 33 Brigade, $11^{\text {th }}$ Division, XVIII Corps, Fifth Army, but the next day was told it would in fact be 126 Brigade 42nd Division, XIII Corps, Fourth Army, a swift and dramatic change. A picture therefore emerges of a talent spotting system on the Western Front for promotable COs which, if Army-based, was capable (presumably via the AMS at GHQ) of swiftly projecting those promoted across the five armies.

\subsubsection{Replacement}

John Bourne lists the reason for replacement of senior commanders during the war as: ${ }^{193}$ (i) Age (especially of 'dug-outs' early in the war); (ii) Scapegoating (especially during the first two to two-and-a-half years of the war); (iii) The 'new broom' phenomenon; ${ }^{194}$ (iv) Rest and recuperation; ${ }^{195}$ and (v) General reordering after specific campaigns.

\footnotetext{
${ }^{191}$ When new brigades were no longer being created.

192 Alexander Colin Johnston was a 30 year-old Regular Lieutenant of the Worcestershire Regiment in August 1914. He commanded $10^{\text {th }}$ Cheshire from 28 August 1916 to 13 September 1917, but had previously had service as a GSO3 and Brigade-Major in 1916.

193 Bourne, 'Hiring and Firing'.

${ }^{194}$ Simon Robbins notes, for instance, that "Major-General E.C. Ingouville-Williams had sent home three of the four battalion commanders of the $16^{\text {th }}$ Brigade, within three months of arrival in France, the fourth going on to command a Division". [S. Robbins, British Generalship on the Western Front 1914-18: Defeat Into Victory (Abingdon: Frank Cass, 2005), p55, quoting Colonel T.T.Grove, Memoir, pp.92-3, NAM]. Grove's memory may have not been as good as he thought as only two COs were removed during this period. Ingouville-Williams commanded 16 Brigade until 16 June 1915, the brigade landing in France on 10 September 1914. Lieutenant-Colonel H.C. de la M Hill, CO $1^{\text {st }}$ Buffs, was 'invalided' on 15 November 1914, becoming Brigadier-General Commanding the Machine Gun Corps Training Centre on 11 October 1915; and Lieutenant-Colonel E.C. Cobbold, CO $2^{\text {nd }}$ York \& Lancaster was most definitely removed on 9/12/1914, commanding a Special Reserve battalion in mid-1916. Lieutenant-Colonel C.P. Higginson left post wounded on 23 October 1914, returning to GSO2 \& 1 posts in mid-1915. Lieutenant-Colonel H.L Croker, $1^{\text {st }}$ Leicester, went on to command 81 Brigade on 21 March 1915. Robbins similarly notes Sir Henry Wilson, GOC IV Corps in 1916, claiming that 68 Brigade in March 1916 had "3 bad COs out of 4". (Robbins, Generalship,
} 
Given that 18 per cent of the 4055 active COs were still in post either at the end of the war or the end of their battalion's life, when the other causes for leaving command already considered in this chapter (11 per cent killed in action, 13 per cent invalided through sickness or wounds, and 10 per cent promoted to General Officer) are removed, (as well as the one per cent who ended their careers as prisoners of war), the figure of 47 per cent of COs leaving command through apparently being simply 'replaced' is arrived at.

\begin{tabular}{|l|c|}
\hline Fate after replacement & \% \\
\hline Transferred to staff post & 19 \\
\hline Used later as CO to a non-active battalion & 15 \\
\hline Not used again as a CO & 61 \\
\hline Retired & 5 \\
\hline
\end{tabular}

Table 3.15: COs' fate after replacement ${ }^{196}$

Table 3.15 shows the fate of those replaced. Nineteen per cent were subsequently transferred to a staff post, and 15 per cent were later used again as a $\mathrm{CO}$ in a non-active battalion. Sixty-one per cent were never used again as CO, and five per cent retired.

p.55, quoting IWM Docs 2040-2, Private papers, Field-Marshall Sir Henry Wilson).Lieutenant-Colonel D.S Stewart, the first CO $10^{\text {th }}$ Northumberland Fusiliers, was replaced on 11 June 1916; Lieutenant-Colonel L.E.C. Elwes, the first CO of $12^{\text {th }}$ Durham Light Infantry was 'invalided' on 26 May 1916, and LieutenantColonel N.T. Biddulph, the third CO of $13^{\text {th }}$ Durham Light Infantry, but the officer who took them on active service, was replaced on15 May 1915. All had been on active service since August 1915. Lieutenant-Colonel E.G Caffin, the fourth CO of $11^{\text {th }}$ Northumberland Fusiliers commanded until 26 October 1916 when he was wounded. What Wilson was describing was three dugouts, not officers who were the product of any meritbased evolution in France. The bald comment of three out of four being bad gives a skewed perception of the rest of the $\mathrm{CO}$ group in France if those referred to are not considered in detail.

${ }^{195}$ No evidence exists that the notion of "six month rest" periods was ever promulgated in orders, yet after 1916 such a system was clearly operating. Lieutenant-Colonel Mordant John Fortescue FitzGerald, late RA, 21st Division wrote to the Official Historian Captain C. Falls on 25 February 1938: "I was sent home for a rest in July 1917 in accordance with a War Office letter, which said that those officers who had been out on the Western Front since August 1914 should be sent home to recuperate for a few months if it was thought desirable. General Newcombe was then the new GRA $21^{\text {st }} \operatorname{Div}^{n} \&$ he thought I looked very white $\&$ fagged out \& that a rest would be desirable to save my getting ill”. TNA PRO CAB45/116.

${ }^{196}$ In the case of COs who had multiple commands, fate after final command is indicated. 
Considering post-CO employment, Table 3.16 shows the distribution of subsequent staff posts. Twenty-two per cent were training posts (Patrick Brennan notes "a pattern during 1917-18 in the Canadian Corps to send able officers who were 'worn out' to command training units in England"); ${ }^{197} 33$ per cent were G, A or Q posts; but 45 per cent were such as Special Appointments or Staff Lieutenant posts, roles which were in the most part not substantial. With respect to non-active battalions, such employment could either represent a competent $\mathrm{CO}$ who had been invalided or rested, or a less than competent $\mathrm{CO}$ 'slotted in'.

\begin{tabular}{|l|c|}
\hline Staff Post & \% \\
\hline Brigade-Major & 4 \\
\hline GSO1/2/3 & 14 \\
\hline AAG & 3 \\
\hline DAAG & 6 \\
\hline AQMG & 1 \\
\hline AAQMG & 2 \\
\hline DAAQMG & 1 \\
\hline DAQMG & 2 \\
\hline Staff Captain & 2 \\
\hline Staff Lieutenant & 5 \\
\hline Other/Special Appointment & 38 \\
\hline Training/School/Officer Company & 22 \\
\hline
\end{tabular}

Table 3.16: Staff posts of replaced COs

The factors which undermine the accuracy of determining how many COs were replaced because they were not 'up to the job' are the twin issues of: (i) knowing which staff postings represent 'side-lining', and (ii) unremarked invalidity through sickness or wounding. Let us assume firstly that that half of the staff posts do not represent side-lining (Brennan, noting a three per cent transfer to staff rate, concludes "it is likely that some

${ }^{197}$ Brennan, Good Men, p.18 
effective battalion commanders were slotted into this work"); ${ }^{198}$ and secondly that the rate of unknown invalidity is 7 per cent, correcting the total in line with that of Canadian COs. By this method, a total of 38 per cent of COs either removed or side-lined into insubstantial posts is arrived at. The comparable figure for the Canadian Corps, (extrapolated from Brennan's data) is the same, 38 per cent. ${ }^{199}$

Brennan observes that "it is simply not possible to identify precise numbers of incompetents or exactly how they were proved to be incompetent". ${ }^{200}$ Noting that "Arthur Currie had a reputation for being ruthless in replacing commanding officers who made mistakes"; he examined the fate of the 102 officers who served as a CO for more than a month under his Corps command. Twelve per cent of replacements were identified as possible incompetence sackings, Brennan seeing even this as a likely overestimation. ${ }^{201} \mathrm{He}$ concluded: "One is struck that so few were removed from their posts". ${ }^{202}$

To give examples of clear scapegoating, both Lieutenant-Colonels H. M. Williams and W. H. Ames of the $2 / 1^{\text {st }}$ and $2 / 4^{\text {th }}$ Oxfordshire and Buckinghamshire were removed within days of their battalions' performances in front of the Sugar Loaf at Fromelles on 19 July

\footnotetext{
${ }^{198}$ Brennan, Good Men, p.17

${ }^{199}$ Brennan, Good Men, p. 17

${ }^{200}$ Brennan, Good Men, p. 18

${ }^{201}$ Brennan, Good Men, p.20. Garth Pratten, with access to better preserved World War Two Australian records also struggled with calculating rates of competence-related replacement. Calculating the number of infantry $\mathrm{CO}$ fates which "suggest competent performance in that they ended with promotion, appointment to a further command, a period of administering command at battalion or brigade level, or demobilisation at the end of the war" generated a competence rate of "only 46 per cent - surely too low". Studying service records he found 12 per cent "removed from command for incompetence. This figure is probably also too low". He finally came up with a competence rate of 84 per cent, but noted that: "The cause of several command failures was sheer physical and mental exhaustion". [G. Pratten, Australian Battalion Commanders in the Second World War (Melbourne: Cambridge University Press, 2009), pp.301-304].

202 Italics in original.
} 
1916. ${ }^{203}$ Williams, his battalion already smashed, struggled to persuade Brigadier-General

C.H.P. Carter, 184 Brigade (also sacked), that his unit could not attack a second time; and Ames, "another plain speaker", ${ }^{204}$ had found that he could not make the attack instead of Williams because of insufficient stores, destroyed trenches, and volume of wounded from the previous attack. ${ }^{205}$ Both were victimised for failures they could not have avoided.

Lieutenant-Colonel H.E. Tizard was originally in command of $1^{\text {st }}$ Munster at the catastrophic landing at V Beach, Gallipoli, on 25 April 1915, ${ }^{206}$ and later that day assumed command of 86 Brigade. On 27 April, Major-General A. Hunter-West, GOC $29^{\text {th }}$ Division relieved him of command for failure to achieve quicker success. His replacement, Captain G.W. Geddes, noted on 1 May: "The Colonel went off for home stellenbosched", ${ }^{207}$ and he was clear it was unfair "as he couldn't have done anything but what he did \& it's a case of someone being made the scape goat of it all". ${ }^{208}$ On the day, however, Commander Edward Unwin of the River Clyde, who had been intimately involved attempting to get men ashore, recorded:

\footnotetext{
${ }^{203}$ IWM 80/32/1, Colonel G.C. Miller, private papers. Heber Martin Williams, was a 56 year-old retired Territorial Lieutenant-Colonel of the Oxfordshire and Buckinghamshire Light Infantry and had commanded $1 / 1^{\text {st }}$ Battalion from 15 January to 9 March 1915 . He commanded the $2 / 1^{\text {st }}$ Battalion from that point until his dismissal, later serving as a Staff Lieutenant. William Herbert Ames was similarly a 46 year-old retired Lieutenant-Colonel of the same regiment in August 1914, commanding the $2 / 4^{\text {th }}$ Battalion from 8 September 1914 until his dismissal, thereafter returning to retirement.

${ }^{204}$ P. Pedersen, Fromelles (Barnsley: Leo Cooper, 2004), p.114

205 Not all Generals were prone to scapegoating. Lieutenant-Colonel R. Feilding, $6^{\text {th }}$ Connaught Rangers noted the comment of one of his fellow COs in $16^{\text {th }}$ Division concerning Brigadier-General G.E. Pereira of 47 Brigade: "You know if he trusts you, that he will defend you, and that no one will be allowed to belittle you except across his mangled corpse”. [R. Feilding, ed. J. Walker, War Letters to a Wife (Staplehurst: Spellmount, 2001), p.103

${ }^{206}$ Henry Ernest Tizard was the 48 year-old CO of $1^{\text {st }}$ Munster at the outbreak of war. He was put on half-pay after his removal, but commanded the $10^{\text {th }}$ (Reserve) Battalion East Lancashire Regiment from 4 September 1915 to 18 June 1916 , when he retired.

207 Stellenbosch was a camp/remount depot in Cape Colony during the Second Boer War where 'sacked' officers were sent to await passage to the UK.

${ }^{208}$ IWM Docs 16976, G.W. Geddes, Private papers dated 1 May 1915. Guy Westland Geddes, a 34 year-old Captain of $1^{\text {st }}$ Royal Munster Fusiliers in August 1914, commanded the battalion from 19 May to 2 December 1915, thereafter serving in staff posts for the remainder of the war.
} 
I soon saw he was not the man for the awful position he found himself in.

It does not inspire men who don't know what is going to happen to see a little man running around with a papier-mâché megaphone in his hands all day - doing nothing - and he never landed till the show was over. He was no coward, but simply was not the man for the part. ${ }^{209}$

It was of course the redoubtable Lieutenant-Colonel C.H.M. Doughty-Wylie, a $29^{\text {th }}$ Division staff officer, ${ }^{210}$ who took charge of the men ashore and personally led the uphill charge into Sedd-el-Bahr, recklessly exposing himself contrary to warning and being shot dead. Doughty-Wylie received a VC for acting like many other senior officers that day "as if they were lowly subalterns and taking unnecessary risks". ${ }^{211}$ He was of course acting in the tradition of leading from the front. Tizard, performing the dull task of simply trying to be a manager, was sent home.

A typical inefficiency dismissal is probably that of Lieutenant-Colonel F.W. Turner, CO $1 / 4^{\text {th }}$ Suffolk. ${ }^{212}$ The regimental history notes:

In view of an expected push in June, the brigade commander decided to recommend Lieut.-Colonel F.W. Turner - who owing to his wound had had little actual war experience - for the command of a training battalion at home. ${ }^{213}$

Reference to the unit war diary, however, shows that Turner was removed within days of an unsuccessful trench raid on 13/14 May, his departure unremarked in the diary. ${ }^{214}$ Lieutenant-Colonel G.A. Lewis, $1 / 5^{\text {th }}$ Sherwood Foresters, was similarly sacked on 26

\footnotetext{
${ }^{209}$ IWM Docs 13473 E. Unwin, 'The Landing from the River Clyde' p.10

${ }^{210}$ Charles Hotham Montagu Doughty-Wylie was an officer of the Royal Welsh Fusiliers, who had pre-war staff service and had served in consular posts in Turkey and Abyssinia.

${ }^{211}$ P. Hart, Gallipoli (London: Profile, 2011) p.158.

${ }^{212}$ He commanded between 17 and 22 May 1916. Aged 44 in August 1914, Frederick William Turner was senior Major of $4^{\text {th }}$ Suffolk in August 1914. He had been wounded on 26 April 1915 at $2^{\text {nd }}$ Ypres, having been in France \& Flanders since November 1914. He returned on18 March 1916 and assumed command of the battalion.

${ }^{213}$ C.C.R. Murphy, The History of the Suffolk Regiment 1914-1927 (London: Hutchinson, 1928), p.145

${ }^{214}$ TNA WO/95/2427 War Diary $1 / 4^{\text {th }}$ Suffolk Regiment
} 
March 1916 the day after the enemy sprung a mine and successfully occupied the resulting crater. $^{215}$ Major B.H. Checkland took over, but the war diary notes: "Lt.-Col Goodman cmdg $6^{\text {th }}$ Sher For brought up 2 companies and took charge of subsequent operations". ${ }^{216}$

Possibly the most undignified dismissal was that of Lieutenant-Colonel H.J. des Voeux, $13^{\text {th }}$ Royal Fusiliers, on 6 August 1916. Guy Chapman described his departure:

We received news of ... (his) ... final withdrawal from the battalion with diarrhoea. He was last seen running down the road past Mametz. Wood, his belt in one hand, his stick agitated in the other, calling on his batman to follow him, while the battalion ensconced in the angle of a quarry jeered ... Our brigadier had declared in writing his wish never to see the fugitive's face again. ${ }^{217}$

The unit war diary shows that on the day of his flight, the battalion was heavily shelled in Mametz Wood. ${ }^{218}$

These examples reflect removal resulting from a lack of organisational and leadership abilities. A competent $\mathrm{CO}$ could, however, be removed if his face spelled trouble. Lieutenant-Colonel H.J.M. Grisewood, $11^{\text {th }}$ Sussex, was described by $2^{\text {nd }}$ Lieutenant E.C. Blunden as "grave and conscientious", ${ }^{219}$ and by Major the Hon. N.S. Lytton as having a

\footnotetext{
${ }^{215}$ George A. Lewis was a Major of the $5^{\text {th }}$ Battalion in August 1914. He commanded from 21 May 1915.

${ }^{216}$ TNA WO/95/2695 War Diary $1 / 5^{\text {th }}$ Sherwood Foresters. The near lip of the crater was successfully occupied and on the 29th Major D.G. Wilson of the 17th Cavalry, Indian Army, took command. C.E Montague, an OR in $23^{\text {rd }}$ Royal Fusiliers, also noted a "court of inquiry" after a trench raid with the "Colonel deprived of his command", but it is not possible to identify the date or the CO concerned. [C.E. Montague, Disenchantment (London: Chatto \& Windus, 1922) p.113]. Lieutenant-Colonel R.A.C. Daunt, $1^{\text {st }}$ Irish Rifles was similarly removed from command four days after the battalion was severely criticised for its response to a German trench raid at La Boisselle on 10 April 1916, but later resumed command.

${ }^{217}$ G. Chapman, A Passionate Prodigality (London: Mayflower-Dell, 1967), p.83. Henry John des Voeux was a 45 year-old retired Lieutenant of the Grenadier Guards in August 1914, and had commanded $13^{\text {th }}$ Royal Fusiliers from 17 June 1915. He later commanded 33 ${ }^{\text {rd }}$ Middlesex from 27 March to 15 April 1917, and thence was transferred to the Labour Corps. (See also Chapter Five section 5.3.6).

${ }^{218}$ TNA WO/95/2532, War Diary $13^{\text {th }}$ Royal Fusiliers

${ }^{219}$ E. Blunden, Undertones of War (London: Penguin, 2000) p.10. Harman Joseph Mary Grisewood was a 34 year-old retired Lieutenant of the $4^{\text {th }}$ Hussars in August 1914. He commanded $11^{\text {th }}$ Sussex from 31 July 1915 to 15 July 1916.
} 
"positive genius for soldiering", the latter naming two defects, the second of which was "a complete intolerance of fools in high places". ${ }^{220}$ Under a new Brigadier, ${ }^{221}$ and with a reputation as "troublesome goods", ${ }^{222}$ Grisewood was asked to plan a raid, and after personal reconnaissance advised that 3 or 4 days preparation would be required to ensure success. Instantly, as Grisewood wrote, an order came from Brigade "that I am to clear off at once". ${ }^{223}$ On return he confronted his divisional HQ with the ultimatum that "if he were not posted to another battalion within one week, he would demand a Court of Inquiry”. He was duly transferred to a battalion of the Manchester Regiment. ${ }^{224}$

Lieutenant-Colonel E. Monteagle-Browne was possibly something of an eccentric. ${ }^{225}$ When Lieutenant-Colonel C.P. Clayton met him on the Somme in 1916, he described him as "somewhat out of place here, with his big beds and costly coats". ${ }^{226}$ Monteagle-Browne commanded successively the $9^{\text {th }}, 8^{\text {th }}$ and $2^{\text {nd }}$ Munster between 12 February 1916 and 10 June 1917, when he was sacked, being "removed from the army" on 14 November $1917 .{ }^{227}$ His sacking led to questions in Parliament between November 1917 and February $1918 .^{228}$

Parliamentary discussion revealed that on divisional transfer in February 1916, BrigadierGeneral G.E. Pereira wrote: "I consider him my best commanding officer and my righthand man ... with great powers of command and discipline ... he was very popular with

\footnotetext{
${ }^{220}$ N. Lytton, The Press and the General Staff (London: Collins, 1920), p.8. The first was of being a devout Catholic and favouring his own kind.

${ }^{221}$ Brigadier-General M.L. Hornby.

${ }^{222}$ Lytton, Press, p.32

${ }^{223}$ Lytton, Press, p.41

${ }^{224}$ He went to $17^{\text {th }}$ Manchester where he commanded between 15 July 1917 and 3 September 1916.

${ }^{225}$ Edgar Monteagle-Browne was a 32 year-old retired Lieutenant of the Royal Irish Fusiliers in August 1914.

${ }^{226}$ Clayton, Hungry, p.168

${ }^{227}$ London Gazette, 13 November 1917, p.11685

${ }^{228}$ The primary questioners were Major Rowland Hunt, MP for Ludlow, and, at greatest length, Captain Daniel Sheehan, MP for Cork.
} 
officers and men, who always had absolute confidence in him". Brigadier-General G.S.G. Craufurd, in recommending him for brigade command, wrote that he "showed the greatest energy and zeal, and worked up the smartness of the battalion to a great extent. He has wide experience of men, and I think he will make a good brigadier". Yet in 1917 Monteagle-Browne was removed for "inefficiency" (with reports that he was not in fact popular with officers, a claim hotly denied), and when asked to resign from the army, refused, and was removed. Monteagle-Browne claimed it was "because of a conflict he had with a superior officer", this being "one General who only knew Colonel MonteagleBrowne for six weeks" (Brigadier-General R.C.A. McCalmont had taken over $3^{\text {rd }}$ Brigade on 21 March 1917). However, the Under-Secretary of State for War, Sir James MacPherson, noted:

The Army Commander signed a report of inefficiency, and not only did he sign it, but it was signed by the Field-Marshal Commanding-in-Chief. It was signed by the brigadier-general, by the divisional general, and by the corps commander, and when the Army Council get a report ... by those distinguished superior officers ... they are bound to regard it as being a just and true estimate of ... character and efficiency. ${ }^{229}$

MacPherson added: "All inefficiency questions are a matter of opinion". If MonteagleBrowne had not gone from efficiency to inefficiency in a short space of time, he had been well and truly stitched-up, the "six weeks" remark giving the impression of the "new broom" phenomenon.

${ }^{229}$ Hansard, House of Commons debate, 27 November 1917, Vol 99 cc1967-76 


\begin{tabular}{|c|c|c|c|c|c|c|}
\hline \multicolumn{7}{|c|}{ 5th Division } \\
\hline Brigade & GOC & From & To & $1 \mathrm{st}$ month & 2nd month & 3rd month \\
\hline \multirow[t]{2}{*}{13} & R. Wanless O'Gowan & 08/02/1915 & $21 / 08 / 1915$ & 0 & 1 & 0 \\
\hline & I.O.W. Jones & $02 / 11 / 1915$ & 08/09/1918 & 0 & 0 & 0 \\
\hline \multirow[t]{4}{*}{$14 / 95$} & F.S. Maude & $23 / 10 / 1914$ & $04 / 05 / 1915$ & 0 & 0 & 0 \\
\hline & C.R.Ballard & $26 / 12 / 1915$ & $20 / 07 / 1916$ & 0 & 0 & 0 \\
\hline & E.C. Gordon-Lennox & 21/07/1916 & $14 / 04 / 1918$ & 0 & 0 & 0 \\
\hline & C.B. Norton & $15 / 04 / 1918$ & $11 / 11 / 1918$ & 0 & 0 & 0 \\
\hline \multirow[t]{4}{*}{15} & Count Gleichen & 04/08/1914 & $02 / 03 / 1915$ & 0 & 0 & 0 \\
\hline & E. Northey & 02/03/1915 & $22 / 06 / 1915$ & 0 & 0 & 0 \\
\hline & M.N. Turner & 28/06/1915 & $06 / 11 / 1917$ & 0 & 0 & 1 \\
\hline & R.D.F. Oldman & 06/11/1917 & $11 / 11 / 1918$ & 0 & 1 & 0 \\
\hline \multicolumn{7}{|c|}{ 9th Division } \\
\hline Brigade & GOC & From & To & 1st month & 2nd month & 3rd month \\
\hline \multirow[t]{4}{*}{26} & E.G. Grogan & $16 / 11 / 1914$ & $31 / 05 / 1915$ & 0 & 0 & 0 \\
\hline & A.B. Ritchie & $31 / 05 / 1915$ & $05 / 12 / 1915$ & 0 & 0 & 0 \\
\hline & J. Kennedy & $05 / 12 / 1915$ & $27 / 07 / 1918$ & 0 & 0 & 0 \\
\hline & A.G.A. Hore-Ruthven & $27 / 07 / 1918$ & 05/11/1918 & 0 & 1 & 0 \\
\hline \multirow[t]{6}{*}{27} & W.E. Scott-Moncrieff & $27 / 08 / 1914$ & $07 / 01 / 1915$ & 0 & 0 & 0 \\
\hline & C.D. Bruce & 07/01/1915 & $26 / 09 / 1915$ & 0 & 0 & 0 \\
\hline & H.E. Walshe & $14 / 10 / 1915$ & $17 / 03 / 1916$ & 0 & 1 & 1 \\
\hline & S.W. Scrase-Dickens & 06/05/1916 & $21 / 10 / 1916$ & 1 & 0 & 0 \\
\hline & F.A. Maxwell & $21 / 10 / 1916$ & $21 / 09 / 1917$ & 0 & 0 & 0 \\
\hline & W.D. Croft & 23/09/1917 & $11 / 11 / 1918$ & 1 & 0 & 0 \\
\hline 28 & S.W. Scrase-Dickens & 09/09/1914 & $06 / 05 / 1916$ & 0 & 0 & 0 \\
\hline \multirow{2}{*}{ South African } & F.S. Dawson & $02 / 12 / 1916$ & $24 / 03 / 1918$ & 2 & 0 & 0 \\
\hline & W.E.C. Tanner & 01/04/1918 & $13 / 09 / 1918$ & 0 & 0 & 0 \\
\hline \multicolumn{7}{|c|}{ 42nd Division } \\
\hline Brigade & GOC & From & To & 1st month & 2nd month & 3rd month \\
\hline \multirow[t]{2}{*}{125} & H.C. Frith & 04/08/1914 & $10 / 01 / 1916$ & 0 & 0 & 0 \\
\hline & H. Fargus & 23/06/1917 & $11 / 11 / 1918$ & 1 & 0 & 1 \\
\hline \multirow[t]{5}{*}{126} & D.G. Prendergast & 04/08/1914 & $13 / 07 / 1915$ & 0 & 0 & 0 \\
\hline & Viscount Hampden & $13 / 07 / 1915$ & $27 / 12 / 1915$ & 1 & 0 & 0 \\
\hline & A.W. Tufnell & $10 / 01 / 1916$ & $13 / 09 / 1917$ & 0 & 0 & 0 \\
\hline & W.W. Seymour & 19/09/1917 & $25 / 05 / 1918$ & 1 & 0 & 0 \\
\hline & G.H. Wedgwood & $25 / 05 / 1918$ & $01 / 09 / 1918$ & 0 & 0 & 0 \\
\hline \multirow[t]{4}{*}{127} & N. Lee & 04/08/1914 & $04 / 06 / 1915$ & 0 & 1 & 0 \\
\hline & G.S. McD. Elliot & $25 / 09 / 1915$ & $17 / 02 / 1916$ & 0 & 0 & 0 \\
\hline & V.A. Ormsby & 01/03/1916 & $02 / 05 / 1917$ & 0 & 1 & 0 \\
\hline & A.M. Henley & 05/05/1917 & $11 / 11 / 1918$ & 0 & 0 & 0 \\
\hline
\end{tabular}

Table 3.17: Number of "new broom" replacements by Brigadier-Generals in $5^{\text {th }}, 9^{\text {th }} \&$ $42^{\text {nd }}$ Divisions 
Replacements were examined in three of the 'best' performing divisions of The Hundred Days $;^{230}$ the $5^{\text {th }}$ (Regular), ${ }^{231} 9^{\text {th }}$ (New Army), ${ }^{232}$ and $42^{\text {nd }}$ (Territorial). ${ }^{233}$ The 14 replacements in $5^{\text {th }}$ Division comprised 19 per cent of all COs; the 21 replacements in $9^{\text {th }}$ Division comprised 43 per cent; and the 36 replacements in $42^{\text {nd }}$ Division comprised 54 per cent. The overall replacement rate was 39 per cent, indicating that together these three divisions are likely representative. The number of replacements, however, was double in the New Army division and treble in the Territorial division in comparison with the Regular division. The indication that the overall 38 per cent replacement rate hides variation, being lower in Regular than New Army and Territorial divisions, is unsurprising. ${ }^{234}$

To estimate the potential "new broom effect", Brigadier-Generals in these three divisions who served for over three months were identified, ${ }^{235}$ and the number of replacements per month (no other reason for departure having been identified) for their first three months in post are noted in Table 3.17. Similarly, the Major-Generals who served for over three months, ${ }^{236}$ and the number of replacements per month for their first three months are noted in Table 3.18. There was no overlap between the replacements in any case.

\footnotetext{
${ }^{230}$ From information supplied to the author by Peter Simkins. See also the latter's 'Co-stars or Supporting Cast? British Divisions in 'The Hundred Days', 1918' in P. Griffith, ed., British Fighting Methods in the Great War (London: Frank Cass, 1996), pp.50-69

${ }^{231}$ Comprising 13, 14 (redesignated 95), and 15 Brigades, the brief transfers in of 84 Brigade (for 13 Brigade) and 83 Brigade (for 15 Brigade) being ignored.

${ }^{232}$ Comprising 26, 27, 28 and South African Brigades, the latter not included elsewhere in the analysis presented in this thesis, but included here for sake of completeness.

${ }^{233}$ Comprising 125, 126 and 127 Brigades.

${ }^{234}$ See Chapter Seven, section 7.2 for further analysis of CO removal in The Hundred Days.

${ }^{235}$ A.F Becke, Order of Battle of Divisions, Part 1, The Regular British Divisions (Uckfield: Naval \& Military Press, 2007).

${ }^{236}$ A.F Becke, Order of Battle of Divisions, Part 1, The Regular British Divisions (Uckfield: Naval \& Military Press, 2007).
} 


\begin{tabular}{|c|l|l|l|c|c|c|}
\hline Division & GOC & From & To & 1st month & 2nd month & 3rd month \\
\hline 5th & T.L.N Morland & $18 / 10 / 1914$ & $15 / 07 / 1915$ & 0 & 0 & 0 \\
& C.T. McM Kavanagh & $15 / 07 / 1915$ & $01 / 04 / 1916$ & 0 & 0 & 0 \\
& R.B. Stephens & $01 / 04 / 1916$ & $04 / 07 / 1918$ & 0 & 0 & 0 \\
& J Ponsonby & $04 / 07 / 1918$ & $11 / 11 / 1918$ & 0 & 1 & 0 \\
\hline \multirow{2}{*}{9 th } & H.J.S. Landon & $21 / 01 / 1915$ & $09 / 09 / 1915$ & 0 & 0 & 0 \\
& H.T. Lukin & $02 / 12 / 1916$ & $04 / 03 / 1918$ & 0 & 0 & 0 \\
& H.H. Tudor & $28 / 03 / 1918$ & $11 / 11 / 1918$ & 0 & 0 & 1 \\
\hline \multirow{2}{*}{ 42nd } & W Douglas & $08 / 08 / 1915$ & $02 / 03 / 1917$ & 1 & 1 & 1 \\
& B.R. Mitford & $10 / 03 / 1917$ & $01 / 10 / 1917$ & 0 & 4 & 2 \\
& A. Solly-Flood & $15 / 10 / 1917$ & $11 / 11 / 1918$ & 1 & 1 & 0 \\
\hline
\end{tabular}

Table 3.18: Number of "new broom" replacements by Major-Generals in $5^{\text {th }}, 9^{\text {th }} \& 42^{\text {nd }}$ Divisions

In the (Regular) $5^{\text {th }}$ Division three replacements $(21$ per cent of the Division's replacements) occurred within 3 months of a Brigadier's appointment, and one (seven per cent) occurred within three months of a Major-General's appointment, giving a possible "new broom" rate of 28 per cent. In the (New Army) $9^{\text {th }}$ Division five replacements $(24$ per cent) occurred within 3 months of a Brigadier's appointment, and one (five per cent) occurred within three months of a Major-General's appointment, giving a possible "new broom" rate of 29 per cent. In the (Territorial) $42^{\text {nd }}$ Division seven replacements (19 per cent) occurred within 3 months of a Brigadier's appointment, and eleven (30 per cent) occurred within three months of a Major-General's appointment, giving a possible "new broom" rate of 49 per cent. Overall the maximum likely "new broom" rate is 35 per cent.

Amongst the Brigadiers, there are none who stand out as marked wielders of the scythe, but in $42^{\text {nd }}$ Division, the arrival of Major-General B.R. Mitford ${ }^{237}$ on 10 March 1917 was followed within three months by six CO replacements, 50 per cent of the division's COs. As discussed further in Chapter Four, however, this followed the division's transfer from

${ }^{237}$ Major-General Bertram Reveley Mitford was GOC $42^{\text {nd }}$ Division from 10 March 1917 to 1 October 1917. 
Egypt to France, and likely reflected 'stiffening' appointments of (Regular) officers familiar with the conditions there.

Brigadier-General F.P. Crozier, who commanded 119 Brigade, $40^{\text {th }}$ Division from 20 November 1916 to the Armistice wrote (apparently concerning the first six months of $1917):^{238}$

Four obviously unsuitable, yet recommended as suitable, colonels had to be sent away in four months on account of their psychological unsuitability to take part in the great and ghastly struggle, and their inability to lead men or to hold the line with confidence. ${ }^{239}$

Simon Robbins notes that "by 1917 and 1918 one of the main attributes of a commander, whether at battalion, brigade, divisional or corps level was his ability to train his command and to pick subordinates who were also able to train their formations". ${ }^{240}$ He refers to Major-General Sir R.J. Pinney ( $33^{\text {rd }}$ Division) who was "constantly looking for better officers to fill posts in his units, particularly as battalion commanders, where necessary removing battalion commanders where they proved incompetent, and recommending those suitable to command brigades". ${ }^{241}$ The references to removing COs relate to diary entries of 8 August $1917,{ }^{242}$ and 3 October and 8 November $1918,{ }^{243}$ it being notable that Pinney was still detecting supposed inadequates on the brink of victory.

\footnotetext{
${ }^{238}$ F.P. Crozier, A Brass Hat in No Man's Land (London: Jonathan Cape, 1930), p.149

${ }^{239}$ The two Lieutenant-Colonels can be identified as replaced; C.B. Hore $\left(17^{\text {th }}\right.$ Welsh, replaced 8 January 1917) and H.R. Wood (18 ${ }^{\text {th }}$ Welsh, replaced 8 May 1917), with two described as 'invalided' who never commanded an active battalion again; Lieutenant-Colonels E.A. Pope $\left(12^{\text {th }}\right.$ South Wales Borderers, invalided 15 April 1917) and J.R. Heelis (18 ${ }^{\text {th }}$ Welsh, invalided 9 July 1917). There were a further three replacements in the first half of 1918.

${ }^{240}$ S. Robbins, British Generalship on the Western Front 1914-18: Defeat into Victory (Abingdon: Frank Cass, 2005), p.60

${ }^{241}$ Robbins, British Generalship, p.60; citing diary, Pinney Papers, IWM (no reference).

${ }^{242}$ The removed officer appears to have been Lieutenant-Colonel E.R. Clayton of the $1 / 5^{\text {th }}$ Scottish Rifles.

${ }^{243}$ The officer referred to on 3 October was likely Lieutenant-Colonel P.C. Esdaile who had commanded $1^{\text {st }}$ West Surrey since 24 June 1918. The officer removed on 7 November 1918 was Lieutenant-Colonel G.J.L.
} 


\subsection{Conclusion}

As the war progressed, the average age of active infantry battalion COs decreased by nearly 13 years, as the Lieutenants and Captains of August 1914 stepped up to command in the climactic battles of The Hundred Days. Arthur Newth, who already had three years fighting experience, commanded a Territorial battalion in 1918 aged 21, an age at which his country deemed him only just suitable to vote.

Regimental particularism loosened its grip on battalion command, within-regiment appointments dropping to an average 50 per cent, yet remained more pronounced in units with a pre-war identity, notably in the Regular battalions.

The Regular officers of 1914 in particular, and professional soldiers in general, contributed disproportionately to battalion command, especially multiple appointments. In terms of career progress, they had a near monopoly on promotion to brigade command and a complete monopoly on divisional command. In contrast, the Territorial Force made a contribution much smaller than its size would have predicted, indicating discrimination against the amateur soldier.

The disproportionate advancement of the Regular to battalion command represents the acknowledgement of the all-round skills granted by military training, yet also reinforces the view that the quality of the younger Regular officer of the pre-war years has been underestimated. Given the existence of only a small overlap between the combat and staff

Stoney who had commanded $2^{\text {nd }}$ Worcestershire since 11 January 1918 , and who was sent to a garrison battalion in England. 
groups, and the evident different skill sub-sets, the 'good fighting CO' may have been a man whose specific skills restricted advancement beyond battalion command.

Keith Simpson calculates that "an officer stood approximately a one in six chance of being killed and a one in three chance of being wounded". ${ }^{244}$ The fact that one in ten COs were killed at the rank of Lieutenant-Colonel indicates that battalion command was a far from safe billet. In the brutal environment of trench warfare, wounding and invalidity may have accounted for a fifth of $\mathrm{CO}$ replacements.

The most pervasive threat to a CO's average eight-and-a-half month career was, however, simple replacement, four in ten meeting such a fate. This replacement rate does not necessarily indicate incompetence, as the reasons for removal were multiple. A third of replacements may have reflected the 'new broom' phenomenon. The British army clearly suffered no complacency concerning battalion command - it was an organisation committed to quality control, and its Military Secretary's organisation was capable of projecting suitable COs beyond 'local' interests across armies to fill gaps appropriately.

By The Hundred Days, however, 1918 having been a year of marked turnover in battalion command, those who had been citizens without military experience in 1914 comprised just under a quarter of COs. On one hand it is unsurprising that the citizen should prove an able commander, on the other, it speaks to the practical, malleable attitude of an organisation supposedly so hidebound in the pre-war period. ${ }^{245}$

\footnotetext{
${ }^{244}$ K. Simpson, 'The Officers', in I. Beckett \& K. Simpson (eds), A Nation in Arms: A Social Study of the British Army in the First World War (London: Tom Donovan, 1985), p.87

${ }^{245}$ See Chapter Six.
} 


\section{Chapter Four}

\section{Evolution of Command - Regular, New Army and Territorial Battalions}

We had seen much of Regular officers, and we believed in them. Our own Colonel, a Regular, was stern and unbending, for it was better so, but he was also just, efficient, and proud of the battalion.

Private W.L. Andrews, $1 / 4^{\text {th }}$ Black Watch $^{1}$

Evolution of command in the Regular, Service and Territorial battalions took different paths. In this chapter development is examined both overall and in detail within the $5^{\text {th }}$ (Regular), $9^{\text {th }}$ (New Army) and $42^{\text {nd }}$ (Territorial) divisions. A case study of each type of unit, namely $1^{\text {st }}$ Hampshire, $13^{\text {th }}$ Essex and $1 / 4^{\text {th }}$ Royal Berkshire is presented to understand the precise circumstances of evolution in each.

\subsection{The Regular Battalions}

Table 4.1 identifies the origins of the COs of all active Regular battalions. Including Indian Army officers, whose contribution was small at half a per cent, ${ }^{2}$ and active/retired Special Reserve/Territorial officers who were retired Regulars, 93 per cent of the COs of the Regular battalions of the BEF were professional soldiers. The professional therefore kept a firm grip on command.

\footnotetext{
${ }^{1}$ W.L. Andrews, Haunting Years (London: Hutchinson, 1930), p. 182. The CO in question was LieutenantColonel George Adinston McLaren Sceales, a Regular Captain of the Argyll and Sutherland Highlanders in August 1914, who commanded from 1 December 1915 to 28 October 1917, moving to command a battalion of the Tank Corps.

${ }^{2}$ Having contributed four per cent to battalion command overall - see Chapter Three, section 3.1.1.
} 
It is notable that apart from professionals, citizens of August 1914 form the largest other single group (three per cent), comprising 29 individuals. ${ }^{3}$ Perhaps unsurprisingly, only two per cent of Territorials were appointed COs of Regular battalions.

\begin{tabular}{|l|c|}
\hline Active/retired Regulars & $92 \%$ \\
\hline Active/retired Indian Army & $0.5 \%$ \\
\hline Active/retired Special Reserve & $2 \%$ \\
\hline Active/retired Territorial & $2 \%$ \\
\hline Active/retired Empire & $0.5 \%$ \\
\hline Citizens & $3 \%$ \\
\hline
\end{tabular}

Table 4.1: Origins of COs of Regular battalions

Given the purpose of the Special Reserve as the reinforcement of Regular units, ${ }^{4}$ the number of officers appointed to command Regular battalions is surprisingly low at two per cent. The number of Special Reserve officers in August $1914(2,557)^{5}$ was, of course, small. Three other factors may also have contributed to this low representation. Firstly, whilst there were 30,376 commissions granted into the Special Reserve during the war, ${ }^{6}$ those commissioned at the start of the war may have got to the Western Front quicker, thereby risking death earlier. Secondly, they were competing with Regular officers in Regular battalions; and, thirdly, they were in a promotion pool in respect of other units in which they bore much the same stamp as those who had volunteered into the Service battalions and $\mathrm{TF}^{7}$

\footnotetext{
${ }^{3}$ These individuals are considered further in Chapter Six.

${ }^{4}$ The Special/Extra Reserve contributed nine per cent to battalion command overall - see Chapter Three, section 3.1.1.

${ }^{5}$ Statistics of the Military Effort of the British Empire During the Great War (London: HMSO, 1922), pp. 234-6

${ }_{7}^{6}$ Statistics, p.234, paragraph 3

${ }^{7}$ See also Chapter Six, section 6.1.4.
} 


\subsection{1 $5^{\text {th }}$ Division}

Seventy-two Lieutenant-Colonels commanded the 15 Regular battalions during their time spent with $5^{\text {th }}$ Division during the war. ${ }^{8}$

Nearly all COs (96 per cent) were active or retired professional soldiers in August 1914, and 90 per cent were active Regulars. One was a retired Special Reserve Captain (Lieutenant-Colonel P.H. Stevenson, who commanded $2^{\text {nd }}$ King's Own Scottish Borderers from 22 July 1916 to 4 November 1916$) ;{ }^{9}$ two were Territorials, and one a citizen of August 1914. One, Lieutenant-Colonel W.H.G. Baker (CO $1^{\text {st }}$ Cheshire from 28 July 1916 to 4 July 1917), was from the Indian Army. ${ }^{10}$ Two were retired Regulars: LieutenantColonel C.B. Norton (CO $1^{\text {st }}$ Duke of Cornwall's Light Infantry from 3 July 1917 to 15 April 1918), ${ }^{11}$ who was a retired Major of that battalion; and Lieutenant-Colonel E.G. Harrison (CO $2^{\text {nd }}$ Duke of Wellington's from 18 October to 11 December 1914), a retired Captain of that battalion. ${ }^{12}$

The one citizen $\mathrm{CO}$ was the extraordinary Lieutenant-Colonel C.F.G Humphries, a New Zealander, who enlisted in August 1914 and rose from Army Service Corps clerk to

\footnotetext{
${ }^{8}$ The battalions were: 13 Brigade - 2nd King's Own Scottish Borderers, 2nd Duke of Wellington's West Riding Regiment, $1^{\text {st }}$ Queen's Own Royal West Kent Regiment, $2^{\text {nd }}$ King's Own Yorkshire Light Infantry (to 28 December 1915); 14 into 95 Brigade - $2^{\text {nd }}$ Suffolk Regiment (to 30 September 1914), $1^{\text {st }}$ East Surrey Regiment, $1^{\text {st }}$ Duke of Cornwall's Light Infantry, $2^{\text {nd }}$ Manchester Regiment (to 30 September 1914), $1^{\text {st }}$ Devonshire Regiment; 15 Brigade - $1^{\text {st }}$ Norfolk Regiment, $1^{\text {st }}$ Bedfordshire Regiment, $1^{\text {st }}$ Cheshire Regiment, $1^{\text {st }}$ Dorsetshire Regiment (to 31 December 1915).

${ }^{9}$ Percival Henry Stevenson, born in 1881, had retired from $3^{\text {rd }}$ West Yorkshire. He was transferred out of 5th Division to command $12^{\text {th }}$ Northumberland Fusiliers from 31 January 1917 to 14 November 1917 and $13^{\text {th }}$ Duke of Wellington's West Riding Regiment (a re-designated Garrison Guard battalion) from 23 July 1918 to 1 October 1918.

${ }^{10}$ William Henry Godney Baker, born in 1888, was a Lieutenant of $31^{\text {st }}$ Lancers in August 1914.

${ }^{11}$ Cecil Barrington Norton, aged 46 in August 1914, served from April 1918 as GOC 95 Brigade until the Armistice.

${ }^{12}$ Edgar Garston Harrison, aged 51 in August 1914, later commanded $12^{\text {th }}$ Manchester from 9 January 1915 to 8 August 1916.
} 
command $1^{\text {st }}$ Duke of Cornwall's Light Infantry from 17 April to 30 May 1918, and $1^{\text {st }}$ Norfolk from 1 June 1918 to 22 August 1918, when he was killed in action. ${ }^{13}$

Both the Territorial officers commanded the same battalion, $1^{\text {st }}$ Bedfordshire, and were from the same TF battalion, $5^{\text {th }}$ Bedfordshire. The first was Lieutenant-Colonel Francis Noel Butler. Born in 1876, Butler was a solicitor. ${ }^{14}$ He joined the Huntingdonshire Volunteer Force as a Captain in 1900 and in January 1909 was promoted Major in $5^{\text {th }}$ Bedfordshire. He commanded the battalion from 20 January 1912 to 25 January 1915 , resigning his commission on 2 May owing to a serious bout of influenza before the unit went to Gallipoli in August 1915. Recovering, he was reappointed Lieutenant-Colonel with the battalion on 17 August 1916, and posted to $1^{\text {st }}$ East Surrey as second-in-command on 20 November 1916, commanding in the absence of Lieutenant-Colonel E.M. WoulfeFlanagan from 3 December. ${ }^{15}$ He was transferred to command $1^{\text {st }}$ Bedfordshire on 18 December following the wounding of Lieutenant-Colonel W. Allason, ${ }^{16}$ interestingly being preferred over a Regular Major, J.J. Moyse, who had assumed command. ${ }^{17}$ He commanded until 3 May $1917 .^{18}$

\footnotetext{
${ }^{13}$ The career of Cecil Frederick George Humphries is discussed in depth in Chapter Six, section 6.2.

${ }^{14}$ Butler joined the firm of Wilkinson \& Butler, of St. Neots, Huntingdonshire.

${ }^{15}$ On leave. Edward Martyn Woulfe-Flanagan was a 44 year-old Regular Captain of the East Surrey Regiment in August 1914. He commanded $1^{\text {st }}$ East Surrey between 26 June 1916 and 17 July 1917, and 2/4 Oxfordshire and Buckinghamshire between 8 August 1918 and the Armistice.

${ }^{16}$ Walter Allason, a 39 year-old Major of $1^{\text {st }}$ Bedfordshire, commanded from 16 July 1916 until he sustained severe accidental wounds from a revolver on 3 December 1916. He served as GOC 52 Brigade from 14 April 1918 to the Armistice.

${ }^{17}$ TNA WO/95/1570 War Diary $1^{\text {st }}$ Battalion Bedfordshire Regiment. John James Moyse, a Lieutenant in August 1914, had served with $6^{\text {th }}$ Bedfordshire. He never had the chance to command, dying of wounds on 8 February 1917.

${ }^{18}$ He was then attached to the $11^{\text {th }}$ Essex, although he never commanded, being retired to the TF Reserve on 23 October 1917.
} 
The second, Lieutenant-Colonel William Stuart Chirnside, an insurance clerk, was commissioned $2^{\text {nd }}$ Lieutenant in the $5^{\text {th }}$ Bedfordshire on 28 March 1914, and commanded from 23 August to 14 October $1918 .{ }^{19}$

Three of the Regular Lieutenant-Colonels commanded two or more different battalions within the division. Lieutenant-Colonel M.W. Halford commanded three, namely $1^{\text {st }}$ Cheshire (15 Brigade) from 27 October to 28 December 1917, $1^{\text {st }}$ Bedfordshire from 16 April to 15 June 1918 (15 Brigade), and $1^{\text {st }}$ Devonshire (95 Brigade) from 15 June to 26 October $1918 .^{20}$ Lieutenant-Colonel J.K. Kay commanded two, namely $2^{\text {nd }}$ King's Own Scottish Borderers (13 Brigade) from 27 August to 9 October 1918, and $1^{\text {st }}$ Queen's Own Royal West Kent (13 Brigade) from 9 October 1918 to the Armistice, ${ }^{21}$ and LieutenantColonel P.R. Worrall also commanded two, namely $1^{\text {st }}$ Bedfordshire (15 Brigade) from 1 April 1917 to 5 February 1918 and $1^{\text {st }}$ Devonshire (95 Brigade) from 5 February to 15 June $1918 .^{22}$

Of the 67 regulars, once the 15 COs who were in post at the outbreak of war are removed from the analysis, 83 per cent of the 52 wartime appointments were internal appointments in terms of regiment; and of this group, 65 per cent were within-battalion appointments. Regimental particularism was to a great extent maintained in these Regular units.

To illustrate some of these individuals, Lieutenant-Colonel Hugh Courtenay, $1^{\text {st }}$ Bedfordshire, was both a within-battalion appointment and an example of one of the 14 per

\footnotetext{
${ }^{19}$ See Chapter Seven, section 7.3

${ }^{20}$ Montague Walter Halford was the fourth senior Lieutenant of $1^{\text {st }}$ Gloucestershire in August 1914, aged 21.

${ }^{21}$ Jack Kilbourne Kay was the fifth senior Lieutenant of $2^{\text {nd }}$ Queen's Own Royal West Kent in August 1914 aged 26.

${ }^{22}$ Percy Reginald Worrall was the most senior Lieutenant of $1^{\text {st }}$ Devonshire in August 1914, aged 34.
} 
cent of Regular COs who had staff posts prior to appointment as $\mathrm{CO}$. $\mathrm{He}$ was commissioned $2^{\text {nd }}$ Lieutenant in $1^{\text {st }}$ Bedfordshire on 19 September 1908 , aged $20 .^{23}$ Promoted Lieutenant on 1 April 1910, he landed in France with the battalion on 16 August 1914, and was wounded at Missy by shellfire on 15 September. Evacuated to England he was promoted Captain on 31 October, and after posting to the $5^{\text {th }}$ Battalion as Adjutant (9 December 1914 to 19 April 1915), returned to France taking over the duties of Adjutant with the $1^{\text {st }}$ Battalion at Ypres. He remained with this unit until 15 November 1915 whence he transferred to staff posts within $5^{\text {th }}$ Division, serving as a Staff Captain until 9 June 1916, and as a DAQMG until 18 June 1918, when he replaced Lieutenant-Colonel M.W. Halford. ${ }^{24}$ He died of wounds when the battalion was subject to severe machine-gun fire assaulting Achiet-le-Petit on 23 August 1918.

Lieutenant-Colonel Rupert Henry Anderson-Morshead followed a different and varied path. Born in $1886,{ }^{25}$ he was commissioned $2^{\text {nd }}$ Lieutenant in $2^{\text {nd }}$ Devonshire on 20 March 1907 and promoted Lieutenant on 30 April 1910. Advanced to company command as a Captain (15 March 1915) he was transferred firstly to the $1^{\text {st }}$ Battalion and then to the $1 / 5^{\text {th }}$ Royal Lancaster as second-in-command on 2 June 1916. He assumed command when Lieutenant-Colonel C.A.W. Anderson was killed at Flers on 18 September 1916, a post he held until 13 June $1917,{ }^{26}$ when he returned to $1^{\text {st }}$ Devonshire. He continued the pattern of stepping into a dead man's shoes, taking over when Lieutenant-Colonel D.H. Blunt was

\footnotetext{
${ }^{23}$ Courtenay was the son of a home and foreign produce agent, and was educated at Hurstleigh School, Tunbridge Wells, and RMC.

${ }^{24}$ Halford had transferred to the 1st Devonshire Regiment.

${ }^{25}$ Anderson-Morshead was the son of a barrister, and attended Wellington College and RMC.

${ }^{26}$ Charles Alfred Walker Anderson, born in 1882, was a Regular Captain of the North Staffordshire Regiment in August 1914. He commanded 1/5 ${ }^{\text {th }}$ Royal Lancaster for exactly three months.
} 
killed at Sanctuary Wood on 3 October $1917 .^{27}$ He left the $1^{\text {st }}$ Battalion on 5 February 1918 in Italy, returning to the 2nd Battalion in France, commanding from 15 April to 27 May 1918 when the dead man's shoes became his own - he was killed at Roucy on the opening day of the German Chemin des Dames offensive. R.A. Colwill, who regarded AndersonMorshead as "something of a tartar on parade", ${ }^{28}$ noted his sangfroid that day: "The Commanding Officer himself was calmly writing his notes with a perfect hail of ... high explosive falling round him. His magnificent courage, dauntless bearing and determination to carry on to the end moved one's emotion". ${ }^{29}$

\begin{tabular}{|l|c|}
\hline Killed & $13 \%$ \\
\hline Wounded & $14 \%$ \\
\hline POW & $3 \%$ \\
\hline Invalided & $3 \%$ \\
\hline Promoted & $31 \%$ \\
\hline Staff & $3 \%$ \\
\hline Transferred as CO to another division & $18 \%$ \\
\hline Replaced not used as CO again & $15 \%$ \\
\hline
\end{tabular}

\section{Table 4.2: Reasons for turnover of COs in $5^{\text {th }}$ Division}

As Table 4.2 shows, the main reason for turnover of COs in $5^{\text {th }}$ Division was promotion to Brigadier-General (31 per cent being a much higher rate than the 10 per cent overall average ${ }^{30}$ an indication both of the quality of the COs and that promotion of the most able did not dent the division's effectiveness). The second most frequent reason was transfer to another active battalion command outside $5^{\text {th }}$ Division. The replacements who did not

\footnotetext{
${ }^{27}$ Duncan Hamilton Blunt, born in 1878, was a Regular Captain of $2^{\text {nd }}$ Devonshire in August 1914. He commanded the $1^{\text {st }}$ Battalion from 14 March 1916 to 3 October 1917, when he was killed with his Adjutant advancing to the assembly position at the Battle of Broodseinde.

${ }^{28}$ R.A. Colwill, Through Hell to Victory (privately published, 1927), p.134

${ }^{29}$ Colwill, Through Hell, p.216

${ }^{30}$ See Chapter Three, section 3.3.7.
} 
serve in an active command again should be treated with caution, for, as stated previously, it may be that some of these represent unrecorded wounding/invalidity. ${ }^{31}$ The figure is, however, much lower than the overall replacement average of 38 per cent.

\subsubsection{Case study $-1^{\text {st }}$ Battalion Hampshire Regiment ${ }^{32}$}

As noted in Chapter Three, Regular battalions had an average of seven COs at the rank of Lieutenant-Colonel. $1^{\text {st }}$ Hampshire had eight during the war. ${ }^{33}$

In August 1914 the battalion was commanded by Brevet Colonel Sydney Charles Fishburn Jackson. ${ }^{34}$ Fifty-one years old in August 1914, Jackson had been commissioned Lieutenant in the Royal Irish Rifles on 9 September 1882, transferring to the Hampshire Regiment a month later. Without attending Staff College he had filled an impressive series of staff posts, ${ }^{35}$ and had served in the Burmese Expedition of $1885-9$ and with the Zhob Field Force, where he was awarded the DSO; and in East Africa 1903-4, being awarded a brevet Lieutenant-Colonelcy. He had commanded since 24 March 1911.

\footnotetext{
${ }^{31}$ The figure is however comparable to that of younger Regular soldiers of August 1914 during the war. (Chapter Six, section 6.1.5).

32 TNA WO/95/1495 War Diary $1^{\text {st }}$ Battalion Hampshire Regiment. The battalion served in 11 Brigade, $4^{\text {th }}$ Division in France and Flanders throughout the war.

${ }^{33}$ With either substantive, Temporary, or Acting rank.

${ }^{34}$ His brevet Colonelcy had been granted on 7 September 1910, between his last staff post as DAA\&QMG, $6^{\text {th }}$ Division, Irish Command (ending 28 February 1910) and his taking command of $1^{\text {st }}$ Hampshire on 24 March 1911).

${ }^{35} \mathrm{He}$ had served as ADC to GOC, Upper Burma Field Force (4 September 1886 to 31 March 1889); ADC to Major-General, Bengal (1 April 1889 to 7 April 1893); ADC to C-in-C, East Indies (8 April 1893 to 12 April 1894); Station Staff Officer $1^{\text {st }}$ Class, India (21 April 1897 to 9 July 1897); DAAG, HQ Bombay (10 July 1897 to 20 April 1902); and lastly DAA\&QMG $9^{\text {th }}$ Division, Irish Command (1 March 1906 , then moving to $8^{\text {th }}$ Division).
} 
The battalion arrived in France on 23 August 1914 and was in action from Le Cateau onwards. ${ }^{36}$ Jackson was wounded, shot in the left ankle at Nauroy on 27 August and subsequently taken prisoner. ${ }^{37}$ The second-in-command, Major Frederick Richard Hicks, took over, but the wound he had sustained the previous day led to Major Nelson William Barlow taking over on the $31^{\text {st }}$. Taken prisoner in the Forest of Compiegne, Barlow was succeeded by Captain L. C. W. Palk the following day. ${ }^{38}$ On 7 September Palk fell ill with fever, and Captain Francis Cecil Moore took over, and being sick himself was almost immediately replaced by Captain Peter Martin Connellan, promoted Major. ${ }^{39}$ On 23 September, Lieutenant-Colonel George Hastings Parker, a $1^{\text {st }}$ Battalion Major who had been attached to the $3^{\text {rd }}$ Battalion as Depot Commander in August 1914, and who had been commanding the newly-raised $10^{\text {th }}$ Hampshire in England, arrived and took over. In a period of four weeks, the battalion had been commanded by seven different officers, all from the $1^{\text {st }}$ Battalion. Two were prisoners of war, one was wounded, two were invalided and one superseded by a senior officer.

On 29 November, the forty-two year old Hicks (who had been commissioned $2^{\text {nd }}$ Lieutenant on 8 October 1890 and was $p s c)^{40}$ returned to the battalion as Lieutenant-

\footnotetext{
${ }^{36}$ At the Battle of Le Cateau, 26 August 1914, Sir Horace Smith-Dorrien, commanding II Corps which had become separated from I Corps under Sir Douglas Haig during the retreat from Mons, decided to stand and fight the pursuing German Army.

${ }^{37}$ Repatriated, he was made a substantive Colonel on 15 December 1914.

${ }^{38}$ Barlow consequently finished the war as he began it, as a Major. He became a Commandant of a Prisoner of War camp in January 1919, was promoted Lieutenant-Colonel, and retired in March 1920.

${ }^{39}$ Promoted Major on 4 May 1915, Moore was moved into staff posts in October 1916. Connellan was killed on 20 October 1918 in command of his company, entrenching East of Armentieres.

${ }^{40} \mathrm{He}$ had been employed in Uganda, 9 January 1898 to 27 May 1900, as a Captain; and as a Special Service Officer in South Africa, 9 May 1900 to 26 July 1900, after which he was employed with the Rand Rifles, 10 October 1909 to 8 March 1912. After being awarded a brevet Majority on 22 August 1902 and being promoted Major within the regiment on 8 August 1908, he served as Brigade-Major, 16th Brigade, Irish Command and GSO2, Coastal Defence, Southern Command, 9 March 1912 to 9 October 1913
} 
Colonel, and Parker, junior in seniority, became second-in-command. ${ }^{41}$ Parker was killed on 19 December in the attack on the Birdcage at Le Gheer, the regimental history noting: “The regiment thus losing another valued officer of much experience, 'a born leader' who had commanded the battalion most successfully". ${ }^{2}$

Major Palk appears to have been in command during the first two weeks of March, the reason for the CO's absence not being clear, but on 28 April, after Brigadier-General J. Hasler had been killed, Hicks assumed command of 11 Brigade for two days and Palk again took over. On 8 May, after distinguishing himself on 25 April plugging a gap in the line at St Julien with "imperturbable coolness", ${ }^{43}$ Hicks was on his way to brigade HQ when he was hit by shellfire. His right leg had to be amputated and he succumbed to enteric fever on 12 June. Palk assumed command.

The Hon. Lawrence Charles Walter Palk was the second son of Baron Haldon. Nearly 44 and a Captain in August 1914, he had been commissioned from Sergeant in the $8^{\text {th }}$ Hussars as $2^{\text {nd }}$ Lieutenant in the Hampshire Regiment in July 1894, and had seen service in South Africa 1901-2, acting briefly as a Station Commandant. He achieved the rank of Captain on 11 November 1900, but had already spent two periods on half-pay and was unlikely to receive further promotion. The war created new opportunities, and he was promoted Major on 29 November 1914 and Lieutenant-Colonel on 8 June 1915. During a period of stability, Palk commanded until 28 January 1916, when he was invalided. During that time

\footnotetext{
${ }^{41}$ Hicks' Majority was dated 8 August 1908, Parker's was dated 14 February 1910.

${ }^{42}$ C.T. Atkinson, The Royal Hampshire Regiment, Volume Two 1914-1918 (Glasgow: Maclehose, 1952), p.37

${ }^{43}$ Atkinson, Hampshire Regiment, p. 58
} 
he had had two periods of leave ${ }^{44}$ and one of sickness ${ }^{45}$ during which Major George Forder Perkins, (who would go on to be GSO3, GSO2 and GSO1 then command $2 / 5^{\text {th }}$ Hampshire from 1 October 1917 to 15 August 1918) and, latterly, Captain Robert Douglas Johnston (who would soon leave to spend the rest of the war on the staff) commanded. Both had been Captains with the $1^{\text {st }}$ Battalion in August 1914.

Temporary Lieutenant-Colonel William Henry Middleton, who had been Captain and Adjutant of the $3^{\text {rd }}$ Hampshire in August 1914 (but who originated from the $1^{\text {st }}$ Battalion) took over in January until Palk returned on 18 May 1916. (He went on to command $2^{\text {nd }}$ Hampshire from 21 May to 1 December 1916, and $10^{\text {th }}$ Northumberland Fusiliers from 19 July 1917 to 26 October 1918). ${ }^{46}$

On 1 July 1916 the battalion attacked the Hawthorn Ridge. Casualties in officers were 100 per cent. ${ }^{47}$ Palk, going forward carrying only a stick, was hit, brought back, and died that morning. ${ }^{48}$ Brigadier H.C. Rees noted:

He ... dressed himself in his best clothes, put on white gloves and led the whole of his battalion headquarters across No Man's Land, when he himself and most of those with him became casualties. Whilst lying mortally wounded in a shell hole, he turned to another man lying near him and said 'If you know of a better 'ole, go to it. ${ }^{49}$

His chosen armament in battle gives credence to the statement of one of his officers: "He was a great character." ${ }^{50}$ An erudite man who "used to read Gibbon to his junior officers

\footnotetext{
${ }^{44}$ 10-18 August and 8-16 November 1915.

4531 August to 11 September 1915.

${ }^{46}$ W.H. Middleton, 35 in 1914, had been commissioned $2^{\text {nd }}$ Lieutenant on 24 January 1900, immediately acting as a Special Service Officer in South Africa.

${ }^{47}$ TNA WO/95/1495, War Diary $1^{\text {st }}$ Battalion Hampshire Regiment.

${ }^{48}$ Atkinson, Hampshire Regiment, p. 171, quoting a fellow officer.

${ }^{49}$ IWM Docs 7166 H.C. Rees, 'A Personal Record of the First 7 Months of the War'.

${ }^{50}$ Rees, 'Personal Record'.
} 
and spoke French and German fluently", he did not hold his tongue: "He was often a thorn in the side of the Division and the Senior Staff officers did not like him. He was utterly outspoken and feared nobody". 51

\section{Lieutenant-Colonel Francis Arthur William Armitage of $1^{\text {st }}$ West Yorkshire Regiment took} over command on 28 July. Armitage was a Captain on the outbreak of war and at the age of nearly 33 was serving as Adjutant in $1916 .{ }^{52}$ An outsider in terms of regiment, brigade and division, Armitage would lead the battalion for nearly two years until his death in action on 22 April 1918 at Pacaut Wood in the German offensive on the Lys, at which point it was said of him: "He had completely identified himself with the battalion from the moment of taking over" ${ }^{53}$ His appointment as an outsider reflects the destruction of the $1^{\text {st }}$

\footnotetext{
${ }^{51}$ Palk was one of a number of officers wielding only a stick in battle. Lieutenant-Colonel M.N. Kennard of $18^{\text {th }}$ West Yorkshire was also killed on 1 July 1916. Private F Burn described how: "It was hell on earth. Everyone dropped flat on their stomachs. Colonel Kennard was standing and carrying only a walking stick. He called out, 'Come on boys, up you get,' and began to walk towards the enemy (and) walked forward into a hail of machine gun, rifle and artillery fire and was killed almost immediately". [D. Raw, Bradford Pals (Barnsley: Pen \& Sword, 2005) pp.186-7]. The Hood Battalion (Royal Naval Division) CO on Gallipoli, Lieutenant-Colonel J.A.C. Quilter was killed on 6 May 1915, Seaman Murray noting: "He went forward carrying an oversize walking stick". [J. Murray, Gallipoli 1915 (Bristol: Cerberus, 2004), p.67)]. LieutenantColonel B. Best-Dunkley peregrinated towards both death and the Victoria Cross on 31 July 1917 at Wieltje, Ypres: "Complacently advancing, with a walking stick in his hand, as calmly as if he were walking across a parade ground". [T.H. Floyd, At Ypres with Best-Dunkley (Boston: Indypublish, n.d.), p. 103]. LieutenantColonel R.R.Willis was always known as "Walking Stick Willis" although this soubriquet was earned from landing on Gallipoli with C Company, $1^{\text {st }}$ Lancashire Fusiliers on 25 April 1915, when he won the VC. He later commanded three battalions ( $2^{\text {nd }}$ Lancashire Fusiliers, 13 August to 18 October 1916; $1^{\text {st }}$ Inniskilling Fusiliers 18 January to 29 March 1917); and $8^{\text {th }}$ West Riding (1 October 1917 to 3 November 1917). Working later as a teacher, the Great Depression of the 1930's found him selling matches on the streets of Manchester, having sold his VC. Lieutenant-Colonel C. Doughty-Wylie, a staff officer, rallied disorganised units and led a bayonet charge uphill at Sedd-el-Bahr after the V beach landing on 26 April 1915 armed only with a stick, but was shot and killed for his pains. Lieutenant-Colonel E. A. Wood, $6^{\text {th }}$ King's Shropshire Light Infantry assisted locomotion in the front line with an alpenstock [G. Dugdale, Langemarck and Cambrai (Uckfield: Naval \& Military, 2005), p.25]. Although no aid to locomotion, Lieutenant-Colonel D.S. Branson of $1 / 4^{\text {th }}$ York and Lancaster always carried "a bright scarlet horsehair fly whisk, which he always carried on his visits. This whisk was a perfect godsend, as he could be spotted 1000 yards away, and, of course, by the time he reached us, we had set our house in order". [D.P. Grant, The 1/4th (Hallamshire) Battalion, York \& Lancaster Regiment 1914-1919 (London: Arden, 1927), p.125].

${ }^{52} \mathrm{He}$ had been commissioned $2^{\text {nd }}$ Lieutenant in the West Yorkshire Regiment on 22 October 1902, had seen service on the North-West Frontier in 1908, and was promoted Captain on 4 February 1911.

${ }^{53}$ Atkinson, Hampshire Regiment, p. 343
} 
Hampshire officer cadre on 1 July, and illustrates the cross-division promotion of an officer seen as good CO material.

Armitage won the DSO on 9 April 1917 when the battalion was in action at the OppyMericourt Line just north of Fampoux:

He commanded his battalion with the utmost skill and determination. Subjected to heavy shellfire throughout, he remained in close touch with the enemy, gaining his objective the first day. He successfully beat off an enemy counter-attack, and held on until relieved. ${ }^{54}$

The list of officers in the War Diary dated 1 November 1916 lists two Majors. Frederick Henry Wickham Guard, (a civilian of August 1914 who was never to command a Hampshire battalion, but who would serve as CO of $15^{\text {th }}$ Royal Scots from 8 July 1917 to 5 April 1918); ${ }^{55}$ and Philip Herbert Hudson, who was at that point attending Senior Officer School, Aldershot, (and hence earmarked for possible command). ${ }^{56}$ Guard was replaced by Major Francis William Earle. ${ }^{57}$ Armitage's periods of leave are not given in the war diary, but Earle was commanding on 1 March 1917, and again in action at Roeux on 11 May 1917 when Armitage was with the 'battle nucleus'. 58

Following Earle's departure to command $1^{\text {st }}$ East Lancashire, ${ }^{59}$ Hudson got the chance to fulfil the role for which he had been prepared, from 28 August to 8 September 1917, when Armitage assumed command of 11 Brigade, and in November when Armitage had to visit a new sector. It was Hudson who took over on Armitage's death in April 1918, but he

\footnotetext{
${ }^{54}$ London Gazette, 18 July 1917, p. 7211

${ }^{55}$ Guard was an interesting character - see Chapter Six, section 6.1.3.

${ }^{56}$ Hudson was a $2^{\text {nd }}$ Lieutenant of $1^{\text {st }}$ Hampshire in August 1914.

${ }^{57}$ Earle was a Captain in the $1^{\text {st }}$ Hampshire in August 1914, having seen service in South Africa 1900-2.

${ }^{58}$ The 10 per cent of the battalion left out of action for purposes of reconstitution in event of disaster.

${ }^{59}$ From 4 June to 22 October 1917.
} 
stood aside when Lieutenant-Colonel John Francis Cumberlege Mordaunt of $1^{\text {st }}$ Somerset Light Infantry took over on 12 May 1918. This second importation of an outsider suggests that despite his course and experience, Hudson did not enjoy the full confidence of 11 Brigade to command permanently. He acted-up again when Mordaunt was gassed on 20 May and succumbed to fever on 16 June, holding command until 29 July. Mordaunt may well have been suffering combat fatigue, as he left "suddenly" on 14 October 1918 "to go to England for a rest”. Hudson took over again until 18 October, when Lieutenant-Colonel Earle returned, commanding until the Armistice. Hudson never achieved even the acting rank of Lieutenant-Colonel.

$1^{\text {st }}$ Hampshire, despite its decimation on 1 July 1916, was blessed with an extraordinary group of senior officers with talent for command, even if not with the unit itself. It was particularly 'traditional' in terms of command, demonstrating the grip of the professional soldier on leadership of the Regular battalion. Of eight COs at the rank of LieutenantColonel, all were Regulars. Two were outsiders to the regiment, the 75 per cent of insiders being not only within regiment, but all from the original $1^{\text {st }}$ Battalion of August 1914. The causes of turnover in the seven departing COs included one instance of being taken prisoner, three of death in action, one of invalidity, and two of replacement due to the return of a more senior officer. $1^{\text {st }}$ Hampshire had an unfortunately high death rate of COs, and none was promoted Brigadier-General, matters undoubtedly linked. 


\subsection{Service Battalions}

In Chapter Two, command in the Service Battalions up to the point of their going on active service was reviewed. Table 4.3 identifies the origins of the COs who commanded on active service.

\begin{tabular}{|l|c|c|c|}
\hline & Active & Retired & \\
\hline Regular & 580 & 151 & $55 \%$ \\
\hline Indian Army & 38 & 28 & $5 \%$ \\
\hline Special Reserve & 79 & 57 & $10 \%$ \\
\hline Territorial & 79 & 52 & $10 \%$ \\
\hline Empire & 17 & 13 & $2 \%$ \\
\hline Royal Navy & 0 & 3 & $>1 \%$ \\
\hline Royal Marines & 0 & 1 & $>1 \%$ \\
\hline Citizens & 241 & n/a & $18 \%$ \\
\hline
\end{tabular}

Table 4.3: Origins of active COs of Service Battalions

Regular officers provided just over half of commands (55 per cent), with 66 per cent of all COs being active or retired professional soldiers. The Special Reserve and Territorials made a bigger contribution (ten per cent each) than to the Regular battalions, but the biggest group apart from the Regulars was, again, citizens of August 1914 at 18 per cent.

\begin{tabular}{|c|c|c|c|c|c|}
\hline $\begin{array}{c}\text { Active } \\
\text { Regular }\end{array}$ & $\begin{array}{c}\text { Active } \\
\text { Territorial }\end{array}$ & $\begin{array}{c}\text { Active Special } \\
\text { Reserve }\end{array}$ & Retired & Empire & Civilian \\
\hline $34 \%$ & $11 \%$ & $6 \%$ & $13.5 \%$ & $1.5 \%$ & $34 \%$ \\
\hline
\end{tabular}

Table 4.4: August 1914 origins of New Army COs in France \& Flanders on 29 September 1918

The changing balance between Regulars and citizens is demonstrated in Table 4.4, for on 29 September 1918 both contributed equally, a third of battalion commands each. 
If only one officer who was a Regular on the outbreak of war was to be taken who might serve as an exemplar of the aggressively effective New Army CO, then that individual might well be Lieutenant-Colonel William Robert Aufrère Dawson. Born in 1891, Dawson was commissioned from Oxford University OTC into the Special Reserve of the Royal Field Artillery. ${ }^{60}$ Bound elsewhere than the family law firm, he obtained a Regular commission in $1^{\text {st }}$ Royal West Kent on 10 June 1914 . He was transferred to $6^{\text {th }}$ Royal West Kent as a $2^{\text {nd }}$ Lieutenant on 3 September 1914, when the battalion was 15 days old, and accompanied it to France on 1 June 1915 as a Captain.

Wounded twice in 1916, Dawson was promoted Major on 12 August, taking over command when Lieutenant-Colonel C.S. Owen was given command of 36 Brigade on 28 November $1916 .{ }^{61} \mathrm{He}$ rose from $2^{\text {nd }}$ Lieutenant to Lieutenant-Colonel in the same battalion in a period of 26 months, commanding until his fatal wounding on 23 October $1918 .^{62}$ One of his officers-to-be, Alan Thomas, was warned at Etaples ${ }^{63}$ en route to the battalion that Dawson was known as "The Fire-Eater". ${ }^{64}$ Thomas leaves us a rare analytic pen-picture: "No man I have ever met was more suited by nature to be a commanding officer: no man succeeded in his job more magnificently than he did ... (being) endowed with peculiar qualities of leadership". ${ }^{65} \mathrm{He}$ continued: "A man secure in his authority, one whose stature was heightened by adversity ... men would follow him to hell". ${ }^{66}$ In all he was wounded

\footnotetext{
${ }^{60}$ Dawson had a military background, his grandfather Henry Hill Dawson having been a Captain of the $19^{\text {th }}$ Foot. He attended Oriel College, his father William also being an Oxford law graduate. His mother was also a solicitor, as was his brother Colin who served in the Royal Army Service Corps during the war.

${ }^{61}$ Charles Samuel Owen, a 35 year-old Regular Captain of the Royal Welsh Fusiliers in August 1914, commanded from 29 November 1915.

${ }^{62}$ Dawson spotted celery in the garden of an empty house and was picking it when a shell shattered his leg, amongst other wounds. He died in hospital at Camiers on 3 December 1918 at the age of 27.

${ }^{63}$ Etaples was the BEF's base camp.

${ }^{64}$ A. Thomas, A Life Apart (London: Gollancz, 1968), p.45

${ }^{65}$ Thomas, Life Apart, p.57-8. See also Chapter Five section 5.3.5.

${ }^{66}$ Thomas, Life Apart, p.100.
} 
six times, and having won the DSO as a Captain, added three bars as $\mathrm{CO},{ }^{67}$ awards which demonstrate Dawson's courage and aggression, his initiative, and his ability to inspire. ${ }^{68}$

Extraordinary individuals came from outside the Regular fold. An example of a Territorial officer who commanded a Service Battalion, and one who also 'led from the front', was Lieutenant-Colonel Bernard Henry Leathes Prior, a 37 year-old solicitor, ${ }^{69}$ who was commanding $6^{\text {th }}$ Norfolk (Cyclist) at the outbreak of war. The battalion remained in the UK, being virtually denuded of its personnel in July 1916, and Prior was transferred on 8 August to the $7^{\text {th }}$ Battalion in France, and then on 27 September to command $9^{\text {th }}$ Norfolk, a post he held until 22 August 1918. He was wounded on four occasions. Firstly, in October and December 1916, (on the latter occasion shot through the right forearm by a sniper in no-man's land whilst returning from a reconnaissance for a raid), again in January 1918 (gassed), and finally on 22 March during the German Spring Offensive. In August, "shattered by wounds and gas", he was finally invalided. ${ }^{70} \mathrm{He}$ was seven times mentioned

\footnotetext{
${ }^{67}$ Being one of only seven officers to be awarded three bars, five of whom served as battalion commanders (the others being W.D. Croft, B. Freyberg, A.N.S. Jackson and E.A. Wood).

${ }^{68}$ The citation for his first bar reads: "When the situation was somewhat critical he displayed conspicuous bravery in organizing the defence. Although his troops were exhausted from prolonged exposure, he completely reorganized the line under heavy shell fire. His total disregard for personal danger was most marked." London Gazette, 18 July 1917, page unknown.

The citation for his second bar, earned during the German spring offensive of 1918, reads: "When a party of the enemy had broken through the brigade front, he led the personnel of his headquarters as a fighting formation, and, co-operating with the counter-attacking battalion, inflicted heavy losses on the enemy and captured two machine guns and some prisoners. On the following day, when the enemy attacked in force, he organized and led a counter-attack with two companies. He repulsed the enemy and re-established and advanced the line. Later, when the enemy attacked some advanced posts, he counter-attacked and drove the enemy off with loss. By his capable leadership, promptness of action and courageous example, he was largely responsible for the position held by his battalion being maintained intact." London Gazette, 22 June 1918, page unknown.

The citation for the final bar, awarded during The Hundred Days advance, reads: "For conspicuous gallantry and good leadership of his battalion from 18 to 29 Sept. 1918, near Epehy and Vendhuille. During the period they took part in three assaults successfully. On the $21^{\text {st }}-22^{\text {nd }}$ and $28^{\text {th }}-29^{\text {th }}$ he was continually in the front line, superintending operations and encouraging his men. The success of his battalion was largely due to his fine leadership and personal example." London Gazette, 4 October 1919, page unknown.

${ }^{69}$ Admitted in 1902 to Pickering \& Co. of Lincolns Inn. He served in South Africa 1900-1.

${ }^{70}$ F.L. Petre, The History of the Norfolk Regiment 1914-1918 (Norwich: Jarrold, 1919), p.292
} 
in dispatches, and awarded the DSO and bar as CO. The citation for his bar, related to 21-2

March 1918, reads:

Throughout two days of an enemy advance, and until wounded, he set a splendid example of coolness and courage under the most trying conditions, personally supervising the readjustments which had to be made to meet the enemy attacks, and the gallant resistance offered by his battalion was largely due to his magnificent example of fearless determination. ${ }^{71}$

Another example of a Territorial who had further to rise to command was LieutenantColonel Morgan Maddox Morgan-Owen, a 34 year-old Captain of $4^{\text {th }}$ Essex who in August 1914 was attached to the OTC of Repton School where he was a teacher. He appears to have served with $2 / 4^{\text {th }}$ Essex, but was transferred to $15^{\text {th }}$ Cheshire, and on 12 December 1916 joined $11^{\text {th }}$ Rifle Brigade as second-in-command. He commanded from 5 September to 31 October 1917 after Lieutenant-Colonel A.E. Cotton was gassed, ${ }^{72}$ moved on 5 December to command the $10^{\text {th }}$ Battalion until its disbandment in February 1918, returning to the $11^{\text {th }}$, where he was wounded in the German spring offensive. He won the DSO whilst commanding the $10^{\text {th }}$ Battalion at Cambrai on 30 November 1917 on the occasion to the German counterattack:

When his battalion was in reserve, he moved it up to resist the attack, and held on to the position for two days ... His steadfast determination to hold his ground against repeated attacks and under heavy fire largely contributed to restoring and keeping in hand the critical situation which had arisen. ${ }^{73}$

\footnotetext{
${ }^{71}$ London Gazette, 26 July 1918, p.8739

${ }^{72}$ Arthur Egerton Cotton, born in 1876, had previously served in India in a mounted unit, enlisting as a Rifleman in the $7^{\text {th }}$ Rifle Brigade, commissioned $2^{\text {nd }}$ Lieutenant on 19 September 1914 . He commanded $11^{\text {th }}$ Rifle Brigade from 26 August 1916 until his gassing. He returned to duty and was in command of the battalion at the Armistice. His bother Ronald Egerton Cotton commanded $10^{\text {th }}$ Lancashire Fusiliers in 1918.

${ }_{73}$ London Gazette, 16 August 1918, p.9561. His brother Lieutenant-Colonel Ll.I.G. Morgan-Owen was a staff officer, becoming GSO1 of $13^{\text {th }}$ Division in Mesoptamia, and a further brother Lt. J.G Morgan-Owen, South Wales Borderers, was killed in action in Mesopotamia in April 1916.
} 
Lieutenant-Colonel Christopher Bushell, a Special Reserve officer, was yet another extraordinary individual who commanded a Service Battalion. Born in 1888 and educated at Rugby and Corpus Christi College, Oxford, he was called to the Bar in 1912 and in the same year was commissioned into the Special Reserve of the West Surrey Regiment. ${ }^{74}$ Bushell went to France with the $1^{\text {st }}$ Battalion and on 14 September 1914 was severely wounded on the Chemin des Dames. ${ }^{75}$ He returned to France in November 1915 as an Aide-de-Camp in $33^{\text {rd }}$ Division until June 1916, and was a Staff Captain with 100 Brigade on the Somme from 10 August to 15 December 1916 when he was transferred to $7^{\text {th }}$ West Surrey as CO. He served until 18 April 1917, when he was superseded, serving as secondin-command, then again as CO from 21 September 1917 to 23 March 1918 when he was wounded, winning the Victoria Cross; and finally from 23 May 1918 to 8 August 1918, when he was killed. His VC citation reads:

Lieut-Colonel Bushell personally led C Company of his battalion ... in face of very heavy machine-gun fire. In the course of this attack he was severely wounded in the head, but continued to carry on, walking about in front of both English and Allied troops, encouraging and reorganising them. He refused even to have his wound attended to until he had placed the whole line in a sound position, and formed a defensive flank to meet a turning movement by the enemy. He then went to Brigade Headquarters and reported the situation, had his wound dressed, and returned to the firing line ... He visited every portion of the line, both English and Allied, in the face of terrific machine-gun and rifle fire, exhorting the troops to remain where they were and to kill the enemy. In spite of the wounds, this gallant officer refused to go to the rear, and had eventually to be removed to the dressing station in a fainting condition. ${ }^{76}$

\footnotetext{
${ }^{74} \mathrm{http}: / /$ www.queensroyalsurreys.org.uk/vc/vc14.html (accessed 23 March 2012).

75 The war diary noted his wounding that day and that "no officers now remain" of the companies engaged. TNA WO/95/1280 War Diary $1^{\text {st }}$ Battalion Queen's Royal West Surrey Regiment.

${ }^{76}$ London Gazette, 30 April 1918, p. 5353
} 
'Quex' left a picture of the "youthful Lieutenant-Colonel" four days before the events of 23 March, when he dined with the artillery: ${ }^{77}$

Tall, properly handsome, with his crisp curling hair and his chin that was firm but not markedly so; the eyes that were reflective rather than compelling; earnest to the point of an absorbed seriousness - we did right to note him well ... My chief recollection of him that night was of his careful attentiveness to everything said by our own colonel on the science of present-day war - the understanding deference paid by a splendid young leader to ... a very complete gunner. ${ }^{78}$

Lastly, the extraordinary contribution that a family who produced a Service Battalion CO could make to the war is exemplified by that of Edward and Emily Stone. Edward, a solicitor, had 10 children, all five of the males seeing service. His eldest son, Edward, joined the $2^{\text {nd }}$ Dragoon Guards in 1902, and as a Major served as a Staff Captain and Brigade-Major in 1917-18. His third eldest son, Reginald Guy, had joined the navy in 1896 and as a Lieutenant-Commander was awarded the DSO for service in the Mediterranean in 1917. ${ }^{79}$ His fourth eldest son, Walter Napleton, emigrated to Canada and became a land surveyor, returning to England to enlist, commissioned into $3^{\text {rd }}$ Royal Fusiliers in 1915 . He was awarded a posthumous VC for his actions on 30 November 1917 at Cambrai, serving with the $17^{\text {th }}$ Battalion. ${ }^{80}$ His youngest son, Francis Le Strange, who had played one rugby union match for England, was gazetted $2^{\text {nd }}$ Lieutenant in $3^{\text {rd }}$ Hussars on 15 August 1914, winning the $\mathrm{MC}$ in $1917 .^{81}$

Arthur Stone, the second eldest son, is an example of a citizen of August 1914, retired from the ranks of the Territorial Force, who rose to command. He was born in 1877 and

\footnotetext{
77 'Quex' was the pseudonym used by George Herbert Fosdike Nichols, who served with field artillery of the $18^{\text {th }}$ Division, and who was a journalist before the war.

${ }^{78}$ Quex, Pushed and the Return Push (Edinburgh: William Blackwood, 1919), p.12

${ }^{79}$ London Gazette, 17 May 1918, p. 5858

${ }^{80}$ London Gazette, 13 February 1918, p. 2004

${ }^{81}$ London Gazette, 17 September 1917, p. 9584
} 
graduated with a BA in Law from King's College Cambridge in 1899. A "well known rifle shot" who played football both for Cambridge University and Kent, he was articled to his father's firm. He had served with the Gloucestershire Engineers Volunteer Battalion, Clifton College Contingent (1894-6), the Cambridge University Rifle Volunteers (1896-9), and the Inns of Court Rifle Volunteers (1899 to 1908) ${ }^{82}$ Attesting as a Private on 11 September 1914 in the Corps of School of Musketry, he was immediately appointed Company Sergeant Major, Instructor at Bisley until 2 October. ${ }^{83}$ Having applied for a commission, he was gazetted to $15^{\text {th }}$ Lancashire Fusiliers, where he appears to have known the CO, Lieutenant-Colonel H.B. Moss, ${ }^{84}$ being promoted Major on 6 December 1914. Proceeding to France with the battalion in November 1915, he was awarded the DSO for actions in command of a raiding party. ${ }^{85} \mathrm{He}$ took over as $\mathrm{CO}$ when Lieutenant-Colonel J.H. Lloyd was given command of 90 Brigade from 28 September to 26 December $1916,{ }^{86}$ reverting to second-in-command before being promoted to command $16^{\text {th }}$ Lancashire Fusiliers from 5 April to 2 October 1918 when he was killed. ${ }^{87}$

\subsection{1 $9^{\text {th }}$ Division}

Fifty Lieutenant-Colonels commanded the 12 Service Battalions during their time spent on active service with 9 th Division during the war. ${ }^{88}$

\footnotetext{
${ }^{82}$ When the Rifle Volunteers became the $27^{\text {th }}$ Battalion London Regiment in 1908, Stone resigned.

${ }^{83}$ TNA WO 339/21909 Officers' Services, Arthur Stone.

${ }^{84}$ Henry Benjamin Moss was a retired Lieutenant-Colonel of the Lancashire Fusiliers. He commanded the $15^{\text {th }}$ Battalion from 1 September 1914 to 6 August 1915, and $21^{\text {st }}$ Lancashire Fusiliers from that point until 8 August 1918. He was a farmer in Cheshire, so the connection with Stone is unclear.

${ }^{85}$ London Gazette, 22 June 1918 p. 7395

${ }^{86}$ John Henry Lloyd was a retired Special Reserve Major of the Royal Lancaster Regiment in August 1914, and commanded the battalion from 7 August 1917, taking over from Moss, to 28 September 1916. He later commanded $3^{\text {rd }}$ Royal Lancaster from 1 January 1918 to 7 August 1918.

${ }^{87}$ The battalion suffered heavily from enfilade machine-gun fire in its attack that day on Ramicourt.

${ }^{88}$ The battalions were: 26 Brigade $-8^{\text {th }}$ Black Watch, $7^{\text {th }}$ Seaforth Highlanders, $8^{\text {th }}$ Gordon Highlanders (to 6 May 1915), $5^{\text {th }}$ Cameron Highlanders, $10^{\text {th }}$ Argyll \& Sutherland Highlanders (from 6 May 1916 to 15 February 1918); 27 Brigade $-11^{\text {th }}$ and $12^{\text {th }}$ Royal Scots, $6^{\text {th }}$ Royal Scots Fusiliers (to 6 May 1916), $10^{\text {th }}$
} 
Thirty-six (72 per cent) were active/retired Regulars; four were Special Reserve (three of whom were retired Regulars); one was from the South African Defence Force; ${ }^{89}$ three were Territorials, and six (12 per cent) were civilians of August 1914. Overall 78 per cent had been professional soldiers in August 1914, in contrast to 66 per cent for the Service battalions overall. It might be thought that the later success of this division was related to the higher level of professional soldiers commanding battalions, but, as is argued in Chapter Seven, the quality of COs of whatever source during The Hundred Days makes this unlikely.

On arrival in France in May 1915, 11 of the 12 battalions were commanded by COs who had been with them from the start, and the remaining $\mathrm{CO}$ had been with his battalion for all but six weeks since it was raised. They were all K1 battalions, but as noted in Chapter Two, only 65 per cent of K1 units were taken overseas by their first COs. The division's battalions had therefore enjoyed a remarkable degree of consistency. Three of the COs commanded two units within the division. ${ }^{90}$

How typical was the case of W.R.A. Dawson, rising from junior officership to command within the same battalion? Twenty-two per cent of subsequent CO appointments in $9^{\text {th }}$ Division on active service were from within the officers that had originally gone overseas

\footnotetext{
Argyll \& Sutherland Highlanders (to 6 May 1916), $6^{\text {th }}$ King's Own Scottish Borderers (from 6 May 1916), $9^{\text {th }}$ Scottish Rifles (from 6 May 1916); 28 Brigade (to 6 May 1916), $6^{\text {th }}$ King's Own Scottish Borderers (to 6 May 1916), $9^{\text {th }}$ Scottish Rifles (to 6 May 1916), $10^{\text {th }} \& 11$ Highland Light Infantry (to 6 May 1916).

${ }^{89}$ The South African Brigade replaced 28 Brigade in $9^{\text {th }}$ Division. Lieutenant-Colonel Ambrose Robin InnesBrowne, a Captain of the South African Defence Force in August 1914, (appropriately enough from the Transvaal Scottish), commanded $6^{\text {th }}$ Scottish Borderers from 9 April 1917 to 8 August 1917. He was killed in action on 18 April 1918.

${ }^{90}$ Lieutenant-Colonel H.P. Burn commanded $10^{\text {th }}$ Argyll \& Sutherland Highlanders from 10 December 1915 to 8 April 1916 and $8^{\text {th }}$ Gordon Highlanders from 11 May to 16 July 1916; Lieutenant-Colonel G.B. Duff commanded $8^{\text {th }}$ Black Watch from 30 October 1915 to 4 March 1916 and $5^{\text {th }}$ Cameron Highlanders from 9 May to 6 July 1916; and Lieutenant-Colonel J. Kennedy commanded $7^{\text {th }}$ Seaforth Highlanders 2 May to 29 July 1916 and 10 Argyll \& Sutherland Highlanders from 29 July to 4 December 1916.
} 
with the battalion in question, in contrast to the 65 per cent of the Regular $5^{\text {th }}$ Division. ${ }^{91}$ Five of these nine individuals were officers who had been Majors in May 1915, and only one of these was appointed post mid-1916. They were, therefore, established senior officers who moved up to command as a matter of course in terms of their seniority early in the battalion's evolution.

Apart from suitability, the simple matter of casualties amongst company and platoon commanders would have limited the number of such officers who could have worked their way up to command. There were, however, four such individuals within $9^{\text {th }}$ Division. Sir G.W. Abercromby, a retired Lieutenant of the Scots Guards and Gordon Highlanders, went to France with $8^{\text {th }}$ Black Watch as a Captain in May 1915, and commanded between 8 March 1916 and 21 May 1917. ${ }^{92}$ P.C Anderson, a $2^{\text {nd }}$ Lieutenant of $2^{\text {nd }}$ Seaforth Highlanders, was transferred to the $7^{\text {th }}$ Battalion as a Lieutenant on 25 September 1914, served as Adjutant between September 1915 and April 1917, and commanded between 15 October 1918 and the Armistice. ${ }^{93}$ R.W. Campbell, a retired Major of the Special Reserve of the Scottish Rifles, went to France with $11^{\text {th }}$ Royal Scots as a Captain, and commanded between 26 September and 3 December $1915 .^{94}$ Finally, A.G.M.M. Crichton, the sole civilian of August 1914, went to France as a Lieutenant with the $5^{\text {th }}$ Cameron Highlanders, and commanded between 26 September 1917 and 6 March 1918. ${ }^{95}$

\footnotetext{
${ }^{91}$ As identified in the June 1915 Monthly Army List.

92 Sir George William Abercromby ( $8^{\text {th }}$ Baronet Birkenbog) was born in 1886, and after leaving the Scots Guards had joined the $6^{\text {th }}$ Gordon Highlanders.

${ }_{93}$ Patrick Campbell Anderson was born in 1894.

${ }^{94}$ Robert Wemyss Campbell had also been a Volunteer of Royal Scots and had served in South Africa 18991901.

95 Andrew Gavin Maitland Makgill Crichton was born in 1881, son of a civil servant, and also commanded $2 / 4^{\text {th }}$ Royal Lancaster from 21 April 1918 to the Armistice.
} 


\begin{tabular}{|l|c|}
\hline Killed & $12 \%$ \\
\hline Wounded & $17 \%$ \\
\hline POW & $0 \%$ \\
\hline Invalided & $5 \%$ \\
\hline Promoted & $17 \%$ \\
\hline Staff & $2 \%$ \\
\hline Transferred as CO to another division & $7 \%$ \\
\hline Replaced, not used as CO again & $40 \%$ \\
\hline
\end{tabular}

\section{Table 4.5: Reasons for turnover of COs of Service Battalions in $9^{\text {th }}$ Division}

As Table 4.5 shows, the main reason for turnover was replacement, not to serve in an active command again. At 40 per cent this rate is virtually identical to the overall 38 per cent average turnover for the BEF during the war, a figure which includes replacements prior to active service. Given the marked early stability in the division, this indicates a higher rate of replacement on active service. Promotion to Brigadier-General at 17 per cent (all were Regulars) is again higher than the 10 per cent average, and was jointly, with wounding, the second most common reason for turnover.

\subsubsection{Case study $-13^{\text {th }}$ Battalion (West Ham) Essex Regiment ${ }^{96}$}

As noted in Chapter Three, Service Battalions had an average of five COs at the rank of Lieutenant-Colonel, and $13^{\text {th }}$ Essex had five substantive, Temporary or Acting COs of such rank during the war. The battalion was raised locally by the Mayor and Borough, recruiting at West Ham from 27 December 1914.

\footnotetext{
${ }^{96}$ TNA WO/95/1358 War Diary $13^{\text {th }}$ Battalion Essex Regiment. Originally in 100 Brigade $33^{\text {rd }}$ Division, landing in France on 17 November 1915, the battalion transferred to 6 Brigade $2^{\text {nd }}$ Division on 22 December 1915, and served in France and Flanders until disbandment on 10 February 1918.
} 
The unit's first $\mathrm{CO}$ was Lieutenant-Colonel Pelham Rawsthorn Papillon, a retired Militia Captain. Born in 1864, he grew up at Lexden Manor, Colchester, in a wealthy and influential landowning family whose principal seat was Crowhurst Park, Sussex. He was educated at Winchester School and obtained a BA in Law in 1887 from University College, Oxford. A keen cricketer and amateur archaeologist, ${ }^{97}$ he was appointed a Sussex Magistrate in $1888,{ }^{98}$ and was commissioned 2nd Lieutenant in $3^{\text {rd }}$ Sussex on 3 April 1889, seeing service in South Africa as a Captain 1899-1901. He retired as an Honorary Major in 1904. On the outbreak of war, Papillon was commissioned Captain in $9^{\text {th }}$ Sussex on 21 September 1914 and Lieutenant-Colonel in $13^{\text {th }}$ Essex on 2 February 1915. The two regiments spanned both his county of residence and that in which he grew up, and his circumstances reflect the observations of Peter Simkins concerning convenient relationships between the raising Mayor and local notables with military connections in the appointment of COs. ${ }^{99}$

The battalion disembarked at Boulogne on 17 November 1915. Between 5 and 16 February 1916 Papillon went on the first of three spells of leave to England of his ten and a half months on active service. His second-in-command, Major A.L. Brown, acted up. Brown was an ex-Regular, a 40 year-old retired Captain of the $12^{\text {th }}$ Lancers with service in South Africa 1899-1902, who had been on active service since November 1914, transferred to $13^{\text {th }}$ Essex as second-in-command on 9 November 1915. This was Brown's only taste of command, as when Papillon took over command of 6 Brigade from 28 March to 9 April

\footnotetext{
${ }^{97}$ His 'Lexden Gladiator' find is displayed in the British Museum.

${ }^{98}$ He became the longest serving Sussex Magistrate, serving the bench until his death on $18^{\text {th }}$ March 1940.

${ }^{99}$ P. Simkins, Kitchener's Army: The Raising of the New Armies 1914-1916 (Barnsley: Pen \& Sword, 2007), p. 219. See Chapter Two section 2.1.5.
} 
1916, Major W.H. Winthrop, the original commander of B Company took over. ${ }^{100}$ Winthrop again took over from 14 to 30 May 1916 when Papillon went on his second leave, but this was for the last time. ${ }^{101}$

In late July 1916 the battalion was transferred to the Somme and went into action at Delville Wood, 28 to 31 July $1916 .{ }^{102}$ Papillon was wounded in the German counter-attack of the $30^{\text {th }}$ but remained at duty. The nature of his wound is set out in his DSO citation:

A shell burst in front of him, knocked him down and cut his eye, but he carried on with the greatest coolness. Next morning another shell severely bruised him and broke the drum of his ear, but he refused to leave his post. ${ }^{103}$

On 8 August 1916 the battalion was in action again, ordered to attack Guillemont from Trones Wood, an attack that had failed earlier in the day. Two companies were annihilated by machine-gun fire in front of uncut wire. Papillon, taking the risk of the 'man on the spot', defied his orders and held back his other companies, referring his dilemma to 6 Brigade. The attack was cancelled. ${ }^{104}$

\footnotetext{
${ }^{100}$ Winthrop was a 41 year old citizen in August 1914. Brown's departure went unrecorded, but he assumed the duties of Assistant Provost-Marshal on 23rd June 1916.

${ }^{101}$ His departure went unrecorded, but on 4th March 1917 he resigned his commission on grounds of ill health.

${ }^{102}$ During the four days the war diary states the casualties were as follows: killed 39; wounded 138; shellshock 20; missing 17; wounded at duty 7.

${ }_{103}$ London Gazette, 20 October 1916, p.10172

${ }^{104}$ Papillon's report on 10 August walks a narrow line between self-defence and indicating lessons to be learnt: "The ground was new to everyone and there had been no opportunity for previous reconnaissance ... reports on previous attacks led me to believe that both wire and parapet were practically non-existent whereas the reverse was found to be the case". He continued: "The time at disposal was far too short for the proper maturing of plans and for making all ranks acquainted with the scheme of attack". TNA WO/95/1358 War Diary $13^{\text {th }}$ Battalion Essex Regiment.
} 
Twenty days later, on 28 August 1916, Papillon returned to England on "special leave". Captain S.E. Collier took over until his return on 5 September. ${ }^{105}$ On 1 October 1916, on route to trenches in the Hebuterne sector Papillon returned to the transport lines "sick". The same diary entry noted that Major W.H. Carter "took over command of the battalion and assumed the rank of Lieut. Colonel".

Papillon was suffering a psychological breakdown. Brigade clearly recognised this and had granted him special leave for rest. ${ }^{106}$ "After several Medical Boards, opinion held that he was clearly suffering 'Shell Shock' ... he was stone deaf in traffic, but could hear a watch at two inches away. He had 'exaggerated knee jerks' as well as suffering 'great restlessness' overall". ${ }^{107}$ His replacement had clearly been identified as it was fully effective within hours. ${ }^{108}$

William Henry Carter was a marked contrast to Papillon. A Signals Sergeant of $2^{\text {nd }}$ South Staffordshire on the outbreak of war, ${ }^{109}$ he was commissioned $2^{\text {nd }}$ Lieutenant on 4 January 1915. He demonstrates not only the rapid rise of the talented Regular OR, 21 months from $2^{\text {nd }}$ Lieutenant to Lieutenant-Colonel (thereby moving faster than Dawson), but also the talent spotting of a promising Major, Carter having already commanded $17^{\text {th }}$ Middlesex at that rank between 27 July and 13 September 1916.

\footnotetext{
${ }^{105}$ Originating from Colchester, and aged 23 in August 1914, Collier had been a citizen, assistant manager at his father's brick and tile works. He had been gazetted $2^{\text {nd }}$ Lieutenant on 8 February 1915 . He was made an acting Major two days after assuming command. He never commanded again, finishing the war as Brigade Transport Officer.

${ }^{106} \mathrm{His}$ leg twitches were noticeable on return from this leave.

107 TNA WO/339/21480, Officers' Services, Pelham Rawsthorn Papillon. He joined Eastern Command, Home Service on 17th February 1917, but relinquished his commission on $22^{\text {nd }}$ March 1917.

${ }^{108}$ The bestowal of temporary Lieutenant-Colonel rank usually following 28 days after appointment.

${ }^{109}$ Born on 1 April 18979, Carter's father was a gas tube maker. He had enlisted in 1899 into the $2^{\text {nd }}$ South Staffordshire, and saw service in South Africa, 1900-2 with the $1^{\text {st }}$ Battalion. http://www.westernfrontassociation.com/great-war-people/brothers-arms/2721-lieutenant-colonel-williamhenry-carter-dso-and-bar-mc-and-bar.html (accessed 14 March 2013).
} 
Carter was to command the battalion in 6 Brigade's unsuccessful attack on the Quadrilateral on 13 November 1916 during the Battle of the Ancre. ${ }^{110}$ His report copied into the war diary on 12/13 November 1916 shows a CO in conflict with his company commanders, deferring, and carefully covering himself against come-back from brigade, from which direction he may have felt particularly vulnerable, ${ }^{111}$ due to his origins in the ranks:

On the night of the 12th I sent for the Company Commanders who were in command of the 1st wave and told them that I thought it was impossible to take the QUADRILATERAL with a frontal attack, and gave orders that it should be taken from the flanks. Both of the officers disagreed with this and on account of the points they raised ... I decided to let my orders for the attack stand as before, although I was still in doubt as to whether I had done right. This consultation took place in the presence of the Adjutant, who heard everything that was said. ${ }^{112}$

In the event, no particular infantry tactics would have taken the Quadrilateral that day, and Carter's reputation did not suffer.

On 16 December 1916 Carter went on leave to England, and Major A.G. Hayward, secondin-command, took over until his return on 31 December. Hayward acted-up again when Carter attended a Commanding Officers Conference at Fifth Army Infantry School from 6 to 9 February 1917. Arthur Gracie Hayward had been commissioned Lieutenant in the battalion on 15 May 1915. He was earmarked for future command being sent to Senior

\footnotetext{
${ }^{110}$ The Quadrilateral was a redoubt forming a salient in the German front line between Beaumont Hamel and Serre.

${ }^{111}$ Not to mention showing a distrust of his company commanders to report events truthfully at a later date.

112 TNA WO/95/1358 War Diary $13^{\text {th }}$ Battalion Essex Regiment.
} 
Officers School at Aldershot on 27 April 1917, ${ }^{113}$ commanding $4^{\text {th }}$ Bedfordshire on active service 22 July to 22 September $1918 .^{114}$

Carter himself was sent to Senior Officer School on 6 April 1917, ${ }^{115}$ and was replaced by a Regular officer, 38 year-old Lieutenant-Colonel C.T. Martin, who was CO $2^{\text {nd }}$ Highland Light Infantry. ${ }^{116}$ Martin commanded during the battalion's unsuccessful attack on Oppy, 28 April 1917, but on the following day assumed temporary command of 6 Brigade until 4 May, at which point he returned to his original battalion. ${ }^{117}$ Major A.D. Derviche-Jones, second-in-command, took over.

Lieutenant-Colonel A.E.F Harris took over command of both the battalion (formally) and 6 Brigade (actively) on 4 May, returning on the $16^{\text {th }}$, Derviche-Jones proceeding the

\footnotetext{
113 Where his performance was rated "very good". http://www.westernfrontassociation.com/great-warpeople/brothers-arms/2721-lieutenant-colonel-william-henry-carter-dso-and-bar-mc-and-bar.html (accessed 14 March 2013).

http://www.westernfrontassociation.com/great-war-people/brothers-arms/2721-lieutenant-colonel-williamhenry-carter-dso-and-bar-mc-and-bar.html (accessed 14 March 2013).

${ }^{114}$ Hayward had gone on active service with the battalion as Officer Commanding the Machine Gun Section. He was a 31 year old citizen in August 1914, Assistant Secretary of a Social Welfare Association. He returned on 2nd December 1917 as second-in-command, and took over when Lieutenant-Colonel Walsh went on leave from 10 to 30 January 1918. After replacement in September 1918 he later commanded $51^{\text {st }}$ Devonshire.

${ }^{115}$ Carter returned on 6 July 1917 and took up duties as second-in-command as a Major, a short-lived appointment as he was transferred on 18 July and commanded the $7^{\text {th }}$ South Staffordshire until the Armistice. He was awarded the DSO and bar and MC and bar. His DSO (20 October 1916) was awarded for his actions in taking command of the $17^{\text {th }}$ Middlesex after the $\mathrm{CO}$ was wounded, the bar being awarded (10 December 1919) for "skilful leading" of his battalion 8-9 November 1918. He became a Brigadier-General in the Army of Occupation, and retired as a substantive Captain in 1922. His post-war career, for a man for whom his home town, Wolverhampton, gave a civic reception on 21 March 1918, naming a street after him, was unsuccessful as his poultry farm failed, as did a taxi business, and he worked subsequently as a motorcycle mechanic and a steel erector. He died in 1951, his health having broken down during World War Two after his foot was amputated due to a 1915 wound. Interviewed by a reporter from the Birmingham Post in 1934 he stated: "Some of the old chaps who used to know me in the army - chaps the same as myself, you know come and see me, because even when I was an officer, I hadn't any bounce". http://www.westernfrontassociation.com/great-war-people/brothers-arms/2721-lieutenant-colonel-williamhenry-carter-dso-and-bar-mc-and-bar.html (accessed 20 February 2013).

${ }_{116}$ Cuthbert Thomas Martin was a 36 year-old Captain of the battalion in August 1914.

${ }_{117}$ Martin was promoted GOC 151 Brigade on 20 October 1917 until he was killed in action on 25 May 1918.
} 
following day to the temporary command of $1^{\text {st }}$ Liverpool. ${ }^{118}$ Arthur Ellis Fowke Harris had been a 39 year-old Captain of $1^{\text {st }}$ Berkshire in August 1914, commanding this battalion from 28 May 1916 to 3 May 1917. Three months after taking over he again assumed command of 6 Brigade on 13 August for 12 days, Major A.A. Mcfarlane-Grieve, secondin-command deputising. On 1 October Harris went again to Brigade, and Mcfarlane-Grieve took over until the following day when he was sent to Senior Officer School. ${ }^{119}$

Major J. Walsh, the new second-in-command, commanded until Harris returned on 8 October. This was repeated from 12 to 23 October. On 21 November Harris "proceeded to England". The reason for his removal is unclear, ${ }^{120}$ but he subsequently served as a Major with the $2 / 19^{\text {th }}$ London on active service in Palestine commanding from 7 to 29 June 1918 as a Major, and was lastly appointed $\mathrm{CO}$ of a battalion of the Manchester Regiment in October 1918.

Walsh was now given command. A 33 year-old Regular NCO on the outbreak of war, James Walsh was commissioned from Warrant Officer Class II as $2^{\text {nd }}$ Lieutenant in the Liverpool Regiment on 30 January $1916 .{ }^{121}$ He was promoted Lieutenant-Colonel on 13 December 1917, his 22 month journey from $2^{\text {nd }}$ Lieutenant to CO being one month longer than Carter's. The battalion was in action on 30 November, nine days after Walsh assumed command, in the German counterattack at Cambrai. Walsh's resulting DSO citation reads:

\footnotetext{
${ }^{118}$ Derviche-Jones is a fine example of the successful citizen CO - see Chapter Six section 6.2.

119 Angus Alexander Macfarlane-Grieve was a 23 year-old Territorial unattached 2nd Lieutenant of Durham University Officer Training Corps in August 1914, subsequently attached to the 1/4th Highland Light Infantry. He commanded $2^{\text {nd }}$ Seaforth Highlanders from 31 August to 14 October 1918, achieving the distinction of being a Territorial officer commanding a Regular unit.

${ }^{120}$ Given his previous acting-up roles in 6 Brigade, and the absence of change in brigade command at the time of his removal, coupled with his later service as a $\mathrm{CO}$, it is more likely that he was rested rather than sacked.

${ }^{121} \mathrm{He}$ was made an acting Captain on 10 August 1916 when a company commander; and an acting Major, second-in-command $17^{\text {th }}$ Middlesex on 6 October 1916.
} 
During continual and heavy hostile attacks he visited all portions of his line, regardless of personal danger, and it was owing to his courage and ability in dealing with critical and constantly changing situations, that his line was held. ${ }^{122}$

The $13^{\text {th }}$ Essex was disbanded on 10 February 1918 but Walsh later served as LieutenantColonel from 17 to 29 May 1918 with $6^{\text {th }}$ Northamptonshire, ${ }^{123}$ and again with the $2 / 2^{\text {nd }}$ London from 10 August to the Armistice.

In summary, $13^{\text {th }}$ Essex showcases evolving merit-based promotion in the BEF. It was commanded by five Lieutenant-Colonels, (none of whom had any connection with the Essex Regiment); and of the last four, two had been Regular ORs, a Private and an NCO on the outbreak of war, both of whom who were still commanding battalions at the Armistice. The other two were Regular Captains in August 1914; one promoted to Brigadier, the other still commanding a battalion in November 1918. All these four appointments came from within $2^{\text {nd }}$ Division, and three of the four from within 6 Brigade, demonstrating a local nature that was not universal. ${ }^{124}$ The reasons for these first four Lieutenant-Colonels leaving command was one case of invalidity, one of replacement, with two being replaced but transferred to other commands.

\footnotetext{
${ }^{122}$ London Gazette 18 July 1918, p. 8443. Walsh produced both a "Narrative" of the Cambrai operation and a separate "Notes on Recent Operations" (7 December 1917) with provides a succinct analysis of 9 points: Supply of Small Arms Ammunition (necessity for dumps behind the lines in case of fall-back); Lewis Guns (problem of rapidly emptying magazines); Musketry (beneficial effects of recent practice); Signalling (especially the importance of communication with Brigade Forward Station); Runners and Relay Posts (importance of having an officer commanding); Bombs and Grenades (more training required); Medical Arrangements (no comment); S.O.S. Signal (weak artillery response); Defensive Barrage (wrongly placed). In 4 of 8 points he identified a problem and proposed a solution; in 3 out of 8 points he identified a problem but had no solution; and in one case he identified a previous strategy that had demonstrated its utility. This was a man with a keen analytic mind and the ability to communicate clearly.

${ }^{123}$ From which appointment he was invalided.

${ }^{124}$ Martin's battalion, $2^{\text {nd }}$ Highland Light Infantry, was in 5 Brigade.
} 
At least three of these individuals are known to have gone to Senior Officer School, Aldershot; one already a Lieutenant-Colonel and two Majors. Those who acted-up during absences, amongst whom are these two Majors, are no less interesting. There were nine such periods, filled by six Majors. The first two early contenders, Brown and Winthrop, were unable to sustain the pace of war. The third, Collier, acted-up only once and was likely unsuitable for command. The last three, all 'talent spotted' and sent to Senior Officer School, namely Hayward, Derviche-Jones and Macfarlane-Grieve, were all commanding battalions at the Armistice, two on active service. Hayward and Derviche-Jones were civilians at the outbreak of war, Macfarlane-Grieve being a TF $2^{\text {nd }}$ Lieutenant who went on to command a Regular battalion.

\subsection{Territorial Battalions}

Table 4.6 identifies the origins of those who commanded first and second-line Territorial battalions on active service.

\begin{tabular}{|l|c|c|c|c|}
\hline & \multicolumn{2}{|c|}{ First-Line } & \multicolumn{2}{c|}{ Second-Line } \\
\hline Territorial & 416 & $52 \%$ & 67 & $27 \%$ \\
\hline Retired Territorial & 35 & $4 \%$ & 37 & $14 \%$ \\
\hline Regular & 193 & $24 \%$ & 83 & $33 \%$ \\
\hline Retired Regular & 46 & $6 \%$ & 25 & $10 \%$ \\
\hline Indian Army/Retired Indian Army & 14 & $2 \%$ & 2 & $1 \%$ \\
\hline Special Reserve/Retired Special Reserve & 28 & $4 \%$ & 15 & $6 \%$ \\
\hline Empire/Retired Empire & 8 & $1 \%$ & 2 & $1 \%$ \\
\hline Citizen & 57 & $7 \%$ & 19 & $8 \%$ \\
\hline
\end{tabular}

Table 4.6: Origins of active COs of first and second-line TF battalions

Of the first-line Territorial battalions, 56 per cent of COs were active/retired Territorials. Thirty per cent were active/retired Regulars, with the next largest group, citizens of August 1914, comprising 7 per cent of COs, a figure a little over a third of the contribution made 
to Service Battalions. The Special Reserve again made a low contribution at three per cent. Overall, including the Indian Army and Territorial/Special Reserve officers who were previously Regulars, 36 per cent of COs were professional soldiers, just over half the percentage for Service Battalions.

As noted in Chapter One, 39 per cent of first-line TF COs did not accompany their battalions on active service. It might be thought that given the circumstances, a younger, militarily-active individual would have succeeded, in particular the senior Major. In fact, 25 per cent of second COs were senior officer 'dugouts' (24 Regular, one Indian Army, 18 Territorial, and 3 Special Reserve). Forty-three per cent of second appointments were, however, active TF Majors, and 13 per cent active Captains. Only 13 per cent were Regulars (5 Majors, 16 Captains and one Lieutenant in terms of August 1914 ranks). Of the third COs, 51 per cent were active TF officers of August 1914, 32 per cent active Regulars, with only 7 per cent 'dugouts'. The position on 29 September 1918 on the Western Front is shown in Table 4.7. At this point the number of active TF officers of 1914 had dropped, largely in favour of appointees who were civilians in August 1914. Of these individuals, twelve had been commissioned into the TF, and twelve into Service Battalions.

\begin{tabular}{|c|c|c|c|c|}
\hline $\begin{array}{c}\text { Active } \\
\text { Regular }\end{array}$ & $\begin{array}{c}\text { Active } \\
\text { Territorial }\end{array}$ & $\begin{array}{c}\text { Active Special } \\
\text { Reserve }\end{array}$ & Retired & Civilian \\
\hline $29 \%$ & $36 \%$ & $3 \%$ & $12 \%$ & $20 \%$ \\
\hline
\end{tabular}

Table 4.7: August 1914 origins of first-line TF COs in France \& Flanders on 29 September 1918

The logic behind appointing 'dugouts' to first-line battalions is difficult to fathom. It does of course reflect the 'retired senior officer' principle in vogue at that point for provision of 
command initially for the later newly-raised Service/TF battalions. ${ }^{125}$ It may reflect lack of confidence in the senior officers of many of these battalions, a lack which may have had some foundation. Alternatively, local politics may have been at work. The lack of confidence persisted, however, for as the dugouts fell by the wayside, the number of active professional soldiers increased, this stiffening of battalions with Regular COs increasing from 13 to 32 per cent between the second and third appointments. This point was, however, the peak of saturation of first-line units with professionals as COs, remaining thereafter at just under a third of appointees. On 29 September 1918, including those who had been commissioned into the TF after August 1914, those with a pure Territorial background comprised just under half (46 per cent) of appointees.

Lieutenant-Colonel F.B. Follett, a Regular Captain of the Warwickshire Regiment was given command of $1 / 9^{\text {th }}$ London on 25 January $1917 .{ }^{126}$ His appointment drew bitter words from the battalion's historian:

Hitherto regiments of the Territorial Force had been commanded by one of their own officers, but dating from about the end of 1916 commands given to members of that Force were very few and far between, no matter how long they had served or how efficient they were in their duties. In practically every case a 'Regular' officer was appointed to the command of a regiment directly a vacancy occurred, and in some instances officers actually commanding a battalion in the field were on one pretext or another posted to a reserve battalion at home or found a job elsewhere. We have nothing to say against the new officers commanding, but the change caused considerable bitterness among those immediately concerned. No matter how brilliant their fighting record the professional soldier was ignorant of the traditions on which many Territorial regiments set great store, and never felt in full sympathy with the amateur, while the latter naturally resented his being passed over. ${ }^{127}$

\footnotetext{
125 See Chapter Two.

${ }^{126}$ Francis Bere Follett, born in 1876 , commanded $1 / 9^{\text {th }}$ London from 25 January to 13 November 1917 , and $10^{\text {th }}$ Warwickshire from 22 July 1918 to the Armistice.

127 C.A.C. Keeson, History \& Records of Queen Victoria's Rifles 1792-1922 (London: Constable, 1923), p. 219
} 
This picture, as is evident, is not entirely accurate, but it indicates clearly the resentment felt about the undoubted difficulties that TF officers faced in achieving promotion to $\mathrm{CO}^{128}$

The Territorial battalions did of course have a Regular officer within their ranks in August 1914 in the form of the Adjutant. Fifty-one per cent of these became COs. A romantic image might be conjured of the $\mathrm{CO}$ falling, his senior officers around him, the Adjutant taking control and being rewarded with permanent command. Whilst Adjutants did find them themselves left in command in battle, only 12 of 207 actually succeeded to command (as Lieutenant-Colonel) of the TF battalion to which they were Adjutant in August 1914, a figure representing only six per cent of the Regulars who commanded TF battalions. ${ }^{129}$ Thirty-six became COs of Service Battalions, 31 of other Territorial units and 27 of Regular battalions. The route Adjutant to CO in the August 1914 battalion of attachment was the least likely journey to command.

In the second-line Territorial battalions, 41 per cent of COs were active/retired Territorials and 41 per cent were active/retired Regulars, the other contributors being in similar proportions to the first-line battalions. Overall, 47 per cent were professional soldiers. The TF therefore proved to have limited resources for command of its second-line battalions, only half as many active Territorials of August 1914 commanding such battalions in comparison with first-line units. There was no strong impetus to denude first-line battalions to command second-line units, the input of professionals being more heavily relied upon than for first-line battalions.

\footnotetext{
${ }^{128}$ See also Chapters Three and Six.

${ }^{129}$ The first to do so was G.B.G. Wood, Adjutant of $1 / 5^{\text {th }}$ Lancashire Fusiliers in August 1914, who assumed command from 7 August 24 September 1915 on Gallipoli.
} 


\subsection{1 $42^{\text {nd }}$ Division}

In $42^{\text {nd }}$ Division, a first-line Territorial division, 70 Lieutenant-Colonels commanded the $12 \mathrm{TF}$ battalions during their time spent on active service with the division during the war. $^{130}$

Forty-seven per cent were Territorials in August 1914, 36 per cent were active or retired Regulars, four per cent were Special Reserve, six per cent Indian Army, and seven per cent citizens. Forty-four per cent were professional soldiers, a slightly higher proportion in comparison with the 36 per cent commanding first-line TF battalions overall during the war.

Nine of the 12 COs of August 1914 of these battalions landed on Gallipoli on 10 May $1915,{ }^{131}$ a figure higher than average, 75 per cent in comparison with the overall figure of 61 per cent taking their units on active service. Service there took a savage toll. LieutenantColonel D.H. Wade was CO $1 / 9^{\text {th }}$ Manchester at the outbreak of war, and his career will stand as illustration. Born in 1865, he had left Oldham for a civil service appointment in Singapore, where he served as a Private in the Volunteer Artillery. Returning to the UK he served as an NCO in the Cheshire and Caernarvonshire Artillery Volunteers, being commissioned in the Manchester Regiment in 1900, working for the local authority as Education Secretary, and becoming CO of the $9^{\text {th }}$ Battalion on 17 July $1913 .{ }^{132}$ Twelve days after arrival on Gallipoli Wade was shot by a sniper "stepping across some men who

\footnotetext{
${ }^{130}$ The battalions were: 125 Brigade $-1 / 5^{\text {th }}, 1 / 6^{\text {th }}, 1 / 7^{\text {th }}$ and $1 / 8^{\text {th }}$ Lancashire Fusiliers; 126 Brigade $-1 / 9^{\text {th }}$ and $1 / 10^{\text {th }}$ Manchester, $1 / 4^{\text {th }}$ and $1 / 5^{\text {th }}$ East Lancashire; 127 Brigade $-1 / 5^{\text {th }}, 1 / 6^{\text {th }}, 1 / 7^{\text {th }}$ and $1 / 8^{\text {th }}$ Manchester.

${ }^{131}$ Of the other three, Lieutenant-Colonel W.S France $\left(1 / 5^{\mathrm{th}}\right.$ Manchester) was removed from command before the battalion went to Egypt; and Lieutenant-Colonels G.G.P. Heywood (1/6 ${ }^{\text {th }}$ Manchester), J.C. Hoyle $\left(1 / 5^{\text {th }}\right.$ East Lancashire) made the voyage, but did not accompany their battalions to Gallipoli. Heywood was invalided with eye trouble.

${ }^{132}$ Manchester Reporter, 8 August 1914, cited at www.ashtonpals.webs.com (accessed 9 May 2012).
} 
were sleeping in order not to disturb them". ${ }^{133}$ After recuperation, Wade returned on 8 February 1916 to command the battalion in Egypt, including the Sinai fighting, a task he continued until 27 April 1917, just after the battalion's return to France. He was transferred to the TF Reserve in June 1917, undoubtedly not up to the Western Front, although he had seen nearly two years of active service.

Of the other eight, Lieutenant-Colonel W.G. Heys, CO $1 / 8^{\text {th }}$ Manchester, was killed in the Third Battle of Krithia, 4 June $1915 .{ }^{134}$ He had been commanding 125 Brigade temporarily, and returned to his battalion as nearly all his officers were casualties. Lieutenant-Colonel H.E. Gresham, CO $1 / 7^{\text {th }}$ Manchester, ${ }^{135}$ was invalided on 28 May 1915. ${ }^{136}$ Lieutenant-Colonel J.A. Fallows, CO $1 / 8^{\text {th }}$ Lancashire Fusiliers, was killed on 7 June, ${ }^{137}$ Lieutenant-Colonel A.F. Maclure, CO $1 / 7^{\text {th }}$ Lancashire Fusiliers, having been wounded two days earlier. ${ }^{138}$ Lieutenant-Colonel F.D Robinson, ${ }^{139}$ CO $1 / 4^{\text {th }}$ East Lancashire, had to be replaced on 15 July; Lieutenant-Colonel J. Isherwood, CO $1 / 5^{\text {th }}$ Lancashire Fusiliers, similarly on 18 July. ${ }^{140}$ Lieutenant-Colonel Lord Rochdale, CO $1 / 6^{\text {th }}$ Lancashire Fusiliers, ${ }^{141}$ had a period in command of 126 Brigade in June, but was

\footnotetext{
${ }^{133}$ Manchester Reporter, 7 August 1915, cited at www.ashtonpals.webs.com (accessed 9 May 2012). In hospital in Alexandria he learnt that his son J.M. Wade, a Lieutenant with the battalion, had been killed.

${ }^{134}$ William George Heys was a 47 year-old chartered patent agent, and had served in South Africa 1901-2.

${ }^{135}$ Harry Edward Gresham was a 50 year-old mechanical engineer and co-proprietor of the Craven Iron Works, Salford.

${ }^{136}$ His successor, Major J.H. Staveacre, was also killed on 4 June alongside Heys.

${ }^{137}$ James Albert Fallows was a 50 year-old India rubber company manager.

${ }^{138}$ Alan Francis Maclure was a 40 year-old solicitor, of Crofton Craven \& Co., Manchester.

${ }^{139}$ Frederick Dixon Robinson was a 53 year-old solicitor in the family firm of Robinson \& Sons, Blackburn and Clitheroe.

${ }^{140}$ James Isherwood was a 52 year-old solicitor practising at Heywood and Bury.

${ }^{141}$ George Kemp, $1^{\text {st }}$ Baron Rochdale, born in 1883, was a flannel manufacture who had played first-class cricket for Lancashire, and had been MP for Heywood and Manchester North-West. He had commanded $32^{\text {nd }}$ Battalion Imperial Yeomanry in the Second Boer War.
} 
invalided on 29 September. Only Lieutenant-Colonel J.B. Rye, CO 1/10 ${ }^{\text {th }}$ Manchester, had a command, like Wade's, that survived Gallipoli, serving until 14 May $1916 .{ }^{142}$

The division was transferred to the Western Front in March 1917. In its first major action in Belgium during Third Ypres on 6 September 1917, when the division attacked Iberian, Borry and Beck House Farms near Frezenberg, a dramatic evolution of command from Gallipoli was evident. Seventy-five per cent of the battalions were now commanded by Regulars, a figure twice the overall percentage. Two-thirds of these appointments dated from mid-1917, indicating an attempt to stiffen the division with professional soldiers after arrival on the Western Front. What role this influx of Regulars may have had on the division's later success, if any, is a matter for speculation.

All four Lancashire Fusilier battalions of 125 Brigade were commanded on 6 September by Regulars of August 1914. The CO of $1 / 5^{\text {th }}$ Lancashire Fusiliers was Lieutenant-Colonel Phillip Vaughan Holberton, a Captain of the Manchester Regiment in August 1914, who had served as Adjutant to $1 / 6^{\text {th }}$ Manchester (127 Brigade), GSO3, GSO2 and BrigadeMajor (126 Brigade) between December 1915 and 17 October 1916, at which point he took over the battalion at the age of 37 , having contributed to all three brigades of the division. Holberton commanded between 17 October 1916 and 25 March 1918, when he was killed near Gomiecourt during the German spring offensive. The divisional history notes: "With his habitual disregard of personal safety" he "walked along the line encouraging and heartening his men and was shot through the head". ${ }^{143}$

\footnotetext{
${ }^{142}$ John Buckley Rye was a 56 year-old yarn merchant from Oldham.

${ }^{143}$ F.P. Gibbon, The $42^{\text {nd }}$ (East Lancashire) Division 1914-1918 (London: George Newnes, 1920), p.134
} 
$1 / 6^{\text {th }}$ Lancashire Fusiliers were commanded by Lieutenant-Colonel Macdonald Freer Hammond-Smith, a Lieutenant of the Royal Inniskilling Fusiliers in August 1914, who had been DAQMG with the division from January 1916 until his appointment as CO on 25 July 1917 at the age of 33 . He was wounded on 12 September $1917.1 / 7^{\text {th }}$ Lancashire Fusiliers were commanded by Lieutenant-Colonel William Edward Maskell, an NCO of August 1914 who was commissioned Lieutenant in the Devonshire Regiment on 8 December 1914, and served with $1 / 6^{\text {th }}$ Manchester before moving to the Lancashire Fusiliers, becoming CO on 29 August 1916, aged 43. Maskell was also wounded on 12 September, and neither he nor Hammond-Smith were able to return to command. Lastly, $1 / 8^{\text {th }}$ Lancashire Fusiliers were commanded by Lieutenant-Colonel George Everard Hope, a Lieutenant of the Grenadier Guards in August 1914, who had variously served as ADC, Staff-Captain, DAAQMG and GSO3 between April 1915 and 1 June 1917 when he took over command aged 31 (being the only one of the quartet not to have a previous connection with $42^{\text {nd }}$ Division). Hope was killed on 10 October 1917 , stumbling into an enemy post at Nieuport in the dark. ${ }^{144}$

In 126 Brigade, ${ }^{145}$ three battalions were commanded on 6 September by Regulars of August 1914. 1/9 ${ }^{\text {th }}$ Manchester were commanded by Lieutenant-Colonel Evan Colclough Lloyd, a Captain of the Royal Irish Regiment in August 1914, who held four battalion

\footnotetext{
${ }^{144}$ Hope's widow plunged into notoriety after his death. She accused her mother-in-law of kidnapping her two orphaned children, an action she believed motivated by her behaviour whilst contesting Herbert Asquith's seat of East Fifeshire, when she "delivered a series of speeches which were characterized by coarse personalities at the expense of the one-time Premier". The Sun, 9 March 1919 p.6. It was sadly noted that George Hope's mother at this point "will not believe that her only son is dead. She is convinced in her own mind that he will appear".

145126 Brigade, the Manchester Infantry Brigade, had a very particular local Territorial character on the outbreak of war as the GOC, Brigadier-General Noel Lee, originated from $6^{\text {th }}$ Manchester which he commanded until 1911. It was Lee's wounding in the throat and jaw on 4 June that led to Lieutenant-Colonel W.G. Heys assuming command of the brigade. Lee died on 21 June at Malta.
} 
commands during the war. ${ }^{146} 1 / 10^{\text {th }}$ Manchester were commanded from 27 May 1917 by Lieutenant-Colonel Richard Percy Lewis, killed by shellfire on 8 September 1917, aged 40. A Captain of the Devonshire Regiment at the outbreak of war, he had served as a Brigade-Major during 1916. ${ }^{147} 1 / 4^{\text {th }}$ East Lancashire were commanded from 29 June 1917 by Lieutenant-Colonel Arthur Henry Seton Hart-Synnot, a Major of the East Surrey Regiment in August 1914. ${ }^{148}$ He had served as a GSO2 from February to June 1917 and commanded until 19 September $1917,{ }^{149}$ when he was transferred to command $1^{\text {st }}$ Lancashire Fusiliers, aged $47 .{ }^{150}$ In contrast, the $\mathrm{CO}$ of $1 / 5^{\text {th }}$ East Lancashire was Lieutenant-Colonel Ernest William Lennard, a 29 year-old Territorial Lieutenant of $1 / 6^{\text {th }}$ Gloucestershire in August 1914, ${ }^{151}$ who commanded until 20 September 1917.

In 127 Brigade, two battalions were commanded by Regulars on 6 September. $1 / 5^{\text {th }}$ Manchester were commanded by Lieutenant-Colonel Henry Clayton Darlington, a 37 yearold solicitor, who was senior Major of the battalion in August 1914, replacing LieutenantColonel W.S. France on 12 September $1914 .^{152}$ Darlington showed considerable endurance, serving in Egypt, Gallipoli, Sinai and France before leaving command on 25

\footnotetext{
${ }^{146}$ He commanded $1^{\text {st }}$ Royal Irish Regiment from 25 June 1915 to 4 November $1915,1^{\text {st }}$ Royal Irish Rifles from 17 July 1916 to 28 April 1917, 1/9 $9^{\text {th }}$ Manchester from 27 May 1917 to 6 April 1918, and $1^{\text {st }}$ Munster from 10 October 1918 to the Armistice, spending 762 days in command in total.

${ }^{147}$ Lloyd was awarded a bar to his DSO commanding during the German spring offensive of 1918: "For conspicuous gallantry and devotion to duty in command of his battalion in action. In spite of very heavy enemy attacks, preceded by gas and accompanied by a dense bombardment, he succeeded in maintaining his position, although nearly surrounded. A subsequent counter-attack enabled him to withdraw the battalion, inflicting casualties on the enemy in doing so. His courage and tenacity gained valuable time to reorganise the defence in the rear of the battle zone. Later he was severely wounded". London Gazette, 26 July 1918, p.8738

${ }^{148}$ Hart-Synnot, being $p s c$, had a good deal of pre-war staff service, having been a Staff Officer, BrigadeMajor and DAAG in South Africa, ADC to the GOC UK, GSO2 China, and GSO2 India.

149 Not with $42^{\text {nd }}$ Division.

${ }^{150}$ He served briefly as GOC 6 Brigade in 1918.

151 His father was William Lennard, a boot retailer, who founded the chain Lennards Ltd, Ernest rising to be managing director in the 1930s. He had commanded 1/7 East Lancashire as a Major briefly in August 1916. He achieved command in 1925 of $6^{\text {th }}$ Gloucestershire.

${ }^{152}$ France served as AAQG from November 1914, and DAQMG from February 1917 until the Armistice.
} 
May $1918 .^{153} 1 / 7^{\text {th }}$ Manchester were commanded by Lieutenant-Colonel Albert Edward Cronshaw, a 42 year-old brassfinisher and Captain of the 1/5 ${ }^{\text {th }}$ Battalion in August 1914. He commanded from 22 April 1916 to 20 September 1917, at which point he was invalided. Of the two Regulars, $1 / 6^{\text {th }}$ Manchester were commanded by Lieutenant-Colonel Gilbert Henry Wedgwood. A 38 year-old Captain of the York and Lancaster Regiment in August 1914, 1/6 ${ }^{\text {th }}$ Manchester was his third battalion command before being promoted to command 126 Brigade on 25 May $1918 .{ }^{154}$ Lastly, $1 / 8^{\text {th }}$ Manchester was commanded from 26 July 1917 until 23 May 1918 by 33 year-old Lieutenant-Colonel Edward Guy Kynaston Cross, a retired Regular and Captain in the Special Reserve of the $7^{\text {th }}$ Hussars in August $1914 .^{155}$

By 29 September 1918, however, the balance had shifted, with (in the reduced battalion composition of the division), ${ }^{156}$ four battalions (45 per cent) being commanded by Regulars, two ( 22 per cent) by Territorials and three by civilians (33 per cent), a position which reflected more Regulars/civilians and fewer Territorials than the overall average.

\footnotetext{
${ }^{153} \mathrm{He}$ was invalided from Gallipoli on 30 September 1915, returning to command on 1 January 1916.

${ }^{154} \mathrm{He}$ was the great-great-grandson of potter Josiah Wedgwood. He commanded $6^{\text {th }}$ York and Lancaster from 6 February to 5 November $1916,8^{\text {th }}$ West Riding from 10 May to 31 August 1917, and 1/6 ${ }^{\text {th }}$ Manchester from 1 September 1917. He was another CO awarded a DSO for actions during the German spring offensive in 1918: "For conspicuous gallantry and devotion to duty when in command of his battalion. He denied an important locality to the enemy by the promptitude and rapidity of his movements. For three days he beat off heavy attacks, without losing a yard of ground, and the fighting spirit shown by him was a fine example to his men".

London Gazette, 26 July 1918, p.8751

${ }^{155} \mathrm{He}$ commanded $4^{\text {th }}$ Reserve Battalion, Leicestershire Regiment, in the UK from 1 July 1918 until the Armistice.

${ }^{156}$ In response to manpower issues, the Cabinet Committee proposed a reduction in the number of battalions per brigade from 4 to 3 in December 1917, although resisted by the Army Council this solution was forced upon the BEF, enacted in February 1918. 147 units were affected (none Regular or first-line Territorial). Twenty-two pairs of TF units were amalgamated and $21 \mathrm{TF}$ and 84 Service Battalions disbanded.
} 


\begin{tabular}{|l|c|}
\hline Killed & $15 \%$ \\
\hline Wounded & $12 \%$ \\
\hline POW & $0 \%$ \\
\hline Invalided & $8 \%$ \\
\hline Promoted & $3 \%$ \\
\hline Staff & $2 \%$ \\
\hline Transferred as CO to another division & $10 \%$ \\
\hline Replaced, not used as CO again & $50 \%$ \\
\hline
\end{tabular}

\section{Table 4.8: Reasons for turnover of COs of battalions in $42^{\text {nd }}$ Division}

As Table 4.7 shows, the main reason for CO turnover in $42^{\text {nd }}$ Division was replacement, not to serve in an active command again. At 50 per cent this is above the 38 per cent overall average for the BEF during the war, and the highest of the three division types. This indicates a highly active approach to assessment of CO suitability in the division. Death in action was the second highest cause of turnover.

\subsubsection{Case Study $-1 / 4^{\text {th }}$ Royal Berkshire ${ }^{157}$}

As noted in Chapter Three, first-line Territorial battalions had an average of between five and six COs with the rank of Lieutenant-Colonel. The $1 / 4^{\text {th }}$ Royal Berkshire had four substantive, Temporary or Acting COs of that rank during the war.

At the outbreak of war the battalion was led by 49 year-old Lieutenant-Colonel Oswald Pearce-Serocold. He represented the growing presence of the mercantile class in the upper

${ }^{157}$ WO/95/2762 War Diary $1 / 4^{\text {th }}$ Royal Berkshire Regiment. Originally in South Midland Brigade, South Midland Division, the battalion landed in Boulogne on 31 March 1915. The formation became 145 Brigade $48^{\text {th }}$ Division. The battalion served in France and Flanders from 31 March 1915, transferring in November 1917 to Italy, where it remained. 
ranks of the TF. The son of a brewer, ${ }^{158}$ he became director and chairman of Watney Combe \& Reid. Educated at Eton and Trinity College, Cambridge, he had been commissioned Lieutenant in the $1^{\text {st }}$ Volunteer Battalion Berkshire Regiment on 7 January 1885, and became Lieutenant-Colonel 27 June 1900. He vacated command on 12 March 1907, and became Supply and Transport Officer of the South Midland Volunteer Infantry Brigade, returning as CO on 31 October $1909 .{ }^{159}$ He had no war service. ${ }^{160}$

The $1 / 4^{\text {th }}$ Royal Berkshire disembarked at Boulogne on 31 March 1915 . From May $7^{\text {th }}$ to the end of the month Pearce-Serocold took command of 145 Brigade, and Major R. J. Clarke, the second-in-command, took over, as he did subsequently. ${ }^{161}$ On 14 February 1916, Pearce-Serocold was recalled to England, playing no further part in the war. ${ }^{162}$ The war diary recorded the "great loss to the battalion for he had put in 32 years in the Regiment, 9 years as Commanding Officer". 163

His departure may have simply reflected the replacement of an older commander, but followed the appointment of Brigadier-General H. R. Done on 15 December 1915, when

\footnotetext{
${ }^{158}$ His father was Charles Pearce-Serocold, the son of a clergyman; his mother was Marie St. Leger Grenfell daughter of Colonel George St Leger Grenfell, a British soldier of fortune, who claimed to have fought in Algeria, Morocco, South America, the Crimea and the Indian Mutiny. Grenfell joined the Confederate Army during the American Civil War, and was part of the 'Chicago Conspiracy,' a plot to establish a NorthWestern Confederacy. He was believed drowned escaping from subsequent imprisonment.

${ }^{159} \mathrm{He}$ was awarded a brevet Colonelcy on 30 April 1910.

${ }^{160}$ His brother Eric was CO $2^{\text {nd }}$ King's Royal Rifle Corps in August 1914, and achieved the rank of Brigadier-General commanding 68 Brigade, $23^{\text {rd }}$ Division.

${ }^{161}$ When Pearce-Serocold went on leave from 15 to 21 August 1915. Clarke took over command of the brigade from 21 August to 1 September 1915 and from 2 to 10 November 1915. Ford Madox Ford, who served as an officer in the Welsh Regiment, put the following words into the mouth of 'General Campion': "The second-in-command of a battalion has nothing to do but sit about in arm-chairs waiting for the Colonel to be killed." [No More Parades (VRE Publishing: 2012, originally published 1925), Kindle edition p.514 Location 10935]. Whilst second-in-commands certainly might inherit command, the comment denigrates their role.

${ }^{162}$ He was transferred to the TF Reserve on 19 April 1916. Subsequently made a CMG, Pearce-Serocold served as Honorary Colonel of the Battalion between 1920 and 1946, and became Deputy Lieutenant and Justice of the Peace for Berkshire, dying in 1951.

${ }^{163}$ TNA WO/95/2762 War Diary $1 / 4^{\text {th }}$ Battalion Royal Berkshire Regiment
} 
Lieutenant-Colonel F.W. Schofield $\left(1 / 4^{\text {th }}\right.$ Oxfordshire \& Buckinghamshire) was also removed (17 December 1915). Clarke took over formally as CO from 14 March. ${ }^{164}$

Aged 40 at the outbreak of war, Robert Joyce Clarke was a Charterhouse-educated Abingdon clothing manufacturer. He was commissioned $2^{\text {nd }}$ Lieutenant in the $1^{\text {st }}$ Volunteer Battalion Berkshire Regiment on 5 February 1896. He served in South Africa 1900-1, briefly as a Railway Staff Officer. He was promoted Major on 18 March 1913, serving again as Railway Transport Officer in August 1914. Clarke was to prove an able and resilient CO. He was awarded the DSO on 1 October 1916 in relation to his battalion's various actions on the Somme: "He has handled his battalion with great skill and determination. On three separate occasions his fine leading has achieved important success". ${ }^{165}$ On 11 January 1918 whilst with the battalion in Italy he was honoured with a CMG. ${ }^{166}$ On 13 April 1918 he was transferred to the command of the newly formed divisional $\left(48^{\text {th }}\right)$ Battalion Machine Gun Corps. Captain C.R.M.F. Cruttwell wrote of him:

His departure was deeply regretted. He had led the Battalion through all its serious fighting, and had gained the complete confidence of all. He had kept a strict discipline without worrying the men about trifles; they could all appreciate his administrative ability, his grasp of detail and practical concern for their comfort. ${ }^{167}$

\footnotetext{
${ }^{164}$ Substantive from 19 April 1916.

${ }^{165}$ London Gazette, 14 November 1916 p.11040

$166 \mathrm{He}$ was mentioned in despatches on 5 occasions and given the French decoration Order of Merit, Agriculture, $4^{\text {th }}$ Class.

${ }^{167}$ C.R.M.F. Cruttwell, The War Service of the 1/4 ${ }^{\text {th }}$ Royal Berkshire Regiment (T.F.) (London: Blackwell, 1922), Kindle version location 1514
} 


\begin{tabular}{|l|l|l|}
\hline \multicolumn{1}{|c|}{ Dates } & \multicolumn{1}{c|}{ Reason } & \multicolumn{1}{c|}{ Replacement } \\
\hline 23 March - 1 April 1916 & Leave & Capt. G.A. Battock \\
\hline 11-12 May 1916 & Acting Brigadier & Capt. J.N. Aldworth \\
\hline 11-17 June 1916 & CO Conference & Capt. G.A. Battock \\
\hline 20-23 November 1916 & Acting Brigadier & Maj. G.A. Battock \\
\hline 3 December 1916 - 4 January 1917 & Leave & Maj. G.A. Battock/ Capt. J.H. Goulden \\
\hline 15-27 January 1917 & Acting Brigadier & Maj. J.N. Aldworth \\
\hline 9-20 April 1917 & Acting Brigadier & Maj. J.N. Aldworth \\
\hline 9-14 May 1917 & Acting Brigadier & Maj. J.N. Aldworth \\
\hline 24 May - 5 June 1917 & Leave & Maj. J.N. Aldworth \\
\hline 2-15 September 1917 & Acting Brigadier & Maj. J.N. Aldworth \\
\hline 17 September - 13 October 1917 & Leave & Capt. O.B. Challenor/Maj. J.N. Aldworth \\
\hline 21-28 October 1917 & CO Conference & Maj. J.N. Aldworth \\
\hline 25 January - 25 February 1918 & Leave & Maj. J.N. Aldworth \\
\hline 23-26 March 1918 & Acting Brigadier & ? \\
\hline
\end{tabular}

Table 4.9: Officers acting as CO during absences of Lieutenant-Colonel R.J.Clarke

Clarke had fourteen absences from the battalion (see Table 4.4) during his two year tenure. On all occasions the replacement was an original officer of the battalion. Two Captains, promoted Major, feature prominently in this list. Firstly, Grenville Arthur Battock, a solicitor, who was a Captain at the outbreak of war and ended it a Major. ${ }^{168}$ Secondly, John Newton Aldworth, the son of a farmer, also a Captain in August 1914. Aldworth became the principal choice as replacement, and on 12 October 1916 was sent to Senior Officer School. He was, however, never given a battalion command, Clarke's replacement being Arthur Barwick Lloyd-Baker, a Major who had commanded $1 / 4^{\text {th }}$ Oxfordshire \& Buckinghamshire Light Infantry between 1 February 1918 and 27 March 1918 within the same brigade.

\footnotetext{
${ }^{168}$ He commanded the battalion between 1924 and 1928.
} 
Born in 1873, second-eldest son of a landowning family of Hardwicke Court, Gloucestershire, Lloyd-Baker had been commissioned $2^{\text {nd }}$ Lieutenant in $1^{\text {st }}$ Buckinghamshire Volunteers on 27 September 1902, and was a Captain in August 1914. ${ }^{169}$ Educated at Eton and New College, Oxford, he had taken up a teaching post at Cheltenham College. He served as a Staff Captain from August 1914 to February 1916 with 145 Brigade, and had attended the Senior Officer Course in January 1917. Cruttwell noted "his characteristic kindness and tact". ${ }^{170}$ After one spell of leave (6-27 July 1918, when Major Aldworth again took over), and a further attendance at a CO's course in Padua in June, he remained $\mathrm{CO}$ until, as his diary notes on 16 August: "Brigadier round line: proposes 6 months at home for me. Rather attractive but almost no hope of coming back to same Bn or even Division". In four months, Lloyd-Baker had clearly built a bond with his new battalion. He noted further on 30 August: "GOC Div talked about my going \& said he couldn't spare me. Apparently Watt put me in without further consultation after $16^{\text {th }},{ }^{171}$ He was, however, given his rest and transferred to the command of a Cyclist Battalion, 2/1 ${ }^{\text {st }}$ Essex Yeomanry in Ireland on 27 October 1918.

Lieutenant-Colonel Hector Fraser Whitehead, a 40 year-old Scot, who arrived on 29 August 1918 and served as CO until the armistice, was a retired OR of 1st Volunteer Battalion Cameron Highlanders (1896-1906), who had risen to the rank of Sergeant in the 2nd Motorcycle Section, Lovat's Scouts, and who had been both a writer and National

\footnotetext{
${ }^{169}$ His brother Michael Granville Lloyd-Baker followed his example by joining the Royal Gloucestershire Hussars three year later, to be killed in action 23 April 1916 in Palestine, at the Battle of Quatia.

${ }^{170}$ Cruttwell, War Service, location 1517

171 J. Popplewell, ed., A Gloucestershire Diarist - Lt. Col. A.B. Lloyd-Baker of Hardwicke Court (Gloucestershire: Thornhill, 1993), p.140. Brigadier General D.M. Watt, GOC 145 Brigade, was replaced on 27 August. Lloyd-Baker's departure was therefore not a side-lining by a new Brigadier, rather, perhaps, the result of a benign gesture from a Brigade HQ that knew him well.
} 
Health Insurance Commission Assistant Inspector in August 1914. ${ }^{172} \mathrm{He}$ was commissioned Lieutenant in $23^{\text {rd }}$ Northumberland Fusiliers on 22 December 1914, transferring to $2 / 5^{\text {th }}$ East Lancashire as a Major on 19 February 1917, assuming command between 28 April 1917 and the disbandment of the battalion on 7 August 1918. Prior to this he was involved in the training of the $131^{\text {st }}$ U.S. Infantry Battalion where he was described as "a hard-headed fighting old Scotchman (who) believed in the extermination of the Hun from the start". ${ }^{173}$ Captain Cruttwell described him as "a brave man, but of a narrow and unsympathetic school, staled by continuous service throughout the war". ${ }^{174}$

These two contrasting assessments should, perhaps, be seen in the light of $1 / 4^{\text {th }}$ Berkshire having been commanded by three career Territorials, two of whom were original officers of the battalion in 1914, comprising 50 per cent of COs. Helen McCartney has commented on the very particular nature of social exchange and command in TF battalions. ${ }^{175}$ Whitehead's career, despite having an OR Volunteer background, suggests a competent officer who established his credentials as $\mathrm{CO}$ in the New Armies and a second-line TF Battalion, and who, in his aggressive and business-like way, probably had no time for the gentlemanly Territorial ethos that had persisted in $1 / 4^{\text {th }}$ Berkshire.

\footnotetext{
${ }^{172}$ He was Secretary of the Cairn Terrier Club and published handbooks on both the Cairn and Yorkshire Terriers.

173 J.B. Sanbourn and G.N. Malstrom, The $131^{\text {st }}$ U.S. Infantry in the World War (Chicago: Unknown publisher, 1919), p.36

${ }_{174}$ Cruttwell, War Service, location 1607

${ }^{175}$ H. B. McCartney, Citizen Soldiers: The Liverpool Territorials in the First World War (Cambridge: Cambridge University Press, 2005), pp.121-161. She notes that the pre-war "social homogeneity ... necessitated relaxed relationships between the ranks and their commanders", and that through this "the paternalistic-deferential exchange was directly threatened". As the social composition of the battalions changed as the war progressed, "the paternalistic-deferential relationship became easier to operate". This may not have been entirely the case in $1 / 4^{\text {th }}$ Berkshire (pp.160-1).
} 
$1 / 4^{\text {th }}$ Berkshire therefore went against the trend of increasing influx of Regulars from second to third appointment, the senior Major of 1914 proving a more than capable soldier, the need for stiffening with a Regular never arising. Two of the three Lieutenant-Colonels were replaced, one retired, the other rested, the other being transferred to another command.

\subsection{Senior Officer School}

The three battalion case studies indicate that potential COs did not evolve solely though practical experience, but also through Senior Officer School, where an attempt was made to impart a coherent body of knowledge and assess suitability.

In March 1916, Lieutenant-Colonel R.J. Kentish, ${ }^{176}$ who had been running Third Army School at Flixécourt, initiated CO conferences "for a week at a time, where 20 or 30 COs and senior officers met for discussions". ${ }^{177}$ Lieutenant-Colonel A.C. Johnston, $10^{\text {th }}$ Cheshire, ${ }^{178}$ attended such a conference, albeit with a larger number of attendees (150 officers) at $2^{\text {nd }}$ Army Central School, Wisques, 24-30 December 1916. It comprised a

\footnotetext{
${ }^{176}$ Reginald John Kentish was born in 1876, entering the army rather than the family publishing business, W.H. Hayden. He attended Malvern College, and scraped into RMC with the help of a crammer. He was commissioned in the $1^{\text {st }}$ Battalion Royal Irish Fusiliers in 1897, and had been a Staff Captain in South Africa in 1901; regimental Adjutant; ADC to GOC $2^{\text {nd }}$ Division at Aldershot 1910-11 (where he began actively upon his interest in facilities for physical recreation, which culminated in the setting up of the National Playing Fields Association in 1924); and Brigade Major, $6^{\text {th }}$ London Infantry Brigade 1913-14, in which post he served until 6 September 1914, when he allegedly smuggled himself to his battalion in France. He was promoted to command $1^{\text {st }}$ East Lancashire from 20 June 1915 to 24 September 1915, thence to Third Army School, transferred on 14 April 1916 to command 76 Infantry Brigade, which office he held until transferred as Commandant (Brigadier-General) of Senior Officer School. Opinionated and a thorn in the side of his superiors, it is possible that a critical 16 page report sent to Fourth Army HQ was the trigger for this. He returned after 14 months to the command of 166 Brigade on 4 December 1917, in which post he remained until the Armistice. [B. Kentish, This Foul Thing Called War (Lewes: Book Guild, 1997)].

${ }^{177}$ Kentish, Foul, p.63. He never actually directed these, being promoted to brigade command.

${ }^{178}$ Alexander Colin Johnston, a Regular Lieutenant of the Worcestershire Regiment in August 1914, served as a GSO3 from January to February 1916 and as a Brigade-Major from March to August 1916 . He commanded $10^{\text {th }}$ Cheshire from 28 August 1916 to 13 September 1917, at which date he was appointed to command 126 Brigade until 16 September 1917.
} 
mixture of lectures, ${ }^{179}$ visits to facilities, ${ }^{180}$ and "war games". Johnston placed most emphasis on the conference dialogue at Army HQ: "Where the authorities who are only too anxious to help were able to learn a lot of our troubles and difficulties at first hand, with the result that a lot of useful and helpful things are going to be done at once". ${ }^{181}$

In October 1916 Kentish was sent to Aldershot to establish these conferences in an extended form as Senior Officer School. He recorded that Sir Douglas Haig directly tasked him with this, allegedly stating:

I am sending you back to Aldershot to organise this new School because, judging from reports from my Army Commanders, I learn that Majors and Senior Captains have little knowledge of the duties of a Commanding Officer. To give them this knowledge I am sending them to you, so that when they return they will not only know how to lead their men in the attack but how to get them in the right mood to follow them. I want you to concentrate on leadership and morale and leave the tactical side to your staff. $^{182}$

In late 1917, C.P. Clayton attended the School. ${ }^{183}$ He described the process of selection as follows: "The Colonel says that he has been asked whether he could spare me to go to the senior officers' course". The recommendation therefore came from brigade at least. A

\footnotetext{
${ }^{179}$ Including map reading, bayonet fighting, and intelligence, and an unspecified but "good lecture by Tim Harrington from $2^{\text {nd }}$ Army Staff".

${ }^{180}$ Including $2^{\text {nd }}$ Army Sniping School at Steenvoorde, the Trench Mortar School at Berthen, the Signal School at Zutpeyne and an Engineering Training Ground.

${ }^{181}$ E. Astill, The Great War Diaries of Brigadier General Alexander Johnston 1914-1917 (Barnsley: Pen \& Sword, 2007), p.194-5. Whether these "useful and helpful things" materialised or not is a topic on which the diary is silent.

${ }^{182}$ Kentish, Foul, p.64. Kentish's one published contribution to the early 1917 course was the lecture: 'On the Role and Responsibilities of the Commanding Officer in a Battalion Mess'. This interest may have served Kentish well, as from 1932, when he fell on financial hard times, he took on a rather curious job at the Dorchester Hotel, London. Part of this fell under the heading of procuring affluent guests, but Robert Graves, it was alleged, accused Kentish of being "procurer to the Dorchester Girls", the eight-strong teenage chorus line, a reputation not improved by his clearly identifiable figure portrayed in a salacious novel, Vinegar and Brown Paper, by J.P. Carstairs. [M. Sweet, The West End Front: The Wartime Secrets of London's Grand Hotels (London: Faber \& Faber, 2011), pp.104-5].

${ }^{183}$ Charles Pritchard Clayton was a 29 year-old teacher who had joined the Special Reserve of the Welsh Regiment in August 1914, and in November/December 1916 was Lieutenant-Colonel commanding $2^{\text {nd }}$ Welsh.
} 
friend was also "offered a vacancy" and "finally we decide that we will both accept", ${ }^{184}$ implying that there was no compulsion. ${ }^{185}$

\section{At Aldershot, Clayton found a "merry company":}

The tutors are for the most part colonels who have just recovered or are recovering from wounds. The "pupils" are an odd mixture. There are a few colonels and majors who, like ourselves, have had a long spell in France and are here really for a rest. There are senior Territorial officers who have been on home jobs and are here to get the hang of work on the Western Front, so that they may take their rank out there despite their inexperience. ${ }^{186}$

H. Lloyd-Williams, ${ }^{187}$ who commanded $9^{\text {th }}$ Royal Welsh Fusiliers between 25 April and 27

July 1918, attended the School between 8 October and 12 December 1918 . He described the teaching format: ${ }^{188}$

The school was divided into three groups, each group forming a mess, and in its turn divided into five or six syndicates, each syndicate comprising about sixteen senior officers under a syndicate Commander.

\footnotetext{
${ }^{184}$ C.P. Clayton, The Hungry One (Llandysul: Gomer, 1978), pp.199-200

${ }^{185}$ Lieutenant-Colonel J.L. Jack, $2^{\text {nd }}$ West Yorkshire, declined to attend in January 1917, viewing it as an "infernal nuisance" and was never invited again. [J. Terraine, General Jack's Diary (London: Cassell, 2000), p.191]. Lieutenant-Colonel E.W. Hermon was sent on a Senior Officer's course in France in February 1917, and wrote to his wife: "We have had a poor day again today \& I am afraid unless things brighten up a bit more the course won't have done one much good. I had hoped that I should have picked up a good deal from the other members of the class in conversation but they don't seem to be overflowing with ideas". The following day he wrote: "I pointed out to the powers that be how very stupid it was to send me there just now and so got off it". [A. Nason, ed., For Love and Courage, The Letters of Lieutenant-Colonel E.W. Hermon from the Western Front 1914-1917 (London: Preface, 2008), p.326-7, letters dated 13 \& 14 February 1917]. ${ }^{186}$ Clayton, Hungry, p.200

${ }^{187}$ Hugh Lloyd-Williams, a 25 year-old barrister in August 1914, was commissioned $2^{\text {nd }}$ Lieutenant in the 9th Royal Welsh Fusiliers on 12 September 1914, the battalion he would command in 1918.

${ }^{188}$ IWM Docs 13838 H. Lloyd-Williams, 'Personal Experiences of the Years of the European War', pp. 97100. Major D. Reitz described how: "We started as privates, gradually working our way through the ranks, from section commander to corporal, thence to sergeant, platoon and company commander, and ultimately to O.C. Battalion, in order to acquaint ourselves in in tabloid form with the whole field of infantry work". D. Reitz, Trekking On (London: Faber \& Faber, 1933), p.123
} 
Clayton scorned the subject matter:

The exercise in drill is what I did in the O.T.C. before this was thought of, and on the methods of attack and defence I am afraid that Baxter and I frequently disagree with Kentish and his instructors. We frequently challenge their principles from our experience and have hot discussions. ${ }^{189}$

Lloyd-Williams, in contrast, found that:

The course was thorough and comprehensive and although we were obliged to carry out the smallest degree and detail of work, drill, and so on there was great liberty of action and opinion. The day's work usually commenced with a syndicate discussion and ended with a lecture.

Lloyd-Williams, who described how "everyone worked, everyone played wholeheartedly", ${ }^{190}$ continued that all participants had to pass riding school, drill, bayonet fighting, and climbing high walls; and participated in "flagged attacks and extended order practice, and graduated tactical schemes". These were carried out on the "Hog's Back near Wellington Memorial, around the Royal Pavilion, on Laffan's Plain, the Basingstoke Canal, Crondall Village, where we employed Canadian troops, Ivelety Farm ... Norris' Bridge, and Foresters' Inn, Caesar's Camp, Twezeldown, and Beacon Hill and Longmoor". This speaks to an active and practical training. ${ }^{191}$

\footnotetext{
${ }^{189}$ Clayton, Hungry, p.200

${ }^{190}$ On exercises, Lloyd-Williams noted: "Sumptuous lunches ... so sumptuous on occasions the instructors themselves were unable to maintain an interest in the conferences".

${ }^{191}$ The French army had a similar school system for COs. Lieutenant-Colonel R. Feilding, $6^{\text {th }}$ Connaught Rangers was attached for three weeks in February 1918 to the 'Court Supérieure d'Infanterie', at Vadenay, near Chalons-sur-Marne. [R. Feilding, War letters to a Wife, ed. J. Walker (Staplehurst: Spellmount, 2001), p.154-6]. He described lectures for three hours or more each morning, and visits "to see different Army Schools etc." in the afternoons. Feilding had not attended Senior Officer School at Aldershot, but had attended a five day COs course at Wisques in February 1917. Whether or not he was contrasting the two experiences he wrote: "I am much struck with the thoroughness and efficiency of these Frenchmen, and the serious way - in contrast to ours - that they go about the war. I wonder if they overdo it. But it is an interesting and valuable experience".
} 
Clayton and his compatriot were "not indiscreet and we both finish up with reports which affirm that we are 'recommended for immediate command of a battalion in the field"". ${ }^{192}$ Kentish would travel to France at the end of each course to deliver reports on candidate suitability.

Whilst no records of Senior Officer School survive, it was the practice to publish the lectures as Notes for Commanding Officers. The fourth course, held in the first half of 1917, can be examined in terms of its tutors and participants, details of which are included in the volume. ${ }^{193}$

There were six Instructional Staff, ${ }^{194}$ three Group Commanders, ${ }^{195}$ and 19 Syndicate Commanders, ${ }^{196}$ as well as one Royal Engineer Instructor. They were rich in battle experience. There were 227 attendees, with ranks from Lieutenant to Lieutenant-Colonel, 20 per cent being Dominion officers. ${ }^{197}$ Eight per cent already had experience of command, and clearly part of the School's purpose was to enhance the knowledge/skills of those already in post. All bar four were infantry. ${ }^{198}$

\footnotetext{
${ }^{192}$ Clayton, Hungry, p.200

${ }^{193}$ Notes for Commanding Officers (Aldershot: Gale \& Polden, 1917). The dedication is dated 31 August 1917.

${ }^{194}$ The four key senior staff were: Brigadier-General R.J. Kentish, Commandant; Lieutenant-Colonel L.J. Wyatt, Assistant Commandant; Lieutenant-Colonel A.G. Bayley psc, Chief Instructor; Lieutenant-Colonel G.C. Hamilton, Officer in Charge of Groups. All of these officers had served as COs except Bayley, who had been in staff posts since 5 August 1914. In addition there were and Adjutant and Quartermaster (Captain F.H.H. Thomas) and a Drill Adjutant (Major S.J. Heath).

${ }^{195}$ Lieutenant-Colonels G.E.N. Hill, G.H. Harrison, and L.W. Lucas, all of whom had commanded battalions.

${ }^{196}$ Lieutenant-Colonels H.P.F. Bicknell, R.M. Birkett, M.F.Day, F.G.W. Draffen, R.M. Dudgeon, G.B. Duff, H.A. Fulton, H.V.R. Hodson, C.A. Howard, L.H. Jardine (NZEF), C.H. Jess (AIF), M. Kemp-Welch, S.R. McClintock, L.H. Nelles (CEF), E.H. Norman, R. Oakley, E.G. St. Aubyn, H.I. Storey, and G.K. Sullivan. All had served as battalion COs apart from M.F. Day, whose war had been spent in staff posts.

${ }^{197}$ Twenty-five Canadians, 14 Australians, four South Africans and three New Zealanders.

198 Three were cavalry, and the most junior participant, a Lieutenant, was from a Light Trench Mortar Battery. Fourteen per cent of those in attendance were from a Regular battalion, 10 per cent from a Special Reserve battalion, and 38 per cent each from Service and TF battalions.
} 
Of the British infantry regiments, 146 officers who had no previous experience of command can be followed in terms of whether they subsequently commanded battalions prior to the Armistice, a timespan of a year and a half following completing the course, a period likely long enough for these officers to achieve command if they were going to. Removing those who were subsequently killed, ${ }^{199} 40$ per cent achieved a CO post as Lieutenant-Colonel. Whilst we do not know how many of these men were approved, as was Clayton, the evidence of this course suggests that there was no foregone conclusion from attendance, to the point that an attendee was less rather than more likely to achieve command. The army at this point in the war evidently possessed clear notions as to who should progress to $\mathrm{CO}$ status and was judicious as to who was appointed.

\subsection{Conclusion}

When the different patterns of command in Regular, New Army and Territorial units are examined, it is revealed that the professional soldier kept a strong grip on the command of Regular battalions, making up 93 per cent of commands. Further, there are strong indications that despite the opportunities opening up for more merit-based promotion, regimental and, to a lesser extent, battalion 'particularity' in promotion continued to a considerable degree in Regular units. Patterns of turnover varied from division to division and battalion to battalion; thus $5^{\text {th }}$ Division had a rate of promotion to Brigadier-General three times the average rate, whilst $2^{\text {nd }}$ Hampshire's CO fatality rate scythed through possible promotion candidates.

\footnotetext{
${ }^{199}$ Thirteen attendees who were subsequently killed are excluded from the analysis.
} 
Professional soldiers similarly made up exactly two-thirds of Service Battalion commands, yet these units also showcased the developing merit-based promotion. This is not only exemplified by the two other ranks who rose to command $13^{\text {th }}$ Essex, but also the rising stars of the citizen CO group, who on 29 September 1918 comprised a third of commands. $^{200}$

Battalions with a pre-war identity kept a stronger grip on ownership of command. Professional soldiers made their lowest contribution to command in first-line TF units, just under a third (rising to a half of second-line units), despite the noted inadequacy of a number of TF senior officers of August 1914. There was a less than wholehearted initial commitment to the appointment of younger, active internal replacements in first-line units. Although the TF officer would struggle to achieve senior command, in the first-line Territorial units, half of commands were retained by TF officers of August 1914, although this had dropped to a third by late 1918. The growing contribution of the citizen of August 1914, however, proceeded more slowly and to a lesser extent in the TF, never matching the contribution to Service Battalions.

What proves equally interesting is the examination of those who took temporary command as Majors. These individuals demonstrate evidence of the grooming of promising individuals for command, and the preparation of many of them for this role by Senior Officer School, providing strong evidence of the growing merit-based approach, and the perceived importance of a skills-based approach to battalion command.

${ }^{200}$ See Chapter Six. 


\section{Chapter Five}

\section{"Men to be Followed, Feared and Loved"1 - Command and Leadership}

There is indeed a great art in knowing how to command.

Major-General T.D Pilcher ${ }^{2}$

Watch me and follow my lead.

Gideon commanding the attack on the Midianites

Judges $7: 17$

The duties of a Commanding Officer were set out in King's Regulations. He was responsible for the maintenance of discipline, efficiency, and "proper system", and the health of his troops. He was accountable for stores and arms, issue of supplies, promulgation of orders, and proper application of regimental funds. He was to prevent disputes, was responsible for "the systematic and efficient instruction of officers under his command", and was to bring to the attention of the inspecting general officer those officers "distinguished for proficiency" as well as those who from "incapacity or apathy" were unsupportive of him or "deficient in knowledge of their duties". 3

\footnotetext{
${ }^{1}$ C.E. Montague, Disenchantment (London: Chatto \& Windus, 1922), p.219.

${ }^{2}$ T.D. Pilcher, A General's Letters to His Son on Obtaining His Commission (London: Cassell, 1917), p.55

${ }^{3}$ War Office, The King's Regulations and Orders for the Army, 1912. Reprinted with Amendments Published in Army Orders up to 1 August 1914 (London: HMSO, 1914), p.20-1. First published in 1731, King's Regulations are a collection of orders and regulations in force in the armed services, forming guidance for officers of these armed services in all matters of discipline and personal conduct.
} 
Colonel W.A.B. Dennys (CO $31^{\text {st }}$ Punjabis) noted: "Till I took up my duties ... I had no conception of the many difficulties, responsibilities, and power (for good or bad) that the command of some 1,100 men carries with it". ${ }^{4}$ He described his peacetime duties:

The system of training all the officers, N.C.O.s and men, the issue of all orders to that end (often for a whole year in advance), the supervising of all work undertaken for training in the field, and in the lines, the maintenance of discipline, and a true "esprit de corps", the responsibility of all the finance, the payment of the men, their food and clothing, the annual confidential reports on British and Indian Officers, in fact the proper organisation of the whole machine ... All orders have to issue from the CO; little can be done without them.

Dennys was putting into practice the precepts of Colonel M. Gosset: ${ }^{5}$

The commanding officer of a Battalion is the life and soul of it - he must have his eye on everything, know everyone's wants, and never imagine, because he has established a good system, that it will keep going without a perpetual greasing of the wheels. ${ }^{6}$

Lieutenant-Colonel J.L. Jack, $2^{\text {nd }}$ West Yorkshire, listed the administration-driven daily schedule for a $\mathrm{CO}$ in the trenches of the Western Front. After being woken by his servant at dawn with tea and biscuit:

6 a.m.:- Breakfast; receive the companies' written reports and send my battalion report by orderly to Brigade Headquarters ... 8-1 o'c:- Walk round the companies' trenches accompanied by the adjutant, medical officer, our three orderlies and one bugler. ${ }^{7} 1$ p.m.:- Lunch and two hours' rest. 3 o'c:- Write and despatch to Brigade Headquarters the Situation Report for the day. 4 p.m.:- Tea, after which, except for dinner, there are papers, organisation and other matters to be dealt with till midnight - often later - when I lie down on my bed. ${ }^{8}$

\footnotetext{
${ }^{4}$ W.A.B. Dennys, Some Reminiscences of my Life (Privately printed, 1935), p.22. Born in 1859, William Annesley Burton Dennys had been commissioned into the Wiltshire Regiment but had transferred to the Bengal Staff Corps in 1880, and had been CO 1903-7.

${ }^{5}$ Gossett had commanded $1^{\text {st }}$ Battalion, Dorsetshire Regiment, 1884-1888.

${ }^{6}$ M. Gossett, 'Battalion Command', Royal United Service Institution Journal, 35 (1891), p.475

7 James Lochead Jack was a Captain of $1^{\text {st }}$ Scottish Rifles in August 1914, and commanded $2^{\text {nd }}$ West Yorkshire from 22 August 1916 to 31 July 1917. He was evidently fond of the sound of wind instruments, sending his battalion 'over the top' at Villers-Guislain on 18 April 1917 with a 'Tally-ho' on his hunting horn. [J. Terraine, General Jack’s Diary (London: Cassell, 2000, originally published 1964), p.214].

${ }^{8}$ Terraine, Jack's Diary, p.164
} 
Lieutenant-Colonel A.G. Horsfall, $2^{\text {nd }}$ Duke of Wellington's, echoed this, writing: ““Curse all paper' is the fervent cry of every CO out here", and again: "the Bumf blizzard has commenced to blow in earnest. I have about 5 hours work in front of me answering papers". ${ }^{9}$ Lieutenant-Colonel W. Fraser, 1/6 ${ }^{\text {th }}$ Gordon Highlanders, found that battle increased his administrative tasks: "The worst part of battle is the amount of writing connected with it. Before, orders and instructions by the thousand; afterwards account of the battle, recommendations, etc". ${ }^{10}$ In respect of the competing demands, "sometimes one thinks the job is almost beyond one". ${ }^{11}$

These were the duties, mostly without glory. This chapter examines how the CO commanded and led, and how this was experienced.

\subsection{Leadership and command}

Leadership and command are not the same concept. The relationship between the two is unidirectional - effective leadership makes for more effective command. ${ }^{12}$ In his study of Second World War Australian battalion commanders, Garth Pratten defines command as

\footnotetext{
${ }^{9}$ IWM Docs 14929 'A gentleman at war - Alfred Horsfall through his letters to his wife October 1916October 1917', letters dated 26 December 1916 and 22 February 1917. Alfred Garnett Horsfall, a Regular Captain of the Duke of Wellington's West Riding Regiment in August 1914 commanded $2^{\text {nd }}$ West Riding between 6 December 1916 and 9 October 1917 when he was killed in action at Third Ypres.

${ }^{10}$ D. Fraser (ed.), In Good Company - The First World War Letters and Diaries of the Hon. William Fraser, Gordon Highlanders (Salisbury: Michael Russell, 1990), p.140. William Fraser, a Regular Lieutenant of the Gordon Highlanders in August 1914 commanded 1/6 $6^{\text {th }}$ Gordon Highlanders between 8 May 1917 and 1 March 1918, and $1^{\text {st }}$ Gordon Highlanders from 5 September 1918 to the Armistice.

${ }^{11}$ Fraser, Good Company, p. 188

${ }^{12}$ Nor does either guarantee successful outcome - many things influence outcome on the battlefield that are not within the commander's control.
} 
consisting of "four basic functions: decision-making, control, leadership and resource management". 13

The era lacked a science of leadership, ${ }^{14}$ yet John Bourne remarks: “'Leadership was a concept which the Army was confident it understood", namely: "Courage, Duty and Discipline". ${ }^{15}$ Leadership skills were not taught. Brigadier-General H.W.M. Watson noted: "Before the war the leader obtained leadership by the light of nature ... no help was given ... it was up to the individual". ${ }^{16}$ It was assumed that such skills had been acquired by osmosis, officer candidates developing within the ethos of the public school. ${ }^{17}$

Leadership is "a process of influence to achieve coordination between individuals for the pursuit of mutual goals", ${ }^{18}$ coordination self-evidently being one of the key 'control' issues

13 G. Pratten, Australian Battalion Commanders in the Second World War (Melbourne: Cambridge University Press, 2009), p.17. All the functions described in King's Regulations were 'resource management' issues under this classification.

14 Gosset's Royal United Services Institution lecture, delivered on 13 March 1891, although perhaps remarkable in that the subject was addressed at all, did not kickstart the science. He advocated discipline ("you cannot rule 800 men with rose-water") balanced with praise. He advocated lashings of regimental history, but also good training. Lastly, he recommended devolution of responsibility down the chain of command.

${ }^{15}$ J.M. Bourne, 'British Generals in the First World War' in G.D. Sheffield, ed. Leadership and CommandThe Anglo-American Military Experience Since 1861 (London: Brassey's, 2002), pp. 94-6. An ideal of military leadership was woven into literature and myth. The officer's code as exemplified in the works of Rudyard Kipling emphasised: "Stoicism, self-denial, obedience, loyalty to Regiment and to their men, and adventurousness". [M. Edwardes, 'Oh to Meet an Army Man', in J. Gross ed., Rudyard Kipling: The Man, His Work and his World (London: Weidenfeld \& Nicolson, 1972), p.40; cited in G.D. Sheffield, Leadership in the Trenches: Officer-Man Relations, Morale and Discipline in the British Army in the Era of the First World War (Basingstoke: Macmillan, 2000).]

16 Notes for Commanding Officers (Aldershot: Gale and Polden, November 1918). Watson, a Regular Captain of the King's Royal Rifle Corps in August 1914, commanded 2/4 ${ }^{\text {th }}$ West Surrey from 21 August 1916 to 2 December 1916, and $1^{\text {st }}$ King's Royal Rifle Corps from 23 July 1917 to 23 February 1918.

${ }^{17}$ Which to define requires simply the substitution of the word 'School' for 'Regiment' in the Kipling quote in footnote 15. Even if the Battle of Waterloo was not won on the playing fields of Eton (a remark attributed to the Duke of Wellington, but probably apocryphal), it was assumed that team sports played an important part in the development of this ethos. For a discussion of these ideas, and a review of criticism, see Sheffield, Leadership, pp.43-8; also C. Moore-Bick, Playing the Game - The British Junior Infantry Officer on the Western Front 1914-18 (Solihull: Helion, 2011); and J. Lewis-Stempel, Six Weeks - The Short and Gallant Life of the British Officer in the First World War (London: Weidenfeld \& Nicolson, 2010).

${ }^{18}$ M. Van Vugt, The Nature in Leadership, p.142 
of a unit in combat. A search for the ideal characteristics of leadership is likely a fruitless quest. ${ }^{19}$ Modern psychology rejects the "heroic myth" of the individual with special qualities, noting: "There is no evidence that any particular quality (or combination of qualities) can guarantee success". ${ }^{20}$

In terms of the anatomy of command, a $\mathrm{CO}$ had legal authority granted to him by King's Regulations. $^{21}$ In terms of its physiology, it was the influence that stemmed from his relationships with his subordinates that created the possibility for most effective command outcomes. Garth Pratten, following John French and Bertram Raven, describes the two

http://www.professormarkvanvugt.com/files/Ch5_VanVugt.pdf (accessed 3 October 2012). Van Vugt is a proponent of "evolutionary leadership theory", suggesting that the leadership and followership psychology is shaped as much as any other characteristic by natural selection. He suggests further that warfare is one of "at least six crucial fitness problems in ancestral environments selecting for leadership: (1) finding resources, (2) conflict management, (3) warfare, (4) building alliances, (5) resource distribution, and (6) teaching"; i.e. humans have evolved to accept leadership in certain activities key to survival (p.147).

${ }^{19}$ Gary Sheffield's discussion of officer-man relations and the paternalism-deference exchange reviews leadership characteristics and styles, (Sheffield, Leadership, p. 41), citing the 1927 work of F.C. Bartlett. Van Vugt, (Nature in Leadership, p.142) outlines four major social science theories of leadership: personality (which focusses on particular personality or behavioural characteristics shared by leaders); cognitive (which focusses on the leader's intelligence and experience); situational (which focusses on leadership styles adapted to the maturity of the group); and contingency (which focusses on optimal adaptation to internal/external events).

${ }^{20}$ S.A. Haslam, S.D. Reicher \& M.J. Platow, The New Psychology of Leadership - Identity, Influence and Power (Hove: Psychology Press, 2011), p.199. Italics in original. Sheffield emphasises the paternalismdeference exchange, the officer's first duty being to look after the needs of his men before his own. Paternalism was the basis of the officer's "battle ... for the hearts of his men"; an OR who felt looked-after would "follow him anywhere". Officers had also: "To be both militarily efficient and ... protective of their men"; courageous under fire yet not foolhardy; and their men expected them "to behave in a fitting, gentlemanly manner when out of action". Sheffield quotes an anonymous OR's composite officer which reflects the required contradictions of balancing something akin to a family atmosphere within platoon/company/battalion and the necessity for discipline: "Boyish and middle-aged, cool and reckless, grave and humorous, aloof and intimate; a martinet lapsing into an indulgent father; a thwarter becoming an aider and abetter; an enemy melting into a friend". (Sheffield, Leadership, p.109).

${ }^{21}$ Garth Pratten, (Australian Battalion Commanders, pp.23-4), refers to John French and Bertram Raven's model of leadership "Founded on the exchange of 'social power' - power being defined as the potential to influence others", which describes five bases of social power, the first three of which are: (i) "legitimate power' - the potential for influence derived from being the incumbent office; (ii) 'reward power' - influence from having the capacity to give/withhold reward; (iii) 'coercive power' - influence derived from having the capacity to impose/withhold punishment. This trio describe the legal authority bestowed by King's Regulations. 
most important aspects of this influence as 'expert' power, influence deriving from skill; and 'referent' power, influence deriving from being 'personally liked and respected'. ${ }^{22}$

Both legal authority and the influence granted by expert and referent power are central to 'contingency leadership' theory, which concerns the relationship between leadership and situation favourableness. ${ }^{23}$ Contingency leadership is described in terms of three decreasingly important dimensions: (i) leader-follower relationship; (ii) degree of task structure; and (iii) the leader's power obtained through formal authority. Situations are favourable if all three of these dimensions are high, i.e. if: (i) the leader is accepted and respected by followers; (ii) the task is very structured; and (iii) a great deal of authority and power are formally attributed to the leader.

This model is a good fit to the nature of battalion command, where a high degree of task structure and formal authority are guaranteed. The key to effective leadership therefore lies in developing dimension (i), the key to which is 'referent power'; and enhancing technical skill, i.e. 'expert power', in the execution of dimension (ii), the structured task.

The army put much emphasis on identity, ${ }^{24}$ and the modern psychology of identity leadership' happily concurs. Four matters can be distinguished within the leader-follower relationship which are critical to referent power, all concerning the creation of a shared identity or sense of "we-ness". Firstly, "being one of us", being representative of the group. Secondly, "doing it for us", championing the interests of the group. Thirdly, crafting a

\footnotetext{
22 'Expert power' and 'referent power' are the remaining two bases of social power in the French and Raven model - see footnote 21. (Pratten, Australian Battalion Commanders, p.24)

${ }^{23}$ F.E. Fiedler, Leadership (New York: General Learning Press, 1971).

${ }^{24}$ See Chapter Three section 3.1.2. for a discussion of 'cap badge' issues.
} 
"sense of us", shaping group identity; and fourthly, "making us matter", defining specific 'good things' that the group stands for. ${ }^{25}$

Senior Officer School began to teach battalion leadership formally in late $1916 .{ }^{26}$ The key question to be addressed by a CO, participants were informed, was: "How am I going to make the most of them, and how are they going to make the most of me?"27 It was emphasised that men needed to be "commanded by a man", the italics in the original conveying the notion of an individual with presence. ${ }^{28}$ Six key factors were identified. (i) Courage, which was "essential" (particularly to the sense of "being one of us"). (ii) Knowledge, "combined with imagination, forethought, and common sense". (iii) Demeanour, being "even-tempered throughout - not rattled on a sudden situation". ${ }^{29}$ (iv) Fairness and justice, (paternalism being the cornerstone of "doing it for us"). (v) Civility; and (vi) "Hard work combined with imagination". Senior Officer School was therefore concentrating closely on the first dimension of "contingency leadership". The second and sixth factors, knowledge, hard work and imagination refer to 'expert power', the rest to 'referent power'.

\footnotetext{
${ }^{25}$ Haslam et al, Leadership, Chapters 4 to 7.

${ }^{26}$ A lecture on leadership is absent from Notes for Commanding Officers dated early 1917 (see Chapter Four section 4.4), but one was delivered by Kentish on the October-December 1917 course (IWM Docs $13838 \mathrm{H}$. Lloyd-Williams) and the full version of such delivered by Brigadier-General H.W.M. Watson is included in the November 1918 edition of Notes.

${ }^{27}$ Notes, November 1918, p.2

${ }^{28}$ Notes, November 1918, p.2. Watson was fascinated by having found a Private who could not remember his CO's name. He was absolutely right to be alarmed about this in terms of the importance of 'we-ness'.

${ }^{29}$ With the CO thinking: "This is a matter of course, which I expect as a common occurrence. I'll just think about it, refrain from trying to do everyone's job - apply my knowledge, and the whole thing will go well". Notes, November 1918, p.4
} 
A CO could not 'know' all the men in his battalion. ${ }^{30}$ The leader-follower relationship had therefore to be managed through others, and Senior Officer School propounded the view that "one of the most important things is to get a strong side of officers". ${ }^{31}$ The interactive nature of command in both transmitting knowledge and values in crafting a "sense of us" was clearly acknowledged:

It is a good plan to consult your section commanders when you have any scheme on foot. Sometimes you get valuable ideas from them, and when they know that they have, so to speak, a share in the business, they will go all out to make your plans successful. ${ }^{32}$

Finally, it was recognised that identity, a "sense of us", was created and skill within task structure was enhanced through activity. Lieutenant-General Sir Ivor Maxse,${ }^{33}$ lecturing at the School, was clear as to what developing this unified purpose entailed: "There is only one known method of creating leaders of men and commanders whom men will follow. It consists in giving the leader his own men to train". ${ }^{34}$ Lieutenant-Colonel H.M.B. de Sales la Terrière, $\mathrm{CO} 9^{\text {th }}$ Essex, claimed ownership of this and the responsibility it entailed, expressing his "pride and anxiety, anxiety for the actual lives of the men whom you have personally trained for the sole purpose of beating the enemy". 35

\footnotetext{
${ }^{30}$ From neuropsychological data, the maximum social network size for humans is approximately 150 individuals, also known as 'Dunbar's number'. (Van Vugt, Nature in Leadership, p.147).

${ }^{31}$ Notes, November 1918, pp.4-6

${ }^{32}$ Notes, November 1918, 'The Battalion Commander's Conference', pp.41-9

${ }^{33}$ Inspector General of Training from June 1918.

${ }^{34}$ It is interesting to compare these ideas with more modern concepts of battalion leadership. Appendix Four sets out a resumé from The Battalion Commander's Handbook, (Pennsylvania: US Army War College, 1996). The overlap is clear.

${ }^{35}$ IWM Docs 14737 H.M.B. de Sales la Terrière, p. 367-8. Howard Montague Bulmer de Sales la Terriere was a Special Reserve Lieutenant of $5^{\text {th }}$ King's Royal Rifle Corps in August 1914. He commanded $9^{\text {th }}$ Essex between 15 October 1917 and 28 April 1918, resuming command just prior to the Armistice.
} 
Brigadier-General R.B. Bradford left rough notes on his view of the science of battalion command: ${ }^{36}$

\begin{abstract}
Army same as any business concern ... Leadership - ability to make comrades follow you. Within power of everyone to become a Leader. Ability to appreciate requirements of human nature ... Power \& ability to set example to subordinates. Knowledge. Determination \& intensity of purpose. Optimistic and enthusiastic. Look after men's comfort \& welfare ... Justice. Friend as well as leader. Fitness \& Endurance. Courage. Cheerfulness. ${ }^{37}$
\end{abstract}

Bradford, his words astonishingly 'modern', understood leadership very well. He could not have demonstrated a better grasp of the 'leader-follower' relationship, 'crafting a sense of us', and 'making us matter', than in his welcome speech to men newly arrived from England:

Most of you will have heard something of our Battalion. It has a great reputation. That reputation is not built up by one or two flash-in-the-pan incidents. It has been built up by the hard, honest and soldierly conduct of the men at all times, and by their skill and pluck in action ... Our battalion is universally respected and envied, so you see a great responsibility rests with you. You have got to help us maintain, and even increase, our present efficiency ... We are all working for the same purpose, the defeat of the enemy, and we must work together, each for each, and all for each.

Bradford did not need to appeal to a regimental history few might care to make any identification with. ${ }^{38} \mathrm{He}$ knew that binding men to the identity and shared purpose of the unit in the present was all that was necessary. ${ }^{39}$

\footnotetext{
${ }^{36}$ Roland Boys Bradford was a $2^{\text {nd }}$ Lieutenant of $2^{\text {nd }}$ Durham Light Infantry in August 1914. He commanded $1 / 9^{\text {th }}$ Durham Light Infantry between 15 September 1916 and 5 November 1917.

${ }^{37}$ Anonymous, Brigadier-General R.B. Bradford, V.C., M.C. and His Brothers (Newport: Ray Westlake, n.d.), pp.95-6

${ }^{38}$ The Senior Officer School leadership lecture specifically encouraged COs to do exactly this at this point. Lieutenant-Colonel S.E. Norris, a Regular Captain of the Liverpool Regiment in August 1914, took over the severely depleted $1^{\text {st }}$ Liverpool on 20 August 1918: "I was told that a draft of 20 officers and 750 other ranks was on its way to bring the battalion up to strength, and that I should be given four days to reconstruct and get ready to go into the line. The draft, which arrived a few hours after I had taken over command, consisted of Manchester Territorials, all thoroughly disconcerted at being sent to a strange unit instead of their own. I remembered my regimental history, and this gave some hint of the best thing to do in the big task of pulling
} 
The remainder of this chapter examines the experience of command and hence the key aspects of the 'leader-follower relationship'.

\subsection{The experience of command - the perspective of the other ranks}

Other ranks (ORs) wrote infrequently about their COs, predictably writing more about their company and platoon commanders. Sergeant J.F. Lucy, $2^{\text {nd }}$ Royal Irish Rifles, the author of a well-regarded memoir, hardly mentions his COs, even though he served with battalion HQ. ${ }^{40}$ A simple comment is sometimes proffered. Private R.H. Sims, $1 / 4^{\text {th }}$ Royal Sussex wrote: "I would do anything for our colonel as he is a real gentleman \& leader of men $\&$ is liked by all ranks". ${ }^{41}$ Private G.R. Husbands, $16^{\text {th }}, 17^{\text {th }}$ and $1 / 8^{\text {th }}$ Sherwood Foresters, in one of the most detailed and extensive OR memoirs, makes scant reference to his COs, and only two analytic comments. He viewed, at least initially, battalion HQ as comprising "the Olympians", and although this remark is undoubtedly ironic, it effectively conveys distance. ${ }^{42}$ Even in September 1917, when he joined $1 / 8^{\text {th }}$ Sherwood Foresters, he wrote of Lieutenant-Colonel J.E. Blackwall: "So little did I see of the CO ... that I am not

\footnotetext{
the battalion together again. I assembled the whole of the new officers and men and told them how closely the King's and Manchester were related, in addition to their recruiting areas being neighbours in South Lancashire. How, in 1758, the 2nd King's was constituted a separate regiment and became the 63rd Foot, the 63rd Foot now being the 1st Battalion, The Manchester Regiment. Instead of being drafted, as they imagine to a strange regiment, they were simply coming back home again, and the old 8th Foot welcomed them back as the descendants of its 2nd Battalion which went away so many years before. Before I had spoken many minutes I could see the men were thoroughly interested. The impression my remarks made was profound, and company commanders told me later that when censoring letters home they noticed that nearly every man mentioned the incident. The new officers and men settled down quietened contentedly, and in a very short time the 1st King's was again an effective fighting battalion”. E. Wyrall, The History of the King's Regiment (Liverpool) 1914-19 (London: Arnold, 1928-1935), p.347

${ }^{39}$ Note his use of the words 'our', 'us' and 'we'. Lieutenant-Colonel H.F.W. Bircham, $2^{\text {nd }}$ King's Royal Rifle Corps, also used the 'we' word in his address to new arrivals: "We are a very happy crowd. Good soldierly qualities are essential, however, and I shall expect all of you to help keep our reputation up". [G.E.M. Eyre, Somme Harvest (London: London Stamp Exchange, 1991), p.17]. Not only was he creating a sense of shared identity, he was 'making us matter', defining the good things the battalion stood for.

${ }^{40}$ J. Lucy, There's a Devil in the Drum (Uckfield: Naval and Military, 1992 - originally published 1938).

${ }^{41}$ IWM Docs 7118 R.H. Sims papers, 16 August 1917, quoted in Sheffield, Leadership, p.95

${ }^{42}$ G.R. Husbands (J.M. Bourne and B. Bushaway, eds), Joffrey's War: A Sherwood Forester in the Great War (Nottingham: Salient Books, 2011), p.60
} 
even positive now that I have the name correctly", ${ }^{43}$ and although he described him as "competent and well-liked", he thought he was not "a "character"”. 44

The distance between Private and CO could be a long one. Private R. Latham of $1 / 5^{\text {th }}$ London Regiment, noted of his first $\mathrm{CO}$, the Earl of Cairns, that he "knew him vaguely as the old man, the omnipotent one, who lived quite comfortably somewhere in the rear". 45 Private F. Lindley, $14^{\text {th }}$ York and Lancaster, described Lieutenant-Colonel W.B. Hulke as “a very unapproachable man. You couldn't get near him". ${ }^{46}$ Degree of distance was, however, up to the CO concerned. Lieutenant-Colonel G.S. Hutchinson believed in getting to know key ORs "individually, just for what (they were) worth. I tested them - a walk here, ten minutes and a cigarette there; the lad by himself, not in the artificiality of the presence of a corporal, or their comrades - I heeded them to do my will: I needed them to do my will". 47

Private F. Richards, Royal Welsh Fusiliers, refers to three COs in his pre-war memoirs. The issue of the enforcement of discipline figures largely in his accounts. Early in his

\footnotetext{
${ }^{43} \mathrm{He}$ was in fact correct.

${ }^{44}$ Husbands, Joffrey's War, p.463. John Eaton Blackwall was a Territorial Major of $1 / 6^{\text {th }}$ Sherwood Foresters in August 1914, and commanded the $1 / 8^{\text {th }}$ Battalion between 15 October 1915 and 14 March 1918, when he was sent home to the UK where he later commanded $51^{\text {st }}$ Graduated Battalion of the Royal Warwickshire Regiment.

${ }^{45}$ Quoted in K.W. Mitchinson, Gentlemen and Officers (London: Imperial War Museum, 1995), p.59. Wilfrid Dallas Cairns, $4^{\text {th }}$ Earl Cairns, was commanding $1 / 5^{\text {th }}$ London at the outbreak of war and continued until invalided on 16 March 1915 after 136 days on active service.

${ }^{46}$ J. Cooksey, Barnsley Pals (London: Leo Cooper, 1986), p.88. Walter Backhouse Hulke was a retired Regular Major in August 1914. He commanded $14^{\text {th }}$ York and Lancaster between 9 July 1915 and 16 February 1918, being promoted to command of 115 Brigade on 16 April 1918. His brother, Lewis Iggleden Backhouse Hulke, (a Regular Major of $2^{\text {nd }}$ Buffs in August 1914), commanded $3^{\text {rd }}$ Yorkshire Light Infantry between 29 January 1917 and the Armistice.

${ }^{47}$ G. Seton, Footslogger (London: Hutchinson, 1933), p.220. Graham Seton Hutchinson had retired from the King's Own Scottish Borderers in 1913, re-joining $2^{\text {nd }}$ Argyll and Sutherland Highlanders before being posted to the Machine Gun Corps, where he rose to battalion command.
} 
career he fell foul of his CO, Lord Mostyn. ${ }^{48}$ He described being dealt with "coldly" and feeling a sense of "injustice". ${ }^{49}$ His second CO, the Hon. R.H. Bertie, was "too much of a martinet to be greatly beloved by the rank and file", a $\mathrm{CO}$ who punished men "to the extreme limits of King's Regulations". ${ }^{50}$ Of his third CO, Lieutenant-Colonel H.T. Lyle, he states in contrast: "Even the hard cases, who could not keep out of trouble if they tried, admitted it was impossible to have a better commanding officer". ${ }^{51}$ A sense of fair play was important. Back with his old battalion at the outbreak of war, the same themes emerged. "Our Colonel was very strict but a good soldier", ${ }^{52}$ Richards noted of his first wartime CO, Lieutenant-Colonel H. Delme-Radcliffe. ${ }^{53}$ Being a "strict disciplinarian" was not only accepted from a well-respected CO, it was seen as important - it crafted identity.

What constituted a 'good soldier' is clarified in Richards' discussion of Lieutenant-Colonel C.H.R. Crawshay, his CO throughout the Somme battle, who:

Proved to be the best we ever had. He was universally liked by everyone, a stickler for discipline, and when in the line, no matter what conditions were, was always visiting the front-line trenches and seeing things for himself. He had a cheery word for everyone and was as brave as they make them. ${ }^{5}$

\footnotetext{
${ }^{48}$ F. Richards, Old Soldier Sahib (Uckfield: Naval and Military Press, 2003, originally published 1936), p.50. The CO was the Hon R. H. Lloyd-Mostyn, a Major of the $4^{\text {th }}$ Royal Welsh Fusiliers, and a retired $2^{\text {nd }}$ Lieutenant from the $23^{\text {rd }}$ Foot.

${ }^{49}$ Richards, Sahib, pp.58-9

${ }^{50}$ Richards, Sahib, p.149. Reginald Henry Bertie retired in 1904 and played no part in the Great War.

${ }^{51}$ Richards, Sahib, p.273. Hugh Thomas Lyle retired in 1907, but commanded $8^{\text {th }}$ Royal Irish Rifles from 29 September 1914 to 19 September 1915, surrendering command before the battalion went on active service, and $17^{\text {th }}$ Royal Irish Rifles, a reserve battalion, from 12 November 1915 until its absorption within the $3^{\text {rd }}$ Battalion in May 1918.

${ }_{52}^{52}$ F. Richards, Old Soldiers Never Die (London: Faber, 1965, originally published 1933), p.31

${ }^{53}$ See Chapter Three section 3.3.6 and Appendix Three for further discussion of Delme-Radcliffe.

${ }^{54}$ Richards, Old Soldiers, p. 180. Codrington Howard Rees Crawshay, aged 33 at the time of the Somme offensive, was a Regular Captain of the Royal Welsh Fusiliers in August 1914. Having previously served as a Brigade-Major, he commanded from 14 June 1916 to 25 January 1917, when he was wounded, never to return to command.
} 
Private G. Eyre, $2^{\text {nd }}$ King's Royal Rifle Corps, valued Lieutenant-Colonel H.F.W.

Bircham's paternalism, lack of distance and courage, and linked these characteristics directly to effectiveness:

A great chap. No wonder every man in the Battalion thinks such a lot of him. Ever careful of the men's comforts, thoughtful for their well-being, foremost in action, always accessible. The ideal C.O. ... able to call on his men for any effort required of them, firing them with his example. The Battalion under his command had become a first-class fighting machine. ${ }^{55}$

Richards regarded his last CO, Lieutenant-Colonel C.C. Norman, as "a very efficient man". ${ }^{56}$ Similarly, Private W.L. Andrews, $1 / 4^{\text {th }}$ Black Watch, wrote of Lieutenant-Colonel G.A.McL. Sceales:

We saw at once Colonel Sceales was a real soldier. He had not been with the battalion a day before every man knew it. His quiet efficiency was felt in every section, and under his leadership our poor battered old battalion was once more made fit to fight. He was big in every way, a little ragged, and deliberate in speech. He made sure of things. Above all, he was just. $^{57}$

He later commented: "We had seen much of Regular officers, and we believed in them.

Our own Colonel, a regular, was stern and unbending, for it was better so, but he was also just, efficient, and proud of the battalion". 58

\footnotetext{
${ }^{55}$ Eyre, Somme Harvest, pp.120-1

${ }^{56}$ Richards, Old Soldiers, p. 299. Richards was not the only person who thought thus. Compton Cardew Norman, a Regular Captain of the Royal Welsh Fusiliers in August 1914 had previously commanded $15^{\text {th }}$ Royal Welsh Fusiliers from 19 September 1916 to 31 July 1917, being wounded on the opening day of Third Ypres; $2 / 7^{\text {th }}$ Durham Light Infantry from 28 January 1918 to 2 July 1918 ; and $17^{\text {th }}$ Royal Welsh Fusiliers from 5 July 1918 to 5 September 1918.

${ }^{57}$ W.L. Andrews, Haunting Years (London: Hutchinson, 1930), p.165. Andrews, later knighted, was a luminary of Northern newspapers, finishing his career as editor of the Yorkshire Post, and was a founder member of the Press Council. Later commissioned, Andrews worked in the battalion Orderly Room, and hence was a close observer of his CO. George Adinston McLaren Sceales was a Regular Captain of the Argyll and Sutherland Highlanders in August 1914, and commanded 1/4 ${ }^{\text {th }}$ Black Watch between 1 December 1915 and 28 October 1917.

${ }^{58}$ Andrews, Haunting Years, p. 182
} 
Sceales' efficiency was achieved through being a "master of method". ${ }^{59}$ Leading Seaman J.

Murray of Hood Battalion also appreciated Lieutenant-Commander A. Asquith's mastery

of method in the attack on Gavrelle, 23 April 1917:

The instruction was that we were not to move until the barrage had lifted off the German front line. Anyone knows to wait until the barrage lifts and walk 400 yards would be murder. Asquith, instead of waiting till the barrage lifted, took us forward to about within 50 yards of the barrage, and we were on top of his line before Jerry knew anything about it. We men of the Hood who survived the battle owe our survival to Asquith. ${ }^{60}$

Private W.L. Andrews had been convinced early on by his first CO Lieutenant-Colonel H. Walker "that to run the battalion on strict military lines would be first-class business efficiency, as indeed it would". ${ }^{61}$ He meant practical efficiency, however, and some aspects of efficiency were viewed as entirely unnecessary. Thus Private A. Lambert, $1^{\text {st }}$ Honourable Artillery Company, noted with disgust the martinet CO: "Every conceivable kind of 'posh' must happen, and some battalion commanders would have ordered their men's memories to be thoroughly scoured if it had been possible". ${ }^{62}$ Private G.R. Husbands noted of the formerly respected Lieutenant-Colonel N. Houghton that he had "fallen into the favourite notion of the military mandarins' mind - that 'spit and polish' was the prime military virtue". ${ }^{63}$

\footnotetext{
${ }^{59}$ Andrews, Haunting Years, p. 249

${ }^{60}$ IWM 15592 (Sound Archive) Interview with J. Murray, reel 41. [Quoted in: K. Tallett \& T. Tasker, Gavrelle (Barnsley: Leo Cooper, 2000), p. 36-7]. Arthur Asquith, the third son of Prime Minister Herbert Asquith, had been commissioned Sub-Lieutenant in the Royal Naval Division, which had been formed out of surplus navy personnel in 1914. He commanded Hood Battalion from 22 April to 16 December 1917.

${ }^{61}$ Andrews, Haunting Years, p.95. Harry Walker was commanding $1 / 4^{\text {th }}$ Black Watch at the outbreak of war until he died of wounds on 27 September 1915.

${ }^{62}$ A. Lambert, Over the Top - A 'P.B.I' in the H.A.C. (London: John Long, n.d.), p.69

${ }^{63}$ Husbands, Joffrey's War, p.400. Noel Houghton, a solicitor in August 1914, commanded $16^{\text {th }}$ the $17^{\text {th }}$ Sherwood Foresters between 4 February 1917 and 10 June 197, and then the $16^{\text {th }}$ Battalion between 17 August and 13 September 1917, on which day he was killed in action outside battalion HQ at Shrewsbury Forest, Ypres.
} 
Private H.S. Clapham, $1^{\text {st }}$ Honourable Artillery Company, valued Lieutenant-Colonel E. Treffry's ability in 'doing it for us', demonstrated in his facility to 'play' Brigade in both a protective and acquisitive sense: "The 'Old Man' came round the first evening to see how we were getting on. He's a jolly good sort and quite capable of keeping up our end, as well as his own, with the powers that be". ${ }^{64}$

The protection of the soldier from unfair demands was another demonstration of paternalism. ${ }^{65}$ Gary Sheffield highlights one CO putting his career in jeopardy in the service of protecting his battalion. On the Somme in September 1916, Lieutenant-Colonel H. Fargus, $1^{\text {st }}$ Duke of Cornwall's Light Infantry, "reported his nominally Regular battalion as 'unfit to go into action'. Two hundred men were sick, largely because of the poor conditions of their trenches and a logistic breakdown" ${ }^{66}$ Fargus was a substantive Lieutenant-Colonel, and may have feared the consequences less than a man of acting or temporary rank, but to take such a stand was, as Lieutenant-Colonel E.M. WoulfeFlanagan, $1^{\text {st }}$ East Surrey, a fellow $5^{\text {th }}$ Division CO noted, an act of "great moral courage". 67

\footnotetext{
${ }^{64}$ H.S. Clapham, Mud and Khaki (London: Hutchinson, 1930), p.46. In terms of being "old,” Edward Treffry was born in 1869, and hence was 45. He was the battalion's senior Major in August 1914, and was an excolonial official. A.O. Pollard, also an OR in the same battalion, noted "I think we owe more than we appreciate to Colonel Treffrey", describing the "tactful way" he handled his command, and his protectiveness: "He insisted on our being broken in by degrees". [A.O. Pollard, Fire-Eater (Uckfield: Naval \& Military, n.d.), p.39].

${ }^{65}$ Perhaps no better statement of the experience of paternalism is that of Private R. Blatchford of the Dublin Fusiliers from his service in the early 1870's: "We loved Old Paddy, as we called the Colonel, like a father". [R.P.G. Blatchford, My Life in the Army (London: Clarion Press, 1910), p.90].

${ }^{66}$ Harold Fargus was a Regular Major of the Duke of Cornwall's Light Infantry in August 1914, and commanded the $1^{\text {st }}$ Battalion between 20 July 1916 and 10 June 1917, becoming Brigadier General 125 Brigade later that month.

${ }^{67}$ Sheffield, Leadership, p.83, citing E.W. Flanagan to J.H. Edmonds, 17 Nov 1935, TNA CAB45/133. Edward Martyn Woulfe-Flanagan had been a regular Captain of $1^{\text {st }}$ East Surrey, and commanded the battalion between 26 June 1916 and 17 July 1917. Similarly, Lieutenant-Colonel A.J.E. Sunderland, commanding $2^{\text {nd }}$ Devonshire on 24 October 1916, reported to brigade that "he could not carry out the attack, the men being utterly exhausted. Eventually it was decided to abandon the attack". [C.T. Atkinson, The Devonshire Regiment 1914-1918 (London: Simpkin, Marshall, Hamilton, Kent \& Co, 1926), p.190].
} 
Other ranks, where they wrote about their $\mathrm{CO}$ therefore seemed to value much the same things that Senior Officer School was teaching: courage, knowledge and skill which protected lives, fairness, paternalistic care, and discipline fairly applied.

\subsection{The experience of command - the battalion officer's perspective}

$2^{\text {nd }}$ Lieutenant Arthur Behrend defined the essence of the CO: "The Colonel is of course the mainspring of the battalion, the man who above all others has the power to set its standards, mould it to his shape, and make or unmake its happiness", ${ }^{68}$

\subsubsection{Paternalism}

There was no less need for the $\mathrm{CO}$ to demonstrate paternalism than any other officer. Lieutenant-Colonel H.M.B de Sales la Terriere, $9^{\text {th }}$ Essex, wrote: “An officer must at all times see to the comfort of the very least of his men before he looks after his own". 69 Lieutenant-Colonel W. Fraser, $1 / 6^{\text {th }}$ Gordon Highlanders viewed his men as: "Such children ... one feels a sort of personal responsibility for every one of them" ${ }^{70}$ Officers recognised and valued this attitude in a CO. The $13^{\text {th }}$ Royal Fusiliers, commanded by Lieutenant-Colonel R.A. Smith, found themselves struggling with trench foot and a dearth of dry socks in the aftermath of Third Ypres. Lieutenant G. Chapman recorded:

\footnotetext{
Lieutenant-Colonel J.H. Patterson, who had commanded the Zion Mule Corps on Gallipoli, demonstrated his "we-ness" with his Jewish $38^{\text {th }}$ Battalion London Regiment by offering his resignation in the UK when the battalion was denied kosher food, and then on active service in Palestine when his Jewish soldiers were discriminated against in hospital. [J.H. Patterson, With the Judeans in the Palestine Campaign (London: Hutchinson, 1922), p.40 and p.169]. Others proved too fearful to do this. Simon Robbins notes how Lieutenant-Colonel H.H.S. Morant (a Depot Major $10^{\text {th }}$ Durham Light Infantry) "admitted frankly after the war that he 'only renewed the attack' on Geudecourt in September 1916 'to save my reputation' and because he was 'more frightened of my superiors than even of the Germans". ${ }^{67}$ [S. Robbins, British Generalship on the Western Front 1914-18: Defeat Into Victory (Abingdon: Frank Cass, 2005), p.9, quoting Brigadier H.H.S. Morant to Edmonds 2 April (1930), TNA PRO CAB45/136].

${ }^{68}$ A. Behrend, Make Me A Soldier - A Platoon Commander in Gallipoli (London: Eyre \& Spottiswoode, 1961), p. 26. Behrend was a TF officer.

${ }^{69}$ IWM Docs 14737 H.M.B. de Sales la Terriere.

${ }^{70}$ Fraser, Good Company, p.133
} 
Now, thanks to salvage, we acquired some thousands of pairs of unauthorized socks. The colonel himself took the lead. Pipe in mouth he might be seen, hopping carrion-crow-wise from body to body ... returning home towards lunch time with his runner, their arms full of necessaries for the battalion. ${ }^{71}$

Looking after others' needs before one's own could be dangerous. Lieutenant-Colonel G.L.B. Du Maurier, $3^{\text {rd }}$ Royal Fusiliers, was killed at the doorway of the house that was his battalion HQ on 9 March 1915: "He had just ordered everyone out and into dug-outs outside and was waiting ... for his Sergeant-Major to report that everyone was in safety before he took cover himself". ${ }^{72}$

\subsubsection{Popularity}

Gary Sheffield has noted that: "Popular, paternal commanding officers were not necessarily efficient soldiers". ${ }^{73}$ He cited the example of Sir G. McCrae, $16^{\text {th }}$ Royal Scots, who, despite being "personally gallant and always efficient, and his men were devoted to him", (high referent power), showed poor leadership in action, (low expert power), and was sacked. ${ }^{74}$ Lieutenant-Colonel E.W. Hermon, $27^{\text {th }}$ Northumberland Fusiliers, ${ }^{75}$ noted

\footnotetext{
${ }^{71}$ G. Chapman, A Passionate Prodigality (London: Mayflower-Dell, 1967), p.169. Robert Arthur Smith, a citizen an August 1914, commanded $10^{\text {th }}$ Royal Fusiliers from 25 April to 16 August 1917, and $13^{\text {th }}$ Royal Fusiliers from 30 September 1917 to the Armistice. In April 1918 Chapman noted the CO of an unnamed Regular battalion being removed due to 200 cases of trench foot (p.192). Major-General H. Bruce-Williams described R.A. Smith as "a bank clerk by profession, a born soldier (and heavy drinker!) and he led (not followed) his men. They would follow him anywhere". (H. Bruce-Williams to J.H. Edmonds, 10 November 1937, TNA CAB 45/187).

${ }^{72}$ C. Davison (ed.), The Burgoyne Diaries (London: Thomas Harmsworth, 1985), p.139. Guy Louis Busson du Maurier was commanding the $3^{\text {rd }}$ Battalion at the outbreak of war. Son of the writer George du Maurier and brother of the actor Gerald, he was also the author of the play An Englishman's Home (1909), an example of pre-war invasion literature. He was guardian to the Llewellyn-Davies boys who inspired J.M. Barrie in writing Peter Pan, and uncle to the writer Daphne du Maurier.

${ }^{73}$ Sheffield, Leadership, p.95. Popularity could be courted at the expense of discipline. A balance clearly existed between 'referent' and 'expert power' - a less popular CO with high 'expert power' was not necessarily viewed as a bad CO. (Pratten, Australian Battalion Commanders, p.116).

${ }^{74}$ Sir George McCrae was a retired Territorial Colonel of the Royal Scots in August 1914, and the $16^{\text {th }}$ Battalion became known as "McCrae's Own". He commanded from 15 December 1914 to 25 November 1916.
} 
that Lieutenant-Colonel J.M. Prior of the $24^{\text {th }}$ "has a very strong 'hail-fellow-well-met' sort of personality (and) an unlimited capacity for whisky", which no doubt made for a certain popularity but was not "altogether an asset in a Battalion". ${ }^{76}$ Popularity itself did not equate with referent power.

Some officers, notably youthful subalterns, experienced the same sort of remoteness from their CO as did ORs. In $1 / 4^{\text {th }}$ East Lancashire, $2^{\text {nd }}$ Lieutenant A. Behrend observed of his CO: "To most of us subalterns he seemed remote and unbending". ${ }^{77}$ Similarly $2^{\text {nd }}$ Lieutenant E C. Blunden noted of Lieutenant-Colonel H.J.M. Grisewood, $11^{\text {th }}$ Sussex: "I seldom rose to the eminence of conversation with him". ${ }^{78}$

Captain G.A. Burgoyne, serving with the $2^{\text {nd }}$ Royal Irish Rifles in Flanders, 1914-1915, ${ }^{79}$ found Lieutenant-Colonel J.W. Alston less remote. ${ }^{80}$ He described him as "a charming gentleman", ${ }^{81}$ but it was Major A.H. Festing, second-in-command, whom he identified as possessing 'referent' power:

\footnotetext{
${ }^{75}$ Edward William Hermon was a retired Captain of $7^{\text {th }}$ Hussars in August 1914, and commanded $27^{\text {th }}$ Northumberland Fusiliers from 13 August to 14 October 196, and $24^{\text {th }}$ Northumberland Fusiliers from 26 October 1916 to 9 April 1917, when he was killed in action at Arras.

${ }^{76}$ A. Nason (ed.), For Love and Courage - The Letters of Lieutenant Colonel E.W. Hermon from the Western Front 1914-1917 (London: Preface, 2008), p.303, letter dated 4 November 1916. Joseph Merriman Prior, a haulage contractor in August 1914, commanded $24^{\text {th }}$ Northumberland Fusiliers from 1 July to 26 October 1916.

${ }^{77}$ Behrend, Soldier, p.26. The CO was Lieutenant-Colonel F.D. Robinson, a notable peacetime solicitor (Carr \& Robinson of Blackburn). Fifty-five years old, he lasted 66 days on Gallipoli before returning home to command the $3 / 4^{\text {th }}$ Battalion.

${ }^{78}$ Blunden, Undertones, p.10. Harman Joseph Mary Grisewood, a retired Lieutenant of the $4^{\text {th }}$ Hussars in August 1914, commanded $11^{\text {th }}$ Sussex from 31 July 1915 to 15 July 1916, and $17^{\text {th }}$ Manchester between 15 July and 3 September 1916.

${ }^{79}$ Late Dragoon Guards.

${ }^{80}$ James William Alston had been $3^{\text {rd }}$ senior Major in the $1^{\text {st }}$ Royal Irish Rifles in August 1914, and found himself the third Lieutenant-Colonel to command the $2^{\text {nd }}$ Battalion on 25 November 1914, a command he held until he was killed by sniper's bullet aimed at his trench periscope, hitting him deflected off a sandbag, on 15 April 1915.

${ }^{81}$ Davison, Burgoyne, p.179
} 
Festing all the men love; he's so cheery and hearty, but he can damn 'em too, as they know; but they all understand he'd never leave them in the lurch, and that's the sort of officer men like to follow, and will always follow. ${ }^{82}$

Lieutenant-Colonel C.B. Benson took over $1 / 6^{\text {th }}$ London in January 1918 and made the most of personal charm. He disguised his badges of rank and visited his new battalion and "without disclosing his identity, chatted and joked freely with officers and men, in such a manner that when, later, it was learned that he was to command them all felt instinctively that it had a friend". In post:

Every day by some act or decision it became clearer that the new Commanding Officer was someone who was watching their every interest, their comfort, their leisure, and their training. He expected and received immediate and implicit obedience to his commands, not because of the military discipline that required it, but because he knew, and his officers learned, that he never gave an unnecessary order. In a short time he became unquestionably the most popular man in the battalion, and his closest companions soon came to love him. Gay, but never irresponsible, strict, but rarely stern, he led as much as commanded, and by his human sympathy won a place in everybody's heart. $^{83}$

At rest, Lieutenant Sydney Rogerson wrote of Lieutenant-Colonel J.L. Jack, $2^{\text {nd }}$ West Yorkshire: "The Colonel was able to set an example both of relaxation in play and of concentration in battle" ${ }^{84} 2^{\text {nd }}$ Lieutenant E.C. Vaughan valued the same in Lieutenant-

\footnotetext{
${ }^{82}$ Davison, Burgoyne, p.25. Arthur Huskyns Festing was a Captain in the Reserve of Officers in August 1914, a brevet Major who had earned a DSO in South Africa. He transferred to the $1^{\text {st }}$ Battalion and died on 15 April 1915. "He was lying wounded in a German trench and refusing to be taken prisoner he blew his brains out. A brave officer and fine soldier", Burgoyne wrote (p. 18).

${ }^{83}$ E.G. Godfrey, The Cast Iron Sixth (Uckfield: Naval \& Military, 2001), p.152. Charles Bingley Benson was a Captain of the Reserve of Officers, Oxfordshire and Buckinghamshire Light Infantry in August 1914, and commanded $2 / 6^{\text {th }}$ London from 24 September 1917 until the end of January 1917 when it merged with the $1 / 6^{\text {th }}$ Battalion which he commanded until the Armistice.

${ }^{84}$ Terraine, Jack's Diary, p.14. Rogerson had much else to say on the subject of Jack: “'A regular soldier of the best type' is the phrase which comes nearest to describing him, but it is inadequate. As punctilious on the parade ground has he was regardless of his safety and unsparing of his energy in action, he had other and rarer qualities. Something of a martinet, and apt to be querulous on occasions, he was at the same time a real friend to his officers and, through them, to his men. In all ways he set us an example, but if asked to name his peculiar characteristic, I should say it was his determination, from which I never saw him relax, to keep up at all times and at all costs proprieties of the old life of peace. 'There's no need to live like a pig even though
} 
Colonel H.T. Dobbin, $1 / 8^{\text {th }}$ Warwickshire, who, when the battalion was having "a cheery time sliding and playing the fool" by the Ypres canal in January 1917, "was one of the cheeriest of the crowd". Vaughan thought him "a thorough sport". ${ }^{85}$ Lieutenant-Colonel W.D. Croft was game enough to take the stage in a concert party in pierrot kit and noted: "I think the unusual exhibition of a battalion commander making an ass of himself had something to do with some of the full houses". ${ }^{86}$ Lieutenant-Colonel C.R.C. de Crespigny, $2^{\text {nd }}$ Grenadier Guards, "maintained a strict discipline on duty", but had a "subversive spirit" that "gave great pleasure to all his battalion". When asked for a "return of rats" in his trenches, 'Crawley' organised a rat shoot, and left sandbags full of rotting rodents piled up outside brigade HQ at night to the joy of all. ${ }^{87}$

Captain F.C. Hitchcock described both being on the receiving end of a CO's sharp tongue, a misfortune universally referred to as "strafing", 88 followed soon after by convivial lunches and dinners at battalion HQ. ${ }^{89}$ Something approaching friendship between officer and CO could indeed form. Captain G. Greenwell, $1 / 4^{\text {th }}$ Oxfordshire \& Buckinghamshire

one is surrounded by filth, you know,' he would say, and he never did. No matter what the circumstances, he was always spick and span, and it was typical of him that before any big attack he would be careful to see that his boots and batons were polished, explaining with a slow smile that one could 'always die like a gentleman - clean and properly dressed"”. [S. Rogerson, Twelve Days on the Somme (London: Greenhill Books, 2006, originally published 1933), p.22].

85 E.C. Vaughan, Some Desperate Glory (London: Macmillan, 1985), p.17. Herbert Thomas Dobbin, a Regular Captain of the Duke of Cornwall's Light Infantry in August 1914, commanded 1/4 $4^{\text {th }}$ Gloucestershire from 29 June to 7 September 1916, 1/8 ${ }^{\text {th }}$ Warwickshire from 7 September 1916 to 24 February 1917, and $1 / 8^{\text {th }}$ Manchester from 30 May to 11 July 1917, serving in 1918 a Brigadier General with both 75 and 42 Brigades.

${ }^{86}$ W.D. Croft, Three Years with the Ninth (Scottish) Division (Leigh-on-Sea: Partizan, 2007), p.142. William Denman Croft was a Regular Captain of the Scottish Rifles in August 1914, and commanded $11^{\text {th }}$ Royal Scots from 4 December 1915 until 14 September 1917, after which he commanded 182 and 27 Brigades. Patrick Macgill noted at one concert: "The democratic nature of the New Army, where a Colonel sings the songs written in the ranks of his own battalion”. P. MacGill, The Amateur Army (London: Herbert Jenkins, 1916), p.76

${ }^{87}$ H. Macmillan, Winds of Change 1914-1939 (London: Macmillan, 1966), p.79. Claude Raul Champion de Crespigny, a Captain of $3^{\text {rd }}$ Grenadier Guards in August 1914, commanded the $2^{\text {nd }}$ Battalion from 1 February 1917 until 22 September 1917 when he became Brigadier-General commanding $1^{\text {st }}$ Guards Brigade.

${ }^{88}$ For example: IWM Docs 11144 R.L. Mackay p.7

${ }^{89}$ Hitchcock, Stand To, p. 212 
Light Infantry, wrote in June 1918 whilst in Italy of dining with his CO, LieutenantColonel A.J.N. Bartlett, with the Medical Officer and Adjutant, playing "bridge till midnight", ${ }^{90}$ and later going on leave with him to Venice. ${ }^{91}$

When Lieutenant-Colonel E.A. Wood was promoted to command 55 Brigade in October 1916, Captain G. Dugdale, his Intelligence Officer, noted: "It suddenly dawned on me what a wonderful friend he had been, and how I should miss him". ${ }^{92}$ Lieutenant E.C. Blunden described Lieutenant-Colonel G.H. Harrison, $11^{\text {th }}$ Sussex, as having a "gift of being friend and commander alike". ${ }^{93}$ Blunden, (whom Harrison called 'Rabbit'), to put no finer point on it, loved him: ${ }^{94}$ "His likeness cannot come again in this life, nor can man be more beloved". ${ }^{95}$ In "On the Portrait of a Colonel", (dedicated to "G.H.H."), Blunden constructed what may be the only paean to a CO, describing Harrison's "honoured face", and: “The eye's shrewd humour, the lip's generous grace, the stirring zest, the power to

\footnotetext{
${ }^{90}$ G. Greenwell, An Infant in Arms (London, Lovat Dickson \& Thompson, 1935), p.266 and p.289. Alfred James Napier Bartlett was a Regular Captain of the Oxfordshire and Buckinghamshire Light Infantry in August 1914, and commanded the $1 / 4^{\text {th }}$ Battalion between 4 June 1916 and the Armistice.

${ }^{91}$ Posed friendliness was easily detected. P.J. Campbell (an artillery officer) wrote: "At the day's end the Colonel would sometimes come into our mess and laugh and make jokes, calling each of us his laddie and asking some pointless questions. We disliked him even more when he was pretending to be friendly than when he was abusive". [P.J. Campbell, In the Cannon's Mouth (London: Hamish Hamilton, 1979), p.7].

${ }^{92}$ G. Dugdale, Langemarck and Cambrai (Uckfield: Naval \& Military, 2005), p.92. Edward Allan Wood had a colourful background. Born in India in 1865 (he lopped seven years off his age at the start of the Great War), he had served as a cavalry OR of both $2^{\text {nd }}$ Dragoon Guards and $17^{\text {th }}$ Lancers, a member of the Bechuanaland Border Police, the Mabeleland Mounted Police, had participated in the Jameson Raid in 1895, and rose to be Inspector in the British South Africa Police, resigning in 1906. He commanded $6^{\text {th }}$ Shropshire from 7 October 1915 until his promotion. Wood liked Dugdale enough to have got him a job as Brigade Intelligence Officer at the same time, even though it was a different brigade. John Bourne has described him as "a liar, a fantasist and an embezzler", Wood being declared bankrupt in 1922. (P. Simkins, 'Forgotten Heroes: Some Personal Reflections', unpublished paper).

${ }^{93}$ E. Blunden, Undertones of War (London: Penguin, 2000, originally published 1928), p. 130

${ }^{94}$ Blunden was heterosexual.

${ }^{95}$ Blunden, Undertones, p.110. George Hyde Harrison, a Regular Captain of the Border Regiment in August 1914 commanded $11^{\text {th }}$ Sussex from 25 July 1916 to 3 March 1917, when he became DAAG, and was later promoted Brigadier-General with 155 Brigade on 23 September 1918.
} 
make and give", with Harrison held as a beacon in life's turmoil: “This man's commanding trust will be my sight". 96

It could thus hit hard when a CO was killed. Major J.M. Findlay of $8^{\text {th }}$ Scottish Rifles wrote of the death of Lieutenant-Colonel H.M. Hannan on Gallipoli. 97 "The awful feeling of loss ... of a real friend". ${ }^{98}$ Loss could affect the whole battalion. Captain F.C. Hitchcock, $2^{\text {nd }}$ Leinster, noted that on 6 November 1918: "It was the anniversary of Colonel Murphy's death; the men had not forgotten him; all day long on the march, and later in billets, I heard them talking about him". ${ }^{99}$ When Lieutenant-Colonel C.H.R. Crawshay, $2^{\text {nd }}$ Royal Welsh Fusiliers, was wounded in January 1917, never to return to command: "The Battalion was in low spirits because the Colonel had been so popular that everyone regarded him as irreplaceable". ${ }^{100}$

\subsubsection{Expert power}

Officers recognised that the intelligence, knowledge and conscientious application that signified 'expert power' were central attributes in a CO. When Lieutenant C.P. Clayton met Lieutenant-Colonel T.O. Marden, $1^{\text {st }}$ Welsh, he noted: "His face is an arresting one. It is of an intellectual type, and his eyes, incisive yet quick to twinkle, give the impression

\footnotetext{
${ }^{96}$ E. Blunden, 'On the Portrait of a Colonel', Poems of Many Years (London: Collins, 1957), p.132

${ }^{97}$ Henry Monteith Hannan was commanding $1 / 8^{\text {th }}$ Scottish Rifles at the outbreak of war. He was shot in the neck by a Turkish sniper at a range of 1100 yards. He was the son of Colonel Henry Monteith Hannan of the $4^{\text {th }}$ Lanarkshire, and brother of James Monteith Hannan who later commanded $3 / 8^{\text {th }}$ Scottish Rifles from 15 March 1915 to 31 August 1916.

${ }^{98}$ J. M. Findlay, With the $8^{\text {th }}$ Scottish Rifles (London: Blackie, 1926), p.30

${ }^{99}$ Hitchcock, Stand To, p.306. Alfred Durham Murphy, a Lieutenant of $2^{\text {nd }}$ Leinster in August 1914 commanded the battalion from 20 August 1916 until he was killed in the battalion HQ mess by a shell on 6 November 1917, aged 27. Codrington Howard Rees Crawshay was a Captain and the Adjutant of $3^{\text {rd }}$ Royal Welsh Fusiliers in August 1914, and commanded the $2^{\text {nd }}$ Battalion from 14 June 1916 until 25 January 1917.

${ }^{100}$ S. Sassoon, The Complete Memoirs of George Sherston (London: Faber \& Faber, 1972), p.409
} 
that they miss nothing". ${ }^{101}$ Lieutenant J.B. Hoyle, $7^{\text {th }}$ South Lancashire, wrote of Lieutenant-Colonel C.R.P. Winser: "If there was ever a conscientious and knowledgeable Colonel he is the man". ${ }^{102}$ When Captain F.C. Hitchcock was tasked with a day-time raid on The Triangle, Loos, on 10 January 1917, his CO watched the training, made personal reconnaissance of the objective, and superintended jumping-off. Hitchcock recognised: "Nothing had been left to chance by the CO", and concluded: "The Triangle was deemed an impregnable position, and I doubt if its prestige would have been lowered but for the skill of Lieut.-Colonel A.D. Murphy", ${ }^{103}$

Lieutenant Siegfried Sassoon, writing of "Colonel Winchell", (Lieutenant-Colonel J.R. Minshull-Ford), suspected an ulterior motive in his emphasis on efficiency in training, believing he "was ... intent on impressing the Brigadier with his keenness and efficiency". ${ }^{104}$ He saw in his successor, "Kinjack", (Lieutenant-Colonel C.I. Stockwell), a man who:

Exceeded all our expectations. He was the personification of military efficiency. Personal charm was not his strong point, and he made no pretension to it. He was aggressive and blatant, but he knew his job, and for that we respected him and were grateful. ${ }^{105}$

\footnotetext{
${ }^{101}$ C. P. Clayton, The Hungry One (Gomer Press: Llandysul, 1978), p.14. Clayton was an August 1914 citizen in the $1^{\text {st }}$ Welsh via a commission in the Special Reserve. Thomas Owen Marden was indeed an intelligent soldier. A psc, he had served as a Special Service Officer in South Africa; DAAG in India; Staff Captain, GSO3 \& GSO2, Army HQ; and DAA\&QMG in Orange River Colony. He served as BrigadierGeneral 114 Brigade from 10 November 1915 to 19 August 1917, and Major-General $6^{\text {th }}$ Division from 21 August 1918 to the Armistice.

102 J.B. Hoyle, Some Letters from a Subaltern on the Western Front (Uckfield: Naval \& Military Press, 2009, originally published 1917), p.226, letter dated 19 June 1916. Charles Rupert Peter Winser was a retired Regular Captain of the South Lancashire Regiment who had served in South Africa 1899-1901 as a Transport Officer, Railway Staff Officer and Station Staff Officer. He was transferred in January 1918 as a LieutenantColonel to the Machine Gun Corps, and then promoted to Brigadier-General with 41 Brigade from 3 April to 3 September 1918.

${ }^{103}$ Hitchcock, Stand To, p. 244.

${ }^{104}$ Sassoon, Sherston, p.254. John Randle Minshull-Ford was a Regular Captain of the Royal Welsh Fusiliers in August 1914, and commanded the $1^{\text {st }}$ Battalion from 1 October 1915 to 3 February 1916, when he was promoted Brigadier-General with 91 Brigade, later commanding 115, 1 and 97 Brigades.

${ }_{105}$ Sassoon, Sherston, pp. 267-8. Stockwell went on to the successful command of 164 Brigade from 18 September 1916 to the Armistice. Reflecting later on his "rough-tongued efficiency", Sassoon "began to
} 


\subsubsection{Consultative style}

Lieutenant Max Plowman, $10^{\text {th }}$ West Yorkshire, approved of the consultative style that Senior Officer School came to recommend, in Lieutenant-Colonel P.R.O.A. Simner, a civilian barrister of August 1914, noting:

If his manner is conceited, that is a minor weakness. He is keen and takes an intelligent interest in the battalion. He has instituted weekly round-table talks with officers at which old indiscriminate cursing is omitted. He has wit and good humour, and at present is the object of much hero worship. ${ }^{106}$

Captain R.B. Ross, $1 / 7^{\text {th }}$ Gordon Highlanders, described the issuing of final orders on 12 November 1916, before the Battle of the Ancre, noting that "suggestions were invited" by Lieutenant-Colonel R. Bruce to "provide for a more complete victory by the assurance of individual initiative if it would be required". He continued:

The Colonel gave each suggestion its just consideration, amplifying here, rejecting there, applying that sound and sympathetic judgement of his which endeared him no less than it commanded admiration. ${ }^{107}$

\subsubsection{Courage, personal example and modelling}

Captain A.O. Pollard depicted the well-respected Lieutenant-Colonel E.C.P. Boyle, $1 / 1^{\text {st }}$ Honourable Artillery Company, as a man who "never knew fear and who inspired all with whom he came into contact with his own enthusiasm". ${ }^{108}$ How much of such behaviour

realise that, in a commanding officer, amiability is not enough". Clifton Inglis Stockwell, (Frank Richards' 'Buffalo Bill'), was a Regular Captain of Royal Welsh Fusiliers in August 1914, and commanded the $1^{\text {st }}$ Battalion from 3 February to 16 September 1916, when he was promoted Brigadier-General with 164 Brigade. Sassoon noted one of Stockwell's successors, Lieutenant-Colonel W.B. Garnett, as "indulgent and conciliatory" and "greater aggressiveness would have been preferred" (p. 409).

${ }^{106}$ Mark VII (M. Plowman), A Subaltern on the Somme (London: Imperial War Museum, 1996), p.230. Percy Reginald Owen Abel Simner commanded 10 ${ }^{\text {th }}$ West Yorkshire from 11 December 1916 to 25 March 1918.

${ }^{107}$ R.B. Ross, The Fifty-First in France (London: Hodder \& Stoughton, 1918), p.307-8. Robert Bruce Ross had been a Major in the battalion in August 1914. He had taken over command from Lieutenant-Colonel G.H. Bower, replaced, on 28 July 1916 and commanded until 27 June 1917.

108 A.O. Pollard, Fire-Eater (Uckfield: Naval \& Military, n.d.), p.178. Ernest Charles Patrick Boyle was a retired Captain of the Imperial Yeomanry in August 1914. He commanded from 3 September 1916 until his 
was deliberate modelling is unclear. Captain F.C. Hitchcock observed Lieutenant-Colonel A.D. Murphy modelling endurance, soaked through and going into action: "The C.O. was in great form. He always showed his 100 per cent soldiering qualities under discomfiture, and would appear to revel in it, which I well knew was not the case". ${ }^{109}$

$2^{\text {nd }}$ Lieutenant A. Thomas viewed Lieutenant-Colonel W.R.A. Dawson, $6^{\text {th }}$ Royal West Kent, as a 'natural' commanding officer. ${ }^{110} \mathrm{He}$ was a "man of moods and uncertain temper", but his positives far outweighed his negatives. Firstly, his 'referent power' was seemingly immense: "His personality overpowered me." Secondly, he had courage. When Thomas found him clinging to the side of a trench, Dawson acknowledged his fear of the shelling, but stated: "I don't show the fear I feel". Dawson clearly understood the importance of modelling coping.

Dawson understood the power of 'hands on' leadership, which maintained the sense of 'we-ness'. Thomas noted: “A Colonel has no business to go out on patrol in no-man's land", thinking Dawson sometimes "reckless and foolhardy". The 'all tasks shared' style of leadership was, however, the keystone of Thomas's statement: "He expected as much as he gave, which was everything".

death. He was killed on 7 February 1917. The unit war diary describes that day how he was returning from a conference at brigade HQ and was hit by a shell splinter, noting: "He welcomed death in the field - and died like a gallant gentleman regretted beyond all words by all who loved him. The Father of the Regiment". (TNA WO/95/3118). Boyle was of course not 'the father of the regiment', which was of ancient lineage, having been a retired Captain of the Imperial Yeomanry, appointed Captain in the battalion on 30 September 1914 , but the hyperbole is instructive of the esteem in which he was held.

${ }^{109}$ Hitchcock, Stand To, p.161

${ }^{110}$ See Chapter Four section 4.2. William Robert Aufrere Dawson was a $2^{\text {nd }}$ Lieutenant in the $1^{\text {st }}$ Battalion Royal West Kent in August 1914. He commanded $6^{\text {th }}$ Royal West Kent from 16 November 1916 until his fatal wounding on 23 October 1918. 
Thirdly, Dawson's 'expert power' was evident in his ultimate competence on the battlefield: "He knew his job ... an instinctive grasp of soldiering". ${ }^{111}$ In addition, Dawson had a deeply protective nature towards his battalion. At Monchy-le-Preux in April 1917, Dawson showed his man-management skills. He prepared Thomas for his exhausted company to attack in the morning. He engaged Thomas's determination first, and only at the end told him that he had requested relief, which in fact arrived. ${ }^{112}$

Leadership from the front was a valued characteristic. Captain C.P. Clayton noted that Lieutenant-Colonel A.W. Pagan, $1^{\text {st }}$ Gloucestershire, was "always with his first line" in battle. ${ }^{113}$ Lieutenant C.E. Carrington, $1 / 5^{\text {th }}$ Royal Warwickshire, whose CO, LieutenantColonel G.C. Sladen, was "my hero", 114 was isolated and under counter-attack beyond Ovillers in late July 1916, when suddenly his CO dropped into his trench. "I feel ten times more confident that the Colonel should merely be in the trench with us ... where Colonels have no business to be", he wrote. ${ }^{115}$ When the Adjutant of $2^{\text {nd }}$ King's Royal Rifle Corps attempted to prevent Lieutenant-Colonel H.W.F. Bircham from being "right up with" the attack, Bircham responded: "You know very well ... where a Colonel of the Rifles should be on such occasions". ${ }^{116}$ The cost of this attitude is reflected, for instance, in the death of

\footnotetext{
${ }_{111}$ A. Thomas, A Life Apart (London: Gollancz, 1968), pp. 57-61

${ }^{112}$ Thomas, Life Apart, pp. 99-100

${ }^{113}$ Clayton, Hungry, p. 144. Alexander William 'Patsy' Pagan, born 1878, was a Regular Captain of the Gloucestershire Regiment in August 1914. He had served in South Africa 1900-2. He commanded $1^{\text {st }}$ Gloucestershire from 5 May 1915 to 24 March 1918, when he left the battalion to command 184 Brigade, a command he held until 10 October 1918.

${ }^{114}$ Gerald Carew Sladen, born 1881, was a Regular Captain of the Rifle Brigade in August 1914. He had served in South Africa 1899-1902 and East Africa 1908-10. He commanded 1/5 Warwickshire from 11 July 1915 to 31 August 1916, when he left the battalion to command 143 Brigade, a command he held until the Armistice.

${ }^{115}$ C. Edmonds, A Subaltern's War (London: Anthony Mott, 1984), p.75

${ }^{116}$ Eyre, Somme Harvest, p.225. The Adjutant was tragically blessed with foresight as Bircham was killed at the junction of the Switch Line and Munster Alley, Pozieres. Humphrey Francis William Bircham, aged 41 on his death on 23 July 1916, was a Regular Major of the Kings' Royal Rifle Corps in August 1914, and had taken command of the battalion on 29 September 1915.
} 
Lieutenant-Colonel J.G. Mignon, $8^{\text {th }}$ Leicestershire on 14 July 1916 on the Bazentin Ridge, "leading a bombing party like a subaltern". 117

Captain D.V. Kelly, in describing Mignon's death, noted: "In the later stages of the War commanders of ... battalions were constantly being enjoined to stay at their headquarters while a battle was in progress". ${ }^{118}$ Lieutenant-Colonel F.P. Crozier thought "this whole idea repulsive. It cut right across the foundations of mutual trust, emphasized in training, between private soldier and officer". ${ }^{119}$ Lieutenant-Colonel A. Carton de Wiart, similarly believed "an invisible commander in a dug-out cannot be a great source of inspiration", but paid the price, being wounded twice during his 133 days in command of $8^{\text {th }}$ Gloucestershire. ${ }^{120}$ In contrast, Lieutenant-Colonel E.W. Hermon, $27^{\text {th }}$ Northumberland Fusiliers, wrote: "If a C.O. goes messing about up in front $\ldots$ he is quite out of touch with

\footnotetext{
${ }^{117}$ D.V. Kelly, 39 Months with the "Tigers" 1915-1918 (London: Ernest Benn, 1930), p.32. Jephson George Mignon was a Captain in the Reserve of Officers of the Leicestershire Regiment in August 1914, who had served with the Imperial Yeomanry in the Second Boer War. He commanded $8^{\text {th }}$ Leicestershire from 28 July 1915 until 14 July 1916.

${ }^{118}$ An example of the way this was enacted is indicated in the operational orders of 2 Canadian Infantry Brigade for the battles of Vimy (9 April 1917) and Arleux (28-9 April 1917). Order 185 Page 25 re. Vimy states: “(a) Two Battalions commanders will be left out of the attack. These will be: Lieutenant-Colonel H M Dyer DSO 5th CIBattalion Lieutenant-Colonel W F Gilson 7th CIBattalion. Not more than 4 Officers per Company and 5 Officers per Battalion Headquarters will take part in the attack. (b) The following Officers must be left behind: (i) Either the $\mathrm{CO}$ or the Second-in-Command; (ii) Either the Company Commander or the Second-in-Command. Not more than two Company Commanders are to go in with their Companies". [LAC, RG9, Militia and Defence, Series III-D-3, Volume 4871, Reel T-10669 File: 206, 2 CIB War Diary, Appendix 2, Operation Order 185 (O.O. 185), 5 April 1917]. The relevant instructions for the attack on the Oppy-Acheville Line of 19 April 1917, Page 3, para 15, state: "The instructions concerning personnel to be left out of the attack, and equipment to be carried, will be the same as for the attack on April 9th. The following Commanding Officers and Seconds-in-Command will not accompany their units in the attack: Lieutenant-Colonel J.M. Prower DSO 8th CIBattalion; Lieutenant-Colonel D.M. Ormond 10th CIBattalion; Major P. Tudor 5th CI Battalion; Major D. Philpot 7th CIBattalion”. [LAC, RG9, Militia and Defence, Series III-D-3, Volume 4871, Reel T-10669 File : 206, 2 CIB War Diary, Appendix 9, Instructions for the attack on Arleux, 27 April 1917].

${ }^{119}$ F.P. Cozier, The Men I Killed (London: Michael Joseph, 1937), p.81. Crozier, who commanded $9^{\text {th }}$ Royal Irish Rifles between 28 March and 28 November 1916, describes how he and Lieutenant-Colonel H.C. Bernard, $10^{\text {th }}$ Royal Irish Rifles, decided to disobey this edict on 1 July 1916 at Thiepval, Bernard paying with his life. Crozier's point was that you could only control what happened with knowledge, which could only be gained by being "in the fight". Bernard's point would have been that command is impossible from beyond the grave.

${ }^{120}$ A. Carton de Wiart, Happy Odyssey (London: Pan, 1950), p.58. Adrian Carton de Wiart, a Captain of the $4^{\text {th }}$ Dragoon Guards in August 1914, commanded $8^{\text {th }}$ Gloucestershire from 15 June to 26 October 1916.
} 
his command \& the result is chaos". ${ }^{121}$ On 27 September 1918 on the Flesquières ridge, Lieutenant-Colonel W. Fraser, $1 / 6^{\text {th }}$ Gordon Highlanders, who had gone with his battalion to the Red Line, where they passed through the leading battalion, returned to Battalion HQ and noted: "It's no good being too far away ... one can do nothing".

The balance had to be struck between inspiration and communication. ${ }^{122}$ The model of battalion command present in the British army prior to and during the First World War was one of leadership integrated within the unit, leading, particularly in the mobile warfare of 1914 and 1918, from the front. In a war fought without the benefit of effective voice control, this served the battalion commander well, fulfilling the two key functions specified by Doron Almog: (i) Getting the "best possible information in the shortest time possible" to make the best possible tactical decisions; and (ii) providing an "inspiring personal example". ${ }^{123}$

\subsubsection{The unpopular $\mathrm{CO}$}

Simply replacing a popular CO could render his successor unpopular. On 5 May 1917 Lieutenant-Colonel C.F. Osmond of the $1 / 1^{\text {st }}$ Honourable Artillery Company was invalided

\footnotetext{
${ }^{121}$ Nason, Love and Courage, p.286, letter dated 19 September 1916.

${ }^{122}$ The CO of the $11^{\text {th }}$ Royal Irish Fusiliers was unable to strike this balance on 1 July 1916. "The Commanding Officer was in great difficulty. Lt. Col. Brush - with the other Commanding Officers in the Brigade - had been ordered not to lead his men in the attack. He was to command and control the attack from Bn. H.Q. in the trenches. This was to be done by telephone, signal flags, runners and scouts. The sheer volume of the German fire made this system of communication almost impossible. The result of having the Commanding Officer at Battalion Headquarters meant the troops on the battlefield lacked specific direction. Reports of the situation did not get back to the brigade headquarters". [W.J. Canning, Ballyshannon, Beloo, Bertincourt (Enniskillen: Trimble, 1996), p.66].

${ }^{123}$ D. Almog, 'Positioning the Battalion Commander: The Advance and Pursuit from Awali to Beirut, 6-13 June 1982', Military Operations, (1) (2012), pp.13-16. The regimental history of the Highland Light Infantry notes of instructions to COs to remain with battalion HQ: "A commanding officer is of no particular account is an individual. Only when he is with his battalion and in full control of it, does his status rise to one of considerable - in battle vital - importance". [L.B. Oatts, Proud Heritage - The Story of the Highland Light Infantry (London: Thomas Nelson, 1952-1963), pp.345-6].
} 
and replaced by Lieutenant-Colonel P.C. Cooper. ${ }^{124}$ His appointment was described by Captain A.O. Pollard as a "cloud" settling on the battalion and "a most unfortunate happening", but that:

I do not see how any blame can be attached to P.C. He was merely a very senior officer, who ... was invalided ... and was kept at home right up to May 1917. That he was senior to our beloved Ossy was a matter of chance and the fault of the system which insists on promotion in time of war by seniority instead of merit. Not that I am questioning P.C. 's merit. He was very capable in some directions... His fault was that he arrived to supersede Ossy. Had he been any other man ... the result would have been the same. ${ }^{125}$

Simple personal ineptitude could rapidly alienate a CO. $2^{\text {nd }}$ Lieutenant D.W.J. Cuddeford, $12^{\text {th }}$ Highland Light Infantry, noted than when the Earl of Rothes was wounded on 3 October 1916, an officer whom he tactfully did not name, (Lieutenant-Colonel W.E. St John), ${ }^{126}$ was appointed who: "I am afraid ... was never very popular with officers or men". ${ }^{127}$ St John, "a man who never seemed to get on with anyone", was "one of those people who seem to have the unfortunate knack of always doing the wrong thing and of getting up against everyone they come into contact with”. Cuddeford, his Adjutant, noted that he had some insight: "Once in private he somewhat regretfully remarked to me that whenever he tried to do anyone a good turn his action always seemed to have the opposite result". He was "fully aware of his unpopularity" and "no one regretted it more than himself", but "he was deficient in ordinary tact and he would impatiently resent any advice, however respectfully offered". Cuddeford was in no doubt that there was an

\footnotetext{
${ }^{124}$ Osmond was a retired Captain of the Imperial Yeomanry, appointed $2^{\text {nd }}$ Lieutenant on 16 September 1914; Cooper was a Captain of the battalion in August, promoted Major on 16 August 1914, who had served with the $2 / 1^{\text {st }}$ Battalion.

${ }^{125}$ Pollard, Fire-Eater, p.231

${ }^{126}$ William Eustace St John, a retired Major of the Buckinghamshire Yeomanry who had fought in the Second Boer War with the Western Light Horse, commanded until 26 September 1917, thereafter commanding $2 / 7^{\text {th }}$ Warwickshire until the Armistice.

${ }^{127}$ D.W.J. Cuddeford, And All For What? (London: Heath Cranton, 1933), p.71
} 
"adverse influence" on the battalion. ${ }^{128}$ Whilst personal charm was not essential, there was a fine balance. Major-General T.D. Pilcher writing to his son on 1 November 1916 identified this exact issue: "Some Commanding Officers obtain cheerful obedience to their commands, whereas others find it difficult to get any orders carried out, and are generally unpopular into the bargain". An unwelcome order, he suggested, "will be rendered less unpalatable if it be tactfully conveyed". ${ }^{129}$

$9^{\text {th }}$ King's Own Yorkshire Light Infantry suffered from an unpopular CO. LieutenantColonel C.W.D. Lynch was a pedantic disciplinarian and rapidly became unpopular. ${ }^{130}$ Immediately prior to the 1 July 1916 attack on the Somme, Lynch gathered his officers together, and the Adjutant suggested to Captain G. Haswell, the senior officer present, that he propose a toast to the CO's health. The degree of Lynch's alienation was such that Haswell replied: “I'm damned if I will, I don't wish him good health and am not prepared to be insincere". Pressed, his proposed toast was to the battalion: "When the barrage lifts". 131

Guy Chapman described the humiliating departure of Lieutenant-Colonel H.J. des Voeux, $13^{\text {th }}$ Royal Fusiliers, on 6 August $1916 .{ }^{132}$ He blamed not only his lack of robustness: "He had been a wash-out from the first; he had succumbed without any effort to the first strain", ${ }^{133}$ but also his "arrogant stupidity" which "had alienated the sympathy of every

\footnotetext{
${ }^{128}$ Cuddeford, For What, pp.80-1

${ }^{129}$ Pilcher, General's Letters, pp.56-7

${ }^{130}$ Colmer William Donald Lynch, a retired Regular Captain of the Duke of Cornwall's Light Infantry in August 1914, commanded from 22 June 1915 until his death.

${ }^{131}$ D. Clayton, From Pontefract to Picardy - The $9^{\text {th }}$ King's Own Yorkshire Light Infantry in the First World War (Stroud: Tempus, 2004), p.61. Lynch was killed the following day at Fricourt, as was Haswell.

${ }^{132}$ Chapman, Prodigality, p.83. See Chapter Three, section 3.3.8.

${ }^{133}$ Chapman had earlier noted with mild disgust that Des Voeux had "retired to England to consult his doctor about suspected rheumatism of the heart". (Chapman, Prodigality, p.58).
} 
person who might have brought him to a counselled leadership". Des Voeux had become so alienated, however, that his failure had resulted in "a curiously democratic control, which had effected a more complete harmony, confidence, and loyalty than was often to be found in units more capably led". This was likely down to the character of the second-incommand, Major G.H. Ardagh, who succeeded as CO. ${ }^{134}$ A popular, "charming” man: "He was always to be found in the front line at night ... or wandering round the bays guided by friendly privates". ${ }^{135}$ Ardagh's 'referent power' created the necessary 'we-ness' ${ }^{136}$

Captain R.L. Mackay, $11^{\text {th }}$ Argyll and Sutherland Highlanders, had two spells under Lieutenant-Colonel H.A. Duncan, who he referred to as the "Conscientious Obstructor". ${ }^{137}$ He had no doubt as to his courage, but it was his inability to identify, thereby alienating his officers, that was fatal. When the officers enjoyed a hearty meal in an estaminet, Duncan "sat aside and watched us", ${ }^{138}$ Mackay later noting: "He lacks that most necessary of all things - common sense, "savoir faire",. ${ }^{39}$ When Major G.L. Wilson took over on Duncan's going sick, Mackay noted: "Hurrah! What a difference". ${ }^{140}$ Wilson was replaced by Major J. Mitchell, 13th Royal Scots, and Mackay celebrated 'we-ness':

He was an original 'sub' of ours, and is tremendously popular, and is acting as a general tonic. We feel it a pleasure to work for such a man.

\footnotetext{
${ }^{134}$ George Hutchins Ardagh, 54 years old in 1916, was a retired Captain of the Imperial Yeomanry. Chapman believed him to be over 60, but this does not appear to be correct. He commanded from 6 August to 9 December 1916, later serving as a Staff Lieutenant.

${ }^{135}$ Chapman, Prodigality, p.58

136 Ardagh's femur was smashed by a shell in November 1916, yet he returned to France six months later, Chapman recording the Quartermaster's comment: "What a tiger, eh?". (Chapman, Prodigality, p.131).

137 IWM Docs 11144 R.L. Mackay, p.13. Horace Adrian Duncan, a Regular Captain of the Argyll and Sutherland Highlanders in August 1914, commanded for two spells from 18 February 1917.

${ }^{138}$ Mackay, p.13

139 Mackay, p.34. Similarly, $2^{\text {nd }}$ Lieutenant F.B. Pitts, $8^{\text {th }}$ Leicestershire, described his CO, LieutenantColonel G.C.I. Hervey as "a dreadful 'snot"”. He continued: "Nobody ever had a good word for Hervey, and I can quite see it ... he never gets to know his subalterns for the simple reason that he won't mix up with them, as they are so beneath him!" [Letter 22 January 1917, Liddle Collection, GS1272].

${ }^{140}$ Mackay, p. 46. Gavin Laurie Wilson, a citizen of August 1914, commanded $11^{\text {th }}$ Argyll and Sutherland Highlanders as a Lieutenant-Colonel between 3 April and 9 June 1918, at which point he was sent to command the $1 / 8^{\text {th }}$ Battalion until the Armistice.
} 
His efficiency, his sense of duty, combined with common sense and his good humour are making us a new lot of men - for the late CO undoubtedly lowered our spirits. ${ }^{141}$

\section{Lieutenant T.H. Floyd described Lieutenant-Colonel B. Best-Dunkley post-war as: “A}

brilliant young man, endowed with a remarkable personality", ${ }^{142}$ but at the time, Floyd's assessment was that he:

Suffers from a badly swelled head; ... fancies himself a budding Napoleon ... with a very bad temper and a most vile tongue ... is inconsiderate of his inferiors wherever his personal whims and ambitions are concerned; and ... is engrossed with an inordinate desire to be in the good graces of the Brigadier-General. ${ }^{143}$

These were all behaviours unlikely to generate 'we-ness', yet his bravery on the day (31 July 1917 at Wieltje), the last officer standing, beating off a German counter-attack and winning the VC only to be fatally wounded by the British counter-barrage he had called up, undoubtedly screwed his men's courage to the sticking-place when it counted. ${ }^{144}$

\footnotetext{
${ }^{141}$ Mackay, p. 48. A citizen of August 1914, James Thomas Rankin Mitchell, was promoted Acting Lieutenant-Colonel with the battalion on 13 December 1917, and died of wounds on 1 April 1918.

${ }^{142}$ T.H. Floyd, At Ypres with Best-Dunkley (Boston: Indypublish, n.d.), Foreword. Bertram Best-Dunkley was a Special Reserve Lieutenant of $4^{\text {th }}$ Lancashire Fusiliers in August 1914. He commanded $2 / 5^{\text {th }}$ Lancashire Fusiliers from 21 October 1916 until his fatal wounding.

${ }^{143}$ Floyd, Best-Dunkley, p.31

${ }^{144}$ Best-Dunkley's VC citation reads: "For most conspicuous bravery and devotion to duty when in command of his battalion, the leading waves of which, during an attack, became disorganised by reason of rifle and machine gun fire at close range from positions which were believed to be in our hands. Lt.-Col. Best-Dunkley dashed forward, rallied his leading waves, and personally led them to the assault of these positions, which, despite heavy losses, were carried. He continued to lead his battalion until all their objectives had been gained. Had it not been for this officer's gallant and determined action it is doubtful if the left of the brigade would have reached its objectives. Later in the day, when our position was threatened, he collected his battalion headquarters, led them to the attack, and beat off the advancing enemy." London Gazette, 4 September 1917, p. 9259. When Major-General H.S Jeudwine, $55^{\text {th }}$ Division, visited the dying man, Best-Dunkley "said that he hoped the General was satisfied". At Best-Dunkley's graveside, Jeudwine remarked: "We are burying one of Britain's bravest soldiers". (Floyd, Best-Dunkley, pp.115-6).
} 
In 1915 a crisis occurred in $1 / 4^{\text {th }}$ Norfolk concerning the command of Lieutenant-Colonel J.R. Harvey, ${ }^{145}$ who was subject to a revolt by his senior officers. Captains H.R. Fletcher and C.P. Hines were promoted Majors in October $1914 .{ }^{146}$ These two officers sought to withdraw their Imperial Service Obligation on account of Harvey's behaviour. ${ }^{147}$ Their complaints were brought to Brigadier-General C.M. Brunker, GOC 163 Brigade, and this led to a Court of Inquiry on 9 July $1915 .{ }^{148}$ Brunker noted a "very serious feeling of discontent", which "had reached the rank and file". He noted that Harvey had a different concept of discipline to his officers, and was "aloof and so is not in sympathy with them". Whilst viewing Harvey "a useful officer in the field", he recommended his removal.

Major-General F.S. Inglefield, GOC $54^{\text {th }}$ Division, noted that he had been aware:

That Colonel Harvey was unpopular and out of sympathy with his officers and on one occasion that the officers were aggrieved at the way he spoke to the btn. but the late Brigadier who was a great personal friend of Colonel Harvey ... assured me that there was no real disagreement in the Regiment.

He continued that he was "brusque in manner, quick of temper and unsympathetic in his bearing towards subordinates. He has however, determination, possesses power of command and I have always considered him a good fighting officer". He recommended, however, that Harvey should not take his battalion on active service.

\footnotetext{
145 John Robert Harvey, born in 1861 , son of Colonel J.E. Harvey of the $41^{\text {st }}$ Foot, was educated at Rugby School and at Trinity College, Cambridge, and served in the 3rd Norfolk 1880-2, 5th Lancers (again resigning as a Lieutenant); joining the Suffolk Hussars as Captain in 1899. He commanded this unit and the $25^{\text {th }}$ Imperial Yeomanry in South Africa, (where he also served on the staff) from 1900 to 1902 . He resigned (for the third time) in 1905, to be appointed CO of $4^{\text {th }}$ Norfolk on 24 January 1910. Harvey wrote Shannon and its Lakes (Dublin:Hodges, Figgis \& Co, 1896); Records of the Norfolk Yeomanry Cavalry, 1782 to 1908 (London: Jarrold, 1908); and Deer Hunting in Norfolk from the Earliest Times (Norwich: Norwich Mercury, 1910). In keeping with his country gentleman status, he was fond of not only of hunting but also polo, shooting, fishing and yachting.

${ }^{146}$ Major E. Mornement had been promoted to command the second-line battalion, and Major F.G.W. Wood had been seconded.

147 With Captains C.W.W. Burrell and S.D. Page. The Imperial Service Obligation was the voluntary agreement the Territorial soldier signed agreeing to serve overseas.

${ }^{148}$ TNA WO 32/18563. The Court was held under the presidency of Brigadier-General G.W. Biddulph, with Brigadier-Generals C.D Winton and F.W. Daniell as members.
} 
At the Court of Inquiry, Major Fletcher stated: "The officers have lost confidence in the ability of Colonel Harvey to efficiently lead or direct the Battalion in the field", and that he had failed to "acquire knowledge with a view to imparting it to his juniors", and that he appeared to have "lost interest in the doings of the Regiment". ${ }^{149}$ Major Hines referred to the "CO's lack of control over the Battalion in field operations", failing to issue written orders. ${ }^{150}$

For his part, Harvey denied knowledge of everything, proclaiming a "pre-arranged conspiracy", suggesting that the battalion was merely "fed up" on account of not going overseas. He asserted Fletcher to be a "truculent character", and produced importuning letters from Hines asking for command of the $2 / 4^{\text {th }}$ Battalion. The Court found in his favour, ignoring the evidence and recommendations of the brigade and divisional commanders, on the basis that his officers had contravened King's Regulations. ${ }^{151}$ Junior officers were never to succeed in getting rid of an unpopular $\mathrm{CO}$ in this fashion.

Two weeks after the inquiry Harvey was found "medically unfit for a period of one month". The battalion embarked for Gallipoli on 29 July under the command of the Adjutant, Captain E.W. Montgomerie, ${ }^{152}$ with no Majors. ${ }^{153}$ Harvey joined the battalion on

\footnotetext{
${ }^{149} \mathrm{He}$ added that Harvey had undermined morale by remarks made at kit inspection.

${ }^{150}$ Captains Burrell and Page echoed these concerns. Hines also alleged "inconsistency and injustice in dealing with defaulters".

${ }^{151}$ Paragraph 443 of King's Regulations states: "Deliberations or discussions by officers or soldiers with the object of conveying praise, censure, or any mark of approbation towards their superiors ... are prohibited". War Office, The King's Regulations and Orders for the Army, 1912, (London: HMSO, 1914).

${ }_{152}^{152}$ A Regular Captain of the Norfolk Regiment.

${ }^{153}$ Henry Rivers Fletcher, "well reported on" by Brunker, was transferred to the TF Reserve, but was made Lieutenant-Colonel in April 1916, and commanded the $3 / 4^{\text {th }}$ Norfolk to 31 August 1916, and the $3 / 5^{\text {th }}$ to the Armistice. The Reverend Charles Percy Hines was also transferred to the TF Reserve, but was seconded as Major to the $66^{\text {th }}$ Provisional Battalion (these battalions were made up from personnel of the 2nd and 3rd line battalions not available for overseas service and soldiers of low medical categories) in November 1915, and later to an Officer Cadet Battalion, resigning his commission in early 1919.
} 
9 September but "fell a victim to dysentery almost immediately". ${ }^{154}$ He never commanded on the battlefield again. ${ }^{155}$

Timothy Bowman describes the South African Major D. Reitz as "incompetent”, using "supposed Sinn Fein infiltration" of his unit to explain his own "shortcomings" as CO. ${ }^{156}$ In 1916 Reitz, a former Boer commando leader, "graduated from Private to Second Lieutenant, to Major, in the course of a week". ${ }^{157}$ After a spell at Senior Officer School, he found himself, without battlefield experience, as second-in-command of $7^{\text {th }}$ Irish Rifles, and culturally out of his depth. Within several months he was temporarily in command of a Catholic battalion suddenly out of control in a pitched battle with a Protestant Ulster Division unit. Reitz was clearly catapulted too rapidly into his position, and had the wrong cultural background for his task. That he was not seen as incompetent with another year's experience under his belt is indicated by the fact that he commanded both $7^{\text {th }}$ King's Shropshire Light Infantry and $1^{\text {st }}$ Royal Scots Fusiliers during The Hundred Days in 1918.

Officers therefore valued the characteristics of cheerfulness, humour and tact that indicated referent power in a CO. Courage, balanced by the expert power characteristics of intelligence and knowledge, were essential. Where a consensual management style was present, it was valued, as was sheer hard work and diligence. The absence of such could damage the morale and efficiency of a unit.

\footnotetext{
${ }^{154}$ F.L. Petre, The History of the Norfolk Regiment $4^{\text {th }}$ August 1914 to $31^{\text {st }}$ December 1918 (Norwich: Jarrold, 1925), p. 134

${ }^{155} \mathrm{He}$ served as a Commandant of a prisoner of war camp from 10 April 1916, being moved to the TF Reserve on 8 May, and as a Staff Lieutenant from 29 May 1917 to 26 November 1917.

156 T. Bowman, Irish Regiments in the Great War: Discipline and Morale (Manchester: Manchester University Press, 2003), p.7. Reitz's command lasted from September to October 1916.

${ }^{157}$ D. Reitz, Trekking On (London:Faber \& Faber, 1933), p.123
} 


\subsection{The experience of command - the CO's perspective}

\subsubsection{Taking over}

Lieutenant-Colonel G.S. Hutchison described "that peculiar disadvantage, sustained by most regular battalions, namely constant change in its command and leadership". Probably overestimating the rate of turnover into staff/brigade posts, he suggested: "Many of them cared little for the battalions which they were privileged to lead, and expended themselves to the utmost in wangling jobs away from the line". ${ }^{158}$ True for some, this was certainly an overly harsh view. Hutchison was judging against his own seemingly inexhaustible energy - stability was a virtue only under a competent CO.

For the professional soldier, promotion to battalion command was a natural goal, yet one that could provoke anxiety. Major R.G.B. Jeffreys, who spent the war to March 1916 with the $3^{\text {rd }}$ Royal Dublin Fusiliers at home, wrote from the Officers' Club at Boulogne on the day he arrived in France: "I am so pleased to be going to the $2^{\text {nd }}$ Battalion and I hope before long I may get the command". ${ }^{159}$ R.B. Bradford envisaged the route to command via a staff posting, but "either felt or had been told that he looked too young". He acquired a monocle "to add to the air of years and dignity that were lacking. He intended to be Brigade-Major, then a Battalion Commander, finally Brigade Commander". ${ }^{160}$

\footnotetext{
${ }^{158}$ Seton, Footslogger, pp. 177-8. He singled out 1st Cameronians, describing only "brief periods" when they were "well led". This battalion had $10 \mathrm{COs,}$, (above the average of seven - see Chapter Three section 3.2.2), of whom three were promoted Brigadier-General, [Lieutenant-Colonels P.R. Robertson, J.G. Chaplin (under whom, in fact there was stability from 27 May 1915 to 19 November 1917), and J.L. Jack (only 40 days in command)], two wounded and one prisoner of war, and three transferred out. It was in the period from November 1917 to the Armistice that the battalion suffered instability.

${ }^{159}$ C. \& L. Dodd (eds), Lieutenant-Colonel R.G.B. Jeffreys, Collected Letters 1916-1918 (Dublin: Old Tough Publications, 2007), p.6, letter dated 13 June 1916. Richard Griffith Basset Jeffreys, a Regular Captain of the Royal Dublin Fusiliers in August 1914 and Adjutant to the $3^{\text {rd }}$ Battalion, commanded the $2^{\text {nd }}$ Battalion from 13 July 1916 to 7 June 1917.

${ }^{160}$ Anonymous, Bradford, V.C., M.C., p. 61, comments of Captain Welch. He, of course, got his ultimate wish, if briefly. He was given command of 186 Brigade on 10 November 1917, being killed on the $30^{\text {th }}$.
} 
Captain R. Feilding, $3^{\text {rd }}$ Coldstream Guards, was asked on 29 August 1916 by BrigadierGeneral J. Ponsonby, ${ }^{161}$ "to come round this morning to talk ... over" the matter that "I ought to get command of one of the New Army battalions". ${ }^{162}$ By the following day, Major-General G.P.T. Feilding (his cousin) had "approved" the proposal "and thought it would be much to my advantage". ${ }^{163}$ On 4 September came news of his appointment to $6^{\text {th }}$ Connaught Rangers. Feilding wrote, however: "I feel very diffident as to whether I can command a battalion efficiently ... It will be a strange feeling, jumping up to find myself a Colonel". ${ }^{164}$ Major A.F.A.N. Thorne wrote to his wife on 18 September 1916 following his appointment as $\mathrm{CO} 3^{\text {rd }}$ Grenadier Guards, sharing Hermon and Feilding's diffidence: "I am too excited and proud to realise for the moment how 'much' I shall have to be fit for its responsibilities. I do pray that I may not let the battalion down". 165

Lieutenant-Colonel E.W. Hermon was a Major of King Edward's Horse and bored of inaction, ${ }^{166}$ when in July 1916 he found himself with an embarrassment of riches. First, Major-General Sir C. St L. Barter offered him command of a battalion: "I am to go and do a fortnight in the trenches first just to get in touch with the work a bit and then, if I am a success, I am to get a Battalion". This, he wrote to his wife, was "an awful problem \& (I) don't in the least know what to do", as "it's not exactly what I wanted but it's a start. ${ }^{167} \mathrm{He}$

\footnotetext{
${ }^{161}$ Ponsonby was the CO of $1^{\text {st }}$ Coldstream Guards in August 1914. Rowland Charles Feilding, a Captain in the City of London Yeomanry in August 1914 commanded $6^{\text {th }}$ Connaught Rangers from 6 September 1916 to 31 March 1918, and 1/15 $5^{\text {th }}$ London from 19 August 1918 to the Armistice.

${ }^{162}$ R. Feilding, War Letters to a Wife, J. Walker, ed., (Staplehurst: Spellmount, 2001), p.63

${ }^{163}$ Feilding, War Letters, p.63. Feilding continued "I have always said before that I would rather command a Coldstream Company than a battalion elsewhere. But the difficulty is my age ... I am double the age of all or nearly all the other Company Commanders of the Division, and there is practically no chance of promotion here". He was also aware that "being only a Special Reserve officer ... and an amateur soldier at that, I can never rise higher than a Company Commander here" (p.65).

${ }^{164}$ Feilding, War Letters, p. 65

${ }^{165}$ D. Lindsay, Forgotten General, A Life of Andrew Thorne (Salisbury: Michael Russell, 1987), p.59

${ }^{166}$ King Edward's Horse was a Special Reserve cavalry regiment.

${ }^{167}$ Nason, Love and Courage, p.236, letter dated 4 July 1916.
} 
added: "The idea of going is not appealing ... but I do want a job of work". ${ }^{168}$ Three weeks later, he wrote: "I met a pal who is a Brigadier. He was horrified to find that I wasn't a Brigadier too ... he at once offered me a Battalion in his Brigade". Hermon found himself "fairly up a gumtree. His Brigade is a New Army one \& his Div. Commander is in a very much better position than C.B. ... I personally would far rather have this than the former one". ${ }^{169}$ Barter was commanding $47^{\text {th }}$ Division, a Territorial formation - Hermon was demonstrating Regular snobbery, his eye being clearly on greater prestige and further promotion. He tried to put Barter off, a ruse which paid off, as 13 days later he wrote that he was to be $\mathrm{CO}$ of $27^{\text {th }}$ Northumberland Fusiliers: "As you will have already gathered I want this Battalion most". ${ }^{170}$ Hermon did not, however, go without qualms, writing: "I expect one will be alright ... everyone has got to make a start". ${ }^{171}$

Major H.E. Trevor, in contrast, seemed bewildered when he became $\mathrm{CO}$ of the $8^{\text {th }}$ Kings Own Yorkshire Light Infantry on 1 November $1915 .{ }^{172} \mathrm{He}$ wrote to his wife on 13 November: "I haven't the slightest idea why I was pitchforked into this job - except that the last $\mathrm{CO}$ was booted and the former second-in-command has gone home sick and I don't know how long I'm expected to remain". ${ }^{173}$

\footnotetext{
${ }^{168}$ Nason, Love and Courage, p.237, letter dated 6 July 1916.

${ }^{169}$ Nason, Love and Courage, p.250, letter dated 26 July 1916.

${ }^{170}$ Nason, Love and Courage, p.258, letter dated 8 August 1916. The "pal" was Brigadier-General H.E. Trevor, 103 Brigade, which was at the point of offer in $37^{\text {th }}$ Division commanded by Major-General Count Gleichen. On 22 August it was transferred back to $34^{\text {th }}$ Division commanded by Major-General C.L. Nicholson. By this time Hermon was doubtless too busy to note whether change of divisional commander disadvantaged him.

${ }^{171}$ Nason, Love and Courage, p.258, letter dated 8 August 1916.

${ }^{172} \mathrm{He}$ moved from the post of Brigade-Major. Herbert Edward Trevor was a Major of $2^{\text {nd }}$ King's Own Yorkshire Light Infantry in August 1914. He commanded the $8^{\text {th }}$ Battalion from 1 November 1915 until 2 July 1916 when he was promoted Brigadier General, 103 Brigade.

${ }^{173}$ IWM Docs 11445 Private papers, H.E. Trevor
} 


\subsubsection{Making a mark}

The arrival of a new $\mathrm{CO}$ to replace even a perfectly adequate $\mathrm{CO}$ could raise morale. The advent of Lieutenant-Colonel E.P.A. Riddell to $1 / 1^{\text {st }}$ Cambridgeshire was such an event for Captain A.I. Adam, who noted: "We are living in really interesting times; the outstanding feature is the extraordinary power and competence of the CO". ${ }^{174}$

Lieutenant-Colonel J.L. Jack left $2^{\text {nd }}$ Scottish Rifles "reluctantly" to command $2^{\text {nd }}$ West Yorkshire. Of the view that "no regiment likes being commanded by a stranger", he realised "my first business is to gain their confidence". ${ }^{175}$ Major A. Johnston, aware of the necessity of a "strong side of officers", noted on 14 August 1916: "Am possibly going to command a battalion, a magnificent job but one of a great difficulty and responsibility in these days of few and inexperienced officers, semi-trained N.C.O.s, and raw recruits sometimes of not too good material". ${ }^{176}$

\footnotetext{
174 A.M. Adam, Arthur Innes Adam 1894-1916 - A Record Founded on His Letters (Cambridge: Bowes and Bowes, 1920), pp.218-9. Edward Pius Arthur Riddell, a Regular Captain of the Rifle Brigade, commanded $1 / 1^{\text {st }}$ Cambridgeshire from 10 June 1916 until to 1 October 1917. Invalided briefly for "shellshock" in October 1916 he was promoted Brigadier-General with 149 Brigade.

${ }^{175}$ Terraine, Jack's Diary, pp.161-2. Lieutenant-Colonel W. Fraser, taking over $1 / 6^{\text {th }}$ Gordon Highlanders wrote: "It is a difficult job, this taking over of a strange battalion - and my predecessor seems to have been a splendid fellow, which does not make it easier ... they must not be let down". (Fraser, Good Company, p.92). Major W.D. Croft received his order to command the 11th Royal Scots "with mixed feelings", if for a different reason. A Regular Captain, he had come to France as Adjutant of the $1 / 5^{\text {th }}$ Cameronians, and "the quality of that particular battalion was of a very special kind, and I didn't feel inclined to start new friends and all that kind of thing". (Croft, Three Years, p.2). The feeling may have been mutual - the war diary of the 11th Royal Scots (TNA WO/951773) makes no mention of his arrival.

${ }^{176}$ E. Astill (ed.), The Great War Diaries of Brigadier General Alexander Johnston 1914-1917 (Barnsley: Pen \& Sword, 2007), p.179. On taking command of 10th Cheshire he felt that "I could not have received a greater compliment or a bigger task; it is a Man's Job and a magnificent one". Alexander Colin Johnston, a Regular Lieutenant of the Worcestershire Regiment in August 1914 commanded $10^{\text {th }}$ Cheshire from 28 August 1916 until 13 September 1917 when he was promoted Brigadier General with 126 Brigade.
} 
A CO would wish to stamp his own type of 'we-ness' on his unit. ${ }^{177}$ Lieutenant-Colonel E.W. Hermon replaced Lieutenant-Colonel G.R.V. Steward as CO of $27^{\text {th }}$ Northumberland Fusiliers. ${ }^{178}$ Initially, however, despite describing the unit as having the reputation as "the best in the brigade", and himself as having "to follow a man whom they all worshipped", ${ }^{179}$ Hermon believed it required improvement: "I expect in a week or so that things will have assumed an entirely different aspect". ${ }^{180}$ He continued: "There begins to show some sign of organization \& tho' things are still very far from being what I want you can simply see them growing every day". ${ }^{181}$ He was delighted when after a matter of two weeks his Adjutant "came \& said that he thought it would make my work easier if I was to know that all the officers were absolutely satisfied \& ready to back one to the last drop of blood." 182 Brigadier-General F.P. Crozier would have approved, writing: "When objectives are not taken; usually the fault is with the Colonel, who is not prepared to push on because he has not taught his men or come to an understanding with them". ${ }^{183}$

\footnotetext{
${ }^{177}$ Lieutenant-Colonel W.D Croft noted: "Brigadiers are an infernal nuisance at times, for in order to get a battalion right the battalion commander must have a free hand". (Croft, Three Years, p.15).

${ }^{178}$ Temporarily as it turned out - Steward was a Regular Captain of The Royal Inniskilling Fusiliers in August 1914, and was away on a spell of brigade command unrewarded by temporary Brigadier-General status.

${ }^{179}$ Nason, Love and Courage, p.270, letter dated 29 August 1916.

${ }^{180}$ Nason, Love and Courage, p.265, letter dated 20 August 1916.

${ }^{181}$ Nason, Love and Courage, p.266, letter dated 21 August 1916. Hermon took the same attitude to his second command with 24th Northumberland Fusiliers, noting: "There is a good deal that wants altering and I shall not want for a job ... it's apparently never had a regular C.O. in its life". Nason, Love and Courage, p.302, letter dated 31 October 1916. When Lieutenant-Colonel F.W. Parish took over $1 / 15^{\text {th }}$ London in July 1917, as a former Adjutant of the battalion, and hence with an edge of "we-ness", he "took the earliest opportunity to tell the troops that he was glad to see them all, but that they were not quite the Battalion of old, and he would not be content until they were. He said they were not as clean as they might be, and although they had fought well, they were not so smart, and their discipline was not so good as it should be. All these things, he said, must be put right, and, as there was no time like the present, he put his preaching and practice right away in the support positions in Bois Confluent". [E. Merrick, The History of the Prince of Wales' Own Civil Service Rifles (London: Wyman, 1921), p.147].

${ }^{182}$ Nason, Love and Courage, p.270, letter dated 29 August 1916. Hermon took the remark at face value rather than considering that his officers might simply have been looking for a less hectic life.

${ }^{183}$ Crozier, Men I Killed, p.93
} 
Starting training 18 days after taking command, Lieutenant-Colonel A. Johnston took the task personally, noting: "Lectured once to the officers and twice to the N.C.O.s" in one day. ${ }^{184}$ Similarly, to make his mark Lieutenant-Colonel A.F.A.N. Thorne was with his men in every training task, writing to his wife in July 1918: "I had an excellent forty minutes physical and bayonet fighting from 6.30 until 7.10 ... I dug between 3.40 and 4.30 p.m. and from 5.30 to 7.30 p.m.". ${ }^{185}$ Lieutenant-Colonel W. Fraser, $1 / 6^{\text {th }}$ Gordon Highlanders, met his company commanders first on taking over, dined with two of them one evening, two the next, and like Johnston, began training immediately, setting up a rifle range. ${ }^{186}$

F.P. Crozier, commanding $9^{\text {th }}$ Royal Irish Rifles, came out of the line to "rest, train and renovate" his unit prior to the Somme and to create 'we-ness' decided "to have a battalion mess once more" to "regain the grip which is inevitably lost in the system of decentralized messing of the line, and without which war cannot be successfully waged". ${ }^{187}$ Similarly, Lieutenant-Colonel A.C.H. Kearsey took over $5^{\text {th }}$ Dorset in December 1915 and "determined to get it thoroughly efficient again he started by at once having men detailed for training as specialists". He very successfully succeeded in 'making us matter' as "before long the Battalion's specialists had carried off several brigade contests". ${ }^{188}$

\footnotetext{
${ }^{184}$ Astill, Johnston, p.185

${ }^{185}$ Lindsay, Forgotten, p.71

${ }^{186}$ Fraser, Good Company, p.100. This sort of ability to train developed with experience during the war. Brigadier-General J.A.L. Haldane wrote in June 1916 that because of rapid promotion: "Most of the brigadiers and COs now are not competent to teach", [Brigadier-General J.A.L. Haldane, War Diary, 22 June 1916, Haldane Papers, NLS, quoted in S. Robbins, British Generalship on the Western Front 1914-18: Defeat Into Victory (Abingdon: Frank Cass, 2005)].

${ }^{187}$ F.P. Crozier, A Brass Hat in No Man's Land (London: Jonathan Cape, 1930), pp.92-3

${ }^{188}$ H.C. Lock \& O.C. Vidler, The History of the Dorsetshire Regiment 1914-1919 Part III (Dorchester: Henry Ling, 1933), p.53. Alexander Horace Cyril Kearsey, psc, was a Captain of $10^{\text {th }}$ Hussars in August 1914, and had served as Brigade-Major of the $2^{\text {nd }}$ Lowland Mounted Brigade before assuming command of $5^{\text {th }}$ Dorset between 26 December 1915 and 1 May 1916. He later served as GSO1 with 54 ${ }^{\text {th }}$ Division, but also commanded $1 / 5^{\text {th }}$ Scottish Borderers between 18 April and 24 November 1917.
} 
Lieutenant-Colonel R.G.B. Jeffreys took over command of $2^{\text {nd }}$ Royal Dublin Fusiliers on

13 July 1916, but it was April 1917 before he got three weeks of training with his battalion.

He entered it with vigour:

I am very busy training all day and in the evenings till late at night. I am making up schemes etc. We start work here at 6.30am and don't finish till $7 \mathrm{pm}$. My earliest start is 8.30 am till $1 \mathrm{pm}, 2.30 \mathrm{pm}-4.30 \mathrm{pm}$ and then a lecture to all officers from $5.30 \mathrm{pm} . . .7 \mathrm{pm}$ to $7.30 \mathrm{pm}$ training programmes etc. and again after dinner ... I am kept fairly busy. ${ }^{189}$

The training created a specific bond, for when he was hospitalised four months later with the sciatica which would end his career in 1918, he wrote: "I want to get back to my battalion ... it is just the time I want to be with them and it will be hard luck if I miss it now at the last moment when I have been doing all the training". 190

Lieutenant-Colonel W.D. Croft was absent, sick, when his battalion took heavy casualties at Fampoux on 12 April 1917, writing:

How shamed I felt to meet those who had gone into action without me; it was indeed the bitterest day of my life ... I was ill and depressed, and for days I had the feeling that everybody was pointing the finger of scorn for ratting. ${ }^{191}$

Taking over command of $1 / 6^{\text {th }}$ Durham Light Infantry in December 1915 , LieutenantColonel G.A. Stevens took a robust approach to achieving a 'strong side of officers': "I believe half the battle has been I have been very very particular with my officers \& I have

\footnotetext{
${ }^{189}$ Dodd, Jeffreys, p.39, letter dated 5 April 1917.

${ }^{190}$ Dodd, Jeffreys, p.39, letter dated 6 August 1917. On 16-17 August 1917 the $2^{\text {nd }}$ Royal Dublin Fusiliers, 48 Brigade, $16^{\text {th }}$ Division, in the Battle of Langemarck, assaulted Vampire Farm, north of St Julien, losing 50 per cent of the officers and men engaged. George Archibald Stevens, a Regular Captain of the Royal Fusiliers in August 1914, commanded 1/6 ${ }^{\text {th }}$ Durham Light Infantry from 19 December 1915 to 27 April 1916, and $2^{\text {nd }}$ Royal Fusiliers from 20 July 1916 to 12 November 1917, commanding 90 Brigade in 1918.

${ }^{191}$ Croft, Three Years, pp.121-2. Lieutenant-Colonel A. Johnston, 10th Cheshire, preparing for the Battle of Messines in June 1917, was "told that I am not to go into the show, which is an awful disappointment". He wanted to see the fruits of his training in action, and, "besides one feels an awful shirker staying out behind". (Astill, Johnston, p.212).
} 
a splendid set, I have 'fired' four to England \& persuaded two to go "sick". ${ }^{192}$ Similarly, Lieutenant-Colonel E.K. Cordeaux, who had served with $10^{\text {th }}$ Lincolnshire for a year and a half before taking over from the invalided Lieutenant-Colonel G.E. Heneage, took the sword to his brother officers. ${ }^{193}$ He wrote some two and a half weeks on: "I have to make one or two rather sweeping changes", ${ }^{194}$ and "I have had to recommend that one of my majors be removed from the battalion ... a very unpleasant task ... I shall have to weed out some other officers". 195

Making a mark created a reciprocal sense of ownership. Captain A.I. Adam noted how "the C.O. becomes more and more a delightful man as the battalion grows more to his liking". ${ }^{196}$ Major F.A. Maxwell took over $12^{\text {th }}$ Middlesex unwillingly on 31 May 1916 as the battalion "had not been doing well, owing, it is said, to C.O. who has mishandled them. ${ }^{197}$ However, I fancy the battalion is not too good ... has had two failures at least - its morale therefore not too good ... I loathe the whole business". ${ }^{198}$ Yet when he left it on 20 October 1916 he wrote publicly to the battalion: "I have spent nearly six months in this happy family, \& these have been amongst the happiest, saddest \& proudest of my life". 199

\footnotetext{
${ }^{192}$ IWM Docs 12339 G.A. Stevens, letter dated 23 March 1916.

${ }^{193}$ George Edward Heneage, a retired Lieutenant-Colonel of Special Reserve in August 1914, commanded $10^{\text {th }}$ Lincolnshire from 1 September 1914 to 26 May 1916.

${ }^{194}$ IWM Docs 16975 E.K. Cordeaux, letter dated 14 June 1916. Edward Kyme Cordeaux was a retired Lieutenant-Colonel of Special Reserve, Lincolnshire Regiment, in August 1914. He commanded $10^{\text {th }}$ Lincolnshire from 26 May 1916 until 1 January 1917, and 12 ${ }^{\text {th }}$ Devonshire from 24 January to 1 April 1917.

${ }^{195}$ IWM Docs 16975 E.K. Cordeaux, letter dated 16 June 1916.

${ }^{196}$ Adam, Adam, p.242

197 The CO in question was Henry Percy Osborne, a Regular Captain of the Middlesex Regiment, who commanded between 20 October 1915 and 18 May 1916. Osborne never commanded again but served as a $\mathrm{GSO} 2$.

${ }^{198}$ C. Maxwell, I Am Ready (London: Hazell Watson and Viney, 1955), p.127. Francis Aylmer Maxwell, an Indian Army Major of $17^{\text {th }}$ Lancers in August 1914, commanded $12^{\text {th }}$ Middlesex from 31 May to 21 October 1916, before becoming Brigadier General 27 Brigade.

${ }^{199}$ TNA WO /95/2044 War Diary $12^{\text {th }}$ Battalion Middlesex Regiment.
} 
Lieutenant-Colonel G.S. Hutchison was missing for three days in Spring 1918 and reported dead. His resurrection revealed that "already a new Commanding Officer ... had arrived to take over command of my beloved battalion. He did not wait long after he had seen me in person". ${ }^{200}$ Shot in the face on 15 September 1918, after eight days in hospital, protesting "my battalion was more than a wife", he got a friend to fly him back to the front line where: "The new Commanding Officer was returned to store". 201

As a Brigadier-General, ${ }^{202}$ W.D. Croft described a CO who "implored me to let him stay with his lads, with whom he had only been a few days". He continued: "Such is the way of British officers, who, whatever they may be commanding, consider that they stand in loco parentis when they have had charge of their men for five minutes!"203 He had already demonstrated this paternalism himself, as when he was briefly sent from $11^{\text {th }}$ Royal Scots to command the divisional tactical school in early 1917 he noted: "It is perfectly beastly leaving one's own family - and we were a very happy family". ${ }^{204}$ Similarly, five weeks after taking over command of $6^{\text {th }}$ Connaught Rangers, Lieutenant-Colonel R. Feilding wrote to his wife of his battalion that "I have got to know it and be proud of it ... I find both officers men magnificent", 205

After action, when a battalion had suffered significant casualties, a CO could grieve. W.L. Andrews wrote of Lieutenant-Colonel G.A.McL. Sceales: "I, who was much with him, knew that he suffered intensely when he lost men, though he would have scorned to show

\footnotetext{
${ }^{200}$ Seton, Footslogger, p.216

${ }^{201}$ Seton, Footslogger, p.233

${ }^{202}$ Croft became Brigadier-General with 182 Brigade from 14 to 23 September 1917 and 27 Brigade from 23 September 1917 to the Armistice.

${ }^{203}$ Croft, Three Years, p.217

${ }^{204}$ Croft, Three Years, p.95

${ }^{205}$ Feilding, War Letters, p. 79
} 
it". ${ }^{206}$ After the attack at Roeux on 3 May 1917, Lieutenant-Colonel A.G. Horsfall wrote of his battalion casualties: "I simply can't bear to think about it". ${ }^{207}$ When $7^{\text {th }}$ Northumberland Fusiliers were smashed at Ypres on 26 October 1917, Lieutenant-Colonel G.S. Jackson came out of action: "And the tears trickled down his weather-beaten face as he said '... this has fairly done me",. ${ }^{208}$ He spoke true, for having commanded the battalion since 18 April 1915 he was sent at the end of December to the RAMC to command a base hospital. $^{209}$

\subsubsection{Stress and strain}

Sir Douglas Haig himself noted: "The strain of commanding a battalion in this kind of warfare", continuing, "only young and strong men can stand it". 210

Specific incidents could induce stress in the ablest commander. Lieutenant E.C. Blunden described Lieutenant-Colonel G.H. Harrison, $6^{\text {th }}$ Sussex, lost during a relief near Thiepval in 1916, "trembling with overstrain". ${ }^{211}$ The summation of a series of such incidents over a long period in command could generate terminal exhaustion. Lieutenant-Colonel A.F.A.N. Thorne wrote to his wife in July $1918,{ }^{212}$ when he had been in command of $3^{\text {rd }}$ Grenadier

\footnotetext{
${ }^{206}$ Andrews, Haunting Years, p. 182

${ }^{207}$ Horsfall, Letters, p. 24

${ }^{208}$ F. Buckley, Q.6.a and Other Places (London: Spottiswoode, Ballantyne \& Co, 1920), p.148. George Scott Jackson was a retired Territorial Captain of the Northumberland Fusiliers in August 1914, and commanded the $1 / 7^{\text {th }}$ Battalion from 18 April 1915 to 29 December 1917.

${ }^{209}$ Garth Pratten draws attention to a different dimension of courage in the CO - moral courage - noting: "The willingness to make difficult decisions, including to risk and expend the lives of his men in pursuit of a larger objective, is a key characteristic of a successful commander". (Pratten, Australian Battalion Commanders, p.159).

${ }^{210}$ Field-Marshall Sir D. Haig, Diary, 3 March 196, Haig Papers TNA WO256/31.

${ }^{211}$ Blunden, Undertones, p.85
} 
Guards virtually without a break for 22 months: "My head is fed up and stale!", ${ }^{213}$ and some days later: "I am afraid that I am always doing things wrong and only take precautions when boldness should be the policy". He was clearly suffering from low mood, largely from simple war-weariness, and this caused him to think negatively about his abilities. He continued: "Evidently other people think the same, otherwise I should have been promoted some time ago", feeling that he now had ceased "to be considered any good and everyone else goes by me". ${ }^{214}$ Others clearly did see him as exhausted, as he was transferred as Commandant IX Corps School in August before being promoted BrigadierGeneral 184 Brigade on 14 October 1918. However, before he left, he led his battalion in the fighting on the old Somme battlefield of 21-3 August 1918, action which reinvigorated him as he wrote: "I have never enjoyed battle fighting so much". 215

Lieutenant-Colonel H.P.F. Bicknell, who commanded $4^{\text {th }}$ Middlesex from 27 October 1915 to 12 March 1917, wrote:

\begin{abstract}
My Divisional General has recommended that I should be sent home for two or three months for 'training duty' on account of 'war weariness' due to prolonged service in the field. I am very sick about it as although the report of course contains no reflection on me in it and I admit that I am not capable of the energy that I possessed two years ago. ${ }^{216}$
\end{abstract}

As 1918 ground on, Lieutenant-Colonel H.M.B. de Sales la Terriere, $9^{\text {th }}$ Essex, recorded how the strain began to tell and he began to drink: "I was so utterly worn out both

\footnotetext{
${ }^{213} \mathrm{He}$ had had a brief period in hospital with a possible thrombosis in his leg, due to a kick received in a football match, in May 1917.

${ }^{214}$ Lindsay, Forgotten, p.71

${ }^{215}$ Lindsay, Forgotten, p.72

${ }^{216}$ IWM Docs 16133 H.P.F. Bicknell, letter dated 9 February 1917. Henry Percy Frank Bicknell was a Regular Captain of $2^{\text {nd }}$ Middlesex in August 1914 and commanded the $4^{\text {th }}$ Battalion from 27 October 1915 to 12 March 1917. He was sent as instructor to Senior Officer School, Aldershot, but returned to command $20^{\text {th }}$ Lancashire Fusiliers from 23 October 1917 until their disbandment in February 1918. The 'Divisional General' in question was Major-General D.G.M. Campbell.
} 
physically and nervously that without some form of dope I could not possibly have carried on". ${ }^{217}$ He complained: "I was getting absolutely exhausted ... most divisions had arranged for their COs to have an official rest of six months commanding a home battalion: ours apparently had not". ${ }^{218}$ His exhaustion was visible to others: "My MO told me as forcibly as possible to go sick or I should break down completely". ${ }^{219}$

Lieutenant-Colonel E.K. Cordeaux had only been in command for just over a month when on 1 July 1916, $10^{\text {th }}$ Lincolnshire assaulted 'The Bloater', La Boisselle, suffering casualties to the tune of 15 officers and 487 other ranks. By 13 July the battalion was up to strength again, but, clearly suffering post-traumatic symptoms, Cordeaux wrote: "I think my brain \& mind need a rest. I don't seem to be able to concentrate on any one thing for more than a few moments". ${ }^{220}$ He continued: "To form a new battalion with all the best of our officers \& NCOs gone is I feel beyond my powers. I feel so lost at times". ${ }^{221}$ He added, "I have never sought my present position \& would very gladly take one of less responsibility \& more within my capacity". ${ }^{22}$ With the decimation of his battalion, the heart had temporarily gone of him - he doubted his own 'expert power'. By January 1917 he was

\footnotetext{
${ }^{217}$ IWM Docs 14737 H.M.B. de Sales la Terriere, p.419

$21812^{\text {th }}$ Division.

${ }^{219}$ IWM Docs 14737 H.M.B. de Sales la Terriere, p.425

${ }^{220}$ IWM Docs 16975 E.K.Cordeaux, letter dated 13 July 1916.

221 IWM Docs 16975 E.K.Cordeaux, letter dated 14 July 1916.Cordeaux was not the only CO to be traumatised by the decimation of his battalion. Lieutenant-Colonel W.A. Eaton, a Depot Major who had seen service in Chitral 1895, the North-West Frontier 1897-8, West Africa 1900, and South Africa 1900-2, who had commanded $6^{\text {th }}$ Buffs from the outset, was so affected by the battle of Loos that he wrote to his Brigade Major asking to be relieved of command, stating: "I feel that there is no course open to me than to report that I do not personally feel physically capable or reorganizing and reforming the battalion". (TNA WO 374/21808 Officers' Services, William Arnold Eaton). Eaton clearly recovered his poise as he attempted throughout 1916 to be reinstated to active command, which he only achieved briefly in 1917, commanding $9^{\text {th }}$ Leicestershire from 23 March to 11 May, after which he commanded a battalion of the Training Reserve.

${ }^{222}$ IWM Docs 16975 E.K.Cordeaux, letter dated 20 July 1916.
} 
referring to himself as "a rather stiff weary sort of old thing. I asked my general if he thought I was the man for it". 223

Lieutenant-Colonel G.A. Stevens, $2^{\text {nd }}$ Royal Fusiliers, also thought that rest would have saved him from collapse, writing on 25 April 1917:

My dear father, I am deeply sorry to say I have had a nervous breakdown and am now in the VI Corps Rest Station (officers). I never thought this would happen to me but I cracked up all of a sudden ... I have had more service in the field than all the CO's in the Division, but just because I wasn't an original 29th Division officer I couldn't get the month's leave that they all got ... I got finished up at Monchy after going through four days heavy bombardment in which we twice had to change dugouts and had two blown in on top of us. On top of the strain was the horror of walking out through the village on the bodies of dead men and horses. I know you will know that I have done my best. ${ }^{224}$

Others seemed oblivious of the strain. After five months in France commanding $9^{\text {th }}$ Rifle Brigade, Lieutenant-Colonel W.D. Villiers-Stuart was surprised to be told in October 1915 by his Brigadier that "he considered I was tired and must have a rest, so he had decided to replace me by a much younger officer of the Rifle Brigade and that I must go home on a medical certificate for a rest". 225

\subsubsection{Promotion}

In December 1916 Lieutenant-Colonel A. Horsfall, taking up post as CO of $2^{\text {nd }}$ Duke of Wellington's West Riding Regiment, wrote: "Everyone who is worth their salt is ambitious

\footnotetext{
${ }^{223}$ IWM Docs 16975 E.K.Cordeaux, letter dated 21 January 1917. At this point Cordeaux was told he could "have command of a battalion at home", but several days later was transferred to command $12^{\text {th }}$ Devonshire, a labour battalion. Cordeaux remained in France, Colonel Labour Commandant.

${ }^{224}$ IWM Docs 12339 G.A. Stevens, letter dated 25 April 1917.

${ }^{225}$ R.M. Maxwell, Villiers-Stuart Goes to War (Kippilaw: Pentland Press, 1990), p.161. See Chapter Two section 2.1.5 for further details of his career. The Brigadier-General in question was F.A.Dudgeon, 42 Brigade.
} 
... there are any number of people waiting for commands". ${ }^{226}$ Similarly, there were many

COs who keenly awaited the call to command a brigade. ${ }^{227}$

Although Lieutenant-Colonel F.A. Maxwell's written sentiment on leaving $12^{\text {th }}$ Middlesex was most likely genuine (and if it was not, it was a masterstroke of "identity leadership"), ${ }^{228}$ his eye had always been on promotion. In August he had written to General W.E. Peyton asking to be "allowed to join 18th L." i.e. the 18th Lancers, his regiment of origin, "command of which was vacant". Peyton replied that he should remain with $12^{\text {th }}$ Middlesex: "In your own interests in the way of advancement I think it is better also". Maxwell noted that staying should not affect his possibility of getting the command eventually, but noted a little wistfully that "the pay ... is about double what I draw as O.C. $12^{\text {th }}$ Middlesex". 229 He appeared to be more concerned with regimental progression (with eye towards, perhaps, the post-war period), rather than brigade promotion. ${ }^{230}$

\footnotetext{
${ }^{226}$ Horsfall, Letters, p. 25, letter dated 2 December 1916.

${ }^{227}$ Attitudes concerning the seniority principle in brigade command were slow to die. In the New Zealand Division in late 1916, Lieutenant-Colonel H. Hart, Wellington Battalion, noted (9 December 1916): “On Tuesday last Brigadier-General Johnston went away on a month's sick leave, and Lieutenant-Colonel Brown was appointed to command the brigade with rank of Temporary Colonel. He is junior to all four COs but it affected Lieutenant-Colonel Plugge the most as he is the senior Lieutenant-Colonel in the Division. It is in fact a deliberate and intended 'turn-down' for him. There was much strafing in consequence and the result is awaited with interest. It has been thought for some time that he would not be given a Brigade, and in the meantime, as he is the senior CO in our Brigade, this matter has stood in the way of the other three COs. It is a relief therefore to find that the situation is being cleared up". Plugge was likely worn out as in early 1917 he was relieved of command and placed in charge of divisional sporting activities. J. Crawford, (ed.), The Devil's Own War: The First World War Diary of Brigadier-General Herbert Hart (Titirangi, Auckland: Exisle, 2008), p.154

${ }^{228}$ See above.

${ }^{229}$ Maxwell, Ready, pp.129-30. He was promoted to command of $18^{\text {th }}$ Lancers at the same time as being promoted GOC 27 Brigade on 21 October 1916.

${ }^{230}$ Lieutenant-Colonel J.H. Patterson's stout defence of the rights of his Jewish $38^{\text {th }}$ London Regiment caused his Brigadier to remark: "You will get nothing out of it", his meaning being clear. (Patterson, Judeans, p.82).
} 
Lieutenant-Colonel G.A. Stevens wrote in April 1916: "I have been recommended for the command of a Brigade - what HO", ${ }^{231}$ but after his breakdown following the attack on Monchy in April 1917 noted: "I suppose all my prospects in the Army are gone" ${ }^{232} \mathrm{He}$ was relieved to learn that "I have heard from my general \& they bear me no ill will \& he is going to keep my Battalion for me and wants me back". ${ }^{233}$ At the start of October he wrote: "I have just heard that the man in front of me has just got his Brigade today", 234 and finally on 14 November 1917, "I am now a real live Brigadier". ${ }^{235}$ It had taken 19 months to work his way up 'the list'.

Lieutenant-Colonel W. Fraser, $1 / 6^{\text {th }}$ Gordon Highlanders, was sent to command XVIII Corps training school in January 1918: "A safe job and supposed to be a leg up towards a Brigade" ${ }^{236}$ but the school fell into abeyance after the German Spring offensive, and Fraser hung hopefully and fretfully about Corps HQ. When finally on 3 September he was sent to command $1^{\text {st }}$ Gordon Highlanders, something that pre-war would have been the pinnacle of his career, he was "a bit disappointed at being sent back to a battalion at first". He noted optimistically: "I'm still on the list for a brigade", calculating himself as "about 3 months off" promotion, but concluding in consolation: "What can one want better then to command one's own battalion?" 237

In contrast, Lieutenant-Colonel W.D. Croft of the $11^{\text {th }}$ Royal Scots woke up in September 1917: "To find Frank Maxwell in the tent with the astounding intelligence that I had got a

\footnotetext{
${ }^{231}$ IWM Docs 12339 G.A. Stevens, letter dated 29 April 1916.

${ }^{232}$ IWM Docs 12339 G.A. Stevens, letter dated 25 April 1917.

${ }^{233}$ IWM Docs 12339 G.A. Stevens, letter dated 10 May 1917.

${ }^{234}$ IWM Docs 12339 G.A. Stevens, letter dated 2 October 1917.

${ }^{235}$ IWM Docs 12339 G.A. Stevens, letter dated 14 November 1917.

${ }^{236}$ Fraser, Good Company, p.208

${ }^{237}$ Fraser, Good Company, p.283
} 
brigade". He seems only to have been depressed by the idea: "So I was to leave the dear old division, and all my old friends in the battalion; it didn't sound a very cheering prospect, especially as they were just about to go into action". ${ }^{238}$ Similarly, even Lieutenant-Colonel H.P. Croft, whose memoirs betray little personal reaction, stated: "I was naturally pleased at promotion, but it is with a heavy heart that you leave men with whom you have lived in the palace of death for sixteen months". 239

Lieutenant S. Sassoon implied that promotion-seeking could be over-aggressively pursued in battalion eyes, writing of "Colonel Winchell" (Lieutenant-Colonel J.R. Minshull-Ford) that: "Everyone knew that he was booked for a brigade, and some said that he'd bought the Brigadier's gold-peaked cap last time he was on leave". ${ }^{240}$ On his elevation Sassoon noted: "He'd had Brigadier on the brain ever since he came back off a leave, and now he'd never be satisfied till he'd got division and another decoration to go with it". ${ }^{241}$

Lieutenant-Colonel A. Johnston, 10th Cheshire, was told on 12 September 1917 that he would be given command of 33 Brigade, but the next day that it would in fact be 126 Brigade. ${ }^{242}$ On the $12^{\text {th }}$ he wrote: "I have had wonderful luck indeed to run from subaltern to brigadier general in under 3 years", but the next day wrote of the change as: "A bad

\footnotetext{
${ }^{238}$ Croft, Three Years, pp.150-1. 'Billy' Croft commanded 182 Brigade in $23^{\text {rd }}$ Division 14-23 September 1917, then 27 Brigade $9^{\text {th }}$ Division until the Armistice.

${ }^{239}$ H. Page Croft, Twenty Two Months Under Fire (London: John Murray, 1917), p.165. Croft commanded 68 Brigade in $23^{\text {rd }}$ Division from 8 February to 18 August 1916 before returning to the politics from whence he had come.

${ }^{240}$ Sassoon, Sherston, p. 257

${ }^{241}$ Sassoon, Sherston, p.268

${ }^{242}$ See Chapter Three section 3.3.8.
} 
exchange I fear", as he now reckoned on having to train a "very inexperienced" brigade rather than a "pretty good" one. ${ }^{243}$

Others found the change of command skill-set frustrating. Lieutenant-Colonel A.F.A.N. Thorne immediately appreciated the quality of the men of 184 Brigade in October 1918, but, as he wrote to his wife, longed "to command them as a Battalion Commander instead of as a Brigadier-General. One cannot get at them except through their COs and I feel I could run their show so much better than they could!"244

\subsubsection{Demotion}

Thirty-eight per cent of COs were removed from command or sidelined into inactive posts. $^{245}$ Lieutenant-Colonel A.G. Horsfall noted in November 1916: "COs have no very safe tenure out here; the slightest thing may cause one's removal". ${ }^{246}$ His anxiety about this was manifest: "I suppose when one has commanded out here for some months you get used to the strain of never knowing when you may not put your foot in it with some General". ${ }^{247}$ Even the redoubtable Lieutenant-Colonel E.A. Wood, $6^{\text {th }}$ King's Shropshire Light Infantry, who, on losing contact with Battalion HQ at the Battle of Langemarck and falling asleep with tiredness, remarked to his battalion Intelligence Officer: "I shall probably get sent home for this". 248

\footnotetext{
${ }^{243}$ Astill, Johnston, p. 227. On his second day, he was noting of one of his units: "The C.O. though quite an old soldier is obviously very inexperienced out here, and I do not think he is fit to command a battalion on this front", (p.228). He never had the chance to sack the offending CO being wounded the following day.

${ }^{244}$ Lindsay, Forgotten, p. 74

${ }^{245}$ See Chapter Three.

${ }^{246}$ Horsfall, Letters, letter dated 21 November 1916.

${ }^{247}$ Horsfall, Letters, letter dated 25 November 1916.

${ }^{248}$ Dugdale, Langemarck, p.75. Wood in fact got a bar to his DSO and the command of 55 Brigade three months later.
} 
An officer promoted to battalion command temporarily could suddenly be displaced. Lieutenant-Colonel G.M. Bullen-Smith had commanded $2^{\text {nd }}$ Leinster since 20 November 1914 when on 3 June 1915 the wounded Lieutenant-Colonel W.T.M. Reeve unexpectedly returned. Lieutenant F.C. Hitchcock noted: "B-S hastily departed to cut off his two stars from his cuffs. We were all exceedingly sorry for him". ${ }^{249}$

Lieutenant-Colonel E.W. Hermon was displaced from $27^{\text {th }}$ Northumberland Fusiliers by the return of the previous incumbent in October 1916. He was, however, confident that "they're not going to lose me. A Battalion Commander nowadays has a price above rubies \& one can almost dictate one's own terms". 250

Not all were unhappy to be replaced. Lieutenant-Colonel H.C.L. Lloyd, a Captain in 1914, commanded $2^{\text {nd }}$ Welsh from 3 October to 14 November 1915 , when he was displaced by Lieutenant-Colonel O.B. Pritchard, a Major in August 1914. ${ }^{251}$ Captain C.P. Clayton noted of Pritchard: "He is much senior to Lloyd, and Lloyd has fallen to second-in-command, but seems no less happy". ${ }^{252}$ Clayton himself would rise to be second-in-command, fall to Adjutant, and rise again to CO in November 1916 when Pritchard was invalided. He was only too aware on the arrival of The Hon. W.F. Somerset that he would be displaced: "He is a Captain in the Regular Army and will therefore, I take it, take precedence". Several

\footnotetext{
${ }^{249}$ Hitchcock, Stand To, p.31. George Moultrie Bullen-Smith was a Major of $2^{\text {nd }}$ Leinster in August 1914 and commanded the battalion between 20 November 1914 and 15 May 1916 (at which point he was promoted Brigadier-General with 5 Brigade). William Tankerville Monypenny "Terrier" Reeve had commanded since the outbreak of war. Having lost his hand to a sniper his return was short-lived, and from 13 August 1915 he commanded the $1^{\text {st }}$ Garrison Battalion Essex Regiment.

${ }^{250}$ Nason, Love and Courage, p.295, letter dated 9 October 1916.

${ }^{251}$ Henry Chester Lewis Lloyd was a Regular Captain of the Welsh Regiment in August 1914. He subsequently commanded $2^{\text {nd }}$ Welsh between 3 October 1915 and 4 May 1917; $1^{\text {st }}$ Dorsetshire from 5 July to 21 December 1917; and $4^{\text {th }}$ Monmouthshire from 20 March 1918 until the Armistice. Osborn Brace Pritchard a Major of $2^{\text {nd }}$ Welsh commanded the battalion between 15 November 1915 and 25 September 1916. He committed suicide following serious wounding on 27 November 1916.

${ }^{252}$ Pritchard, Hungry, p.133
} 
days after showing him around the trenches: "When it comes time for Commanding Officer's Orderly Room I have pulled down my badges and insist upon Somerset taking the duties of command". Clayton was conscious of demotion: "Partly, I suppose, to soften my fall ... I am given three weeks' leave to England". ${ }^{253}$ By August 1918, when he had been Lieutenant-Colonel again for nearly four months, Clayton was actively pleased to hand over command in exchange for leave.

In summary, whilst promotion to battalion command was the hope of many officers, when it arrived it was often accepted with diffidence. The efficient CO knew, however, that he had to stamp his mark, and he did this by both training his battalion and selectively weeding his officers. Many COs became conscious of command as a burden, and in response to either cumulative strain or the acute stress of a particular action, a $\mathrm{CO}$ could easily become worn out. Some, particularly Regulars, kept their enthusiasm alive by focussing on the possibility of brigade command. For others there was a constant anxiety about displacement, a fate which some accepted with relief.

\subsection{Decorations}

The award of decorations gives insight into institutional expectations of how a $\mathrm{CO}$ should behave. List A awards of the Distinguished Service Order or Bar, ${ }^{254}$ i.e. awards for service

\footnotetext{
${ }^{253}$ Pritchard, Hungry, p.178. Wellesley Fitzroy Somerset, a Lieutenant of $2^{\text {nd }}$ Welsh in August 1914, commanded the battalion between 22 December 1916 and 5 March 1917.

${ }^{254}$ The Distinguished Service Order (DSO) was instituted on 6 September 1886 (and the Bar on 23 August 1916), as the Royal Warrant states, for "meritorious or distinguished service in the Field, or before the enemy". From 1914 to 1917 increasing awards were made to those whose meritorious service was far from the front line. In 1917 the Army Council ordered that there were to be two separate lists; A list awards were to be "for Conspicuous Gallantry in Action" with citations appearing in the London Gazette; and B list, i.e. 'the others', where there would be no citation. During 1918 GHQ was limited to 200 DSOs per month, unlimited from May 1918. [See 'Honours and Awards' in C. Messenger, Call to Arms: The British Army 1914-18 (London: Weidenfeld \& Nicolson, 2005), pp. 474-495]. 8,981 DSOs were awarded during the war
} 
in action for which citations were recorded in the London Gazette, have been analysed in respect of the reasons for which they were awarded. ${ }^{255}$

Between 1 January 1918 and 31 December 1918, 703 awards were made to officers of infantry battalions of regiments of the line, and a remarkable 307 (42 per cent) of these were made to battalion commanders. ${ }^{256}$ This reflects the focus in the mobile warfare of 1918 on effective battalion leadership, a focus likely sharpened by the increased presence of the brigade commander at the forefront of action. ${ }^{257}$

Given that citations were nearly always prefaced with the statement: "For conspicuous gallantry and devotion to duty", ${ }^{258}$ the five key additional features of the behaviour of the CO recognised were, in order of importance: (i) Provision of "example" (50 per cent); (ii) “Ability" (48 per cent); (iii) Organisational skills (33 per cent); (iv) Quality of leadership (26 per cent); and (v) "Initiative" (14 per cent). Both 'referent' and 'expert' power were being rewarded.

The fact that "example" is the most frequently recorded category reflects the importance placed on the modelling function of the CO. Words/phrases used most often include: "Disregard of danger", "courage", “coolness", "cheerfulness", "energy", “enthusiasm", "determination", "tenacity", and "confidence". This is clearly expressed in the citation to

with 708 first, 71 second, and 7 third Bars [Statistics of the Military Effort of the British Empire During the Great War (London: HMSO, 1922), p.554].

${ }^{255}$ O'M. Creagh \& E.M Humphris, The V.C. and D.S.O. Book: Distinguished Service Order 1916-1923 (London: Standard Art Book Company, 1924), pp.61-137

${ }^{256}$ Changboo Kang draws attention to the fact that a remarkable 18 per cent of VCs won by officers during the First World War were by officers with the rank of Lieutenant-Colonel. [C. Kang, 'The British Regimental Officer on the Western Front in the Great War, with Special Reference to the Royal Warwickshire Regiment', unpublished PhD Thesis, University of Birmingham (2007)].

${ }^{257} \mathrm{I}$ am grateful to Peter Simkins for this latter point.

${ }^{258}$ The second part of this opening statement became more variable in the last months of 1918. 
Lieutenant-Colonel J.H. Levey, $13^{\text {th }}$ Royal Sussex: "He displayed coolness, courage and determination, and by his cheerfulness he kept those under him in good heart. His personal example was an incentive to all". ${ }^{259}$

A close second was the issue of ability, in essence skilful handling of the battalion. Thus, Lieutenant-Colonel A.E. Blackwood, $2^{\text {nd }}$ Cheshire, conducting a successful raid on a village in the German lines was rewarded for "forethought and skilful handling of his command". ${ }^{260}$ Third most frequently mentioned was organisational prowess, a sub-division of ability. Much of this stemmed from "personal" intervention, often following personal reconnaissance leading to some specific direction or reorganisation. Thus LieutenantColonel G.B. Wauhope, $13^{\text {th }}$ York and Lancaster, was awarded the DSO for a surprise night attack: "The successful result of which was due to the skill and resource with which this officer supervised every detail of preparation". ${ }^{261}$ Fourthly, leadership was cited specifically, described variously as "fine", "able", or "skilful". Lieutenant-Colonel G.E. King, $7^{\text {th }}$ East Yorkshire, was awarded the DSO following a two battalion raid on German trenches when: "His utter disregard of personal danger, skill and cheerfulness throughout,

\footnotetext{
${ }^{259}$ London Gazette, 9 January 1918, p.564. Joseph Henry Levey, aged 36 in 1917, was a Warrant Officer with the Royal Scots, commissioned $2^{\text {nd }}$ Lieutenant in the Gordon Highlanders on 10 October 1914. He was appointed Chief Instructor to the Royal Naval Division, and in April 1917 was Commandant of a Corps School. After his spell with $13^{\text {th }}$ Sussex, his DSO being won at Third Ypres, he became Deputy Inspector of Training in July 1918.

${ }^{260}$ London Gazette, 16 August 1918, p.9560. Albemarle Price Blackwood, aged 37 in 1918, was a Regular Captain of the Border Regiment in August 1914, who commanded $2^{\text {nd }}$ Cheshire from April 1917 to January 1918.

${ }^{261}$ London Gazette, 15 October 1918, p.12055. George Boothby Wauhope, aged 36 in 1918, was a Captain in the York and Lancaster Regiment in August 1914 and commanded continuously from December 1916 to the Armistice, first with $11^{\text {th }}$ East Lancashire to May 1917, then with $13^{\text {th }}$ York and Lancaster.
} 
inspired all under his command and proved him to be a leader of a high order". ${ }^{262}$ Last was initiative. Thus, Lieutenant-Colonel D.E. Prideaux-Brune, $8^{\text {th }}$ Rifle Brigade:

Commanded his battalion and elements of other units with consummate skill ... He stubbornly defended positions one after another, then skilfully extricated his men and organised fresh ones. He showed great presence of mind, initiative, and resource at all times. ${ }^{263}$

\subsection{Conclusion}

On 16 December 1917 Lieutenant-Commander A. Asquith was promoted from his post as CO Hood Battalion to the command of 189 Brigade. Brigadier-General J.F.S.D Coleridge's recommendation probably encapsulates what constituted the best CO:

He has developed military qualities of a high order. Possessed of great personal courage, he inspires confidence in his men, and leads them successfully in action: he possesses decision, driving power, and energy, \& has a good capacity for organisation. ${ }^{264}$

The judgements made by Coleridge map almost exactly onto the five DSO award factors of example, ability, organisational skill, quality of leadership, and initiative. That these correspond well to the principles taught at Senior Officer School indicates a broadly shared view of effective command and leadership. The army moved between 1914 and 1917 from having an unspoken concept of battalion leadership to having a taught vision. The principles fall broadly within modern concepts of both 'contingency' and 'identity' leadership, and encouraged the development of 'referent' and 'expert power'.

\footnotetext{
${ }^{262}$ London Gazette, 24 September 1918, p.11276. Gilbert East King, aged 30 in 1918, retired from the South African forces in August 1914, gazetted Lieutenant 4 November 1914 in the $10^{\text {th }}$ East Surrey, and Captain in $7^{\text {th }}$ East Yorkshire on 1 February 1915, commanding from 20 August 1916 to the Armistice.

${ }^{263}$ London Gazette, 26 July 1918, p.8739. Denys Edward Prideaux-Brune, aged 27 in 1918, was a Lieutenant of $3^{\text {rd }}$ Rifle Brigade in August 1914, and commanded the $13^{\text {th }}$ Battalion from July to November 1916, and the $8^{\text {th }}$ Battalion from January 1917 to May 1918.

${ }^{264}$ C. Page, Command in the Royal Naval Division (Staplehurst: Spellmount, 1999), p.167
} 
Officers and other ranks appear to have a shared view of what they valued in a $\mathrm{CO}$, which happily fell in line with what was being taught; namely courage, intelligence, knowledge, hard work, diligence and skill which protected lives. Other ranks in particular valued fairness, paternalistic care, and discipline fairly applied. Officers, being that much 'closer', valued cheerfulness, humour and tact in a $\mathrm{CO}$, as well as something approaching friendship where possible. Consequently, a consensual management style was valued. Where these features were lacking, the morale and efficiency of the unit was invariably affected and the removal of 38 per cent of COs from command no doubt reflects these factors to a greater or lesser degree.

Promotion to battalion command was the hope of many officers, but the best never took it up without diffidence. The most able COs followed the tenets of "identity leadership", stamping their mark through training and shaping their officer cadre. Physical exhaustion and war-weariness, however, were never far away. Patrick Brennan notes that COs "endured a more solitary existence than those in the lower ranks", often lacking the companionship that "was a critical bulwark against stress", suffering "exhausting workloads and an almost paralyzing responsibility" which were layered on top of the stresses they shared with their whole unit. ${ }^{265}$ For some, displacement was a relief, and for others, particularly Regulars, there was the distraction of the hope of brigade command. Battalion command and leadership was a weighty charge for all but the very few.

\footnotetext{
${ }^{265}$ P.H. Brennan, 'Completely Worn Out by Service in France', Canadian Military History, 18 (2) (2009), pp. 5-14
} 


\section{Chapter Six}

\section{"Professional Men of War" - The Citizen COs}

General Gater was a product of the new Army; he had never seen or thought of soldiering before the war ... He was a first-class Brigade Commander, very able and quick; indeed it was difficult to imagine him in any other capacity.

Brigadier-General H.R. Cumming ${ }^{1}$

At the outbreak of war the officer corps numbered 28,060, and at the Armistice it numbered 164,255; 229,316 commissions having been granted. ${ }^{2}$ In all, 257,376 officers served. Table 6.1 breaks this figure down into the officers of the Regular, New Army, Special Reserve and Territorial units. Whilst the exact number of 'pure' citizens of August 1914 (i.e. men with no previous service) who were commissioned will never be known, the figures for commissions granted during the war indicate the massive contribution of the citizen to officering.

This chapter examines the citizens who rose to command infantry battalions. The definition of 'citizen' for these purposes is an individual who had not previously served in the Regular army, Special Reserve, or Territorial Force. As Peter Simkins notes: "Once war was declared there was no shortage of applicants for temporary commissions at a more junior level. The main source of supply was the Officers' Training Corps". ${ }^{3}$ Gary Sheffield

\footnotetext{
${ }^{1}$ H.R. Cumming, A Brigadier in France (London: Jonathan Cape, 1922), p.96. G.H. Gater was CO 6th Lincolnshire, 1916-17 - see later in this chapter.

${ }^{2}$ Statistics of the Military Effort of the British Empire during the Great War 1914-1920 (London: HMSO, 1922), pp.234-35

${ }^{3}$ P. Simkins, Kitchener's Army - The Raising of the New Armies 1914-1916 (Barnsley: Pen \& Sword, 2007), p.221. Although some OTCs had an earlier origin, the OTC that faced the Great War was a product of the 1908 Haldane Army reforms. The OTC had a Senior Division, established in 24 universities (issuing Certificate B), and a Junior Division established in 166 public and grammar schools. Between August 1914 and March 1915, 20,577 members/former members of OTCs were commissioned.
} 
describes the "usual insistence that potential officers possess OTC certificates". ${ }^{4}$ Some citizen COs who originated from the 1914/early 1915 volunteers thus potentially possessed experience which made them "familiar with the groundwork of military training" and "accustomed to lead". 5

\begin{tabular}{|c|c|c|c|c|}
\hline & $1914^{6}$ & $\mathbf{1 9 1 8}^{7}$ & & $\begin{array}{c}\text { Total 1914- } \\
1918 \\
\end{array}$ \\
\hline Regular & 12,738 & \multirow[t]{2}{*}{74,200} & 16,544 commissions granted during war $^{8}$ & $32,494^{9}(13 \%)$ \\
\hline New Army & 0 & & 124,022 commissions granted $^{10}$ & $124,022(48 \%)$ \\
\hline Special Reserve & 2,557 & 28,000 & 30,376 commissions granted $^{11}$ & $32,933(13 \%)$ \\
\hline Territorial Force & 9,563 & 60,055 & 60,044 commissions granted $^{12}$ & $67,927^{13}(26 \%)$ \\
\hline $\begin{array}{l}\text { Reserve of } \\
\text { Officers }\end{array}$ & 3,202 & 2,000 & & \\
\hline
\end{tabular}

Table 6.1: Officer numbers and commissions granted 1914-1918

\subsection{The Citizen COs}

Two hundred and sixty citizens of August 1914 were identified as being appointed Lieutenant-Colonels to infantry battalions of regiments of the line during the war.

\footnotetext{
${ }^{4}$ G.D. Sheffield, Leadership in the Trenches (Basingstoke: Macmillan, 2000), p.30

${ }^{5}$ A.R. Haig-Brown, The O.T.C. and the Great War (London: George Newnes, 1915), p.84

${ }^{6}$ Statistics, p.234, paragraph 1

${ }^{7}$ Statistics, p.234, paragraph 1

${ }^{8}$ Statistics, p.234, paragraph 2

${ }^{9}$ Total includes the Reserve of Officers of 1914.

${ }^{10}$ The missing figure from Statistics is New Army commissions. Logically, this figure should be arrived at by the addition of the three known 'Total 1914-1918' figures and subtraction from the total, hence the figure of 124,022 .

${ }^{11}$ Statistics, p.234, paragraph 3

12 Statistics, p.235, paragraph 4

${ }^{13}$ Excluding RAMC. Statistics, p.235, paragraph 4 splits this figure up between the various elements of the $\mathrm{TF}$, giving a rough $66 \%$ infantry $34 \%$ others split.
} 


\subsubsection{Age}

The citizen COs had an average age of 29 years two months in August 1914. Table 6.2 sets out the range of their ages and juxtaposes them with the series of 1,009 officers of the Royal Warwickshire Regiment analysed by Changboo Kang. ${ }^{14}$ The citizen CO cohort proves to be skewed towards the older end of the age distribution, containing a third of the under-20s and double the over-30s in comparison. Those in post on 29 September 1918 were on average 35 years three months old in August 1914 and hence nearly four years above the BEF average, being 39 years four months old in September $1918 .^{15}$

\begin{tabular}{|c|c|c|}
\hline Age & $\begin{array}{c}\text { Citizen } \\
\text { COs }\end{array}$ & $\begin{array}{c}\text { Warwickshire } \\
\text { officers }\end{array}$ \\
\hline$<20$ & $6 \%$ & $19 \%$ \\
\hline $20-24$ & $23 \%$ & $40 \%$ \\
\hline $25-29$ & $32 \%$ & $23 \%$ \\
\hline$>30$ & $39 \%$ & $18 \%$ \\
\hline
\end{tabular}

Table 6.2: Ages of citizen COs compared with all officers, Warwickshire Regiment

There was a tendency therefore for citizen COs to have had more life experience, a possible counterweight to their lack of previous military experience.

\footnotetext{
${ }^{14}$ C. Kang, 'The British Regimental Officer on the Western Front in the Great War, with Special Reference to the Royal Warwickshire Regiment', unpublished PhD Thesis, University of Birmingham, (2007), pp.4950 .

${ }^{15}$ See Chapter Three section 3.2.1. The average age of a CO in France and Flanders on 29 September 1918 was 34 years 11 months.
} 


\subsubsection{OTC experience}

20,577 members/ex-members of the OTC were commissioned, ${ }^{16}$ some nine per cent of all officer commissions. In a series of 75 officer files of citizen COs,${ }^{17}$ over half (55 per cent) proved to have had no experience with university or school OTCs or their predecessors. ${ }^{18}$ Of those who did, 48 per cent were from university OTCs, ${ }^{19}$ and 52 per cent from school corps. The latter figure, given the average age, indicates that over half of the citizen COs had enjoyed this 'military' experience in the more distant past. Less than a quarter of the whole group had therefore had more recent OTC experience. However, five times the number of citizen COs had OTC experience than the overall figure of nine per cent would predict. It is interesting to speculate whether this early choice of experience reflected personal characteristics which would manifest themselves in war as aptitude for command.

\subsubsection{Pre-war occupations and social status}

The occupations of 78 per cent of the citizen COs were identified. Statistics of the Military Effort of the British Empire during the Great War provides an analysis of the occupations of 140,325 officers demobilised between the Armistice and 12 May $1920,{ }^{20}$ with which the citizen CO cohort can be compared (Table 6:3).

\footnotetext{
${ }^{16}$ Haig-Brown, The O.T.C., pp.99-106

${ }^{17}$ TNA WO339 and WO374

${ }^{18}$ In the Royal Warwickshire Regiment, Changboo Kang notes that at least 63.3 per cent of officers commissioned during the period 4 August 1914 to 31 December 1914 had experience of the Junior or Senior divisions of the OTC. [C. Kang, 'The British Regimental Officer on the Western Front in the Great War, with Special Reference to the Royal Warwickshire Regiment', unpublished PhD Thesis, University of Birmingham (2007), p103]. Ninety-one per cent of the citizen COs who had OTC experience were commissioned during this period.

${ }^{19}$ Three were noted as from Oxford, six from Cambridge, and one each from London, Birmingham, Belfast, Manchester, Edinburgh and Durham.

${ }^{20}$ Statistics, p.707. Some categories have been collapsed.
} 


\begin{tabular}{|l|c|c|c|c|}
\hline \multirow{2}{*}{ Occupations } & \multicolumn{2}{|c|}{$\begin{array}{c}\text { All officer } \\
\text { demobilisations }\end{array}$} & \multicolumn{2}{c|}{ Citzen COs } \\
\hline Agriculture & $5 \%$ & 7495 & $4 \%$ & 8 \\
\hline Seamen/fishermen & $0.5 \%$ & 638 & $0.5 \%$ & 1 \\
\hline Coal mining & $1 \%$ & 1016 & $1 \%$ & 2 \\
\hline Other mining/quarrying & $>1 \%$ & 146 & & \\
\hline Food/drink/tobacco & $1 \%$ & 1499 & $1 \%$ & 2 \\
\hline Explosives & $>1 \%$ & 371 & & \\
\hline Indiarubber & $>1 \%$ & 159 & $1 \%$ & 2 \\
\hline Paper/printing & $1 \%$ & 880 & & \\
\hline Woolen & $0.5 \%$ & 579 & $0.5 \%$ & 1 \\
\hline Cotton & $0.5 \%$ & 701 & $0.5 \%$ & 1 \\
\hline Textile & $0.5 \%$ & 753 & $0.5 \%$ & 1 \\
\hline Bootmakers & $>1 \%$ & 213 & & \\
\hline Leather trades & $>1 \%$ & 313 & & \\
\hline Clothing & $0.5 \%$ & 657 & $0.5 \%$ & 1 \\
\hline Sawmill & $>1 \%$ & 405 & & \\
\hline Furniture & $>1 \%$ & 128 & & \\
\hline Coachbuilding & $>1 \%$ & 157 & & \\
\hline Shipbuilding & $>1 \%$ & 342 & & \\
\hline Iron/steel/tin manufacture & $>1 \%$ & 317 & & \\
\hline Engineering & $8 \%$ & 11389 & $11 \%$ & 23 \\
\hline Other metal trades & $1 \%$ & 838 & & \\
\hline China/glass/pottery & $>1 \%$ & 140 & & \\
\hline Brick/cement & $>1 \%$ & 168 & & \\
\hline Building trades & $6 \%$ & 7739 & $0.5 \%$ & 1 \\
\hline Railway & $1 \%$ & 1122 & $0.5 \%$ & 1 \\
\hline Dock/wharf & $>1 \%$ & 184 & & \\
\hline Carters & $>1 \%$ & 148 & & \\
\hline Motor drivers & $>1 \%$ & 220 & & \\
\hline Public employees & $4 \%$ & 5533 & $6 \%$ & 13 \\
\hline General labourers & $>1 \%$ & 363 & & \\
\hline Commercial/clerical & $28 \%$ & 38572 & $17 \%$ & 35 \\
\hline Warehousing & $>1 \%$ & 266 & & \\
\hline Domestic/personal & $>1 \%$ & 341 & & \\
\hline Professional & 21740 & $24 \%$ & 49 \\
\hline Students/teachers & 25577 & $23 \%$ & 47 \\
\hline Other & 9216 & $8 \%$ & 16 \\
\hline
\end{tabular}

Table 6.3: Occupations of demobilised officers and 1914 occupations of citizen COs 
Gary Sheffield notes that the OTC-biased recruiting practices "suggest that it was hoped that officers could be provided for the enlarged wartime army with the minimum disturbance to the social status quo". He suggests that nevertheless "a revolutionary change occurred in the social composition of the wartime British army". ${ }^{21}$ Using the figures provided in Statistics, he notes that 59.5 per cent of officers came from "broadly middleclass occupations", 22 namely 'students and teachers', 'professional men' and 'commercial and clerical'. Sheffield further suggests that 40 per cent of commissions represented upwards social mobility from the "artisan class", ${ }^{23}$ notably engineering ( 8 per cent of officers), men who would previously have been "excluded on educational and social grounds" 24 from the Regular army and TF.

As Table 6.3 shows, 64 per cent of citizen COs came from Sheffield's "broadly middle class group", seemingly an overall similarity with the picture for all officers. There are key differences, however. The 'commercial and clerical' group comprised 28 per cent of the total officer group but only 17 per cent of the $\mathrm{CO}$ group, whilst conversely the 'professional group' rises from 15 per cent of all officers to 24 per cent of COs, and 'students and teachers' from 18 per cent to 23 per cent. A.D. Harvey's claim that these COs were "of undoubtedly middle-class background" 25 is therefore largely substantiated. Citizens with enhanced educational and professional status had a greater likelihood of achieving battalion command. The only area in which this trend appears reversed is the

\footnotetext{
${ }^{21}$ Sheffield, Leadership, p.31

${ }^{22}$ Sheffield, Leadership, p.31

${ }^{23}$ Sheffield, Leadership, p.32

${ }^{24}$ Sheffield, Leadership, p.32

25 A.D. Harvey, 'A Good War: Wartime Officers Who Rose to Command Level in the First World War', RUSI Journal, 153 (2) (2008), p.77
} 
increase in 'engineering' and 'public employees' in the CO group, but in both these areas it is often well-educated men in senior positions who appear to cause this reversal.

\begin{tabular}{|l|c|c|}
\hline \multicolumn{1}{|c|}{ Occupation } & $\begin{array}{c}\text { Royal } \\
\text { Warwickshire } \\
\text { Officers (\%) }\end{array}$ & $\begin{array}{c}\text { Citizen } \\
\text { COs } \\
(\%)\end{array}$ \\
\hline Clerk & 14.3 & 14.5 \\
\hline Student & 10.7 & 10 \\
\hline Teacher & 7.6 & 13.5 \\
\hline Merchant/salesman & 6.5 & 2 \\
\hline Military & 6.1 & \\
\hline Engineer & 5.8 & 11 \\
\hline Bank clerk & 4.7 & 1.5 \\
\hline Manager/proprietor & 3.8 & 2.5 \\
\hline Solicitor/barrister & 3.3 & 12.5 \\
\hline Civil servant & 3.1 & 6 \\
\hline Actuary/surveyor/valuer/broker & 3.1 & 4.5 \\
\hline Manufacturer & 3 & \\
\hline None & 3 & \\
\hline Accountant & 2.8 & 5 \\
\hline Independent/gentleman & 2.4 & 3 \\
\hline Architect/builder & 2.2 & 2 \\
\hline Agricultural & 2.2 & 4 \\
\hline Chemist & 1.6 & 1.5 \\
\hline Apprentice & 1.6 & \\
\hline Jeweller/goldsmith/silversmith & 1.4 & \\
\hline Textile trades & 1.3 & 2 \\
\hline Policeman & 0.9 & \\
\hline Other & & \\
\hline
\end{tabular}

Table 6.4: Civilian occupations of officers of the Royal Warwickshire Regiment and citizen COs

Changboo Kang criticises the use of the War Office demobilisation statistics on the grounds that, being based only on survivors, they can only be "usefully employed in tracking down the changes in the social composition of officers between pre-war time and 
the last part of the war". ${ }^{26}$ His own analysis of occupations of Warwickshire Regiment officers of suggests that while the middle class dominated, "the true picture is one of variation rather than standardization". ${ }^{27}$ Some ten per cent of Warwickshire officers were 'lower middle-class' or 'working class'.

Table 6.4 contrasts the occupations of the Warwickshire officers and the citizen COs. This only reinforces the conclusion reached above concerning the middle class professional bias evident in COs, where teachers and solicitors/barristers made a major contribution, 26 per cent of all known occupations. ${ }^{28}$

Amongst the teachers were two extraordinary men, both VC winners. Wilfrith Elstob, CO $16^{\text {th }}$ Manchester from 13 October 1916 to 21 March 1918, had attended Christ's Hospital, where he had achieved the rank of Lance-Corporal in the school OTC. A graduate of Manchester University and language master at Merchiston College, Edinburgh, he was commissioned in $16^{\text {th }}$ Manchester on 3 October $1914 .^{29}$ Promoted to Captain commanding a company on 3 March 1915 and to Major second-in-command on 1 August 1916, he took over command almost exactly two years after his commission as a $2^{\text {nd }}$ Lieutenant. $H e$ achieved fame defending Manchester Hill on 21 March $1918,{ }^{30}$ when he famously declared to his men: "There is only one degree of resistance and that is to the last round and to the last man. Here we fight and here we die". Utterly identified with his unit, he had written to

\footnotetext{
${ }^{26}$ Kang, 'British Regimental Officer', p.45

${ }^{27}$ Kang, 'British Regimental Officer', p.73

${ }^{28}$ Garth Pratten notes of the largely citizen COs of the Australian army in World War Two that "the COs represented a command class with a narrow social base". [G. Pratten, Australian Battalion Commanders in the Second World War (Melbourne: Cambridge University Press, 2009), p.291].

29 TNA WO339/56791 Officers' Services, Wilfrith Elstob. He had first applied for a commission in 6th Manchester (17 August 1914).

${ }^{30}$ Manchester Hill was a redoubt in the Fifth Army defensive positions facing St Quentin.
} 
a friend on the eve of battle: "If I die, do not grieve for me, for it is with the Sixteenth that I would gladly lay down my life". Fighting with revolver, rifle, bayonet and bombs, Elstob encouraged his 168 men: "You are doing magnificently boys! Carry on - keep up a steady fire and they'll think there's a Battalion here". Wounded twice, he said to his Signalling Sergeant: "Arrundale, they can't damn well kill me". ${ }^{31}$ A direct hit with a bomb proved him wrong. ${ }^{32}$ The second VC, Bernard Vann, CO 1/6 ${ }^{\text {th }}$ Sherwood Foresters from 23 September 1917 to 3 October 1918, was both teacher and chaplain at Wellingborough Grammar School, and will be considered later in this chapter.

Another teacher, Albert Edward Scothern, CO $6^{\text {th }}$ Border from 26 July 1917 to 9 February 1918, and $9^{\text {th }}$ Sherwood Foresters from 3 April 1918 to the Armistice, was a graduate of St John's, Oxford, and played football for his university, Oxford City from 1903 to 1911, and England four times between 1908 and 1910. A science teacher at the outbreak of war,

\footnotetext{
${ }^{31}$ http://www.themanchesters.org/Manchester\%20Hill.htm (accessed 9 February 2013). There is some dispute as to how many times Elstob was wounded prior to death. His officers file reveals that Warrant Officer J. Franklin (2 $2^{\text {nd }}$ Bedfordshire) who buried both Elstob and his Adjutant found him to have apparently been "shot at close quarters" nearby being "a large supply of ... Mills hand grenades ... ready for use and it appeared to me that these officers had been bombing the Huns when they were shot down". Sergeant S. Banks (Manchester Regiment) described him after death as "wounded in the neck, left arm and head". Private W.E. Smith $\left(16^{\text {th }}\right.$ Manchester $)$ noted he was "hit by a bomb and died instantly".

${ }^{32}$ His VC citation reads: "For most conspicuous bravery, devotion to duty and self-sacrifice during operations at Manchester Redoubt, near St. Quentin, on the 21 March 1918. During the preliminary bombardment he encouraged his men in the posts in the Redoubt by frequent visits, and when repeated attacks developed controlled the defence at the points threatened, giving personal support with revolver, rifle and bombs. Single-handed he repulsed one bombing assault driving back the enemy and inflicting severe casualties. Later, when ammunition was required, he made several journeys under severe fire in order to replenish the supply. Throughout the day Lieutenant-Colonel Elstob, although twice wounded, showed the most fearless disregard of his own safety, and by his encouragement and noble example inspired his command to the fullest degree. The Manchester Redoubt was surrounded in the first wave of the enemy attack, but by means of the buried cable Lieutenant-Colonel Elstob was able to assure his Brigade Commander that 'The Manchester Regiment will defend Manchester Hill to the last'. Sometime after this post was overcome by vastly superior forces, and this very gallant officer was killed in the final assault, having maintained to the end the duty which he had impressed on his men - namely, 'Here we fight, and here we die'. He set throughout the highest example of valour, determination, endurance and fine soldierly bearing." London Gazette, 6 June 1919, p.31395
} 
during which he was mentioned in despatches six times and awarded both DSO and $\mathrm{CMG}^{33}{ }^{33}$ he returned to teaching to become headmaster of Redditch County High School. ${ }^{34}$

Of the solicitors, Noel Frederick Barwell, a Cambridge graduate who commanded $5^{\text {th }}$ Oxford \& Buckinghamshire from 29 April to 20 June 1918 and $18^{\text {th }}$ Gloucestershire from 20 June to 7 September 1918, went on to be the last British barrister of the Calcutta High Court. Author of a number of law books, he became the mentor of the Indian author Mani Shankar Mukherjee, his clerk, who wrote the novel Kato Anjare based on Barwell. ${ }^{35}$ George Stanley Brighten, of Brighten \& Lemon, CO $2 / 5^{\text {th }}$ Lancashire Fusiliers from 1 August 1918 to the Armistice, was awarded the DSO twice as CO, for "ability, coolness and grasp", ${ }^{36}$ and for "fine example of coolness" and skill. ${ }^{37}$ His post-war career did not follow the same glowing trajectory as Barwell's. On 18 October 1932 he was convicted of fraud and sentenced to three year's penal servitude. He wrote from Wormwood Scrubs: "To lose the rank I have had the honour to bear adds heavily to the existing punishment for my offence". ${ }^{38}$

\footnotetext{
${ }^{33}$ The DSO was a New Year honour on 1 January 1918.

${ }^{34}$ TNA WO339/3483 Officers' Services, Albert Edward Scothern. He was also President of Redditch British Legion, and a Home Guard battalion commander during World War Two.

${ }^{35}$ Mukherjee, known as Shankar, stated that the book, whose title translates as "The Great Unknown", was an "attempt to express my gratitude and pay my respects to a remarkable man". The Telegraph India, 26 April 2011.

36 "When his battalion could advance no further owing to intense machine-gun fire, he went forward and personally reorganised it and established a strong defensive line. Later, when this hostile fire slackened, he at once initiated an advance which gained a considerable amount of ground. Throughout, his admirable reports were of the greatest assistance. His ability, coolness, and grasp of the situation had a marked effect on all ranks". London Gazette, 6 April 1918, p.4196

37 "During an enemy attack ... he was commanding the battalion in reserve, and employed it with such advantage that the attack was held up and the enemy repulsed with heavy loss, many prisoners being taken. His clever disposal of his forces and his fine example of coolness did much to restore the position". London Gazette, 16 September 1918, page not known.

${ }^{38}$ The 24 year-old Brighten had joined the $20^{\text {th }}$ Public Schools Battalion of the Royal Fusiliers as a Private on 2 September 1914, being commissioned on 17 November into the Liverpool Regiment where he served as Adjutant, an Assistant Postmaster General, no less, vouching for his good character. Bankrupt, he embezzled a cheque for $£ 202$ 2s. 5d. from La Societe Anonyme des Hotels et Casino de Deauville. He had also presented a number of dud cheques at Les Etablissements Gaston Duperay in Brussels, passing himself off as an active serving officer. (TNA WO374/9054 Officers' Services, George Stanley Brighten).
} 
Maurice Rhynd Dickson, of McKenzie \& Kermack of Edinburgh, commanded three battalions: $8^{\text {th }}$ Royal Scots Fusiliers from 15 January 1917 to 15 October $1917 ; 8^{\text {th }}$ Duke of Cornwall's Light Infantry from 6 May to 28 October 1918; and $12^{\text {th }}$ Argyll \& Sutherland Highlanders from 29 October 1918 to the Armistice. A law graduate of Merton College, Oxford, he represented Scotland at both cricket and rugby union. ${ }^{39}$

Another fine solicitor-athlete was Arnold Nugent Strode-Jackson, CO $13^{\text {th }}$ King's Royal Rifle Corps from 7 October 1917 to 23 August 1918. "Jackers" had been head of athletics at Malvern and rowed, played football, and captained at hockey for Brasenose College, winning the mile race for Oxford against Cambridge three times as President of the Oxford University Athletic Club. A private entry, he was gold medallist at 1500 metres at the 1912 Stockholm Olympics. ${ }^{40}$ He was awarded the DSO with two bars, ${ }^{41}$ the final award as CO for "powers of command". 42

\footnotetext{
${ }^{39}$ Born in 1882, a right-handed bat with a highest international score of 98 , he represented Scotland 13 times, captaining in 11 games. In rugby, he was capped for Scotland once as a forward, but he had played for Marlborough College, Oxford and Edinburgh universities, and the Barbarians.

${ }^{40}$ http://www.passportland.com/images/jackson-arnold-1947/jackson-arnold-1947.html (accessed 9 February 2013). In 1913 he visited America with the combined Oxford and Cambridge team. During his time serving with $13^{\text {th }}$ KRRC a: “'Grand Athletic Meeting' was organised. Strode-Jackson ran in the mile handicap, and according to the record, 'did not appear to take the race seriously until the bell sounded for the last lap, when he got into a raking stride and gave us an idea of his record performance in the Olympic Games'. He won, "but like the good sport he was, he allowed the first prize to go to a small Welshman with plenty of pluck, but much shorter legs"'. Letters, The Times, 31 May 2012, p.27

${ }^{41}$ The first bar to his DSO was awarded prior to his formal elevation but indicates why this took place: "During lengthy operations, when he assumed command of the battalion and, although wounded on two separate occasions, was able to carry out most valuable work. By his skill and courage he offered a splendid example to all ranks with him". London Gazette, 18 July 1917, page unknown.

42 "His battalion was subjected to an intense bombardment throughout a whole day, which caused many casualties and cut off all communication by wire with the front-line companies. He handled the situation with such skill and initiative that when the enemy attacked towards evening the casualties caused by the bombardment had been evacuated and replaced by reinforcements and communication with the front line had been re-established. It was entirely due to his powers of command and the splendid spirit with which he inspired his men that the attack on the greater part of the front was repulsed, and that the enemy, though they had penetrated into parts of the front line, were counter-attacked and held at bay until the arrival of reinforcements. By his skilful dispositions he materially assisted the counter-attack which drove the enemy back with heavy losses and completely re-established the position". London Gazette, 13 May 1918, page unknown
} 
Two dental students chose to fight rather than pull teeth, ${ }^{43}$ and there were at least three medical students. ${ }^{44}$ A further four were students of divinity. Walter Hubert Baddeley, CO $8^{\text {th }}$ East Surrey from 11 September 1918 to the Armistice, was later Bishop of the diverse locations of Melanesia, Whitby and Blackburn. ${ }^{45}$ Noel Baring Hudson, CO $8^{\text {th }}$ Berkshire from 21 April to 8 August and 24 October 1918 to the Armistice, became Bishop to the equally exotic locations of Labuan and Sarawak, Newcastle and Ely. ${ }^{46}$ His personal courage and "able leadership" were rewarded with the DSO as CO in $1918 .{ }^{47}$

\footnotetext{
${ }^{43}$ Arthur Dixon Bleakley, who commanded $11^{\text {th }}$ Manchester briefly in September 1918, and Aubrey Ernest Burt who commanded $8^{\text {th }}$ Oxford \& Buckinghamshire for a month between April and May 1917.

${ }^{44}$ John Henry Crosskey commanded 1/4 ${ }^{\text {th }}$ Gloucestershire between 5 June 1917 and 15 October 1917. Crosskey's wife Evelyn was a relative of Prime Minster Neville Chamberlain, and the couple were described as "two wealthy physicians belonging to Birmingham's upper crust". [M. Doerry, My Wounded Heart - The Life of Lilli Jahn 1900-1944 (London: Bloomsbury, 2004), p.72]. Hector William Sutherland commanded $7^{\text {th }}$ Scottish Borderers from 13 October 1918 to the Armistice, and later specialised in surgery. Ronald Gethen commanded $7^{\text {th }}$ Norfolk from 9 October 1917 to 20 May 1918, and later practised as a GP in Surrey.

${ }^{45}$ A graduate of Keeble College, Oxford, Baddeley was ordained in 1921 and served as Bishop of Melanesia from 1932 to 1947. He was known as the "Fighting Bishop", serving in Melanesia under occupation, having won both MC [at Arras in 1917, taking command when his company commander was killed and completing an essential digging operation (London Gazette, 16 August 1917, p.8358)] and bar [commanding his company with "great skill and determination" having "reorganised and directed his men in a masterly manner" with "fine powers of command" (London Gazette, 16 September 1918, p.10880)]; and the DSO (3 June 1919 , no citation).

${ }^{46}$ A graduate of Christ's College, Cambridge, Hudson was ordained in 1921.He had commanded $8^{\text {th }}$ Royal Berkshire from 21 April 1918, having won both MC [for organising his company "skilfully in attack" (London Gazette, 17 April 1917 p.3682)] and bar [having carried out a "dashing advance under exceptional difficulties" showing "great resource and ... a fine example" (London Gazette, 7 March 1918, p.2900)]; and DSO when: "In the attack by his battalion by night on the enemy positions on Mount Carmel (east of Le Cateau), on the 26th October, 1918, the assaulting troops had owing to the darkness become dispersed, and no information could be obtained of the progress of the attack. He went forward, and under heavy fire located the position of his companies. When his battalion was compelled to withdraw he succeeded in establishing a defensive line west of Mt. Carmel. Though wounded in three places by shell fire, he remained at duty until the operation was completed. His gallantry and ability to command were most marked". (London Gazette, 4 October 1919 p.12216). Of the other two, William John Phythian-Adams, CO $22^{\text {nd }}$ Royal Fusiliers from 18 November 1917 to 26 February 1918 became Keeper of the Museums in Palestine and was later ordained, becoming Cannon of Carlisle, Royal Chaplain, and editor of the Church Quarterly Review, publishing extensively on religious topics. William Harley Brindley, CO $10^{\text {th }}$ Warwickshire from 8 May to 22 July 1918 , was never ordained.

47 "For consistent gallantry and able leadership, particularly on 8th August, 1918, south of Morlancourt, when he personally led his battalion forward to the attack through heavy fog and intense shell and machinegun fire. When they were held up by machine guns he pushed forward alone, knocking out one machine gun and getting wounded in doing so. In spite of this, he rushed two other machine guns which were holding up the advance, and continued to lead his battalion forward until he was again seriously wounded by machinegun fire in three places. He showed splendid courage and determination”. London Gazette, 4 October 1919, p.12224
} 
Two notables are found amongst the architects. Thomas Cecil Howitt, CO initially of $9^{\text {th }}$ Leicestershire from 15 November 1917, then $7^{\text {th }}$ Leicestershire from February 1918 until 15 July 1918, showed "conspicuous ability" in command. ${ }^{48}$ He was responsible for a range of municipal architecture, particular in his home town of Nottingham, as well as a range of 1930's Odeon cinemas. Secondly, Gerald Unsworth, CO $1 / 4^{\text {th }}$ York \& Lancaster in the last eight days of the war, was responsible for a range of Art Deco London flats as well as country houses. $^{49}$

The straitjacket which Statistics forces on occupational classification loses much of the varied nature of these individuals. One was titled, namely the Honourable Arthur Michael Bertie, son of the $7^{\text {th }}$ Earl of Abingdon, Honorary Attaché at Petrograd 1906-7, who commanded $11^{\text {th }}$ Rifle Brigade from 8 March to 23 April 1918. Five did not need to work, being reliant on their own means.

Thirty-five men comprised Sheffield's "broadly middle-class" "commercial and clerical" group. Of these, one stands out. Spencer Percy Vaughan Weston was a stock exchange clerk. He joined the Public Schools Special Corps as a Private and was commissioned Lieutenant in December 1914 in the Royal Berkshire Regiment. Transferred to the $1^{\text {st }}$ Battalion he was promoted Captain, company commander, on 14 January 1916, and Major on 19 September 1916. He commanded $17^{\text {th }}$ Royal Fusiliers from 21 April 1917 to the date he became Brigadier-General, 122 Brigade, on 8 June 1918, a post he held until the

\footnotetext{
48 "For conspicuous gallantry and devotion to duty when in command of his battalion during an enemy counter-attack. He displayed conspicuous ability in handling his battalion and in reorganising the defences of the front line. He went forward through a very heavy enemy barrage to make a personal reconnaissance, and his coolness and decision contributed very largely to the defence of the line". London Gazette, 22 March 1918 , p.3951

${ }^{49}$ Cottesmore Court, Kensington \& Chelsea is a notable example of the flats. Sparsholt Manor in Hampshire (with Sussex his main stamping ground) is a good example of the country houses.
} 
Armistice. The first bar to his DSO was awarded as CO for "tactical skill, coolness and example", 50 the second for "fine powers of leadership". 51

Sheffield did not judge 'public employees' as "broadly middle class", but again, the enforced categorisation of Statistics hides the social status of many of this group. George Henry Gater, CO $6^{\text {th }}$ Lincolnshire from 15 August 1916 to 1 November 1917, who led his battalion with "brilliant skill and resolution", 52 and who was to be the most notable of the citizen promotions to Brigadier-General, ${ }^{53}$ was assistant Director of Education for Nottinghamshire. ${ }^{54}$ Ronald Semphill Stafford, CO $1^{\text {st }}$ King's Royal Rifle Corps from 9 to 23 July 1917 and 23 February to 1 June 1918, as well as 2/7 ${ }^{\text {th }}$ Liverpool from 2 to 7 September 1917 and $17^{\text {th }}$ Middlesex from 9 September 1917 to 22 February 1918, was an Exhibitioner at Jesus College, Cambridge whence he joined the Egyptian Civil Service.

\footnotetext{
50 "When the enemy launched a heavy attack on his position he moved up his reserves and organised the defence with such skill that, though the enemy attacked continually for six hours, his battalion withstood all the enemy's attempts to break through and inflicted very heavy casualties. His tactical skill, coolness, and example were mainly responsible for the successful resistance offered by his battalion". London Gazette, 18 July 1918, page unknown

51 "During the trying period of a retreat. Despite heavy losses, he withdrew the battalion in good order, inflicting severe casualties on the enemy, and it was largely due to his coolness and personal courage that the retirement was so well carried out. He invariably displayed fine powers of leadership and his splendid example was of the greatest encouragement all ranks". London Gazette, 26 July 1918, page unknown

${ }^{52}$ The citation for the bar of Gater's DSO reads: "He led his battalion with brilliant skill and resolution during an attack, minimising their casualties during three days' intense shelling by his able dispositions and good eye for ground. He directed the consolidation, and remained in command for three days, although severely wounded in the face early in the action". London Gazette, 17 September 1917, p.9555

${ }_{53}$ With 62 Brigade from 1 November 1917. Another whose career might have rivalled Gater's was William Colsey Millward. Born in 1886, Millward played cricket for the Worcestershire second XI, but was also a keen footballer. He was a clerk in August 1914, and enlisted in the $11^{\text {th }}\left(1^{\text {st }}\right.$ South Down) Battalion, Sussex Regiment as a Private on 9 September 1914. He was appointed $2^{\text {nd }}$ Lieutenant (from Corporal) on $1^{\text {st }}$ November. He was made Captain commanding a company on 18 August 1915, and Major second-incommand on 25 July 1916, taking command of the battalion he had started in as a Private two and a half years earlier on 4 March 1917. He was promoted Brigadier-General in March 1918 with 116 Brigade but on 29 March suffered gunshot wounds to his leg which resulted in its loss. (TNA WO 339/54848 Officers' Services, William Colsey Millward).

${ }^{54}$ Born in 1886, the son of a solicitor, he was educated at Winchester College and obtained a BA in Modern History and a Diploma in Education at New College, Oxford. He was appointed Director of Education for Lancashire in 1919, and moved in 1924 to be Director of Education for the London County Council, later becoming its Clerk, in which role he was knighted. He then joined the Civil Service as Permanent Secretary, Head of the Colonial Office from 1942 to 1947.
} 
Stafford was awarded the DSO as CO for courage and "quickness of decision". 55 Harold Samuel Eaton Stevens, CO $13^{\text {th }}$ Royal Scots from 26 July 1918 until the Armistice, was an Indian civil servant who became Secretary to the Government of Bengal in the Agriculture and Industries Department post-war.

More grandly, Basil Frederic Bishop, CO $9^{\text {th }}$ South Lancashire from 13 May to 18 September 1918 was Assistant District Commissioner and Magistrate in Rhodesia. More humbly, but no less worthy, Albert Arthur Aldworth, $\mathrm{CO} 7^{\text {th }}$ Leicestershire from 30 September to 3 December 1916, 18 May to 15 July 1917 and 15 August 1917 to 15 February 1918, was the secretary to the Divorce Law Reform Union. Arthur Gracie Hayward, CO $4^{\text {th }}$ Bedfordshire from 22 July to 22 September 1918, was similarly Assistant Secretary to a Social Welfare Association.

In the creative sphere, Robert Bingham Harkness, $\mathrm{CO} 19^{\text {th }}$ Welsh from 17 October 1918 to the Armistice, was a musician; and Arthur Driver, CO $9^{\text {th }}$ West Riding from 16 September 1918 to the Armistice, was a textile designer, whose "able leadership" as CO was reflected in his DSO award. ${ }^{56}$ John Jackson Cameron, CO $2 / 5^{\text {th }}$ Royal Lancaster from 20 September 1917 to 30 May 1918, an illustrator, was awarded a DSO as CO for "the greatest ability

\footnotetext{
55 "During a rearguard action lasting over a period of five days he behaved with consistent coolness and courage. On one occasion, the left flank of his battalion having been driven in and the battalion ordered to establish a defensive flank, he carried out a personal reconnaissance under direct machine-gun fire, gaining valuable information as to the dispositions on his right flank, and personally placed each company in its position. During this time the enemy was fast approaching in massed formation, and artillery fire was opened on his battalion at point-blank range. His total disregard of danger and quickness of decision said the situation on this and other occasions". London Gazette, 26 July 1918, page unknown

56 "For conspicuous gallantry and able leadership when in command of his battalion during active operations, especially on $12^{\text {th }}$ Oct. 1918 , in the attack on Neuvilly, when he very ably led his battalion, and, although himself wounded, reorganised it under heavy shell and machine gun fire at a critical stage of the battle. He also distinguished himself on 4 Nov. 1918, at the capture of Futoy". London Gazette, 10 December 1919, page unknown
} 
and skill". ${ }^{57}$ Two were journalists; Thomas Joseph Kelly, CO 1/7 ${ }^{\text {th }}$ Lancashire Fusiliers from 26 October 1918 to the Armistice; and Louis Henry Dawson, CO $13^{\text {th }}$ Middlesex from 16 May to 24 July 1917. Douglas Ainslie Foulis, CO $10^{\text {th }}$ Scottish Rifles from 29 September to 19 October 1918 , was a publisher. ${ }^{58}$

Several had been working abroad. Herbert Cooper Cannon, CO 3/4 ${ }^{\text {th }}$ West Surrey from 15 October to 21 November 1917 was a rubber planter; ${ }^{59}$ as was Francis John Fielding Crook, who commanded $17^{\text {th }}$ Lancashire Fusiliers from 23 July 1916 to 12 August $1918,{ }^{60}$ and 4/5 $5^{\text {th }}$ Lancashire Fusiliers from 3 October 1918 to the Armistice, and who showed “conspicuous ability” as CO. ${ }^{61}$ Similarly, John Ryrie Webster, CO $16^{\text {th }}$ Sherwood Foresters from 13 September 1917 to 22 March 1918, was a timber merchant in Ceylon. Henry Abrahall Robinson, CO $26^{\text {th }}$ Royal Fusiliers from 24 March to 31 August 1918, was a farmer in Canada, having joined the $6^{\text {th }}$ Canadian Battalion as a Private before applying for a British commission.

Of the groups whose status was deemed lower than "broadly middle class", twenty-three engineers rose to command battalions. Where this was specified further, five were mining engineers, three electrical, two marine, two railway and one each chemical, civil, and mechanical. Their demotion to "artisan" status is clearly not entirely warranted.

\footnotetext{
57 "He made a thorough reconnaissance of the ground on which his battalion were to assemble and advance in support of an attack. He guided his battalion to the position, which he found was being heavily shelled, and he assembled them successfully in another position. He showed the greatest ability and skill throughout". London Gazette, 25 April 1918, page unknown.

${ }^{58}$ With the firm of Hunter and Foulis, Edinburgh.

${ }^{59} \mathrm{He}$ returned to Malaya after the war, and was working in oil distribution when World War Two broke out. He served again as a Lieutenant-Colonel, and rests in Kandy War Cemetery.

${ }^{60}$ Another Malayan rubber planter, he was the son of Colonel H.T Crook, a retired Volunteer.

${ }^{61}$ At Le Falfemont Farm, on 25 August 1916:"For conspicuous gallantry and ability when in command of a battalion. Covering the left flank of our Allies in attack he carried out a difficult task with much skill. The success of the operation was largely due to his ability". London Gazette, 20 October 1916, page unknown.
} 
Of the two classified under 'coal mining', Charles Bertram Charlesworth, CO $12^{\text {th }}$ King's Own Yorkshire Light Infantry from 31 August 1918 to the Armistice, was in fact a colliery owner; and Charles Godfrey Jones, CO $9^{\text {th }}$ Border from 23 December 1917 to the Armistice, was a colliery manager.

In the areas of manufacturing and retail, James Charles Burdett, $\mathrm{CO} 6^{\text {th }}$ Leicestershire from 25 August 1918 to the Armistice, a hosiery manufacturer and former rugby international, may have found fighting more engaging than socks. John Clayton Beadle, CO $11^{\text {th }}$ West Kent from 20 September 1917 to 8 January 1918, was in the motor trade; ${ }^{62}$ as was Julius Guthlac Birch, CO $7^{\text {th }}$ King's Royal Rifle Corps from 18 October 1917 to 24 March $1918 .^{63}$

Perhaps the most humble occupation was that of Sydney Douglas Rumbold, who commanded $9^{\text {th }}$ York and Lancaster from 18 July 1917 to the Armistice, who was a draper's assistant. His courage and skill, reflected in the citations for his DSO and bar which note his "able organisation" and "ability to command", were not in doubt. ${ }^{64}$ Sadly, he was cashiered in 1920 for "acts of indecency", and stripped of his awards.

\footnotetext{
${ }^{62}$ His firm, Beadles, has ten retail sites in Kent still. He was also in the timber business.

${ }^{63}$ Birch served as a GSO3 between 23 August and 5 October 1916. He was wounded and taken prisoner on 24 March 1918.

${ }^{64}$ His DSO citation reads: "For conspicuous gallantry and devotion to duty. His battalion having taken over a portion of the captured front, this officer organised the defences, arranging and superintending the digging for the protection of his flank. It was in great measure due to the able organisation and gallant leading of Lt.Col. Rumbold that a counter-attack was repulsed. Though his battalion had been relieved, he voluntarily remained in the front line through another more violent counter-attack, supported by powerful artillery concentration. His valuable aid to the new commanding officer as to the terrain, this able leading of the men and his skilful handling of the situation resulted in the enemy being again repulsed". London Gazette, 18 March 1918, p. 3417. The citation to the bar to his DSO reads: "For conspicuous gallantry and leadership in the Piave battle from 29th to 31st October, 1918. When his battalion was in support of other troops who were three times held up at the crossing of the Monticano, near Vazzola, Lt.-Col. Rumbold, on his own initiative, determined to attack, and led his men over the bridge and gained the objective, taking many prisoners and machine guns. On 30th October, by rapid marching, he came to the support of our cavalry, who were held upon the River Mescia. On $31^{\text {st }}$ October he again had heavy fighting in the taking of Sacii, and in bridging
} 
The seemingly humble profession of railwayman hides an interesting character in Frederick Henry Wickham Guard. Born in 1889 and having travelled in Canada where he worked variously as a fruit grower and branch manager of a refrigeration company, he returned to the UK in 1910, finding employment in London on The Times. Here he fell in with "bad company" and was in "very poor shape indeed" by the time his father bailed him out. He subsequently found employment on the West African Railways in Sierra Leone, and obtained a commission in the West African Frontier Force in August 1914. Invalided, he joined the Hampshire Regiment in February 1915, and was promoted to command $15^{\text {th }}$ Royal Scots from 8 July 1917 to 5 April 1918. In the summer of 1918 , Guard went to North Russia, where he served as CO of Force 'A' on the Vologda railway, where he was described as a "born guerrilla leader". ${ }^{65} \mathrm{He}$ was a clear example of a man for whom the lack of structure of civilian life led to failure and the structure of the military life channelled his energies.

These details create the picture of a middle-class, well educated, varied and richly talented body of men.

the River Lwenza. Throughout the operations he showed great coolness and ability to command". Edinburgh Gazette, 5 February 1919, p.619

$65_{\text {http://www.dnw.co.uk/medals/auctionarchive/viewspecialcollections/itemdetail.lasso?itemid=67027 }}$ (accessed 8 February 2013) 


\subsubsection{Commission routes}

Table 6.5 sets out the original commission routes of the citizen COs. Just over threequarters had been commissioned into Service battalions, the rest into the Special Reserve and Territorial Force. When compared with the distribution of officers presented in Table 6.1 , it becomes clear that all did not have an equal chance of rising to command. Special Reserve and Territorial citizen officers were just over half as likely to rise to battalion command as their overall numbers might predict, and New Army officers were over one and half times more likely.

\begin{tabular}{|l|c|c|c|c|}
\hline & Regular & $\begin{array}{c}\text { New } \\
\text { Army }\end{array}$ & $\begin{array}{c}\text { Special } \\
\text { Reserve }\end{array}$ & $\begin{array}{c}\text { Territorial } \\
\text { Force }\end{array}$ \\
\hline First commission & N/A & $78 \%$ & $8 \%$ & $14 \%$ \\
\hline Distribution of officers 1914-1918 & $13 \%$ & $48 \%$ & $13 \%$ & $26 \%$ \\
\hline
\end{tabular}

\section{Table 6.5: Entry routes of citizen COs v. distribution of officers}

There is no objective reason to suppose that these men differed in quality simply by virtue of their commission route. The disparity mirrors that already discussed in Chapters Three and Four, ${ }^{66}$ namely that Territorials were underrepresented in terms of battalion command, particularly in the middle part of the war, with the Special Reserve making a limited contribution throughout. ${ }^{67}$ Given that the main purpose of the Special Reserve was to reinforce the Regular units, it is unsurprising that when the 29 commands achieved by such officers are analysed, Regular commands were found to comprise 42 per cent of the total (Table 6.6). It is an inescapable conclusion, however, that Territorial Officers were always at a disadvantage in terms of senior command.

\footnotetext{
${ }^{66}$ See Section 3.1 .1 and 4.3

${ }^{67}$ John Bourne notes a similar pattern of poor rates of promotion to General Officer of Special Reserve and TF officers. [J. Bourne, 'The BEF's Generals on 29 September 1918: An Empirical Portrait with Some British and Australian Comparisons", in P. Dennis \& J. Grey, eds, 1918 Defining Victory (Canberra: Department of Defence, 1999), pp. 96-113].
} 


\begin{tabular}{|l|c|c|c|c|}
\hline First commission & \multicolumn{4}{|c|}{ Battalion commands } \\
\hline & Regular & $\begin{array}{c}\text { New } \\
\text { Army }\end{array}$ & Territorial & Special Reserve \\
\hline New Army & $5 \%$ & $86 \%$ & $8 \%$ & $1 \%$ \\
\hline Territorial & & $19 \%$ & $81 \%$ & \\
\hline Special Reserve & $42 \%$ & $31 \%$ & $27 \%$ & \\
\hline
\end{tabular}

Table 6.6: Type of first commission and battalion command

Eighty-six per cent of the 248 commands of those who were commissioned into New Army battalions were in Service battalions; and 81 per cent of the 43 commands of those who were commissioned into Territorial battalions were in TF units. Type of commission therefore exerted a strong influence over location of later command.

\subsubsection{Pace of promotion}

Whatever the differential likelihood of reaching the rank of Lieutenant-Colonel dependant on an officer's type of commission, the speed of promotion to $\mathrm{CO}$ was fairly uniform. A New Army and a Territorial officer took on average three years one month; and a Special Reserve officer three years two months. The promotional impetus of war is evident when it is recalled that a Regular officer in 1914 had taken 26 years 11 months to make the same professional journey. ${ }^{68}$ Sixty per cent had been first commissioned in 1914,36 per cent in 1915, and four per cent in 1916, only half of the latter being the product of the Officer Cadet Battalions created in February $1916 .^{69}$

\footnotetext{
${ }^{68}$ See Chapter One section 1.1.2.

${ }^{69}$ From this time onwards passage through the four month Officer Cadet Battalion course was the only route to commission.
} 
Figure 6.1 shows the number of citizen $\mathrm{CO}$ appointments per month. These begin to escalate during the Somme offensive, August to November 1916, and escalated further from the Battle of Messines through Third Ypres, June to November 1917, and reached a peak during the German Spring offensive March-April 1918. In the run-up to and during The Hundred Days, a steadily rising rate of elevation of citizens is observed.

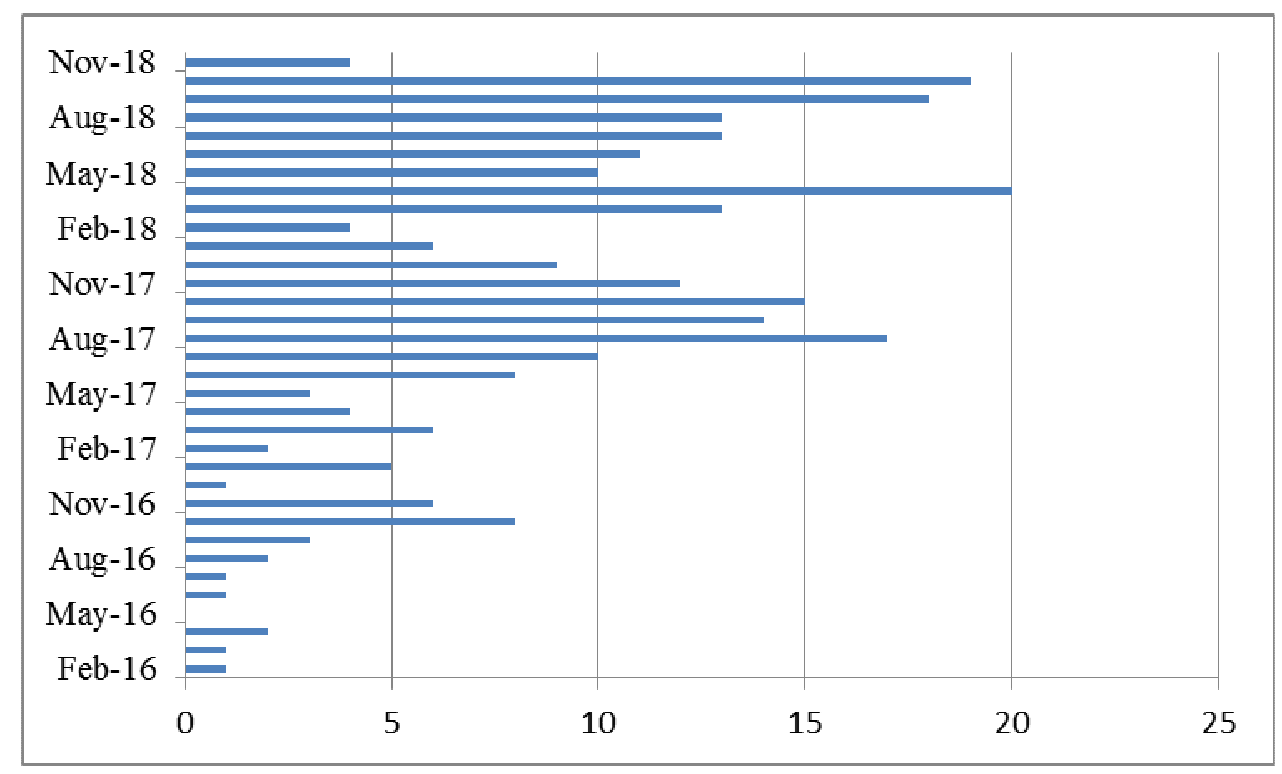

Figure 6.1: Number of monthly citizen $\mathrm{CO}$ appointments

Some citizens had very early appointments, but these tended to be quite particular. George Sydney Guy was the first to be appointed, ${ }^{70}$ to $2 / 6^{\text {th }}$ Cheshire on 11 February 1916 . Guy was the manager of a labour exchange in August 1914, and the battalion, like his next command, $2 / 7^{\text {th }}$ Cheshire, never served overseas. It is easy to speculate that he was appointed for his management experience. Similarly, Arthur Victor Cowell was appointed to command $2 / 4^{\text {th }}$ Buffs on 2 March 1916. As with his second command, $1 / 1^{\text {st }}$ Highland

\footnotetext{
70 Barring the two early citizen politician appointments of Henry Webb $\left(13^{\text {th }}\right.$ Gloucestershire, $14^{\text {th }}$ Worcestershire, and $23^{\text {rd }}$ Liverpool); and William Raley $\left(14^{\text {th }}\right.$ and $15^{\text {th }}$ York \& Lancaster $)$ - see Chapter Two section 2.1.4.
} 
Cyclists, the battalion never served overseas. Cowell, who lived at Aldershot in August 1914, was an army schoolmaster.

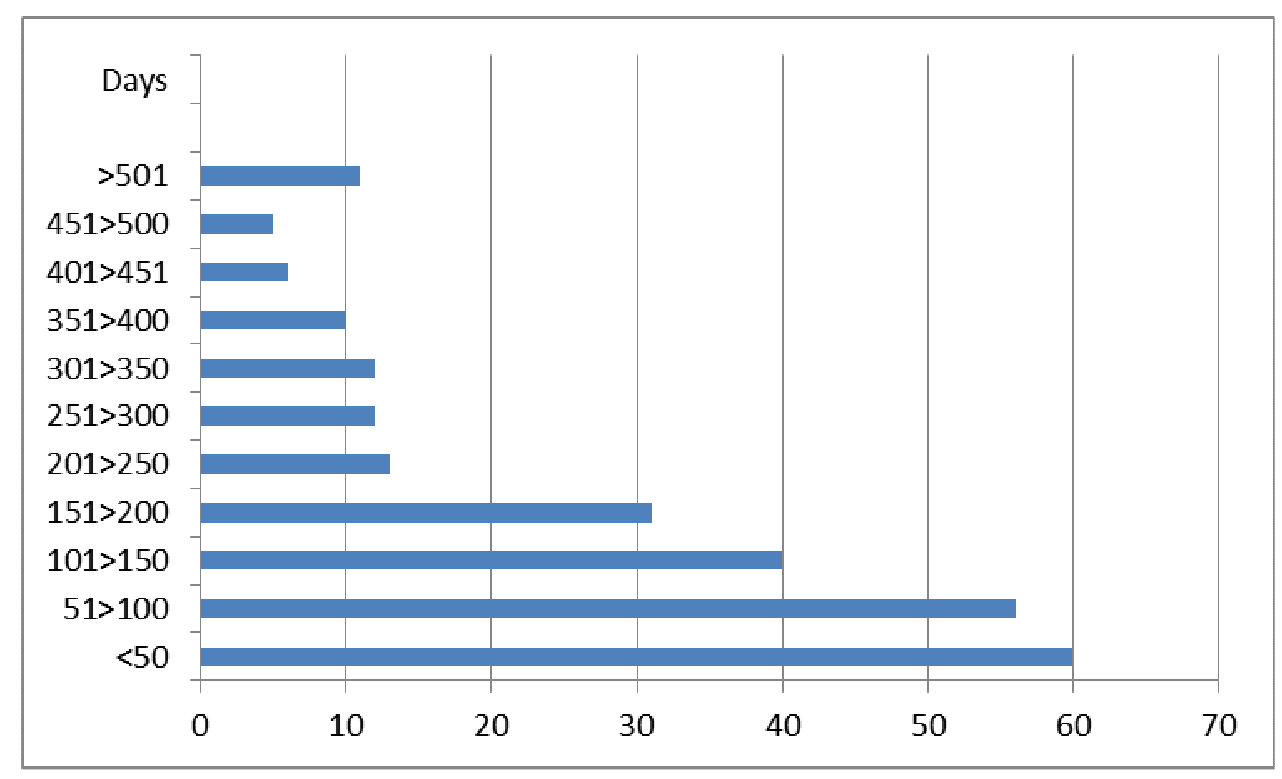

Figure 6.2: Length of citizen CO commands

As can be seen from Figure 6.2, 76 per cent of citizen $\mathrm{CO}$ appointments lasted less than 200 days, and 25 per cent less than 50 days. These figures, which on the face of it suggest short appointments, have, however, the potential to mislead. The most telling statistic is that forty-three per cent of all citizens who rose to command battalions were in post on 11 November 1918.

Of the whole citizen $\mathrm{CO}$ group 13 per cent were killed in action (a figure not dissimilar to the 11 per cent overall). Sixteen per cent were wounded/invalided, slightly less than the overall figure of 20 per cent. ${ }^{71}$ Removal from command or sidelining occurred in 25 per

\footnotetext{
${ }^{71}$ See Chapter Three section 3.3.6.
} 
cent of cases, compared with the overall wartime figure of 38 per cent. ${ }^{72}$ The latter figure, of course, contains older active officers and 'dug-outs' who were replaced earlier in the war. The replacement rate was therefore calculated for comparison purposes for Regular officers who were Lieutenants in August $1914,{ }^{73}$ on the basis that they had similarities with the citizen group, namely: (i) they were being promoted roughly during the same period, i.e. later in the war; and (ii) they were younger, fitter etc. Their removal/sidelining rate was 19 per cent. This reinforces the contention that during the latter part of the war, when CO removals were still a regular occurrence, the younger and more rugged and adapted men of 1918 were giving less cause for removal. ${ }^{74}$ Further, whilst the removal rate for citizens was higher that the group of Regular Lieutenants of August 1914, it was not markedly so, and it is likely that a number of such removals were not competence-based but predicated upon the return of a more senior officer.

\section{2 "Military geniuses"?}

A.D. Harvey suggests that the appointment of citizen officers to:

Command battalions ... does not indicate that they were, or were ever considered, military geniuses of a calibre superior to what might be found in the regular army: there were career officers of a comparable ability ... but obviously not enough of them for the hugely expanded army. ${ }^{75}$

Very few appraisals of citizen COs exist in the weeded officer files in The National Archives. Only one in a series of 75 files yielded a confidential report. The hosiery manufacturer James Charles Burdett was 30 years old when he enlisted as a Private in $21^{\text {st }}$

\footnotetext{
${ }^{72}$ See Chapter Three section 3.3.8.

${ }^{73}$ A total of 228 officers.

${ }^{74}$ See further in Chapter Seven, section 7.2.

${ }^{75}$ Harvey, 'Good War', p.80
} 
Royal Fusiliers in August 1914, rising to Corporal by December at which point the CO of $6^{\text {th }}$ Leicestershire, Lieutenant-Colonel E.L. Challenor, ${ }^{76}$ wrote to the War Office recommending him for a commission. ${ }^{77}$ Burdett was gazetted Lieutenant on 19 January 1915. He went to France in July 1915, and was wounded on 14 July 1916 on the Bazentin Ridge, ${ }^{78}$ a bullet entering his right cheekbone and exiting by his left eye. ${ }^{79}$ He returned to France a Captain on 2 January 1917, was promoted Major on 4 April 1917, ${ }^{80}$ and was made second-in-command on 4 August 1917. He took over command on 25 August 1918, when Lieutenant-Colonel M.C. Martyn was captured at Le Sars. ${ }^{81}$

The confidential report made on him by Brigadier-General, H.R. Cumming describes:

A born soldier and leader of men. Has great capacity of command; a good disciplinarian, and a reliable trainer with knowledge and tact, and great determination. He has kept his Battalion in a high state of efficiency in difficult circumstances. Powerfully built and very active; a fair rider with great powers of endurance; cool and resourceful in action, he has proved himself a very efficient Commander.

\footnotetext{
${ }^{76}$ Edward Lacy Challenor, a Major and Depot Commander of the Leicestershire Regiment in August 1914 commanded $6^{\text {th }}$ Leicestershire from August 1914 to March 1917, and commanded 63 Brigade from 16 March 1917 to 26 September 1918.

${ }^{77}$ Noting that his brother was already an officer in his battalion. John Wilder Burdett, four years junior, never rose above Captain in the battalion his brother commanded, and ended the war as a Brigade Transport Officer.

${ }^{78}$ As was Challenor, who had recommended him.

${ }^{79} \mathrm{He}$ was also by this time suffering from sciatica in the right leg with muscle wasting, which left him walking with a limp.

${ }^{80}$ Few examples of 'Promotion Form Army Form W. 3025' are extant in civilian COs' files. The form for Burdett's promotion to Major exists, which shows he was recommended in turn by his CO, LieutenantColonel W.N. Stewart; his Brigadier, Lord Loch, (27 October 1917); and Lieutenant-Colonel G. J. AclandTroyte AA\&QMG with $21^{\text {st }}$ Division on behalf of Major-General D.G.M Campbell (undated). The vacancy was approved by the department of "Military Secretary to C-in-C" on 10 September 1917, and 'approved' in that department by Colonel A. Keene (a 63-year old officer who had retired 23 years earlier) on 16 November 1917. The process had taken seven months and 12 days. When Burdett was promoted from Temporary Major, (having been Acting Lieutenant-Colonel from 25 August 1918), on 10 September 1918 to Temporary Lieutenant-Colonel, his form W. 3025 shows the process only took four and a half months. His form on this occasion was actually signed by Brigadier-General H.R. Cumming (4 January 1919); MajorGeneral D.G.M 'Soarer' Campbell (5 January 1919); and Lieutenant-General C.D. 'Tiger' Shute (11 February 1919).

${ }^{81}$ Going forward in the dark with his Intelligence Officer and orderly to locate his forward companies he walked into a quarry North-West of Le Sars where he was ambushed, and after a struggle, was captured and his orderly killed, the Intelligence Officer escaping. [H.R.Cumming, A Brigadier in France (London: Jonathan Cape, 1922) p.215].
} 
Major-General D.G.M. Campbell added: "I entirely agree. A very fine officer who has done excellent work. Thoroughly fit for command of a Batt ${ }^{\mathrm{n},}{ }^{82}$ Coming from such luminaries as these two general officers, it must be assumed that Burdett was at the top of his game in 1918. Cumming also demonstrates what was being sought in a CO in 1918, namely leadership and command ability, physical fitness, knowledge and resourcefulness, and ability to train effectively.

Lieutenant-Colonel C.F.G. Humphries provides a fine example of a citizen with no military experience of any sort who showed extraordinary qualities, becoming one of the select band of citizens who commanded a Regular battalion. Cecil Frederick George Humphries was born in Mataura, New Zealand, but he was on holiday in England with his mother in August 1914, aged just under 27. ${ }^{83}$ A keen footballer and golfer, and a clerk by occupation, he enlisted on 7 August 1914, and was posted as a clerk to the Army Service Corps at Le Havre, ${ }^{84}$ being promoted Corporal 18 days later. It is a measure of the man that he chose to exchange rank for action, obtaining a transfer as a Private to $1^{\text {st }}$ Manchester on 15 October. Promoted from Lance-Corporal to acting Sergeant over the period 30 October to 21 December, he was shot in the left forearm at Givenchy on 20 December, where he was awarded the Distinguished Conduct Medal for endeavouring to recover the body of his company commander. ${ }^{85}$

\footnotetext{
${ }^{82}$ TNA WO374/10838 Officers' Services, James Charles Burdett.

${ }^{83}$ Humphries was born on 28 October 1886. His father was 55 at his birth and died when he was 10 . His mother remarried two years later, becoming Mrs Ada Rouse, but it is clear that the two remained very close, his mother remaining in England during the duration of the war. He wrote in his diary just before going into action: "If the fates are against me I hope I will die an honourable death with my heart full of love for my darling mother". http:digital.theensign.co.nz Soldier's Deeds Recalled. (Accessed 21 July 2011).

${ }^{84}$ Humphries has five medal index cards in TNA WO329. Other details come from TNA WO339/4177 Officers' Services Cecil Frederick George Humphries. Fascinatingly, but without explanation, his file yields the information that his right nipple had been removed.

${ }^{85}$ http://themanchesters.org/forum/index.php?topic=3388.0; wap2 Accessed 21 July 2011
} 
He was wounded again on 12 March 1915, shot in the left buttock, in the failed attack on the Bois du Biez, Neuve Chapelle. Convalescing, he applied for a commission, and was gazetted $2^{\text {nd }}$ Lieutenant on 11 June 1915 in the $12^{\text {th }}$ Highland Light Infantry, which proceeded to France the following month. He was promoted Captain on 26 September 1915. Wounded again, he was transferred to the Labour Corps in February 1917, being awarded his first Military $\operatorname{Cross}^{86}$ when:

At great personal risk he directed operations at a fire, which resulted in saving eight trucks of ammunition from a burning train. Assisted by a serjt.-major, he uncoupled the eighth truck himself, whilst the ninth was burning fiercely and heavy shells exploding freely around them.

He returned to active service with $1^{\text {st }}$ Duke of Cornwall's Light Infantry on 22 October 1917, where he won a bar to his MC for his handling of his company in action. Taking command of the battalion on 17 April 1918 when Lieutenant-Colonel C.B. Norton was promoted, ${ }^{87}$ Humphries was gassed four days later in the Forest of Nieppe, but returned to duty to win the DSO:

For conspicuous gallantry and fine leadership. Having taken his objective, he reorganised his battalion, and, on hearing that the attack on the final objective was held up, he went forward under heavy fire and reconnoitred the whole position, after which he returned and led the battalion forward. Later, he personally controlled his men during a very determined counter-attack by the enemy under the heaviest machine-gun fire. His courage inspired great confidence throughout the operations. ${ }^{88}$

On 30 May 1918 he was posted to take command of $1^{\text {st }}$ Norfolk. Seriously wounded by shellfire at Achiet-le-Petit, he died of wounds on 22 August 1918.

\footnotetext{
${ }^{86}$ Both his two Military Cross awards were gazetted in September 1917: London Gazette, 16 September 1918, p. 10893 \& 17 September 1917, p.9574.

87 To command 95 Brigade.

${ }^{88}$ London Gazette, 2 December 1918.
} 
Richard Owen Wynne commanded both a Regular and a New Army battalion. Born at Moss Vale, New South Wales, on 12 June 1892, he left Australia in 1902, attended Marlborough College, and at the outbreak of war was at Clare College, Cambridge. At Marlborough he played rugby for the school, and was a member of the school shooting eight, competing for the Ashburton Shield at Bisley from 1907 to 1910 . He rowed for his college in 1913 and 1914.

He was commissioned $2^{\text {nd }}$ Lieutenant in 3rd Bedfordshire on 15 August 1914, and went to France on 21 March 1915, joining $2^{\text {nd }}$ Bedfordshire as a Lieutenant on 27 June 1915, in which battalion he served until May 1918. For much of this early period he commanded C Company, and it was whilst commanding both B and C companies on 31 July 1916 that he won the DSO. ${ }^{89}$

He first commanded the battalion from 8 November 1916 to 17 November 1916 when the CO, Major J.W.H.T. Douglas, was at Third Army School. ${ }^{90}$ From 25 November to 5 December he was in temporary command of $17^{\text {th }}$ Liverpool. All his commands were within 89 Brigade, and it is clear that he had established a reputation for sound leadership. On 4 January 1917 he was sent to Senior Officer School, Aldershot, returning on $6^{\text {th }}$ April. He did not have to wait long, for on $8^{\text {th }}$ April, Lieutenant-Colonel H.S. Poyntz went sick and Wynne took over until 15 June, thus commanding the Battalion during its operations at

\footnotetext{
${ }^{89}$ For consolidating a trench on the Maltzhorn Ridge. His efforts at Trones Wood on 11-12 July were also commended. London Gazette, 1 January 1917, page unknown

${ }^{90}$ John William Henry Tyler Douglas (1882-1930) was also a citizen CO. A timber importer, he was England (1911 \& 1920/1) and Essex (1911-28) cricket captain, his defensive style earning him the nickname amongst Australians as "Johnny Won't Hit Today." He commanded 1/6 ${ }^{\text {th }}$ North Staffordshire from 19 January 1917 to 11 March 1917, and 20 th Liverpool from 11 March 1917 to 1 February 1918. A man who survived both the Western Front and the Australian series 5-0 "whitewash" of 1920-1, he was claimed by the seas seven miles south of the Laeso Trindel lightship, Denmark, returning from a trip to the Baltic buying pine, attempting to rescue his father when two ships collided in fog.
} 
Arras. On $10^{\text {th }}$ July he was sent to command $19^{\text {th }}$ Liverpool for six days. He assumed command of his battalion again on $2 \& 22$ August, and 1 November 1917. On 22 February 1918, he took command again, this time as Acting Lieutenant-Colonel, commanding virtually continuously until 22 May, when he went to train American units. ${ }^{91}$ He won a bar for his DSO as CO for "great skill and bravery". ${ }^{92}$ He was given command of $18^{\text {th }}$ Liverpool in August 1918 and continued in this role beyond the Armistice, being wounded in October 1918 in the offensive around Le Cateau, but remaining at duty. After the war, Wynne returned to his home town in Australia, where he described himself as "a worker among workers". 93 The citation for the bar to his DSO suggests this was not an empty claim. $^{94}$

John Ryrie Webster, born in 1886, had an unusual start to his career long before commanding a New Army battalion, and was one of the few COs to leave a diary. ${ }^{95}$ A Liverpool football player, Webster had worked in timber in India for five years, and his firm was asked to raise eight motor cyclists, Webster being made Corporal. He thus became part of 32nd Signalling Company, Jullundur Brigade, and arrived in France on 25 September 1914. His diary suggests he had the most extraordinary freedom, roaming on

\footnotetext{
${ }^{91}$ TNA WO95/1658 War Diary $2^{\text {nd }}$ Bedfordshire Regiment

92 "For conspicuous gallantry and leadership in action between March 21st and 28th, 1918, and especially for his action on March 27th, at La Folies, when parties of Germans succeeded in working some machine guns close up to the front line held by the Battalion. Observing this, Wynne personally led an attack against the machine guns, and succeeded in driving them off, and himself killed the Officer commanding the Germans. At all times Col. Wynne commanded his men with great skill and bravery, and showed complete disregard for his own safety". London Gazette, 16 September 1918, page unknown.

${ }^{93} \mathrm{http}: / / \mathrm{www} . \mathrm{mtwilson.com} . \mathrm{au} / \mathrm{mt}$-wilsonmt-irvine-historical-society/miscellaneous-articles/215-2005remembrance-day-transcript.html Accessed 29 July 2011

${ }^{94}$ For eight years he held the post of Aide-de-Camp to Lord Wakehurst, Governor of New South Wales from 1937 to 1945. On his departure, Wakehurst wrote: "My dear Owen, I feel I cannot leave NSW without expressing my very deep gratitude for your loyal and devoted service, during the eight years of my term of office. I should like you to realise how much it has meant to my wife and to myself to know that we could always rely on your help. There have been times, especially during the war years, when difficulties and inconveniences have been numerous, but you have always accepted them cheerfully, and have always risen to the occasion".

${ }^{95}$ IWM Docs 13948 Private Papers of Lieutenant-Colonel J.R. Webster
} 
his motorcycle behind the front. On 10 January 1915 he "applied to be sent to the Training School at Bailleul" and was offered a commission a week later. On January $20^{\text {th }}$ he "met Colonel Marshall ... of the Sherwood Foresters ... (he) asked me why I did not apply for a commission and when I told him that I had he promptly asked me to come to his Regiment. He there and then applied for me. Most awfully pleased about this". 96

He joined the 1st Battalion on 10 March as $2^{\text {nd }}$ Lieutenant, being wounded at Neuve Chapelle the following day. He was only able to return to duty on 3 September 1915. Promoted Captain, company commander, he was wounded on 1 June 1916 and again on 5 July 1916 during the attack on the Tara Line on the Somme. Awarded an MC on 6 August 1916 and now a Major, he joined $17^{\text {th }}$ Sherwood Foresters in May 1917, and was transferred to command the 16 th Battalion on 14 September $1917 .{ }^{97}$ Six days later he was leading his new battalion in action, albeit suitably fortified: "After a cup of tea with a stiff tot of rum in it, I went out and joined my men". He wrote of his battalion's participation in the Battle of the Menin Road Ridge: "I shall never forget 'Sept $20^{\text {th }}$ - it was the greatest day of my life. The dash of the men was simply amazing". He was awarded the DSO for "splendid example and leadership" in taking blockhouses in Bulgar Wood. ${ }^{98}$ November 22-

\footnotetext{
${ }^{96}$ William Raine Marshall was commanding $1^{\text {st }}$ Sherwood Foresters at the outbreak of war and continued to do so until the day after he encountered Webster. He subsequently served as Brigadier-General (24 January 1915 to 2 June 1915) 87 Brigade; Major-General with 42, 29 and 53 Divisions between 3 June 1915 and 14 September 1916; and finally Lieutenant-General from 24 September 1916 with III Indian Corps in Mesopotamia.

${ }^{97}$ He recorded: "Poor Houghton of the 16th Bn was killed by a shell and later in the evening I was sent to take command of them".

98 "For conspicuous gallantry and devotion to duty when in command of a battalion in an attack. When a strong point, manned by four machine guns, had been passed over by the leading troops in the attack, he promptly organised a party and led it to the capture of the strong point. He then led his battalion forward in the advance and, in spite of serious opposition, took all his objectives and held them against three enemy counter-attacks. The remarkable dash and determination of his battalion during the operations was mainly due to his splendid example and leadership". London Gazette, 6 April 1918, p.4199
} 
251917 found him commanding 117 Brigade as his Brigadier was on leave. ${ }^{99}$ On Christmas Eve 1917, "all the COs of the Brigade dined with the Brigadier and we had a very cheery evening", a situation which did not last as he was removed to hospital with a poisoned toe, writing: "I am awfully sick about it, for I have been so much away from the Battalion lately \& I want to get back to them". This bond with his battalion was soon put to the test.

On 20 January he was told that either the $16^{\text {th }}$ or $17^{\text {th }}$ Battalions, and probably the $16^{\text {th }}$, would be disbanded and "as I am only an acting Lt.-Colonel I am frightfully worried about it, for although I am feeling the strain a bit I do not want to give up the command of the Battalion and it would just about break Col. Stepney's heart". ${ }^{100}$ After being told it would be the $16^{\text {th }}$ : "I took my courage in my hands and went to the Brigadier and told him he was making a mistake ... I told him that I knew both Battalions intimately and that I believed the spirit de corps in the $16^{\text {th }}$ was deeper than in the $17^{\text {th }}$." His unit was reprieved, ${ }^{101}$ but his command was not to last long. On 22 March 1918, as $2^{\text {nd }}$ Lieutenant F.E. Allen, $1^{\text {st }}$ Hertfordshire, described:

Amid a murderous machine gun fire on the right of Solcourt Wood, near Villers Faucon, Lt-Col Webster ... bravely re-organised remnants of scattered units into a line of resistance and held up the enemy on all sides for two or three hours ... he set a fine example to subordinate ranks by his dauntless courage in running to and fro across a front swept by machine gun fire, and others were not slow to follow him.

\footnotetext{
${ }^{99}$ Brigadier-General G.A. Armytage.

${ }^{100}$ Cecil Champagne Herbert-Stepney, a Captain in the Reserve of Officers of the Kings' Royal Rifle Corps, commanded $16^{\text {th }}$ Sherwood Foresters from 1 May 1915 to 15 August 1917 when he was shot by a sniper resulting in the amputation of his left arm.

${ }^{101}$ A personal hiatus however now occurred. Put forward for promotion to Temporary Lieutenant-Colonel, his name was returned by VII Corps "as my name has never been put on the list of 'officers recommended for the Command of a Battalion"”, due to "oversight in the Brigade Office". He was gazetted Temporary Lieutenant-Colonel on 14 February 1918.
} 
He was shot dead. Colonel Herbert-Stepney remarked: "I suppose no more gallant soldier ever lived". ${ }^{102}$

Arthur Daniel Derviche-Jones is another prime, yet unknown, example of the highly successful citizen $\mathrm{CO} .{ }^{103}$ Educated at Winchester College, he was a 42 year-old Liverpool solicitor on the outbreak of war. ${ }^{104}$ He enlisted in September 1914 in $10^{\text {th }}$ Liverpool as a Private, and was commissioned Lieutenant in 3rd Liverpool on $12^{\text {th }}$ November 1914 . He was posted to France and Flanders on 4 April 1915 and given command of a company in the $1^{\text {st }}$ Battalion a month later. In May 1915, at Festubert, a bullet grazed his head, and he was wounded again in September that year at Loos. During 1916 he spent two months as 6 Brigade Intelligence Officer, and was attached for 10 days to $2^{\text {nd }}$ Division as Acting GSO3 Intelligence and finally served as Brigade-Major 142 Brigade from 21 June 1916 to 28 August 1916.

In January 1917 he attended Senior Officer School where he was "recommended for immediate command". He was sent to $13^{\text {th }}$ Essex on 7 April 1917 as second-in-command, and commanded this battalion from 4-16 May when he returned to command $1^{\text {st }}$ Liverpool, both as Major. He had three periods of command as a Lieutenant-Colonel. On 27 May 1917 he took command of $2 / 8^{\text {th }}$ London which post he held until its amalgamation with $1 / 8^{\text {th }}$ London, commanding between 31 July and 17 August 1918 , when he was invalided with neurasthenia having "lost his memory and could not sleep". He returned to action at his own request, Major-General A.C. Daly, $24^{\text {th }}$ Division, stating: "He is a very fine, experienced and exceptionally brave officer" - indeed, Derviche-Jones had been

\footnotetext{
${ }^{102}$ IWM Docs 13948 Private papers, J.R. Webster

${ }^{103}$ See Chapter Four section 4.2.2 concerning his period as second-in-command of $13^{\text {th }}$ Essex.

${ }^{104}$ He qualified in 1897.
} 
recommended for brigade command in November 1917. He commanded $1 / 12^{\text {th }}$ London from 11 to 14 October and $1 / 8^{\text {th }}$ London again from that date until the Armistice.

His experience of battle included Festubert, Loos, Vimy Ridge (May 1916), Beaumont Hamel, Arras, Bullecourt, Third Ypres [St Julien (September) and Passchendaele (October)], St Quentin, Crozat Canal, Tergnier, Viry Noreuil, Chauny (German Spring Offensive); Somme (Malard Wood) in August 1918, and Annay-Waudgnies, October to Nov 1918. At the end of the war he went to India as a GSO2 where a grateful army pursued him for an $£ 11$ bootmaker's bill.

Last, but by no means least, the extraordinary Bernard William Vann was a teacher and ordained clergyman who won the VC whilst commanding $1 / 6^{\text {th }}$ Sherwood Foresters. Born in 1887, Vann attended Chichele College ${ }^{105}$ and Jesus College, Cambridge, ${ }^{106}$ where he served for two years in the OTC achieving the rank of Sergeant. He was a notable sportsman. ${ }^{107}$ He was ordained deacon in 1910, serving as curate of St Barnabas, New Humberstone, until he took up post as chaplain and assistant master at Wellingborough School (1912). Frustrated by the delay in his application for an army chaplaincy he joined the ranks of the Artists Rifles, 31 August to 1 September 1914, gazetted that day $2^{\text {nd }}$ Lieutenant in $8^{\text {th }}$ Sherwood Foresters; subsequently being promoted Lieutenant (26 April 1915), and Captain (6 June 1915). He was transferred to the $1 / 7^{\text {th }}$ Battalion, promoted

\footnotetext{
${ }^{105}$ Where his father, Alfred George Collins Vann, was headmaster.

${ }^{106}$ College records indicate he obtained a third class in part I of the History Tripos in 1909 and a second in part II (1910).

${ }^{107} \mathrm{He}$ was captain of soccer, hockey and cricket at Chichele. On leaving school he played football for Northampton, Burton United and Derby County. In 1906, whilst teaching at Ashby-de-la-Zouche school he qualified for Leicestershire hockey colours. That year he toured with New Pilgrim soccer club in Bohemia, Austria and Hungary. Going up to Cambridge in 1907, he represented the university at football on several occasions, going on to Eastern Counties trials, and obtained college colours at soccer and hockey. The Chanticlere, Lent Term 1910, pp.14-15
} 
Major, on 20 June 1916, and must have been on the first Senior Officers Course at

Aldershot where he went in September 1916 whilst invalided. Buried by a trench mortar in May $1915^{108}$ and wounded at the Hohenzollern Redoubt in October $1915,{ }^{109}$ after which he carried on "an incessant bombing fight", Vann had succumbed to wound-related neuritis in his neck, ${ }^{110}$ and finally received electrical treatment in February $1917 .{ }^{111}$

He was promoted Lieutenant-Colonel on 6 October 1917 in the $1 / 6^{\text {th }}$ Battalion. His supreme achievement was in the $46^{\text {th }}$ Division's crossing of the St Quentin Canal on 29 September 1918. Attacking the German guns at Lehaucourt, he:

Led his men straight for the guns, shot down the German gunners as they fired, and having emptied his revolver, he gave one man a kick which sent him down a dug-out and maimed the last two men who showed fight with his riding crop. ${ }^{112}$

He was awarded the $\mathrm{VC},{ }^{113}$ posthumously as he was killed five days later on 3 October 1918 at Ramicourt, shot in the head by a sniper whilst encouraging his men.

\footnotetext{
${ }^{108}$ For which his MC was awarded: "At Kemmel on 24 April 1915 when a small advance trench which he occupied was blown in, and he himself wounded and half buried, he showed the greatest determination in organising the defence and rescuing buried men under heavy fire, although wounded and severely bruised he refused to leave his post until directly ordered to do so. At Ypres on 31 July 1915, and subsequent days, he ably assisted another officer to hold the left trench of the line, setting a fine example to those around him. On various occasions he has led patrols up to the enemy's trenches and obtained valuable information". London Gazette, 15 September 1915, page unknown.

${ }^{109}$ Gunshot wound left forearm. Estimates of the number of times Vann was wounded vary between seven and 13.

${ }^{110}$ After winning a bar to his MC: "For conspicuous gallantry in action. He led a daring raid against the enemy's trenches, himself taking five prisoners and displaying great courage and determination. He has on many previous occasions done fine work". London Gazette, 14 November 1916, p.11084

${ }^{111}$ TNA WO 374/70397 Officers' Services, Bernard William Vann

112 W.D. Jamieson (ed. C. Housey), Men of the High Peak: A History of the 1/6th Battalion the Sherwood Foresters 1914-1918 (Long Eaton: Millquest, n.d.), p.118

113 "For most conspicuous bravery, devotion to duty and fine leadership during the attack at Bellenglise and Lehaucourt on September 29th, 1918. He led his battalion with great skill across the Canal Du Nord through a very thick fog and under heavy fire from field and machine guns. On reaching the high ground above Bellenglise the whole attack was held up by fire of all descriptions from the front and right flank. Realising that everything depended on the advance going forward with the barrage, Col. Vann rushed up to the firing line and with the greatest gallantry led the line forward. By his prompt action and absolute contempt for danger the whole situation was changed, the men were encouraged and the line swept forward. Later, he rushed a field-gun single-handed and knocked out three of the detachment. The success of the day was in no small degree due to the splendid gallantry and fine leadership displayed by this officer. Lt.-Col. Vann, who
} 
In his obituary, ${ }^{114}$ a brother officer, "A.H.", described him as "a fighter, not merely against the enemy in the field, but a fighter against everything and everybody that was not an influence for good to his men". Vann "had no use for 'slackers' ... but 'slackers' in his platoon, his company or his battalion were few, for he inspired all by his wonderful example of courage and energy". On his death another officer remarked: "So died a man than whom no braver lived, a leader who really led, a fighter who fought to the last ounce, an enthusiast who stirred the very soul of his men". 115

Humphries and Wynne would have had to have shown the highest professionalism to have been given command of Regular battalions, when, as we have seen, ${ }^{116}$ Regular officers held a virtual monopoly on such positions. Derviche-Jones showed that citizens could become rounded soldiers and not just combat leaders in his staff work and post-war role as GSO2. Vann and Webster showed both extraordinary courage and leadership, Vann demonstrating that essential balance between discipline and paternal care, qualities ingrained in the army in the maintenance of morale. These skills were honed on the anvil of experience, Derviche-Jones' career in battle being quite extraordinary.

had on all occasions set the highest example: of valour, was killed near Ramicourt on 3rd October, 1918, when leading his battalion in attack". London Gazette, 14 December 1918, p.14774

${ }^{114}$ The Times, 19 December 1918, p.12

115 Jamieson, High Peak, p. 122

${ }^{116}$ See Chapter Four section 4.1 


\subsection{Conclusion}

A.D. Harvey suggests that "the rapid promotion of civilians in uniform ... demonstrates the unusual flexibility of British institutions in this period". ${ }^{117} \mathrm{He}$ is undoubtedly referring largely to flexibility of expectation of social status. Laura Roots' analysis of personal accounts confirms that "temporarily, in the trenches, social class had ceased to be the measure of an officer", and that "an 'efficient' officer was highly valued, whatever his social background". ${ }^{118}$ Whilst this flexibility was creditable it was simply a reflection of sheer pragmatism.

Harvey doubts whether the citizen officers were "military geniuses". He continues that it was "perfectly understood that brilliant performance in the specialised conditions of trench warfare did not mean that one had acquired a perfect all-round knowledge of soldiering in all conditions". ${ }^{119}$ Obviously, such officers had not the experience of the range of warfare many Regulars had, and had little or no experience of staff work. Brigadier Cumming's appreciation of Burdett acknowledged this aspect of the rounded soldier when he added: "He would require training and experience for the staff". As a senior officer of the Australian army in World War Two remarked to citizen soldiers: "You are not professional soldiers but you are professional men of war". 120

There have been few "military geniuses" in history. Nor would their genius have tipped the balance in the attrition of positional warfare. Harvey is, however, setting up a straw man.

\footnotetext{
${ }^{117}$ Harvey, 'Good War', p.80

118 L. Root, "Temporary Gentlemen" on the Western Front: Class Consciousness and the British Army Officer, 1914-1918', paper presented at the National Council on Undergraduate Research Conference Virginia Military Institute, Lexington ,VA, April 2005

119 Harvey, 'Good War', p.80

${ }^{120}$ Quoted in Pratten, Australian Battalion Commanders, p.235
} 
The typical experience of warfare of the British officer had outlived its usefulness by 31 December 1914. By 1918 he faced modern war, with weapons systems unknown four years earlier, and the citizen officer knew it as well as the Regular. The citizen soldiers were modern men who were quick learners. As Guy Chapman noted: “The New Army cared nothing for soldiering as a trade; thought of it only as a job to be done, and the more expeditiously the better". ${ }^{121}$ Nor after March 1918 were the experienced citizen soldiers fighting solely "in the specialised conditions of trench warfare", and the fact that they had cut their teeth in such circumstances did not hold them back. As Cyril Falls noted in The Hundred Days: "A couple of days of this open fighting and manoeuvre taught them more than a series of trench-to-trench attacks". ${ }^{122}$

Sergeant J.F. Lucy, a Regular of $2^{\text {nd }}$ Royal Irish Rifles, suggested that the particular style of thinking of the civilian brought new and enviable qualities to soldiering when he wrote:

The New Army leaders, a large number of whom were practical business men with no time for obsolete customs ... showing an unexpected flair for fighting, brought critical and well-trained minds to bear on every aspect of the war, and won not our respect, but our admiration. ${ }^{123}$

Lieutenant-Colonel E.W. Hermon, $27^{\text {th }}$ Northumberland Fusiliers, an ex-Regular, wrote disparagingly of the superficial differences that marked out Lieutenant-Colonel J.M. Prior of the $24^{\text {th }}$ as different from a pre-war officer: "He wears a diamond ring on the first finger \& another huge one on his little finger \& I asked my adjutant who \& what he was in civil

\footnotetext{
${ }^{121}$ G. Chapman, A Passionate Prodigality (London: Mayflower-Dell, 1967), p.141-2

${ }^{122}$ C. Falls, The Life of a Regiment Vol. IV (Aberdeen: Aberdeen University Press, 1958), p.245-8

${ }^{123}$ J.F. Lucy, There's a Devil in the Drum (Eastbourne,: Naval \& Military, 1993), p.343
} 
life \& he told me 'A commercial traveller' \& very well known in the North". Hermon had genuine reservations about Prior, ${ }^{124}$ but backed Lucy's appreciation of civilian COs:

Sounds so awfully odd after the old soldiering life, but these fellows are doing grand work, and after all they can't be bettered these times $\&$ to tell you the truth I don't believe that some of them could have been equalled in earlier days. ${ }^{125}$

Hanway Cumming's appreciation of George Gater, which opened this chapter, and his report on James Burdett leaves no doubt that as a Regular with the psc qualification, and with a wealth of experience, he thought that certain citizens could make extraordinary commanders.

The citizen COs were older than the average in 1918. They had life experience. For half, military interest (the OTC) had featured in their youth; perhaps, as John (later Lord) Reith claimed for himself, they "had war in (their) bones". ${ }^{26}$ They were well educated and mostly professional, and it took them only a fraction over three years to learn and practice the craft of command. On 29 September 1918, 22 per cent of active infantry battalions were commanded by civilians. ${ }^{127}$ At the Armistice, 43 per cent of all the citizens who ever held commands were in post. Undoubtedly, the era of the civilian infantry battalion commander had well and truly arrived.

\footnotetext{
${ }^{124}$ See Chapter Five section 5.3.2.

125 A. Nason (ed.), For Love and Courage- The Letters of Lieutenant Colonel E.W. Hermon from the Western Front 1914-1917 (London: Preface, 2008), p.267, letter dated 23 August 1916.

${ }^{126}$ J. Reith, Wearing Spurs (London: Hutchinson, 1966), p.15

${ }^{127}$ See Chapter Three section 3.1.1.
} 


\title{
Chapter Seven
}

\section{Meritocracy in Battalion Command in the Hundred Days - Lions Led by Tigers? ${ }^{1}$}

\author{
They are like little lions - these London men. \\ Lieutenant-Colonel R. Feilding, CO $1 / 15^{\text {th }}$ London \\ Regiment 26 August $1918^{2}$
}

It is a cursed war... yet I love it: it has been the breath of life to me.

Lieutenant-Colonel R. Feilding, 18 September $1918^{3}$

In his review of the British officer corps, Gary Sheffield states that "a limited meritocracy emerged in the British army during the Great War". ${ }^{4}$ Simon Robbins claims that "by 1918 a meritocracy based on promotion for able and experienced officers was established within the army leadership". 5 Field-Marshal Sir Douglas Haig asserted in 1919: "Promotion has been entirely by merit, and the highest appointments were open to the humblest, provided he had the necessary qualifications of character, skill, and knowledge ... A mess sergeant, a railway signalman, a coal miner, a market gardener, an assistant secretary to a haberdasher's company have risen to command battalions". ${ }^{6}$

\footnotetext{
${ }^{1}$ This phrase of John Bourne's parodies the supposed 1914 description of the BEF as "lions led by donkeys", a phrase impossible to attribute clearly to any German if indeed it was ever used. The original epithet likely dates to the Crimean War, where Russians supposedly used it to describe the British at Sebastopol; the FrancoPrussian War where the British may have used it to describe the French, or even Sir James Grierson (the original commander of II Corps in August 1914), to describe the Russians during the Boxer Rebellion.

${ }^{2}$ R. Fielding, War Letters to a Wife, ed. J Walker, (Staplehurst: Spellmount, 2001), p.173

${ }^{3}$ Feilding, War Letters, p. 186

${ }^{4}$ G.D. Sheffield, Leadership in the Trenches - Officer-Man Relations, Morale and Discipline in the British Army in the era of the First World War (Basingstoke: Macmillan, 2000), p.33

${ }^{5}$ S. Robbins, British Generalship on the Western Front 1914-18: Defeat Into Victory (Abingdon: Frank Cass, 2005), p.134. He adds: "Until the end of 1916 it cannot be said that there was a proper system of promotion based on professional expertise because there was no sustained reservoir of experience of continental warfare" (p.53).

${ }^{6}$ Final Despatch, London Gazette, 8 April 1919, page unknown
} 
In Chapter Five, the core views held from Private to GHQ on what was valued in a CO were identified. In Chapter Six the rising military stars of the citizens of August 1914 were examined. Did the COs of the victorious armies of The Hundred Days epitomise a distillation of these values, and did they represent a meritocracy, i.e. a group selected for excellence. ${ }^{7}$ If not, what were the limitations?

\subsection{Rat-Catchers and Fire-Eaters}

Jonathan Boff suggests that:

By 1918, most field commanders were probably, to use Andrew Gordon's phrase, 'rat-catchers', aggressive and self-sure, who had literally fought their way to the top, rather than the more institutionally comfortable 'regulators' who tend to populate the higher ranks of a peacetime force. ${ }^{8}$

Jim Storr equates the 'rat-catcher' with the 'autocrat", , who exercises "tight control, but only when the situation demands it" and who is "forceful" and "driving" but is "thoughtful and reflective", demonstrating "a deep humanity, even if only because they realise that the welfare of the people under them is vital to their effectiveness". He associates the 'regulator' with the 'authoritarian', who is "controlling, highly conformist, status-conscious, antiintellectual and punitive". ${ }^{10}$

\footnotetext{
${ }^{7}$ The concept of 'meritocracy' is a modern one, coined in 1958 by the sociologist Michael Young. [M. Young, The Rise of the Meritocracy, 1870-2033: An Essay on Education and Inequality (London: Thames and Hudson, 1958)]. The Oxford Reference Dictionary, $2^{\text {nd }}$ Edition (Oxford: Oxford University Press, 1996) defines merit as "1. The quality of deserving well. 2. Excellence, worth"; and meritocracy as "government by persons selected competitively according to merit". Young, whose thrust was critical, defined merit as "intelligence-plus-effort". ${ }^{8}$ J. Boff, Winning and Losing on the Western Front: The British Third Army and the Defeat of Germany in 1918 (Cambridge: Cambridge University Press, 2012), Kindle edition location 4646. Boff is referring to A. Gordon, The Rules of the Game: Jutland and British Naval Command (London: John Murray, 1996).

${ }^{9}$ The dichotomy between 'autocrat' and 'authoritarian' in senior army officers was drawn by Norman Dixon. [N. Dixon, On the Psychology of Military Incompetence (London: Jonathan Cape, 1977)].

${ }^{10}$ J. Storr, The Human Face of War (London: Continuum, 2009 ), Kindle edition, location 3674
} 
Storr emphasises that "tactical decision-making should be very quick" and "naturalistic", 11 rather than relying on the over-analysis of information. It is clear, therefore, why the "ratcatcher' might thrive in The Hundred Days. Boff, however, is indicating more than an organisational type, he is referring to the commander who knew that the war would only be won with an appetite for killing the enemy. This, in contemporary terms, was the 'Fire-Eater', and in John Bourne's words, the 'tiger'.

The creed of the 'Fire-Eater' is best expressed in Lieutenant-Colonel F.A. Maxwell's departing message to 12th Middlesex on 21 October 1916:

No failure has spoiled our record since real business began nearly four months ago, and none is going to. In that period we have begun to learn that the only way to treat the German is to kill him, but that lesson is only halflearned, for we either do not want to kill him enough, or we forget to use that best of weapons, our rifles, to down him. We shout for bombs, instead of shooting with our guns ... Remember that the 12 $2^{\text {th }}$ 'Die Hards' do kill, don't get taken prisoner unless wounded, and don't retire". 12

Brigadier-General F.P. Crozier (119 Brigade) once damned a Lieutenant-Colonel: "A charming fellow, a staff college graduate and a one-time instructor ... at some military establishment", sent for a month "to qualify for a brigade", because "he is unable to kick the Germans out of his line quickly on his own initiative, and prefers to write orders instead of doing things". Whilst Crozier's views on officers of the Regular army from which he had been forced to resign due to bankruptcy were undoubtedly jaundiced, ${ }^{13}$ he had an eye for a 'tiger', identifying aggression and initiative. "We all have our métiers and his is neither the command of men nor the slaughtering of the enemy", he concluded. ${ }^{14}$

\footnotetext{
${ }^{11}$ Storr, Human Face, location 2800

12 TNA WO /95/2044 War Diary $12^{\text {th }}$ Battalion Middlesex Regiment, 21 October 1916

${ }^{13}$ See Introduction. Crozier was scathing about appointments from Lieutenant-Colonel to Brigadier: "Personal friendships and ability to tell good stories over a glass of port or to toady to military magnates are made the hidden reasons for recommendations for promotion". [F.P.Crozier, A Brass Hat in No Man's Land (London: Jonothan Cape, 1930), p.148].

${ }^{14}$ Crozier, Brass Hat, pp.148-9
} 
Whether the British armies of 1918 were composed of 'lions' is outside the scope of this work. But to what extent were they 'led by tigers'? Frank Crozier found $12^{\text {th }}$ North Staffordshire under his command in 1918, and noted that they were "in trouble; the same old cause - colonels". ${ }^{15}$ Crozier allegedly found his 'tiger' to command them in a shell-hole. Thirty-two year-old Lieutenant-Colonel Ernest Robert O'Connor had been in the ranks for 14 years, rising to Company Sergeant-Major in the $2^{\text {nd }}$ Grenadier Guards, and had been in France and Flanders since 13 August 1914. Commissioned into the Manchester Regiment as a $2^{\text {nd }}$ Lieutenant in January 1915 , he had served as Adjutant with $11^{\text {th }}$ Manchester from January 1916 to September 1917, and then briefly as second-in-command with a battalion of the Munster Fusiliers. On being appointed CO on 24 October 1918: "He transforms the battalion and electrifies the men in under a week". "Follow me", shouted O'Connor, in the vanguard crossing the Scheldt in November $1918 .^{17}$

Crozier's memoirs refer specifically to three 'tigers', two in particular being "first-class colonels". ${ }^{18}$ The first, Lieutenant-Colonel James Frederick Plunkett, commanded $19^{\text {th }}$ Royal Welsh Fusiliers from 6 August 1917 until he was invalided during the Battle of Cambrai in November 1917, the "strain of thirty hours continued and sustained valour" having "upset his heart". ${ }^{19}$ Forty years-old, he had served in the ranks for 19 years, and was a Warrant Officer Class 1 in the $2^{\text {nd }}$ Royal Irish Regiment in August 1914. Commissioned $2^{\text {nd }}$ Lieutenant in the Royal Inniskilling Fusiliers in May 1915, he served as a Captain in the Middlesex, and a Major in the Sussex regiments. ${ }^{20}$ He finally served as CO $13^{\text {th }}$ Inniskilling Fusiliers from 10

\footnotetext{
${ }^{15}$ Crozier, Brass Hat, p.228. Formerly the 11th Garrison Guard battalion, from 11 June $191812^{\text {th }}$ North Staffordshire were commanded by Lieutenant-Colonel C.H. Kitching, a retired Special Reserve Captain.

${ }^{16}$ Crozier, Brass Hat, pp.228-9

${ }^{17}$ Crozier, Brass Hat, p.231

${ }^{18}$ Crozier, Brass Hat, p.149

${ }^{19}$ Crozier, Brass Hat, p.191

${ }^{20}$ Whilst being appointed substantive Captain in the Royal Dublin Fusiliers.
} 
June 1918 to the Armistice. Crozier noted: "If every man behaved as does Plunkett in action, every objective would be taken, every point held, provided the wire is cut, or all would die". ${ }^{21}$ The second, Lieutenant-Colonel Robert Benzie, commanded $12^{\text {th }}$ South Wales Borderers. A merchant and Lieutenant in the Ceylon Planters Rifle Corps, ${ }^{22}$ he had arrived in Egypt in November 1914 and when the unit was transferred to the ANZAC Corps, landed with them on Gallipoli. In France, Benzie was commissioned Captain in $2^{\text {nd }}$ Scottish Rifles in June 1916. Promoted Major he was attached to $12^{\text {th }}$ South Wales Borderers, commanding from 16 April 1917 to 19 February $1918 .^{23}$ Transferred on the disbandment of his battalion to command $14^{\text {th }}$ Argyll \& Sutherland Highlanders, he was wounded in the German spring offensive on 25 March 1918 at Gomiecourt, ${ }^{24}$ "thus losing his brigade-promotion". ${ }^{25}$ The citation for the bar to his DSO gives a flavour of his 'tiger' qualities:

During lengthy operations ... he constantly forced back the enemy and readjusted his line under heavy fire. After nearly all the officers of the brigade had become casualties, he organised the remnants into a unit, which he personally led, with the greatest courage, in a counter-attack, remaining in command of the advanced elements until relieved by another division. ${ }^{26}$

The last of this trio was Lieutenant-Colonel Richard John Andrews. Aged 38 at the outbreak of war, Andrews had served in South Africa as a Lance-Sergeant with the Imperial Yeomanry, ${ }^{27}$ and then allegedly as a Captain with the Chilean army. ${ }^{28}$ (He was certainly an engineer working on the Antofagasta and Bolivia Railway). He returned to the UK on 13

\footnotetext{
${ }^{21}$ Crozier, Brass Hat, p.191. Even the rural New Zealand newspaper The Feilding Star reported on 12 April 1918 that in the award of a bar to his DSO: "He is stated to be the first 'ranker' to win the equivalent of two D.S.O.s", having won the DCM in the August 1914 retreat and the MC in 1915, not to mention being six times mentioned in dispatches". However, despite Plunkett's return, Crozier concluded: "Bourlon did him in". (Crozier, Brass Hat, p.229).

${ }^{22}$ Established in 1900, the CPRC sent 8 officers and 229 other ranks to Egypt under the command of a Major.

${ }^{23}$ Crozier noted: "He returned to Ceylon but was invalided for good", (Brass Hat, p.245).

${ }^{24}$ A gunshot wound in the right arm-pit. TNA WO339/79058, Officers' Services, Robert Benzie

${ }^{25}$ Crozier, Brass Hat, p.196. Whether this is true is an open question, but it makes clear that Crozier thought highly of his organisational abilities.

${ }^{26}$ London Gazette, 16 July 1918, p.8437

${ }^{27} 128^{\text {th }}$ Company, $28^{\text {th }}$ Battalion Imperial Yeomanry.

${ }^{28}$ Obituary, The Times, 19 January 1923.
} 
January 1915 and enlisted in $14^{\text {th }}$ London five days later, reverting from Sergeant to Private on transfer to the $1^{\text {st }}$ Battalion in France on 4 July 1915. Promoted Corporal three months later, he was commissioned into the Devonshire Regiment as $2^{\text {nd }}$ Lieutenant in March 1916, and posted to the $2^{\text {nd }}$ Battalion in France, was commanding a company within 4 months. Obviously the object of talent-spotting, he was one of the first attendees of Senior Officer School in late 1916, and was sent to $17^{\text {th }}$ Welsh as second-in-command on 18 April 1917 , leading the battalion at the capture of Welsh Ridge, Cambrai six days later. Crozier noted: "There is no holding these intrepid men". ${ }^{29}$ He took over full command of the battalion on 1 July $1917,{ }^{30}$ and was wounded at Bourlon Wood, 24 November 1917, shot through the sciatic nerve. He commanded $18^{\text {th }}$ York and Lancaster in the UK during June 1918, whereafter, again complaining of his COs, Crozier noted: "I am saved, for Andrews, limping, yet still the old fire-eating Andrews, has put his foot in France". ${ }^{31}$ He finished the war commanding $13^{\text {th }}$ East Lancashire, and "thruster, fighter and man of action", ${ }^{32}$ was in the vanguard of his battalion on 8 November 1918 crossing the Scheldt crying "Allez, Allez". 33

An additional 'tiger' was William Ernest Brown, a 32 year-old land surveyor in 1914, who was commissioned $2^{\text {nd }}$ Lieutenant in $12^{\text {th }}$ South Wales Borderers in May 1915, having served as a Private in the Inns of Court OTC since 9 February. He served as Captain and Adjutant

\footnotetext{
${ }^{29}$ Crozier, Brass Hat, p.146.

30 Andrews won the DSO whilst attached to this battalion: "For conspicuous gallantry and resource when in command of a brigade. Early in the operations he was wounded in the foot by a shell, but, with great courage and skill, he took effective measures to carry out an original plan, and subsequently directed a successful withdrawal. He personally supervised the retirement of the last supporting platoon in order to ensure, so far as possible, the safety of the wounded. He has been previously noted for gallantry and skill when in command of a battalion". London Gazette, 18 July 1917, page unknown

${ }^{31}$ Crozier, Brass Hat, p. 228

${ }^{32}$ Crozier, Brass Hat, p. 235

${ }^{33}$ On 8-9 November 1918. Crozier, Brass Hat, p.231. Crozier notes: “Andrews became mentally deranged for a time, in France after the war finished - he snapped" (p.245). On 9 April 1918 he was sent to Russia but on the mutiny of the $5^{\text {th }}$ North Russian Rifles on 20 July 1920 was arrested and detained in Russia until 1920. After a brief period whilst MI5 debated as to whether he was a spy, he was then posted to the Auxiliary Division of the Royal Irish Constabulary from October 1920 to February 1921, when he resigned, his file noting "good riddance". He was killed on 16 January 1923 in the garage he ran, using equipment he had little knowledge of operating. (TNA WO/374/1827 Officers' Services Richard John Andrews).
} 
from 1 August 1916 to his promotion as Major second-in-command on 24 July $1917 .^{34}$ Crozier described him as "a product of Pope and Benzie", indicating how the promising officer learned from the skilled $\mathrm{CO} .{ }^{35}$ He took over command of $18^{\text {th }}$ Welsh on 13 March 1918, earning Crozier's admiration in the German Spring Offensive eight days later, and remained CO until the Armistice, although he commanded 47 Brigade from 10 to 29 October 1918. His DSO, awarded as CO, reflects his abilities:

While commanding his battalion ... he held a position successfully with very few men. His fine example of courage and cheerfulness under heavy fire was mainly responsible for the retention of the ground. ${ }^{36}$

What model of leadership is Crozier setting out for us in his descriptions of these five COs? Given that three were ex-ORs, one a civilian, and one a colonial volunteer it might be thought that he was biased against Regular officers, but it will be remembered how highly he rated the performance of the somewhat elderly Lieutenant-Colonel H.C. Metcalfe ( $21^{\text {st }}$ Middlesex), a retired Regular Captain, in March $1918 .{ }^{37}$ Crozier's template for successful battalion command in The Hundred Days clearly included stamina (all of his nominees had fought their ways through the entire war), experience, initiative, vanguard leadership, courage, example and aggression. Frank Maxwell, had he lived, would likely have agreed. ${ }^{38}$

How many COs of 1918 lived up to these standards is impossible to know. In 1917, Crozier described having seven Lieutenant-Colonels of the 'right' type in his brigade, and, to extrapolate from his memoirs, he had five in the period following the German Spring Offensive in 1918. He was, however, complaining in mid-1918: "My troubles over colonels

\footnotetext{
34 TNA WO339/4587 Officers' Services William Ernest Brown

${ }^{35}$ Crozier, Brass Hat, p.196

${ }^{36}$ London Gazette, 16 September 1918, page unknown

${ }^{37}$ See Chapter Three section 3.2.1.

${ }^{38}$ Maxwell was killed, shot by a sniper, on 21 September 1917. Crozier has little to say about organisational ability.
} 
have been fierce". ${ }^{39}$ It was noted in Chapter Three that Major-General Sir R. Pinney (33 ${ }^{\text {rd }}$ Division) was still removing COs as late as October 1918, and Lieutenant-Colonel R. Feilding echoed this, writing on 18 September: "A good many Battalion Commanders have been un-gummed during the last few weeks". ${ }^{40}$ The army of 1918 clearly still had quality control issues with battalion command, but remained active in dealing with them.

Whilst the German Spring Offensive of March 1918 was attritional of COs, ${ }^{41}$ there was no shortage of possible replacements due to the battalion disbandments of February and the summer of 1918. However, numbers did not necessarily equate with quality, BrigadierGeneral W.H.E. Seagrave, 152 Brigade, apparently remarking in September 1918: “Good Battalion Commanders are very hard to get". ${ }^{42}$ Lieutenant-Colonel R. Fielding returned to France following recuperation from injury in August 1918, and, $6^{\text {th }}$ Connaught Rangers having been disbanded, found himself in "the Commanding Officers' pool", which Crozier called the "pot-luck pool", ${ }^{43}$ at Etaples. After four days he was ordered to proceed to command $1 / 15^{\text {th }}$ London writing: "This, to say the least of it, was unexpected, since (COs) are usually kept waiting for weeks, and sometimes months". ${ }^{4}$

\subsection{The COs of The Hundred Days}

Seven hundred and thirty one COs with the rank of Lieutenant-Colonel were identified as serving with the 465 battalions active during The Hundred Days, ${ }^{45}$ of whom thirty had two

\footnotetext{
${ }^{39}$ Crozier, Brass Hat, p. 228

${ }^{40}$ Feilding, War Letters, p. 186

${ }^{41}$ See Chapter Three.

${ }^{42}$ Feilding, War Letters, p.187. Italics not in original.

${ }^{43}$ Crozier, Brass Hat, p. 228

${ }^{44}$ Feilding, War Letters, p. 172

${ }^{45}$ Including pioneer battalions.
} 
commands, and one had three. ${ }^{46}$ There were thus an average 1.6 COs per battalion during the campaign.

In terms of command experience, 58 per cent had been in post before The Hundred Days campaign commenced. However, as noted in Table 3.13, they had been in post an average 185 days at the start of the campaign, in comparison with 277 days for COs at the opening of the Somme battle in 1916, and 252 days at the opening of Third Ypres in 1917. They had therefore the least average experience of command in terms of tenure as $\mathrm{CO}$, but the longest experience of battle as officers of any Great War COs embarking on a major campaign. Six had been in command since 1915, although four had only commanded pioneer battalions. ${ }^{47}$ Thirty-two had been in command since 1916, of whom five commanded pioneer battalions and three battalions which were not front-line troops. Ninety-seven (21 per cent at the opening of the campaign) had commanded since 1917. Seventy-one per cent were 1918 appointees.

\begin{tabular}{|l|c|}
\hline Promoted & $3 \%$ \\
\hline Killed in action & $5 \%$ \\
\hline Invalided/wounded & $9 \%$ \\
\hline Replaced & $17 \%$ \\
\hline
\end{tabular}

Table 7.1: Reasons for COs leaving command during The Hundred Days

As Figure 3.1 indicated, there was a roughly similar rate of turnover over of COs during The Hundred Days in comparison with 1917 overall, although the rate increased as the campaign progressed. The reasons for this are set out in Table 7.1. The killed in action total is half the

\footnotetext{
46 Albert Grover commanded 3/4 ${ }^{\text {th }}$ London from 18 June to 12 September $1918,1 / 8^{\text {th }}$ London from 24 September to 14 October 1918 , and $1 / 12^{\text {th }}$ London from 15 October to the Armistice.

${ }^{47}$ The COs of pioneer battalions often had long tenure. The two long serving infantry COs were LieutenantColonel James Anderson who had first commanded 1/6 ${ }^{\text {th }}$ Highland Light Infantry on 27 September 1915 and commanded until 24 August 1918 broken by a spell in command of the $8^{\text {th }}$ Battalion; and Lieutenant-Colonel Thomas William Parkinson who commanded $15^{\text {th }}$ Welsh between 10 November 1915 and 31 August 1918.
} 
average for the war as a whole, indicating greater care being taken of the $\mathrm{CO}$ resource. By far the most frequent cause of turnover was replacement, which at 17 per cent is less than half the overall replacement rate (38 per cent) for the war as a whole. ${ }^{48}$ This, coupled with a wounding/invalidity rate half the average for the war, again implies a fitter and more competent group of COs. Conversely, active weeding of battalion command continued even at this late stage, indicating that, unsurprisingly, refinement was never complete.

To examine more closely the nature and attributes of these men, $5^{\text {th }}, 9^{\text {th }}$ and $42^{\text {nd }}$ Divisions will be considered in detail.

${ }^{48}$ See Chapter Three. 


\begin{tabular}{|c|c|c|c|c|c|c|c|c|c|c|c|}
\hline Regiment & Btn & \multicolumn{2}{|c|}{$\mathrm{CO}$} & From & To & $\begin{array}{c}\text { August } \\
1914 \\
\end{array}$ & $2 \mathrm{Lt}$ & $\mathbf{L t}$ & Capt & Major & Lt-Col \\
\hline Royal Warwickshire & 14th & Wilberforce & W. & $13 / 05 / 1918$ & $11 / 11 / 1918$ & Ret (Reg) & N/A & $15 / 08 / 1905$ & $31 / 10 / 1916$ & 09/09/1917 & $13 / 05 / 1918$ \\
\hline Royal Warwickshire & 15th & Miller & G. S. & $01 / 10 / 1916$ & $29 / 09 / 1918$ & Spec Res & $04 / 06 / 1904$ & $01 / 05 / 1906$ & $05 / 08 / 1914$ & $10 / 09 / 1916$ & $01 / 10 / 1916$ \\
\hline Royal Warwickshire & 16th & Deakin & G. & $02 / 07 / 1917$ & $11 / 11 / 1918$ & Ret (TF) & $02 / 03 / 1909$ & $21 / 08 / 1910$ & $20 / 11 / 1914$ & $09 / 12 / 1915$ & $02 / 07 / 1917$ \\
\hline Norfolk & $1 \mathrm{st}$ & Humphries & C. F. G. & $01 / 06 / 1918$ & $22 / 08 / 1918$ & Citizen & $11 / 06 / 1915$ & N/A & $26 / 09 / 1915$ & $?$ & $17 / 04 / 1918$ \\
\hline Norfolk & $1 \mathrm{st}$ & de Grey & G. & $03 / 09 / 1918$ & $11 / 11 / 1918$ & Reg & $06 / 01 / 1904$ & $19 / 01 / 1906$ & $01 / 09 / 1912$ & $26 / 11 / 1916$ & $06 / 09 / 1918$ \\
\hline Devonshire & $1 \mathrm{st}$ & Halford & M. W. & 15/06/1918* & $11 / 11 / 1918$ & Reg & $05 / 10 / 1910$ & $06 / 03 / 1912$ & $15 / 11 / 1914$ & 05/09/1916 & $14 / 11 / 1917$ \\
\hline Bedfordshire & $1 \mathrm{st}$ & Courtenay & $\mathrm{H}$. & 18/06/1918 & 23/08/1918 & Reg & $19 / 09 / 1908$ & $01 / 04 / 1910$ & $31 / 10 / 1914$ & 03/06/1918 & 05/07/1918 \\
\hline Bedfordshire & $1 \mathrm{st}$ & Chirnside & W. S. & $23 / 08 / 1918$ & $14 / 10 / 1918$ & $\mathrm{TF}$ & $28 / 03 / 1914$ & $30 / 08 / 1914$ & $16 / 08 / 1915$ & $12 / 11 / 1917$ & $23 / 08 / 1918$ \\
\hline Bedfordshire & $1 \mathrm{st}$ & Shearman & C. E. G. & $14 / 10 / 1918$ & $11 / 11 / 1918$ & Reg & $06 / 11 / 1909$ & 01/03/1911 & $15 / 11 / 1914$ & N/A & $14 / 10 / 1918$ \\
\hline Cheshire & $1 \mathrm{st}$ & Roddy & E. L. & $\begin{array}{c}28 / 12 / 1917 * \\
08 / 10 / 1918\end{array}$ & $\begin{array}{l}17 / 09 / 1918 \\
31 / 10 / 1918 \\
\end{array}$ & Reg & 09/12/1896 & $24 / 08 / 1898$ & $19 / 02 / 1902$ & $05 / 09 / 1914$ & 08/10/1915 \\
\hline Cheshire & $1 \mathrm{st}$ & Clarke & M. F. & $\begin{array}{l}17 / 09 / 1918 \\
31 / 10 / 1918\end{array}$ & $\begin{array}{l}08 / 10 / 1918 \\
11 / 11 / 1918\end{array}$ & Reg & 28/05/1898 & $17 / 08 / 1899$ & $15 / 04 / 1905$ & $01 / 09 / 1915$ & $14 / 04 / 1916$ \\
\hline Scottish Borderers & 2 nd & Furber & C. T. & $\begin{array}{l}24 / 07 / 1917 \\
15 / 09 / 1918 \\
\end{array}$ & $\begin{array}{l}15 / 08 / 1918 \\
11 / 11 / 1918\end{array}$ & Reg & $20 / 05 / 1905$ & 03/07/1907 & $19 / 02 / 1914$ & $17 / 02 / 1917$ & 08/08/1917 \\
\hline Scottish Borderers & 2 nd & Kay & J. K. & $27 / 08 / 1918$ & $15 / 09 / 1918$ & Reg & $16 / 12 / 1908$ & $22 / 01 / 1912$ & $10 / 06 / 1915$ & 28/05/1918 & $27 / 08 / 1918$ \\
\hline Gloucestershire & 12th & Colt & H. A. & $25 / 10 / 1917$ & $23 / 08 / 1918$ & Ret (RN) & N/A & N/A & $28 / 10 / 1914$ & $26 / 10 / 1916$ & $25 / 10 / 1917$ \\
\hline Gloucestershire & 12th & Chapman & W.G. & $24 / 08 / 1918$ & $11 / 10 / 1918$ & Reg & $10 / 12 / 1913$ & $08 / 11 / 1914$ & $28 / 04 / 1916$ & $04 / 01 / 1918$ & $07 / 09 / 1918$ \\
\hline East Surrey & $1 \mathrm{st}$ & Minogue & M. J. & $17 / 07 / 1917$ & $11 / 11 / 1918$ & Reg & 03/09/1902 & $21 / 04 / 1904$ & $01 / 04 / 1910$ & $24 / 07 / 1916$ & 05/08/1918 \\
\hline Duke of Cornwall's LI & $1 \mathrm{st}$ & Kirk & J. W. C. & 01/06/1918* & $11 / 11 / 1918$ & Reg & $18 / 10 / 1899$ & $16 / 02 / 1901$ & $04 / 05 / 1907$ & $01 / 09 / 1915$ & $29 / 12 / 1915$ \\
\hline Royal West Kent & $1 \mathrm{st}$ & Johnstone & B. & 25/08/1917 & 09/10/1918 & Reg & $26 / 06 / 1901$ & 04/01/1904 & 28/03/1911 & 08/05/1916 & 09/09/1917 \\
\hline Royal West Kent & $1 \mathrm{st}$ & Kay & J. K. & 09/10/1918 & $11 / 11 / 1918$ & & & $\mathrm{Sec}$ & above & & \\
\hline
\end{tabular}

Table 7.2: Career progression of COs of 5th Division who commanded during The Hundred Days

(*Commanded a battalion previously) 


\section{3 $\quad 5^{\text {th }}$ Division}

$5^{\text {th }}$ Division was a Regular Third Army formation in $1918 .{ }^{1}$ During The Hundred Days it comprised 13 battalions [eight Regular, four New Army (one pioneer), and one Territorial (pioneer)], ${ }^{2}$ and had 18 COs. $^{3}$ Two COs were killed in action. ${ }^{4}$

Twelve of the 18 COs were active Regulars in August 1914 (see Table 7.2). ${ }^{5}$ Their average age of 34 years three months was close to the 29 September 1918 average of 34 years 11 months. ${ }^{6}$

The one ex-Regular, William Wilberforce, a retired 2nd Lieutenant of the Royal West Kent Regiment in August 1914, commanded 14 ${ }^{\text {th }}$ Royal Warwickshire. Assessments of his abilities remain in his personal file. ${ }^{7}$ He had resigned in November 1908 , having had a $£ 70$ cheque dishonoured, ${ }^{8}$ and went to work in Russia as court correspondent of the Daily Mail. ${ }^{9}$ Reenlisting, and described as "quick, clever and capable, certainly above the average of his rank", he was posted to Collingwood Battalion, Royal Naval Division. He served as a company commander during the Antwerp Expedition of October $1914,{ }^{10}$ and as Adjutant

\footnotetext{
${ }^{1}$ During The Hundred Days it took part in the Battle of Albert (21-23 August); the Second Battle of Bapaume (31 August to 3 September); the Battle of Epéhy (18 September); the Battle of the Canal du Nord (27-30 September); the Pursuit to the Selle (9-12 October) and the Battle of the Selle (17-23 October).

${ }^{2} 15^{\text {th }}$ Royal Warwickshire was disbanded on 6 October 1918 , and $12^{\text {th }}$ Gloucestershire on 19 October $1918.14^{\text {th }}$ Royal Warwickshire became the division's pioneer battalion on 5 October 1918, taking over from $1 / 6^{\text {th }}$ Argyll and Sutherland Highlanders. This unit was commanded during The Hundred Days by Lieutenant-Colonel Stewart Coats, a Captain with the battalion in August 1914.

${ }^{3}$ Excluding pioneers.

${ }^{4}$ Lieutenant-Colonel C.F.G Humphries was killed on 22 August 1918 and Lieutenant-Colonel H. Courtenay died of wounds on 23 August 1918, both losses occurring during the Battle of Albert. Lieutenant-Colonel H.A. Colt was also wounded and relinquished command on 23 August.

${ }^{5}$ Two more had a professional military background.

${ }^{6}$ Four were over 40, E.L. Roddy being the oldest, having been born on 19 April 1874, and hence 10 years above the average. W.G. Chapman was the youngest at 27 years 11 months.

${ }^{7}$ TNA WO 339/6297 Officers' Services, William Wilberforce.

${ }^{8} \mathrm{He}$ subsequently lost his temper and been "insubordinate" to a Captain using "language ... of a very offensive kind".

${ }^{9}$ Where he had learnt to speak Russian and French.

${ }^{10}$ The newly-formed Royal Naval Division landed in Antwerp on 6 October 1914 to assist in the defence of the besieged city. They arrived too late, the city surrendering on the $10^{\text {th }}$, the division being withdrawn on the $11^{\text {th }}$.
} 
from October until he was appointed Staff Captain to 1st Royal Naval Brigade from 1 December 1914 to April 1916. He showed "ability, tact and zeal" in the Gallipoli campaign 26 April to 1 November 1915 . $^{11}$ Transferred as Adjutant to 3rd Royal West Kent in August 1916, he was recommended for a more senior staff appointment in January 1917, when it was noted: "This officer has done well as adjutant under difficult conditions. Is a good disciplinarian and capable organiser". ${ }^{12}$ He was, however, given an active posting, and on 9 September 1917 was promoted Major, $1^{\text {st }}$ Royal West Kent, from whence he was transferred to command 14th Royal Warwickshire on 13 May 1918, being awarded a DSO for his skills as CO, when on 27 September 1918 "he successfully controlled a very difficult advance diagonally across three parallel lines of trenches". ${ }^{13}$

The four COs of the other three New Army infantry battalions represent an interesting spread. One was a Regular. ${ }^{14}$ First of two representatives of the TF in the division, Grahame Deakin commanded $16^{\text {th }}$ Warwickshire. He had served with $8^{\text {th }}$ Worcestershire from 1909 to 1912 , resigning as a Lieutenant, and was an estate agent in Birmingham in August 1914. He is an example of progression within a single unit, being commissioned Captain in $16^{\text {th }}$ Warwickshire on 30 November 1914, rising to Major second-in-command on 16 June 1916,

\footnotetext{
${ }^{11}$ From whence he was invalided with dysentery.

${ }^{12}$ After interview it was recorded: "Rather an awkward manner but should make a good Staff Officer with his experience".

${ }_{13}$ "For conspicuous gallantry and devotion to duty near Gouzeaucourt on 27th September, 1918, in the attack on the trench system up to Dunraven Trench, and then the formation of a defensive flank to the right. He successfully controlled a very difficult advance diagonally across three parallel lines of trenches. When the enemy counterattacked with fresh troops and specially trained bombers, driving back his battalion and another, it was largely due to his efforts that a new line of defence was formed and held". London Gazette, 1 February 1919 , p.1611

${ }^{14}$ Willoughby George Chapman, a Regular 2nd Lieutenant of 2nd Gloucestershire in August 1914. A Special Reserve entrant, Chapman served with the $2^{\text {nd }}$ Battalion before appointment as a Staff Captain Commanding an Officer Cadet Company from 1 October 1916 to 9 January 1917. He had served with 12th Gloucestershire as a Captain since 11 February 1917. After $12^{\text {th }}$ Gloucestershire were disbanded, Chapman ended the war commanding $4^{\text {th }}$ Middlesex.
} 
and taking over command on 2 July 1917. Deakin was awarded the DSO for his "good leadership" as CO, personally organising scattered companies and leading them forward. ${ }^{15}$

George Swiney Miller, CO $15^{\text {th }}$ Warwickshire, had been commissioned in the Royal Warwickshire Regiment in 1904, promoted Captain in the $4^{\text {th }}$ Battalion on the day war broke out, and was the only representative of the Special Reserve. His first active service was in March 1916 with $1^{\text {st }}$ Royal Warwickshire, being transferred to $15^{\text {th }}$ Royal Warwickshire in August, promoted Major second-in-command on 10 September, and taking over command on 1 October. He commanded until 29 September 1918, at which point he was wounded. His "admirable leadership", including his skilled planning in an attack, led to the award of a bar to his DSO. ${ }^{16}$

The remaining New Army CO was Henry Archer Colt, who had become a midshipman in 1898, retiring from the Navy as a Lieutenant-Commander in $1912 .{ }^{17} \mathrm{He}$ is another example of progression within a single unit. He was appointed Captain in $12^{\text {th }}$ Gloucestershire on 28 October 1914, becoming Major second-in-command in March 1917, and taking over command on 25 October 1917. His reign was terminated by wounding in the assault on Irles

\footnotetext{
15 "For conspicuous gallantry and initiative in an attack. He personally went forward and under heavy machinegun fire, organised one of his companies and some other scattered units which had become mixed owing to the dense fog. He led them forward and captured his final objective, together with an enemy battery, and later, when both his flanks were exposed, he held his ground in spite of heavy counter-attacks until he had organised an orderly withdrawal. He set a splendid example of courage and good leadership." London Gazette, 2 December 1918, p.14210. Deakin's courage was certainly not in question; during operations near Achiet-le-Petit on 21 August 1918 "a Battery of 5.9 howitzers was found firing into the advancing line of the $95^{\text {th }}$ Brigade; Lieut.-Col. Deakin, accompanied by a few men, himself shot down the gunners". A.H. Hussey and D.S. Inman, The Fifth Division in the Great War (London: Nibet \& Co. Ltd, 1921), p.231

16 "For conspicuous gallantry and devotion to duty. The skill with which he made his plans, and his untiring devotion to duty in reconnoitring the position and training his men preparatory to an attack largely contributed to the success of the operation. When the objective was gained, his gallantry and admirable leadership, which had been conspicuous during the engagement, greatly cheered and encouraged his men during the difficult work of consolidation under heavy shell and machine-gun fire". London Gazette, 15 October 1918, p.12052. His DSO was gazetted on 3 June 1918.

${ }^{17}$ See Chapter Three.
} 
on 23 August 1918, an attack organised "on his own initiative", ${ }^{18}$ when his DSO citation notes his "very great ability" as a CO. ${ }^{19}$

With respect to the Regular units, one citizen commanded, namely C.F.G. Humphries, $1^{\text {st }}$ Norfolk, whose extraordinary career was reviewed in Chapter Six. William Stuart Chirnside was the second Territorial $\mathrm{CO}$ in the division, and his skills must have been considerable to be given command of a Regular battalion. ${ }^{20}$ A 29 year-old insurance clerk and $2^{\text {nd }}$ Lieutenant of $5^{\text {th }}$ Bedfordshire at the outbreak of war, he was wounded (for the second time) on Gallipoli on 17 November 1915 during bomb throwing training. ${ }^{21}$ After convalescence he was sent to the $1^{\text {st }}$ Battalion on the Western Front, commanding from 23 August to 14 October 1918, achieving a reputation as "a superb combat leader". 22

Eleven active Regular officers of August 1914 commanded the Regular battalions. At 92 per cent this is virtually identical to the 90 per cent maintained by the Regular units of $5^{\text {th }}$ Division throughout the war. In August 1914 (see Table 7.2) four were Lieutenants and seven Captains. ${ }^{23}$ Four had landed in France with the original BEF in August $1914,{ }^{24}$ and one in November 1914 in Mesopotamia. ${ }^{25}$ Three arrived in France ${ }^{26}$ and one in Mesopotamia ${ }^{27}$ in

\footnotetext{
${ }^{18}$ Hussey \& Inman, Fifth Division, p.233. His action secured a safe flank for the attack on Miraumont.

19 "For conspicuous gallantry and fine leadership. He commanded his battalion during three days' severe fighting, including the capture of an important village, with very great ability and courage. In spite of heavy casualties he pushed forward to his successive objectives with great determination, being himself severely wounded when leading the final assault on the village. His example greatly inspired his men”. London Gazette, 7 November 1918, page unknown.

${ }^{20}$ But the second of the war, see Chapter Four section 4.1.1.

${ }^{21}$ TNA WO 95/4325 War Diary, $5^{\text {th }}$ Battalion Bedfordshire Regiment. He had been previously wounded between 15 and 19 August, winning the MC, but remaining at duty.

${ }^{22}$ http://bedfordregiment.org.uk/5thbn/5thbtnmedalwinners.html (accessed 23 February 2012).

${ }^{23}$ Of these officers, only Martin Joseph Minogue, $1^{\text {st }}$ East Surrey, had spent just under 6 years in the ranks, moving from Sergeant, South Lancashire Regiment to a commission in the Manchester Regiment in 1902, transferring as a Lieutenant to the East Surrey Regiment in 1908.

${ }^{24}$ M.W. Halford ( $\left({ }^{\text {st }}\right.$ Gloucestershire); H. Courtenay $\left(1^{\text {st }}\right.$ Bedfordshire $)$; C.E.G. Shearman ( $\left(1^{\text {st }}\right.$ Bedfordshire $)$; and M.J. Minogue ( $1^{\text {st }}$ East Surrey).

${ }^{25}$ The Hon. G. de Grey ( $2^{\text {nd }}$ Norfolk), eldest son of the $7^{\text {th }}$ Baron Walsingham. He was wounded three times during the war.
} 
early 1915; another arrived in June $1915 .^{28}$ Only one could be viewed as having been protected from the toll of active service by not having been in a theatre of war. Cecil Tidswell Furber, CO $2^{\text {nd }}$ King's Own Scottish Borderers, served in India as a Brigade-Major until December 1916, arriving in France in January $1917 .{ }^{29}$ Three more could be considered as having been protected by periods of staff employment whilst on active service. Hugh Courtenay served as a Staff Captain from November 1915 to June 1916 and as DAQMG from June 1916 to June $1918 ;{ }^{30}$ Charles Edward Gowran Shearman served as GSO3 from February to May 1917 and Brigade-Major (173 Brigade) from May 1917 to October 1918; ${ }^{31}$ and Bede Johnstone served as Brigade-Major from February 1916 to September $1917 .^{32}$

E.L. Roddy, whose first command dates from 7 September 1915, was the earliest appointment, closely followed by J.W.C Kirk on 29 December 1915. One CO had achieved command in 1916, three in 1917, the remaining five in 1918 (see Table 7.2).

Four had multiple commands. Edwin Louis Roddy commanded $2^{\text {nd }}$ Cheshire from 7 September to 2 November 1915; $1^{\text {st }}$ Cheshire from 8 to 31 October 1916, 28 December 1917 to 17 September 1918 , and 8 to 31 October 1918; and 2/10 ${ }^{\text {th }}$ Liverpool from 27 April to 9

\footnotetext{
${ }^{26}$ E.L. Roddy ( $2^{\text {nd }}$ Cheshire); M.F. Clarke (serving as Adjutant to $3^{\text {rd }}$ Cheshire); and B. Johnstone (serving as Adjutant with $1 / 7^{\text {th }}$ Warwickshire).

${ }^{27}$ J.K. Kay ( $2^{\text {nd }}$ Royal West Kent).

${ }^{28}$ J.W.C Kirk, Duke of Cornwall's Light Infantry, who was in Staff Posts at Sandhurst until going on active service.

${ }^{29}$ A Militia entrant, Furber had served in South Africa 1901-2 and later as Adjutant to his battalion. Furber's file reveals a dispute concerning the period he held the Temporary rank of Lieutenant-Colonel as distinct from Acting rank. The matter would be related to pension. (TNA WO339/6190 Officers' Services, Cecil Tidswell Furber). Certainly, in 1915-6 it was common for Temporary rank to be granted for a matter of days. During 1917, much more use was made of Acting rank for extended periods. It seems likely that a deliberate decision was made to reduce the future pension bill.

${ }^{30}$ Courtenay had no pre-war active service or staff experience. The spell in which he might be viewed as protected did him no good as he died of wounds on 23 August 1918.

${ }^{31}$ Sherman had no pre-war active service or staff experience.

${ }^{32}$ As noted in Chapter Three section 3.1.2, Johnstone had served as Adjutant to $1 / 7^{\text {th }}$ Warwickshire. He had been commissioned into the Royal West Kent Regiment in 1901 in South Africa from a Corporal in the Gloucestershire Regiment where he had served for nearly six years. He had also been attached to the West African Frontier Force between 1905 and 1909.
} 
December $1917 .{ }^{33}$ Montague Walter Halford commanded $1^{\text {st }}$ Cheshire from 27 October to 28

December $1917,1^{\text {st }}$ Bedfordshire from 16 April to 15 June 1918 , and $1^{\text {st }}$ Devonshire from 15

June to 26 October 1918. ${ }^{34}$ John William Carnegie Kirk commanded $2^{\text {nd }}$ Duke of Cornwall's Light Infantry from 29 December 1915 to 25 April 1916 and 2 June 1916 to 24 April 1918, and the $1^{\text {st }}$ Battalion from 1 June 1918 to the Armistice. ${ }^{35}$ Lastly, Jack Kilbourne Kay had two commands during The Hundred Days; $2^{\text {nd }}$ Scottish Borderers from 27 August to 15 September 1918, and $1^{\text {st }}$ Royal West Kent from 9 October to the Armistice.

The absence of formal evaluations of these men forces reliance on DSO citations to obtain a flavour of their abilities. Eight of the 11 received such an award as $\mathrm{CO} .{ }^{36}$

H. Courtenay was awarded a DSO for his initiative in the attack on Achiet-le-Petit on 23

August 1918 in which he was fatally wounded:

While directing the advance of his battalion one company became slightly disorganized owing to heavy fire. He rushed forward and led the men on. He then went to the left of the attack, where it was held up by wire, and encouraged short rushes, himself setting the example. Finally, he led the first wave himself until the last objective was reached. ${ }^{37}$

The circumstances of C.T. Furber's DSO similarly reflect initiative and courage:

When his right attacking company was driven back, this officer left his battalion headquarters, rallied the company, and he himself led the counter-

\footnotetext{
${ }^{33}$ Roddy had served in four campaigns in West Africa between 1901 and 1903 whilst attached to the West African Frontier Force, and had subsequently served as Adjutant with both Volunteers and TF.

${ }^{34}$ Of the multiple command group, M.W. Halford had served in no pre-war campaigns and had no staff service.

${ }^{35}$ Kirk was a Captain of the Duke of Cornwall's Light Infantry serving at the RMC from January 1913 to June 1915. He had been an Adjutant to his battalion and served in South Africa 1899-1902. He had seen active service in East Africa in 1904 whilst attached to the King's African Rifles between 1902 and 1905.

${ }^{36}$ Five of the eight were either 'New Year' or 'Birthday' list DSOs and no citation was given. The Hon G. de Grey was not awarded a DSO as a CO, rather "in the performance of his duties as Adjutant" of 2nd Norfolk. "He repeatedly crossed fire-swept zones in order to take orders, send up ammunition and direct reinforcements until he was severely wounded. His cool bravery had twice previously been brought to notice". London Gazette, 14 March 1916, p.2875

${ }^{37}$ London Gazette, 2 December 1918, page number unknown
} 
attack, regaining the ground that had been lost. His dash and personal example undoubtedly saved a critical situation. ${ }^{38}$

In addition, Furber was rewarded for his organisational ability as the citation for the bar to his DSO shows: "The untiring efforts and great ability with which this officer made his preparations for an attack largely contributed to the success of the operation". 39

J.K. Kay's citation also reflects both courage and skill:

He was commanding the battalion previous to and during an important attack ... and the skill and ability with which he made the preparatory arrangements were no less marked than his gallantry and soldierly bearing during the engagement. ${ }^{40}$

Whilst the Regular units of $5^{\text {th }}$ Division showed, with interesting exceptions, the typical adherence to Regular COs, the non-Regular battalions demonstrated an eclectic mix in command. Whatever their origins, these Commanding Officers clearly possessed both great depth of experience and skills of command, which in some had been identified relatively early in the war. Where we are allowed glimpses of their qualities, they demonstrated courage, organisational skill, and initiative.

\footnotetext{
${ }^{38}$ London Gazette, 6 April 1918, page number unknown.

${ }^{39}$ The citation continues: "His gallantry and devotion to duty during the engagement were conspicuous, and when the objective had been gained he supervised the difficult work of consolidation, under heavy fire, with perfect coolness and disregard of danger, setting a fine example which greatly encouraged all ranks of his battalion". London Gazette, 11 October 1918, p.12052

${ }^{40}$ The citation continues: "When the objectives had been gained, hearing that the two senior officers and a large number of men of his left company had become casualties, he immediately went to the spot, and by his coolness and cheerful example of courage inspired the men with his own resolution". London Gazette, 11 October 1918, p. 4
} 


\begin{tabular}{|c|c|c|c|c|c|c|c|c|c|c|c|}
\hline Regiment & Btn & $\mathrm{CO}$ & & From & To & $\begin{array}{c}\text { August } \\
1914 \\
\end{array}$ & $2 \mathbf{L t}$ & $\mathbf{L t}$ & Capt & Major & Lt-Col \\
\hline Royal Scots & 12 th & Murray & $\mathrm{J}$. & $15 / 06 / 1918$ & $11 / 11 / 1918$ & $\mathrm{TF}$ & $29 / 02 / 1904$ & $01 / 05 / 1907$ & $01 / 08 / 1911$ & 05/08/1914 & $15 / 06 / 1918$ \\
\hline Royal Scots & 11th & Campbell & J. B. S. & $14 / 09 / 1917$ & $15 / 10 / 1918$ & Ret (Emp) & N/A & $?$ & $20 / 03 / 1915$ & $14 / 05 / 1916$ & $14 / 09 / 1917$ \\
\hline Royal Scots & 11 th & Boyd & E. R. H. & $15 / 10 / 1918$ & $11 / 11 / 1918$ & Citizen & $15 / 08 / 1914$ & $02 / 02 / 1915$ & $10 / 06 / 1915$ & $18 / 04 / 1918$ & $15 / 10 / 1918$ \\
\hline Royal Scots Fusiliers & $2 \mathrm{nd}$ & Utterson-Kelso & J. E. & $11 / 10 / 1917$ & $06 / 10 / 1918$ & Reg & $04 / 09 / 1912$ & $19 / 10 / 1914$ & $06 / 06 / 1915$ & $28 / 03 / 1916$ & $13 / 10 / 1917$ \\
\hline Royal Scots Fusiliers & 2nd & Campbell & R. & $23 / 10 / 1918^{*}$ & $07 / 11 / 1918$ & Reg & $08 / 03 / 1899$ & $05 / 03 / 1900$ & $23 / 10 / 1905$ & $01 / 09 / 1915$ & $12 / 07 / 1916$ \\
\hline Royal Scots Fusiliers & 2 nd & Nairne & C. S. & 07/11/1918* & $11 / 11 / 1918$ & Reg & $18 / 04 / 1900$ & $22 / 12 / 1901$ & $13 / 08 / 1910$ & $01 / 09 / 1915$ & $14 / 01 / 1917$ \\
\hline Scottish Rifles & 9th & Lumsden & W. V. & $19 / 06 / 1917$ & $11 / 11 / 1918$ & Reg & $11 / 12 / 1907$ & $20 / 05 / 1909$ & $06 / 10 / 1914$ & $15 / 05 / 1916$ & $19 / 06 / 1917$ \\
\hline Scottish Borderers & 6th & Smyth & G. B. F. & $01 / 06 / 1918$ & $03 / 10 / 1918$ & Reg & $29 / 07 / 1905$ & $03 / 02 / 1908$ & $30 / 10 / 1914$ & $03 / 06 / 1916$ & $02 / 12 / 1916$ \\
\hline Scottish Borderers & 6th & Ker & R. F. & $03 / 10 / 1918$ & $11 / 11 / 1918$ & Citizen & $29 / 12 / 1914$ & $?$ & $01 / 10 / 1916$ & $11 / 05 / 1918$ & $03 / 10 / 1918$ \\
\hline Black Watch & 8 th & Hadow & R. W. & $02 / 06 / 1917$ & $17 / 08 / 1918$ & Ret (Reg) & $08 / 05 / 1901$ & $16 / 09 / 1905$ & $14 / 02 / 1914$ & $06 / 05 / 1917$ & $02 / 06 / 1917$ \\
\hline Black Watch & 8 th & French & $\mathrm{W}$. & $19 / 08 / 1918$ & $11 / 11 / 1918$ & Citizen & $23 / 09 / 1914$ & $17 / 05 / 1915$ & $01 / 09 / 1916$ & $30 / 09 / 1917$ & $19 / 08 / 1918$ \\
\hline Seaforth Highlanders & 9th & Petty & W. & $08 / 04 / 1917$ & $15 / 08 / 1918$ & $\mathrm{TF}$ & ? & $28 / 05 / 1909$ & $20 / 09 / 1913$ & $05 / 01 / 1916$ & $08 / 04 / 1917$ \\
\hline Seaforth Highlanders & 9th & Sharp & S. F. & $15 / 08 / 1918$ & $11 / 11 / 1918$ & Ret (Vol) & $09 / 11 / 1914$ & N/A & $02 / 12 / 1914$ & $02 / 06 / 1916$ & $15 / 08 / 1918$ \\
\hline Seaforth Highlanders & 7th & Bruce & D. & $18 / 04 / 1918$ & $14 / 10 / 1918$ & Reg & $10 / 06 / 1908$ & $01 / 09 / 1911$ & $26 / 04 / 1915$ & N/A & $18 / 04 / 1918$ \\
\hline Seaforth Highlanders & 7 th & Anderson & P. C. & $15 / 10 / 1918$ & $11 / 11 / 1918$ & Reg & $25 / 02 / 1914$ & $26 / 04 / 1915$ & $25 / 10 / 1915$ & $23 / 03 / 1917$ & $15 / 10 / 1918$ \\
\hline Cameron Highlanders & 5 th & Inglis & J. & 06/03/1918* & $15 / 09 / 1918$ & Reg & $08 / 05 / 1901$ & $09 / 06 / 1906$ & $12 / 06 / 1912$ & $08 / 05 / 1916$ & $17 / 07 / 1917$ \\
\hline Cameron Highlanders & 5 th & Angus & A. W. & $15 / 09 / 1918$ & $11 / 11 / 1918$ & Ret (?) & $19 / 091914$ & N/A & $30 / 10 / 1914$ & $05 / 11 / 1915$ & $15 / 09 / 1918$ \\
\hline $\begin{array}{l}\text { Argyll \& Sutherland } \\
\text { Highlanders }\end{array}$ & 10th & Sotheby & H. G. & $04 / 12 / 1916$ & $11 / 11 / 1918$ & Spec Res & 06/01/1900 & $?$ & $04 / 02 / 1902$ & $20 / 02 / 1916$ & $04 / 12 / 1916$ \\
\hline
\end{tabular}

Table 7.3: Career progression of COs of 9th Division who commanded during The Hundred Days

$\left({ }^{*}\right.$ Commanded a battalion previously) 


\section{4 $\quad 9^{\text {th }}$ (Scottish) Division}

$9^{\text {th }}$ Division was a New Army formation in Second Army from April 1918. ${ }^{1}$ During The Hundred Days the ten battalions (nine excluding Pioneers) ${ }^{2}$ were all New Army except for one Regular unit, and had $16 \mathrm{COs},{ }^{3}$ hence having moderate stability. No COs died in action. ${ }^{4}$

At exactly 33 years old, these COs were on average younger than the Regulars of $5^{\text {th }}$ Division and nearly two years younger than the 29 September 1918 average of 34 years 11 months. ${ }^{5}$

Three of the 16 COs were citizens of August 1914 (19 per cent, slightly lower than the 22 per cent average for the BEF on 29 September 1918$)^{6}$ and all were appointed for the first time during The Hundred Days. Edward Robert Hugh Boyd, born in 1892, had been a LanceCorporal in Charterhouse School OTC (where his "general efficiency" was only rated "fair"). He was commissioned $2^{\text {nd }}$ Lieutenant in $3^{\text {rd }}$ Royal Scots (Special Reserve) on 15 August 1914, and was sent to the $1^{\text {st }}$ Battalion in 1915. He served at Fifth Army School as an Instructor in late 1917 , and was promoted Major second-in-command of the $11^{\text {th }}$ Battalion in April 1918. He took over command on 15 October $1918 .^{7}$

\footnotetext{
${ }^{1}$ Having taken part in the highly successful capture of Meteren (19 July), during The Hundred Days $9^{\text {th }}$ Division took part in the Capture of Hoegnacker Ridge (18 August); the Battle of Ypres (28 September to 2 October); the Battle of Courtrai (14-19 October); and Ooteghem (25 October).

2 The Pioneer battalion was $9^{\text {th }}$ Seaforth Highlanders. The two COs during The Hundred Days both had a Territorial background. Born in 1875, William Petty was a TF Captain attached to Edinburgh Academy OTC in August 1914, and commanded from 8 April 1917 to 15 August 1918. He had been a Trooper promoted Corporal in the South African Constabulary during the Boer War 1901-2, and had been commissioned in the TF in 1909. (TNA WO339/19637 Officers' Services, William Petty). His replacement was Stuart Forbes Sharp, born in 1880, who in the Boer War had been a Trooper in 52 Company (Paget's Horse) 19 Battalion Imperial Yeomanry. A motor agent in August 1914, he was gazetted Lieutenant in $9^{\text {th }}$ Seaforth Highlanders on 9 November 1914, taking over command from Petty. http://theauxiliaries.com/men-alphabetical/mens/sharp/sharp.html (accessed 21 December 2012).

${ }^{3}$ Excluding two pioneer COs.

${ }^{4}$ Two departed wounded; Lieutenant-Colonel J. Inglis when a stray shell hit his battalion HQ; and LieutenantColonel J.E. Utterson-Kelso, also badly wounded by a shell. J. Ewing, The History of the Ninth (Scottish) Division 1914-1919 (London: John Murray, 1921), p.346

${ }^{5}$ Two were over 40, H.G. Sotheby being the oldest, having been born in 1871, and hence 13 years above the average. R.F. Ker was the youngest at 25 years 4 months.

${ }^{6}$ See Table 3.2

${ }^{7}$ Boyd had been court-martialled for possessing a camera and posting photographs (date uncertain, sentence remitted). His lack of respect for authority post-war included libelling an Englishman as a "German solicitor";
} 
Robert Fordyce Ker, an Edinburgh banker born in 1893, attested Private in $9^{\text {th }}$ Royal Scots (Territorial) on 9 September 1914, and was commissioned in $9^{\text {th }}$ King's Own Scottish Borderers on 29 December $1914 .^{8}$ He went to France in 1915 with $6^{\text {th }}$ Scottish Borderers, and became a Captain commanding a company on 1 October $1916 .{ }^{9}$ He assumed command on 3 October 1918, his rise to command being within the same unit on active service.

Lastly, William French was commissioned on 28 September 1914 in $10^{\text {th }}$ Argyll and Sutherland Highlanders (Service), and landed in France on 11 May 1915. He was made Adjutant whilst a Captain on 31 January 1917, but was transferred to be Major second-incommand $8^{\text {th }}$ Black Watch on 30 September 1917, taking over command on 19 August 1918. His organisational and leadership abilities are evident from his two DSO citations, although neither was awarded as $\mathrm{CO} .^{10}$

The only active TF officer of August 1914 to command a battalion in the division was Captain John Murray of the Scottish Horse. ${ }^{11}$ He served with this battalion as infantry on Gallipoli and in Egypt, and after the Scottish Horse became the $13^{\text {th }}$ Black Watch, he served as a GSO3 from 1 December 1916 to 15 September 1917, and again from 10 March 1918

and never returning a $£ 45$ army pay overpayment, a debt for which he was pursued to India post-war, where he worked for the Imperial Tobacco Company of India. (TNA WO339/17095 Officers' Services, Edward Robert Hugh Boyd).

${ }^{8}$ This despite having blotted his copybook on 17 December 1914 "causing a disturbance after "lights out", for which he received the punishment of "three days confined to barracks". TNA WO 339/5186 Officers' Services Robert Fordyce Ker.

${ }^{9}$ His DSO was won as a company commander: "For conspicuous gallantry and devotion to duty in an attack. He led his company in a flanking attack, which resulted in the capture of a wood. He then reorganised his company and led them to a further objective. He displayed the greatest coolness and courage in most difficult circumstances". London Gazette, 18 March 1918, p.3426

10 Firstly: "For conspicuous gallantry and devotion to duty. He displayed great courage and ability in maintaining the supply of ammunition and stores during the operations". London Gazette, 10 January 1917, p.458. Secondly: "For conspicuous gallantry and devotion to duty during a withdrawal, and subsequent fighting and retirements. On one occasion he displayed the greatest courage and ability in rallying and commanding a part of the battalion, and his invariable coolness and disregard of danger had the most inspiring effect upon all ranks with him”. London Gazette, 26 July 1918, p.8757

${ }^{11}$ Born in 1884 and educated at Eton and Magdalen College, Oxford, he was the son of John Murray, head of the John Murray publishing house. 
until taking over command of $12^{\text {th }}$ Royal Scots on 15 June 1918 . His DSO was won on 1

October 1918 during the attack on Ledeghem, showing courage and attention to detail:

The flanks of the battalion under his command became exposed and very heavy casualties were suffered by enfilade machine gun fire. Col. Murray realising that the dispositions of his battalion needed immediate alteration, went forward and carried this out under close range-rifle and machine-gun fire. His fearless disregard for danger which was evident to all ranks and the splendid example which he showed undoubtedly renewed the confidence of his men during a very critical period. ${ }^{12}$

Similarly, on 15 October, at Laaga Cappelle Wood, Murray showed his initiative when "after passing the wood, (he) swung south and ejected the enemy from Steenbeek village and Hill $40 "{ }^{13}$

The one active representative of the Special Reserve of August 1914 was Herbert George Sotheby. ${ }^{14}$ Born in 1871 and of independent means, ${ }^{15}$ he was posted as Captain from $4^{\text {th }}$ Argyll and Sutherland Highlanders to the $2^{\text {nd }}$ Battalion in October 1914 (where he served as Adjutant) and the $10^{\text {th }}$ Battalion in 1916, serving as CO from December 1916 until the Armistice. $^{16}$

The one retired Regular, Ronald Walter Hadow, late Captain of the Black Watch, ${ }^{17}$ served as a DAAG from September 1914 into 1917, and then commanded $8^{\text {th }}$ Black Watch from 2 June 1917 to 17 August 1918, being awarded the DSO as CO for his skilful handling of his unit in attack. ${ }^{18}$ Another with a military past, Sir John Bruce Stuart Campbell, who had been

\footnotetext{
${ }^{12}$ London Gazette, 30 July 1919, p.9682. His bar was a Birthday List honour on 3 June 1919.

${ }^{13}$ Ewing, History of the Ninth, p.364

${ }^{14} \mathrm{He}$ was commissioned in 1900. His grandfather was Admiral Thomas Sotheby and his father was Admiral Sir Edward Southwell Sotheby, another relative being Major-General Frederick Edward Sotheby. He served as a railway Staff Officer and a Station Staff Officer in South Africa.

${ }^{15}$ He took over the Ecton estate, Northamptonshire, in 1921.

${ }^{16}$ His DSO was a New Year's List honour, 1 January 1918.

${ }^{17}$ He had fought in South Africa 1900-1 and in Sudan 1910, and had only retired in 1914.

18 "For conspicuous gallantry and devotion to duty in personally reconnoitring the ground and forming up his battalion in the correct alignment after the taping party and guides had become casualties. He handled his
} 
working in mining in Malaya, had served with the Australian forces in the Second Boer War. Commissioned in $14^{\text {th }}$ Royal Scots, he was posted to the $11^{\text {th }}$ Battalion, where he became CO on 14 September 1917. He was awarded the DSO with two bars, all as CO. Firstly, on 12 April 1917 at Roeux: "He brought his battalion into action under very difficult circumstances and commanded it with conspicuous courage". ${ }^{19}$ His first bar garnered no citation, ${ }^{20}$ but his second, awarded for actions on 28 September 1918 at Becelaere, indicates both courage and initiative:

While reconnoitring the line ... he was fired at from 200 yards by an enemy field gun. He immediately got a machine gun into action, and with a few men, under machine gun fire and the direct fire of the gun, surrounded the field gun, the battery teams running away. It was entirely due to his gallantry and quick action that the battery was captured, thus saving many casualties. $^{21}$

Lastly, Alexander William Angus, a chartered accountant, ${ }^{22}$ may possibly have had pre-war service, ${ }^{23}$ being commissioned $2^{\text {nd }}$ Lieutenant in the $10^{\text {th }}$ Gordon Highlanders on 19 September 1914, and promoted Major in the battalion on 9 November 1915. Detached from his regiment in mid-1916 he served as Commandant of a Musketry and Reinforcement Camp from July 1917, but was sent to command $5^{\text {th }}$ Cameron Highlanders on 15 September 1918. He was awarded the DSO during his period of command for "initiative", "prompt action", "skilful leading" and "excellent work" during a 16 day period of action. ${ }^{24}$

battalion skilfully in the attack and rendered most useful reports on the situation”. London Gazette, 23 April 1918 , p.4854

${ }^{19}$ London Gazette, 26 July 1917, page unknown. Campbell was commanding the battalion as a Major.

${ }^{20}$ London Gazette, 15 February 1919, page unknown.

${ }^{21}$ London Gazette, 30 July 1919, page unknown.

${ }^{22}$ An Australian by birth he came to Scotland aged 11, and was a double international for that country at rugby and cricket.

${ }^{23}$ Judging by the rapidity of his promotion.

24 "For marked gallantry and initiative, from 28 Sept. to 14 Oct. 1918, and for skilful leading near Rolleghem Capelle on the latter date. He took one of his own companies and led it through troops who had been held up. His prompt action enabled the whole line to advance. Throughout the operations he did excellent work". London Gazette, 15 February 1919, page unknown. 
Fifty per cent (eight) of the infantry COs of the division were Regulars. Two had arrived in France in August $1914,{ }^{25}$ one in October, ${ }^{26}$ and two in December $1914 .{ }^{27}$ The remaining three had arrived in 1915, two in May, ${ }^{28}$ and the last in July. ${ }^{29}$ They were thus highly experienced on the Western Front. In terms of being sheltered in a staff post, as will be seen below, R. Campbell had a three month training school stint in 1918, and C.S. Nairne spent the first seven months of 1917 as the Commandant of a School of Instruction. Similarly, W.V. Lumsden spent five weeks as a Staff Captain from September to November 1915. The only officer who was truly sheltered for a long period was J. Inglis, who spent the period from July 1915 to April 1917 training officer cadets at RMC.

Two had assumed command in 1916, four in 1917, and two in 1918. Three commanded two battalions. Charles Sylvester Nairne commanded $10^{\text {th }}$ Black Watch from 3 January 1918 to 15 September when his reign would have continued if it were not for his breaking his collarbone running in a relay race, but he returned to command $2^{\text {nd }}$ Royal Scots Fusiliers from 7 November to the Armistice. John Inglis commanded $17^{\text {th }}$ Highland Light Infantry from 20 July 1917 until its disbandment on 10 February 1918, and was transferred to command $5^{\text {th }}$ Cameron Highlanders from 6 March to 15 September 1918. Lastly, Robert Campbell was a Captain of $2^{\text {nd }}$ Cameron Highlanders in August 1914, and he commanded for the longest period. After service in France, Campbell did not transfer to Salonika with his battalion in December 1915, taking over as CO of $1 / 8^{\text {th }}$ Argyll and Sutherland Highlanders from 12 July 1916 to 12 July 1918. After a period as Commandant of the School of Musketry from 13 July to 17 October, which must have represented rest, he finally served as $\mathrm{CO} 2^{\text {nd }}$ Royal Scots

\footnotetext{
${ }^{25}$ D. Bruce (wounded three times) and G.B.F Smyth (wounded five times).

${ }^{26}$ J.E. Utterson-Kelso, (wounded four times).

${ }^{27}$ R. Campbell and J. Inglis.

${ }^{28}$ W.V. Lumsden (who had been serving with the $3^{\text {rd }}$ Battalion of his regiment) and P.C. Anderson.

${ }^{29}$ C.S. Nairne, who had been Adjutant to the $3^{\text {rd }}$ Battalion of his regiment.
} 
Fusiliers from 23 October to 7 November 1918. The divisional history gives us a glimpse of

him in the attack on the Oooteghem ridge two days after taking command:

Lieut.-Colonel Campbell ... was ubiquitous; clad in his jerkin, since the day was warm though the night had been cold, he was perspiring profusely from the kit he carried, his rapid pace, the distance he had covered, and the discomfort of one or two nasty crawls, but he seemed to be absolutely tireless. ${ }^{30}$

In terms of DSO citations, six of the eight received such an award as CO. The bar to Robert

Campbell's DSO reflects his skill and understanding of battle:

At a critical moment, when the enemy had pierced our line and were consolidating a position to our rear, he skilfully and energetically counterattacked, forcing the enemy to surrender with heavy loss. He subsequently rendered valuable assistance to another unit by bringing enfilade fire to bear upon the enemy. His promptness and energy saved a very awkward situation. ${ }^{31}$

The DSO awarded to the CO of $2^{\text {nd }}$ Royal Scots Fusiliers, John Edward Utterson-Kelso, reflected leadership and example when he:

Organised counter-attacks, leading his men with great skill and daring throughout prolonged fighting. Though twice buried by shell bursts and badly concussed, he remained at duty, setting a fine example, until his battalion was relieved. ${ }^{32}$

The bar to his DSO was awarded for similar example and initiative between 28 September and 5 October in the final advance on the Passchendaele Ridge when:

Although he was knocked down by a shell and severely shaken, he continued in command, refusing to leave. The battalion captured several guns and 200 prisoners. The next day, at a critical period when the front line was held up, he pushed forward his battalion, which was then in support, and relieved the situation. ${ }^{33}$

\footnotetext{
${ }^{30}$ Ewing, History of the Ninth, p.379

${ }^{31}$ London Gazette, 24 July 1917, pp.7615-6. His DSO was a New Year List honour gazetted 1 January 1917.

${ }^{32}$ London Gazette, 23 July 1918, p.8750

${ }^{33}$ London Gazette, 1 February 1919, pp.1603-4
} 
William Vernon Lumsden was awarded the DSO and two bars as CO of $9^{\text {th }}$ Scottish Rifles.

With respect of the original award he "handled his battalion with great skill. His personal example and coolness under heavy fire contributed largely to the stout defence put up by his battalion." ${ }^{34}$ Whilst no citation exists for the first bar, ${ }^{35}$ the second was awarded for his leadership in the final advance on the Passchendaele ridge when, suffering from malaria, ${ }^{36}$ "he was in the thick of the fighting", and demonstrated initiative "when he found that Dadizeele could not be reached by troops on his right, he deflected his advance and ... captured it".37

The DSO awarded to Patrick Campbell Anderson, CO $7^{\text {th }}$ Seaforth Highlanders reflects similar example and initiative when:

During seven critical days of a withdrawal ... he commanded his battalion with the greatest courage and skill under most trying conditions. Again and again he rallied his men, and, on his own initiative, held on to vital points, keeping his men steady by his magnificent example. When relieved, noticing that some of the troops then in the line were slightly unsteady, he remained with them for several hours, helping to keep the situation in hand. His able leadership and constant courage were of inestimable value during these critical days. ${ }^{38}$

\footnotetext{
${ }^{34}$ London Gazette, 26 July 1918, page unknown

${ }^{35}$ London Gazette, 3 June 1918, page unknown

${ }^{36}$ The divisional history notes that he "was ill and had a very high temperature on the eve of the battle, but this officer, who had never missed an action since he crossed to France with the division in 1915, refused to go sick". Ewing, History of the Ninth, p.337

${ }^{37}$ London Gazette, 1 February 1919, page unknown. Lumsden was, however, not afraid to decline to attack when necessary. During the First Battle of Passchendaele, 12 October 1917: "Of battalion commanders Lieut.Colonel Lumsden alone, seeing that the attack of the $26^{\text {th }}$ Brigade had been checked, kept his men back, and the net result of over-zealous leading was that General Lukin, instead of a brigade, had one battalion intact". Ewing, History of the Ninth, p.244

${ }^{38}$ London Gazette, 26 July 1918, p.8741
} 
The award of the DSO to John Inglis reflects identical abilities:

He ably handled his battalion at a very critical moment. Under heavy fire he made many personal reconnaissances, and was always thoroughly in touch with the situation, sending back most valuable information. His leadership enabled difficult rearguard actions to be fought successfully for seven days. $^{39}$

Lastly, Gerald Brice Ferguson Smyth, CO $6^{\text {th }}$ Scottish Borderers, was awarded a bar to his

DSO as CO. The citation gives some flavour of the man:

Although seriously wounded, he remained at the telephone in an illprotected trench for many hours during a critical time to report the course of events to Brigade Headquarters. He realized that there was no officer of experience to replace him, and his sense of duty may cost him his remaining arm, the other having been amputated as the result of a previous wound. He was five times wounded. ${ }^{40}$

Smyth's career is interesting. He was commissioned into the Royal Engineers in 1905, and was a Lieutenant at the outbreak of war, serving with noted ability until transferred to the infantry, taking over command in December 1916. Wounded several times as CO, the "one armed Irish warrior of dauntless courage" was promoted to the command of 93 Brigade on 3 October $1918 .^{41}$

\footnotetext{
${ }^{39}$ London Gazette, 26 July 1918, p.8746

${ }^{40}$ London Gazette, 18 July 1917, page unknown. The wound which resulted in the loss of his arm was sustained in 1914 and is reflected in his DSO citation: "For consistent skill, daring and hard work in reconnaissance and defensive preparations by night and day throughout the Campaign, and especially during the battle of the Aisne, and in the trenches at Givenchy, until wounded on the 25th of October by a shell entailing the loss of his left arm”. London Gazette, 11 November 1914, p.9229

${ }^{41} \mathrm{He}$ was born in 1885, son of the British High Commissioner of the Punjab. Whilst stationed at Gibraltar he was nearly killed by a falling boulder in the Sierra Nevada whilst on an expedition to photograph the Lammergeyer vulture. He was offered a Professorship of Mathematics at Chatham in 1914, but opted to stay with his unit, $17^{\text {th }}$ Field Company RE. After his wounding in October 1914 he returned to active duty with $90^{\text {th }}$ Field Company but was injured in an explosion at the bomb factory, Nieppe Station, but was able to take over from the CO who had also been wounded. On 13 July 1916 he was shot through the neck at Trones Wood on the Somme. On recovery he was sent to $6^{\text {th }}$ King's Own Scottish Borderers as a company commander in November 1916, taking over as CO the following month. He was wounded at Arras on 3 May 1917, returning to command in October 1917. He was wounded yet again in the German Spring Offensive on 23 March 1918 on the Somme, returning to command on 1 June 1918. He commanded 93 Infantry Brigade into 1919, and after attending Staff College was posted to the Royal Irish Constabulary, being murdered by Sinn Fein activists in the smoking room of the Cork and County Club on 21 July 1920, after making controversial comments. His brother, Major George Osbert Stirling Smyth (Royal Field Artillery) was shot in Ireland in October of the same year. http://www.countydown.x10.mx/html/banbridge_g.1.htm accessed 29 December 2012. See also J. \& J. Murland, Departed Warriors: The Story of a Family in War (Leicester: Matador, 2008).
} 
At first glance, the COs of $9^{\text {th }}$ Division present as an even more stellar cast than $5^{\text {th }}$ Division, but this may simply be a vagary of the information available. Again, they had great depth of experience built up since 1914/15, and clearly shared the command and leadership skills evident in the COS of the Regular division. 


\begin{tabular}{|c|c|c|c|c|c|c|c|c|c|c|c|}
\hline Regiment & Btn & C & & From & To & August 1914 & $2 \mathbf{L t}$ & $\mathbf{L t}$ & Capt & Major & Lt-Col \\
\hline Northumberland Fusiliers & $1 / 7$ th & Liddell & H. & 29/12/1917 & $11 / 11 / 1918$ & Citizen & $22 / 08 / 1914$ & $26 / 09 / 1914$ & $18 / 04 / 1915$ & N/A & $29 / 12 / 1917$ \\
\hline Lancashire Fusiliers & $1 / 5$ th & Castle & G. S. & 06/04/1918 & $11 / 11 / 1918$ & $\mathrm{TF}$ & $14 / 07 / 1911$ & $19 / 12 / 1912$ & $01 / 05 / 1915$ & $22 / 03 / 1917$ & 06/04/1918 \\
\hline Lancashire Fusiliers & $1 / 7$ th & Brewis & G. S. & $13 / 09 / 1917$ & $25 / 10 / 1918$ & Regular & 05/10/1910 & $01 / 04 / 1912$ & $26 / 04 / 1915$ & $13 / 07 / 1916$ & 28/09/1917 \\
\hline Lancashire Fusiliers & $1 / 7$ th & Kelly & T. J. & $26 / 10 / 1918$ & $11 / 11 / 1918$ & Citizen & $25 / 10 / 1914$ & $26 / 03 / 1915$ & $31 / 07 / 1916$ & $23 / 11 / 1916$ & $26 / 10 / 1918$ \\
\hline Lancashire Fusiliers & $1 / 8$ th & MacLeod & J. S. & $10 / 04 / 1918$ & $11 / 11 / 1918$ & Retired (Vol) & N/A & N/A & $24 / 10 / 1914$ & $11 / 07 / 1915$ & $20 / 04 / 1918$ \\
\hline East Lancashire & $1 / 5$ th & Clare & O. C. & 02/06/1918* & $11 / 11 / 1918$ & Retired (Emp) & $24 / 03 / 1915$ & N/A & 09/04/1915 & 08/06/1916 & $24 / 05 / 1917$ \\
\hline Manchester & $1 / 5$ th & Panton & W. F. & $10 / 06 / 1918$ & $21 / 10 / 1918$ & Regular & 04/06/1904 & $30 / 12 / 1906$ & $19 / 02 / 1913$ & $21 / 01 / 1918$ & $10 / 06 / 1918$ \\
\hline Manchester & $1 / 5$ th & Tickler & W. M. & 21/10/1918 & $11 / 11 / 1918$ & Citizen & 06/01/1916 & $27 / 04 / 1916$ & $25 / 07 / 1916$ & $11 / 04 / 1918$ & $21 / 10 / 1918$ \\
\hline Manchester & $1 / 6$ th & Blatherwick & $\mathrm{T}$. & 26/05/1918 & $11 / 11 / 1918$ & $\mathrm{TF}$ & 02/07/1909 & $07 / 06 / 1912$ & $01 / 05 / 1915$ & 04/05/1917 & $26 / 05 / 1918$ \\
\hline Manchester & $1 / 7$ th & Manger & E. V. & 30/04/1918* & $11 / 11 / 1918$ & Regular & 03/08/1901 & $14 / 07 / 1904$ & 05/08/1914 & 03/08/1916 & $14 / 08 / 1917$ \\
\hline Manchester & $1 / 8$ th & Tetley & F. E. & 26/05/1918* & 01/09/1918 & $\mathrm{TF}$ & $16 / 01 / 1904$ & 01/08/1905 & $30 / 12 / 1907$ & $04 / 06 / 1916$ & $07 / 11 / 1916$ \\
\hline Manchester & $1 / 8$ th & Hodge & A. & $\begin{array}{l}02 / 09 / 1918 \\
23 / 10 / 1918 \\
\end{array}$ & $\begin{array}{l}06 / 10 / 1918 \\
11 / 11 / 1918 \\
\end{array}$ & $\mathrm{TF}$ & $07 / 12 / 1915$ & $?$ & $11 / 05 / 1916$ & 04/07/1918 & 02/09/1918 \\
\hline Manchester & $1 / 10$ th & Peel & W. R. & 09/09/1917 & $11 / 11 / 1918$ & Citizen & $19 / 09 / 1914$ & $?$ & $13 / 03 / 1915$ & $29 / 10 / 1916$ & 09/09/1917 \\
\hline
\end{tabular}

Table 7.4: Career progression of COs of 42nd Division who commanded during The Hundred Days

( ${ }^{*}$ Commanded a battalion previously) 


\section{5 $42^{\text {nd }}$ (East Lancashire) Division}

$42^{\text {nd }}$ Division was a Territorial formation of Third Army in $1918 .{ }^{1}$ During The Hundred Days the ten battalions (nine excluding Pioneers) ${ }^{2}$ had $12 \mathrm{COs}^{3}$ and hence had good stability. No COs died in action.

Three of the 12 infantry COs were active Regulars in August 1914 (see Table 7.4). At 23 per cent this is lower than the average for the BEF on 29 September 1918, and lower than the 31 per cent for $42^{\text {nd }}$ Division overall (as we have seen, $42^{\text {nd }}$ Division had had a particular stiffening of Regulars in 1917), yet is comparable with the overall picture for first-line TF units.

Firstly, Walter Forbes Panton was a Regular Captain of the Leicestershire Regiment in August 1914, serving as Adjutant to $1 / 4^{\text {th }}$ Dorsetshire. He appears to have gone to India with the battalion and then to Mesopotamia in February 1916, probably being posted to France in July 1917 and promoted Major second-in-command 1/5 ${ }^{\text {th }}$ Manchester on 21 January 1918, assuming command in May $1918 .^{5}$

Geoffrey Sydney Brewis was a Lieutenant of $1^{\text {st }}$ Welsh in August 1914, and had landed in France on 16 January 1915 . He spent a period with the $3^{\text {rd }}$ Battalion in the UK during 1916 before being posted as Major second-in-command to $13^{\text {th }}$ Welsh on 13 July 1916 . He was

\footnotetext{
${ }^{1}$ During The Hundred Days it took part in the Battle of Albert (21-23 August); the Second Battle of Bapaume (31 August to 3 September); the Battle of the Canal du Nord (27-29 September); the Pursuit to the Selle (9-12 October) and the Battle of the Selle (17-23 October).

${ }^{2}$ The Pioneer battalion was $1 / 7^{\text {th }}$ Northumberland Fusiliers (North Eastern Railway Pioneers). Their CO was Hugh Liddell, a citizen of August 1914, by profession a Consulting Engineer. He had joined the battalion as $2^{\text {nd }}$ Lieutenant in August 1914, commanded B company as a Captain, and served as Adjutant in 1917.

${ }^{3}$ Excluding the pioneer battalion.

${ }^{4}$ See Chapter Four, section 4.3.1.

5 At this point the long-serving Lieutenant-Colonel H.C. Darlington finally relinquished command. Panton had however commanded 1/8th Manchester as a Major from 23 to 26 May 1918.
} 
transferred to command $1 / 7^{\text {th }}$ Lancashire Fusiliers on 13 September 1917 . He won a bar to his DSO "when commanding a battalion during a withdrawal he inspired great confidence by his skilfulness and contempt for personal danger". 6

Finally, Edward Vincent Manger, promoted Captain in $2^{\text {nd }}$ Durham Light Infantry on the day war broke out and Major on 3 August 1916, commanded $11^{\text {th }}$ Essex from 11 November to 9 December 1916, and 2/9 ${ }^{\text {th }}$ Liverpool from 4 August 1917 to 29 April 1918, whence he was transferred to command $1 / 7^{\text {th }}$ Manchester.

Territorials comprised 42 per cent of COs, (four active in August 1914 and one a retired Volunteer), a level similar to other first-line TF units on 29 September 1918. Gilbert Stacey Castle, a lead shot maker, was a Lieutenant of $4^{\text {th }}$ Gloucestershire in August 1914 and landed in France on 31 March $1915 .^{7}$ On 22 March 1917 he was transferred to a battalion of the North Lancashire Regiment as Major, and again on 17 February 1918 to 1/5 ${ }^{\text {th }}$ Lancashire Fusiliers as second-in-command, assuming command on 6 April 1918.

Thomas Blatherwick is an example of steady progression within a single unit. A cotton worker, he was a Lieutenant of $6^{\text {th }}$ Manchester in August 1914. Promoted company commander just prior to his arrival in France on 6 May 1915, he was appointed Adjutant in mid-1916, and Major second-in-command on 19 October 1917, taking command on 26 May 1918. He won a DSO crossing the Selle in October 1918, displaying "the greatest

\footnotetext{
${ }^{6}$ London Gazette, 26 July 1918, page unknown

${ }^{7} \mathrm{He}$ won a DSO on the Somme taking command of another company as well as his own and resisting a bombing attack on a captured trench. London Gazette, 22 September 1916, p.9272
} 
courage and skill when personally supervising" the crossing "in face of a position strongly held by the enemy", leading his battalion on after "personal reconnaissance". 8

Francis Eric Tetley, a tanner, was a Captain of $4^{\text {th }}$ Lincolnshire in August $1914 .^{9}$ Landing in France on 1 March 1915 he was promoted Major on 4 June 1915. He commanded his battalion between November and December 1916, and in April 1917 went to command $1 / 4^{\text {th }}$ Leicestershire until the end of July. There followed a period as second-in-command of $1 / 5^{\text {th }}$ Manchester until on 26 May 1918 he assumed command of $1 / 8^{\text {th }}$ Manchester. His successor, when he left command on 1 September 1918 was Arthur Hodge. Hodge had been a TF Company Sergeant-Major in the Liverpool Regiment, commissioned $2^{\text {nd }}$ Lieutenant in December 1915 in $7^{\text {th }}$ Manchester. He had won an MC as a platoon commander showing "the most skilful and determined leadership", ${ }^{10}$ and the DSO as a company commander, showing "gallantry and example". ${ }^{11} \mathrm{He}$ was promoted Major second-in-command of one of the Lancashire Fusilier battalions in the division on 4 July 1918, assuming command of $1 / 8^{\text {th }}$ Manchester on 1 September 1918.

Lastly, James Strachan MacLeod had been a Sergeant promoted Lieutenant in the $17^{\text {th }}$ Imperial Yeomanry during the Boer War. He was commissioned into the $10^{\text {th }}$ Black Watch

\footnotetext{
8 "He displayed the greatest courage and skill when personally supervising the crossing of a river in face of a position strongly held by the enemy. Later, his battalion was ordered to relieve another battalion at short notice in an attack on positions which had not previously been reconnoitred. He went forward and made a personal reconnaissance, amidst heavy shell bursts and machine-gun fire, and returning led the battalion successfully forward under extremely difficult circumstances". London Gazette, 11 January 1919, p.581

${ }^{9}$ His brother Charles Harold Tetley, a Major of $7^{\text {th }}$ West Yorkshire in August 1914 commanded that battalion from 28 September 1915 to 30 April 1918. Both were scions of the Tetley brewing family. Francis Eric Tetley had been awarded a DSO in 1917 (no citation). He later became Lord Mayor of Leeds.

${ }^{10}$ London Gazette, 14 September 1917 p. 9573 . Hodge led his platoon against an enemy working party.

${ }^{11}$ London Gazette, 26 July 1918 p.8746. Hodge was commanding his company when all companies about his withdrew, Hodge holding the line for some 12 hours.
} 
as a Captain in October 1914, and promoted Major in July 1915 in the $8^{\text {th }}$ Durham Light Infantry. He took command of 1/8 ${ }^{\text {th }}$ Lancashire Fusiliers on 10 April 1918.

Oliver Cecil Clare, a foreign banker, had served as a Sergeant in colonial forces, namely the Border Horse and the South African Light Horse during the Second Boer War. ${ }^{12} \mathrm{He}$ attested as a Private in the $10^{\text {th }}$ Royal Fusiliers on 29 August 1914, and progressed up the ranks, being promoted Corporal on 19 October, and Lance-Sergeant on 30 November. He was commissioned $2^{\text {nd }}$ Lieutenant in $8^{\text {th }}$ East Surrey on 24 March 1915 , promoted Captain on 9 April. The battalion landed in France on 28 May, Clare serving as Adjutant. He was appointed Major on 8 June 1916, and, wounded at Trones Wood on 14 July, returned as second-in-command on 5 September. From November 1916 to April 1917 he was invalided to England suffering from influenza, returning to command $7^{\text {th }}$ West Kent on 24 May 1917 until the Armistice. ${ }^{13}$ He won a bar to his DSO as CO:

During an enemy attack ... he promptly counter-attacked with his battalion and caused a position to be held. Throughout he showed fine leadership and coolness under heavy machine-gun and shell fire. ${ }^{14}$

Finally, there were three COs who had been citizens in August 1914, none commissioned into the TF. Thomas Joseph Kelly, a journalist, was commissioned in $18^{\text {th }}$ Manchester, and rose from $2^{\text {nd }}$ Lieutenant (25 October 1914) to Major (23 November 1916) serving with one of the Regular battalions of his regiment before commanding $1 / 7^{\text {th }}$ Lancashire Fusiliers from 26 October 1918 to the Armistice.

\footnotetext{
${ }^{12}$ Clare must have been working in South Africa as the Border Horse was raised in the East Cape in February 1900. He transferred to the South African Light Horse as soon as it was formed in November 1900, and served with it for a year.

${ }^{13}$ TNA WO339/37181 Officers' Services, Oliver Cecil Clare. Clare left the Western Front on 17 November 1918 suffering from severe varicose veins and was discharged.

${ }^{14}$ London Gazette, 16 September 1918, p.10855. His DSO was gazetted 4 June 1917.
} 
William Marshall Tickler, a commercial traveller in fruit preserves, ${ }^{15}$ attested Private in $10^{\text {th }}$ Royal Fusiliers on 29 August 1914, and was commissioned $2^{\text {nd }}$ Lieutenant on 10 October 1914 in the Cheshire Regiment, serving for some period with the Garrison Guard Battalion to whom he was Adjutant in 1916, later commanding 1/5 ${ }^{\text {th }}$ Manchester from 27 October 1918 to the Armistice.

William Ralph Peel, a land agent, was commissioned $2^{\text {nd }}$ Lieutenant in $9^{\text {th }}$ East Yorkshire on 19 September 1914, promoted Lieutenant on 10 December 1914, Captain on 13 March 1915, and Major on 29 October 1916. He commanded 1/10 ${ }^{\text {th }}$ Manchester from 9 September 1917 to the Armistice. Peel won two bars to his DSO in quick succession in 1918 as CO, the citations for which demonstrate his qualities:

Throughout two days' very hard fighting he displayed great courage and marked ability in dealing with situations of considerable difficulty ... his cheerful disregard of all considerations of personal safety was an example to his men, which inspired them with confidence and resolution. ${ }^{16}$

He led his battalion for four days in continuous rain without shelter, and captured the town of Hautmont. To accomplish, this he had to supervise the construction of a hasty bridge over the Sambre river and cross it while the enemy troops were still in the town. ${ }^{17}$

In composition, $42^{\text {nd }}$ Division was broadly similar to most first-line TF units during The Hundred Days in respect of its COs. They were youthful, having an average age of 32 years 3 months, some three years below the BEF average of 34 years 11 months on 29

\footnotetext{
${ }^{15}$ A partner in J.E. Tickler Ltd, he had served five years in his school cadet corps. TNA WO339/24778 Officers' Services, William Marshall Tickler.

${ }_{17}^{16}$ London Gazette, 16 September 1918, p.10859. His DSO had been gazetted 4 June 1917.

${ }^{17}$ This in operations in the Forest of Mormal, 6-8 November 1918. London Gazette, 10 December 1919, p. 15280
} 
September 1918, demonstrating the youngest average of the three divisions studied. ${ }^{18}$ None had multiple commands; only one had been in command since late 1916; and none appointed in 1917 had been elevated earlier than May that year. They were therefore slightly less experienced in command than their counterparts in $5^{\text {th }}$ and $9^{\text {th }}$ Divisions. They had not, however, been sheltered by any staff positions, having earned their considerable experience from the early months of 1915 in constant exposure to warfare. Where we are allowed glimpses of their qualities, there is no reason to believe their abilities to be less diverse than their Regular or New Army division counterparts.

\subsection{Initiative and Devolved Command in The Hundred Days}

Did The Hundred Days present a canvas on which these men were free to paint with their talents? Jonathan Boff reminds us that this was not a period of "manoeuvre warfare, but ... a form of mobile attrition". ${ }^{19}$ It was a period of set-piece attacks, 'semi-open' warfare, and pursuit, ${ }^{20}$ the latter two allowing increasing degrees of improvisation. To the competent $\mathrm{CO}$, the first should have been meat and drink; to the skilled $\mathrm{CO}$ the latter were opportunities to show initiative. Having four years' experience of the tactics of positional warfare, The Hundred Days tested both what COs had learnt and their ability to go beyond.

Organisationally, however, how far was a CO's initiative allowed to show itself? Jonathan Boff identifies that in Third Army during this period "decentralisation was not consistently achieved. It is not possible to establish a coherent pattern of either top-down devolution, or

\footnotetext{
${ }^{18}$ Two were aged 40 or over, E.V. Manger being the oldest at 42 years 11 months, whilst G.S. Castle was the youngest at 25 years five months.

${ }_{19}$ Boff, Winning, Kindle location 1178

${ }^{20}$ Boff, Winning, Kindle location 1186. Boff calculates Third Army spent 11 days in set-piece attacks, 17 days in 'improvised' warfare, and 15 days in pursuit.
} 
bottom-up assumption, of responsibility". ${ }^{21}$ The reasons for this were manifold, including “a combination of circumstance, subordinates' skill and published guidance". ${ }^{22}$

Peter Simkins, whilst accepting that decentralisation/devolution of command to brigade and battalion level was not uniform, argues that because of the higher operational tempo of The Hundred Days, with some battalions 'at the sharp end' every three days or so, and with little time to issue detailed written orders, decentralisation inevitably happened, formally recognised or not. He further suggests that whilst examples of 'sticky' or inefficient battalion COs can be found, average standards of leadership and initiative at this level were generally at their highest. This, Simkins suggests, was a necessity given the great variety of tactical challenges that many battalions faced during this period, and the lack of time that COs had to refer to higher authorities when conducting attacks and responding to counterattacks. $^{23}$ Simon Robbins states that in 1918: "The emphasis was on flexibility and elasticity and much depended on the initiative of junior officers and battalion commanders". 24

Whilst the November edition of SS135, ${ }^{25}$ which presumably reflected thinking current during The Hundred Days stated: "Nothing should be done to hamper the initiative and freedom of manoeuvre of subordinate commanders", hampering occasionally occurred. Personality was one issue, as was mutual trust, both in Brigadier/CO relationships, and $\mathrm{CO} / \mathrm{CO}$ relationships. A Brigadier had to be confident in both himself and his relationships

\footnotetext{
${ }^{21}$ Boff, Winning, Kindle location 6773

${ }^{22}$ Boff, Winning, Kindle location 6211

${ }^{23}$ Peter Simkins, personal communication, 17 March 2013.

${ }^{24}$ S. Robbins, British Generalship on the Western Front 1914-18: Defeat Into Victory (Abingdon: Frank Cass, 2005), p.113

${ }^{25}$ SS135 The Training and Employment of Divisions November 1918 (quoted in Boff, Winning, Kindle location 6495).
} 
with both his divisional and battalion commanders to allow "the decision threshold to sink down the chain of command". ${ }^{26}$

In terms of differing peer attitudes, Boff gives the example of one battalion commander, apparently Lieutenant-Colonel C.A. Howard, $1^{\text {st }}$ King's Royal Rifle Corps, losing the opportunity for exploitation as the neighbouring battalion's $\mathrm{CO}$ would not move beyond the objective without orders. Howard viewed this as the "habit" of acquiring limited objectives having been laid down in a period when exploitation was not encouraged. ${ }^{27}$

Conversely, a good example of two COs using their initiative alone and jointly furthering progress is given in $9^{\text {th }}$ Division on 29 September 1918 in front of the Flanders I Stellung position at Ypres, when:

Finding that the leading troops had been brought to a standstill, Lieut.Colonel Smyth, who had been reconnoitring well ahead of the brigade, consulted with Lieut-Colonel Sir J. Campbell, and they sent forward two companies each of the K.O.S.B and the $11^{\text {th }}$ Royal Scots. The additional momentum thus thrown into the onset carried the whole line forward. ${ }^{28}$

Brigadier-General H.R. Cumming gave an example of his approval of a $\mathrm{CO}$ in whom he had confidence using his initiative in the advance across the old Somme battlefield on 24 August 1918:

The night assembly was carried out without any undue hitch; but as the $6^{\text {th }}$ Leicesters (the leading battalion) approached Battery Valley, they found that the Southern end, and the trench line south of it, was still held by the enemy in some force. Lieutenant-Colonel Martyn ... at once

\footnotetext{
${ }^{26}$ Boff, Winning, Kindle location 6476

${ }^{27}$ TNA CAB 45/185 Letter, Charles Howard, 23 June 1938, Official History Correspondence. Charles Alfred Howard was a Regular Captain of the King's Royal Rifle Corps who served almost exclusively in a range of staff posts (with a short period in command of $16^{\text {th }}$ KRRC in August 1916) until taking command of $1^{\text {st }}$ KRRC on 3 July 1918, a post he held until the Armistice.

${ }^{28}$ Ewing, History of the Ninth, p.345
} 
realised the situation, and without hesitation or waste of time attacked at once and drove them out. ${ }^{29}$

In his study of the East Kent Regiment, ${ }^{30}$ Mark Connelly refers frequently to two highlyregarded New Army COs. The first is Arthur Sidney Smeltzer, an OR in August 1914, ${ }^{31}$ who had served with $6^{\text {th }}$ Buffs since his commission. Smeltzer demonstrated verve and initiative to a high degree in The Hundred Days.

On 23 October the $6^{\text {th }}$ Buffs took Cubray, and "realising that only a thin screen was in front of him, Smeltzer organised a rapid night movement, and smashed through to the village of Haute Rive". Keeping momentum, he sent Lewis gun teams forward early next morning, capturing Buridon, and "refusing to rest on his laurels, he dashed on and snatched Bruille

\footnotetext{
${ }^{29}$ H.R. Cumming, A Brigadier in France, (London: Jonathan Cape, 1922), p.214. Martyn was captured later that night going forward to locate his forward companies. Cumming gave further indication that in his brigade the spirit of initiative was delegated downwards from COs, describing how in the 7th Leicestershire, commanded by Lieutenant-Colonel G.H. Sawyer, two support companies under Captains Horne and Vanner in the final advance across the old Somme battlefield in late August 1918 deviated to the left due to enfilade fire, found themselves on the outskirts of Courcelette which they proceeded to occupy "and made a considerable number of prisoners, including a battalion commander", then simply handing it over to the 17th Division, in whose area it was (p.211). Such confident relationships between CO and junior officers were not universal. Jonathan Boff emphasises the importance of the skill of the CO quoting the view that "in these days of untrained soldiers, a commanding officer's presence in the immediate attack is necessary" (TNA WO 95/2560 War Diary, 115 Brigade, 31 October 1918), and the fate that befell 7th Border, which became "rudderless" (TNA WO 95/1985 War Diary 17 Division 21 August to 11 November 1918) when LieutenantColonel W.E. Thomas was killed on 20 October 1918, due to the shortage of experienced junior officers. Boff, Winning, Kindle location 6476. Lieutenant E.R.M Fryer, 3rd Grenadier Guards clearly valued the importance of his very active CO in the attack on Moyenneville on the foggy morning of 21 April 1918: "The Commanding Officer, Col. Thorne, had gone on ahead of the reserve company to direct the front wave; he was second to none on an occasion of this sort; the fog had no terrors for him, and he always knew exactly where he was on the map; we were fortunate indeed to have him leading us, as he converted what looked like a ghastly muddle into a brilliant success". [E.R.M Fryer, Reminiscences of a Grenadier 1914-1919 (London: Digby, Long \& Co, 1921), p.192].

${ }_{30}$ M. Connelly, Steady the Buffs: A Regiment, a Region, and the Great War (Oxford: Oxford University Press, 2006).

${ }^{31}$ Born in 1881, Smeltzer (who changed his surname to Keates in 1920) had served in the ranks for 15 years, rising to the rank of Sergeant in the $12^{\text {th }}$ Lancers and having active service in South Africa 1902. He landed in France on 15 August 1914 and was commissioned in the field on 13 October 1915 as $2^{\text {nd }}$ Lieutenant in the East Kent Regiment. Posted to the $6^{\text {th }}$ Buffs, he was promoted Captain and company commander on 18 May 1916, Major on 21 January 1917 and CO on 9 June 1917, a post he held until the Armistice.
} 
... taking the enemy by surprise, the majority of whom were captured while still eating their breakfasts". Major-General A.B. Scott described his actions as a "masterly stroke". 32

Connelly's second exceptional CO is Algernon Lee Ransome, ${ }^{33} 7^{\text {th }}$ Buffs. Ransome had acquitted himself well in the German Spring offensive on 23 March 1918 at Frières Wood, Brigadier-General E.A. Wood, writing: “The stand made ... by Lt-Col Ransome's force was of the greatest value not only to the rest of the brigade, but to the whole line in this vicinity ... this stand was due ... to the skill and foresight of Lt-Col Ransome in establishing a line outside the wood on which the withdrawing troops ... could be rallied and reorganized". ${ }^{34}$ Connelly describes Ransome as acquiring "more and more autonomy" as the retreat went on, and suggests that this "appears to be a precursor of the devolved command systems of the summer and autumn advances". ${ }^{35}$ Other historians support this view, Chris McCarthy suggesting that "the process of devolution in tactical command in the BEF gained extra momentum during the defensive battles of the spring of 1918 ", 36 breakdown in command and control in the new mobile defensive warfare necessitating and vindicating initiative. ${ }^{37}$

Whether these opinions on the Spring 1918 origins of devolution are correct as an organisational point is currently a matter of conjecture. There was obviously no policy or

\footnotetext{
${ }^{32}$ Connolly, Steady, Kindle edition location 3406

${ }^{33}$ Born in 1883 in San Francisco, son of American barrister L.J. Ransome, he was commissioned into the Dorset Regiment in 1903, where he had served as Adjutant. He was appointed Brigade-Major from June 1915 to February 1916, when he was posted as CO to the $7^{\text {th }}$ Buffs. On 5 September 1918 he was promoted to the command of 170 Brigade.

34 Quoted in R.S.H. Moody, Historical Records of the Buffs (East Kent Regiment) $3^{\text {rd }}$ Foot 1914-1919 (London: Medici Society, 1922) p.346

${ }^{35}$ Connolly, Steady, Kindle edition location 2979

${ }^{36}$ C. McCarthy, 'Queen of the Battlefield: The Development of Command, Organisation and Tactics in the British Infantry Battalion during the Great War', in G. Sheffield \& D. Todman eds. Command and Control on the Western Front - The British Army's Experience 1914-18 (Staplehurst: Spellmount, 2004), p.162

${ }^{37}$ A view supported by Peter Simkins - personal communication.
} 
even clear pattern. In practice, as reviewed above, it may have simply reflected local opportunity and the quality of local relationships.

It is certainly the case that Ransome and Wood had a close co-operative relationship. ${ }^{38}$ Wood was at Ransome's HQ on 22 August: "Thus, when things began to go wrong on the Buffs' front he was able to talk to Ransome and reassess the situation on the spot. Wood stayed forward to reconnoitre the ground with Ransome in order to prepare for the evening assault". ${ }^{39}$ Connelly describes this modulation of command style as "a hugely experienced battalion commander and his brigadier unilaterally (deciding) to revise the plans in the light of the situation". ${ }^{40}$ Wood and Ransome, in Connelly's opinion, generally had "the chance to exercise their own initiative and authority far more effectively. They improvised new plans, countermanded redundant or inoperable orders, and maintained command and control". ${ }^{41}$ They were able to do this because their higher formation trusted them and "rarely interfered in local decision-making". ${ }^{2}$ Chris McCarthy supports this view in describing the short 'flash to bang' planning time of an operation whereby the CO of $1^{\text {st }}$

\footnotetext{
${ }^{38}$ Observations on the developing relationship between a Brigadier and his COs are given in Peter Sadler's study of Sir John Gellibrand when he was commanding $6^{\text {th }}$ Infantry Brigade, AIF: "One aspect of Gellibrand's command style grated on some of his battalion commanders: his close supervision until they proved their capabilities and earned his trust, and his quickness to overrule them if he thought they were not doing what was required. It was the practice in the British Army to give an officer a job and let him get on with it. While this may have been acceptable with experienced officers who had spent years climbing up the regimental hierarchy, gaining solid practice, and supervised experience at various levels of command, Gellibrand saw it as inappropriate with young and inexperienced men who had to be promoted quickly, sometimes without regard to how good they were (and not all were 'good'). Gellibrand appreciated - as some of his contemporaries seemed not to have done - that to make up for lack of experience and formal job training, they needed close supervision and fatherly guidance. Gellibrand was also probably influenced by what he had seen of Hamilton's disastrous refusal to intervene during the Gallipoli campaign, when his subordinates were patently not doing what they had been told to do. In this regard Gellibrand demonstrated that he possessed 'that ruthlessness towards his subordinates which is one of the essentials of a great commander"'. [P.S. Sadler, The Paladin: The Life of Major-General Sir John Gellibrand (Melbourne: Oxford University Press, 2000), p.88].

${ }^{39}$ Connelly, Steady, Kindle edition location 3201. $7^{\text {th }}$ Buffs' advance had been stalled by the artillery not having bombarded Tara Hill outside Albert as it had been falsely reported that it had been captured. Ransome broke off his attack, and he and Wood planned a night assault supported by tanks.

${ }^{40}$ Connelly, Steady, Kindle edition location 3144

${ }^{41}$ Connelly, Steady, Kindle edition location 3454

${ }^{42}$ Connelly, Steady, Kindle edition location 3458
} 
Welsh Guards, R.E. Luxmoore-Ball was ordered to take a position around Buvignies village on 5 November $1918,{ }^{43}$ suggesting that the fact that "the brigade commander felt able to issue verbal orders, to be confirmed in writing later, is a sign of the trust that had been built up between commanders at different levels". ${ }^{4}$

British tactics during The Hundred Days have been the subject of considerable discussion. ${ }^{45}$ Jonathan Boff concludes, at least within Third Army, that there was "an impressive level of flexibility at the small unit tactical level" with a "diverse repertoire of methods". ${ }^{46}$ This diversity was partly due to "improvised 'bottom-up' innovation", ${ }^{47}$ i.e. the inventiveness of COs was a direct contributory factor. Tactical diversity remained within the CO's direct control, ${ }^{48}$ in both set-piece and semi-open warfare attacks.

Patrick Brennan, in his study of Canadian COs, claims that battalion commanders "were central" 49 to the process of "tactical learning" that brought battlefield success. He states: "Successful battalion commanders shared a few characteristics. They were interested in new tactical developments, and in fact were responsible for encouraging innovation from below". ${ }^{50}$ Their 'after-battle' reports went upwards and the distilled wisdom returned

\footnotetext{
${ }^{43}$ Richard Edmund Coryndon Luxmoore-Ball had served in South Africa 1901-2 and had retired as a Lieutenant from the South African forces. He commanded $1^{\text {st }}$ Welsh Guards from 8 September 1918 to the Armistice.

${ }^{44}$ McCarthy, Queen, p.191

${ }^{45}$ See Boff, Winning, Chapter 5 'British tactics: 'the true elixir'; P. Griffith, Battle Tactics of the Western Front (New Haven: Yale University Press, 1994); and J.P. Harris and N. Barr, Amiens to the Armistice (London: Brassey's, 1998).

${ }^{46}$ Boff, Winning, Kindle location 4212

${ }^{47}$ Boff, Winning, Kindle location 4622

48 Jonathan Boff however gives examples of micromanagement with corps commander wanting to know of 13 Brigade in the Battle of the Selle "not only details of battalion and company objectives, but even how many platoons each company intended to use for their attack, and how they were to be used". Boff, Winning, Kindle location 6168

${ }^{49}$ Italics in original.

${ }^{50}$ P.H. Brennan, 'Good Men for a Hard Job: Infantry Battalion Commanders in the Canadian Expeditionary Force', Canadian Army Journal, 9 (1) (2006), pp.9-28. In stating this Brennan was quoting the views of
} 
downwards in the form of codified learning, which they then implemented in training.

Peter Simkins says of the BEF's after-battle reports that:

This process of rigorous, and sometimes brutal, self-examination not only fertilised but also nourished and propagated the shoots of tactical and technical improvement which subsequently enabled the BEF to win a succession of impressive victories in the second half of $1918 .^{51}$

This was an ongoing process even in the last month of the war. In October 1918, for instance, $13^{\text {th }}$ Liverpool were in action twice. Firstly, on the $8^{\text {th }}$ near Cambrai; and secondly, between 23 and 26 October in the approach to the River Selle. On both occasions, three and four page after-battle reports were produced. ${ }^{52}$ The first was completed by Lieutenant-Colonel W.J.H Howard, ${ }^{53}$ and lists six "Lessons". ${ }^{54}$ Interestingly, the report gives good examples of de facto devolved command in terms of inter-battalion cooperation between COs in the absence of brigade orders (and the successes and failures thereof), ${ }^{55}$ supporting the view of Peter Simkins that devolved command operated frequently and unnoticed, simply because situations demanded. The second report was by

\footnotetext{
Major-General W. A. Griesbach, $1^{\text {st }}$ Canadian Brigade. Brennan continues: "Battalion commanders were the last link in the process of 'universalizing learning,' for the implementation of learning was training, the great bulk of which occurred at the battalion level and under the battalion commander's supervision".

${ }^{51}$ P. Simkins, 'Building Blocks: Aspects of Command and Control at Brigade level in the BEF's Offensive Operations, 1916-1918', in G. Sheffield and D. Todman, eds, Command and Control on the Western Front The British Army's Experience 1914-18 (Staplehurst: Spellmount, 2004) p.148

52 TNA WO/95/1429 War Diary $13^{\text {th }}$ Battalion King's Liverpool Regiment.

${ }^{53}$ William James Holdsworth Howard, aged 29 in 1918, is an excellent example of a junior officer rising to command, having been a Regular Lieutenant of King's Liverpool Regiment in August 1914. He had commanded from 22 September 1918.

${ }^{54}$ The lessons include: (i) the importance of supporting battalions "hugging the leading battalions" in attack to avoid enemy artillery barrages; (ii) the issue of slow communications; (iii) the usefulness of using advanced anti-tank guns when counter-attack involved use of tanks; (iv) the importance of advanced machine gun companies; (v) the need for more practice in fire and movement tactics as thin artillery fire could not adequately suppress enemy machine guns; (vi) the facility to withdraw without fear of censure to prevent needless sacrifice.

${ }_{55} 13^{\text {th }}$ King's attacking "in conjunction with the $2^{\text {nd }}$ Division and in co-operation with the $2^{\text {ND }}$ SUFFOLKS on the right", with $4^{\text {th }}$ Royal Fusiliers. "An officer of the M.G. Corps reported himself to the O.C. $13^{\mathrm{TH}}$ KING'S in the RED LINE asking if his guns could assist. His offer was gladly accepted". Howard then approached "the nearest officer of the ROYAL BERKS in the RED LINE ... to find out if he had received orders to attack in conjunction. He said he had not, but on the request of O.C. KING'S he promised ... to attack FOREVILLE". The machine gun barrage occurred, but "the BERKS did not cooperate", leaving the two attacking battalions isolated.
} 
Major R.P. Heywood, the acting $\mathrm{CO},{ }^{56}$ which list three topics for future consideration. ${ }^{57}$ The BEF was clearly still keen to process its COs' learning points even on the brink of victory.

\subsection{Conclusion}

As noted in Chapter Three, ${ }^{58}$ on 29 September 1918, the pivotal moment of The Hundred Days, the COs of the British Army comprised 40 per cent professional soldiers, ${ }^{59} 31$ per cent Territorials, ${ }^{60}$ four per cent Special Reserve, 22 per cent citizens of August 1914, and three per cent empire soldiers.

\begin{tabular}{|l|c|c|}
\hline & $\begin{array}{c}\text { 5th, 9th \& 42nd } \\
\text { Divisions }\end{array}$ & $\begin{array}{c}\text { BEF } \\
\text { 29 September1918 }\end{array}$ \\
\hline Active Regulars & $48 \%$ & $32 \%$ \\
\hline Retired professional officers & $6 \%$ & $8 \%$ \\
\hline Territorial & $15 \%$ & $25 \%$ \\
\hline Special Reserve & $4 \%$ & $2 \%$ \\
\hline Retired non-professional officers & $6 \%$ & $6 \%$ \\
\hline Citizens & $15 \%$ & $22 \%$ \\
\hline Retired empire unit officers & $4 \%$ & $2 \%$ \\
\hline Unknown & $2 \%$ & $>1 \%$ \\
\hline
\end{tabular}

\section{Table 7.5: Comparison of August 1914 status of $\operatorname{COS}$ of $5^{\text {th }}, 9^{\text {th }} \& 42^{\text {nd }}$ Divisions with COs of entire BEF on 29 September 1918}

\footnotetext{
${ }^{56}$ Howard was wounded in the knee by a machine gun bullet on 23 October. Richard Percival Heywood was commanding the battalion as Lieutenant-Colonel at the Armistice.

57 Heywood's three points were negatives, concerning absence of low-flying air support, inaccuracy of barrage, and absence of assistance from machine guns.

58 See Table 3.2

5932 per cent active in August 1914, eight per cent retired

${ }^{60} 25$ per cent active, six per cent retired
} 
In the three successful divisions of The Hundred Days examined, the differential contribution is even more marked, as Table 7.5 shows. Professional soldiers made a higher contribution at 54 per cent of commands during this period and pre-war amateur soldiers and citizens a lower contribution at 25 and 15 per cent respectively.

Given the exploration in this chapter of the non-Regular COs, and their very evident skills, it seems unlikely that the higher proportion of Regulars as COs was a significant factor in divisional success. What these divisions possessed was a store of talented officers of varied backgrounds with a depth of war experience built up over a period of three or four years. ${ }^{61}$ As the GSO1 Lieutenant-Colonel Sir Cuthbert Headlam wrote to his wife as early as 14 November 1916, it was neither the type of unit nor the origin of the CO that counted:

The value of a battalion depends very largely on its Commanding Officer and adjutant. If they are keen and know their work, they can get anything out of their men - be they regulars, territorials, [Kitchener's] Army, Derby recruits or conscripts. The material is the same to all intents and purposes ... the Regular Army ... does not exist any longer. ${ }^{62}$

A number of the COs of the three divisions studied had lengthy or multiple commands. Their talents had been recognised mid-point in the war, but in terms of further promotion, only one, G.B.F. Smyth, was promoted to brigade command during this period from the three divisions under study. ${ }^{63}$ In fact, only three per cent of the whole Hundred Days CO cohort, 19 individuals, were promoted.

\footnotetext{
${ }^{61}$ Whilst they had indeed "fought their way to the top", they had also survived their way to the top, and undoubtedly many other talented individuals were killed, and had no opportunity to command.

${ }^{62}$ J. Beach, The Military Papers of Lieutenant-Colonel Sir Cuthbert Headlam 1910-1942 (Stroud: The History Press for The Army Records Society, 2010) p.148

${ }^{63} 93$ Brigade.
} 
Of the 98 British brigade commanders in post on the Western Front at the Armistice, 58 had been in post throughout the Hundred Days campaign, indicating a turnover of 40 individuals. ${ }^{64}$ Active infantry COs during The Hundred Days therefore only provided half of this turnover. ${ }^{65}$ This raises the question as to how many of them would be ranked amongst Patrick Brennan's “men who obviously performed well, clearly possessing the requirements for the job, and yet were never promoted", 66 i.e. 'good fighting battalion commanders' rather than men suitable for commanding larger formations. Whilst the question is impossible to answer, it is certain that both types are represented in the cohort. Some simply never got the chance for promotion due to position on 'the list'; others, who had served for a lengthy period as $\mathrm{CO}$, had likely been considered and discounted.

Whether the COs of The Hundred Days were "rat-catchers" is a question to which the available evidence does not allow a clear answer. Many were clearly self-assured, as was Smeltzer in his triumph of 23 October, but they likely worked within the limits of confidence they enjoyed with their commanding Brigadiers. Undoubtedly they possessed personal courage, their DSO citations bearing testimony to this. No doubt many were 'tigers', aggressive fighters, but few demonstrated the showy aspects of a Maxwell or a Crozier. Undoubtedly, as their DSO citations again indicate, they had command/leadership skills in terms of planning, care in execution of plans, and had the facility to inspire others with their example. Many were also evidently quick, naturalistic thinkers, who had initiative and ability to know what to do when operations went awry. Some, given the

\footnotetext{
${ }^{64}$ Personal communication, Dr John Bourne.

${ }^{65}$ Two were promoted from the command of MGC battalions.

${ }^{66}$ P.H. Brennan, 'Good Men for a Hard Job: Infantry Battalion Commanders in the Canadian Expeditionary Force', Canadian Army Journal, 9 (1) (2006), p.28
} 
evidence of degumming during this period, were found wanting. The reduced frequency of degumming, however, indicates that the BEF had achieved a more settled level of ability.

Do they represent a meritocracy? Undoubtedly the promotion of a commercial traveller in fruit preserves, William Marshall Tickler, from Private in 1914 to Lieutenant-Colonel in 1918 was based on merit. The community of COs do not, however, represent a meritocracy in terms of a modern definition as a group "selected competitively according to merit". 67 Selection was not made against explicitly stated and mutually agreed criteria, and was always at the mercy of personal recommendation which could be influenced by a variety of factors. Not least of all, the understandable bias towards the Regular soldier and away from the pre-war amateur meant that promotion to $\mathrm{CO}$ was always a weighted process, but one in in which the unstructured assessment of merit always played a part, and, in a temporary sea-change for the British army, seniority did not.

\footnotetext{
${ }^{67}$ Definition of meritocracy as per the Oxford English Reference Dictionary $2^{\text {nd }}$ Edition (Oxford: Oxford University Press, 1996).
} 


\section{Conclusion}

In the Introduction, four questions were posed respecting the evolution of infantry battalion commanders. The first concerned who these men were, and how and where resources were found to cope with the mushrooming requirement for COs.

The body of Regular officers who numbered 12,738 at the outbreak of hostilities shouldered a major burden, providing 45 per cent of active infantry battalion commands. Professional soldiers overall provided 60 per cent of active COs. It is unsurprising that the British army should have sought COs from this stock both out of the habit of institutional 'business-as-usual', and the simple drive of necessity, there being no other place to look for candidates. This was particularly the case during the first two years of the war, in response to turnover in the field and the demands of the New Armies. In doing so, the army dug deep into the stock of retired professionals and young Regular officers. That clearly competent COs continued to be found despite the attrition of officers in 1914-15 is an indication that the quality of the pre-war Regular was higher than critics have assumed.

Whatever the limitations of the professional development of the pre-war officer, the learning environment of the battlefield produced graduates who at the level of battalion command met the only criteria that mattered in 1918 - beating the enemy. Even on 29 September 1918, when the army was less reliant on professional experience, Regular officers of August 1914 still comprised 32 per cent of COs overall and professional soldiers 40 per cent. 
'Business-as-usual' is reflected in the professional's grip on 92.5 per cent of commands of Regular units. Necessity is indicated by their contribution to 66 per cent of commands of New Army units, and to 36 and 41 per cent of commands of first and second-line Territorial units respectively. In the New Armies this contribution was an absolute necessity. With respect to first-line TF units it was a matter of perceived necessity related to the quality of the existing officer stock. Infusion of Regular command peaked at the third appointment in first-line TF units, falling away somewhat as younger officers of quality rose on the back of experience, citizens of August 1914 forming 20 per cent of commands on 29 September 1918. The same principle operated in the New Armies, citizens holding the same number of commands as Regulars, a third each, on that date. Professional soldiers of 1914 held the structure of the command of the infantry battalion whilst the talent that the army garnered in 1914-15 matured.

Pre-war amateur soldiers faced an uphill struggle in ascending to battalion command. The Special Reserve, although not strictly a completely amateur body, made a uniformly low contribution; and the TF continually made one less than its size predicted. That this was based on prejudice is difficult to dispute. As Ian Beckett notes, at the outset: "Regulars had little confidence in the auxiliaries". ${ }^{1}$ Lieutenant-Colonel S.C. Peel described a divisional conference where battalion command appointments were discussed, ${ }^{2}$ the only Territorial present joking that "no one in his battalion could be a candidate, as they were all Territorials. 'No jest ever fell flatter, for no one in the room regarded the statement as other

\footnotetext{
${ }^{1}$ I. Beckett, 'The Territorial Force', in I. Beckett \& K. Simpson (eds), A Nation in Arms: A Social Study of the British Army in the First World War (London: Tom Donovan, 1985), p.129. Even as the war progressed, Beckett states: Territorials "might hold an increasing number of appointments, but rarely on a long-term basis, and rarely those that mattered" (p.141). He notes that Lord Derby "was forced to defend the War Office in a speech at the Aldwych Club" in January 1918 in which he claimed that "sixty-one Territorials below the rank of Lieutenant in 1914 had achieved (the rank) of Lieutenant-Colonel".

${ }^{2}$ The Hon. S.C. Peel was a Major of the Bedfordshire Yeomanry in August 1914.
} 
than a perfectly natural statement of fact"'. 3 On 29 September 1918 only 36 per cent of first-line TF units were commanded by pre-war Territorials compared with 20 per cent by civilians, with a citizen commissioned into the TF being less likely to achieve command than one commissioned into a Service Battalion.

The second question concerned the quality of commanding officers. As already noted, in the absence of data historians have found it easy to ridicule the pre-war officer corps, and have done so inaccurately. Quality is, of course, very difficult to assess. There is no quantified assessment of officers' abilities to mine in retrospect for statistical analysis. There is no doubt that there were COs in post in August 1914 who lacked ability, and it is also the case that a number of those appointed during the war proved to lack the required skills. Failure to stand the rigours of this war should not, however, be taken to indicate lack of ability, as even competent officers could be undermined by their health in the harsh conditions of trench warfare, and could 'burn-out' in response to stress.

Given that the British Army showed no reluctance during the war to remove COs, viability based on simple endurance in post and further promotion is as good an indication of quality as is likely to be achieved. Using these criteria, Tim Travers' conclusion that in 1914 the 3:1 "ratio of incompetent (commanding) officers in the 10th Infantry Brigade was probably not unique" is shown to be incorrect. ${ }^{4}$ The Regular COs of August 1914 demonstrated a viability rate of 64 per cent. Analysis of their experience shows a rich texture of staff and active service that other armies, held up by critics as supposedly more

\footnotetext{
${ }^{3}$ S. Peel, 'The Territorial Force', Army Quarterly, 1:1 (1920) pp.26-54; quoted in Beckett, 'Territorial Force', p.142

${ }^{4}$ T. Travers, The Killing Ground: The British Army, the Western Front, and the Emergence of Modern Warfare 1900-1918 (Barnsley: Pen \& Sword, 2003), p.14
} 
professional, might have envied. Even the 'dugouts', unearthed to command the battalions of the New Armies, had a viability rate of 75 per cent, with their counterparts in the second-line Territorial battalions having a 57 per cent rate.

The same analysis shows, however, that problems initially lay with the first-line Territorials. The TF COs of August 1914 showed a viability rate of 31 per cent. This demonstrates that there were grounds for the suspicion shown of the quality of the senior auxiliary officer. The necessary thinking through of the likely role of the TF in a European war, and staffing it accordingly, had been avoided in the face of the vested interests of the County Associations.

The matter of quality can be thought of as presenting different issues in the period 1914-16 compared to 1917-18. In the years up to and including the Somme offensive, the army was in the most part relying on the quality of the senior officers it already had. In the latter period it was relying on the quality of the senior officers it could create. The army demonstrated responsibility for the process of creation by establishing the Senior Officer School, itself an example of the fact that whatever the pre-war inattention to professional development, a growing commitment to this had evolved.

The 38 per cent rate of removal of COs during the war shows that the army was an organisation committed to quality control. This figure, however, reflects a disproportionate turnover earlier in the war. An increasing commitment to merit-based appointment developed in the New Armies and second-line TF units as they went on service and in the first half of 1916, a process accelerating into 1917 and 1918, the early reliance on seniority 
being shed. In the group who earned command in the last two years of the war by learning, demonstrating their qualities, and being trained to lead and command, the replacement rate was lower. During The Hundred Days the overall replacement rate was 17 per cent; that of citizen COs was 25 per cent, and that of Regular COs who were Lieutenants in August 1914 was 19 per cent. Whilst removal of COs continued up until the Armistice, the number requiring replacement dropped even though the tempo of the war increased.

During the first two years of war, it has been observed that the British Army suffered a process of 'deskilling'. Ian Beckett notes that this was partly due to the rapid expansion which had the effect of "diluting experience at all levels", and partly due to attrition; and that "the inexperience of new officers as casualties mounted would take time to correct". One of the most telling statistics that Beckett presents is that "by 1918, there were an estimated 12,000 officers in staff appointments, or almost as many as in the entire Regular officer corps four years previously". ${ }^{5}$ Officers with the $p s c$ qualification or a perceived ability for staff work were combed out of Regular battalions, particularly in these first two years.

This combing process may be causally related to the observation that towards the end of the war there were many battalion commanders who had been in post for an extended period, but who were never likely to be promoted further. The 'deskilling' of units by advancement of particular officers may have removed many who had the organisational and management abilities for commanding larger formations from potential command at battalion level. The process was, however, less likely to remove men who were able and

\footnotetext{
${ }^{5}$ I. F. W. Beckett, The Great War 1914-1918 (Harlow: Pearson Longman, 2007), p.219
} 
suitable for command solely at this level, thus potentially allowing them to develop into the $\mathrm{CO}$ role. This again reflects positively on the quality of the junior Regular officers of August 1914, and raises the question as to whether 'deskilling' is an entirely appropriate description in this respect. Whilst this turnover certainly created some developmental lag, because it took time for experience and practice to demonstrate skill, it did allow many officers to rise to a level of appropriate ability.

The third question concerned exactly what qualities were perceived as making an effective CO. This would have been a question that the pre-war army would have thought it did not have to answer, given the belief that leadership ability was assured by social status and education, and that the ability to command was generated simply by experience. The process of "reskilling", coupled with the emphasis on quality and merit, gave rise to what was a new development for the British Army - the recognition that the practice of battalion command needed to be actively fostered. The massive influx of citizens lacking a military background and the expanding emphasis on a range of specific training activities in response to an increasingly technical war, led the army to codify and communicate what it meant by 'command' and 'leadership'. It was thereby becoming increasingly professional and modern. Senior Officer School was one of the developments that long outlasted the war.

By 1918, in addition to a range of technical skills, potential COs were being taught the importance of having presence and being known; the importance of personal characteristics of civility, even-temperedness, fairness and justness; the essential nature of personal courage; and the importance of the abilities of hard work, common sense and 
forethought, balanced by imagination. Emphasis was put on the ability to train and motivate, partly through personal example. In terms of institutional approval, COs were rewarded for quality of leadership through demonstrating ability, organisational skill, and initiative; and for providing example. Officers and men had a shared view of what they valued in a commander, which happily fell in line with what was being taught and rewarded, namely courage, intelligence, knowledge, hard work, diligence and skill that protected lives. These precepts have stood the test of time.

By The Hundred Days most of the COs studied were demonstrating the characteristics demanded. The fourth question concerned whether they had, in an organisation dominated largely by seniority in 1914, risen to battalion command by the virtue of the development of a meritocracy. Measured against a strict definition in terms of competitive selection against set criteria, there was no true meritocracy. In an organisation where personal recommendation had ruled, formalised assessment of such characteristics was a project for the distant future. Yet perception of ability clearly sharpened, and the concept of merit became a growing consideration in selection, dominating in the last two years of the war. The process of promotion to $\mathrm{CO}$ was, however, weighted and filtered - weighted, as we have seen, in favour of the Regular soldier, and filtered (to some degree) to exclude the Territorial. Whilst this filtering allowed the able citizen to rise, particularly in the last year or two of war, the army should not be seen as opening itself to 'all-comers' in terms of senior command. That the social status of the officer group as whole was very different in 1918 to 1914 is undeniable, yet the great preponderance of professional civilians of 1914 
achieving battalion command was only a continuation of the growing trend observable in 1914 for the sons of professional men to enter the army. ${ }^{6}$

It is important not to confuse trends in appointment that arose out of necessity and see them as evidence of merit-based promotion. That the average age of COs had dropped from 48 in 1914 to 35 years on the Western Front in 1918 is not evidence of a meritocracy of youth - it is a reflection of the winnowing of the officer group of older members through retirement, death, the exhaustion of warfare and promotion. Indeed, the citizen COs themselves bucked the trend of youth, tending to be a somewhat older group than the average.

The real indicants of merit-based promotion are the citizen COs, those survivors from a group whittled down by death on the Somme and subsequent actions, rising through a three-year incubation on the back of the attrition of professional officers. The fact that a third of Service Battalions were commanded by citizens on 29 September 1918 is undoubtedly a reflection of the attitude change being forced upon the army not only by attrition but also from sheer evidence of suitability. It became clear that the citizens brought an appetite and aptitude both for fighting and the organisation of men for war. The progressive rise in the number of citizen $\mathrm{CO}$ appointments during The Hundred Days invites speculation as to how the army would have looked at battalion command level if the war had persisted into 1919. The hypothesis that the rise of the citizen CO would have continued unabated is likely correct, if untestable. Whether such individuals would have risen beyond this level is a different matter.

\footnotetext{
${ }^{6}$ C.B. Otley records that in $1910,32.2$ per cent of entrants to Sandhurst were the sons of 'civilian professionals' (23 per cent) and 'businessmen and managers' ( 9.2 per cent). [C.B. Otley, 'The Social Origins of British Army Officers', Sociological Review, 18 (2) (1970), pp.213-40].
} 
The weighting and filtering became even more apparent in the issue of promotion to brigade command, a stage which contained a significant bottleneck. The 'waiting list' represented a preponderance of potential supply over demand. Whilst 10 per cent of COs were promoted Brigadier General, 82 per cent of these were Regulars of August 1914, and 93.5 per cent professional soldiers. Only 3.5 per cent were Territorials and less than one per cent citizens. Simple ingrained prejudice in favour of the professional and against the amateur may have played a sizeable part in this pattern of promotion. The leap from commanding men to commanding a formation may, however, have been one in which the more rounded skills of the professional soldier rather than simply being a "professional man of war' really counted.

Brigadier-General W.H.E. Segrave remarked: "Commanding a battalion is four times more difficult and ten times more interesting than commanding a brigade". Whatever the comparative difficulties, Patrick Brennan's distinction between a 'good fighting battalion commander' and an officer suitable for commanding larger formations may be based on differential skills. ${ }^{8}$ The brigadier not only had to have the authority to command commanders, he also had to have a broader base of organisational skills, with a more developed facility for planning, as well the ability to manage both COs and a range of staff officers. He also had to have a wider tactical grasp of integrating combined arms. ${ }^{9}$ George Gater's organisational abilities as a senior educational administrator must, however, have

\footnotetext{
${ }^{7}$ In September 1918 [Feilding, R. War Letters to a Wife - France and Flanders, 1915-1919 (London: Medici Society, 1929) p. 187]. William Henry Erik Segrave served in a range of staff posts from the outbreak of war until taking over command of $1 / 15^{\text {th }}$ London on 23 September 1917, being promoted Brigadier-General, 152 Brigade, in August 1918.

${ }^{8}$ P.H. Brennan, 'Good Men for a Hard Job: Infantry Battalion Commanders in the Canadian Expeditionary Force', Canadian Army Journal, 9 (1) (2006), pp.9-28

${ }^{9}$ These points were developed in discussion with Trevor Harvey in connection with his study of brigade command at the Battle of Arras.
} 
been truly outstanding to have trumped the absence of all-round military experience. The fact that only 50 per cent of appointments to brigade command made during The Hundred Days were from amongst active infantry COs suggests that ability was only as good as it matched the requirements.

What beast had the infantry COs of 1918 evolved into? They were largely young, fit and mentally agile. They possessed both training in and accumulated experience of the conditions of combined-arms set-piece warfare, and were ready and able to learn swiftly the new variation of mobile attrition, in which so many demonstrated their tactical competence.

Garth Pratten's account of the development of infantry battalion command in the expanding Australian Army during the Second World War indicates that it went through a similar process of evolution. His observations on the average 30 year-old Australian COs of 1945 are equally pertinent to the BEF COs of 1918, namely that "they possessed a common doctrinal understanding and were fit, determined and earnest in their application to their commands". ${ }^{10}$

The Australians began by using older officers with experience of the First World War as COs, and as a result of learning on the battlefield, developed a body of "up-to-date military experience and ... a new cohort of battalion commanders. These were officers with

${ }^{10}$ G. Pratten, Australian Battalion Commanders in the Second World War (Melbourne: Cambridge University Press, 2009), pp.128-9 
personal experience of this new war, proven in battle, younger, fitter and more thoroughly trained than any before them". ${ }^{11}$

There seems to be an inevitability to the evolutionary process that as each war in the $20^{\text {th }}$ Century threw up a different series of challenges to the last, the 'Queen of the Battlefield'12 would go through a learning process. This would involve tactical development coupled with a revolution in equipment and weaponry, and a new generation of COs would evolve to act upon that learning and develop 'common doctrinal understanding'.

John Bourne states: "There is little doubt ... that the war did bring to the fore young, ambitious, ruthless leaders, not least at the battalion and brigade levels". ${ }^{13}$ Simon Robbins describes "the fit, adaptable, energetic, resourceful men who served as battalion, battery, brigade and divisional commanders in 1918", 14 "battle-hardened veterans" who had "ruthlessly replaced" the "older commanders unfit for the strenuous life of trench warfare". ${ }^{15}$ Robbins emphasises that the evolution of battalion command was part of an overall evolution of command, and Garth Pratten concurs, stating of the Australian COs in the Second World War that their evolution "took place simultaneously with the development of the command system of which they were part". ${ }^{16}$ He notes that the relationships between COs and brigade commanders "if not based on a long period of shared experience ... were grounded at least on the knowledge of demonstrated

\footnotetext{
${ }^{11}$ Pratten, Australian Battalion Commanders p. 235

${ }^{12}$ A soubriquet for the infantry attributed to Joseph Stalin.

${ }^{13}$ J.M Bourne, 'British Generals in the First World War', in. G.D. Sheffield ed., Leadership \& Command: The Anglo-American Military Experience Since 1861 (London: Brassey, 2002), pp.93-116

${ }^{14}$ S. Robbins, British Generalship on the Western Front 1914-18: Defeat Into Victory (Abingdon: Frank Cass, 2005), p.2

${ }^{15}$ Robbins, British Generalship, p.57

${ }^{16}$ Pratten, Australian Battalion Commanders, p.129
} 
competence". This is just as applicable to The Hundred Days as it is to the fighting in the Pacific jungles.

It was this command system that was put to the test in 1918. As Peter Simkins has noted, even during The Hundred Days, "examples of bad staff work, inadequate co-ordination and liaison and faulty command decisions are spread throughout the operations of the BEF". ${ }^{17}$ War being a human process, this was inevitable. It is impossible to typify the BEF's command system as anything other than 'still evolving' in 1918, John Bourne describing how at least at the teeth end of the organisation, "at battalion, brigade and, to a great extent, at divisional level" a group of men had emerged who "understood the relationship between leadership and command". As Bourne states, "experience was the BEF's greatest teacher, not GHQ". ${ }^{18}$ The evolution was therefore largely bottom-up, and towards more flexible models of command. It was the commanders at the sharp end in The Hundred Days, the BEF's evolved battalion and brigade commanders, working so often hand-inhand with mutual trust, who frequently, as Peter Simkins observes, "required, and got, effective local control of the battle". ${ }^{19}$

If war encourages leaps forward, peacetime can lead to stultification. Jim Storr suggests that the environment of force reduction and underfunding between the wars "seems to have bred conservatism and rewarded those who appeared to correspond to the prevailing stereotype". ${ }^{20}$ Any 'rat-catcher' ethos in infantry command was dissipated, and "anti-

\footnotetext{
${ }^{17}$ P. Simkins, 'Building Blocks: Aspects of Command and Control at Brigade level in the BEF's Offensive Operations, 1916-1918', in G. Sheffield and D. Todman, eds, Command and Control on the Western FrontThe British Army's Experience 1914-18 (Staplehurst: Spellmount, 2004), p.165

${ }^{18}$ Bourne, 'British Generals', pp.111-112

${ }^{19}$ Simkins, 'Building Blocks', p.165.

${ }^{20}$ J. Storr, The Human Face of War (London: Continuum, 2009 ), Kindle edition, locations 3547-3554
} 
intellectual" junior officers reasserted themselves as the British Army reverted to its former role as 'policeman of the Empire'. ${ }^{21}$ The BEF beaten by the Wehrmacht in 1940 suffered from commanders, Storr argues, with "little disposition to prepare themselves". ${ }^{22}$

The broad scope of this thesis leaves at least four areas of issues worthy of further investigation.

The first area concerns exactly what makes a successful battalion commander, a question that may never be answered to complete satisfaction. Effective command, at peace and in war, will lie at the intersection of several dimensions. The first dimension includes the characteristics of the individual, particularly leadership skills and the ability to relate to and understand his subordinates (referent power). The second involves training and experience (expert power). Understanding of these two dimensions could clearly be refined by further research. Length of command and successful battlefield performance, for instance, is an interesting issue arising from the data presented here; with the relevance of battle experience prior to elevation to $\mathrm{CO}$ and experience after that point worthy of more detailed analysis.

The third dimension relates solely to performance in battle, concerning the situational 'on the day' issues which place differential demands on the first two dimensions. Such issues are those partly taken into account in the study of British First World War divisional performance, including weather, terrain, unit strength and fitness, and the quality of the

\footnotetext{
${ }^{21}$ Storr, Human Face, location 3554

${ }^{22}$ Storr, Human Face, location 3587
} 
enemy; ${ }^{23}$ to which one might add communication, the quality of senior and junior commanders, and the simple good and bad luck issues of the 'fog of war'. This list is not exhaustive, and expanding the range of factors may simply mean that an understanding of the equation that balances the relative importance of the three dimensions slips beyond our grasp.

The second historiographical area concerns the tactical development of the BEF, involving more detailed examination of the formal written output of COs, charting the progress of 'bottom-up' change. The role of the infantry battalion commander in tactical refinement could be explored through the vehicle of the after-battle reports contained in unit war diaries, examining the ways in which unit recommendations were synthesised in brigade after-battle reports. Similarly, unit diaries could be examined for schedules of training promulgated by COs to examine the role they played in within-battalion skill development. The degrees of tactical freedom of the CO, particularly in the latter stages of the war, could also be appraised by contrasting the operational orders they issued. Further, the issue of devolved command in The Hundred Days could be examined by systematically searching for examples within unit war diaries to understand more clearly the balance between actions initiated by a $\mathrm{CO}$ alone; a $\mathrm{CO}$ in cooperation with brigade; and a $\mathrm{CO}$ in cooperation with a fellow $\mathrm{CO}$, focussing on the ratio of successful and unsuccessful attempts at cooperation.

A third area involves a more extensive examination of $\mathrm{CO}$ personal files in search of additional examples of confidential assessment of abilities associated with promotion, to

\footnotetext{
${ }^{23}$ J. Lee, 'The SHLM Project - Assessing the Battle Performance of British Divisions' in P. Griffith (ed.) British Fighting Methods in the Great War (Abingdon: Frank Cass, 1996) pp.175-181
} 
establish a broader and more evidence-based understanding of the qualities sought for elevation to Lieutenant-Colonel, and CO to Brigadier.

Fourthly, the Dominions of Canada and Australia contributed two highly successful corps to the BEF, the accomplishments of which have been the subject of much discussion. ${ }^{24}$ Given that the units of these formations were comprised almost entirely of amateur soldiers, without the stiffening of native Regular battalion commanders, a more detailed comparison of the development of command in comparison with British units is warranted to understand further the progress of merit-based promotion. ${ }^{25}$

\footnotetext{
${ }^{24}$ See, for instance, B. Rawling, Surviving Trench Warfare - Technology and the Canadian Corps (Buffalo: University of Toronto, 1992); and C. Pugsley, The ANZAC Experience - New Zealand, Australia and Empire in the First World War (Auckland: Reed, 2004).

${ }^{25}$ Patrick Brennan's published research, (notably Brennan, 'Good Men') necessarily lacks the required depth. A study of Australian First World War Infantry COs is currently underway conducted by William Westerman of the Australian Defence Force Academy, University of New South Wales.
} 


\section{Appendix One \\ Database of Infantry Battalion Commanding Officers of Regiments of the Line}




\section{Appendix Two}

\section{The Special/Extra Reserve Commanding Officers of August 1914}

A sample of Special/Extra Reserve COs had an average age of 48 years two months. ${ }^{1}$ The youngest was 41 . Thirty-eight per cent were over 50, the eldest being Lieutenant-Colonel J. L. Vaughan, $3^{\text {rd }}$ South Lancashire, who was nearly $63 .^{2}$

\section{A2.1 Ex-Regulars as Special Reserve COs}

Forty-two (40 per cent) of were ex-Regulars, who had an average age of 48 years seven months and who had been retired on average exactly seven years. One had retired as a Colonel and one as a Lieutenant-Colonel. Fifty-seven per cent had retired as Majors, and 33 per cent as Captains. ${ }^{3}$ Fifty-four per cent were COs of SR battalions in the same regiment they had retired from as Regulars.

\begin{tabular}{|l|c|c|c|}
\hline & Ranks & Militia & RMC/University/Probationer \\
\hline Regular COs & $1 \%$ & $28 \%$ & $71 \%$ \\
\hline Ex-Regular SR COs & $12 \%$ & $49 \%$ & $39 \%$ \\
\hline
\end{tabular}

Table A2.1: Comparison of entry routes of ex-Regular SR COs and Regular COs

Table A2.1 shows that the ex-Regular SR COs were much more likely to have been commissioned from the ranks or to have come from the Militia in the first place. It was

\footnotetext{
${ }^{1} 26 \mathrm{COs}$, ages accurate to 1.5 months with a quarter midpoint taken from the Registrar General's quarterly registers of births, marriages and deaths.

${ }^{2}$ John Lewis Vaughan remained in command until January 1917, and then served as a Major in the Labour Corps.

${ }^{3}$ One had retired almost before his career had begun, as a Second-Lieutenant. Three were retired from the Indian Army.
} 
exactly these two groups who were less likely to have achieved a Lieutenant-Colonelcy in a Regular regiment. ${ }^{4}$

\begin{tabular}{|l|c|c|}
\hline & Pre-WW1 Staff Service & Pre-WW1 war Staff Service \\
\hline Regular COs & $82 \%$ & $91 \%$ \\
\hline Ex-regular SR COs & $59 \%$ & $44 \%$ \\
\hline
\end{tabular}

\section{Table A2.2: Comparison of peace and wartime staff service of ex-Regular SR COs and Regular COs}

Table A2.2 shows that ex-Regular SR COs were less likely to have pre-war staff service and half as likely to have had wartime staff experience. It is probable that this did not result from deficient competence - they were handicapped in gaining this experience because men with their entry route into the Regular army were less likely to be groomed to rise to battalion command. They probably retired early due to promotional frustration.

\section{A2.2 Former Militia COs}

A sample of SR COs who had never been Regulars had an average age of 48 years two months. ${ }^{5}$ The youngest was 41 . Thirty-eight per cent were over 50 , the eldest being Lieutenant-Colonel J. L. Vaughan, $3^{\text {rd }}$ South Lancashire, who was nearly $63 .^{6}$ They had been in post on average almost exactly three years.

\footnotetext{
${ }^{4}$ Militia officers were generally from the same social class as Regular officers. Six of the 64 former Militia COs were, however, titled (as were two of the ex-Regulars), reflecting the greater aristocratic link with parttime infantry soldiering. These were: Lord Ampthill, $\mathrm{CO} 3^{\text {rd }}$ Bedfordshire; the Marquis of Salisbury, $\mathrm{CO} 4^{\text {th }}$ Befordshire; Sir A.A. Weldon Bt., CO $4^{\text {th }}$ Leinster; Earl (G.H.) Champion de Crespigny, CO $3^{\text {rd }}$ Northamptonshire; Sir A.S.T. Griffith-Boscawen, $\mathrm{CO} 3^{\text {rd }}$ Royal West Kent; the Earl of Ellesmere, CO $3^{\text {rd }}$ Royal Scots; Lord Heytesbury, $\mathrm{CO} 3^{\text {rd }}$ Wiltshires; and Sir R.B.N. Gunter Bt., CO $3^{\text {rd }}$ Yorkshire.

${ }^{5} 26 \mathrm{COs}$, ages accurate to 1.5 months with a quarter midpoint taken from the Registrar General's quarterly registers of births, marriages and deaths.

${ }^{6}$ John Lewis Vaughan remained in command until January 1917, and then served as a Major in the Labour Corps.
} 
The changes in army organisation of 1881 had made it compulsory for a Militia CO to retire at the age of 55 (or 60 under "special circumstances") but had not specified a maximum period of tenure. ${ }^{7}$ There was clear reason for an SR CO to keep hold of his command, as relinquishing it was very likely to be the end of his career. Of the 101 predecessors of the COs of August 1914, only one was active (as a Territorial CO). ${ }^{8}$

\section{A2.3 War Service}

Three of the ex-Regulars (7 per cent) had no previous war service. Two had served in five campaigns, (R. Byron, CO $5^{\text {th }}$ King's Royal Rifle Corps; and J.O'B. Minogue, CO $3^{\text {rd }}$ West Yorkshire $;^{9}$ nine out of their ten campaigns having been in Asia). Three had served in four campaigns; two in three; seven in two, and the remaining 25 in one campaign.

Eighteen of the 63 ex-Militia COs (29 per cent) had no previous war service. With the exception of two, the remaining 45 had all acquired their war service in South Africa. ${ }^{10}$

Table A2.3 shows the spread of active service. Thirteen per cent of the collective war experience had been gained against African tribes; 20 per cent had been gained in Asia, (primarily India and Burma); and 67 per cent against the Boers.

\footnotetext{
${ }^{7}$ HMSO, Parliamentary Paper C.2922, Revised Memorandum Showing Principal Changes in Army Organization from July 1881 (1881).

${ }^{8}$ Lieutenant-Colonel John Edward Rhodes had moved from the Special Reserve of the King's Royal Rifle Corps to be $\mathrm{CO} 8^{\text {th }}$ Hampshire. Two, Lieutenant-Colonel Henry Charles Hardinge, late Rifle Brigade; and the Earl of Westmorland, late Northamptonshire Regiment, were ADCs to the King.

${ }^{9}$ Minogue became CO $9^{\text {th }}$ West Yorkshire for a short period from March 1915 but died in October 1916.

${ }^{10}$ Cecil Hodgson Colvin, CO 3rd Essex in August 1914 had been attached to the 2nd Essex during the campaign on the Nile 1884-5; and George Wensley Clotworthy Soden CO 4th Royal Munster Fusiliers had been seconded as a Commissioner on the Gold Coast and saw service in the conquest of Ashanti, 1900. Colvin served until January 1917 and then became Commandant of a POW camp.
} 


\begin{tabular}{|l|c|c|}
\hline War service & $\begin{array}{l}\text { Ex- } \\
\text { Militia }\end{array}$ & $\begin{array}{l}\text { Ex- } \\
\text { Regular }\end{array}$ \\
\hline Egyptian Expedition (1882-4) & & 2 \\
\hline First Sudan War 1884-5 & & 4 \\
\hline Third Burma War 1885-9 & & 1 \\
\hline Kaffir Campaign (South Africa) 1887-8 & & 1 \\
\hline Zulu War (South Africa) 1888 & & 1 \\
\hline Chin-Lushai War (Burma) 1889-90 & & 3 \\
\hline Hazara Expedition (North-West Frontier) 1891 & & 2 \\
\hline Miranzai Expeditions (North-West Frontier) 1891 & & 2 \\
\hline Isazai Expedition (North-West Frontier) 1892 & & 1 \\
\hline Defence and Relief of Chitral (North-West Frontier) 1895 & & 1 \\
\hline Operations British Central Africa 1895 & & 1 \\
\hline Third Ashanti War (West Africa) 1895-6 & & 1 \\
\hline Dongola Expedition (Sudan) 1896 & & 8 \\
\hline Niger Operations (West Africa) 1897-8 & & 2 \\
\hline North-West Frontier (including Tirah campaign) 1897-8 & 44 & 32 \\
\hline Reconquest of Sudan 1896-9 & 1 & \\
\hline Second Boer War 1899-1902 & & 1 \\
\hline Fourth Ashanti War (West Africa) 1900 & & 2 \\
\hline Waziristan (North-West Frontier) 1901-2 & & \\
\hline Tibet Expedition 1903-4 & & \\
\hline
\end{tabular}

Table A2.3: War service of Special Reserve COs 


\section{Appendix Three}

\section{Commanding the Infantry Battalions of the Home Army}

Of the 1695 infantry battalions of the regiments of the line that either existed at the start of, or came into existence during the war, 959 saw active service. Of the 736 that did not, 51 saw non-active service (or active service unrelated to the war) in various locations including eight Regular battalions; ${ }^{1}$ eleven first-line Territorial battalions; ${ }^{2}$ eight secondline and other late-formed Territorial battalions; ${ }^{3}$ the remainder being Garrison battalions fulfilling their designated purpose.

Of the battalions that remained in the United Kingdom, the purpose of 453 was the provision of reinforcements to the active battalions, 95 being Special Reserve battalions, and 358 Reserve battalions (five being Guards Reserve; the rest being K4/locally-raised battalions and third and fourth-line territorial battalions that were designated Reserve battalions). Twenty-four were home service Labour battalions. The purpose of the remaining 208 was home defence, including Garrison battalions, Territorial cyclist battalions, and second-line Territorial battalions.

\footnotetext{
${ }^{1} 2^{\text {nd }}$ Liverpool; $2^{\text {nd }}$ Somerset; $1^{\text {st }}$ Yorkshire; $1^{\text {st }}$ Duke of Wellington's; $1^{\text {st }}$ Sussex; $1^{\text {st }}$ South Lancashire; $2^{\text {nd }}$ North Staffordshire; and $1^{\text {st }}$ Durham, all in India.

${ }^{2} 1 / 4^{\text {th }}$ West Surrey; $1 / 4^{\text {th }}$ Buffs; $1 / 1^{\text {st }}$ South Wales Borderers; $1 / 6^{\text {th }}$ East Surrey; $1 / 4^{\text {th }}$ Border; $1 / 5^{\text {th }}$ and $1 / 9^{\text {th }}$ Hampshire; $1 / 4^{\text {th }}$ West Kent; $1 / 10^{\text {th }}$ Middlesex; $1 / 25^{\text {th }}$ London; and $1 / 1^{\text {st }}$ Kent Cyclist; all in India (although the $1 / 4^{\text {th }}$ Buffs and $1 / 6^{\text {th }}$ East Surrey also spent time in Aden).

${ }^{3}$ Four in India, one in Bermuda.
} 
Four areas of Home Army command will be examined, namely, in the three types of reserve battalions (Special Reserve, New Army and Territorial) and the second-line Territorial battalions.

\section{A3.1 Special Reserve Battalions}

Command in the home-based Special Reserve battalions remained reasonably stable throughout the war. Sixteen battalions retained the same CO; 56 had only two COs; and 23 had three. Figure A3.1 shows the number of changes of CO during the war per month. The pace of replacement, as might be expected, accelerated during the war; and the periods

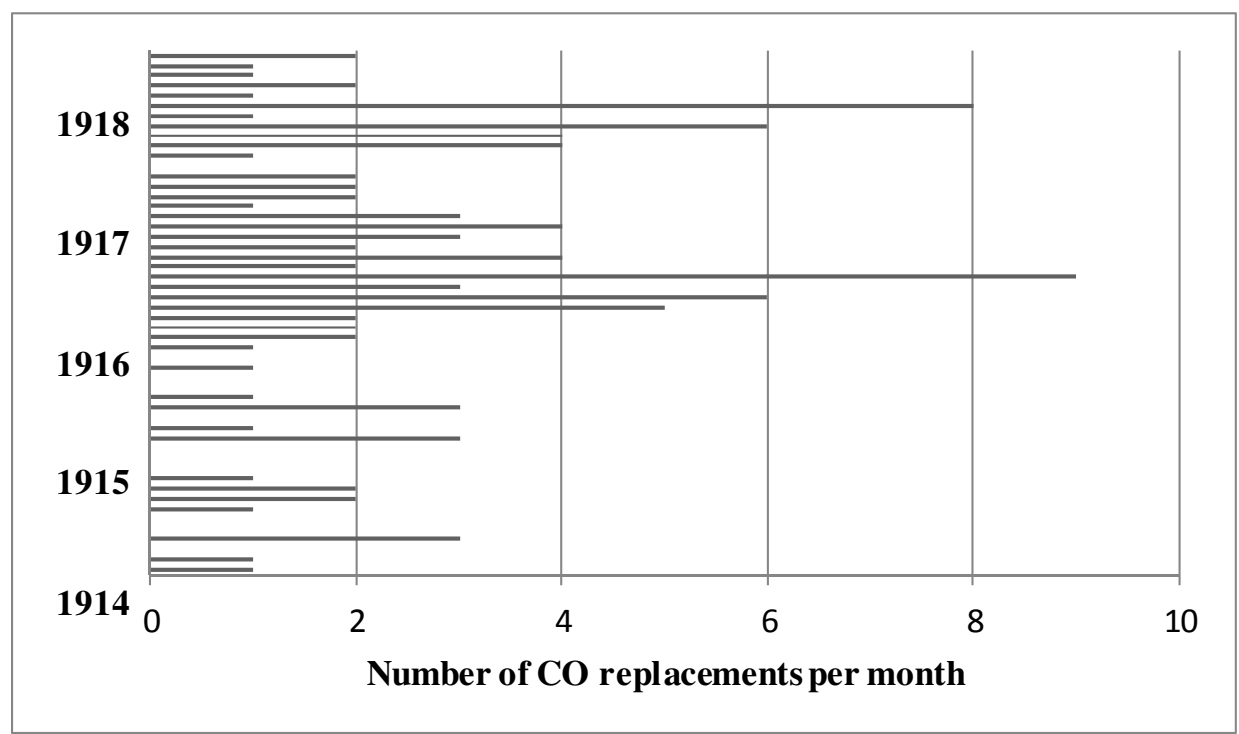

Figure A3.1: Changes of CO in Special/Extra Reserve Battalions 1914-1918 
October 1916 to January 1917 and February to June 1918 demonstrate higher levels of turnover, reasons for which are obscure. ${ }^{4}$

Eighty-two per cent of appointments were within the regiment. Forty-three of all replacements represent the simple elevation of a Major serving in the battalion in August 1914, and eleven an officer who had been a Captain at that point, comprising 54 per cent of appointments. Ten appointees were retired Special Reserve/Militia officers; ${ }^{5}$ and 13 were retired Regulars. ${ }^{6}$

The emphasis on appointees having a within-regiment Special Reserve background strongly suggests a traditional regimental 'business as usual' seniority approach. Twentyone appointees (26 per cent), however, were active Regular officers in August 1914 (one Indian Army Colonel, two Lieutenant-Colonels, fourteen Majors and five Captains) all who had seen varying degrees of active service. All but four had commanded battalions in action. $^{7}$ Some had had careers cut short by wounding. Lieutenant-Colonel H.M. Biddulph, $1^{\text {st }}$ Rifle Brigade, was wounded on the Aisne on 15 September 1914, recovering to serve as a GSO1 from 15 June 1915 to 18 June 1917, and subsequently as CO of $6^{\text {th }}$ Rifle Brigade from 11 November 1917 until the Armistice. Captain F.C. Hitchcock, temporarily attached

\footnotetext{
${ }^{4}$ These two periods correspond to the 1916 Somme offensive and the 1918 German Spring offensives. There is no evidence that the turnover in the two periods was related to turnover in battalion command in France, as only three changes in command were of this type. In the Special Reserve, Lieutenant-Colonel Lord Ampthill went from $3^{\text {rd }}$ Bedfordshire on 9 November 1916 to the command of $13^{\text {th }}$ Leicestershire, a Labour Battalion; and secondly, Lieutenant-Colonel A.J. Digan went from $3^{\text {rd }}$ Connaught Rangers on 19 January 1918 to command of $6^{\text {th }}$ Connaught Rangers on 1 April 1918, a command which was brief as the battalion was shortly thereafter disbanded. In the Extra Reserve Lieutenant-Colonel A.E. Williams went from $4^{\text {th }}$ Warwickshire on 11 October 1916 to command of $1^{\text {st }}$ Wiltshire.

${ }^{5}$ Two Colonels, one Lieutenant-Colonel, three Majors, and three Captains.

${ }^{6}$ Two Colonels, two Lieutenant-Colonels, five Majors, three Captains and one Lieutenant.

${ }^{7}$ Lieutenant-Colonels K.A. Macleod ( ${ }^{\text {rd }}$ Duke of Wellington's West Riding); L.I.B. Hulke (3 ${ }^{\text {rd }}$ King's Own Yorkshire Light Infantry); W.S.W. Parker-Jervis ( $5^{\text {th }}$ King's Royal Rifle Corps); and P. Gould ( $4^{\text {th }}$ Connaught Rangers).
} 
to $3^{\text {rd }}$ Leinster in early 1917 , described: "Training for war ... at full swing under the directions of Lieut.-Colonel R.G. Currey who had been severely wounded at Gallipoli”. ${ }^{8}$

A number of later-appointed COs had significant experience of command. LieutenantColonel H.S. Tew ( $3^{\text {rd }}$ East Surrey) had commanded the $1^{\text {st }}$ Battalion from 29 May 1915 to 5 June 1916, at which point he was promoted to command 18 Brigade in $6^{\text {th }}$ Division from 12 June to 16 August, returning to command $9^{\text {th }}$ East Surrey from 4 September 1916 to 17 October 1916, when he was invalided. ${ }^{9}$ He served as CO of a Yeoman Cyclist Regiment from 12 October 1916 to February 1918, and then $3^{\text {rd }}$ East Surrey from 13 February to 27 July 1918. Lieutenant-Colonel H.E. Walshe had four active commands before taking over $3^{\text {rd }}$ Berkshire, home service being the result of likely 'burn-out' on the Western Front. ${ }^{10}$ His tenure was brief, 1 March to 13 April 1917, transferred to command $8^{\text {th }}$ Dorsetshire, a home service battalion until December 1917. Lastly, Lieutenant-Colonel H. P. CreaghOsborne, another Western Front reject, commanded $7^{\text {th }}$ King's Own Yorkshire Light Infantry in the UK until 18 March 1915 , at which point he was transferred to command $5^{\text {th }}$ Middlesex until 11 December 1916.

Clearly, the Special Reserve was used as a convenient billet for officers mostly of proven quality injured, invalided, or possibly simply exhausted by war. It is unclear whether such appointments were made for the good of the individual unit, for, as we have seen, there is no evidence that merit-based appointment played any great part. Lieutenant-Colonel C.C.R. Murphy, historian of the Suffolk Regiment in the Great War, described the Special

\footnotetext{
${ }^{8}$ Robert Gore Tappenden Currey, a Regular Captain of the Leinster Regiment, had commanded $6{ }^{\text {th }}$ Leinster from 10 August to 28 September in Gallipoli. He recovered sufficiently to command $12^{\text {th }}$ Lancashire Fusiliers 14 November to 10 December 1917 on the Western Front.

${ }^{9}$ Harold Stuart Tew, aged 45 in August 1914, was the senior Major of $1^{\text {st }}$ East Surrey at the outbreak of war.

${ }^{10}$ See Chapter Three.
} 
Reserve COs' duties as "arduous and sometimes disheartening", ${ }^{11}$ but they did not demand up-to-date experience of trench warfare. Siegfried Sassoon passed through the Litherland war station of the $3^{\text {rd }}$ Royal Welsh Fusiliers in 1917 and gave a typically alternative picture, describing Lieutenant-Colonel H.R. Jones-Williams, and his Majors as "convivial characters ... ostensibly directing the interior economy of the camp", ${ }^{12}$ with "the training of recruits left to sergeant-instructors". ${ }^{13}$

\section{A3.2 New Army Reserve Battalions}

The New Army reserve battalions were of two different types. Firstly, it was decided in April 1915 to break up the divisions of the Fourth New Army (K4) and for the battalions to become reserve battalions to train recruits and send drafts to the first three new armies. ${ }^{14}$ Secondly, the locally-raised battalions formed depot companies which became reserve battalions in summer 1915. On 1 September 1916, in response to the casualties of the Somme, all 143 reserve battalions were absorbed into 112 battalions of 24 brigades of the newly created Training Reserve and their regimental identity was lost.

\section{A3.2.1 K4 Reserve Battalions}

Of the $75 \mathrm{~K} 4$ battalions, to whom the first CO was appointed on 21 September $1914 ;{ }^{15} 25$ had two COs, six had three COs, and one had four during the 23 months of their existence.

\footnotetext{
11 C.C.R. Murphy, The History of the Suffolk Regiment 1914-1927 (London: Hutchinson, 1928), p.322. 'Disheartening' due to the instability of constant turnover.

${ }^{12}$ Italics not in original.

${ }^{13}$ Sassoon, S. The Complete Memoirs of George Sherston (London: Faber \& Faber, 1972), p.382. Howell Richard Jones-Williams, born in 1863, was CO $3^{\text {rd }}$ Royal Welsh Fusiliers in August 1914, and served until 16 March 1918.

${ }^{14}$ These second reserve battalions were organised in 18 reserve infantry brigades.

${ }^{15}$ Lieutenant-Colonel B.C. Quill, $11^{\text {th }}$ York \& Lancaster.
} 
Of these 109 Lieutenant-Colonels, 62 were transferred as COs into the Training Reserve and 38 were replaced and never served as COs again, a 35 per cent redundancy rate. ${ }^{16}$

\begin{tabular}{|l|c|c|c|c|c|c|c|c|}
\hline & \multicolumn{2}{|c|}{ Regular } & \multicolumn{2}{c|}{ Indian Army } & \multicolumn{2}{c|}{ SR/Militia } & \multicolumn{2}{c|}{ TF/Volunteers } \\
\hline & Ret & Active & Ret & Active & Ret & Active & Ret & Active \\
\hline Colonel & $10(14 \%)$ & 0 & $7(10 \%)$ & $1(1 \%)$ & $2(3 \%)$ & 0 & 0 & 0 \\
\hline Lt-Col & $8(12 \%)$ & $3(4 \%)$ & $5(7 \%)$ & $8(12 \%)$ & $3(4 \%)$ & $1(1 \%)$ & 0 & 0 \\
\hline Major & $14(19 \%)$ & $1(1 \%)$ & 0 & 0 & 0 & $5(7 \%)$ & 0 & 0 \\
\hline Captain & $1(1 \%)$ & 0 & 0 & 0 & $2(30 \%)$ & $1(1 \%)$ & 0 & 0 \\
\hline Lt & $1(1 \%)$ & 0 & 0 & 0 & 0 & 0 & 0 & 0 \\
\hline
\end{tabular}

\section{Table A3.1: First COs of $K 4$ reserve battalions}

Table A3:1 shows that of the first appointed COs 28 per cent were active in August 1914, including one Colonel and eight Lieutenant-Colonels from the Indian Army, and three Regular Lieutenant-Colonels. ${ }^{17}$ Five active Special Reserve Majors were given command. The remaining 72 per cent were retired officers, with 10 Regular Colonels, seven Indian Army Colonels and two from the Special Reserve/Militia. The retired Lieutenant-Colonels were similarly distributed, eight Regulars, five Indian Army, and two from the Special Reserve/Militia. Fourteen retired Regular Majors were also given command. The Territorial Force was shunned. When compared with Tables 2.1 and 2.2 it can be seen that first appointments fell into the same pattern as for K3. ${ }^{18}$

These reserve battalions, like the Special Reserve provided a home for some of the wounded, sick or exhausted Regular battalion commanders. Lieutenant-Colonel E.H. Swayne, invalided from command of $1^{\text {st }}$ Somerset in France, took command of $9^{\text {th }}$

\footnotetext{
${ }^{16}$ Twenty-two of these were given staff posts, mostly as Staff-Lieutenants.

${ }^{17}$ Lieutenant-Colonel E.H. Swayne, $9^{\text {th }}$ Somerset Light Infantry, invalided from France; Lieutenant-Colonel C. Wanliss, $10^{\text {th }}$ South Lancashire, transferred from the $2^{\text {nd }}$ Battalion in France; and Lieutenant-Colonel G. Gunn, $8^{\text {th }}$ Cameron Highlanders, who having been on half-pay until 13 March 1914, had no command on the outbreak of war.

${ }^{18}$ See Chapter Two.
} 
Somerset on 20 November $1914 .{ }^{19}$ Similarly, following his invalidity on psychological grounds from command of $2^{\text {nd }}$ Royal Welsh Fusiliers in October $1914,{ }^{20}$ LieutenantColonel H. Delme-Radcliffe took command of $12^{\text {th }}$ Royal Fusiliers on 8 April $1915 .^{21}$ Lieutenant-Colonel W.M. Campbell $2^{\text {nd }}$ Black Watch, was invalided on 1 December 1914 and took command of $13^{\text {th }}$ Argyll and Sutherland Highlanders on 22 January $1916^{22}$ Lieutenant-Colonel H.M. Ainslie, who had already been invalided from command of $1^{\text {st }}$ Northumberland Fusiliers in November 1914, returned to be promoted Brigadier-General 18 Brigade between 29 May and 5 August 1915, was invalided again, and then took command of $13^{\text {th }}$ Worcestershire on 12 April $1916 .^{23}$

The reserve battalions also provided a home for Regular COs whose careers had fallen under a cloud. Lieutenant-Colonel C. Wanliss, $2^{\text {nd }}$ South Lancashire, sent home during the

19 Edward Hopton Swayne, born 1863, was commanding $1^{\text {st }}$ Somerset at the outbreak of war, and commanded $9^{\text {th }}$ (Reserve) Somerset from 20/11/1914 until 31 August 1916, and $13^{\text {th }}$ Somerset, a home service battalion from 30 August 1918 until the Armistice, never returning to active duty.

${ }^{20}$ See Chapter Three.

${ }^{21}$ Here he became mired in scandal. Mrs Mary Cornwallis-West, mother of the Duchess of Devonshire, began to visit one Sergeant Patrick Barrett, $2^{\text {nd }}$ Royal Welsh Fusiliers, who had been nursed in her daughter's hospital in France, and became infatuated with him. She approached Delme-Radcliffe about recommending him for a commission, which he duly did, the commission being granted. Expecting reward, Mrs CornwallisWest stepped up her amorous advances with letters and visits, and Barrett, sensing he was now out of his depth, wrote a rejecting letter to her. Mrs Cornwallis-West, scorned, now complained that Barrett was pestering her. The complaint landed back on Delme-Radcliffe's desk, but he, himself under the lady's spell, declined to investigate it properly and humiliated Barrett in front of fellow officers, refusing to read Mrs Cornwallis-West's letters to Barrett. Barrett promptly responded with a nervous breakdown, and DelmeRadcliffe attempted to shift him to the $3^{\text {rd }}$ Battalion. Barrett applied for a Court of Enquiry in relation to Delme-Radcliffe's behaviour. This was refused, but, the matter snowballing, even Lord Kitchener now asked Delme-Radcliffe to read the letters with a view to revising his actions. Delme-Radcliffe, extraordinarily, refused. In 1916, the matter was resurrected, a Court of Enquiry was held, Barrett was vindicated, and Delme-Radcliffe was dismissed. [C. Messenger, 'Scandal in High Places', (British Commission for Military History Newsletter, no date)].

${ }^{22}$ William Maclaren Campbell, born in 1864, was commanding $2^{\text {nd }}$ Black Watch at the outbreak of war. A soldier of rich experience he had seen active service in Burma 1891-3 and in South Africa in 1902. He had been Staff Officer in the Chin Hills expedition; ADC to the Major-General and Governor of Madras; ADC and Military Secretary to the Viceroy of India; and Military Secretary to the Governor of Madras. He was promoted Temporary Brigadier-General Home Forces 2 November 1916 to 8 March 1918, serving as Commander (AAG) thereafter.

${ }^{23}$ Henry Sandys Ainslie born in 1861, was commanding $1^{\text {st }}$ Northumberland Fusiliers at the outbreak of war. His war concluded as a member of a travelling medical board. 
retreat from Mons, ${ }^{24}$ took command of $7^{\text {th }}$ South Lancashire on 7 November 1914. Lieutenant-Colonel H.E. Tizard, relieved of command of $1^{\text {st }}$ Royal Munster Fusiliers at Gallipoli on the night of the 26-27 April 1915, took command of 10 ${ }^{\text {th }}$ East Lancashire on 4 September $1915 .^{25}$

One character demands attention, namely Lieutenant-Colonel 'Mad Jack' Hugh de Berdt Hovell, a 51 year-old retired Lieutenant-Colonel who had commanded both Regular Battalions of the Worcestershire Regiment, the latter in India. Undeniably brave, he had won a DSO in South Africa, and also the Royal Humane Society's medal for rescuing a Private from drowning. A fitness enthusiast, he could in his day swim round the island of Gozo. He was deeply concerned about the comfort of his men, and as a Captain of $1^{\text {st }}$ Worcestershire disguised himself on $2^{\text {nd }}$ Battalion manoeuvres as a Private so that he could understand the OR's experience. ${ }^{26}$ Intelligent, he claimed in his Who's Who entry to have originated the use of telephones on rifle ranges (1886) and the use of field telephones (1888), and was most definitely the author of two manuals, Soldiers' Shooting $^{27}$ and Soldiers' Training and Other Notes. ${ }^{28}$ Appointed to command $13^{\text {th }}$ Worcestershire on 11 November 1914, he swiftly came to grief. "Early in December 1914, rumours were rife that private soldiers were making indecent suggestions about (his) conduct ... and these rumours continued. A court of inquiry was ordered, and of the two private soldiers who gave evidence one tried to commit suicide". Colonel P. Holland reported:

The Court having most carefully considered the evidence brought before them are of opinion that although they do not consider there is any ground for

\footnotetext{
24 See Chapter One.

${ }^{25}$ See Chapter Three.

${ }^{26} \mathrm{http} / / / \mathrm{www}$. angloboerwar.com/forum/9-gallery/127-hovell-h-de-b-hugh-de-berdt-dso accessed 4 August 2011.

${ }^{27}$ London: Gale \& Polden, (1888).

${ }^{28}$ London: Gale \& Polden, (1900).
} 
specific charges such as suggested by the allegations made by Privates Fletcher and Baugh regarding Colonel Hovell, at the same time they are of opinion that Colonel Hovell is undoubtedly eccentric in his manner and methods in dealing with his men, and that these peculiarities of his in conjunction with the treatment rendered necessary to his back are liable to misconstruction. ${ }^{29}$

Hovell suffered from acne across the top of his back, and in India the pustules were pressed by hand by soldier-servants. It was this requirement of his Worcester servant which had started the rumour. Hovell was removed from his command on 14 March 1915. Seeking to retrieve his reputation, and demonstrating his old courage, at the age of 52 he enlisted secretly under an assumed name as a private soldier in his old $\left(2^{\text {nd }}\right)$ Battalion and served in France for five months until his health broke down. He died of bronchopneumonia in 1923, having brought a libel action against Holland in 1920 and lost.

\section{A3.2.2 Locally Raised Reserve Battalions}

Of the 54 locally-raised reserve battalions, 12 per cent had active officers as their first CO (see Table A3:2). Three had an active Regular $\mathrm{CO},{ }^{30}$ one an active Indian Army CO, and one each a Special Reserve and Territorial CO. Of the retired officers, 42 per cent were Regulars, six per cent Indian Army, 17 per cent Special Reserve, and 24 per cent Territorial. When compared to Chapter Two Tables 2.1 and 2.2 it can be seen that first appointments fell into roughly the same pattern as for the active locally-raised battalions. ${ }^{31}$

\footnotetext{
${ }^{29}$ The Times, Thursday May 6 1920, p. 4, issue 42403.

${ }^{30}$ Lieutenant-Colonel F.G. Montagu-Douglas-Scott, 28th Royal Fusiliers; Lieutenant-Colonel R.S. Weston, 12th East Lancashire, who had already briefly commanded 2nd Manchester; and Lieutenant-Colonel E.K. Purnell, 19th King's Royal Rifle Corps.

${ }^{31}$ See Chapter Two.
} 


\begin{tabular}{|l|c|c|c|c|c|c|c|c|}
\hline & \multicolumn{2}{|c|}{ Regular } & \multicolumn{2}{c|}{ Indian Army } & \multicolumn{2}{c|}{ SR/Militia } & \multicolumn{2}{c|}{ TF/Volunteers } \\
\hline & Ret & Active & Ret & Active & Ret & Active & Ret & Active \\
\hline Colonel & $3(5 \%)$ & 0 & $2(4 \%)$ & $1(2 \%)$ & $1(2 \%)$ & 0 & $4(6 \%)$ & 0 \\
\hline Lt-Col & $2(4 \%)$ & 0 & 0 & 0 & $3(5 \%)$ & 0 & $2(4 \%)$ & 0 \\
\hline Major & $13(24 \%)$ & $1(2 \%)$ & $1(2 \%)$ & 0 & $4(6 \%)$ & 0 & $2(4 \%)$ & $1(2 \%)$ \\
\hline Captain & $3(5 \%)$ & $2(4 \%)$ & 0 & 0 & $1(2 \%)$ & $1(2 \%)$ & $4(6 \%)$ & 0 \\
\hline Lt & $2(4 \%)$ & 0 & 0 & 0 & $1(2 \%)$ & 0 & $2(4 \%)$ & 0 \\
\hline
\end{tabular}

Table A3.2: First COs of locally-raised reserve battalions

Eleven battalions had one change of command and two had two, a turnover rate lower than K4 reserve battalions. ${ }^{32}$ Four of the replacements were active Regular officers; LieutenantColonel H.O. Bishop (19 $9^{\text {th }}$ West Yorkshire), wounded commanding the $1^{\text {st }}$ Lancashire Fusiliers ${ }^{33}$ Lieutenant-Colonel C.H. Young $\left(21^{\text {st }}\right.$ Welsh Regiment $)$, replaced as CO of the $9^{\text {th }}$ Welsh; ${ }^{34}$ Lieutenant-Colonel B.R. Roche $\left(28^{\text {th }}\right.$ Middlesex $)$, replaced as CO of the $1^{\text {st }}$ Bedfordshire ${ }^{35}$ and Lieutenant-Colonel R.D. Keyworth ( $19^{\text {th }}$ King's Royal Rifle Corps), who had had no previous command. ${ }^{36}$

\section{A3.3 Territorial Reserve Battalions}

The 190 original TF reserve battalions comprised four second-line battalions, ${ }^{37}$ ten fourthline battalions, with the remainder being third-line. In April 1916 the third-line designation was replaced with the title Reserve Battalion; thus, the $3 / 4^{\text {th }}$ Battalion of a regiment

\footnotetext{
${ }^{32}$ Because of their shortened existence as regimental units, this analysis will not be carried further.

${ }^{33}$ Harry Oswald Bishop was a 46 year-old Major of $1^{\text {st }}$ Lancashire Fusiliers in August 1914. He finished the war commanding $3 / 6^{\text {th }}$ Lancashire Fusiliers.

${ }^{34}$ Charles Henry Young, born in 1866, was a Regular Lieutenant-Colonel of the Welsh Regiment on half-pay in August 1914. The remainder of his war was spent with training reserve battalions.

${ }^{35}$ Benjamin Robert Roche, born in 1865, was a Major of $1^{\text {st }}$ Bedfordshire in August 1914 . He commanded $6^{\text {th }}$ Worcestershire from 21 September 1916 until the Armistice.

${ }^{36}$ Robert Denbigh Keyworth, born in 1878, was a Regular Captain of Oxfordshire and Buckinghamshire Light Infantry in August 1914, attached to the West Africa Regiment.

${ }^{37} 2 / 4^{\text {th }}$ Royal Lancaster, $2 / 5^{\text {th }}$ Duke of Cornwall's Light Infantry, $2 / 12^{\text {th }}$ Loyal North Lancashire, and $2 / 9^{\text {th }}$ Highland Light Infantry.
} 
became the $4^{\text {th }}$ Reserve Battalion. The sheer number of battalions generated a considerable demand for COs, reducing when the Training Reserve was created when all the Reserve Battalions of a regiment were generally amalgamated into the lowest numbered battalion. ${ }^{38}$

Many third-line appointments were not made until well into 1915 and even early 1916, and battalions remained for some time under a senior Major. ${ }^{39}$ As Table A3.3 shows, in terms of first appointments, only one active Regular officer was available as CO. LieutenantColonel F.W. Foley, a Depot Major in August 1914, was on active service with the $5^{\text {th }}$ Berkshire from 31 May 1915 until 22 December 1915 when he was wounded, ${ }^{40}$ thereafter commanding 3/5th Loyal North Lancashire. Two active Indian Army officers were also appointed. $^{41}$

Of the first appointees, 11 Lieutenant-Colonels from first-line TF battalions passed on to the Reserve battalions, three without having seen active service, five after brief active service in $1915,{ }^{42}$ and one, Lieutenant-Colonel C.C. Moxon, after active service with $1 / 5^{\text {th }}$

\footnotetext{
${ }^{38}$ Exceptions occurred in Regiments with large numbers of reserve battalions. Thus in the King's Liverpool Regiment, the $6^{\text {th }}$ Reserve Battalion was amalgamated with the $5^{\text {th }}$, the $8^{\text {th }}$ and $9^{\text {th }}$ with the $7^{\text {th }}$, the $10^{\text {th }}$ remaining unamalgamated.

${ }^{39}$ Only five of 177 third line appointments were made in 1914, and 24 were made between 1 January 1916 and 1 September 1916.

${ }^{40}$ Frank Wigram Foley, born in 1865, had commanded from 19 August 1914. His jaw was broken during shelling.

${ }^{41}$ Lieutenant-Colonel H. Lowther, of $96^{\text {th }}$ Russell's Infantry, was appointed to command $3 / 5^{\text {th }}$ West Riding (and thereafter $2 / 8^{\text {th }}$ Durham Light Infantry and finally $1^{\text {st }}$ Garrison Battalion Munster Regiment, after which he was appointed a Staff-Lieutenant); and Captain W.R. Carey, on half-pay from the $67^{\text {th }}$ Punjabis, was appointed to command $3 / 5^{\text {th }}$ West Yorkshire.

${ }^{42}$ Lieutenant-Colonel W.F.A. Wadham left $1 / 4^{\text {th }}$ Royal Lancaster on 10 June 1916 for $3 / 4^{\text {th }}$ Royal Lancaster on 3 November 1915; Lieutenant-Colonel J.B. Butler left $1 / 4^{\text {th }}$ Gloucestershire on 7 February 1915 for 3/4 ${ }^{\text {th }}$ Goucestershire on 10 April 1915; Lieutenant-Colonel H.C. Woodcock left 1/6 ${ }^{\text {th }}$ Gloucestershire on 7 March 1915 immediately to $3 / 6^{\text {th }}$ Gloucestershire; Lieutenant-Colonel F.D. Robinson from $1 / 4^{\text {th }}$ East Lancashire on 15 July 1915 immediately to $3 / 4^{\text {th }}$ East Lancashire; Lieutenant-Colonel A. Stockton left $1 / 4^{\text {th }}$ Oxford \& Buckinghamshire on 1 January 1915 for 3/4 ${ }^{\text {th }}$ Oxford \& Buckinghamshire on 30 April 1915; LieutenantColonel W. Garner left $1 / 8^{\text {th }}$ Middlesex on 11 May 1915 for $4 / 8^{\text {th }}$ Middlesex on 18 December 1915; Lieutenant-Colonel C.C. Moxon left $1 / 5^{\text {th }}$ Yorkshire Light Infantry on 1 November 1917 immediately to $3 / 4^{\text {th }}$ Wiltshire; Lieutenant-Colonel H.C. Watson left 1/6th Durham Light Infantry on 28 April 1915 for 3/6 ${ }^{\text {th }}$ Durham on 15 June 1915; Lieutenant-Colonel C.C. Murray left $1 / 9^{\text {th }}$ Highland Light Infantry on 22
} 
Yorkshire Light Infantry until 1 November $1917 .{ }^{43}$ Eighteen retired Colonels and 15 Lieutenant-Colonels from the $\mathrm{TF} /$ Volunteers were appointed. This was a smaller percentage (17 per cent) than the 37 per cent of the first appointees to the second-line battalions. ${ }^{44}$ Conversely, 34 active TF Majors and 23 active TF Captains comprised thirty per cent of the total appointments, as against 14 per cent for the second-line battalions. This is unlikely to represent a commitment to the merit-based appointment of active officers, rather the later pigeon-holing of those who proved unsuitable for active service.

\begin{tabular}{|l|c|c|c|c|c|c|c|c|c|c|c|}
\hline & \multicolumn{2}{|c|}{ Colonel } & \multicolumn{2}{c|}{ Lt-Col } & \multicolumn{2}{c|}{ Major } & \multicolumn{2}{c|}{ Captain } & \multicolumn{2}{|c|}{ Lt } & ORs \\
\hline & Act & Ret & Act & Ret & Act & Ret & Act & Ret & Act & Ret & Ret \\
\hline Regular & 0 & 1 & 0 & 3 & 1 & 8 & 0 & 11 & 0 & 1 & 1 \\
\hline Ind Army & 0 & 2 & 1 & 3 & 0 & 0 & 1 & 0 & 0 & 0 & 0 \\
\hline TF/Vols & 0 & 18 & 12 & 15 & 34 & 14 & 23 & 16 & 2 & 4 & 0 \\
\hline SR/Militia & 0 & 3 & 0 & 1 & 0 & 7 & 2 & 1 & 0 & 1 & 0 \\
\hline Empire & 0 & 0 & 0 & 1 & 0 & 0 & 0 & 1 & 0 & 0 & 0 \\
\hline
\end{tabular}

Table A3.3: First appointments to TF Reserve Battalions

Two individuals require further remark. Firstly, Lieutenant-Colonel G.D. Hale of the $3 / 5^{\text {th }}$ Loyal North Lancashire, ${ }^{45}$ a citizen (brewer) in August 1914, who was appointed on 5 November 1915. His elder brother was (and father had been) the Agent for the Earl of Derby's Lancashire estates, a connection which may have accounted for his rapid

\footnotetext{
November 1915 immediately to $3 / 9^{\text {th }}$ Highland Light Infantry; Lieutenant-Colonel R.G. Hayes left $1 / 15^{\text {th }}$ London on 9 October 1914 to $3 / 15^{\text {th }}$ London on 15 May 1915 , by way of command of the $2 / 15^{\text {th }}$; and Lieutenant-Colonel G.P. Botterill left $1 / 4^{\text {th }}$ London on 30 May 1915 immediately to $4 / 4^{\text {th }}$ London.

${ }^{43}$ Moxon then commanded $4^{\text {th }}$ Reserve Battalion Wiltshire Regiment until the Armistice. A 48 year-old doctor in August 1914, Charles Carter Moxon resigned his commission as Surgeon-Major to serve in South Africa in 1900 as a Lieutenant with the York \& Lancaster Regiment, and had risen to be Lieutenant-Colonel of $5^{\text {th }}$ Yorkshire Light Infantry on 8 October 1912. Having survived the Western Front without a wound, Moxon died in 1924 after contracting septicaemia from a slight wound obtained conducting a post-mortem on a scarlet fever victim. (British Medical Journal 12 April 1924 1(3302) p.691).

${ }^{4}$ See Chapter Two.

${ }^{45}$ George Duckworth Hale was born in 1868.
} 
elevation. Secondly, Lieutenant-Colonel E.J. McFarlane, a retired Regular Sergeant-Major of the Manchester Regiment, ${ }^{46}$ was appointed to command $3 / 5^{\text {th }}$ Warwickshire, the only representative of other ranks without officer experience appointed as first $\mathrm{CO}$ to the New Armies.

\begin{tabular}{|c|c|c|c|c|c|c|c|c|c|c|}
\hline & \multicolumn{2}{|c|}{ Regular } & \multicolumn{2}{|c|}{ Indian Army } & \multicolumn{2}{|c|}{ TF/Vols } & \multicolumn{2}{|c|}{ SR/Militia } & \multirow{2}{*}{$\frac{\text { Empire }}{\text { Ret }}$} & \multirow[t]{2}{*}{ Citizen } \\
\hline & Ret & Active & Ret & Active & Ret & Active & Ret & Active & & \\
\hline Colonel & $\begin{array}{l}0.5 \% \\
(0 \%)\end{array}$ & & $\begin{array}{c}1 \% \\
(0 \%)\end{array}$ & & $\begin{array}{l}10 \% \\
(1 \%)\end{array}$ & & $\begin{array}{l}1.5 \% \\
(0 \%)\end{array}$ & & & \\
\hline Lt-Col & $\begin{array}{l}1.5 \% \\
(2 \%)\end{array}$ & & $\begin{array}{l}1.5 \% \\
(0 \%)\end{array}$ & $\begin{array}{l}0.5 \% \\
(0 \%)\end{array}$ & $\begin{array}{l}8 \% \\
(2 \%)\end{array}$ & $6 \%(7 \%)$ & $\begin{array}{l}.5 \% \\
(0 \%)\end{array}$ & & $\begin{array}{l}.5 \% \\
(0 \%)\end{array}$ & \\
\hline Major & $\begin{array}{l}4 \% \\
(5 \%)\end{array}$ & $\begin{array}{l}.5 \% \\
(0 \%)\end{array}$ & & & $\begin{array}{l}7 \% \\
(7 \%)\end{array}$ & $\begin{array}{c}18 \% \\
(17 \%)\end{array}$ & $\begin{array}{l}4 \% \\
(7 \%)\end{array}$ & & & \\
\hline Captain & $\begin{array}{l}6 \% \\
(7 \%)\end{array}$ & $\begin{array}{c}0 \% \\
(8 \%)\end{array}$ & & $\begin{array}{l}0.5 \% \\
(0 \%)\end{array}$ & $\begin{array}{l}0 \% \\
(7 \%)\end{array}$ & $\begin{array}{c}12 \% \\
(15 \%)\end{array}$ & $\begin{array}{l}0 \% \\
(1 \%)\end{array}$ & $\begin{array}{c}0 \% \\
(2 \%)\end{array}$ & $\begin{array}{c}0 \% \\
(1 \%)\end{array}$ & \\
\hline $\mathrm{Lt}$ & $\begin{array}{l}.5 \% \\
(1 \%)\end{array}$ & $\begin{array}{c}0 \% \\
(4 \%) \\
\end{array}$ & & & $\begin{array}{l}2 \% \\
(2 \%)\end{array}$ & $1 \%(0 \%)$ & $\begin{array}{l}.5 \% \\
(0 \%)\end{array}$ & & & \\
\hline $2 \mathrm{Lt}$ & & & $\begin{array}{c}0 \% \\
(1 \%)\end{array}$ & & & & & & & \\
\hline ORs & $\begin{array}{l}.5 \% \\
(1 \%) \\
\end{array}$ & & & & & & & & & \\
\hline Citizen & & & & & & & & & & $\begin{array}{l}0.5 \% \\
(3 \%)\end{array}$ \\
\hline
\end{tabular}

\section{Table A3.4: First and last (brackets, italics) appointments to TF Reserve Battalions expressed as percentages in terms of rank in August 1914}

Of 94 battalions whose identity was kept throughout the war, 24 per cent had one CO, 43 per cent had two, 23 per cent had three, five per cent had four and five per cent had five. The turnover, as Table A3.4 shows, involved the retirement of nearly all the Colonels, and a reduction in the number of retired TF Lieutenant-Colonels, and an increase in the number of officers who had been active Regular Captains and retired and active TF Captains in August 1914.

\footnotetext{
${ }^{46}$ Edward John McFarlane was born in 1868 and had been pensioned since 1907 . He commanded $3 / 5^{\text {th }}$ Warwickshire from 4 February to 1 June 1916 1916, and $27^{\text {th }}$ Durham Light Infantry from 1 January 1917 to 20 September 1918.
} 


\section{A3.4 Second-line Territorial Battalions}

Ninety-one second-line Territorial battalions remained in the UK for the duration of the war. These had a different role to the reserve battalions, performing home defence duty. ${ }^{47}$

\begin{tabular}{|l|c|c|c|c|c|c|c|c|}
\hline & \multicolumn{2}{|c|}{ Regular } & \multicolumn{2}{c|}{ Indian Army } & \multicolumn{2}{c|}{ SR/Militia } & \multicolumn{2}{c|}{ TF/Vols } \\
\hline & Ret & Active & Ret & Active & Ret & Active & Ret & Active \\
\hline Colonel & $2(2 \%)$ & 0 & 0 & 0 & 0 & $1(1 \%)$ & $15(17 \%)$ & 0 \\
\hline Lt-Col & 0 & 0 & 0 & 0 & $5(6 \%)$ & 0 & $16(18 \%)$ & $12(14 \%)$ \\
\hline Major & $3(3 \%)$ & 0 & 0 & 0 & $3(3 \%)$ & 0 & $6(7 \%)$ & $24(26 \%)$ \\
\hline Captain & $1(1 \%)$ & 0 & 0 & 0 & $1(1 \%)$ & $1(1 \%)$ & 0 & 0 \\
\hline
\end{tabular}

\section{Table A3.5: First COs of home service second-line TF battalions}

As might be expected, the pattern of appointments, as Table A3.5 demonstrates, (as it would not have been decided at the outset which battalions would go overseas and which would not), followed a similar pattern to the active second-line battalions. When compared with Table 2.3, the only differences revealed are a lower number of retired Territorial Colonels in the home service group (17 per cent as against 29 per cent), and a higher number of active Territorial Majors (26 per cent as against 12 per cent). Unsurprisingly, 12 Territorial Lieutenant-Colonels who were commanding first-line battalions in August 1914 percolated down to these home service battalions. ${ }^{48}$

\footnotetext{
${ }^{47}$ None of these battalions were, however, amongst the 12 second-line TF infantry battalions who were sent to Ireland after the April 1916 uprising, the nearest thing to active service in the UK, all of whom went on to active service in France.

${ }^{48}$ Lieutenant-Colonel C.M. Cowan from $1 / 8^{\text {th }}$ to $2 / 8^{\text {th }}$ Royal Scots; Lieutenant-Colonel D.R. MacDonald from $1 / 5^{\text {th }}$ to $2 / 5^{\text {th }}$ Northumberland Fusiliers; Lieutenant-Colonel H. Barnett from $1 / 4^{\text {th }}$ to $2 / 4^{\text {th }}$ Royal Scots Fusiliers; Lieutenant-Colonel A.B. Hopps from $1 / 4^{\text {th }}$ to $2 / 4^{\text {th }}$ Cheshire; Lieutenant-Colonel H.J. Roberts from $1 / 6^{\text {th }}$ to $2 / 6^{\text {th }}$ Royal Welsh Fusiliers; Lieutenant-Colonel G. Dixon from $1 / 5^{\text {th }}$ to $2 / 5^{\text {th }}$ Border; LieutenantColonel W.C. Blackett from $1 / 8^{\text {th }}$ to $2 / 8^{\text {th }}$ Durham Light Infantry; Lieutenant-Colonel E.G. Bulk from $1 / 5^{\text {th }}$ to $2 / 5^{\text {th }}$ Seaforth Highlanders; Lieutenant-Colonel W.R. Black from $1 / 6^{\text {th }}$ to $2 / 6^{\text {th }}$ Seaforth Highlanders; Lieutenant-Colonel A.W.G.T. Leith-Buchanan from $1 / 9^{\text {th }}$ to $2 / 9^{\text {th }}$ Argyll \& Sutherland Highlanders; Lieutenant-Colonel P.B. Ford from $1 / 3^{\text {rd }}$ to $2 / 3^{\text {rd }}$ Monmouthshire; and Lieutenant-Colonel L. Tebbutt from $1 / 1^{\text {st }}$ to $2 / 1^{\text {st }}$ Cambridgeshire.
} 
In comparison with the Territorial reserve battalions which can be followed until November 1918, there was a somewhat more marked turnover in command. Of the 75 units whose history can be traced until the Armistice, ${ }^{49}$ only 17 per cent retained their original CO; 31 per cent had two, 33 per cent three, 17 per cent four, and two per cent five. As Table A3.6 shows, there was a decrease in the number of retired senior officers, and an increase in the number of officers active in 1914. However, the changes are not great, and there is no evidence of a move to install younger officers with recent active service to repel possible enemy invasion, perhaps because that threat was seen as becoming more remote the longer the war went on.

\begin{tabular}{|c|c|c|c|c|c|c|c|c|c|}
\hline & \multicolumn{2}{|c|}{ Regular } & \multicolumn{2}{|c|}{ Indian Army } & \multicolumn{2}{|c|}{ TF/Vols } & \multicolumn{2}{|c|}{ SR/Militia } & Citizen \\
\hline & Ret & Active & Ret & Active & Ret & Active & Ret & Active & \\
\hline Colonel & $\begin{array}{c}2 \% \text { to } \\
1 \%\end{array}$ & $\begin{array}{c}0 \% \text { to } \\
7 \%\end{array}$ & & & & $\begin{array}{c}0 \% \text { to } \\
1 \%\end{array}$ & $\begin{array}{c}17 \% \text { to } \\
6 \%\end{array}$ & & \\
\hline Lt-Col & & & $\begin{array}{c}0 \% \text { to } \\
3 \%\end{array}$ & & $\begin{array}{c}6 \% \text { to } \\
1 \%\end{array}$ & $\begin{array}{c}0 \% \text { to } \\
3 \%\end{array}$ & $\begin{array}{c}18 \% \text { to } \\
6 \%\end{array}$ & $\begin{array}{c}14 \% \text { to } \\
8 \%\end{array}$ & \\
\hline Major & $\begin{array}{c}3 \% \text { to } \\
1 \%\end{array}$ & & & & $\begin{array}{c}3 \% \text { to } \\
1 \%\end{array}$ & & $7 \%$ to $3 \%$ & $\begin{array}{c}26 \% \text { to } \\
23 \%\end{array}$ & \\
\hline Captain & $\begin{array}{c}1 \% \text { to } \\
3 \%\end{array}$ & $\begin{array}{c}0 \% \text { to } \\
8 \%\end{array}$ & & & $\begin{array}{c}1 \% \text { to } \\
1 \%\end{array}$ & $\begin{array}{c}0 \% \text { to } \\
1 \%\end{array}$ & $0 \%$ to $3 \%$ & $\begin{array}{l}0 \% \text { to } \\
13 \%\end{array}$ & \\
\hline $\mathrm{Lt}$ & & & $\begin{array}{c}0 \% \text { to } \\
1 \%\end{array}$ & & & & $0 \%$ to $1 \%$ & & \\
\hline $2 \mathrm{Lt}$ & & & & & & & $0 \%$ to $1 \%$ & $\begin{array}{c}0 \% \text { to } \\
1 \%\end{array}$ & \\
\hline Citizen & & & & & & & & & $0 \%$ to $3 \%$ \\
\hline
\end{tabular}

Table A3.6: Status in August 1914 of first and last COs of the second line TF Battalions

Of interest are the two citizen soldiers. Lieutenant-Colonel A.V. Cowell was an Army Schoolmaster in 1914 and commanded 2/4 ${ }^{\text {th }}$ Buffs from 2 March 1916 to 1 November 1917 (when he was transferred to command $1 / 1^{\text {st }}$ Highland Cyclist Battalion) ${ }^{50}$ Lieutenant-

\footnotetext{
${ }^{49}$ Not cut short by amalgamation.

50 Arthur Victor Cowell was born in 1883. He commanded $1 / 1^{\text {st }}$ Highland Cyclist Battalion until the Armistice.
} 
Colonel S.G. Guy was a Labour Exchange manager in 1914 , and commanded $2 / 6^{\text {th }}$ Cheshire from 11 February 1916 to 6 May 1917 (when he was transferred to command the $2 / 7^{\text {th }}$ Cheshire).

\section{A.3.5 Conclusion}

The home service battalions were undeniably the poor relations in the evolution of battalion command during the war. The Special and Extra Reserve battalions were the best off, with a quarter of appointments from amongst either wounded or invalided senior officers with experience of the new warfare, perhaps because of their role in reinforcing Regular units. Otherwise, they demonstrated a traditional within-regiment seniority approach.

The other training reserve battalions and second-line Territorials received an even more sparse leavening of active officers as the war progressed. No attempt is evident to extend the emerging merit-based appointment approach within the active battalions to the nonactive. The likely reason is simple, in that there was no need to. The training battalions were training other ranks, and there were efficient and experienced NCOs to achieve this. The CO remained an administrative figurehead. The home defence battalions similarly had no need to develop battle-hardened command as the threat of German invasion rapidly receded. 


\section{Appendix Four}

\section{From: The Battalion Commander's Handbook (US Army War College, Pennsylvania, 1996)}

\section{Leadership}

1. No one can take your integrity - you have to give it away.

2. Soldiers want to know how much you care before they care how much you know.

3. What you do is more important than anything you say.

4. Never give anyone reason to question your integrity.

5. Accept responsibility for the shortcomings of the unit; pass credit for success on to your subordinates.

6. Never allow yourself to be perceived as self-serving. If subordinates believe you're trying to get ahead at their expense, all you'll get is minimum effort and little initiative. Be selfless, always.

7. Be compassionate.

8. Never violate or be perceived to violate your own rules or policies.

9. Be willing to admit when you are wrong.

10. Reward soldiers and publicly recognize those that make the tough decisions - those who choose the harder right over the easier wrong.

11. Use the chain of command to pass on new information and policies. Avoid making too many "public announcements."

12. Let your leaders know that mistakes are $\mathrm{OK}$ as long as we learn from them. Explain to them the difference between mistakes and mission failure, versus doing something illegal or immoral.

13. Allow subordinates to "change your mind" now and then. 
14. Identify your lane and stay in it.

15. Share hardships; be visible. Do what your soldiers do, eat what they eat, sleep where they sleep. Ensure your subordinate leaders do the same. There is no substitute for personal example.

16. Give young officers and NCOs a chance to grow. Spend time with them, listen to them and let them talk to you one-on-one.

17. Mentorship takes time. Ensure you take the time with your lieutenants and captains.

18. Be consistent with rewards, awards and punishment. Formulate your philosophy before you deal with the first case. Be just.

19. Praise in public, criticize in private. Recognize good soldiers at every possible opportunity.

20. Be technically and tactically proficient. If there is something you don't know, say so and ask a soldier or NCO to teach you - they'll love it.

21. Let your leaders lead. Give them mission-type orders. Don't micromanage.

22. Foster teamwork and camaraderie among your commanders and staff. Discourage too much competition, except at sports events.

23. Have a sense of humor.

24. Be open and accessible. Make yourself available to soldiers by getting out into their work areas.

25. Perceptions are reality.

26. Prepare your unit to function without you. 
27. Sexual harassment - ensure your leaders know what it is, how to identify it, and how to deal with it quickly and justly. Ensure you do the same.

28. Establish a good relationship with your fellow battalion commanders.

29. Insist on leaders giving orders in their own names.

30. If you don't understand an order, talk to your boss and ask for clarification.

31. Never walk past something that is not right; if you do you have set a new and lower standard.

32. Bad news never improves with age. Insist that your leaders make timely reports, even if all information is not immediately available. Then give them time to get follow-up information. If necessary, assist them in confronting challenges.

33. Lead from the front. Your personal example counts more than you will ever know. Your behavior in a variety of situations will shape and guide the actions of others.

34. Don't let superior performance go unrewarded. Don't allow continued poor performance to go unpunished. 


\section{Bibliography}

The bibliography is organised as follows:

I. UNPUBLISHED SOURCES 393

I.1 The National Archives of the United Kingdom: Public 393 Record Office, Kew

I.1.1 Special Reports, Instructions, Proceedings 393

I.1.2 Formation \& Unit War Diaries 393

I.1.3 Officers' Personal Service Records 394

$\begin{array}{lll}\text { I.1.4 Other } & 397\end{array}$

$\begin{array}{lll}\text { I.2 The Imperial War Museum } & 397\end{array}$

$\begin{array}{llr}\text { I.3 The National Army Museum, London } & 398\end{array}$

I.4 The Liddell Hart Centre for Military Archives, King's 399 College, London

$\begin{array}{lll}\text { I.5 Army Personnel Centre } & 398\end{array}$

I.6 Directorate of History and Heritage, Ottawa 398

$\begin{array}{lll}\text { I.7 } & \text { Libraries and Archives Canada } & \\ \text { I.8 } & \text { National Library of Scotland } & 398\end{array}$

$\begin{array}{lll}\text { I.9 Unpublished Theses } & 398\end{array}$

II. PUBLISHED SOURCES 399

$\begin{array}{llr}\text { II.1 General Books on the Great War } & 399\end{array}$

$\begin{array}{llr}\text { II.2 Books on Britain and the Great War } & 400\end{array}$

$\begin{array}{llr}\text { II.3 Books on the British Army } & 300\end{array}$

II.4 Regimental Histories 405

II.5 Formation Histories 416

$\begin{array}{llr}\text { II.6 Unit Histories } & 419\end{array}$

$\begin{array}{lll}\text { II.7 Biographies } & 421\end{array}$

II.8 Autobiographies, Diaries, Memoirs and Letters 421

II.9 Articles in Scholarly Journals and Chapters in Books 428

II.10 Unpublished and Conference Papers 430

II.11 Works of Reference 430

$\begin{array}{ll}\text { II.12 Official Publications } & 431\end{array}$

II.10.1 General 431

II.10.2 Manuals etc. $\quad 432$

II.10.3 Army Lists 432

$\begin{array}{lll}\text { II.13 Other } & 434\end{array}$

II.14 Newspapers 434

III. THE INTERNET 435 


\section{UNPUBLISHED SOURCES}

\section{I.1 The National Archives of the United Kingdom: Public Record Office, Kew}

\section{I.1.1 TNA: PRO}

ADM 1/8477-309

CAB 45/116

CAB 45/185

WO $32 / 13253$

WO $32 / 18563$

WO 95/2538

WO $162 / 2$

WO $162 / 3$

WO $163 / 44$

WO $163 / 44$

WO 279/57

\section{I.1.2 TNA: PRO}

WO 95/1280

WO 95/1358

WO 95/1495

WO 95/1570

WO 95/1658

WO 95/2044
Special Reports, Instructions, Proceedings

Correspondence: Admiralty-War Office 1916-7

Correspondence: Lieutenant-Colonel J.F.

FitzGerald with Official Historian Captain C. Falls

Correspondence: C.A. Howard with Official Historian

Memo of Military Secretary, 25 November 1946.

Court of Inquiry $1 / 4^{\text {th }}$ Norfolk Regiment

Extracts from the Diary of Brevet-Colonel C.S. Collison

Notes on Supply of Officers: Instructions of Secretary Of State, 6 September 1914, Adjutant General's papers

Circular from Adjutant-General's Department to GOCsin-C of Commands, 24 August 1914

Minutes of meeting of the Military Members of the Army Council, 27 August 1914

Minutes of meetings of the Military Members of the Army Council, 9 October 1914

Report on the Staff Conference held at the Staff College, Camberley, 17-20 January 1927

Formation \& Unit War Diaries

$1^{\text {st }}$ Queen's Royal West Surrey Regiment

$13^{\text {th }}$ Essex Regiment

$1^{\text {st }}$ Hampshire Regiment

$1^{\text {st }}$ Bedfordshire Regiment

$2^{\text {nd }}$ Bedfordshire Regiment

$12^{\text {th }}$ Middlesex Regiment 


\begin{tabular}{|c|c|}
\hline WO 95/2536 & 112 Infantry Brigade \\
\hline WO 95/2756 & $1 / 7^{\text {th }}$ Royal Warwickshire Regiment \\
\hline WO 95/2762 & $1 / 4^{\text {th }}$ Royal Berkshire Regiment \\
\hline WO 95/2427 & $1 / 4^{\text {th }}$ Suffolk Regiment \\
\hline WO $95 / 2695$ & $1 / 5^{\text {th }}$ Sherwood Foresters \\
\hline WO 95/3118 & $1 / 1^{\text {st }}$ Honourable Artillery Company \\
\hline WO $95 / 4325$ & $5^{\text {th }}$ Bedfordshire Regiment \\
\hline I.1.3 TNA: PRO & Officers' Personal Service Records \\
\hline WO 339/10150 & Alderman, W.J. \\
\hline WO $339 / 46469$ & Aldworth, A.A. \\
\hline WO 339/12865 & Beardsley, H.L. \\
\hline WO 339/79058 & Benzie, R. \\
\hline WO 339/14813 & Birt, C.W.H.B. \\
\hline WO $339 / 20163$ & Bishop, B.F. \\
\hline WO 339/29778 & Blake, T.J.E. \\
\hline WO 374/7817 & Bottomley, R.A.A. \\
\hline WO 339/38966 & Bowden, E.G \\
\hline WO 339/17095 & Boyd, E.R.H \\
\hline WO 374/9054 & Brighten, G.S. \\
\hline WO 339/15328 & Brock-Williams, D. \\
\hline WO 339/11498 & Browne, G.E.A. \\
\hline WO 339/4587 & Brown, W.E. \\
\hline WO 339/12793 & Bull, J.C. \\
\hline WO $374 / 10838$ & Burdett, J.C. \\
\hline WO $374 / 11040$ & Burnett, R.P. \\
\hline WO 339/15660 & Campbell, J.B.S. \\
\hline WO 339/26217 & Cassy, J.S. \\
\hline WO 339/26696 & Chadwick, J.H. \\
\hline WO 339/14756 & Champion, A.T. \\
\hline WO 339/37181 & Clare, O.C. \\
\hline WO 339/32529 & Colley, F. \\
\hline WO 339/20495 & Cotton, A.E. \\
\hline WO 339/7138 & Courtenay, H. \\
\hline WO $374 / 16243$ & Craddock, W.M. \\
\hline WO 374/16876 & Crosskey, J.H. \\
\hline WO 339/22337 & Cunningham, T.L. \\
\hline WO 339/8922 & Dawson, W.R.A. \\
\hline WO $374 / 19281$ & de Paula, W.M. \\
\hline WO 339/21797 & Deakin, G \\
\hline WO 339/888 & Derviche-Jones, A.D. \\
\hline
\end{tabular}




\begin{tabular}{|c|c|}
\hline WO 339/34542 & Dove, R.S. \\
\hline WO $374 / 22347$ & Elkington, W.E.W. \\
\hline WO 339/56791 & Elstob, W. \\
\hline WO 339/39558 & English-Murphy, W.R. \\
\hline WO 339/15337 & Etchells, T. \\
\hline WO 339/16365 & Fearenside, E. \\
\hline WO 339/26401 & Fitch, C.E. \\
\hline WO 339/12852 & Fitzhugh, V.M. \\
\hline WO 339/21607 & Fletcher, G.D.A. \\
\hline WO 339/2633 & Ford, S.W. \\
\hline WO 339/13245 & Forde, G.M. \\
\hline WO $339 / 11350$ & Forty, J.E.H. \\
\hline WO 339/12494 & Foster, J.H. \\
\hline WO 339/5172 & Foulis, D.A. \\
\hline WO $374 / 25856$ & Frisby, L.C. \\
\hline WO $374 / 26035$ & Fullerton, G. d'E. H. \\
\hline WO $339 / 26223$ & Fulton, G.K. \\
\hline WO 339/6190 & Furber, C.T. \\
\hline WO 3339/11355 & Gater, G. \\
\hline WO 339/21767 & Gielgud, H.L.F.A. \\
\hline WO 339/21767 & Green, G. \\
\hline WO $374 / 29963$ & Hadow, R.W. \\
\hline WO $339 / 524$ & Hancock, C. \\
\hline WO $339 / 35948$ & Hardyman, J.H.M. \\
\hline WO 339/21957 & Hawkes, G.W. \\
\hline WO 339/21868 & Hill, M.V.B. \\
\hline WO $339 / 5474$ & Hinman, C.P. \\
\hline WO $339 / 22723$ & Hone, P.C. \\
\hline WO 339/30935 & Houghton, N. \\
\hline WO 339/1003 & Howitt, T.C \\
\hline WO 339/19530 & Hudson, H.H. \\
\hline WO 339/4177 & Humphries, C.F.G. \\
\hline WO $339 / 24759$ & Huntington, R.H. \\
\hline WO 374/35906 & Hurlbatt, E.S. \\
\hline WO $374 / 36434$ & Ionides, P.D. \\
\hline WO $339 / 10013$ & James, A.H. \\
\hline WO $339 / 24351$ & James, C.K. \\
\hline WO $339 / 13256$ & Janson, J.T. \\
\hline WO 339/20177 & Johnston, F. \\
\hline WO $374 / 38794$ & Kay, R.C. \\
\hline WO 339/29287 & Kennedy, W. \\
\hline WO $339 / 15874$ & Kennington, J. \\
\hline WO 339/5186 & Ker, R.F. \\
\hline WO $339 / 13801$ & King, G.E. \\
\hline WO 339/13379 & Kirkwood, J.G. \\
\hline WO $339 / 21412$ & Kyle, R. \\
\hline WO $339 / 17103$ & Lindsay, D. \\
\hline WO 339/16899 & Longden, J.M. \\
\hline
\end{tabular}




\begin{tabular}{|c|c|}
\hline WO $339 / 60159$ & Mackereth, G. \\
\hline WO $339 / 49809$ & Marshall, J.N. \\
\hline WO $339 / 54848$ & Millward, W.C. \\
\hline WO $339 / 15240$ & Mobbs, E.R. \\
\hline WO $374 / 49183$ & Morton, G.D. \\
\hline WO $374 / 49671$ & Murdoch, C. \\
\hline WO $339 / 18439$ & Murray, W.A. \\
\hline WO 339/10696 & Musgrave, E.C. \\
\hline WO 339/17226 & Osborne, D.R. \\
\hline WO $339 / 21480$ & Papillon, P.R. \\
\hline WO $339 / 12081$ & Parkes, W. \\
\hline WO 339/47005 & Peck, J.N. \\
\hline WO 339/20289 & Peel, W.R. \\
\hline WO $339 / 19635$ & Petty, W. \\
\hline WO $339 / 27221$ & Poyntz, E.S.M. \\
\hline WO $339 / 15310$ & Prior, J.M. \\
\hline WO $339 / 12583$ & Ritchie, H. \\
\hline WO $339 / 31043$ & Robinson, H.A. \\
\hline WO $339 / 40081$ & Robinson, W.T.K. \\
\hline WO 339/18477 & Rosher, J.B. \\
\hline WO $339 / 37740$ & Samuel, A.F. \\
\hline WO 339/3483 & Scothern, A.E. \\
\hline WO $339 / 25825$ & Scott, L.D. \\
\hline WO 339/43644 & Sebastian, S.R. \\
\hline WO $339 / 23126$ & Selby, H.J. \\
\hline WO $339 / 13469$ & Sherwood-Kelly, J. \\
\hline WO 339/15995 & Smalley, E. \\
\hline WO $339 / 54877$ & Smith, H.F. \\
\hline WO $339 / 25825$ & Smith, R.A. \\
\hline WO $339 / 6322$ & Smyth, G.B.F. \\
\hline WO $339 / 21234$ & Somervail, W.F. \\
\hline WO $339 / 8378$ & Sotheby, H.G. \\
\hline WO $339 / 21909$ & Stone, A \\
\hline WO 339/3398 & Sulman, A.E. \\
\hline WO 339/20806 & Tanner, A.G. \\
\hline WO $339 / 34782$ & Thomas, W.E. \\
\hline WO $339 / 38441$ & Thompson, A.C. \\
\hline WO $339 / 24778$ & Tickler, W.M. \\
\hline WO 374/69019 & Tolerton, R.H. \\
\hline WO $339 / 38441$ & Troughton, L.H.W. \\
\hline WO $374 / 70397$ & Vann, B.W. \\
\hline WO $339 / 25458$ & Walkley, A.J. \\
\hline WO 339/25019 & Webster, J.R. \\
\hline WO 339/44265 & Wenyon, H.J. \\
\hline WO $339 / 4967$ & West, G. \\
\hline WO $339 / 14010$ & Weston, S.V.P. \\
\hline WO $339 / 28853$ & White, A.C. \\
\hline WO $374 / 73824$ & Whitehead, H.F. \\
\hline
\end{tabular}


WO $339 / 6297$

WO $339 / 14412$

WO 339/23535

\section{I.1.4 TNA PRO}

WO $256 / 31$
Wilberforce, W.

Wilson, G.L.

Wynne, R.O.

\section{I.2 The Imperial War Museum, London}

Bicknell, H.P.F 'Letters’ IWM Docs 16133

Cordeaux, E.K. 'Letters' IWM Docs 16975

de Sales la Terriere, H.M.B. 'Papers' IWM Docs 14737

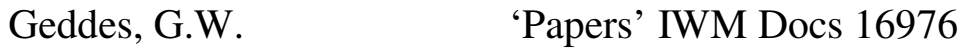

Horsfall, A. 'A Gentleman at War - Alfred Horsfall through his Letters to his Wife 1916-October 1917' IWM Docs 14929

Kentish, R.J.

'Papers' IWM Docs 7806

Lloyd-Williams, $\mathrm{H}$.

'Personal Experiences of the Years of the European War' IWM Docs 13838

Mackay, R.L.

'Papers' IWM Docs 11144

Murray, J.

'Interview' IWM 15592 (Sound archive)

Rees, H.C.

'A Personal Record of the First 7 Months of the War' IWM Docs 7166

Sims, R.H.

'Papers' IWM Docs 7118

Stafford, R.S.S.H.

'Papers' IWM Docs 13956

Stevens, G.A.

'Letters' IWM Docs 12339

Trevor, H.E.

'Letters' IWM Docs 11445

Unwin, E.

'The Landing from the River Clyde" IWM Docs 13473

Webster, J.R

'Papers' IWM Docs 13948

Weldon, K.C.

'Papers' IWM Docs 7190 


\section{I.3 The National Army Museum, London}

Ellison, G. F. 'Considerations Influencing the Selection of

Officers for Command and the Staff', NAM 8704-35 Ellison Mss. No. 30.

Mills, A.M.

'Papers' NAM 1965-06-17

\section{I.4 The Liddell Hart Centre for Military Archives, King's College, London}

Macleod, R.

Macleod Papers - 'Memoirs' GB0099 KCLMA

\section{I.5 Army Personnel Centre}

Lieutenant-Colonel

D/APC/HD/ABLW/187116

C. Wanliss

\section{I.6 Directorate of History and Heritage, Ottawa}

ON 92/252 Series 7

Department of National Defence memorandum

Box 125 File 102

19 March 1941

\section{I.7 Libraries and Archives Canada}

LAC, RG9, Militia and Defence, Series III-D-3, Volume 4871, Reel T-10669 File: 206, 2 CIB War Diary, Appendix 2, Operation Order 185 (O.O. 185), 5 April 1917

LAC, RG9, Militia and Defence, Series III-D-3, Volume 4871, Reel T-10669 File : 206, 2 CIB War Diary, Appendix 9, Instructions for the attack on Arleux, 27 April 1917

\section{I.8 National Library of Scotland}

Haig, D

Acc. 3155 Field-Marshal Sir Douglas Haig, Manuscript

Diary

Haldane, J.A.L.

Acc.10306 Brigadier-General J.A.L. Haldane Papers

\section{I.9 Unpublished Theses}

Kang, C.

'The British Regimental Officer on the Western Front in the Great War, with Special Reference to the Royal Warwickshire Regiment', PhD, University of Birmingham, (2007) 
Jones, S.

Penny, S.

Radley, K.

Risio, A.J.

Simpson, A.
'The Influence of the Boer War (1899-1902) on the Tactical Development of the Regular British Army 19021914', PhD, University of Wolverhampton (2009)

'Discipline and morale : the British Non-Commissioned Officer on the Western Front 1914-1918', M.Phil, De Montfort University, (2003)

'First Canadian Division, CEF 1914-1918', PhD, Carleton University, Ottawa, (2000)

'Building the Old Contemptibles: British Military Transformation and Tactical Development from the Boer War to the Great War 1899-1914', Master of Military Art \& Science, Georgia Institute of Technology and Fort Leavenworth, (2005)

'The Operational Role of British Corps Command on the Western Front, 1914-18', PhD, University College, London, (2001)

\section{PUBLISHED SOURCES}

\section{II.1 General Books on the Great War}

Beckett, I.F.W.

Cecil, H. et al (eds.)

Clayton, A.

Horne, A.

Ousby, I.

Stevenson, D.

Stone, N.
The Great War 1914-1918 (Harlow: Pearson Longman, 2007), p.219

Facing Armageddon: The First World War Experienced (London: Leo Cooper, 1996)

Paths of Glory - The French Army 1914-18 (London: Cassell, 2003)

The Price of Glory - Verdun 1916 (London: Macmillan, 1962)

The Road to Verdun (London: Jonathan Cape, 2002)

1914-1918 - The History of the First World War (London: Allen Lane, 2004)

The Eastern Front 1914-1917 (London: Hodder \& Stoughton, 1975) 
Strachan, H.

The First World War, Vol.1: To Arms (Oxford: Oxford University Press, 2001)

\section{II.2 Books on Britain and the Great War}

Bond, B. et al (eds.)

Bourne, J.M.

French, D.

Gordon, A.

Massie, R.K.
'Look To Your Front' (Staplehurst: Spellmount, 1999)

Britain and the Great War 1914-1918 (London: Edward Arnold, 1989; 1991)

British Strategy and War Aims, 1914-1916 (London: Allen \& Unwin, 1986)

The Rules of the Game: Jutland and British Naval Command (London:John Murray, 1996)

Castles of Steel - Britain, Germany and the Winning of the Great war at Sea (London: Jonathan Cape, 2004)

\section{II.3 Books on the British Army}

Ashworth, T.

Beckett, I. F.W. \&

Simpson, K. (eds)

Beckett, I. F.W.

Beckett, I. F.W.

Bidwell, S. \&

Graham, D.

Bird, A.

Boff, J.

Bond, B. (ed)
Trench Warfare, 1914-1918: the Live and Let Live System (London: Macmillan, 1980)

A Nation in Arms: A Social Study of the British Army in the First World War (Manchester: Manchester University Press, 1985)

The Amateur Military Tradition 1558-1945 (Manchester: Manchester University Press, 1991)

Ypres - The First Battle 1914 (Harlow: Pearson, 2004)

Firepower: British Army Weapons and Theories of War (London: Allen \& Unwin, 1982)

Gentlemen, We Will Stand and Fight - Le Cateau, 1914 (Marlborough: Crowood press, 2008)

Winning and Losing on the Western Front: The British Third Army and the Defeat of Germany in 1918 (Cambridge: Cambridge University Press, 2012)

The First World War and British Military History (Oxford: Clarendon Press, 1991) 
Bond, B.

Bowman, T. \&

Connelly, $\mathrm{M}$.

Bristow, A.

Cobb, $\mathrm{P}$.

Connelly, M.

Dennis, P \& Grey, J.

Dixon, J.

Duffy, C.

French, D.

Fuller, J.F.C.

Fuller, J.G.

Griffith, P.

Griffith, P. (ed)

Haig-Brown A.R.

Hammond, B.
The Victorian Army and the Staff College (London:

Eyre Methuen, 1972)

The Edwardian Army: Recruiting, Training and

Deploying the British Army 1902-1914 (Oxford: Oxford University Press, 2012)

A Serious Disappointment - The Battle of Aubers Ridge 1915 and the Munitions Scandal (London: Leo Cooper, 1995)

Fromelles, 1916 (Stroud: Tempus, 2007)

Steady the Buffs! A Regiment, A Region and the Great War (Oxford: Oxford University Press, 2006)

1918 Defining Victory (Canberra: Department of Defence, 1999)

Magnificent But Not War - The Second Battle of Ypres 1915 (London: Leo Cooper, 2003)

Through German Eyes: the British \& The Somme 1916 (London; Weidenfeld \& Nicholoson, 2006)

Military Identities: The Regimental System, the British Army, and the British People, c.1870-2000 (Oxford: Oxford University Press, 2005)

Generalship, Its Diseases and their Cure: A Study of the Personal Factor in Command (London: Faber \& Faber, 1933)

Troop Morale and Popular Culture in the British and Dominion Armies, 1914-19 (Oxford: Clarendon Press, 1990)

Battle Tactics of the Western Front: The British Army's Art of Attack 1916-18 (New Haven \& London: Yale University Press, 1994)

British Fighting Methods in the Great War (London: Frank Cass, 1996)

The O.T.C. and the Great War (London: George Newnes, 1915)

Cambrai 1917 - The Myth of the First Great Tank Battle (London: Weidenfeld \& Nicholson, 2008) 
Hart, P.

Harris, J.P.

\& Barr, N.

Homes, R.

James, R.R.

Jones, S.

Kendall, P.

Langlois, $\mathrm{H}$.

Lewis-Stempel, J.

Liddle, P. (ed.)

Lloyd, N.

Messenger, C.

Mitchinson, K.W.

Mitchinson, K.W.

Moore-Bick, C.

Nasson, B.

Nicholls, J.
Gallipoli (London: Profile, 2011)

Amiens to the Armistice: The BEF in the Hundred Days' Campaign, 8 August-11 November 1918 (London: Brassey's, 1998)

Tommy - the British Soldier on the Western Front 19141918 (London; Harper Collins, 2004)

Gallipoli (London: Macmillan, 1989)

From Boer War to World War: Tactical Reform of the British Army 1902-1914 (Oklahoma: University of Oklahoma Press, 2012)

Aisne 1914 - The Dawn of Trench Warfare (Stroud:Spellmount, 2012)

The British Army in a European War (London: Hugh Rees, 1910)

Six Weeks - The Short and Gallant Life of the British Officer in the First World War (London: Weidenfeld \& Nicholson, 2010)

Passchendaele in Perspective - The Third Battle of Ypres (London: Leo Cooper 1997)

Loos 1915 (Stroud, Tempus, 2006)

The Day We Won The War - Turning Point at Amiens 8 August 1918 (London: Weidenfeld \& Nicholson, 2008)

Defending Albion (Basingstoke: Palgrave Macmillan, 2005)

England's Last Hope - The Territorial Force, 1908-14 (Basingstoke: Palgrave Macmillan, 2008)

Playing the Game: The British Infantry Officer on the Western Front 1914-1918 (Solihull: Helion, 2011)

Springboks on the Somme - South Africa in the Great War 1914-1918 (Johannesberg: Penguin, 2007)

Cheerful Sacrifice - The Battle of Arras 1917

(Barnsley: Leo Cooper, 1995) 
Norman, $\mathrm{T}$.

Passingham, I.

Pedersen, $\mathrm{P}$

Philpott, W.

Prior, R.

Prior, R. \& Wilson, T.

Prior, R. \& Wilson, T.

Prior, R. \& Wilson, T.

Pugsley, C.

Rawling, B.

Robbins, S.

Samuels, M.

Samuels, M.

Scott, P. T.

Sheffield, G.D.
The Hell the Called High Wood - The Somme 1916

(Barnsley: Leo Cooper, 2003)

Pillars of Fire - The Battle of Messines Ridge June 1917 (Stroud: Sutton, 1998)

Fromelles (Barnsley: Leo Cooper, 2004)

Bloody Victory - the Sacrifice on the Somme and the Making of the Twentieth Century (London; Little Brown, 2009)

Gallipoli - The End of the Myth (New Haven; Yale University Press, 2009)

Command on the Western Front: The Military Career of Sir Henry Rawlinson 1914-1918 (Oxford: Blackwell, 1992)

The Somme (New Haven: Yale University Press, 2005)

Passchendaele: The Untold Story (New Haven; Yale University Press, 2003)

The ANZAC Experience - New Zealand, Australia and Empire in the First World War (Auckland: Reed, 2004)

Surviving Trench Warfare: Technology and the Canadian Corps, 1914-1918 (Toronto: University of Toronto Press, 1992)

British Generalship on the Western Front 1914-18:

Defeat Into Victory (Abingdon: Frank Cass, 2005)

Doctrine and Dogma: German and British Infantry Tactics in the First World War (Westport, Connecticut: Greenwood Press, 1992)

Command or Control?: Command, Training and Tactics in the British and German Armies (London: Frank Cass, 1995)

"Dishonoured": The "Colonels' Surrender" at St. Quentin, The Retreat from Mons, August 1914 (London, 1994)

The Somme (London: Cassell Military, 2003) 
Sheffield, G.D. \&

Todman, D. (eds)

Sheffield, G.D.

Sheppard, A.

Simkins, P.

Simpson, A.

Simpson, A.

Simpson, A.

Snape, M.F.

Spiers, E. M.

Spiers, E. M.

Stevenson, D.

Strong, P. \&

Marble, S.

Tallett, K. \&

Tasker, T.

Travers, $\mathrm{T}$.

Travers, $\mathrm{T}$.
Command and Control on the Western Front: The British Army's Experience 1914-19 (Staplehurst: Spellmount, 2002)

Leadership in the Trenches: Officer-Man Relations, Morale and Discipline in the British Army in the Era of the First World War (Basingstoke: Macmillan in Association with King's College, London, 2000)

Sandhurst (Aylesbury: Country Life, 1980)

Kitchener's Army: The Raising of the New Armies, 1914-16 (Manchester: Manchester University Press, 1988)

Hot Blood \& Cold Steel: Life and Death in the Trenches of the First World War (London: Tom Donovan, 1993)

The Evolution of Victory: British Battles on the Western Front 1914-1918 (London: Tom Donovan, 1995)

Directing Operations: British Corps Command on the Western Front 1914-18 (Stroud: Spellmount, 2006)

God and the British Soldier: Religion and the British Army in the First and Second World Wars (London: Routledge, 2005)

The Army and Society, 1815-1914 (London: Longman, 1980)

The Late Victorian Army 1868-1902 (Manchester: University Press, 1992),

With Our Backs To The Wall - Victory and Defeat in 1918 (London: Allen Lane, 2011)

Artillery in the Great War (Barnsley: Pen \& Sword, 2011)

Gavrelle (Barnsley: Leo Cooper, 2000)

The Killing Ground: The British Army, the Western Front and the Emergence of Modern Warfare (London: Allen \& Unwin, 1987)

How the War Was Won: Command and Technology in the British Army on the Western Front (London: Routledge, 1992) 
Walker, J.

Wallace, E.

Williams, B.
The Blood Tub - General Gough and the Battle of Bullecourt, 1917 (Staplehurst: Spellmount, 1998)

Kitchener's Army and the Territorial Force (London: Newnes, 1916)

Raising and Training the New Armies (London: Constable \& Co. Ltd, 1918)

\section{II.4 Regimental Histories}

\section{Argyll and Sutherland Highlanders}

Anderson, R.C.B.

Cavendish, A.E.J.

\section{Bedfordshire Regiment}

Maurice, F.

Barrow, T.J., French, V.A Seabrook, J.

\section{Black Watch}

Wauchope, A.G.

Cassells, J.

\section{Border Regiment}

Wylly, H.C.

The Border Regiment in the Great War (Aldershot: Gale \& Polden, 1924)

\section{Buffs}

Ponsonby, C.
History of the Argyll \& Sutherland Highlanders, $1^{\text {st }}$ Battalion (1909-1939) (Printed for Private Circulation. Edinburgh: T. \& A. Constable, 1954)

The 93rd Sutherland Highlanders, now 2nd Battalion (1799-1927) (Printed for Private Circulation. Frome: Butler \& Tanner, 1928)

The 16th Foot. A History of the Bedfordshire and Hertfordshire Regiment (London: Constable, 1931)

The Story of the Bedfordshire and Hertfordshire \& Regiment Vol 2: 1914-1918 (Farnham: The Royal Anglian Regiment, 1986)

History of the Black Watch, Royal Highlanders, 191419183 vols (London: Medici Society, 1922-26)

The Black Watch, a Record in Action (New York: Doubleday, Page \& Co, 1918) 
Moody, R.S.

Historical Record of the Buffs, East Kent Regiment, $3^{\text {rd }}$ Foot, Vol 3 (London: Medici Society, 1922)

\section{Cambridgeshire Regiment}

Riddell, E.P.A

The Cambridgeshires, 1914-1919 Cambridge: Bowes \& \& Clayton, M.C.

Bowes, 1934)

\section{Cameronians (Scottish Rifles)}

Story, H.H.

History of the Cameronians (Scottish Rifles), Vol 2

1910-1933 (Aylesbury: Hazell, Watson \& Viney, 1961)

\section{Cheshire Regiment}

Crookenden, A.

The History of the Cheshire Regiment in the Great War (Chester: Crookenden, 1939)

\section{Coldstream Guards}

Ross of Bladensberg

The Coldstream Guards, 1914-1918 3 vols (London:

Sir J.F.G.

Oxford University Press, 1928)

\section{Connaught Rangers}

Jourdain, H.F.N \&

Fraser, E.

The Connaught Rangers 3 Vols (London: Royal United Service Institution, 1924-28).

\section{Devonshire Regiment}

Atkinson, C.T.

The Devonshire Regiment, 1914-1918 (Exeter: Eland Brothers, 1926)

\section{Dorsetshire Regiment}

Lock, H. C. \&

History of the Dorsetshire Regiment, 1914-1919

Vidler, O.C.

(Dorchester: Henry Ling, 1933)

\section{Duke of Cornwall's Light Infantry}

Wyrall, E.

The History of the Duke of Cornwall's Light Infantry 1914-1919 (London: Methuen, 1932)

\section{Duke of Wellington's Regiment}

Bruce, C.D.

History of the Duke of Wellington's Regiment 18811923 (London: Medici Society, 1927) 
Fisher, J.J.

\section{Durham Light Infantry}

Moore, W.

Miles, W.

\section{East Lancashire Regiment}

Nicholson, Sir C.L.

\& Macmullen, $\mathrm{H}$.

\section{East Surrey Regiment}

Pearse, H. W. \&

Sloman, H.S.

\section{East Yorkshire Regiment}

Wyrall, E.

Bilton, D.

\section{Essex Regiment}

Burrows, J.W.

Burrows, J.W.

\section{Gloucestershire Regiment}

Grazebook, R.M.

Wyrall, E.
History of the Duke of Wellington's Regiment during the First Three Years of the Great War (Halifax, Yorks: Fisher, 1918)

The Durham Light Infantry by William Moore (London: Leo Cooper, 1975)

The Durham Forces in the Field 1914-18, The Service Battalions of the D.L.I. (London: Cassell, 1920)

History of the East Lancashire Regiment in the Great War, 1914-1918 (Liverpool: Littlebury, 1936)

History of the East Surrey Regiment 2 Vols (London: Medici Society, 1924)

The East Yorkshire Regiment in the Great War (London: Harrison, 1918)

Hull Pals: $10^{\text {th }}, 11^{\text {th }}, 12^{\text {th }}$, \& $13^{\text {th }}$ (Service) Battalions of the East Yorkshire Regiment: A History of 92 Infantry Brigade $31^{\text {st }}$ Division (Barnsley: Pen \& Sword, 1999)

The Essex Regiment: 1st Battalion (Southendon-Sea: Burrows, 1931)

The Essex Regiment: 2nd Battalion (56 ${ }^{\text {th }}$ ) (Pompadours) (Southend-on-Sea: Burrows, 1937)

The Gloucestershire Regiment during the War, 191419182 Vols (Aldershot: Gale \& Polden, 1951)

The Gloucestershire Regiment in the War, 1914-1918:

The Records of the 1st (28th), 2nd (61st), 3rd (Special Reserve), and 4th, 5th and 6th (First Line T.A.) Bns (London: Methuen, 1931) 


\section{Gordon Highlanders}

Falls, C.

Life of a Regiment: Vol. 4 The Gordon Highlanders in the First World War, 1914-1919 (Aberdeen: Aberdeen University Press, 1958)

\section{Green Howards}

Wylly, H.C.

The Green Howards in the Great War (Privately Printed, 1926)

\section{Grenadier Guards}

Ponsonby, F.

The Grenadier Guards in the Great War, 1914-1918 3 Vols (London: Macmillan, 1920)

\section{Hampshire Regiment}

Atkinson, C.T.

The Royal Hampshire Regiment: Vol. 2, 1914-1918

(Winchester: Regimental HQ, 1952)

\section{Hertfordshire Regiment}

Sainsbury, J.D.

The Hertfordshire Regiment: An Illustrated History

(Ware, Herts:, Castlemead Publications, 1988)

\section{Highland Light Infantry}

Oatts, H.B.

Proud Heritage: The Story of the Highland Light

Infantry. Volume 3: 1882-1918 (London: Thomas Nelson \& Sons, 1961)

\section{Honourable Artillery Company}

Walker, G.G.

The Honourable Artillery Company in the Great War, 1914-1919 (London: Seeley, 1930)

Irish Guards

Kipling, R.

The Irish Guards in the Great War, 2 Vols (London: Macmillan, 1923)

\section{King's (Liverpool) Regiment}

Burke-Gaffney, J.J. The Story of the King's Regiment, 1914-1918

(Formby: Regimental HQ, 1954) 
Wyrrall, E.

Maddock, Graham
The History of the King's Regiment (Liverpool) 3 Vols (London: Arnold, 1928-35)

Liverpool Pals: $17^{\text {th }}, 18^{\text {th }}, 19^{\text {th }}, \& 20^{\text {th }}$ Battalions of the King's (Liverpool) Regiment, 1914-1919 (London: Leo Cooper, 1991)

\section{King's Own (Royal Lancaster) Regiment}

Cowper, J.M.

The King's Own, The Story of a Royal Regiment, Vol. 3 1914-1950 (Aldershot: Gale \& Polden, 1957)

\section{King's Own Scottish Borderers}

Gillon, S.

The King's Own Scottish Borderers in the Great War

(Berwick-on-Tweed: Regimental HQ, 1930)

\section{King's Own Yorkshire Light Infantry}

Bond, R.C.

The History of the King's Own Yorkshire Light Infantry in the Great War (London: Percy Lund Humphries, 1930)

\section{King's Royal Rifle Corps}

Hare, Sir S.

Annals of the King's Royal Rifle Corps: Volume 5 "The Great War" (London: John Murray, 1932)

\section{King's Shropshire Light Infantry}

Wood, W. de B.

The History of the King's Shropshire Light Infantry in the Great War (London: Medici Society, 1925)

\section{Lancashire Fusiliers}

Latter, J.C.

The History of the Lancashire Fusiliers, 1914-1918, 2 Vols (Aldershot: Gale \& Polden, 1949)

Stedman, M.

Salford Pals: A History of the $15^{\text {th }}, 16^{\text {th }}, 19^{\text {th }}$, \& 20 ${ }^{\text {th }}$ Battalions, Lancashire Fusiliers, 1914-1919: A History of the Salford Brigade (London: L. Cooper, 1993)

\section{Leicestershire Regiment}

Wylly, H.C.

History of the 1st and 2nd Battalions, the Leicestershire Regiment in the Great War (Aldershot: Gale \& Polden, 1928) 
Richardson, $\mathrm{M}$.

\section{Leinster Regiment}

Whitton, F.E.

\section{Lincolnshire Regiment}

Simpson, C.R.

\section{London Regiment}

Grey, W.E.

Grimwade, F.C.

Anon.

Maurice, Sir F.

Mitchinson, K.W.

Godfrey, E.G.

Planck, C.D.

Messenger, C.
The Tigers. 6th, 7th, 8th \& 9th (Service) Battalions of the Leicestershire Regiment (Barnsley: Leo Cooper, 2000)

The History of the Prince of Wales's Leinster Regiment (Royal Canadians) 2 Vols (Aldershot: Gale \& Polden, 1924)

The History of the Lincolnshire Regiment, 1914-1918 (London: Medici Society, 1931)

The 2nd City of London Regiment (Royal Fusiliers) in the Great War (London: Regimental HQ, 1929)

The War History of the 4th Bn. the London Regiment (Royal Fusiliers), 1914-1919 (London: Regimental HQ, 1922)

The History of the Old 2/4th (City of London) Battalion The London Regiment Royal Fusiliers (London, 1919)

The History of the London Rifle Brigade (London: Constable 1921)

Gentlemen and Officers: The Impact and Experience of War on a Territorial Regiment 1914-1918 [5th London Regiment (London Rifle Brigade)] (London: Imperial War Museum, 1995)

The "Cast-Iron" Sixth - A History of the 6th Battalion London Regiment (The City of London Rifles) (Published by F.S. Stapleton for the Old Comrades' Association, The City of London Rifles, 1938)

The History of the "Shiny Seventh" (London, 1946)

Terriers in the Trenches. The Post Office Rifles at War 1914-1918 (Chippenham: Picton, 1982) 
Keeson, C.A.C.

Wheeler-Holohan, A.V. \& Wyatt, G.M.G.

Bailey, O.F. \& Hollier, H.M.

Lindsay, J.H.

Hill, A.W.

Henriques, J.H.

Falls, C.

Elliot, W.R.

Shaw, R.J.H.
The History and Records of Queen Victoria's Rifles 1792-1922 (London: Constable, 1923)

The Rangers' Historical Records from 1859 to the Conclusion of the Great War (London: Harrison \& Sons, 1921)

The 'Kensingtons': 13th London Regiment (London: Regimental Old Comrades Association, n.d.)

The London Scottish in the Great War (London: Regimental Headquarters, 1926)

The History of the Prince of Wales's Own Civil Service Rifles (London: Wyman \& Sons, 1921)

War History of the 1st Battalion, Queen's Westminster Rifles, 1914-1918 (London: Medici Society, 1923)

War Record of the 21st London Regiment, First Surrey Rifles, 1914-1919 (London: Skinner, 1928)

The Second Twentieth. The History of the $2 / 20^{\text {th }} \mathrm{Bn}$. London Regiment (Aldershot: Gale \& Polden, 1920)

The 23rd London Regiment 1798-1919 (London: Times Publishing Co., 1936)

\section{Loyal North Lancashire Regiment}

Wylly, H.C.

A History of the Loyal North Lancashire Regiment. Vol. 2: 1914-1918 (London: RUSI, 1933)

\section{Manchester Regiment}

Wylly, H.C.

History of the Manchester Regiment (Late the 63rd and 96th Foot). Volume 2: 1883-1922 (London: Forster Groom \& Co Ltd, 1925)

Campbell, G.L.

The Manchesters. A History of the Regular, Militia, Special Reserve, Territorial, and New Army Battalions since their Formation: With a Record of the Officers now Serving, and the Honours and Casualties of the War of 1914-1916 (London: Picture Advertising Co., Ltd., 1916) 
Stedman, M.

Manchester Pals, 16th, 17th, 18th, 19th, 20th, 21st, 22nd \& 23rd Battalions of the Manchester Regiment. A History of the Two Manchester Brigades (London: Leo Cooper, 1994)

Middlesex Regiment

Wyrall, E.

The Die-Hards (Middlesex Regiment) in the Great War 2 Vols (London: Harrison, 1926-30)

\section{Monmouthshire Regiment}

Hughes, L. \&

Dixon, J.

"Surrender be Damned". A History of the $1 / 1^{\text {st }}$

Battalion The Monmouthshire Regiment 1914-1918

(Caerphilly: Cwm Press, 1995)

Dixon, J.

Out Since'14. A History of the 1/2nd Battalion The Monmouthshire Regiment 1914-1919 (Abertillery: Old Bake House Press, 2000)

Somerset, W.H.B.

On the Western Front. 1/3rd Battalion Monmouthshire Regiment (Abergavenny: Sergeant Bros, 1926)

\section{Norfolk Regiment}

Petre, F.L.

The History of the Norfolk Regiment 4 August 1914 to

31 December 1918 (Norwich: Jarrold \& Sons, 1953)

\section{Northamptonshire Regiment}

Anon. The Northamptonshire Regiment 1914-1918

(Aldershot: Gale \& Polden, ndl)

\section{North Staffordshire Regiment}

Anon.

History of the 1st and 2nd Bns. the North Staffordshire

Regiment, 1914-1923 (Longton: Hughes \& Harber, 1933)

\section{Northumberland Fusiliers}

Sandilands, H.R.

The Fifth in the Great War. A History of the 1st and

2nd Battalions, Northumberland Fusiliers, 1914-1918

(Dover: Grigg \& Sons, 1938) 


\section{Oxfordshire and Buckinghamshire Light Infantry}

Neville, J.E.H. History of the 43rd \& 52nd (Oxfordshire \& Bucks) Light Infantry in the Great War, 1914-1919

(Aldershot: Gale \& Polden, 1938)

\section{Queen's (Royal West Surrey Regiment)}

Wylly, H.C. History of the Queen's Royal (West Surrey) Regiment in the Great War (Aldershot: Gale \& Polden, 1925)

\section{Queen's Own (Royal West Kent Regiment)}

Atkinson, C.T.

The Queen's Own Royal West Kent Regiment, 19141919 (London: Simkin Marshall, 1924)

\section{Rifle Brigade}

Berkeley, R. \&

Seymour, W.W.

The History of the Rifle Brigade in the War of 191419183 Vols (London: Rifle Brigade Club, 1927-36)

\section{Royal Berkshire Regiment}

Petre, F.L.

The Royal Berkshire Regiment Volume 2: 1914-1918 (The Regiment, 1925)

\section{Royal Dublin Fusiliers}

Wylly, H.C.

Neill's 'Blue Caps': The History of the 1st Battalion, The Royal Dublin Fusiliers (Dublin: Maunsell, 1924)

Wylly, H.C.

Crown and Company: The Historical Records of the 2nd Battalion Royal Dublin Fusiliers, formerly the 1st Bombay Regiment Volume 2 1911-1922 (London: Arthur L. Humphreys, 1925)

\section{Royal Fusiliers}

O’Neill, H.C.

The Royal Fusiliers in the Great War (London: Heinemann, 1922)

\section{Royal Inniskilling Fusiliers}

Fox, Sir F.

The Royal Inniskilling Fusiliers in the Great War (London: Constable, 1928) 


\section{Royal Irish Fusiliers}

Burrowes, A.R.

\section{Royal Irish Regiment}

Geoghan, S.

\section{Royal Irish Rifles}

Falls, C.

\section{Royal Munster Fusiliers}

McCance, R.S.

Royal Scots

Ewing, J.

\section{Royal Scots Fusiliers}

Buchan, J.

\section{Royal Sussex Regiment}

Martineau, G.D.
The 1st Battalion, the Faugh-a-Ballaghs, Irish Fusiliers in the Great War (Aldershot: Gale \& Polden, 1926)

The Campaigns and History of the Royal Irish Regiment (Edinburgh: Blackwood, 1927)

The History of the First Seven Battalions, the Royal Irish Rifles (now the Royal Ulster Rifles) in the Great War (Aldershot: Gale \& Polden, 1925)

History of the Royal Munster Fusiliers

(Privately printed, 1937; Cork: Schull Books, 1995)

The Royal Scots, 1914-1919 2 Vols. (Edinburgh: Oliver \& Boyd, 1925)

The Royal Scots Fusiliers 1678-1918 (Edinburgh: Nelson, 1928)

A History of the Royal Sussex Regiment 1701-1953

(Chichester: Moore \& Tillyer, 1953)

\section{Royal Warwickshire Regiment}

Kingsford, C.L.

Carter, T.
The Story of the Royal Warwickshire Regiment (London: Newnes, 1921)

Birmingham Pals - 14th, 15th \& 16th Battalions of the Royal Warwickshire Regiment. A History of the Three City Battalions Raised in Birmingham in World War One (Barnsley: Pen \& Sword, 1997) 


\section{Royal Welsh Fusiliers}

Dudley-Ward, C.H.

Regimental Records of the Royal Welch Fusiliers $\left(23^{\text {rd }}\right.$ Regiment) (Vol. III) 1914-1918 (London: Forster Groom, 1921)

\section{Scots Guards}

Petre, F.L, Ewart, W. \&

The Scots Guards in the Great War, 1914-1918 Lowther C. (London: Murray, 1925)

\section{Seaforth Highlanders}

Haldane, M.M.

A History of the Fourth Battalion the Seaforth Highlanders (London: Witherby, 1928)

Sutherland, D.

War Diary of the Fifth Seaforth Highlanders, $51^{\text {st }}$ (Highland) Division (London: Lane, 1920)

Peel, R.T. \& The Great War 1914-1918: $6^{\text {th }}$ Seaforth Highlanders -

Macdonald, A.H. Campaign Reminiscences (Elgin: W.R. Walker, 1923)

\section{Sherwood Foresters}

Truscott, R.F.

A Short History of the Sherwood Foresters (Nottinghamshire and Derbyshire Regiment (Aldershot: Gale \& Polden, 1919)

\section{Somerset Light Infantry}

Wyrall, E.

The History of the Somerset Light Infantry, Prince Albert's, 1914-1919 (London: Methuen, 1927)

\section{South Lancashire Regiment}

Whaley-Kelly, H.

The South Lancashire Regiment, 1914-34: Ich Dien, The Prince of Wales's Volunteers (Aldershot, 1935; reprinted D. P. \& G. Military Publishers, 2002)

\section{South Staffordshire Regiment}

Vale, W.L.

A History of the South Staffordshire Regiment

(Aldershot: Gale \& Polden, 1969) 
South Wales Borderers

Atkinson, C.T.

Suffolk Regiment

Murphy, C.C.R.

\section{Welch Regiment}

Marden, T.

Welsh Guards

Dudley-Ward, C.H.

West Yorkshire Regiment

Wyrall, E.

\section{Wiltshire Regiment}

Astill, E.

Shepherd, W.S.
The History of the South Wales Borderers, 1914-1918 (London: Medici Society, 1931)

The History of the Suffolk Regiment, 1914-1927 (London: Hutchinson, 1928)

A History of the Welsh Regiment (Cardiff: Western Mail, 1932)

History of the Welsh Guards (London: Murray, 1920)

The West Yorkshire Regiment in the War, 1914-1918

(London: Lane, 1924)

The $1^{\text {st }}$ Battalion the Wiltshire Regiment in the Great War (Salisbury: RGBW (Salisbury) Museum, 2005)

The 2nd Battalion Wiltshire Regiment (99th): A Record of their Fighting in the Great War, 1914-18 (Aldershot: Gale and Polden, 1927)

\section{Worcestershire Regiment}

Stacke, H.FitzM.

The Worcestershire Regiment in the Great War (Kidderminster: Cheshire \& Sons, 1929)

\section{York and Lancaster Regiment}

Cooksey, J.

Pals: The 13th \& 14th Battalions, York and Lancaster Regiment (London: Leo Cooper, 1996)

\section{II.5 Formation Histories (listed in order of formation)}

Headlam, C.

History of the Guards Division in the Great War 2 Vols (London: John Murray, 1924) 
Wyrall, E.

McNish, R.

Hussey, A.H. \& Inman, D.S.

Marden, T.O.

Atkinson, C.T.

Boraston, J.H.

Bax, C.E.O.

Ewing, J.

Scott, A.B. \&

Brumwell, P.M.

Stewart, J. \&

Buchan, J.

Denman, T.

Atteridge, A.H.

Nicholls, G.H.F.

Wyrall, E.

Jeffrys, G.D.

Inglefield, V.E.

Sandilands, H.R.
History of the Second Division, 1914-1918 2 Vols

(2v. London: Nelson, 1921)

Iron Division: The History of the Third Division

(London: Ian Allan, 1978)

The Fifth Division in the Great War

(London: Nisbet, 1921)

A Short History of the 6th Division August 1914-March 1919 (London: Rees, 1920)

The Seventh Division, 1914-1918 (London: John Murray, 1927)

The Eighth Division in War (London: Medici Society, 1926)

The History of the 9th (Scottish) Division, 1914-1919

(London: John Murray, 1921)

History of the 12th (Eastern) Division in the Great War (London: Nisbet, 1923)

The Fifteenth (Scottish) Division, 1914-1919

(London: Blackwood, 1926)

Ireland's Unknown Soldiers. The 16th (Irish) Division in the Great War, 1914-1918 (Dublin: Irish Academic Press, 1992)

History of the 17th (Northern) Division (Glasgow:

Maclehose, 1929)

The 18th Division in the Great War (London:

Blackwood, 1922)

History of the 19th Division, 1914-1918 (London:

Arnold, 1932)

A Short History of the 19th (Western) Division

(London: John Murray, 1919)

History of the Twentieth (Light) Division

(London: Nisbet, 1921)

The 23rd Division, 1914-1919 (London: Blackwood, 1925) 
Kincaid-Smith, $\mathrm{M}$.

Gillon, S.

Flenley, R.

Hutchison, G.S.

Shakespear, J.

Davson, H.M.

Falls, C.

Anon.

Munby, J.E.

Whitton, F.E.

Gibbon, F.P.

Priestley, R.E.

Johnston, P.S.C.C.

MacDonald, A.

Maude, A.H.

Wyrall, E.
The 25th Division in France and Flanders (London: Harrison, 1920)

The Story of the 29th Division (London: T. Nelson, 1925)

A Brief History of the 30th Division (War Narratives Publishing, 1919)

The Thirty-Third Division in France and Flanders, 1915-1919 (London: Waterloo, 1921)

The Thirty-Fourth Division, 1915-1919 (London: Witherby, 1921)

The History of the 35th Division in the Great War (London: Sifton Praed, 1927)

History of the Thirty-Sixth (Ulster) Division (London: McCaw, Stevenson \& Orr, 1922)

The Golden Horseshoe. The Journal of the $37^{\text {th }}$ Division (London: Cassell, 1919)

A History of the 38th Division (London: Rees, 1920)

History of the 40th Division (Aldershot: Gale \& Polden, 1926)

The 42nd East Lancashire Division, 1914-1918 (London: Country Life, 1920)

Breaking the Hindenburg Line: The Story of the $46^{\text {th }}$ Division (London: Fisher \& Unwin, 1919)

The $46^{\text {th }}$ Division at Lens in 1917 (London: Fisher Unwin, 1919)

A Lack of Offensive Spirit? The $46^{\text {th }}$ (North Midland) Division at Gommecourt, 1 July 1916 (Iona Books, 2008)

The 47th (London) Division, 1914-1919

(London: Stapleton, 1922)

The History of the Fiftieth Division, 1914-1919

(London: Percy Lund Humphries, 1939) 
Bewsher, F.W.

Thompson, R.R.

Dudley-Ward, C.H.

Coop, J.O.

Dudley-Ward, C.H.

Bradbridge, E.U.

Dalbiac, P.H.

Wyrall, E.

Jerrold, D.

Dudley-Ward, C.H.
History of the 51st (Highland) Division, 1914-1918

(Edinburgh: Blackwood, 1921)

The Fifty-Second (Lowland) Division, 1914-1918

(Glasgow: Maclehose, Jackson \& Co, 1923)

History of the 53rd (Welsh) Division, 1914-1918

(Cardiff: Western Mail, 1927)

The Story of the 55th (West Lancashire) Division (Liverpool: Daily Post Printers, 1919)

The 56th Division - 1st London Territorial Division (London: John Murray, 1921)

The 59th Division 1915-1918 (Chesterfield:

Wilfred Edmunds, 1928)

History of the 60th Division - 2/2nd London Division (London: Allen \& Unwin, 1927)

The History of the 62nd (West Riding) Division, 191419192 Vols (London: Lane, 1924-25)

The Royal Naval Division (London: Hutchinson, 1923)

The 74th (Yeomanry) Division in Syria and France (London: John Murray, 1922)

\section{II.6 Unit Histories}

Baynes, J.

Morale: A Study of Men and Courage, The Second Rifles at the Battle of Neuve Chapelle (London: Cassell, 1967)

Bowman, T.

Irish Regiments in the Great War: Discipline and Morale (Manchester: Manchester University Press, 2003)

Canning, W.J.

Ballyshannon, Beloo, Bertincourt (Enniskillen : Trimble 1996)

Clayton, D.

From Pontefract to Picardy. The 9th King's Own Yorkshire Light Infantry in the First World War (Stroud: Tempus Publishing, 2004)

Crutwell, C.R.M.F.

The War Service of the 1/4th Royal Berkshire Regiment (T.F.) (London : Blackwell, 1922) 
Gibson R. \& Oldfield, P. Sheffield City Battalion (Barnsley: Pen \& Sword, 2006)

Jamieson, W.D.

Men of the High Peak: A History of the 1/6th Battalion

(Housey, C. ed)

the Sherwood Foresters (Long Eaton : Millquest, N.D.)

Knight, J.

The Civil Service Rifles in the Great War (Barnsley: Pen \& Sword, 2004)

Langley, D.

Duty Done : $2^{\text {nd }}$ Battalion The Royal Welch Fusiliers in the Great War (Caernarfon : Royal Welch Fusiliers Museum, 2001)

MacCartney, H. B.

Citizen Soldiers: The Liverpool Territorials in the First World War (Cambridge: Cambridge University Press, 2005)

Merrick, E.

The History of the Prince of Wales' Own Civil Service Rifles (London: Wyman, 1921)

Milner, L.

Leeds Pals: A History of the $15^{\text {th }}$ (Service) Battalion $\left(1^{\text {st }}\right.$ Leeds), the Prince of Wales' Own (West Yorkshire Regiment), 1914-1918 (London: Leo Cooper, 1991)

Ponsonby, Sir F.

The Grenadier Guards in the Great War, 1914-1918, Vol.1 (London Macmillan, 1920)

Raw, D.

Bradford Pals: A Comprehensive History of the 16th and 18th (Service) Battalions the Prince of Wales' Own West Yorkshire Regiment (Pen \& Sword: Barnsley, 2005)

Sanbourn, J.B. and Malstrom, G.N.

The $131^{\text {st }}$ U.S. Infantry in the World War (Chicage: unknown publisher, 19190

Skirrow, F.

Massacre on the Marne: The Life and Death of the 2/5th Battalion West Yorkshire Regiment in the Great War (Barnsley: Pen \& Sword, 2007)

Turner, W.

Pals: The $11^{\text {th }}$ (Service) Battalion (Accrington) East Lancashire Regiment (Barnsley: Pen \& Sword, 1998)

Pagan, A.W.

Infantry. An Account of the $1^{\text {st }}$ Gloucestershire Regiment during the War, 1914-18 (Aldershot: Gale \& Polden, 1951)

Dunn, J.C.

The War the Infantry Knew, 1914-1919 (London: Jane's, 1987) 
V.M. (ed.)

\section{II.7 Biographies}

Anon

Baynes, J.

Bojerud, S.

Bujak, P.

Kentish, B.

Lindsay, D.

Murland, J. \& J.

Page, C.

Pedersen P.A.

Sadler, P.S.
Record of the XIth (Service) Battalion Border Regiment (Lonsdale) from September 1914 to July 1 st 1916 (Whitehead: Appleby, N.D.)

Brigadier-General R B Bradford VC MC and His

Brothers (Newport: Ray Weslake, n.d.)

Far from a Donkey (London: Brassey’s 1995)

Ivor Thord-Gray - Soldat under 13 Fanor (Stockholm, Sivart Förlag AB, 2008)

Undefeated: The Extraordinary Life and Death of Lt. Col. Jack Sherwood Kelly VC, CMG, DSO (Great Britain: Forster Consulting, 208)

This Foul Thing Called War. The Life of Brigadier General $R J$ Kentish (Lewes, Sussex: The Book Guild, 1997)

Forgotten General: A Life of Andrew Thorne by (Salisbury: Michael Russell, 1987)

Departed Warriors: The Story of a Family in War (Leicester: Matador, 2008)

Command in the Royal Naval Division. A Military Biography of Brigadier General A $M$ Asquith DSO by Christopher Page (Staplehurst: Spellmount, 1999)

Monash as Military Commander (Victoria: Melbourne University Press, 1992)

The Paladin: The Life of Major-General Sir John Gellibrand (Melbourne: Oxford University Press, 2000)

\section{II.8 Autobiographies, Diaries, Memoirs and Letters}

Adams, B.

Nothing of Importance: A Record of Eight Months at the Front with A Welsh Battalion (Herts: Strong Oak Press, 1988)

Adam, A.I.

Arthur Innes Adam 1894-1916 - A Record Founded on

(Adam, A.M. ed) His Letters (Cambridge: Bowes \& Bowes, 1920)

Andrews, W.L.

Haunting Years (London: Hutchinson, 1930) 
Ashurst, G.

Astill, E. (ed)

Beach, J.

Beauman, A.B.

Behrend, A.

Behrend, A.

Bell, D.H.

Bendall, F.W.D

Bickersteth, J. (ed.)

Bishop, A. \&

Bostridge, M.

Bishop, H.C.W.

Blacker, C.P.

Blatchford, R.P.G

Blunden, E.

Blunden, E.

Buckley, F.

Burgoyne, G.A.

(Davison, C. ed.)

Cadogan, $\mathrm{H}$.
My Bit (Marlborough: Crowood Press, 1987)

The Great War Diaries of Brigadier-General Alexander Johnston 1914-1917 (Barnsley: Pen \& Sword, 2007)

The Military Papers of Lieutenant-Colonel Sir Cuthbert Headlam 1910-1942 (Stroud: The History Press for The Army Records Society, 2010)

Then A Soldier (London: P.R. Macmillan Ltd., 1960)

Make Me a Soldier (London: Eyre \& Spottiswoode, 1961)

As From Kemmel Hill: An Adjutant in France and Flanders (London: Eyre \& Spottiswoode, 1963)

A Soldier's Diary of the Great War (London: Faber, 1929)

Front Line Lyrics (London: E. Mathews, 1918)

The Bickersteth Diaries 1914-1918 (London: Leo Cooper, 1996)

Letters from a Lost Generation. First World War Letters of Vera Brittain and Four Friends (London: Little, Brown, 1998)

A Kut Prisoner (London: John Lane, 1920)

Have You Forgotten Yet?: The First World War Memoirs of C.P. Blacker, M.C., G.M., M.A., M.D., F.R.C.P., M.R.C.S. (Barnsley: Leo Cooper, 2000)

My Life in the Army (London: Clarion Press, 1010)

Undertones of War (London: Collins, 1965)

Poems of Many Years (London: Collins, 1957)

Q.6.A. and Other Places (London: Spottiswoode Ballantyne, 1920)

The Burgoyne Diaries (Avon: Bath Press, 1985)

The Road to Armageddon (Wrexham: Bridge Books, 2009) 
Campbell P.J.

Campbell, P.J.

Carrington, C.E.

Carton de Wiart, Sir A.

Chapman, G.

Chapman, G.

Charatan, K \&

Cecil C. (eds.)

Clapham, H.S.

Clayton, C.P.

Cloete, S.

Colwill, R.A.

Congreve, B

Coppard, G

Crawford, J. (ed)

Croft, H.P.

Croft, W.D.

Crozier, F.P.

Crozier, F.P.

Cuddeford, D.J.
The Ebb and Flow of Battle (London: Hamish Hamilton, 1977)

In the Cannon's Mouth (London: Hamish Hamilton, 1979)

Soldier from the Wars Returning (London: Hutchinson, 1965)

Happy Odyssey (London: Jonathan Cape, 1950)

A Passionate Prodigality (London: Nicholson \& Watson, 1933)

Vain Glory (London: Cassell, 1937)

Under Fire in the Dardanelles - The Great War Diaries \& Photographs of Major Edward Cadogan (Barnsley; Pen \& Sword, 2006)

Mud and Khaki (London: Hutchinson, 1930)

The Hungry One (Gomer Press:Llandysul, 1978)

A Victorian Son (London: Collins, 1972)

Through Hell to Victory - From Passchendaele to Mons with the 2nd Devons in 1918 (Torquay: Colwill, 1927)

Armageddon Road (London: William Kimber, 1982)

With a Machine Gun to Cambrai (London: HMSO, 1969)

The Devil's Own War: The First World War Diary of Brigadier-General Herbert Hart (Titirangi, Auckland: Exisle, 2008)

Twenty Two Months Under Fire (London: John Murray, 1917)

Three Years With The 9th (Scottish) Division (London: John Murray, 1919)

A Brass Hat In No Man's Land (London: Jonathan Cape, 1930)

The Men I Killed (London: Michael Joseph, 1937)

And All For What? (London: Heath Cranton, 1933) 
Cumming, H.R.

Dawson, A.J.

Devenish, G.W .

Dennys, W.A.B.

Douie, C.

Dugdale, G.

Dunn, J.C. (ed)

Edmonds, C.

Eyre, G.

Feilding, R.

Findlay, J.M.

Floyd, T.H.

Fraser, W.

Fraser-Tytler, N.

Fryer, E.R.M.

Gillam, J.G.
A Brigadier in France, 1917-1918 (London: Jonathan Cape, 1922)

A "Temporary Gentleman" in France: Home Letters from an Officer in the New Army (London: Cassell, 1916)

A Subaltern's Share in the War: Home Letters of the Late George Weston Devenish (London: Constable and Company Ltd., 1917)

Some Reminiscences of My Life (Privately printed, 1935)

The Weary Road: Recollections of a Subaltern of Infantry (London: Murray, 1929)

Langemarck and Cambrai (Uckfield: Naval \& Military, 2005)

The War the Infantry Knew, 1914-1919: A Chronicle of Service in France and Belgium with the Second Battalion, His Majesty's Twenty-third Foot, the Royal Welsh Fusiliers (1938; London: Janes, 1987)

A Subaltern's War (1929; London: Anthony Mott Ltd, 1984)

Somme Harvest (London: London Stamp Exchange, 1991)

War Letters to a Wife: France and Flanders, 1915-1919 (London: Medici Society, 1929)

With the $8^{\text {th }}$ Scottish Rifles 1914-1919 (London: Blackie \& Sons, 1926)

At Ypres With Best-Dunkley (Boston: Indypublish, n.d.)

In Good Company - The First World War Letters and Diaries of the Hon. William Fraser, Gordon Highlanders(Salisbury: Michael Russell, 1990)

Field Guns in France (London: Hutchinson, 1922)

Reminiscences of a Grenadier 1914-1919 (London: Digby, 1921)

Gallipoli Diary (London: George Allen \& Unwin, 1918) 
Gladden, N.

Godfrey, E. G.

Graves, R.

Greenwell, G.

Hamilton, R.G.A.
Ypres, 1917: A Personal Account (London: William Kimber, 1967)

The Cast Iron Sixth (Uckfield: Naval \& Military, 2001)

Goodbye to All That (London: Cape, 1929)

An Infant in Arms: War Letters of a Company Officer (London: Dickson \& Thompson, 1935)

The War Diary of the Master of Belhaven 1914-1918

(Barnsley: Wharncliffe, originally published 1924)

Hanbury-Sparrow, A.A.H. The Land-locked Lake (London: Arthur Barker, 1932)

Hankey, D.

A Student in Arms (London: Andrew Melrose, 1917)

Harington, C.

Tim Harington Looks Back (London: John Murray, 1940)

Hart, B.H.L.

Hay, I. B.

Hermon, E.W.

Hitchcock, F.C.

Hoyle, J.B.

Husbands G.R (Bourne, J. Joffrey's War: A Sherwood Forester in the Great \& Bushaway B. eds)

Jeffreys, R.G.B.

(Dodd, C. \& L. eds)

Jones, D.

Kelly, D.V.

Lambert, A.

Laurie, G.B.
Some Letters from a Subaltern on the Western Front (Uckfield: Naval \& Military Press, 2009, originally published 1917) War (Nottingham: Salient Books, 2011)

The Memoirs of Captain Liddell Hart, Vol. 1 (London: Cassell, 1965)

The First Hundred Thousand (London: William Blackwood \& Sons, 1915)

For Love \& Courage (Lomdon: Preface, 2008)

'Stand To': A Diary of the Trenches, 1915-1918 (London: Hurst \& Blackett, 1937)

Lieutenant- Colonel R.G.B. Jeffreys, Collected Letters 1916-1918 (Dublin: Old Tough, 2007)

In Parenthesis (London: Faber \& Faber, 1937)

39 Months with the 'Tigers' (London: Benn, 1930)

Over the Top - A 'P.B.I.' in the H.A.C. (London John Long, N.D.)

Letters (Aldershot: Gale \& Polden, 1921) 
Lucy, J.

MacGill, P.

MacGill, P.

Macmillan, $\mathrm{H}$.

Mark VII (Plowman, M.)

Martin, B.

Maxwell, F.

(Maxwell, C. ed)

Maxwell, R.M.

Montague, C.E.

Montgomery, B.L.

Murray, J.

Nason, A.

Nicholls, G.F.H. (Quex)

Nicholson, W.N.

'Orex’ (Bidder, H.F.)

Parker, E.W.

Patterson, J.H.

Pilcher, T.D.
There's a Devil in the Drum (London: Faber, 1938)

The Amateur Army (London: Herbert Jenkins, 1916)

Great Push - An Episode of the Great War (London: Herbert Jenkins, 1916)

Winds of Change, 1914-1939 (London: Macmillan, 1966)

A Subaltern on the Somme (London: Dent, 1927)

Poor Bloody Infantry (London John Murray, 1987)

I Am Ready (London: Hazell Watson and Viney, 1955)

Villiers-Stuart Goes to War (Kippielaw: Pentland Press, 1990)

Disenchantment (London: Chatto \& Windus, 1924)

The Memoirs of Field-Marshal the Viscount Montgomery of Alamein, K.G. (London: Collins, 1958)

Gallipoli 1915 (Bristol: Cerberus, 2004, originally published 1965)

For Love and Courage - The Letters of Lieutenant Colonel E.W. Hermon from the Western Front 1914-1917 (London: Preface, 2008)

Pushed and the Return Push (Edinburgh: William Blackwood, 1919)

Behind the Lines: An Account of Administrative Staffwork in the British Army 1914-1918 (Herts: Strong Oak Press, 1939)

Three Chevrons (London; John Lane, 1919)

Into Battle - A Seventeen-Year-Old Joins Kitchener's Army (London: Leo Cooper, 1994)

With the Judeans in the Palestine Campaign (London: Hutchinson, 1922)

A General's Letters to his Son on Obtaining his Commission (London: Cassell, 1917) 
Pollard, A.F.

Popplewell, J. (ed)

Quigley, H.

Reith, J.

Reitz, D.

Richards, F.

Richards, F.

Rifleman, A.

Rogerson, S.

Ross, R.B.

Sansom, A.J.

Sassoon, S.

Sassoon, S.

(Hart-Davis, R. ed)

Seeley, J.

Seton, G. (G.S. Hutchinson) Footslogger (London: Hutchinson, 1933)

Sheffield, G.D. \&

Bourne, J.M. (eds)

Terraine, J.

Thomas, A.

Vaughan, E. C.
Fire Eater - The Memoirs of a V.C. (London:

Hutchinson, 1932)

A Gloucestershire Diarist - Lt. Col. A.B. Lloyd-Baker of Hardwicke Court (Gloucestershire: Thornhill, 1993)

Passchendaele and the Somme - A Diary of 1917 (Uckfield: Naval \& Military, originally published 1928)

Wearing Spurs (London: Hutchinson, 1966)

Trekking On (London: Faber, 1933)

Old Soldier Sahib (Uckfield: Naval and Military Press, 2003 originally published 1936)

Old Soldiers Never Die (London: Faber, 1965)

Four Years on the Western Front (London: Odhams, 1922)

Twelve Days on the Somme (London: Greenhill, 2006)

The Fifty-First in France (London: Hodder \& Stoughton, 1918)

Letters from France, June 1915-July 1917 (Melrose: n.d.)

The Complete Memoirs of George Sherston (London: Faber \& Faber, 1972)

Siegfried Sassoon Diaries 1915-1918

(London: Faber \& Faber, 1983)

Adventure (London: Heinemann, 1930)

Douglas Haig: War Diaries and Letters 1914-1918

(London: Weidenfeld \& Nicholson Military, 2005)

General Jack's Diary, 1914-1918: The Trench Diary of Brigadier-General J. L. Jack (London: Eyre \& Spottiswoode, 1964)

A Life Apart (Letchworth: Garden City Press, 1968)

Some Desperate Glory: The Diary of a Young Officer, 1917 (London: Frederick Warne, 1982) 
West, A.G.

The Diary of a Dead Officer (London: George Allen \& Unwin, n.d.)

\section{II.9 Articles in Scholarly Journals and Chapters in Books}

Almog, D.

Bourne, J.M.

Bourne, J.M.

Bourne, J.M.

Bowman, T.

Brennan, P.H.

Brennan, P.H.

Bryson, R. N.

Corbett, J.

Gossett, M.
'Positioning the Battalion Commander: The Advance and Pursuit from Awali to Beirut, 6-13 June 1982', Military Operations, 1 (2012) pp.13-16

'British Generals in the First World War', in G.D. Sheffield (ed), Leadership and Command in War: The Anglo-American Military Experience since 1861 (London: Brasseys, 1997, 2002), pp. 93-116

'The BEF's Generals on 29 September 1918: An Empirical Portrait with Some British and Australian Comparisons', in Peter Dennis \& Jeffrey Grey (eds), 1918 Defining Victory. Proceedings of the Chief of Army's History Conference Held at the National Convention Centre, Canberra, 29 September 1998 (Canberra, Australia: Army History Unit, Department of Defence, 1999), pp. 96-113

'British Divisional Commanders during the Great War: First Thoughts', Gun Fire: A Journal of First World War History 29 (nd)

'Officering Kitchener's Armies: A Case Study of the 36th (Ulster) Division,' War In History 16 (2) (2009) pp.189-212

'Good Men for a Hard Job: Infantry Battalion Commanders in the Canadian Expeditionary Force', Canadian Army Journal 9 (1) (2006)

'Completely Worn Out by Service in France', Canadian Military History, 18 (2) (2009)

'The Once and Future Army', in Brian Bond et al, eds., 'Look to Your Front': Studies in the First World War (Staplehurst: Spellmount, 1999)

'The Colonel and his Command,' American Historical Review, 2(1) (1896)

'Battalion Command', Royal United Services Institution Journal, 35 (1891), pp.469-486 
Griffith, P.

Harvey, A.D.

Harris, P. \&

Marble, S.

Keats-Rohan, K.S.B

Lee, J.

Lee, $\mathrm{J}$.

McCarthy, C.

Nadin, D.L. (ed.)

Otley, C.B.

Peel, S.

Razzell, P.E.
'The Extent of Tactical Reform in the British Army', in Paddy Griffith, ed., British Fighting Methods in the Great War (London: Frank Cass, 1996), pp. 1-22

'A Good War: Wartime Officers Who Rose to Command Level in the First World War', Royal United Services Institution Journal 153 (2) (2008)

'British Military Thought and Operational Method on the Western Front, 1915-1917', War in History, 15 (1) (2008), pp. 184-5

'Prosopography and Computing: A Marrigae Made in Heaven?', History and Computing, 12 (2000) pp.1-11

'Some Lessons of the Somme: The British Infantry in 1917', in Brian Bond et al eds., 'Look to Your Front': Studies in the First World War (Staplehurst: Spellmount, 1999), pp. 79-88

'The SHLM Project - Assessing the Battle Performance of British Divisions' in P. Griffith (ed.) British Fighting Methods in the Great War (Abingdon: Frank Cass, 1996) pp.175-181

'Queen of the Battlefield: The Development of Command Organisation and Tactics in the British Infantry Battalion during the Great War' in G. Sheffield \& D. Todman, eds. Command and Control on the Western Front (Staplehurst: Spellmount, 2004)

'Frank Naden', Roots and Branches, the Naden/Nadin/Neden/Nedin Family Society Magazine, 10 (2).

'The Social Origins of British Army Officers', Sociological Review, 18 (2) (1970), pp.213-40

'The Territorial Force', Army Quarterly, 1:1 (1920) pp.26-54

'Social Origins of Officers in the Indian and British Home Army: 1758-1862.' British Journal of Sociology 14 (1963), pp. $248-260$ 
Simkins, $\mathrm{P}$.

Simkins, $\mathrm{P}$.

Simpson, K.

Slater, C.G.

Travers, $\mathrm{T}$.

Vagts, A.

Vandam, A.D.
'Co-Stars or Supporting Cast?: British Divisions in the "Hundred Days", 1918', in Paddy Griffith, ed., British Fighting Methods in the Great War (London: Frank Cass, 1996), pp. 50-69

'Somme Reprise: Reflections on the Fighting for Albert and Bapaume, August 1918', in Brian Bond et al eds., 'Look to Your Front': Studies in the First World War (Staplehurst: Spellmount, 1999), pp. 147-62

'The Officers', in Ian F.W. Beckett \& Keith Simpson (eds), A Nation in Arms. A Social Study of the British Army in the First World War (Manchester: Manchester University Press, 1985), pp. 63-97

'The Problem of Purchase Abolition in the British Army 1856-1862,' South African Military History Society Journal 2(6) 1979, www.samilitaryhistory.org

'The hidden army: structural problems in the British officer corps, 1900-1918', Journal of Contemporary History (Issue 17, 1982)

"Age and Field Command', Military Affairs 6 (1942), pp. 1320

'Officers in the French Army', North American Review, 165 (413) (1897), pp.722-732

\section{II.10 Unpublished and Conference Papers}

Root, L.

Simkins, P.
'Temporary Gentlemen on the Western Front: Class Consciousness and the British Army Officer 1914-1918', paper presented at the National Council on Undergraduate Research, Virginia Military Institute, Lexington VA, April 2005.

'Forgotten Heroes: Some Personal Reflections' (unpublished)

\section{II.11 Works of Reference}

Anon

Anon
Soldiers Died in the Great War Version 2.5

(Naval \& Military Press, (2011)

The VC and DSO Book Vol III (Uckfield: Naval \& Military Press, 2010) 
Anon

Becke, A.F.

Becke, A.F.

Becke, A.F.

Becke, A.F.

Beckett, Ian F.W.

Edmonds, J.E.

Edmonds, J.E.

Edmonds J.E. and Maxwell-Hyslop, R.

James, E.A.

Jarvis, S.D. \& D.B.
The Territorial Year Book (London: Hodder \& Stoughton, 1909)

Order of Battle of Divisions, Part 1 - The Regular British Divisions (Uckfield: Naval \& Military, 2007)

Order of Battle of Divisions, Part2 - The Territorial Force Mounted Divisions and The First-Line Territorial Force Divisions (Uckfield: Naval \& Military, 2007) Order of Battle of Divisions, Part 3a-New Army Divisions (Uckfield: Naval \& Military, 2007)

Order of Battle of Divisions, Part 4 - The Army Council, G.H.Q.s, and Corps 1914-1918 (Uckfield: Naval \& Military, 2007)

The First World War: The Essential Guide to Sources in the UK National Archives (Surrey: Public Record Office, 2002)

Military Operations, France and Belgium 1914, Vol. 1 (Nashville: Battery Press, 1996)

Military Operations, France and Belgium 1914, Vol. II (London: Macmillan 1925)

Military Operations, France and Belgium 1918, Vol. V (London: Imperial War Museum, original date 1947)

British Regiments 1914-1918 (London: Samson, 1978)

The Cross of Sacrifice: Officers Who Died in the Service of British, Indian and East African Regiments and Corps, 1914-1919 (Reading: Roberts Medals, 1993)

\section{II.12 Official Publications}

\section{II.10.1 General}

Anon

Notes for Commanding Officers (Aldershot: Gale

Polden, 1917)

Anon

Notes for Commanding Officers (Aldershot: Gale

Polden, November 1918)

Hansard

House of Commons debate, 22 April 1915, Vol

71 cc $434-552$ 
Hansard

HMSO

HMSO

HMSO

HMSO

War Office

II.10.2 Manuals etc.

General Staff

General Staff

General Staff

General Staff

General Staff

War Office

II.10.3 Army Lists

War Office
House of Commons debate, 29 November 1917, Vol 99 cc1967-76

Return as to the Number of Commissions granted during each of the years 1885 to 1906 inclusive Parliamentary Paper 111 (1907)

Report of the Royal Commission on Army

Promotion and Retirement Parliamentary Paper C.1569 (1876)

Revised Memorandum Showing Principal Changes in Army Organization from July 1881 Parliamentary Paper C.2922 (1881)

Report of the Committee appointed to consider the Education and Training of Officers of the Army Cd. 982 (1902)

Statistics of the Military Effort of the British Empire during the Great War, 1914-1920 (London: HMSO, 1922)

Combined Training 1902 (London: HMSO, 1902)

Field Service Regulations : Part I (London : HMSO, 1909)

Field Service Regulations : Part II - Organization and Administration (London : HMSO, October 1914)

SS143: Instructions for the Training of Platoons for Offensive Action (February 1917)

SS135: The Training and Employment of Divisions (November 1918)

The King's Regulations and Orders for the Army, 1912. Reprinted with Amendments Published in Army Orders up to 1 August 1914. (London: HMSO, 1914)

The Official Army List for the Quarter Ending 31st December 1901 (London : HMSO, 1902) 
War Office

War Office

War Office

War Office

War Office

War Office

War Office

War Office

War Office

War Office

War Office

War Office

War Office

War Office

War Office

War Office
The Quarterly Army List for the Quarter Ending 31st March 1914 (London: HMSO, 1914)

The Quarterly Army List for the Quarter Ending 31st December 1915 (London: HMSO, 1916)

The Quarterly Army List for the Quarter Ending 31st December 1917 (London: HMSO, 1918)

The Quarterly Army List for the Quarter Ending 31st December 1917 (London: HMSO, 1918)

The Quarterly Army List for the Quarter Ending 31st December 1919 (London: HMSO, 1919)

The Quarterly Army List for the Quarter Ending 31st December 1919 - Part II. War Services of the Officers of the Army, etc. 4 Vols (London: HMSO, 1919)

The Monthly Army List, July 1911 (London: HMSO, 1911)

The Monthly Army List, August1914 (London: HMSO, 1914)

The Monthly Army List, October1914 (London: HMSO, 1914)

The Monthly Army List, January 1915 (London: HMSO, 1915)

The Monthly Army List, July 1915 (London: HMSO, 1915)

The Monthly Army List, January 1916 (London: HMSO, 1916)

The Monthly Army List, July 1916 (London: HMSO, 1916)

The Monthly Army List, November 1916 (London: HMSO, 1916)

The Monthly Army List, April 1917 (London:

HMSO, 1917)

The Monthly Army List, October 1917 (London: HMSO, 1917) 
War Office

War Office

War Office

Hart, H.G.

\section{II.13 Other}

Dixon, $N$.

Doerry, M.

Fiedler, F.E.

Gross, J. (ed)
The Monthly Army List, August 1918 (London:

HMSO, 1918)

The Monthly Army List, December 1918 (London:

HMSO, 1919)

The Monthly Army List, December 1919 (London:

HMSO, 1920)

Hart's Annual Army List 1915 (London: John Murray, 1915)

On the Psychology of Military Incompetence (London: Jonathan Cape, 1977)

My Wounded Heart - The Life of Lilli Jahn 1900-1944 (London: Bloomsbury, 2004)

Leadership (New York: General Learning Press, 1971)

Rudyard Kipling: The Man, His Work and His World (London: Weidenfeld \& Nicholson, 1972)

Haslam, S.A., Reicher, S.D The New Psychology of Leadership - Identity, and Platow, M.J. Influence and Power (Hove: Psychology Press, 2011)

Lytton, N.

The Press and the General Staff (London: Collins 1920)

Pratten, G.

Australian Battalion Commanders in the Second World War (Melbourne: Cambridge University Press, 2009)

Sheffield, G.D. (ed)

Leadership and Command - The Anglo-American Military Experience since 1861 (London:Brassey’s, 2002)

Storr, J.

The Human Face of War (London: Continuum, 2009)

Sweet, M.

The West End Front: The Wartime Secrets of London's Grand Hotels (London: Faber \& Faber, 2011)

US Army

The Battalion Commander's Handbook (Pennsylvania: US Army War College, 1996)

Young, M.

The Rise of the Meritocracy: 1870-2033: An Essay on Education and Inequality (London: Thames and Hudson, 1958). 


\section{II.14 Newspapers}

Andrews, R.J.

Colt, H.A.

Harris, C.

Hope, G.E.

Mukherjee, M.S.

Sandys, E.T.F

Shaw, T.B.
Obituary, The Times, 19 January 1923

Obituary, The Times, 13 February 1951

Letter - 'Kitchener and the Territorials', The Times, 28 August 1928

Article, The Sun, 9 March 1919

Interview, The Telegraph India, 26 April 2011

Obituary, The Times, 15 September 1916

Obituary, Birmingham Daily Post, 11 September 1915

\section{THE INTERNET}

II(AC) Squadron

Association

AngloBoerWar.com

Ashton Territorials

Banbridge County Down

Battlefront.com

Bourne, J.M.

Driscoll, Daniel P.

Dix Noonan Webb

Greatwar.co.uk

Hampson, T. www.twosqnassoc.co.uk/pages/bosses/burke.htm

$\underline{\text { www.angloboerwar.com }}$

www.ashtonpals.webs.com

www.countydown.x 10.mx/html/banbridge_g.1.ht

www.battlefront.com/community/

showthread.php?t=32644

'Hiring and Firing on the Western Front, Cheshire Western Front Association, 14 January 2011.

http://www.youtube.com/watch?v=qSOHzMjobvs

nigeldriscoll.com.au/24

www.dnw.co.uk/medals/auctionarchive/

www.greatwar.co.uk/french-flanders-artois/memorial-loosmemorial.htm

'A Medical Officer's Diary and Narrative of the First World War', http://myweb.tiscali.co.uk/philsnet/T\%20Hampson\%20 WW1\%20Diary\%20100.htm 
Kent War Memorials

Transcription Project

McMaster University

Mark van Vugt

Messenger C.

Mount Wilson \& Mount

Irvine

The Old Front Line:

Battlefields of World War

One

Passport Land

Queen's Royal Surreys

The Auxiliary Division of the RIC

The Bedfordshire Regiment in the Great War

The Border Regiment

The Manchester Regiment

Veterans Affairs

Canada www.kentfallen.com/pdf\%20reports/

$\underline{\text { sandwich.pdf }}$

www.pw20c.mcmaster.ca/case-study/adrian-grant-duffpreparing-first-world-war

http://www.professormarkvanvugt.com/files/

Ch5_VanVugt.pdf

'Scandal in High Places',

http://www.bcmh.org.uk/archive/articles/

ScandalinHighPlacesMessenger.pdf

$\underline{\text { www.mtwilson.com.au }}$

$\underline{\text { www.battlefields1418.50megs.com }}$

www.passportland.com

http://www.queensroyalsurreys.org.uk/

$\underline{\text { www.theauxiliaries.com }}$

$\underline{\text { www.bedfordregiment.org.uk }}$

$\underline{\text { www.border-regiment.kerchi.co.uk }}$

http://www.themanchesters.org/

www.veterans.gc.ca/eng/history/firstwar/canada/

Western Front Association http://www.westernfrontassociation.com/ 